Universidade de São Paulo

Faculdade de Arquitetura e Urbanismo

Departamento de História e Estética de Projeto

Fernanda Maria das Chagas Carvalho

\title{
Liceu de Artes e Ofícios de São Paulo Artium Severum Gaudium (A alegria séria das artes)
}

São Paulo

Março de 2019

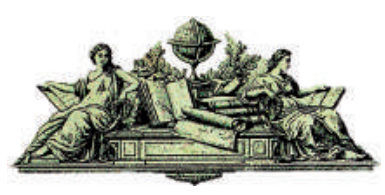





\author{
Universidade de São Paulo
}

Faculdade de Arquitetura e Urbanismo

Departamento de História e Estética de Projeto

Programa de Pós-Graduação

\author{
Fernanda Maria das Chagas Carvalho
}

\title{
Liceu de Artes e Ofícios de São Paulo Artium Severum Gaudium (A alegria séria das artes)
}

EXEMPLAR REVISADO E ALTERADO EM RELAÇÃO À VERSÃO ORIGINAL.SOB

RESPONSABILIDADE DO AUTOR (A) E ANUÊNCIA DO (A) ORIENTADOR (A)

Dissertação apresentada ao Programa de Pós-Graduação do Departamento de História e Estética de Projeto da Arquitetura e Urbanismo para a obtenção do título de Mestre em Ciências

Área de Concentração: História e Fundamentos da Arquitetura e Urbanismo

Orientador: Prof. ${ }^{a}$ Dr. ${ }^{a}$ Beatriz Piccolotto Siqueira Bueno

Março de 2019 
Autorizo a reprodução e divulgação total ou parcial deste trabalho, por qualquer meio convencional ou eletrônico, para fins de estudo e pesquisa, desde que citada a fonte.

Catalogação na Publicação

Serviço Técnico de Biblioteca

Faculdade de Arquitetura e Urbanismo da Universidade de São Paulo

Carvalho, Fernanda Maria das Chagas

Liceu de Artes e Ofícios de São Paulo: Artium Severum Gaudium (A alegria séria das artes) / Fernanda Maria das Chagas Carvalho; orientador Beatriz Piccolotto Siqueira Bueno. - São Paulo, 2019.

$338 \mathrm{p}$.

Dissertação (Mestrado) - Faculdade de Arquitetura e Urbanismo da Universidade de São Paulo. Área de concentração: História e Fundamentos da Arquitetura e do Urbanismo.

1. Liceu de Artes e Oficios de Sao Paulo. 2. Arquitetura. 3. Arte Aplicada. I. Bueno, Beatriz Piccolotto Siqueira, orient. II. Título.

Elaborada eletronicamente através do formulário disponível em: <http://www.fau.usp.br/fichacatalografica/> 
Nome: CARVALHO, Fernanda Maria das Chagas

Título: Liceu de Artes e Ofícios de São Paulo Artium Severum Gaudium (A alegria séria das artes)

Dissertação apresentada à Faculdade Arquitetura e Urbanismo da Universidade de São Paulo para obtenção do título de Mestre em Ciências

Aprovado em:

Banca Examinadora

Prof. Dr. Instituição:

Julgamento: Assinatura:

Prof. Dr. Instituição:

Julgamento: Assinatura:

Prof. Dr. Instituição: Julgamento: Assinatura: 

Para Helena e Caio Lucchesi 


\section{Agradecimentos}

Agradeço ao CNPQ - Conselho Nacional de Desenvolvimento Científico e Tecnológico pela bolsa de estudos para dedicar-me à pesquisa.

Sou grata à Professora Beatriz Piccolotto Siqueira Bueno, amiga e orientadora, por incentivar-me e conduzir-me nas investigações acompanhando todas as suas etapas.

O apoio do Liceu de Artes e Ofícios de São Paulo foi fundamental para a execução deste trabalho. Agradeço a toda a equipe do Liceu e, em particular, à Diretora Institucional Senhora Patrícia Loureiro Marques Macedo pelo voto de confiança e pelo entusiasmo.

Agradeço a Denise Mattar, por partilhar franca e amplamente o gosto pelo trabalho e pela arte.

Pelas críticas e valiosas sugestões durante o exame de qualificação agradeço às Professoras Heloisa Maria Silveira Barbuy e Solange Ferraz de Lima.

Pela generosidade e estímulo agradeço às Professoras Aracy A. Amaral, Áurea Pereira da Silva, Ana Maria de Moraes Belluzzo, Maria Lúcia Caira Gitahy, Diana Gonçalves Vidal, Maria Cristina Bruno e aos Professores Jacques Marcovitch, Paulo César Garcez Marins, Marcelo Mattos Araújo. À Professora Joana Mello de Carvalho e Silva e ao Professor José Tavares Correia de Lira agradeço por 
franquearem meu ingresso no programa de pós-graduação ao acreditarem no projeto. À Professora Ximena Suarez Villagran, sou gratíssima pelas revelações fascinantes da 'visibilidade' da matéria em nível atômico.

Contei com a competência de Alex Ivan Peirano Chacon e Cássia Roberta Araújo Oliveira na resolução de problemas técnicos e estéticos impostos pela documentação provecta de grande formato. E com o desprendimento de José Ranieri Netto por ter conduzido de Nova York até São Paulo o Czur ET16 Plus, robot que reproduziu digitalmente preciosidades reservadas.

À Ricardo Brito, responsável pela diagramação do trabalho, minha gratidão junta-se aos melhores elogios.

Agradeço ainda pela cumplicidade e apoio afetivo dos amigos Flávia Serson, Suzana Martins, Mariana Godoy, Carmen Azevedo, Heloisa Helena Cunha, Betty Mirocznick, Rachel Vallejo, Isa Grinspum Ferraz, Renato de Lucca, Pedro Pio Filho, Osvaldo Ribeiro e André Queiróz.

A ajuda e o afeto de meus familiares Anna Maria Lucchesi Carvalho, Felipe Carvalho Moreira, Antônio Augusto das Chagas Carvalho e João Bezerra Carvalho, sempre e ao longo de todo o trabalho, foi inestimável. 

ARS UNA SPECIES MILLE 


\section{Resumo}

Esta dissertação utilizará a abordagem da História Cultural da Arte refletindo sobre suas confluências com a História Social do trabalho para descrever, categorizar e investigar o que foi a cultura artística e arquitetônica veiculada pela biblioteca do Liceu de Artes e Ofícios de São Paulo quanto à sua configuração e seu papel como receptor, produtor e difusor de know-how no contexto de transferências de modelos culturais.

Palavras-chave: Biblioteca, Liceu de Artes e Ofícios, Arte aplicada, Arquitetura, Ecletismo, São Paulo 


\section{Abstract}

This dissertation will use the approach of Cultural History of Art reflecting on its confluences with the Social History of the work to describe, categorize and investigate what was the artistic and architectural culture conveyed by the library of the Lyceum of Arts and Crafts of São Paulo regarding his configuration and its role as a receiver, producer and diffuser of know-how in the context of transfers of cultural models.

Key-words: Library, School of Arts and Crafts, Applied Art, Architecture, Eclecticism, São Paulo 



\section{Lista de llustrações}

Todas as ilustrações aqui publicadas pertencem ao acervo do Liceu de Artes e Ofícios de São Paulo, salvo quando indicadas as fontes.

- Figuras 1 e 2 Capa e ilustração de Nouvelle Encyclopédie Autodidactique Illustrée D’Enseignement Moderne, 1922 p. 41

- Figuras 3 e 4 Páginas internas de Cours de Sciences Appliquées aux Arts. Traité de Stéréotomie de PILLET, 1923 p. 42

- Figura 5 e 6 Frontispício e Figura interna de Encyclopedia e Diccionario Internacional de W. M. Jackson Inc. p. 42

- Figura 7 Frontispício de História de uma viagem feita à Terra do Brasil de Jean de Léry p. 43

- Figura 8 Frontispício de Metodologia Especial de la enseñanza primaria de Mercante p. 43

- Figura 9 Frontispício de Sheet Steel and Tinplate de R.W. Shannon p. 43

- Figura 10 Frontispício de Teoria delle Ombre e del Chiaroscuro de Bonci p. 43

- Figura 11 Frontispício de Handzeichnungen alter meister p. 44

- Figura 12 Prancha fotográfica de Das Haus Neue Folge p. 45

- Figura 13 Prancha baixa de Das Haus Neue Folge p. 45

- Figura 14 Capa de Der Moderne Schlosser p. 45

- Figura 15 Capa de de Nuevo trazado de Perspectiva p. 46

- Figura 16 Capa de Intérieurs Français au Salon des Artistes Décorateurs en 1926 p. 46

- Figura 17 Capa de Serrurerie Moderne p. 46

- Figura 18 Capa de Architecture Internationale Moderne p. 47

- Figura 19 Capa de Le Luminaire. Procedes D'Éclairages nouveaux p. 47

- Figuras 20 e 21 Capa e prancha com Croquis de Ruhlmann présentés par Léon Moussinac p. 47

- Figura 22 Cobertura de Devantures de Boutiques e et Installations de Magasins p. 48

- Figura 23 Carpeta aberta de Devantures de Boutiques e et Installations de Magasins p. 48 
- Figura 24 Cortes e detalhes geometrais da fachada da loja Pigier em Paris p. 48

- Figura 25 Fachada da loja Pigier em Paris p. 48

- Figura 26 Capa de La Décoration et L'Ameublement à L'Exposition de 1900 p. 48

- Figura 27 Prancha com pintura decorativa do Collège de France p. 48

- Figura 28 Decoração pictural da sala de jogos do Cassino Biarritz p. 48

- Figura 29 Decoração para sala de jantar p. 48

- Figuras 30 e 31 Capa e fotografia de interior de Hotels Particuliers. Intérieurs Décoration et Ameublement p. 49

- Figura 32 Frontispício de Profils et Tournages. Recueil de Documents de Styles. Gothique p. 49

- Figura 33 Frontispício de Répertoire de L'Architecture Moderne p. 50

- Figura 34 Decoração de studio em Répertoire de L'Architecture Moderne p. 50

- Figura 35 Capa de Petites Constructions Françaises par un comité D'Architectes p. 50

- Figura 36 Casa de comerciante em Petites Constructions Françaises par un comité D'Architectes p. 50

- Figura 37 Capa de English Decoration and Furniture of the Early Renaissance 1500-1650 p. 51

- Figura 38 Capa de L'Arte Nell'Industria p. 51

- Figura 39 Frontispício de L'Arte Nell'Industria p. 51

- Figura 40 Página interna de L’Arte Nell'Industria p. 51

- Figura 41 Capa de Le Costruzioni Moderne in Itália p. 52

- Figura 42 Capa de Scuole p. 52

- Figura 43 Capa de Raccolta di mobili Moderni D’Arte Italiana p. 52

- Figura 44 Capa de Il Bronzo e il Rame nell'arte Decorativa Italiana p. 52

- Figura 45 Capa de Modern American Sculpture p. 53

- Figura 46 Capa de A Arte e a Natureza em Portugal p. 53

- Figura 47 Carpeta da École Spéciale des Travaux Publics de Batiment et de l'Industrie. M. Léon Eyrolles p. 54

- Figura 48 Pranchas internas de École Spéciale des Travaux Publics de Batiment et de 1'Industrie. M. Léon Eyrolles p. 54

- Figura 49 Capa do manual-catálogo da Fábrica de Moveis de Antonio Demosso p. 54

- Figura 50 Frontispício de guia de estilo francês no manual-catálogo da Fábrica de Moveis de Antonio Demosso p. 54

- Figura 51 Frontispício de guia de estilo austríaco no manual-catálogo da Fábrica de Moveis de Antonio Demosso p. 54

- Figura 52 Capa do Manual del Hojalatero y Plomero por Carlos Schneider p. 55

- Figura 53 Capa de Il Montatore Elletricista de Barni p. 55

- Figura 54 Capa do Cours de Machines- Outils do General Gages p. 55 
- Figura 55 Capa do Manual del cajista de Imprenta de Fábregues p. 55

- Figura 56 Capa de Principi Fondamentali delle Macchine Utensili de Hülle p. 55

- Figura 57 Capa de Elementi di Agrimensura de Mitoldi p. 55

- Figura 58 Capa do catálogo comercial [Wilhelm Knoll] p. 56

- Figura 59 Capa do catálogo comercial Upholstered Living-Room Furniture p. 56

- Figura 60 Capa do catálogo comercial Illustrations de Meubles. Maple and Co. p. 56

- Figura 61 Capa do catálogo comercial Éditions Nouvelles. Céramiques d'art, Marcel Guillard p. 56

- Figura 62 Capa do catálogo comercial S. Karpen \& Bros. p. 56

- Figura 63 Capa do catálogo comercial Stucchi Gattino p. 56

- Figura 64 Frontispício do catálogo de politecnia Maschinenfabrik Weingarten p. 57

- Figura 65 Frontispício do catálogo de politecnia fabricante de fáquinas Pedro Merlini p. 57

- Figura 66 Frontispício do catálogo de politecnia How to run a Lathe de O’Brien p. 57

- Figura 67 Frontispício do catálogo de politecnia Cerraduras e Ferratería Sargent p. 57

- Figura 68 Frontispício do Anuário do Museu Histórico Nacional p. 57

- Figura 69 Frontispício do Anuário da Escola Polytechnica de São Paulo p. 57

- Figura 70 Frontispício de The Furniture Journal p. 58

- Figura 71 Anúncio de Dutch Kitchnet em The Furniture Journal p. 58

- Figura 72 Sumário da revista The Fine Arts p. 58

- Figura 73 Carpeta da revista L'Ambiente moderno p. 58

- Figura 74 Prancha de L'Ambiente moderno p. 58

- Figura 75 Capa da revista Innen Dekoration p. 58

- Figura 76 Anúncio na revista Innen Dekoration p. 58

- Figura 77 Capa da revista Art et Industrie p. 58

- Figura 78 Anuncio de Daum na revista Art et Industrie p. 58

- Figura 79 Capa da revista Machinas e Construcções p. 59

- Figura 80 Frontispício da revista Marelli p. 59

- Figura 81 Frontispício da revista La Science et la Vie p. 59

- Figura 82 Página interna da revista La Science et la Vie p. 59

- Figura 83 Prancha impressa por Anton Andel Gez p. 60

- Figura 84 Prancha impressa Denticules. D'Apres des Platres de l'Ecole des Beaux-Arts p. 60

- Figura 85 Prancha impressa Motivos decorativos, com putto p. 60

- Figura 86 Prancha impressa [Figura] Cours de dessin, Monrocq p. 60

- Figura 87 Prancha impressa Camillo Boito. Arte utile. Decorazione policroma p. 60

- Figura 88 Prancha impressa [Ameublements complets de Tous Styles] p. 61

- Figura 89 Prancha impressa Il Disegno nella scuola p. 61 
- Figura 90 Prancha impressa Desenho geométrico p. 61

- Figuras 91 e 92 Prancha impressa "A Editora", Lisboa e detalhe do cordame p. 61

- Figuras 93 e 94 Liceu de Artes e Ofícios. Desenhos de Ornatos para aula, 1930 p. 61

- Figura 95 Planta do Sétimo Pavimento da Sede do Serviço Técnico do Café projetada pelo Escritório Técnico "Ramos de Azevedo" Severo \& Villares p. 62

- Figura 96 Fachada da Sede do Serviço Técnico do Café projetada pelo Escritório Técnico Ramos de Azevedo" Severo \& Villares p. 62

- Figura 97 Frontispício do Relatório de Domingos Jaguaribe, 1895 p. 63

- Figura 98 Capa de impresso da Diretoria Geral Do Ensino p. 63

- Figura 99 Detalhe de entalhe em mesa do acervo artístico do Liceu p. 64

- Figura 100 Escultura em bronze [Outono] do acervo artístico do Liceu p. 64

- Figura 101 Retrato de Ramos de Azevedo por Enrico Vio p. 65

- Figura 102 Cabeça de Davi, Michelangelo pertencente à coleção de gessos do Liceu p. 65

- Figura 103 Modelos de ornatos pertencentes à coleção de gessos da instituição p. 65

- Figura 104 Capitel pertencente à coleção de gessos do Liceu p. 65

- Figura 105 Bustos pertencentes à coleção de gessos da instituição p. 65

- Figura 106 Foto-mostruário da Cristallerie Baccarat p. 66

- Figura 107 Carimbo no verso da foto-mostruário da Cristallerie Baccarat p. 66

- Figura 108 Vista do Pavilhão Brasileiro na Exposição Internacional de Saint Louis, 1904 p. 66

- Figura 109 Página do Livro de termo de exames do Liceu de Artes e Ofícios de São Paulo, 1884-1940 p. 67

- Figura 110 Página do Livro de matrículas na aula de desenho 1911-1917 do Liceu de Artes e Ofícios de São Paulo p. 67

- Figura 111 Ata da diretoria do Liceu de Artes e Ofícios de São Paulo Mobiliário, 27 de janeiro, 1895 p. 67

- Figura 112 Capa do Álbum mostruário de Mobiliário para dormitórios p. 67

- Figura 113 Fotografias do Álbum mostruário de Mobiliário para dormitórios p. 67

- Figura 114 Capa do Álbum mostruário Móveis Liceu p. 68

- Figura 115 Fotografia do Álbum mostruário Cerâmicas p. 68

- Figura 116 Capa do Álbum mostruário Alfândega de Santos p. 68

- Figura 117 Fotografia do Álbum mostruário Carro leito p. 68

- Figuras 118 e 119 Fotografias do Álbum mostruário Banca Italiana di Sconto, São Paulo p. 69

- Figura 120 Fotografia do interior do Club Comercial, São Paulo p. 69

- Figura 121 Fotografia da fachada do Teatro Santana, São Paulo p. 69

- Figura 122 Fotografia da fachada do Banco Ítalo Belga, São Paulo p. 69

- Figura 123 Fotografia do interior da Igreja Ordem 3a do Carmo, São Paulo p. 69 
- Figura 124 Fotografia da Oficina de serralheria do Liceu de Artes e Ofícios de São Paulo p. 70

- Figura 125 Fotografia dos Alunos formados no $3^{\circ}$ ano do Curso Profissional de Mecânica do Liceu de Artes e Ofícios em 1932 p. 70

- Figura 126 Desenho avulso do projeto de hall para Adolfo Milani p. 70

- Figura 127 Projetos de lustres em Álbum de Desenhos de lustres p. 70

- Figura 128 Projeto da Sala do Palácio da Justiça, São Paulo p. 71

- Figura 129 Projeto de sala para o Departamento da Metro Goldwyn Mayer, São Paulo p. 71

- Figura 130 Capa do álbum de desenhos impressos Halls, Cabides, porta chapéus, bases, bancos e mesas p. 71

- Figura 131 Capa do álbum de desenhos impressos Cerâmicas p. 71

- Figura 132 Diploma oferecido pelo Liceu de Artes e Ofícios aos alunos habilitados p. 72

- Figura 133 Diploma oferecido pelo Liceu de Artes e Ofícios Escola Técnica Ramos de Azevedo p. 72

- Figura 134 Dyplome de Médaille d'or. Exposition Universelle de Bruxeles, 1910 p. 72

- Figura 135 Carteira de trabalho de Cleto Correia, professor e mecânico na marcenaria do Liceu de Artes e Ofícios p. 73

- Figura 136 Página do registro de Cleto Correia em Livro de Registro de empregados do Liceu p. 73

- Figura 137 Folha do catálogo Mercier Frères, 100 Faubourg Saint Antoine, Paris com carimbo Oficinas de Carpintaria e Marcenaria do Liceu e assinatura de Luiz Scattolini p. 74

- Figura 138 Detalhe de carimbo das Oficinas de Carpintaria e Marcenaria do Liceu p. 74

- Figura 139 Página de Mercier Frères, 100 Faubourg Saint Antoine, Paris p. 74

- Figura 140 O Palácio de Cristal em Londres pp. 76-77

- Figura 141 Moulages d'après Gherardi. École nationale supérieure des Beaux-Arts, Paris. Photo (C) Beaux-Arts de Paris, Dist. RMN-Grand Palais / image Beaux-arts de Paris p. 78

- Figura 142 Baltard. Graveur. Vue de la Cour du Louvre prise pendant l'exposition des produits de l'industrie française dans les jours complémentaires de l'an IX: [estampe]. [s.n.][s.n.]. Bibliothèque nationale de France, département estampes et photographie, Paris p. 79

- Figura 143 Ficha de admissão de Antonio Baccaglini, Mestre geral admitido 1903, Italiano p. 82

- Figura 144 Ficha de admissão de Antonio Borsoi, Auxiliar do mestre geral, admitido em 1902, brasileiro p. 82 
- Figura 145. Ficha de admissão de Giacomo Cadrobbi, mestre geral da oficina de serralheria, admitido 1909, italiano p. 82

- Figura 146 Ficha de admissão de Francisco Scattolin, Chefe da seção de marcenaria, admitido em 1902, brasileiro p. 82

- Figura 147 Mapa da Capital da Província de São Paulo, 1877 por Jules Martin e detalhe com a Rua São José. Arquivo Histórico Municipal Washington Luís, São Paulo p. 83

- Figura 149 Catálogo Delagrave, 1892. Bibliothèque nationale de France, Paris p. 84

- Figura 150 Ilustração da Encyclopedia e Diccionario Internacional de W. M. Jackson Inc. p. 84

- Figura 151 Ilustração do Diccionário dos Animaes do Brasil pelo Dr. Rodolpho von Ihering p. 84

- Figura 152 Frontispício de Élements D’Arithmétique par M. Bourdon, 1878 e detalhe do timbre da Livraria Garnier p. 86

- Figura 153 Ilustração do livro de Victor Mercante, 1912 p. 87

- Figura 154 Capa e frontispício de El Autografo Americano, 1874 p. 89

- Figura 155 Prancha impressa Karl Georg Weitzel. Die Schule des Maschinentechnikers p. 89

- Figura 156 Figura constante de Uhland Pressen. Leipzig: Verlag von H. A. Ludwig Degene, [1920] p. 89

- Figura 157 Esquema de instalação em Traité de la Fabricatión du sucre de Betteraves et de cannes pp. 90-91

- Figura 158 Ornamento Foglia d'acanto di un capitello desenhando por Giocondo Albertolli p. 92

- Figura 159 Ornamento di uma Metopa per in Fregio Dorico desenhando por Giocondo Albertolli p. 92

- Figura 160 Prancha impressa com elementos arquitetônicos p. 92

- Figura 161 Prancha impressa com elementos arquitetônicos p. 92

- Figura 162 Prancha impressa com ornamento para fachada p. 92

- Figura 163 Rua da Boa Morte, antiga rua do Carmo, década de 1870. Casa da Imagem/DPH São Paulo p. 96

- Figura 164 Museu Industrial Dorangeon. Catálogo Delagrave, 1892. Bibliothèque nationale de France, Paris p. 99

- Figura 165 Móveis para salas de desenho. Catálogo Delagrave, 1892. Bibliothèque nationale de France, Paris p. 103

- Figura 166 Regras de precisão para o desenho em perspectiva. Catálogo Delagrave, 1892. Bibliothèque nationale de France, Paris p. 103

- Figura 167 Museu de Lição de Coisas. Catálogo Delagrave, 1892. Bibliothèque nationale de France, Paris p. 105 
- Figuras 168 e 169 Frontispício e página interna do Traité théorique et pratique d'Élétricité de Pécheux, 1904 p. 107

- Figura 170 Antoine-Isidore-Eugène Godeboeuf. Palais pour l'exposition d'objets d'art et des produits de l'industrie [Corte longitudinal]. Trabalho de aluno, Prix de Rome de Arquitetura, 1836, pluma e aquarela sobre papel, 55,8 x $330 \mathrm{~cm}$. Acervo l'école nationale supérieure Beaux-arts de Paris p. 110

- Figura 171 Prancha impressa com ornamento grego desenhado por Andrea De Vico p.

- Figura 172171 Prancha impressa com ornamento romano desenhado por Andrea De Vico p.

- Figura 173 Frontispício de Histoire de l'Art dans Antiquité, volume relativo à Assíria p.

- Figura 174 O touro alado do palácio de Sargon, ilustração de Histoire de l'Art dans Antiquité $\mathrm{p}$.

- Figura 175 Capa de Histoire de l'Art dans Antiquité, volume relativo à Persia p.

- Figura 176 Coluna de Bronze do templo descrito na Bíblia, ilustração de Histoire de l'Art dans Antiquité p.

- Figura 178 Frontispício de Historia general del arte p. 113

- Figura 179 Figura de Vênus de Milo em Historia general del arte p. 113

- Figura 180 Etiqueta da biblioteca de Ramos de Azevedo em Historia general del arte p. 113

- Figura 181 Figura de estofado veneziano em Les arts Décoratifs A Toutes les Époques p. 113

- Figura 182 Figura de faiança de Urbino em Les arts Décoratifs A Toutes les Époques p. 113

- Figura 183 Frontispício de Les arts Décoratifs A Toutes les Époques p. 113

- Figura 184 A cidade de Persópolis, em Histoire de l'Art dans Antiquité p.

- Figura 185 Escola de desenho e escultura em em Dessins D’Architecture impresso por Monrocq Frères p. 115

- Figura 186 Mercado coberto em Dessins D'Architecture impresso por Monrocq Frères p. 115

- Figura 187 Palácio de Justiça, Tribunal Civile Justiça de Paz em Dessins D’Architecture impresso por Monroq Frères p. 115

- Figura 188 Quiosque para concertos em Dessins D'Architecture impresso por Monrocq Frères p. 115

- Figura 189 Museu Industrial em Dessins D’Architecture impresso por Monrocq Frères p. 115

- Figura 190 Capa de L'Architettura Pratica Disegni di Edifizzi Rispondenti ai Bisogni Moderne, s.d.p. 115 
- Figuras 191 a 193 Projetos de casa operária em L'Architettura Pratica Disegni di Edifizzi Rispondenti ai Bisogni s.d p. 115

- Figura 194 Salão do Grand Hotel La Plage Guarujá p. 118

- Figura 195 Chandelier de Cristal em catálogo alemão p. 118

- Figura 196 Cassino do Grand Hotel La Plage Guarujá p. 118

- Figura 197 Lustre em catálogo alemão p. 118

- Figura 198 Frontispício do catálogo Interieurs. D. G. Fischel Söhne p. 119

- Figura 199 Página interna do catálogo da empresa F. Frisoni p. 119

- Figura 200 Lista de preços em catálogo da empresa F. Frisoni p. 119

- Figura 201 Frontispício do catálogo S. Karpen \& Bros. p. 120

- Figura 202 Ilustração com anotações constantes do catálogo S. Karpen \& Bros. p. 120

- Figura 203 Casa Palmares, São Paulo p. 121

- Figura 204 Residência Chedid Jafet, São Paulo p. 121

- Figura 205 Fachada do Banco da Indústria e Comércio de São Paulo p. 121

- Figura 206 Edifício [Germaine Burchard], São Paulo p. 121

- Figura 207 Exemplo de modelagem, sem identificação, São Paulo p. 122

- Figura 208 Exemplo de modelagem, sem identificação, São Paulo p. 122

- Figura 209 Outro exemplo de modelagem, sem identificação, São Paulo p. 122

- Figura 210 Interior do Banco Italiano de Desconto, São Paulo p. 122

- Figura 211 Fachada do Banco Italiano de Desconto, São Paulo p. 122

- Figura 212 Interior de residência, São Paulo p. 122

- Figura 213 Interior da biblioteca Jayme Loureiro,São Paulo p. 122

- Figura 214 Frontispício de FRULLINI, L. Panneaux et ornaments. Bois Sculpte p. 125

- Figura 215 Página interna de FRULLINI, L. Panneaux et ornaments. Bois Sculpte p. 125

- Figura 216 Frontispício de Le Mobilier National. Reproduction des objets d'art. Réunis à la 7e. Exposition de L'Union Centrale des Arts Décoratifs. p. 125

- Figura 217 Página interna de Le Mobilier National. Reproduction des objets d'art. Réunis à la 7e. Exposition de L'Union Centrale des Arts Décoratifs p. 125

- Figuras 218 e 219 Ilustrações da revista Architektonisches Skizzenbuch p. 126

- Figuras 220 e 221 Pranchas impressas de Der Praktische Bautischiler p. 126

- Figuras 222 e 223 Detalhes das pranchas impressas de Der Praktische Bautischiler p. 127

- Figuras 224 e 225 Página interna e tarifa do catálogo Rother \& Kuntze Möbelfabrik-Chemnitz p. 128

- Figuras 226 e 227 Capa e ilustração de serra vertical da empresa Ernst Kirchner \& Co. Leipzig p. 129

- Figuras 228 e 229 Torno ornamental e peças torneadas no catálogo Ernst Kirchner \& Co. Leipzig p. 130 
- Figura 230 Página do Livro de termos de exames de 1885 p. 131

- Figura 231 Prêmio de Pedro Vaz de Mello em desenho superior, 1895 Livro de termos de exames do Liceu, 1885 p. 132

- Figura 232 Autógrafo de Francisco de Paula Ramos de Azevedo, em Ata da Diretoria do Liceu em 27.01.1895 p. 133

- Figuras 233 e 234 Capa e ilustração de ornamentos em Ausgeführte Bau Ornamente p. 138

- Figuras 235 e 236 Fachada de hotel privé e sistema construtivo em Petites Constructions Françaises par un comité D'Architectes p. 138

- Figuras 237 e 238 Capa e ilustração com ornamentos em Particolari di Architettura Classica p. 139

- Figura 239 Prancha impressa com modo de erigir pilastra em Serie Entwürfe du Modern p. 139

- Figuras 240 e 241 Frontispício e figuras de mobiliário em Documents d'Atelier. Art Décoratif Moderne p. 140

- Figura 243 Exemplos de mobiliário em Styl. Salon Wohn p. 140

- Figura 244 e 245 Capa e fotografia de ambiente em Choix d' Intérieurs Belges p. 141

- Figuras 246 e 247 Figuras de bronze no catálogo Argentor p. 141

- Figuras 248 e 249 Pranchas impressas com motivos ornamentais Anton Andel Gez Ornament p. 142

- Figuras 250, 251 e 252 Frontispício e pranchas com elementos decorativos para aplicação em Arte Italiana Decorativa e Industriale pp. 142-143

- Figura 253 Projeto da sede do Liceu de Artes e Ofícios de São Paulo por Domizziano Rossi p. 144

- Figura 254 Detalhe do projeto da sede do Liceu de Artes e Ofícios de São Paulo por Domizziano Rossi p. 146

- Figuras 255 a 260 Pranchas do Curso de Desenho linear geométrico de J. Esteves Ribeiro da Silva pp. 148-149

- Figura 261 Planta de res do chão da sede do Liceu de Artes e Ofícios de São Paulo, risco II, escala 1:100 p. 152

- Figura 262 Planta do primeiro pavimento da sede do Liceu de Artes e Ofícios de São Paulo, escala 1:100, s.d.p. 153

- Figura 263 Planta do segundo pavimento da sede do Liceu de Artes e Ofícios de São Paulo p. 154

- Figura 264 Planta do primeiro pavimento do Liceu de Artes e Ofícios de São Paulo conforme publicada por Severo, 1934 p. 155

- Figura 265 Produtos do Álbum Mostruário Salões. Mesas, consolos, floreiras e vitrinas Luiz XVI e Império p. 156 
- Figura 266 Produtos do Álbum Mostruário Salões. Mesas, consolos, floreiras e vitrinas Luiz XVI e Império p. 156

- Figura 267 Produtos do Álbum Mostruário Salões. Mesas, consolos, floreiras e vitrinas Luiz XVI e Império p. 156

- Figura 268 Produtos do Álbum Mostruário Pratas repuxadas e cinzeladas Época Dom João V p. 156

- Figura 269 Produtos do Álbum Mostruário Salões. Mesas, consolos, floreiras e vitrinas Luiz XVI e Império p. 156

- Figura 270 Oficina de escultura em madeira no Liceu de Artes e Ofícios de São Paulo p. 157

- Figura 271 e 272 Showrooms em Álbum-mostruário Dormitórios ingleses e Salas de jantar e dormitórios p. 160

- Figura 273 Showroom em Álbum-mostruário Dormitórios ingleses p. 160

- Figuras 274 e 275 Frontispício e vista da Exposição de Arte Francesa em 1913 p. 162

- Figuras 276 e 277 Peças da coleção de gessos nos corredores do Palácio Tiradentes, São Paulo p. 163

- Figura 278 Réplica em gesso de Davi de Michelangelo p. 164

- Figura 279 Réplica em gesso de Moisés p. 164

- Figura 280 Parte da coleção de gessos e parte da Pinacoteca do Estado em corredores do Palácio Tiradentes, São Paulo p. 164

- Figura 281 Projeção geometral de escada francesa, do Traité Théorique et Pratique de Charpente, 1900 p. 167

- Figura 282 Modelos de monogramas por Carl Klimsch, [1870] p. 167

- Figura 283 Prancha impressa representando Capitel jônico do templo Fortune Virile p. 168

- Figura 284 Modelo de capitel pertencente à coleção de gessos do Liceu p. 168

- Figura 285 Sala do curso de desenho arquitetônico no Palácio Tiradentes, São Paulo p. 169

- Figura 286 e 287 Pranchas de Die Neuzeit, [1900] p. 169

- Figura 288 Prancha impressa com modelo de arte aplicável em Arte Italiana Decorativa e Industriale, 1900 p. 170

- Figuras 289 e 290 Frontispício e figuras de Desenho mecânico para escolas, por Edwin S. Youngberg p. 171

- Figuras 291 e 292 Pranchas da Collecção de Modelos para desenhos de machinas editada por Robert Mange, 1925 p. 172

- Figura 293 Regulamento das oficinas do Liceu de Artes e Ofícios, 1927 p. 173

- Figuras 294 a 297 Fichas de admissão Cataldo Rocco, aprendiz da sala brinquedos, admitido em 1927; Henrique Cegove Moreno Filho, aprendiz, admitido em 1928, 
brasileiro; Geraldo de Souza, aprendiz de marceneiro, admitido em 1929, brasileiro e Francisco Nascimento, aprendiz lampadários, admitido em 1924 p. 173

- Figuras 298 a 301 Salões e galerias expositivas do Liceu de Artes e Ofícios de São Paulo, década de 1920 pp. 174-175

- Figura 302 Galerias expositivas do Liceu de Artes e Ofícios de São Paulo, década de 1920 p. $176-177$

- Figura 303 Escritório Central Técnico e Artístico do Liceu de Artes e Ofícios de São Paulo p. 179

- Figura 304 Fachada das Oficinas do Liceu na rua João Theodoro, São Paulo p. 180

- Figura 305 Seção de preparação da Oficina de marcenaria do Liceu de Artes e Ofícios de São Paulo, década de 1920 p. 180

- Figura 306 Planta das oficinas do Liceu de Artes e Ofícios na Rua da Cantareira, 27.07.1945, desenhada por Wenceslau G. p. 181

- Figura 307 Ficha de admissão do desenhista Ernesto Helmich, admitido em 1926 p. 182

- Figura 308 Ficha de admissão do arquivista de plantas e almoxarife Gino Franroia, admitido em 1918 p. 182

- Figura 309 Desenho de projeto de luminária para Eduardo Prado, no 995, arq. 2-26, s.d. p. 182

- Figura 310 Desenho de projeto de cômoda Álvaro Bento, M. nº 140, arq. 1-4, s.d., desenhista A.G 8.8.1936 p. 182

- Figura 311 Oficina de marcenaria do Liceu de Artes e Ofícios de São Paulo, década de 1920 p. 183

- Figura 312 Estoque de madeiras do Liceu de Artes e Ofícios de São Paulo, s.d. p. 184

- Figura 313 Oficina de serralheria do Liceu de Artes e Ofícios de São Paulo, década de 1920 p. 185

- Figura 314 Oficina de hidrômetros do Liceu de Artes e Ofícios de São Paulo, s.d. p. 186

- Figura 315 Oficina de fundição do Liceu de Artes e Ofícios de São Paulo, s.d. p. 187

- Figura 316 Aprendizes mecânicos no Liceu de Artes e Ofícios, s,d. p. 187

- Figura 317 Oficina de modelagem do Liceu de Artes e Ofícios de São Paulo, s.d. p. 188

- Figura 318 Oficina de cerâmica do Liceu de Artes e Ofícios de São Paulo, s.d. p. 189

- Figura 319 Oficina de encadernação do Liceu de Artes e Ofícios de São Paulo, s.d. p. 190

- Figura 320 Oficina de metais do Liceu de Artes e Ofícios de São Paulo, s.d. p. 193

- Figura 321 e 322 Interiores do Teatro Municipal, São Paulo 1910-1911 p. 194

- Figura 322 e 323 Fachada e interior do Banco Português do Brasil, São Paulo, 1919 p. 195

- Figura 324 e 325 Mobiliário do Palácio dos Campos Elíseos, São Paulo, 1936 p. 195

- Figura 326 e 327 Ambientes internos de residências, São Paulo, s.d. p. 195

- Figura 328 Fotografia do Álbum mostruário Paraventos, floreiras e vitrinas, s.d. p. 197 
- Figura 329 Liceu de Artes e Ofícios de São Paulo. Projeto José Kalil, no M 219, arq. 1-4 s.d., avulso p. 198

- Figura 330 Liceu de Artes e Ofícios de São Paulo. Projeto José Kalil, no M 219, arq. 1-4 s.d., avulso, detalhe p. 198

- Figura 331 Liceu de Artes e Ofícios de São Paulo. Berço José Kalil. Fotografia avulsa entre registro de berços, s.d. p. 198

- Figura 332 Liceu de Artes e Ofícios de São Paulo. Residência Lauro Cardoso de Almeida. Fotografia avulsa entre registros de ambientes internos s, s.d. p. 199

- Figura 333 Liceu de Artes e Ofícios de São Paulo. Projeto Adolfo Milani, no M 1389, arq. 1-7, s.d., avulso p. 199

- Figura 334 Liceu de Artes e Ofícios de São Paulo. Fotografia avulsa entre registros de mesas e cadeiras, s.d. p. 200

- Figura 335 Liceu de Artes e Ofícios. Álbum de desenhos Escritórios, cadeiras, mesas, carteiras, bureaux, secretarias, estantes caixas, giratórias, conjuntos e grupos, s.d. p. 200

- Figura 336 Vaso composto de três mulheres. In Coupes, Vases, Candélabres (...) déssinés et gravés par J.B. Piranesi. Paris: Auguste Vincent Éditeur, 1905 p. 201

- Figura 337 Liceu de Artes e Ofícios de São Paulo. Vaso. Álbum mostruário Cerâmicas, s.d. p. 201

- Figura 338 Vista do Salon des Industries du Mobilier, Paris, 1908 p. 202

- Figura 339 Liceu de Artes e Ofícios de São Paulo. Álbum Mostruário Dormitórios e salões, s.d. p. 202

- Figura 340 Fotografia de móveis em estilo art deco em Meubles. Présenté par Pierre Chareau, [1920] p. 203

- Figura 341 Liceu de Artes e Ofícios de São Paulo. Álbum Mostruário Alfândega de Santos, 1938 p. 203

- Figura 342 Liceu de Artes e Ofícios de São Paulo. Desenho de lustre [tipo plafond]. [Álbum de desenhos de lustres], s.d. p. 204

- Figura 343 Ilustração de lustre em catálogo [Lustres M9], S.l.: S.n., s.d. p. 204

- Figura 344 Móvel em Lavori Stipetteria. Porte. Portoni. 42 Tavole. Torino: Società Italiana di Edizioni Artistiche C. Crudo \& C., [1927] p. 204

- Figura 345 Liceu de Artes e Ofícios de São Paulo. Móvel em Álbum Mostruário Paravento, Floreiras e Vitrinas, s.d. p. 204

- Figura 346 Liceu de Artes e Ofícios de São Paulo. Fotografia avulsa entre registros de armários, s.d. p. 205

- Figura 347 Lombada do catálogo Cerraduras e Ferratería Sargent, 1912 p. 205

- Figura 348 Liceu de Artes e Ofícios de São Paulo. Álbum Mostruário Alfândega de Santos, 1938 p. 205

- Figura 349 Capa de Nouvelle Encyclopédie Autodidactique, 1922 p. 205 


\section{Sumário}

$\begin{array}{ll}\text { Introdução } & 29\end{array}$

Capítulo 1. Artes e ofícios em São Paulo- 1873-1940: rol de cultura material 35

1.1 Monumentalidade 35

1.2 O acervo do Liceu de Artes e Ofícios de São Paulo 38

1.3 Memórias do saber-fazer $\quad 40$

Capítulo 2. Saberes em trânsito (1873-1885) 75

2.1 Modernidade enciclopédica $\quad 75$

2.2 A "metrópole do café" $\quad 80$

2.3 Lápis, papel, tinta e compassos $\quad 82$

2.3.1 Diagramas $\quad 89$

Capítulo 3. Laboratórios de vocações (1895-1906) 109

3.1 Ecletismo e beaux-arts 109

3.2 O Organizador: Chef dos chefs d'atelier 116

3.3 A alegria séria das artes 144

Capítulo 4. Práticas do saber (1906-1940) 159

4.1 As belas artes 159

4.2. 'Agentes de produtividade' 165

4.2.1 'Núcleo gerador de realidades' 174

$\begin{array}{ll}\text { 4.2.2 Pulsos de aço } & 179\end{array}$

4.3 Entre mudança e tradição 193

$\begin{array}{ll}\text { Ensaios de seriação visual } & 197\end{array}$

Considerações finais $\quad 207$

Fontes e Bibliografia $\quad 211$

Apêndice - Liceu de Artes Ofícios: rol de cultura material 1870-1940 235 



\section{Introdução}

Arte, indústria, ciência e comércio concorrendo juntos foram capazes, em um determinado período histórico, de construir catálogos de maravilhas. Que o digam os exemplares constantes do acervo do Liceu de Artes e Ofícios de São Paulo. Este trabalho tenta sistematizar as muitas questões advindas da aproximação a este patrimônio admirável reunido em território restrito e pouco explorado.

Nossas fontes primárias foram as relativas ao acervo bibliográfico do Liceu: enciclopédias, tratados, dicionários, manuais e guias de estilo, livros, catálogos, pranchas impressas, diplomas, prêmios, modelos e alguns outros itens pertencentes ao acervo. Para nos guiar em nossas buscas elegemos como fonte elementar o perfil histórico da instituição realizado por Ricardo Severo da Fonseca e Costa (1869-1940) - engenheiro e arquiteto português, sócio do Escritório Técnico F. P. Ramos de Azevedo e diretor do Liceu de Artes e Ofícios de São Paulo entre 1928 e 1940. Tomamos como esquadro e inspiração a tese lapidar de Ana Maria Belluzzo sobre o Liceu. Como vetores dos conceitos basilares de enciclopedismo ilustrado e do ecletismo elegemos $L a$ jeunesse des musées: les musées de France au XIXe siècle, organizada por Chantal Georgel e Comprendre l'éclectisme, de Jean Pierre Epron, respectivamente.

Em 1934 o diretor fez editar, publicar e encadernar pela gráfica da escola o livro Liceu de Artes e Ofícios de São Paulo: Histórico, Estatutos, Regulamentos, Programas, Diplomas no qual faz uma espécie de 'arqueologia' da instituição traçando minuciosamente o desenvolvimento histórico do Liceu desde sua concepção original em 1873 até 1933, marcando as adaptações técnicas e administrativas pelas quais passou o estabelecimento, apontando as mudanças nos programas de ensino e descortinando o universo do ensino das artes aplicadas. 
Severo, ao discorrer sobre o regulamento e programas da escola de cultura geral e profissional e da escola prática de artes e ofícios enumera no caput XIII os recursos pedagógicos existentes e disponíveis para alunos e professores:

1 o museu pedagógico franqueado às escolas públicas da cidade, conforme informado à Assembleia Provincial em 1889, composto de quadros, mapas, modelos, exemplares, amostras, aparelhos, maquinismos, reproduções, etc., próprios para o ensino e exercício práticos" e que abrangia diferentes seções; ${ }^{1}$

2 a galeria de artes composta de quadros de gênero e exemplares típicos para exposição da aula de pintura, e duma coleção de reproduções em gesso para as aulas de modelação, escultura e arquitetura composta de estátuas, grupos, bustos, composições decorativas, modelos clássicos e modernos reproduzidos dos mais notáveis museus da Europa. A valiosa coleção constitui um importante museu de arte preparado como galeria expositiva da futura Escola Superior de Artes;

2 a biblioteca, contendo livros de ensino técnico preparatório, de cultura profissional, de álbuns formados com desenhos e reproduções fotográficas das principais obras primas, de pastas de estampas, gravuras e desenhos concernentes ao estudo do desenho à vista, da arquitetura, as artes decorativas $e$ constituindo séries de modelos exemplares para as aulas dos diferentes cursos. ${ }^{2}$

O diretor indica que o catálogo das coleções enumeradas fazia parte de opúsculo em separata reproduzido do arquivo do Liceu e à disposição do corpo docente e discente mediante requisição. Assinala ainda que a guarda e conservação das coleções estavam a cargo do Gerente Geral e do Almoxarife do Escritório Central, sendo que a este último competia o arquivo e fichário completo de todos aqueles bens móveis do Liceu.

Em Artesanato, arte e indústria, até hoje o estudo crítico mais ousado sobre a instituição, Ana Maria Belluzzo estudou a última geração

1. Ver Ricardo Severo (1934).

2. Ver Ricardo Severo (1934). 
de artífices ali atuantes destacando o papel da instituição como "testemunho da transferência do saber-fazer transmitido diretamente na prática do trabalho para os métodos escolares". ${ }^{3}$

Estudando o Liceu sob o ponto de vista da organização do trabalho, a tese persegue as relações entre "a idealização e a operação" atinentes à objetivação artística. Ao longo do estudo, a autora demonstra que a labutação nas oficinas-escola contava com o parcelamento das tarefas e clara separação entre o trabalho de concepção e o de execução salientando a concepção de desenho "fundada em preceitos clássicos, na qual a geometria aparece como disciplina fundamental. Não seria demasiado supor que fosse a base de todo o sistema de ensino".

Ana Maria Belluzzo aponta a "clara separação entre o trabalho de concepção e o de execução", concluindo que os aspectos estéticos da produção de bens de consumo utilitários advêm do uso de repertório de estilos internacionais animado pela internacionalização dos modelos, municiando a escola de uma imensa gama de partidos segundo os padrões de conveniência vigentes. Para a autora a diferenciação do Liceu frente a seus congêneres reside em sua capacidade de recepcionar e adaptar estilos distintos, criando repertórios variados na repetição da diferença, tornando sua produção única e extremamente refinada.

Relativamente à questão das técnicas tradicionais vis-à-vis com os esforços de adaptação das 'receitas' para sua produção material, Belluzzo sugere que a imitação da tradição subjacente ao sistema de ensino do Liceu, tributário e responsável pela sistematização internacional dos estilos, apoiou-se no uso de catálogos e manuais artísticos produzidos para o ensino. Nesta chave, a autora afirma que "as ilustrações, as plantas e os perfis levam a reproduzir em série as soluções artísticas consagradas. O que os catálogos mostravam, os manuais ensinavam a praticar. A arte imitava a arte".

A autora considera, em nota, que o Liceu contou com "uma considerável quantidade de livros e manuais de estilos históricos", nomeando as edições milanesas de Hoepli e indicando também a presença de edições inglesas sobre a história da decoração e mobiliário além de revistas francesas, nominando os catálogos comerciais da "Maple and Co. de Paris e Londres, da Korbmobel, da S. Karpen and Bros." de Chicago e

3. Ver Ana Maria de Moraes Belluzzo (1988), para toda esta seção. 
Nova Iorque; registra ainda a existência de informações sobre as exposições internacionais do começo do século XX que "renovam as artes decorativas a exemplo da coleção L'Art Internacional D'Aujourd 'Hui”. ${ }^{4}$

As afirmações e glosas de Ricardo Severo e Ana Maria Belluzzo são as únicas informações consistentes que encontramos sobre a biblioteca do Liceu, pois que o fichário e o catálogo registrados por Severo não foram localizados. Consta do acervo o Extrato e resumo do Catálogo Geral da Galeria de Arte, datado de 1934 e extraído do Inventário e Catálogo Geral, constituindo-se em sumário das peças e exemplares artísticos relativos exclusivamente à gipsoteca.

$\mathrm{Na}$ falta do rol oficial, os autores nos municiam com descrições sumárias dos gêneros e tipos documentais existentes na biblioteca e utilizados no ensino do Liceu de Artes e Ofícios. De modo a ampliar o conhecimento sobre as peças remanescentes nos propusemos a identificar as unidades.

Diante do exposto, valendo-nos da história cultural da arte e refletindo sobre suas confluências com a história social do trabalho, procuramos descrever e categorizar a documentação bibliográfica do acervo do Liceu de Artes e Ofícios de São Paulo, levando em conta suas intersecções com outros tipos documentais remanescentes na instituição.

Perseguimos neste estudo a configuração da biblioteca e suas práticas, tomando como objeto de análise unidades e séries por vezes incompletas, procurando iluminar simultaneidades compartilhadas e apontando registros de elementos concorrentes para a invenção do artesão moderno.

Ao descrevermos e sistematizarmos o corpus documental bibliográfico e parte do corpus fotográfico existentes e integrantes do arquivo permanente do Liceu, nos deparamos com uma variada gama de recursos e repertórios estrangeiros utilizados nas práticas didático-pedagógicas, educativas e produtivas pertinentes à habilitação de artífices responsáveis pela configuração da forma paulista de cidade moderna durante a belle époque.

Intentamos reunir e analisar indícios da cultura artística e arquitetônica disponível aos atores sociais envolvidos na constituição

4. cf. Ana Maria de Moraes Belluzzo (1988, p. 361). 
e operação dos saberes e fazeres relacionados ao ensino das artes e ofícios e à produção de artes mecânicas para a "metrópole do café" entre 1873 e 1940.

Embora constem do acervo exemplares biográficos datados das décadas de 1950 a 2000, o fim da gestão de Ricardo Severo, que durou de 1928 a 1940, pode ser entendido como o último bastião de defesa da tradição diante dos reclames da funcionalidade que deslocava a beleza para segundo plano na escala alargada da produção. O perfil da produção do Liceu mudara voltando-se mais para o campo dos instrumentos de precisão do que para as artes decorativas, ao mesmo tempo em que foram estabelecidas novas regras para a educação profissional no país.

Feita a reunião, investigamos os objetos bibliográficos a partir de sua própria fisicalidade relacionando-os aos circuitos de apropriação e trânsito de métodos de ensino e modelos científicos, operações de concepção e produção com elenco de tipos, modelos, manuais, a noção de desenho para projetar e operações de difusão.

No capítulo 1 demonstramos os critérios e o processo de fatura do arrolamento sublinhando amostras de exemplares notáveis e alguns insights que as peças estudadas promoveram. Circunscritas as peças, no capítulo 2 conferimos os contextos dos saberes circulantes e as simultaneidades compartilhadas, desde a configuração do positivismo que informou a fundação do Liceu destacando algumas práticas relacionadas à produção e leitura do desenho na escola. No capítulo 3 revisitamos os marcos teóricos do ecletismo identificando os pontos de contato com as aspirações propugnadas pela gestão de Ramos de Azevedo, para depois, no capítulo 4, apresentarmos uma seleção de produtos originários das práticas do saber-fazer desempenhadas no Liceu. Por fim ensaiamos aproximações visuais ao conteúdo das peças estudadas marcando algumas constantes e analogias observáveis a partir da enorme diversidade das unidades.

$\mathrm{O}$ arrolamento consta deste trabalho como apêndice. E conquanto não se trate de um inventário ou catalogação científica, dadas as limitações de tempo e competências, produzimos um rol dos objetos constantes do acervo datados entre 1873 a 1940 e sob guarda institucional. O arrolamento da base empírica deu-se através do embate pessoal e direto com peças centenárias de grande valor histórico e documental durante os anos de 2011, 2017 e 2018. 
O primeiro contato com o acervo e o material bibliográfico foi em 2011, quando integramos o grupo de trabalho responsável pela proposição de um programa museológico para o Centro Cultural do Liceu de Artes e Ofícios de São Paulo, a cargo da Pinacoteca do Estado sob coordenação de Marcelo Mattos Araújo, Maria Cristina Bruno e Paulo César Garcez Marins e colaboração de Marilia Bonas. Nesta ocasião ficamos responsáveis pela realização do levantamento dos tipos documentais constantes do acervo do Liceu de Artes e Ofícios de São Paulo, relação que serviu de alicerce para a revisão da base material, realizada parcialmente entre abril e julho de 2017 e retomada para finalização entre julho e dezembro de 2018.

A revisão parcial deveu-se à participação no grupo de trabalho coordenado por Denise Mattar durante a preparação das edições da exposição comemorativa dos 145 anos do Liceu, servindo como preâmbulo na reorganização dos grandes conjuntos documentais para o presente estudo.

A questão central do estudo foi tentar conferir a potencialidade da coleção bibliográfica disponível no Liceu relativamente à apropriação, uso e interpretações de modelos e fontes importadas operadas na formação de artesãos manufatureiros, buscando visualizar camadas entrelaçadas de tempo. Sem enveredarmos por questões teóricas próprias da teoria da arte e da estética, procuramos estabelecer outras referências para a recuperação e análise da construção e permanências no patrimônio arquitetônico da cidade de São Paulo. 


\section{Capítulo 1. Artes e ofícios em São Paulo 1873-1940: rol de cultura material}

\subsection{Monumentalidade}

Diante da monumentalidade do corpus documental que compõe o arquivo histórico do Liceu de Artes de Ofícios de São Paulo, entrevimos a vitalidade de exemplares formidáveis. Durante a belle époque, artefatos relacionados aos estudos das artes nos processos de habilitação dos artesãos responsáveis pela configuração da forma paulista de cidade moderna resistiram aos caprichos da Fortuna. Raros e envoltos em uma espécie de reserva exótica, os componentes do acervo bibliográfico nos pareceram em compasso de espera por explorações aprofundadas através das quais poderiam demostrar suas índoles e sua eficiência.

Como este estudo pretende demonstrar, o universo dos repertórios dirigidos para a instrução e produção das artes e ofícios congregava tipos e modelos de natureza bastante diversas. No Liceu, como em outras escolas técnicas e profissionais do período, as práticas didático-pedagógicas e educativas contavam com modelos pedagógicos e inúmeros repertórios circulantes no cenário internacional, denotando não apenas identidades superficiais, mas profundas homologias. Apresentando simultaneidades compartilhadas, hábitos e usos de matrizes europeias que perduraram em longa duração podem ser considerados plurivalentes.

A coleção pedagógica e seus acervos e séries remanescentes no Liceu, como referidos na introdução deste trabalho e no arrolamento sumário apenso, embora interseccionada com outras coleções do arquivo (especialmente a institucional) mesmo não se referindo a um museu de 
arte decorativa, compõem-se de modelos de saber técnico e de objetos artísticos, para tomar emprestada a expressão de Rossela Froissart ${ }^{5}$.

Os conjuntos de livros, desenhos e estampas restantes no acervo podem ser considerados recueils organizados para uso didático no ensino do fazer, suporte visual de uma escola de arte industrial, sendo por sua vez, uma seleção feita, em última instância, para informar a composição, a invenção e a produção de objetos práticos, por vezes atualizando o vocabulário das formas. O conhecimento ali condensado, fora organizado em sistemas, sendo objeto de memória, de cultura local e também fruto de trocas entre os meios artísticos nacional e internacional.

Estabelecidas estas premissas e circundadas as esferas para coleta e avaliação, desafios de ordens variadas se ofereceram antes de podermos isolar os tipos para análise material.

A materialidade dispersa do acervo do Liceu e a falta de organização dos exemplares, sem inventário, sem quadros de arranjo, guias, descritores, índices históricos ou outros instrumentos de pesquisa além da lista que havíamos elaborado sete anos antes, dificultaram a identificação das lacunas. Para estabelecimento de conjuntos estáveis lançamos mão de uma catalogação quase intuitiva, os itens foram reunidos e agrupados em grandes coleções, separando-se os de sabido valor inestimável e os fragilizados.

Para os originais fragilizados a opção foi minimizar a sujidade e reunir os fragmentos na tentativa de estabilizá-los envolvendo-os em papel de $\mathrm{pH}$ neutro para acomodação em estantes horizontais, garantindo apenas o manuseio indispensável.

As peças permaneceram reservadas em ambiente climatizado e foram sistematizadas para focalizarmos os tipos para análise. Em uma espécie de prelúdio de revisão da base empírica algumas peças foram separadas, curadas, reproduzidas digitalmente e movimentadas para a exposição comemorativa dos 145 anos da instituição inaugurada em 2018.

Os exemplares não mobilizados para a mostra foram revistos, reagrupados e inspecionados para passarem por nova fase de

5. Ver Rossela Froissart. Les collections du musée des Arts décoratifs de Paris: modèles de savoir techique ou objets d'art? In Chantal Georgel (1994 p. 83 e ss.); no artigo a autora discute com muita propriedade a questão da beaux-arts appliquées à l'industrie. 
reprodução digital em alta definição com o equipamento Czur ET 16 Plus, adquirido especialmente para este fim. Foram reproduzidos integralmente todos os álbuns-mostruários, desenhos avulsos e em álbuns, uma seleção de manuais, repertórios e guias de estilo, catálogos comerciais e de politecnia, revistas especializadas, livros e impressos sendo que para outros exemplares de interesse do estudo foram executadas reproduções parciais.

A seleção para reprodução integral privilegiou a raridade, a antiguidade e as condições de conservação das peças. Contabilizamos cerca de 12 mil arquivos digitais referentes às unidades digitalizadas relativas a enciclopédias, dicionários, tratados, manuais, repertórios, guias de estilos, manuais de politecnia, revistas especializadas em arte, decoração e tecnologia, pranchas impressas/álbuns seriados, catálogos comerciais e de politecnia que associamos à Coleção Pedagógica, desenhos, projetos, estudos e esboços originais, álbuns fotográficos (mostruário) e fotografias avulsas que relacionamos à Coleção Institucional.

Todos os arquivos digitais foram organizados por tipos e copiados em unidade de disco rígido depositada na instituição.

Mesmo considerando as dificuldades na recomposição de seus lugares nas práticas, métodos e programas de ensino assim como seu desempenho nos circuitos comerciais, a investigação das unidades partiu de indagações simples: que o eram, de onde tinham vindo, como chegaram e como foram selecionadas a fim de perscrutar as intenções e as escolhas por trás delas.

Formando uma coleção peculiar, as diversas publicações, impressos, álbuns fotográficos e desenhos, na maioria das vezes sem datação precisa, são complementares à coleção de cópias em gesso e alguns exemplares de mobiliário, os quais trataremos muito superficialmente quando e se as correlacionarmos com algumas séries e unidades eleitas para exame. A seleção para comentários também privilegiou a raridade e a antiguidade, além de aspectos singulares das peças.

Através do embate com cada uma das unidades estudadas ao longo dos anos quase podemos reconhecê-las de olhos fechados. Além dos tipos convencionais alguns manuais e guias de etilo, livros e periódicos contam com caraterísticas físicas próprias, variando de grande a médio formato, sendo às vezes compostos por pranchas avulsas arranjadas em carpetas de papelão com cordões 
embainhados que lhe servem de capa. Estas pranchas e as que consideramos pranchas impressas/álbuns seriados podem conter representações litográficas ou fotográficas, incluindo outras técnicas usuais no período como heliotipia, fototipia, zincografia, sendo que certos exemplares trazem cordões, dobras, ilhoses, amassaduras etc. Suas "marcas de guerra" sugerem muitas questões e dentre elas seu uso repetido desde o final do século XIX e início dos anos 1920 até serem recolhidas para arquivo.

Quando interrogados mais detalhadamente os exemplares nos apontaram valiosos indícios e evidências da produção e circulação de repertórios e transposição dos modelos entre os meios intelectuais de Paris, São Paulo, Viena, Buenos Aires, Gênova, Chicago, Hamburgo, Berlin, Nova York e outras capitais. Além disso, denunciaram redes de sociabilidade, entrecruzamentos, expedientes comerciais, atos administrativos etc. Nos fizerem vislumbrar receitas para experimentações e práticas do saber-fazer disponíveis no Liceu. Apontaram, ainda, dimensões variadas do trabalho de sujeitos sociais capazes de estabelecer o diálogo da tradição com a práxis de seu tempo.

Dos conjuntos de artefatos remanescentes no acervo, ativados na transferência de práticas artísticas, científicas e educativas compartilhadas, e na produção de bens artísticos destacaremos aqui os manuais de estilo, pranchas impressas/álbuns seriados, catálogos comerciais e de politecnia, desenhos que, mesmo eventualmente consideradas séries incompletas, nos pareceram mais insinuantes. Para estes teceremos alguns comentários verticais e para os demais tipos indicaremos somente uma nota sucinta, quando não apenas um exemplo visual. Outros exemplares relevantes comparecerão ilustrando temas relacionais abordados nos capítulos.

\subsection{0 acervo do Liceu de Artes e Ofícios de São Paulo}

O acervo do Liceu de Artes e Ofícios de São Paulo abrange distintas áreas de conhecimento e documentação. Suas coleções referemse às Artes Visuais (incluindo Artes Aplicadas), História, Ciência e Tecnologia, Imagem e Som, contando com bens culturais de valor histórico e artístico datados entre 1860 e 1970, muito embora em nosso recorte cronológico tenhamos considerado apenas os exemplares datados entre 1870 e 1940. 
A coleta de dados e a identificação de documentos textuais, tridimensionais e iconográficos não devem ser tomadas como descrições documentais desde que não estabeleceram códigos de referência, derivando em processamento de dados sem recontagem analítica das unidades, especialmente quanto aos exemplares bibliográficos.

$\mathrm{O}$ arrolamento, que é apêndice deste estudo, utilizou tantos títulos formais quanto títulos atribuídos, assim como assumiu a falta da datação quando não foi possível atribuir datas às peças. O rol pretende ser subsídio para a elaboração de futuros instrumentos de pesquisa ou mesmo base topográfica dos bens a serem inventariados e quantificados analiticamente em tempo.

Dada a quantidade e diversidade dos bens componentes da base empírica e de modo a organizarmos nossos estudos, optamos por dividir os conjuntos coerentes e significativos em duas grandes áreas e respectivas subáreas conforme o índice do arrolamento.

I. Coleção Pedagógica, subdivida em:

I.1 Acervo bibliográfico

I.2 Acervo artístico

I.3 Acervo fotográfico (modelos)

II. Coleção Institucional, relativa aos registros corporativos administrativos, escolares, de produção e extroversão (comercialização), subdividida em:

II.1 Acervo de manuscritos

II.2 Acervo fotográfico

II.3 Acervo de projetos (desenhos)

II. 4 Outros

Dentro das áreas propostas, identificamos e isolamos séries amplas (coleções) e pequenos grupos (miscelâneas) compostos de tais tipos documentais para cada acervo:

\section{Acervo bibliográfico}

I.1 enciclopédias, tratados, dicionários, manuais, repertórios, guias de estilos, manuais de politecnia, catálogos comerciais, catálogos de politecnica, livros técnicos, obras de referência, periódicos e revistas especializadas em arte, decoração e tecnologia, pranchas impressas/álbuns seriados e impressos 


\section{Acervo artístico}

I.1 mobiliário

I.2 esculturas, pinturas, gipsoteca (galeria de reproduções em gesso)

I.3 fotografias avulsas (modelos)

\section{Acervos manuscrito, fotográficos, de projetos e outros estes}

II.1 atas e livros manuscritos

II.2 álbuns fotográficos (mostruário) e fotografias avulsas

II. 3 desenhos, projetos, estudos e esboços originais

II.4 diplomas, prêmios, documentos e impressos

Além destes, assinalamos que integram o acervo gravuras, arte sacra, mobiliário, marchetaria, placas, medalhas, objetos decorativos, ferramentas, hidrômetros, exemplares audiovisuais e filmográficos e outros objetos tridimensionais.

Optamos por empreender a descrição sumária para a organização de unidades (peças) documentais por organicidade, relacionando -as às coleções a que pertencem e fundos 'espontâneos' sem, entretanto, propormos procedimentos técnicos tais como indexação, quadros de arranjo, plano de gestão ou classificação documental ou procedimentos de conservação e restauro, dado serem atribuições de arquivistas e outros profissionais especializados a serem empreendidos no futuro.

Apresentado o acervo sobre qual nos debruçamos, no próximo segmento verificaremos mais pormenorizadamente parte da produção e qual receituário esteve à disposição do ensino prático e técnico no Liceu entre 1873 e 1940, apontando algumas questões sobre suas matrizes e o vocabulário que carregam.

\subsection{Memórias do saber-fazer}

Num dos conjuntos raros, de pranchas impressas com desenhos de ornamentos arquitetônicos gregos e romanos assinados pelo arquiteto Giocondo Albertolli (1743-1839), uma sentença nos sugere que, para conhecermos os exemplares ali representados, os examimemos scrupulosamente, parte por parte. Mais do que reconhecê-los, ao divisarmos os conteúdos ali expressos, tomamos contato com saberes técnicos mobilizados no universo do ensino das artes manuais e industriais. 
Perseguiremos, daqui em diante, os vestígios dos conhecimentos ligados ao saber-fazer, observando pistas sobre sua circulação e sobre o modo como foi apropriado e invertido nos processos do ensino profissinal nas oficinas-escolas do Liceu para, no limite, ser extrovertido. A categorização dos itens aqui mostrados seguirá a tipologia indicada no arrolamento, estabelecendo os destaques das séries amplas de ambas as grandes áreas.

\section{Coleção Pedagógica}

\section{I.1 Acervo bibliográfico}

\section{Enciclopédias}

Luxuosas, raras e maciças, por vezes incompletas, contêm livros com ilustrações 'articuladas' mostrando as partes dos objetos representados como os da Nouvelle Encyclopédie Autodidactique Illustrée D’Enseignement Moderne. Publié en collaboration par un Comité D' Universitaires. Paris: [Librairie Aristide Quillet], 1922.
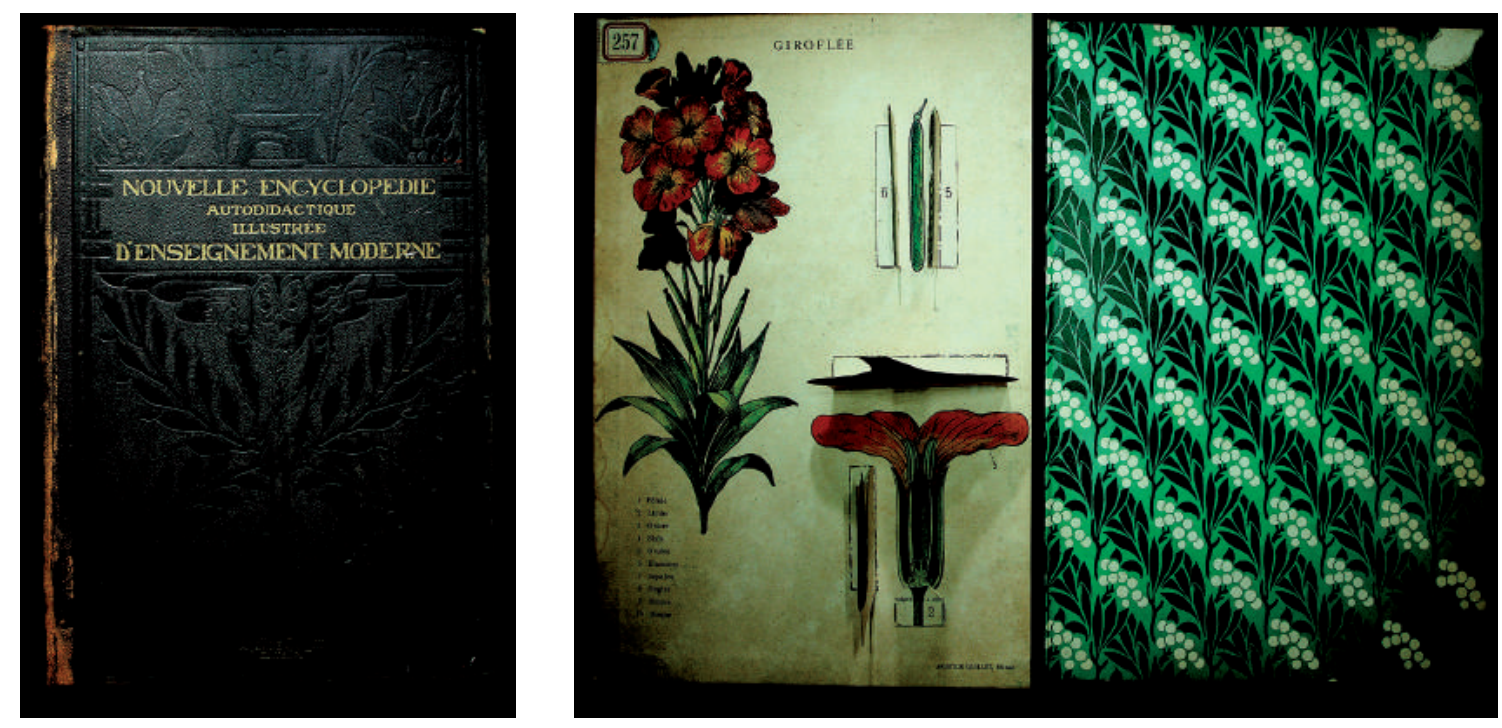

\section{Tratados}

São muito poucos, em geral teóricos e práticos, como a edição de 1923 do Cours de Sciences Appliquées aux Arts. Traité de Stéréotomie. Charpente et Coupe des Pierre de PILLET havendo apenas um relacionado à litografia sendo os demais relativos a processos técnicos da eletricidade, da fabricação de sabão e de açúcar. 

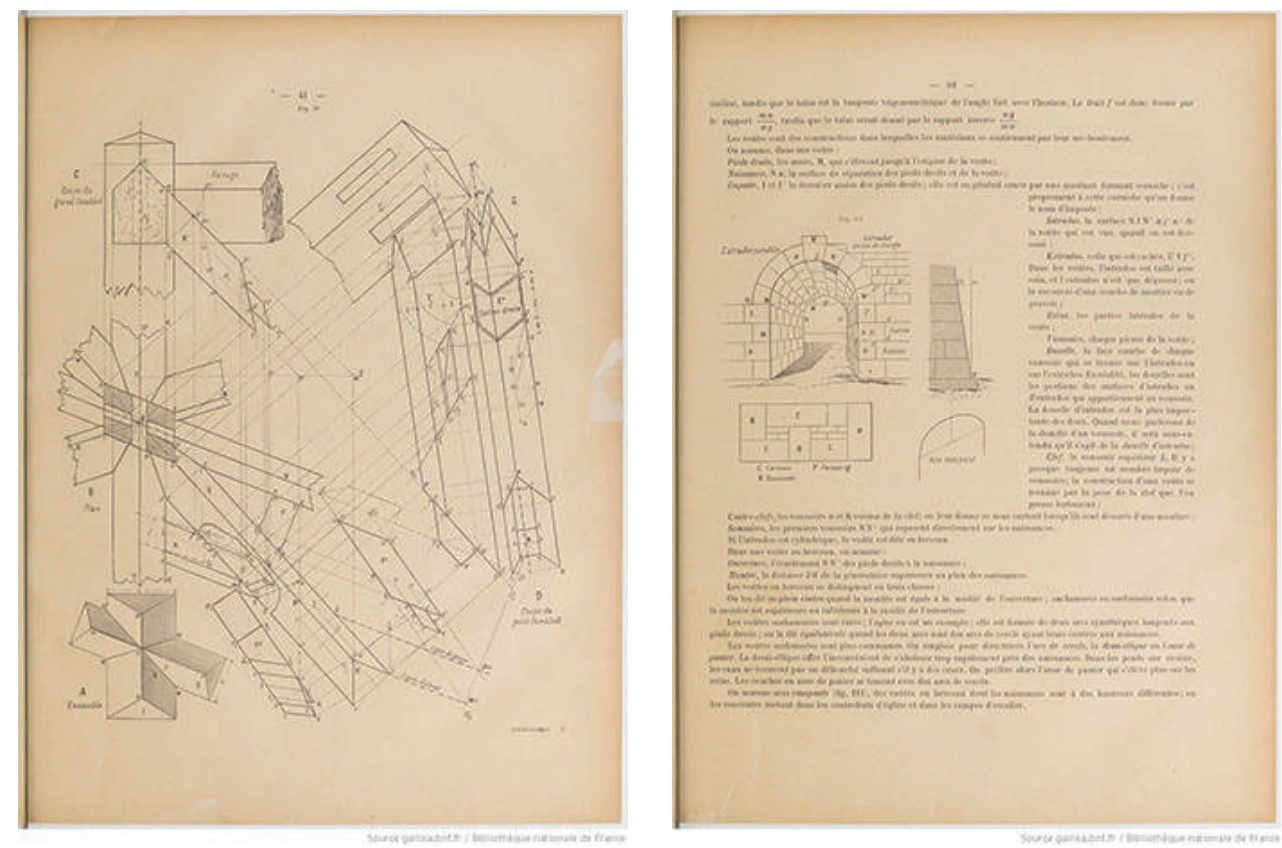

\section{Dicionários}

Poucos, um escolar e os demais técnicos, relativos às ciências naturais e da engenharia industrial. Há o híbrido Encyclopedia e Diccionario Internacional organizado e redigido com a collaboração de distinctos homens da sciencia e de lettras brasileiros e portugueses. Edição ricamente illustrada com milhares de gravuras, muitas em cor. Rio de Janeiro, Nova Iorque: W. M. Jackson Inc., s.d., volume 5.
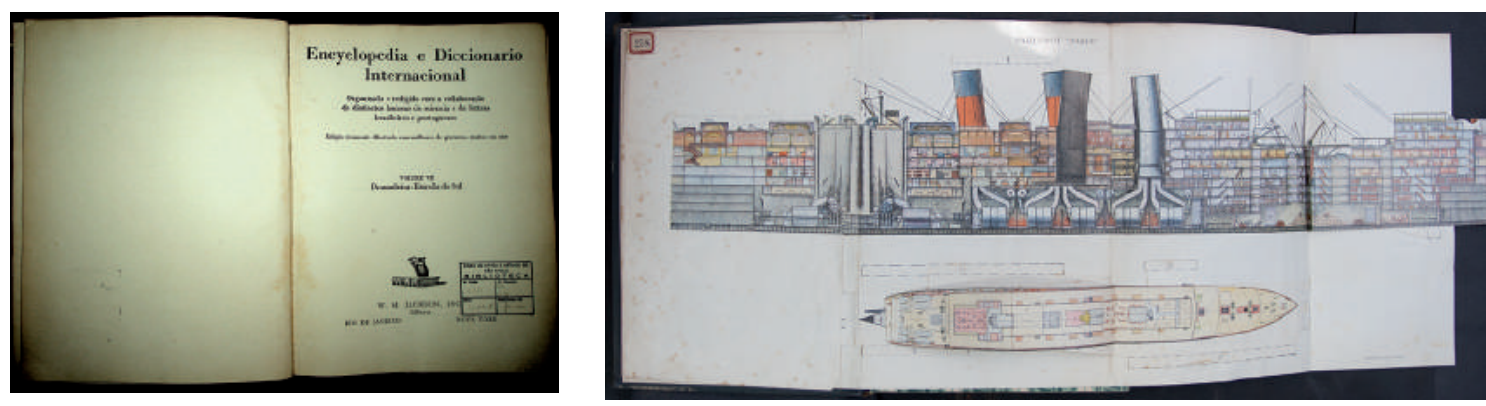

\section{Livros, livros técnicos e metodologias}

Sobre história do Brasil, metodologias, artes e temas relacionados a temas industriais destacamos a História de uma viagem feita à Terra do Brasil, de Jean de Léry; a Metodologia Especial de la enseñanza primaria, de Mercante; Sheet Steel and Tinplate, de R.W. Shannon e Teoria delle Ombre e del Chiaroscuro, de Bonci. 

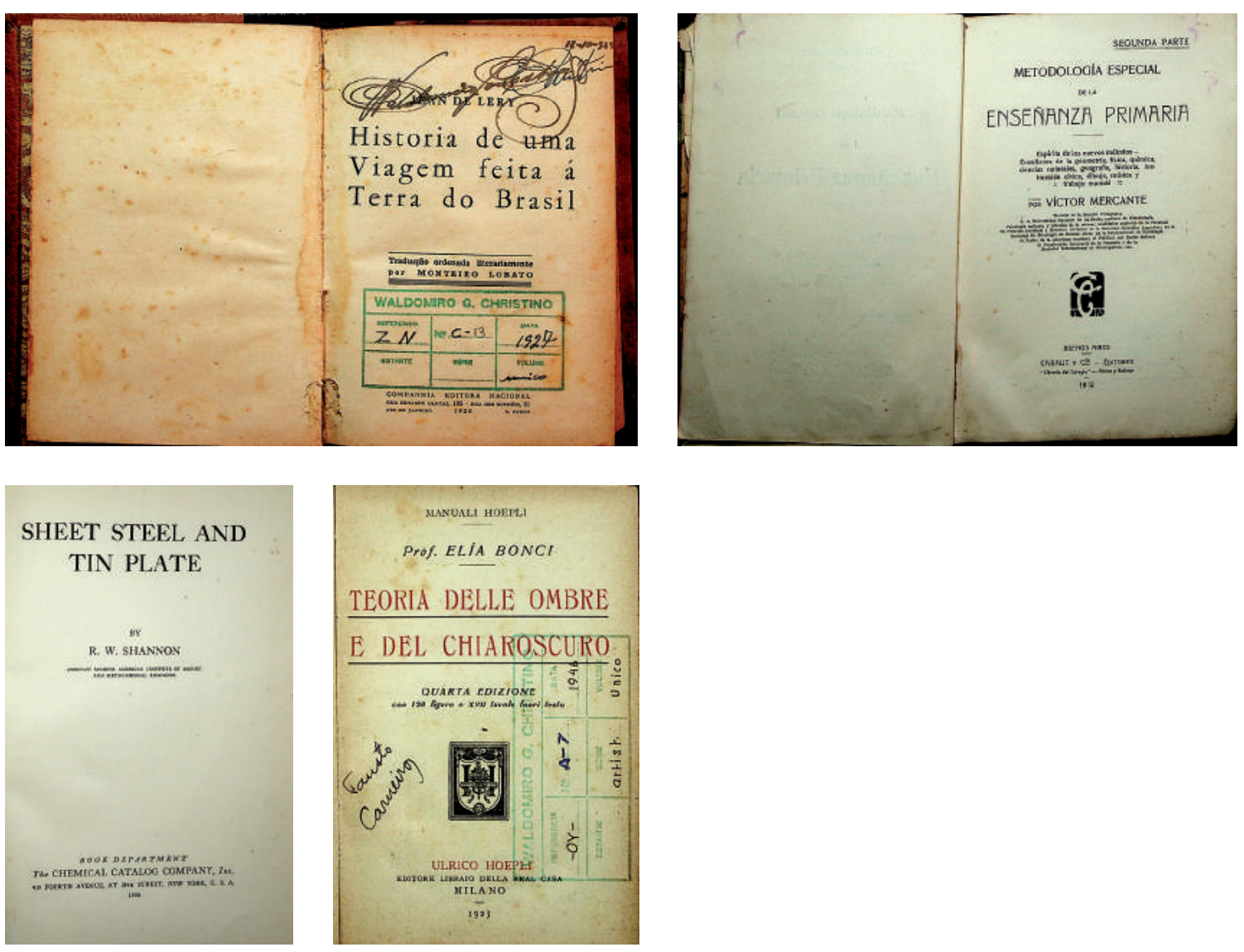

\section{Manuais, repertórios, guias de estilos}

No Liceu, entre 1874 e 1930, transitaram e foram apropriados manuais, repertórios e guias de estilo publicados por diferentes librairies ${ }^{6} \mathrm{e}$ casas editoras europeias especializadas responsáveis pela produção de inventários da produção artística, arquitetônica, de arte decorativa e obras técnicas em diferentes épocas. As próprias publicações podem ser consideradas catálogos artísticos do saber-fazer, bibliotecas documentais testemunhos da profusão de preceitos/sistemas e tipos ensinados nas lições ecléticas.

6. Librairie entendida tanto como casa editora especializada quanto livraria para o comércio de livros. Na França, o libraire-éditeur editava e comercializava livros, podendo também ter a função de redator. Na Alemanha, por exemplo, Alexander Koch foi editor e redator de revistas além de organizador da competição House for an Art Lover e outras iniciativas ligadas à arte e arquitetura. Ver Mackintosh Architecture, University of Glasgow. Disponível em https://www.mackintosh-architecture.gla. ac.uk/catalogue/name/?nid=KochAx Acesso em 15.01.2019. 
Ilustradas, dirigidas por arquitetos, engenheiros e intelectuais eram endereçadas não apenas aos seus pares, mas para quem lidasse com e se interessasse pelas artes integradas à arquitetura. Na maioria das vezes, as reuniões de tipos estiveram a cargo de editores, autores e especialistas, espécie de colecionadores de obras de arquitetos e artistas renomados, tornando-se expressões de diferentes modernidades.

Dentre as inúmeras 'bibliotecas' e editoras destacamos as relacionadas abaixo.

\section{Austríacas}

Especializadas em arquitetura e artes e ofícios

- Gerlach \& Ferdinand Schenk Verlag für Kunst und Kunstgewerbe, Viena Albertina und Anderen Sammlungen. [..]

Wien: Gerlach \& Ferdinand Schenk Verlag für Kunst und Kunstgewerbe, 1896, carimbo

Libreria Especial Arquitectura, Artes y Bellas-Artes Juan Cañero, Buenos Aires

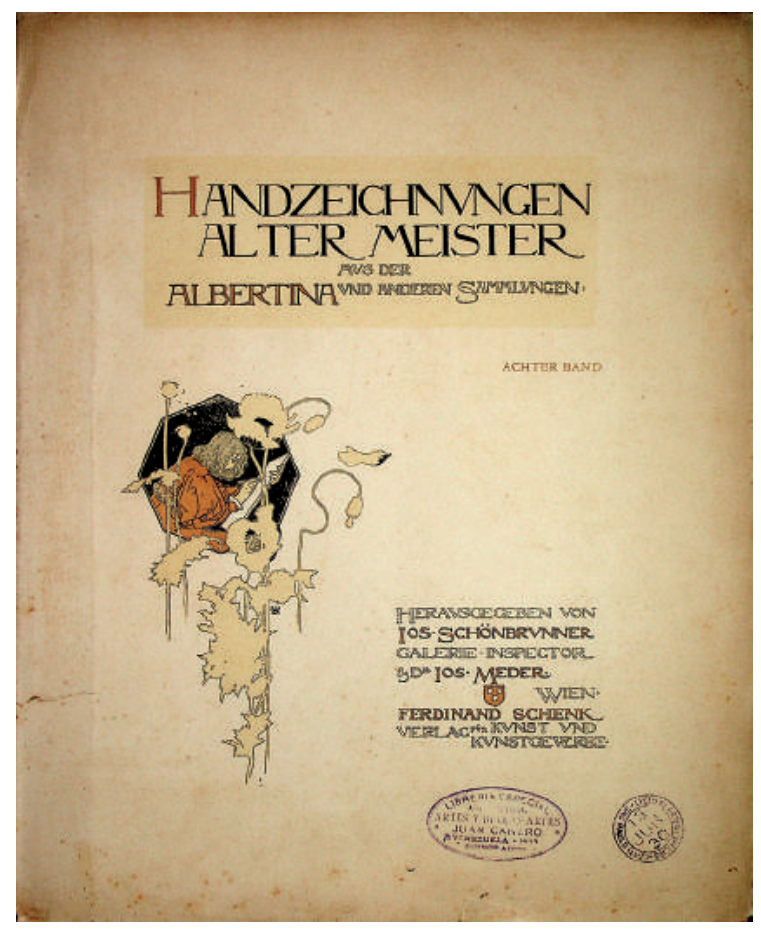

- von Anton Schroll \& Co., Viena

\section{Alemãs}

- Bauformen Bibliotethek de Julius Hoffmann, Stuttgart

- Friedrich Wolfrum, livraria editorial para arquitetura e artes e ofícios, Düsseldorf 

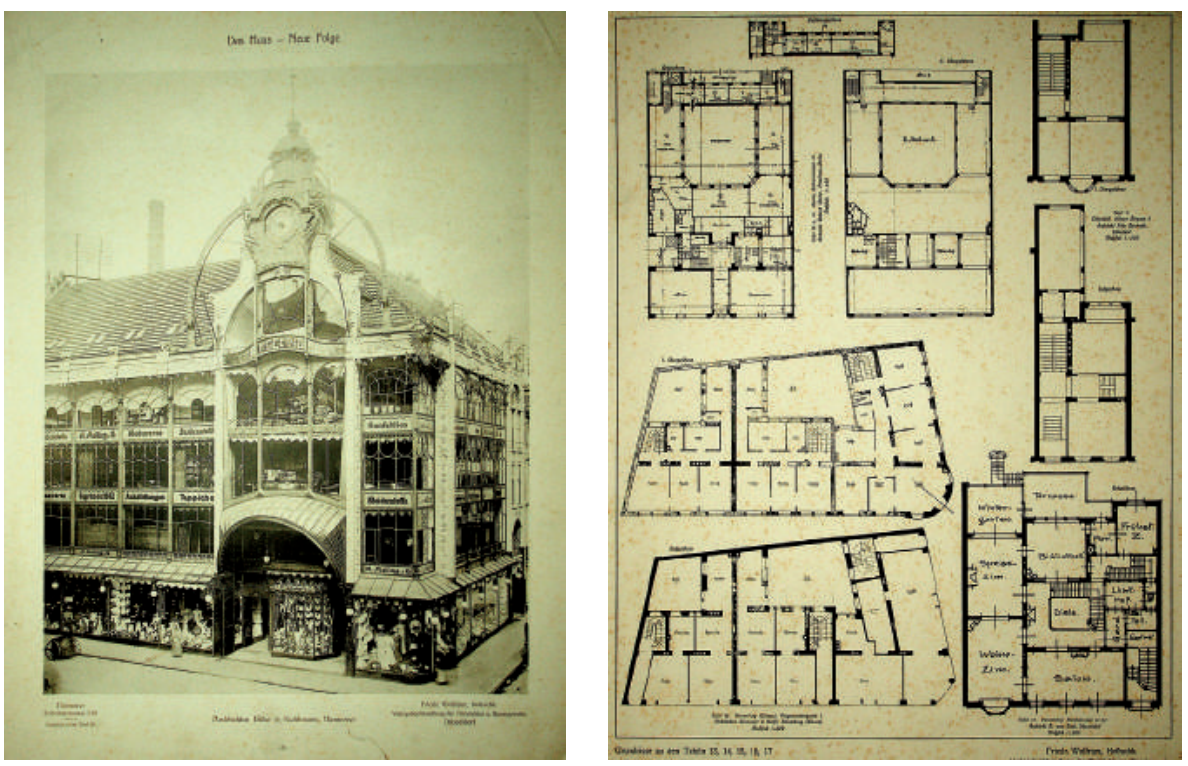

Das Haus Neue Folge. Verlagsbuchhandlung, für architektur und Kunstgewerbe.

Düsseldorf: Verlag

von FriedrichWolfrum, Hofbuchhandlung, 1900

- Librairie D'Architecture et D'Arts Décoratifs et Industriels de Bruno Hessling, Berlin

- Otto Maier, em Ravensburger editor de amostras práticas de livros em tamanho de bolso para uso por escolas comerciais

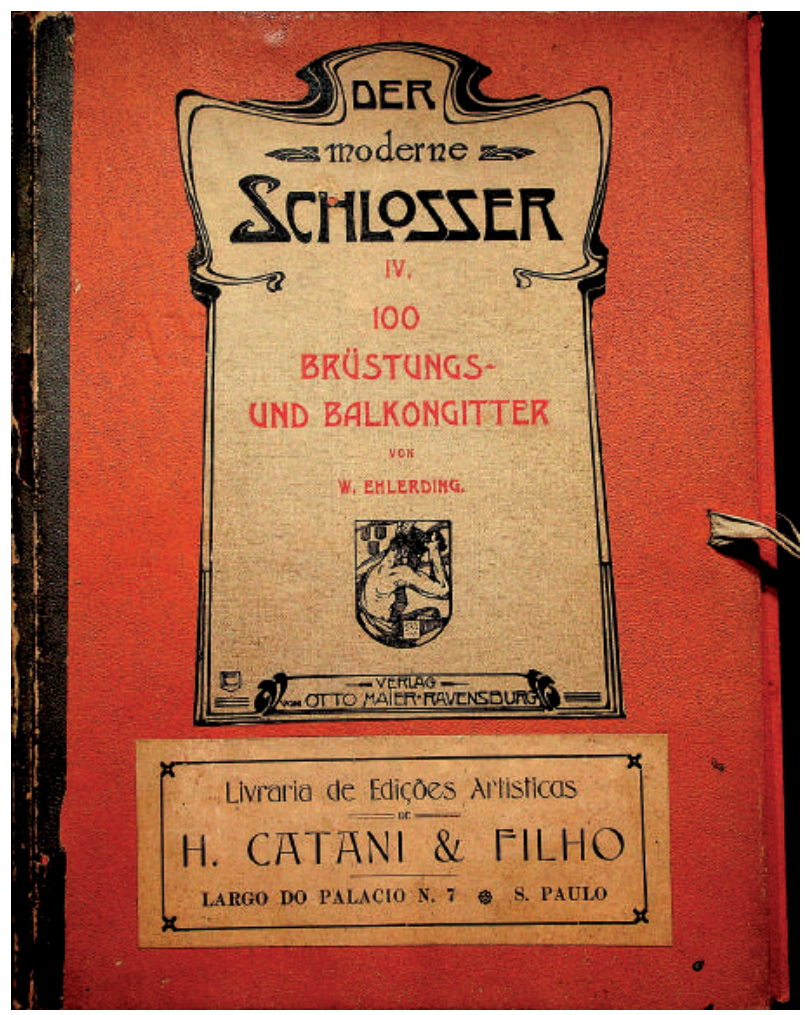

Der Moderne Schlosser.

Praktische Musterbücher in

Taschenformat. II Band. 50

Türen und Tore. Herausgegeben

von W. Ehlerding. Ravensburg:

Verlag Otto Maier, [1910] 


\section{Espanhola}

- Casa Editorial Canosa, Barcelona

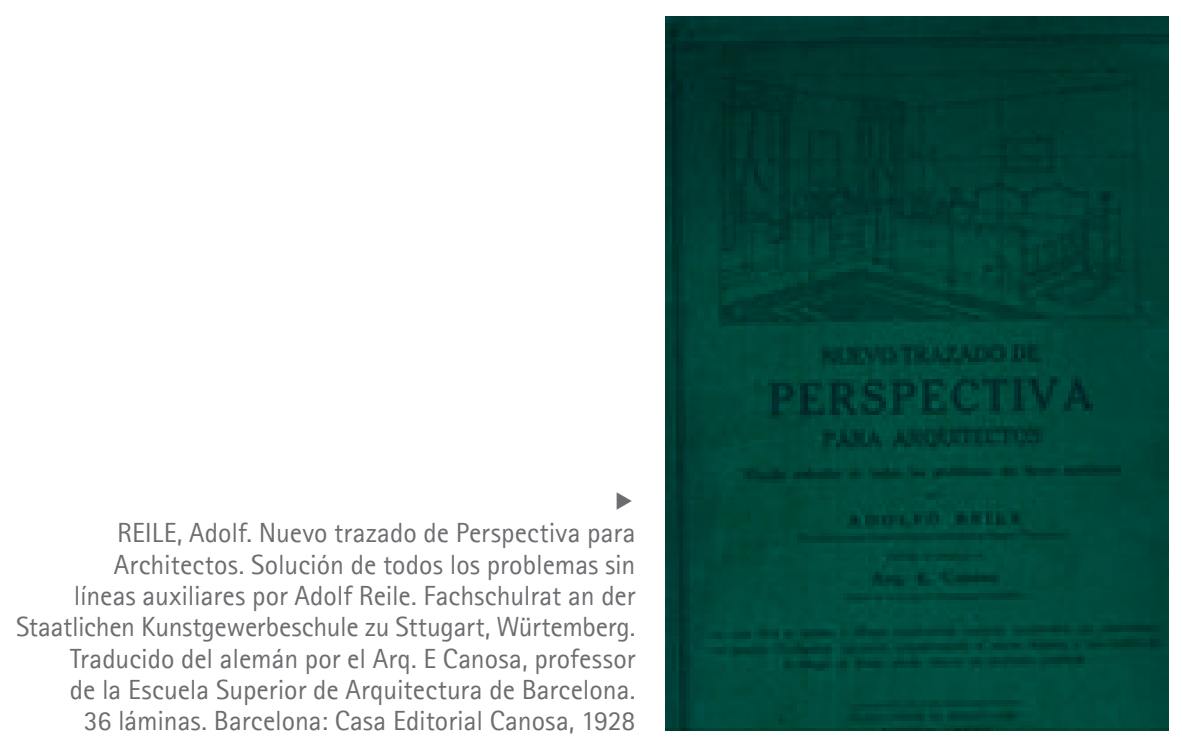

\section{Francesas}

Com sede em Paris

- Éditions Albert Morancé

- Éditions D'Art Charles Moreau que mantinha a Librairie des arts du bâtiment e a Librairie Industrielle et D'Ameublement. Publicou a coleção L'Art international d'aujourd'hui e inúmeros outros títulos relacionados à arte moderna na França.

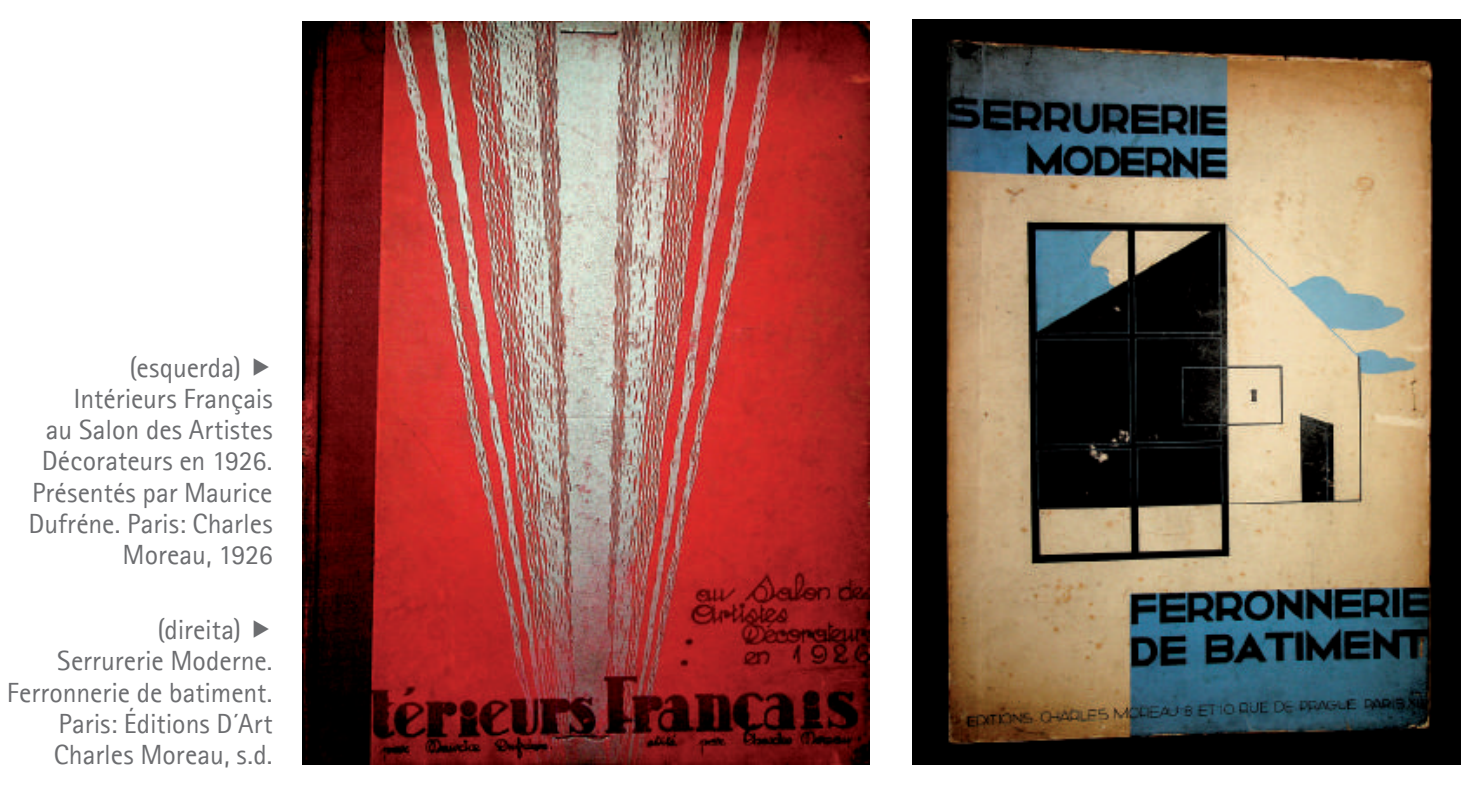



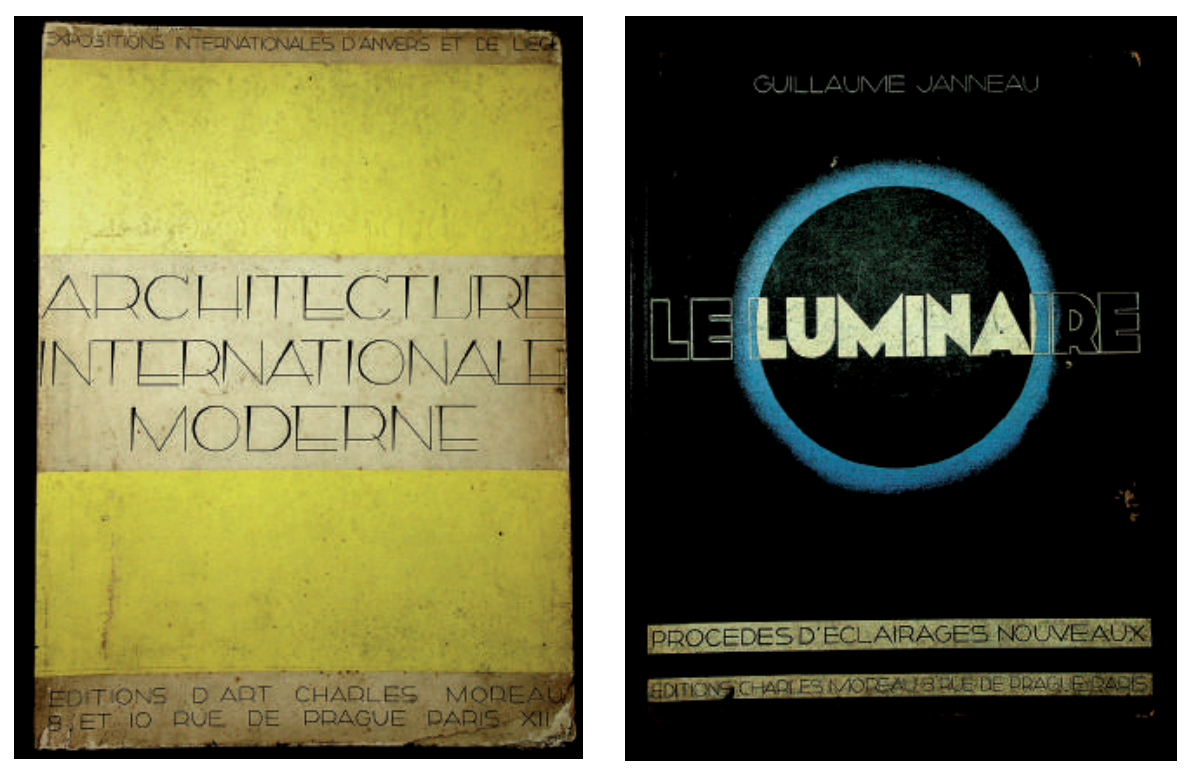

$\triangleleft$ (esquerda)

Architecture

Internationale

Moderne. Expositions

Internationales D'Anvers

et de Liége. Paris:

Éditions D'Art Charles

Moreau, Paris, [1930]

4 (direita)

JANNEAU, Guillaume.

Le Luminaire. Procedes

D'Éclairages nouveaux.

Paris: Éditions D'Art

Charles Moreau, 1925

- Librairie Centrale des Beaux- Arts de Albert Lévy
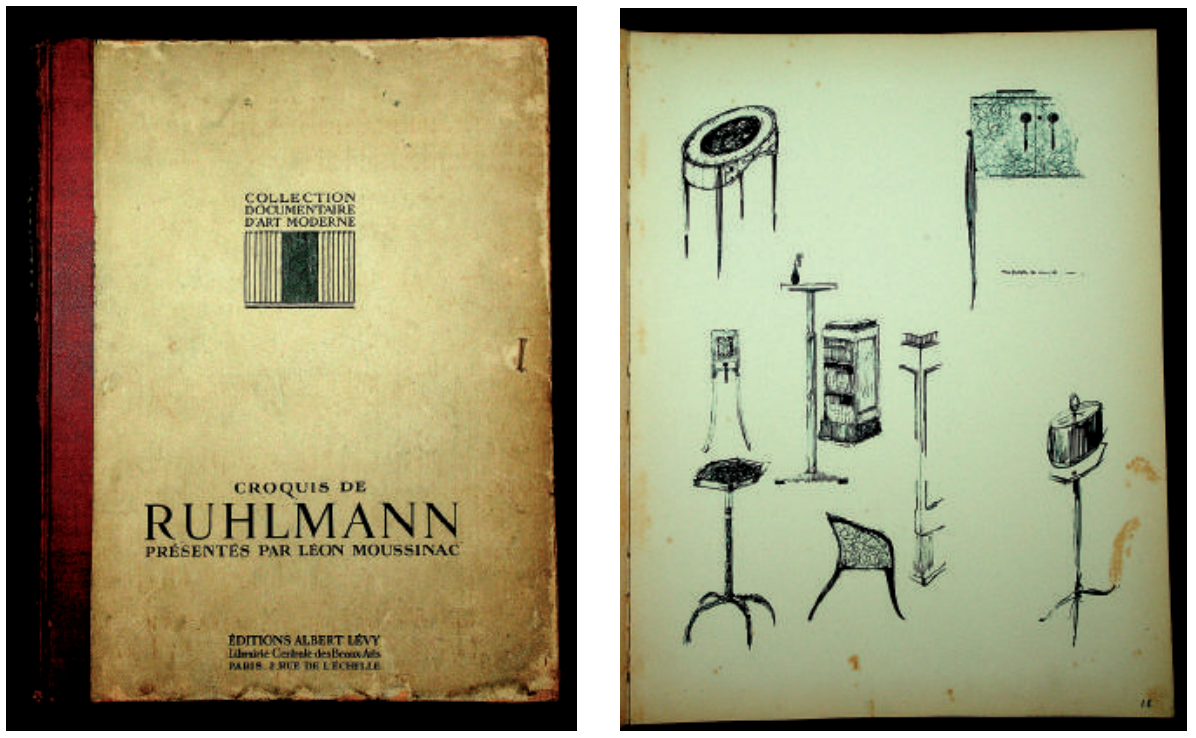

4

Croquis de Ruhlmann

présentés par Léon

Moussinac. 53 planches publiées sous la Direction et avec une introduction de Léon Moussinac.

Librairie Centrale des

Beaux-Arts. Paris:

Éditions Albert Lévy., 1924

(Collection Documentaire

d'Art Moderne).

- Librairie Centrale D'Art et D'Architecture de Ch. Eggimann Succr.

- Librairie D'Architecture de R. Ducher 

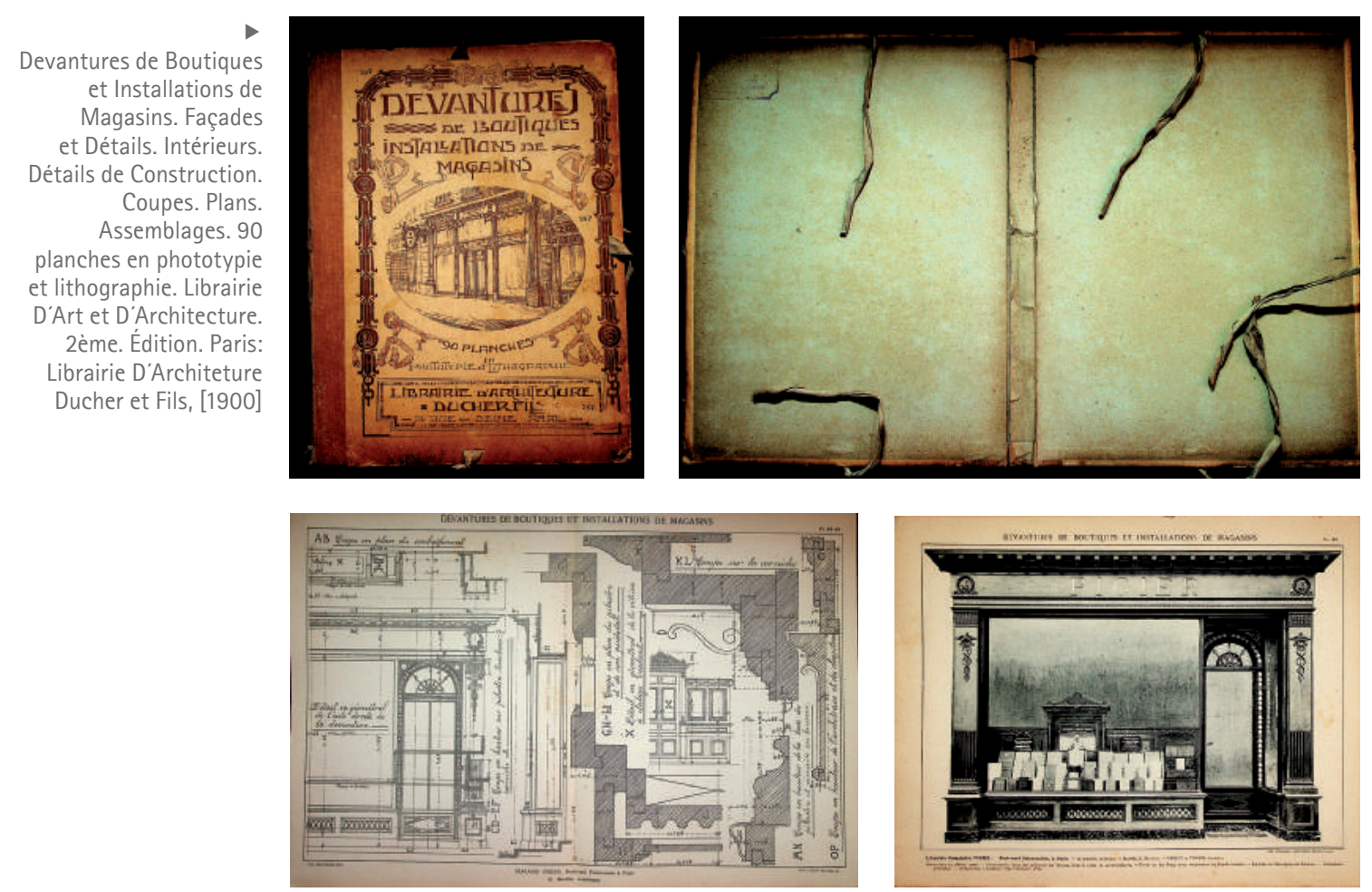

- Librairie D'Architecture et D'Art Décoratif de Armand Guérinet

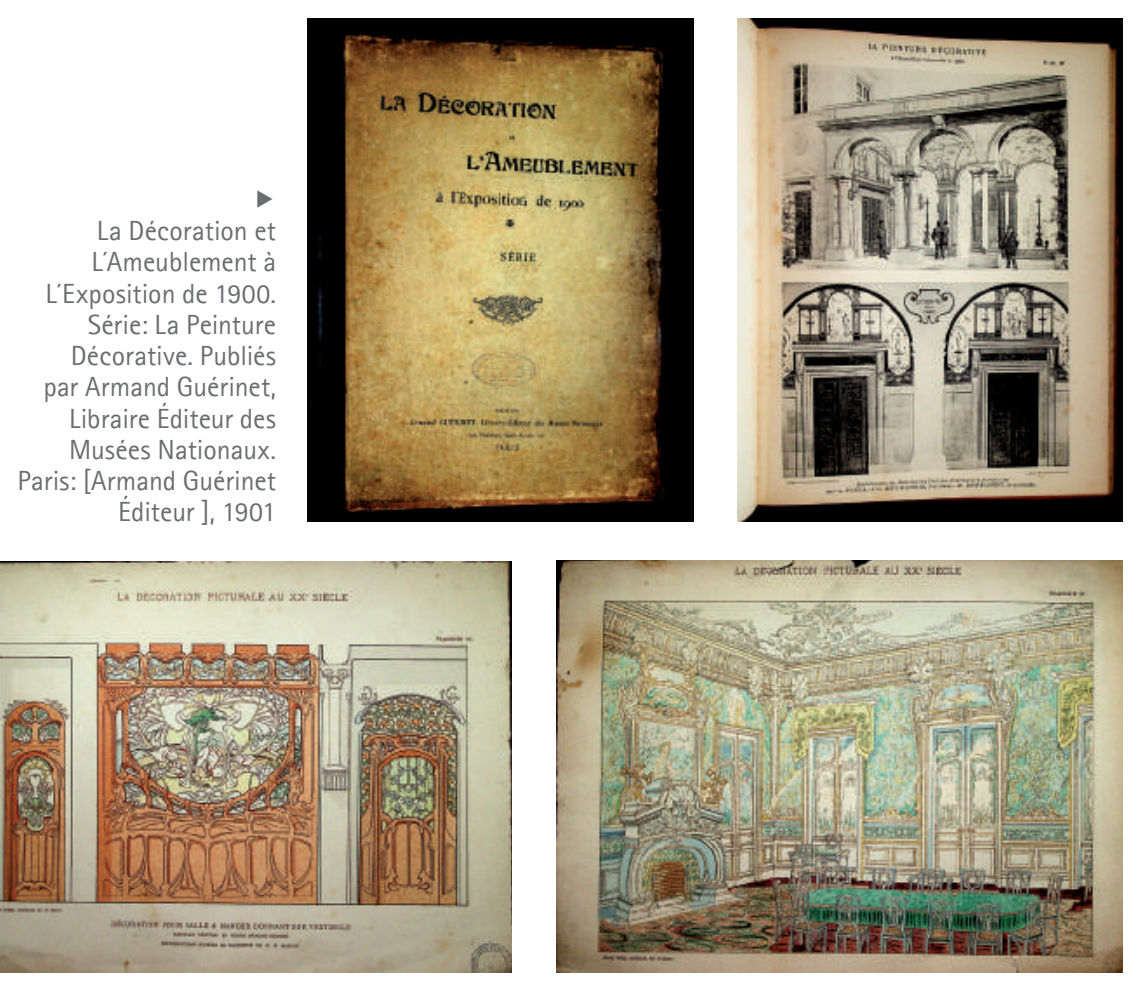


- Librairie D'Art Ludovic Baschet èditeur

- Librairie Générale de L'Architecture et des Arts Décoratifs. Paris: Charles Massin
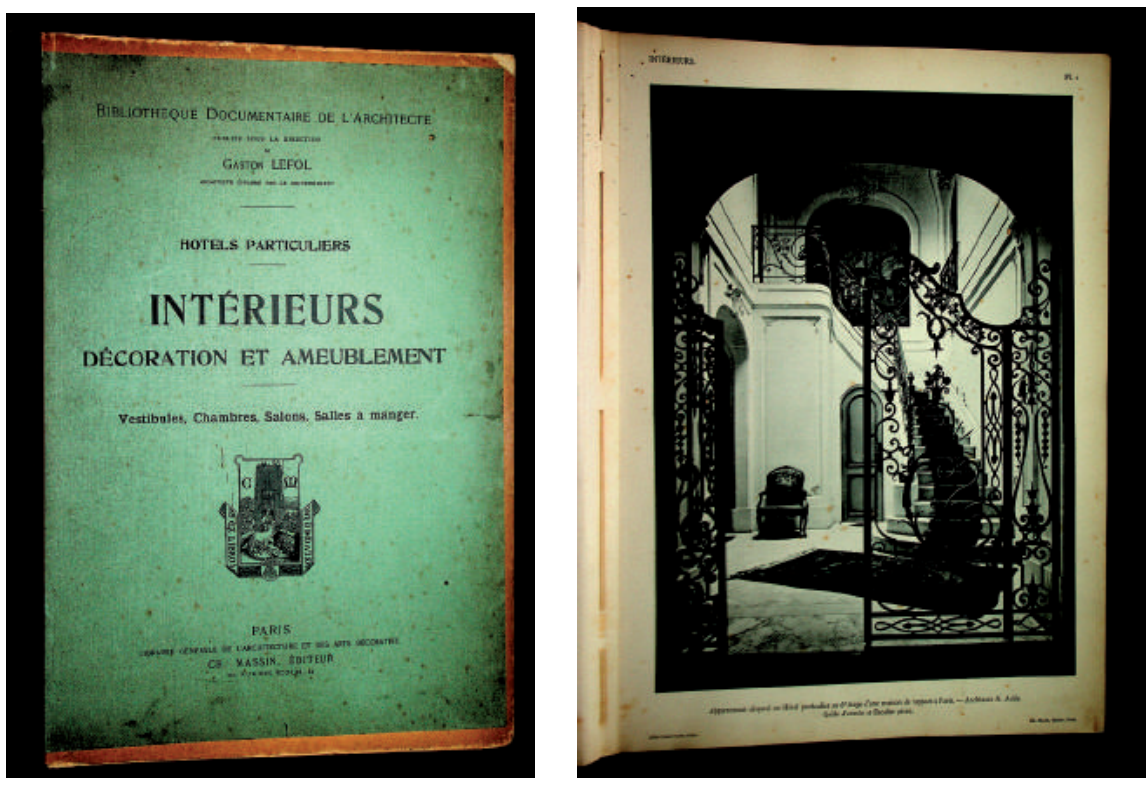

4

LEFOL, Gaston.

Hotels Particuliers.

Intérieurs Décoration et Ameublement. Vestibules, Chambres, Salons, Salles a manger. Bibliothèque Documentaire de L'Architect. Publiée sous la Direction de Gaston Lefol, Architecte Diplomé par le gouvernement. Librairie Générale de L'Architecture et des Arts Décoratifs. Paris: Charles Massin Éditeurs, [1925]

- Librairie Gènerale D'Architecture et des Arts Décoratifs de Charles Schmid

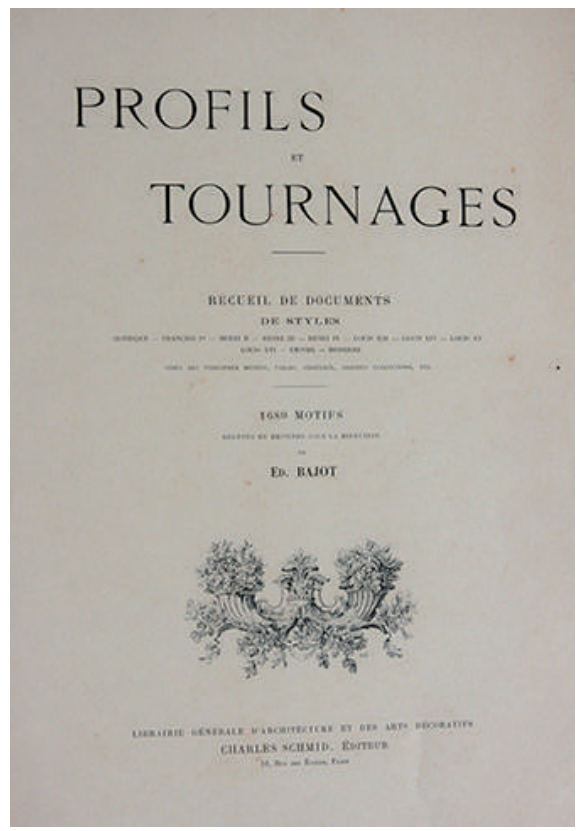

BAJOT, Édouard. Profils et Tournages. Recueil de Documents de Styles. Gothique-François ler -Henri II - Henri III - Henri IV - Louis XIII - Louis XIV - Louis $X V$ - Louis XVI - Empire - Moderne. Tirés des principauxs musées, palais, châteaux, grandes collections, etc. (sic) 1680 motifs. Relevès et dessinés sous la Direction de Ed. Bajot. Librairie Gènerale D'Architecture et des Arts Décoratifs. Paris: Charles Schmid Éditeur,[1899] 
- Librairie Nouvelle de L'Architecture et des Beaux-Arts de S. de Bonadona
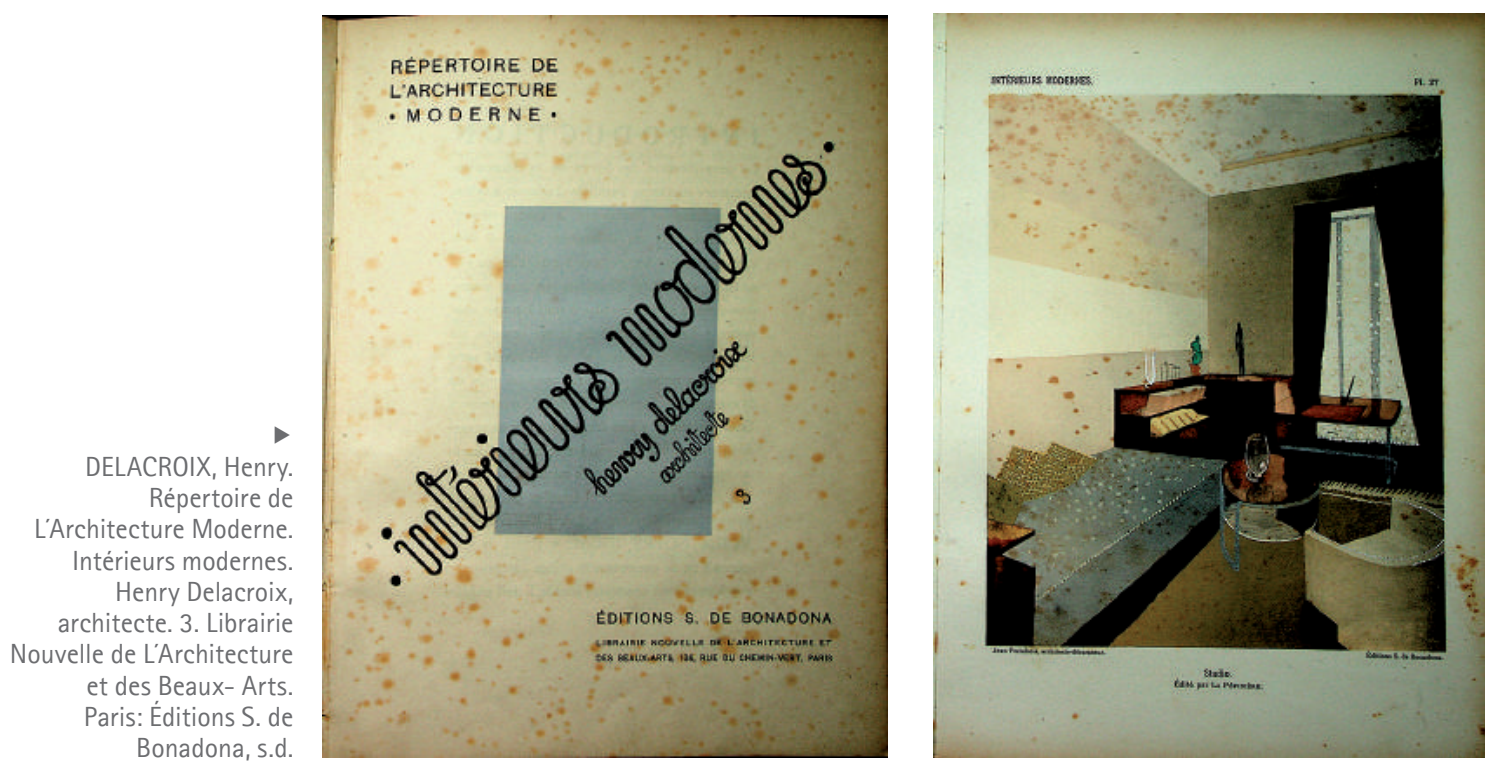

- Libraire Profissionnelle de l'Architecture et des Beaux-Arts de Alexis Sinjon

- Librairie Renouard de Henri Laurens Éditeurs

- Monroq Frères Imp. Edit

- Librairie Spéciale D’Architecture de Émile Thézard Éditeur, em Dourdan
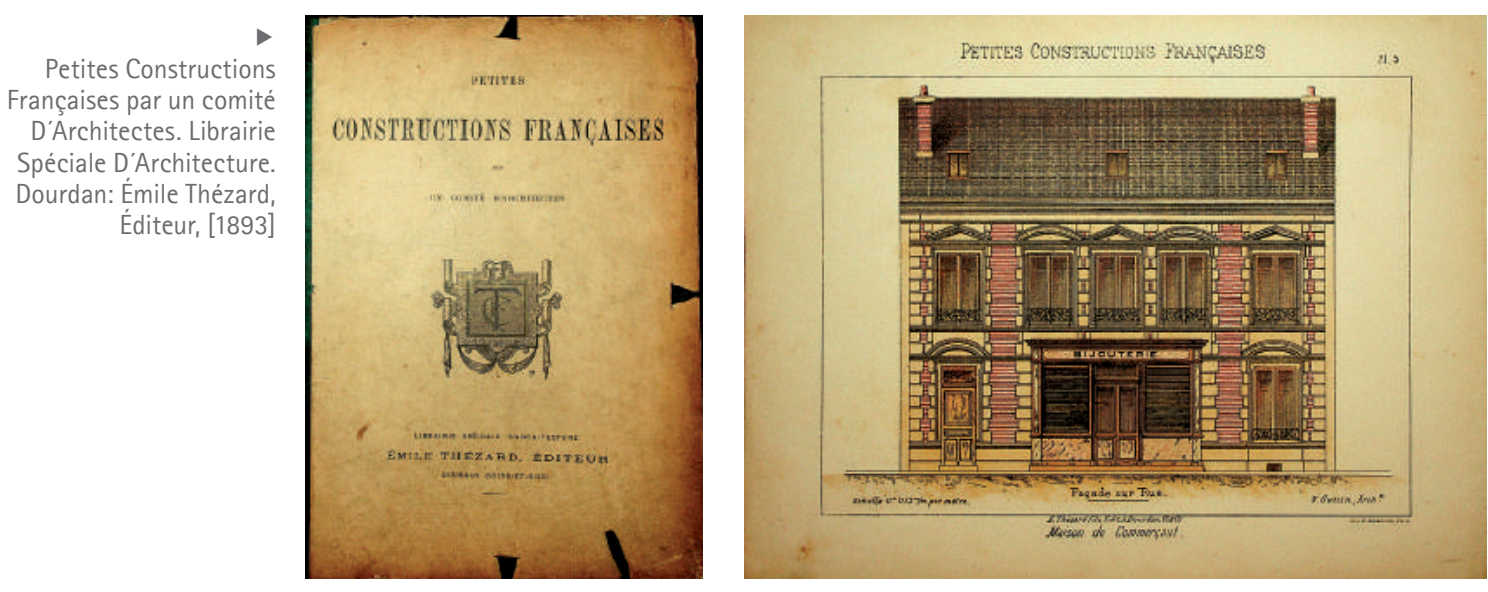


\section{Inglesa}

- [The Library of Decorative Art] de B. T. Batsford Ltd., Londres

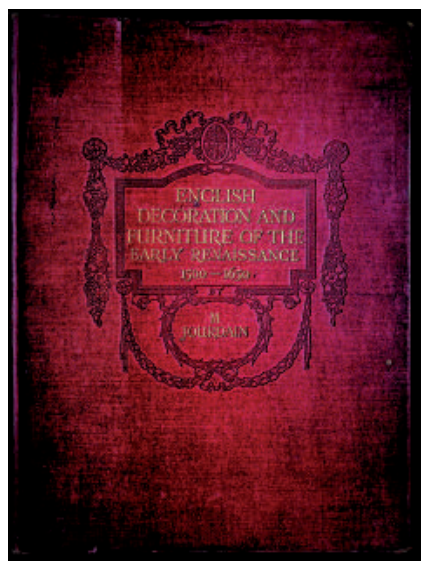

JOURDAIN, M. English Decoration and Furniture of the Early Renaissance 1500-1650. The Library of Decorative Art. An account of its development and characteristics by M. Jourdain. London: B. T. Batsford Ltd., [1924]

\section{Italianas}

- Casa Editrice Bestetti e Tumminelli, Roma

- Casa Editrice Dott. Francesco Vallardi, Milão
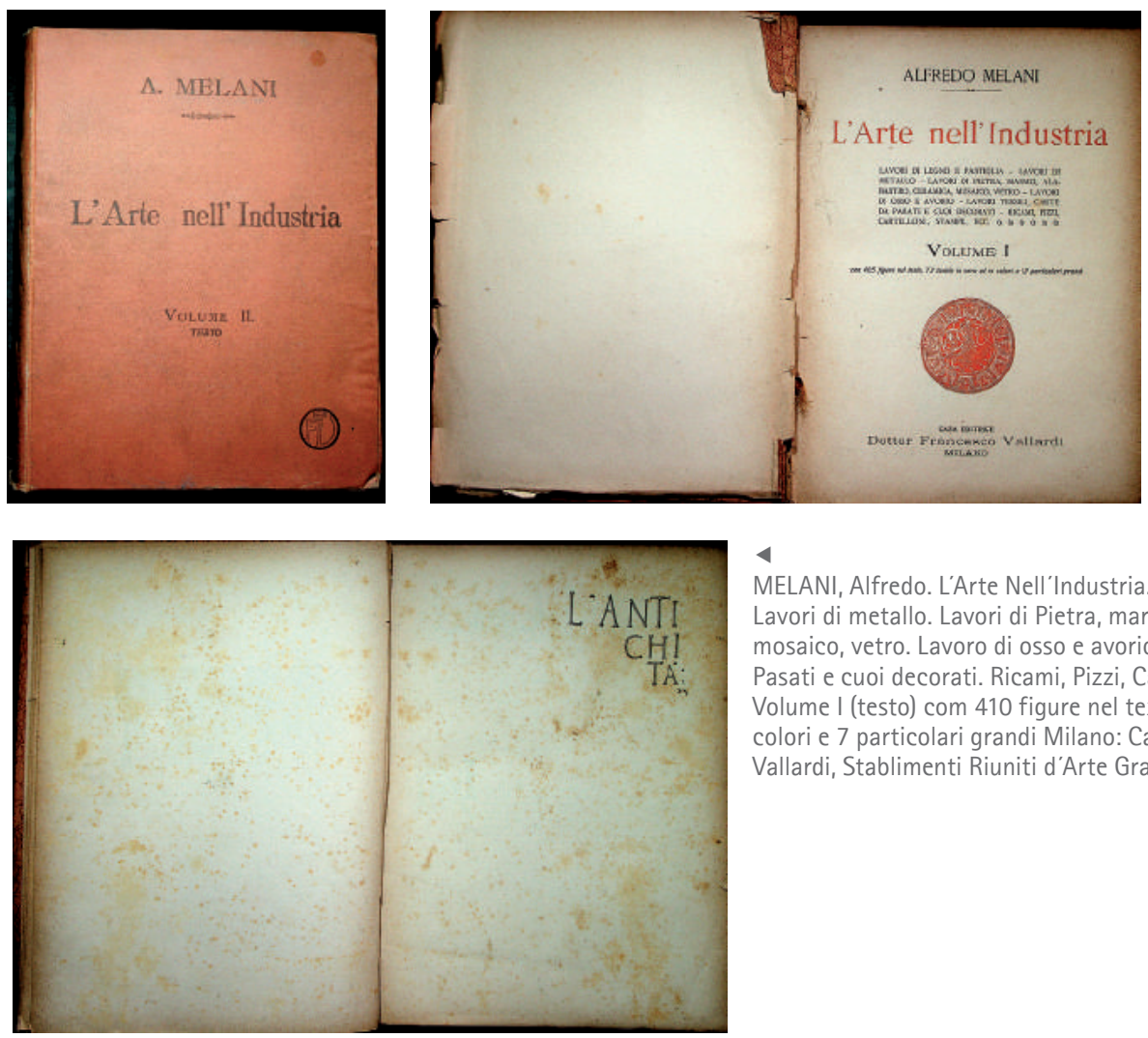

4

MELANI, Alfredo. L'Arte Nell'Industria. Lavori di Legno e pastiglia. Lavori di metallo. Lavori di Pietra, marmo, alabastro, cerâmica, mosaico, vetro. Lavoro di osso e avorio. Lavore Tessili. Carte da Pasati e cuoi decorati. Ricami, Pizzi, Cartelloni, Stampe, ecc. (sic). Volume I (testo) com 410 figure nel texto 160 tavole in Nero e in colori e 7 particolari grandi Milano: Casa Editrice Dott. Francesco Vallardi, Stablimenti Riuniti d'Arte Grafiche, [1902-1912] 
- Casa Editrice Ítala Ars, Torino

- Editrice D'Opere Tecniche Gerardo Molfese, Torino

- Giuseppe Giotti Editore, Firenze

- Preiss, Bestetti e C. Editore, Milão

- Società Italiana di Edizioni Artistiche. C. Crudo \& C., Torino

Le Costruzioni Moderne in Itália. Facciate di Edifici in Stile Moderno.

Genova. 60 Tavole in Eliotipia.

Torino: Società Italiana di Edizion

Artistiche C. Crudo \& C., 1910

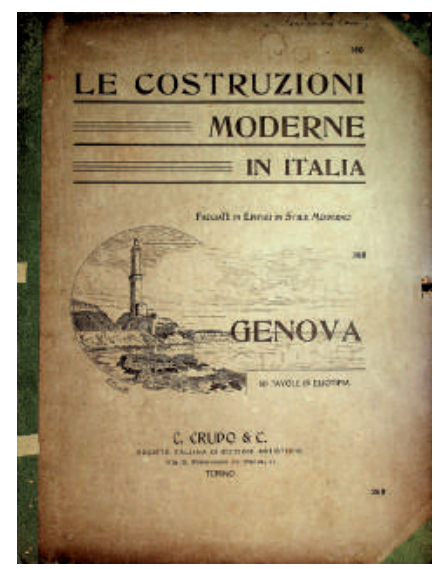

- Tipo. Lit. Camilla e Bertolero Editori, Torino

- Ulrico Hoepli Editore, Milão

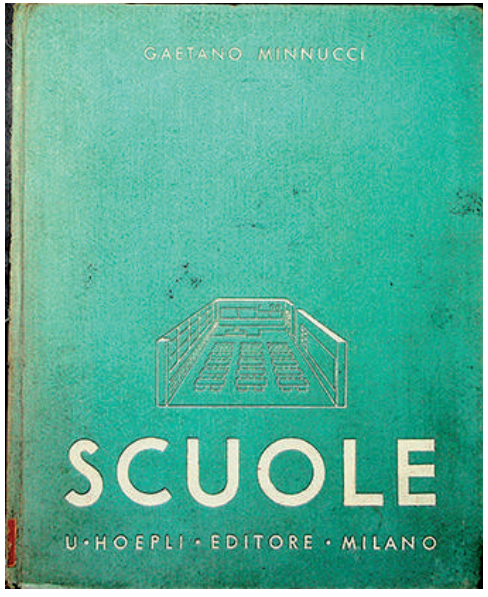

MINNUCl, Gaetano. Scuole. d'Infanzia, Scuole All' Aperto Elementari e Medie, Case del Balilla. Palestre e Impianti Sportivi. Prefazione di S.E. L' Architetto Marcelo Piacentini. Criteri,

dati, esempi per la progettazione per la costruzione e l' arredamento. Quattrocentocinquantasei figure e piante. Milano: Ulrico Hoepli Editore, 1936

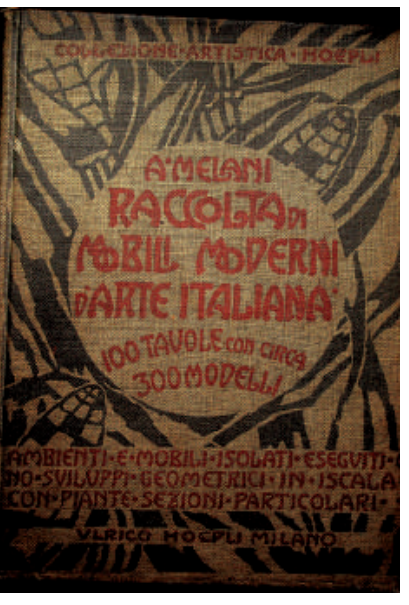

$\Delta$

MELANI, Alfredo. Raccolta di mobili Moderni D'Arte Italiana. 100 tavole com circa 300 Modelli.

Ambienti e mobili, Isolati, Eseguiti.

0 no. Sviluppi, Geometrici, in Iscala com piante. Sezioni particulari. Milano: Ulrico Hoepli, [1913], (Collezione Artistica Hoelpli)

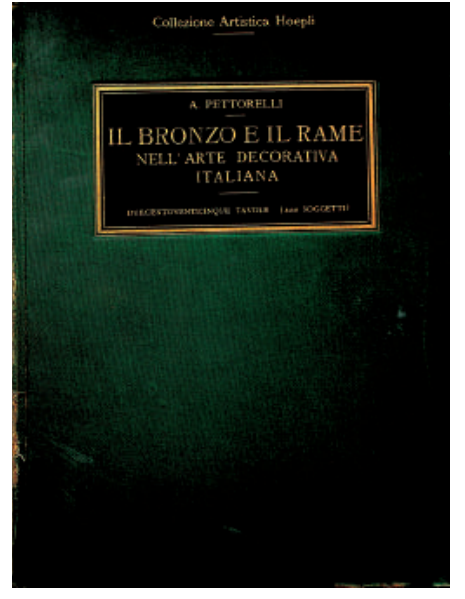

PETTORELLI, A. II Bronzo e il Rame nell'arte Decorativa Italiana. Duecentoventi cinque tavole (400 soggetti). Riproduzioni in parte inedite di opere dal periodo etrusco all'Epoca Moderna. Texto esplicativo Studio sulla técnica fusoria e saggio bibliografico di Arthur Pettorelli. Milano: Ulrico Hoepli, 1926 


\section{Norte-americanas}

- Architectural and Art Industrial books, Nova Iorque

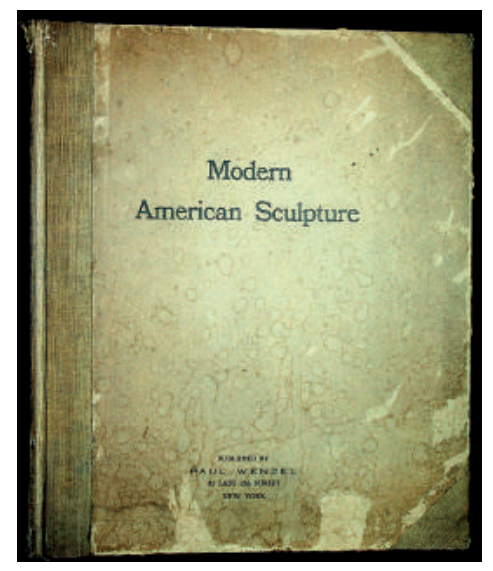

Modern American Sculpture. Edited by

Sadakichi Hartmann; 60 plates. Published by Paul Wenzel, Publisher of Architectural and Art Industrial books. New York:The Architectural Book Publishing Company, [década de 1920]

- The Pencil Points Press, Inc., Nova Iorque

\section{Portuguesa}

- Emilio Biel e Cia. Editores, Porto

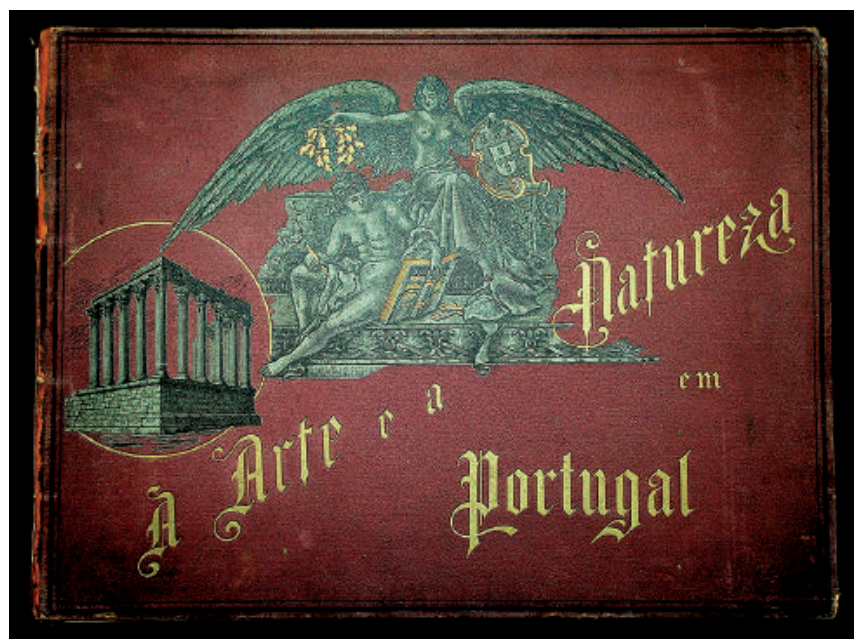

A Arte e a Natureza em Portugal. Álbum de photographias com descripções, clichês originaes; cópias em phototypia inalterável; monumentos, obras d'arte, costumes, paisagens. [Porto]: Emilio Biel e Cia. Editores, 1903

O exemplar École Spéciale des Travaux Publics de Batiment et de l'Industrie. M. Léon Eyrolles C, I. Ingénieur-Director. Enseignement par correspondence. (L'École chez boi). A e D. Garnitures cuivre Louis XVI e XV Style Empire de Fenêtres, ébénisterie, bois plint, bois doré, baldaquins et couronnes, baldaquins et décor de lits. Paris: S.n., 1926, denota que a prática do ensino à distância talvez tenha sido adotada no Liceu, embora este seja o único exemplar deste tipo que remanesceu no acervo. 

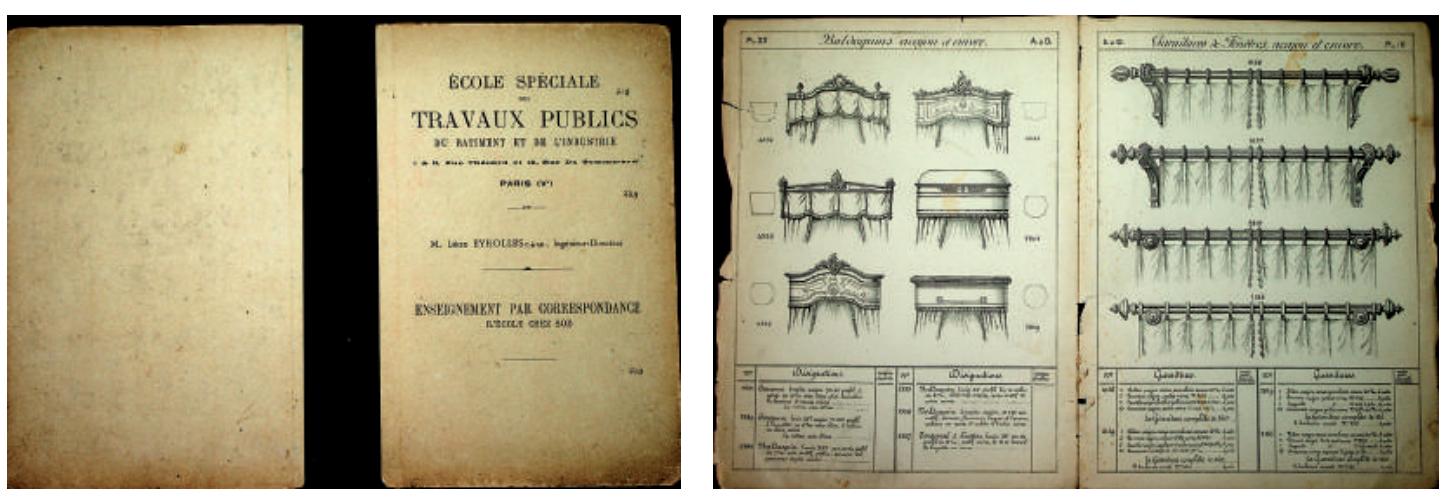

O manual-catálogo da Fábrica de Móveis de Antonio Demosso São Paulo é um caso híbrido, chamando atenção como encadernação de miscelânea dos manuais Meubles de Style Moderne. Exposition Universelle de 1900 editado por Charles Schmid e Wierner Vorlagen für moderne Bautischrerei. Haus Thore Zimmer und Salon Thüren, Plafonds wandverkleidungen, Lademvorbauten, Glasverschläge und berge.Zumeist im barockstyl. Entworfen und Gezeichret von Anton Novak architekt, 36 Blatt Lithographie Wien. Kunstverlag Anton Schroll \& C., além de algumas pranchas referentes a Gerlach és Schenk Budapest Bécs, Mibr talapok. O exemplar contém carimbo Marcenaria e carpintaria de Demosso Antonio, Rua Brigadeiro Tobias, 100, antiga Alegre, São Paulo. No acervo encontra-se ainda exemplar Meubles de Style Moderne. Fábrica de Móveis de Antonio Demosso, São Paulo.
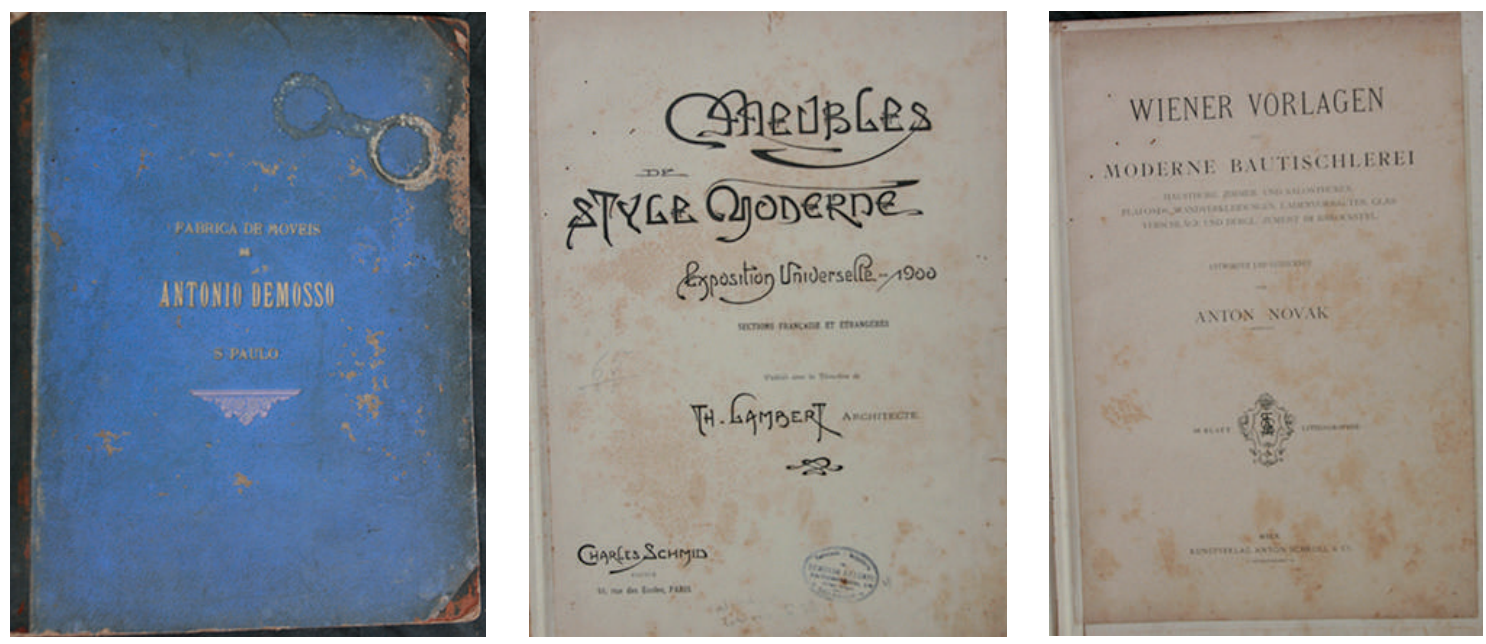


\section{Manuais de politecnia}

Dirigidos a especialidades são ilustrados e graficamente bem cuidados trazendo lições e exemplos de máquinas e obras como usinas e barragens; Manual del Hojalatero y Plomero por Carlos Schneider; Il Montatore Elletricista de Barni; Cours de Machines-Outils do General Gages; Manual del cajista de Imprenta de Fábregues; Principi Fondamentali delle Macchine Utensili de Hülle; Elementi di Agrimensura de Mitoldi.
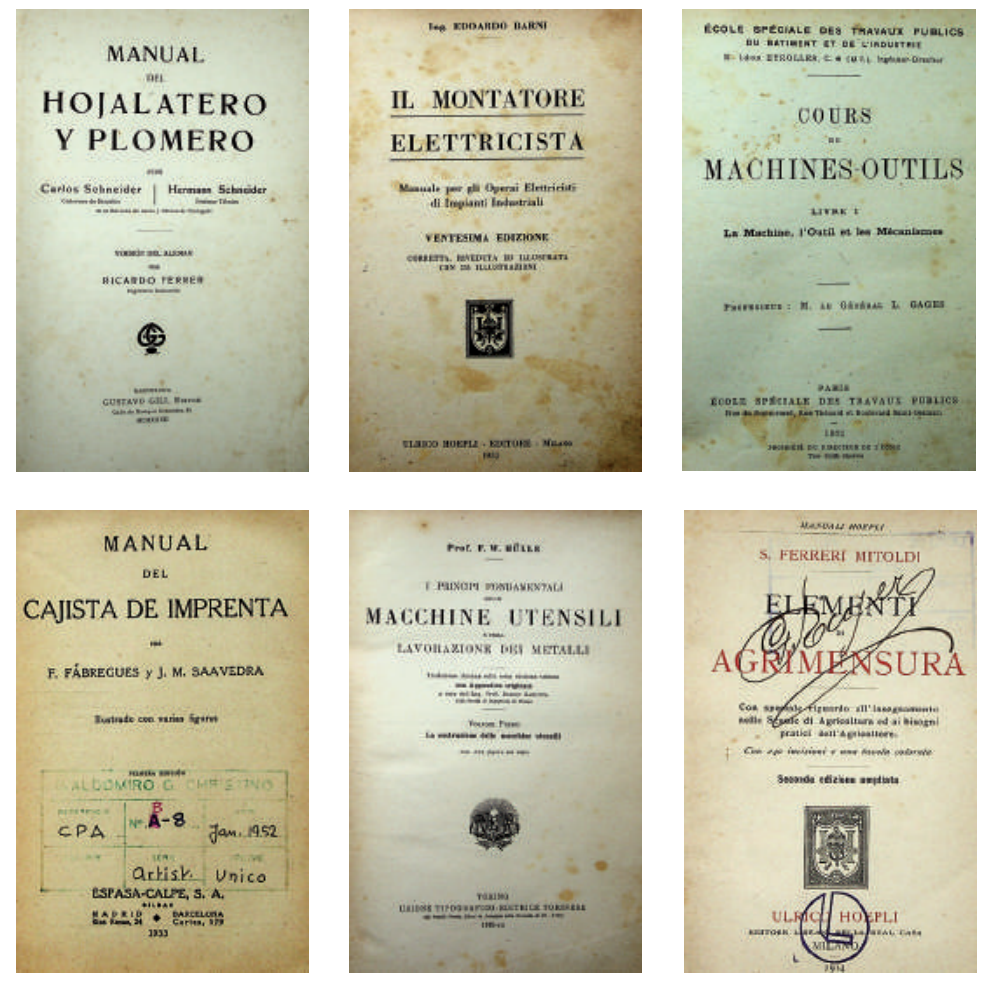

\section{Catálogos comerciais}

Podem ser considerados testemunhos sofisticados da força do trade no período: robustos, com mais de mil páginas, contam com esmerado tratamento gráfico, apresentando inovações na programação visual usando processos como a fototipia e relevos. Muitos têm edição poliglota com textos impressos em alemão, francês, inglês, espanhol e português.

Referem-se à produção de objetos específicos como elevadores artísticos ou genéricos e ocasionalmente peças criadas a partir de modelos feitos por artistas como maçanetas, lustres, bronzes, serralheria artística, nas quais de aplicava a concepção de autores e artistas decoradores devidamente creditados. Eventualmente apresentam as instalações 
fabris e lojas dos fabricantes, trazendo produtos em catálogo, preços e políticas de preços.

Recheados de repertórios civilizatórios, embora alguns sejam relativos a uma era em que ainda se fazia uso do carvão, propunham possiblidades para customizar os itens e comprá-los by appointment. Alguns publicavam sugestões de arranjos de mobílias do mesmo estilo, ditos suites, acompanhados de comentários e glosas sobre os estilos e sobre as combinações propostas.

Alguns encontram-se sem capa ou outras marcas identitárias, portando siglas e números sem remissão, constando em cabeçalhos apenas uma tipologia e nos rodapés endereços das lojas ou fábricas, restando indeterminados principalmente quando as séries, mesmo trazendo dados escassos, por vezes compõem-se de quatro ou cinco folhas avulsas.
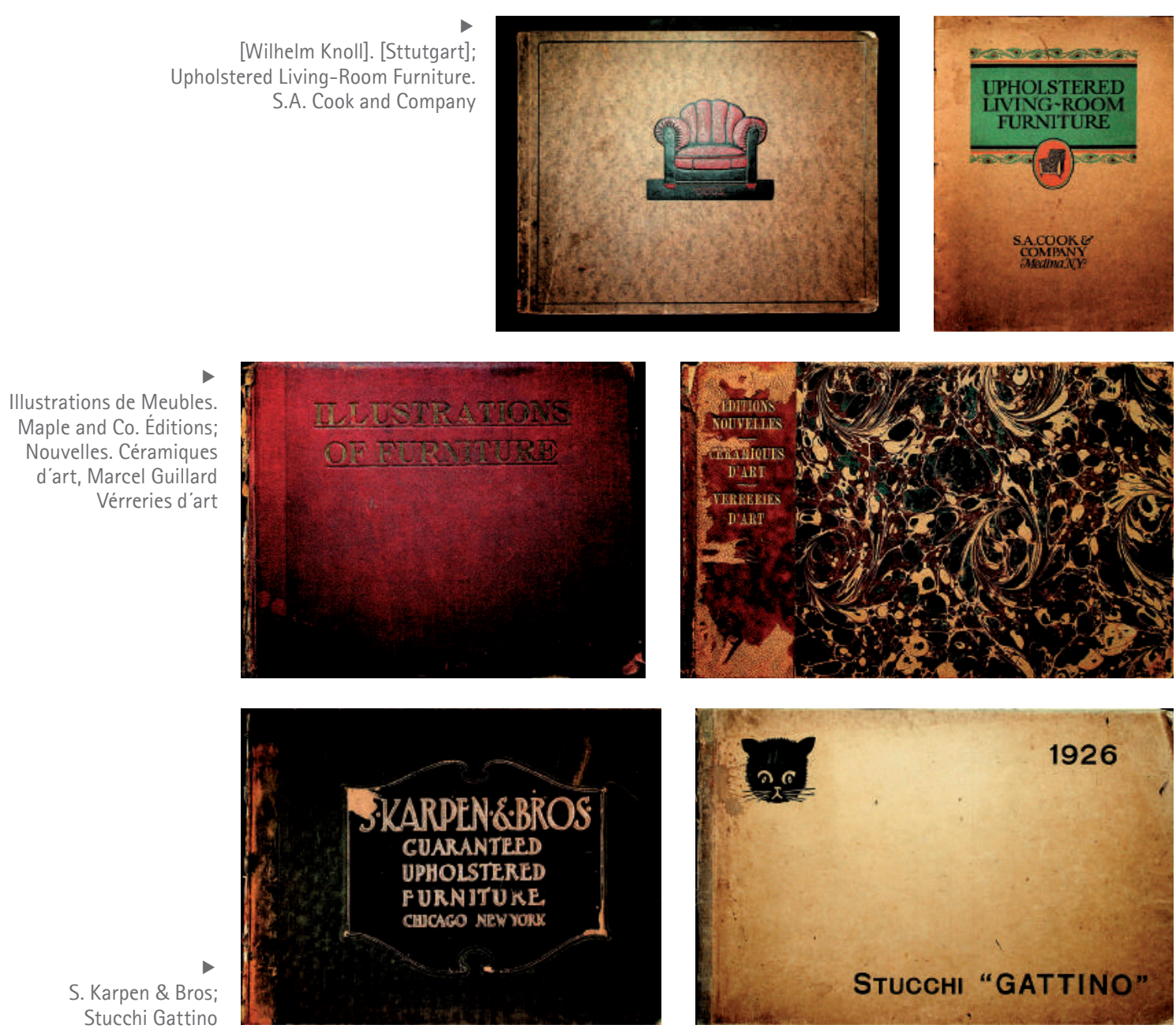


\section{Catálogos de politecnia}

Relativos às fábricas e ateliês de construção de máquinas e trabalhos em metal, preciosamente ilustrados, estampando as unidades fabris em seus frontispícios, alguns traduzidos para o português, outros dirigidos os 'pares' industriais que equipam escolas técnicas com máquinas. Distinguem-se Maschinenfabrik Weingarten; Fabricante de Máquinas Utensiles y de todos los elementos para instalaciones de máquinas Pedro Merlini; How to run a Lathe, de O'Brien e o corpulento Cerraduras e Ferratería Sargent, nova-iorquino.
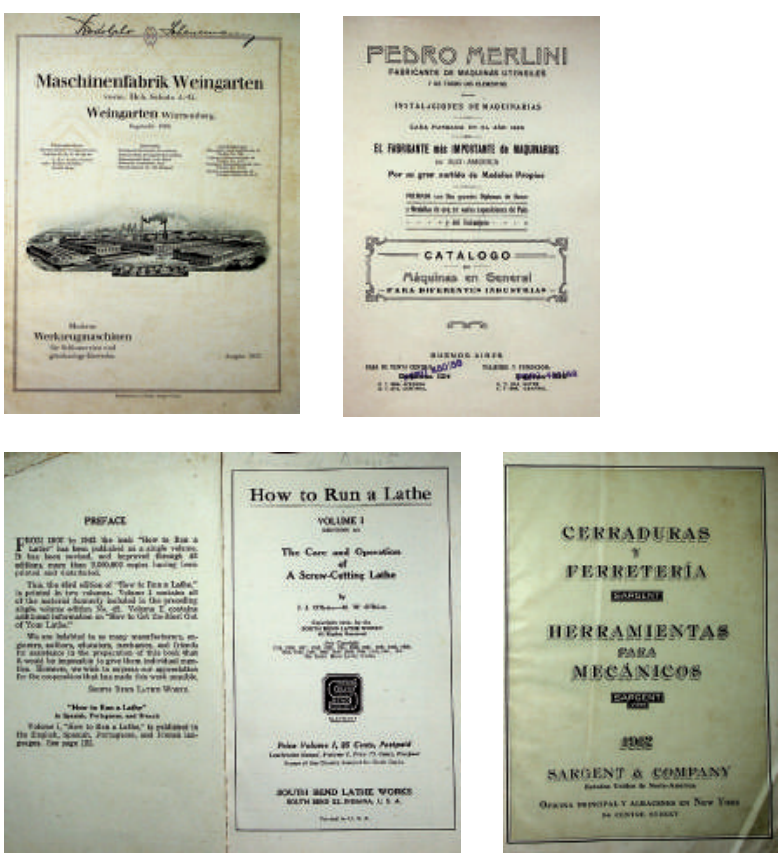

\section{Periódicos}

\section{Anais e anuários}

Coleção irregular e diminuta tendo relevo o Anuário do Museu Histórico Nacional e o Anuário da Escola Polytechnica de São Paulo.
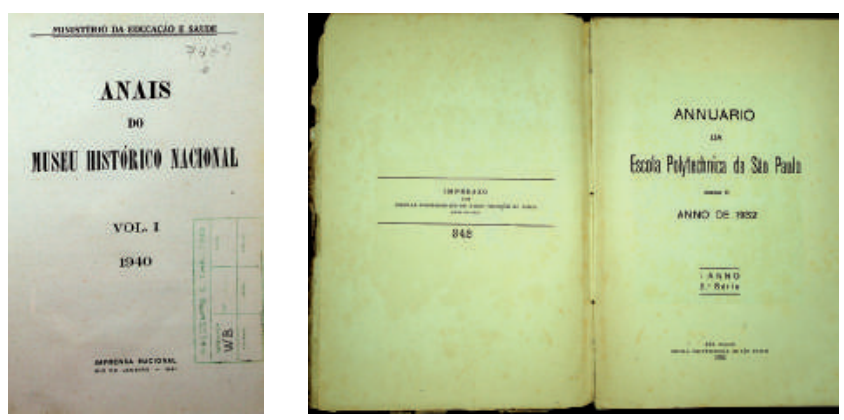


\section{Revistas especializadas em artes e decoração}

Algumas em carpetas e alguns títulos em coleções robustas encadernados por ano e outras coleções incompletas. Algumas revistas são eminentemente comerciais ou dirigidas para fabricantes de mobiliário e indústrias aliadas tratando do trade como The Furniture Journal, 1917 ou edições especiais para o comércio como The Fine Arts, 1932.

Outras trazem anúncios relacionados ao comércio de luxo e ao mercado da decoração.

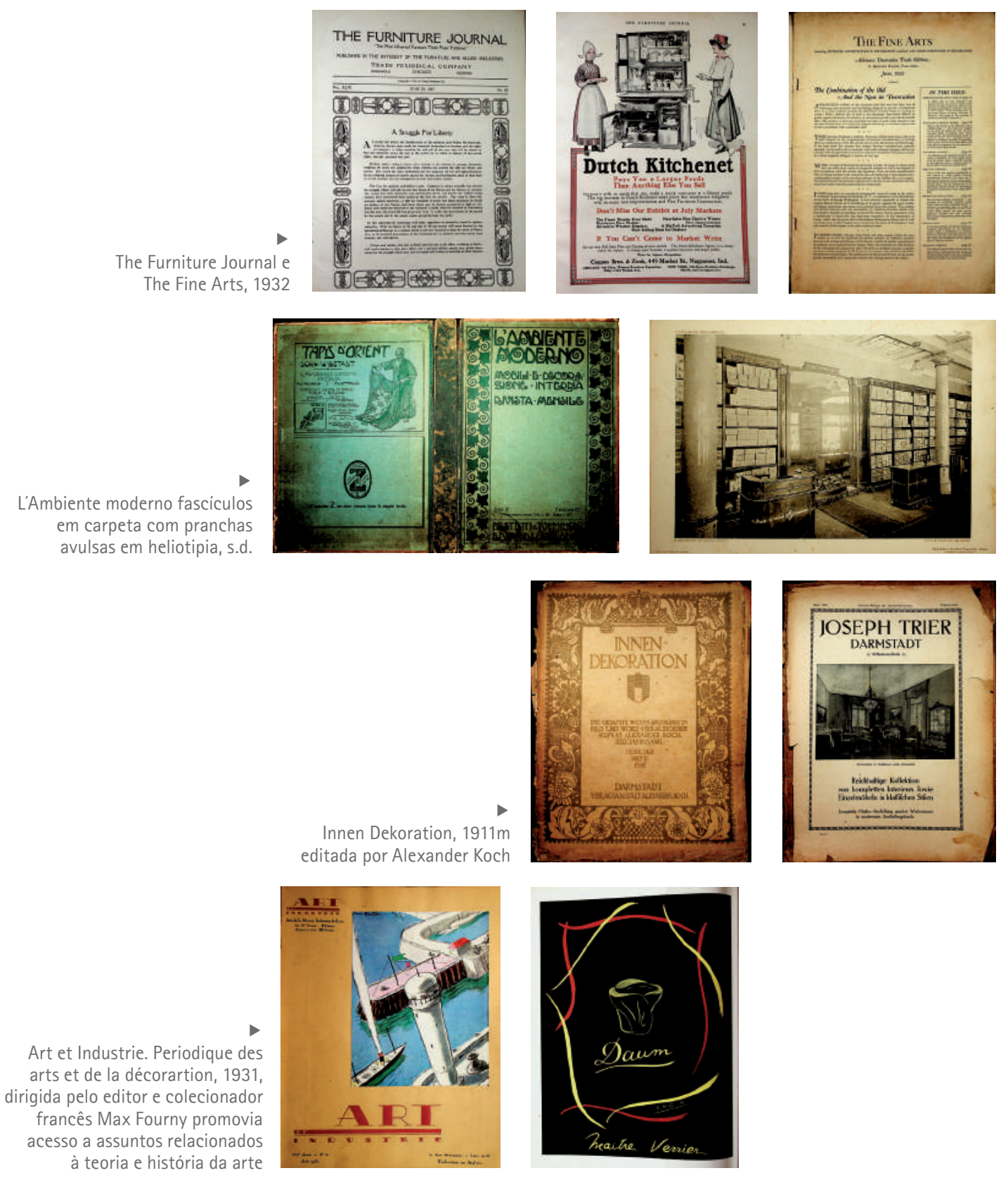




\section{Revistas especializadas em tecnologia}

Difusores técnicos e comerciais da indústria mecânica brasileira e internacional com esmerado cuidado gráfico, trazem anúncios de fabricantes, artigos científicos, resumos e seções como a de vocabulário técnico.
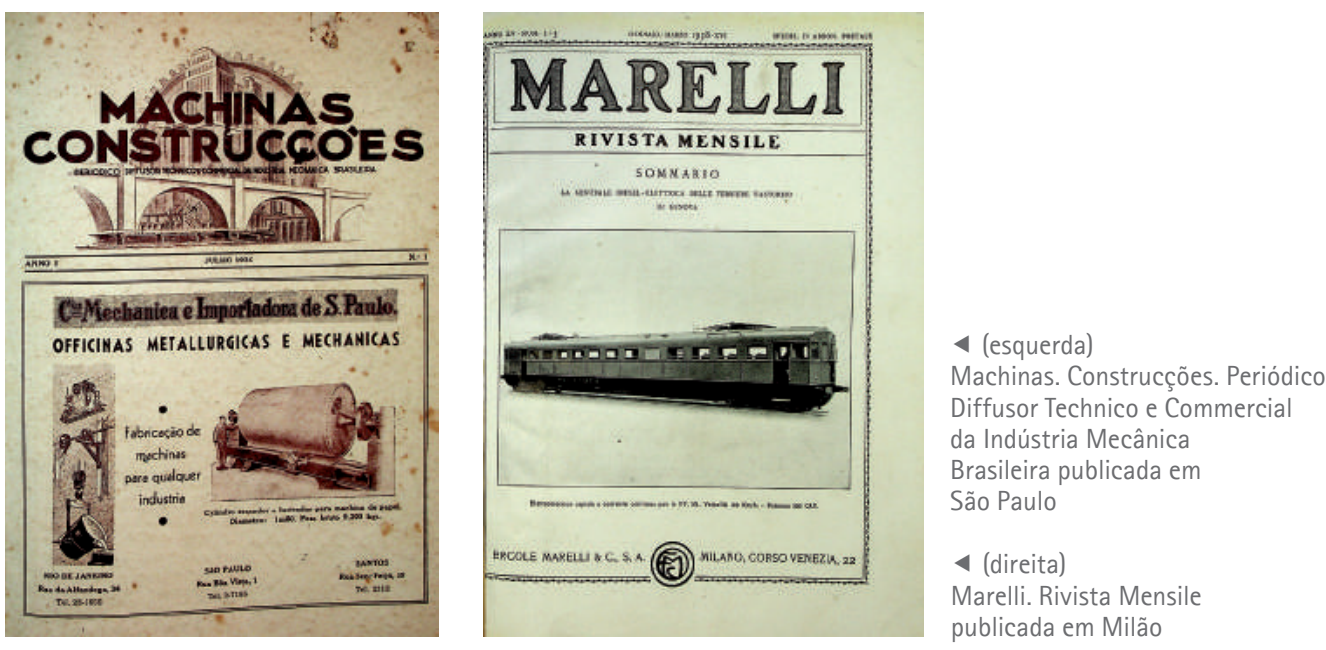

Destaca- se a única revista científica da coleção: La Science et la Vie. Magazine Mensuel des Sciencies et de leurs applications a la vie Moderne. [Paris] com edições encadernadas datadas 1925, 1928, 1929, 1931, 1932, 1934, 1937.
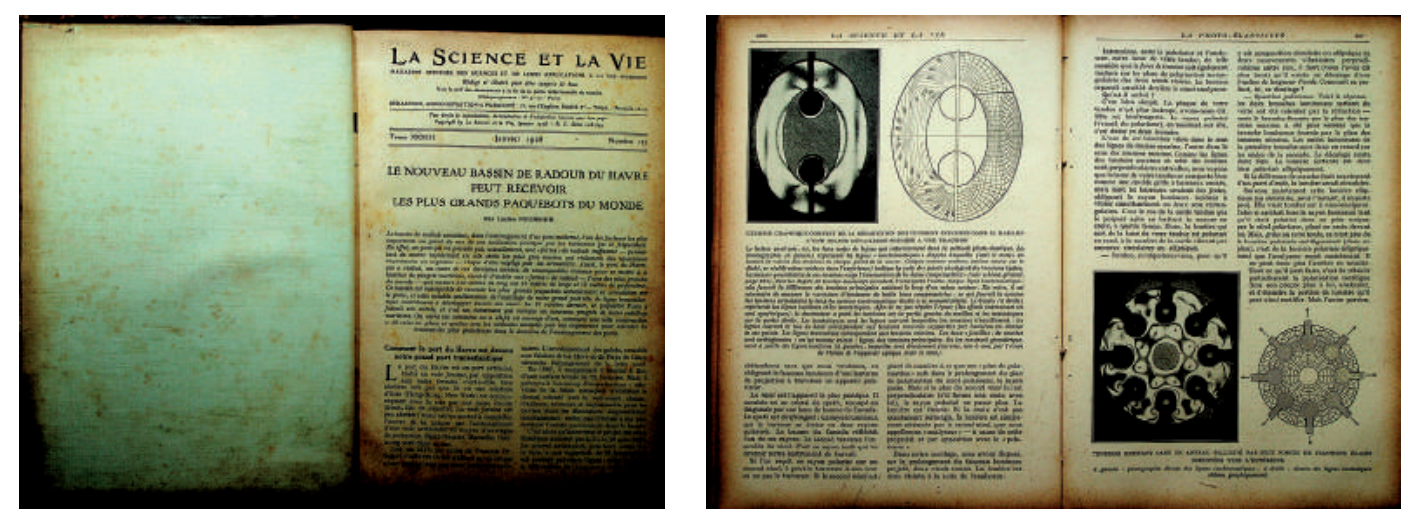

\section{Pranchas impressas/Álbuns seriados}

Dentre os recursos visuais de ensino, as pranchas impressas/ álbuns seriados são acessórios excelentes. Podendo ser adquiridos prontos ou confeccionados formam coleções organizadas de folhas ou pranchas impressas relacionadas entre si, compostas de figuras, textos, gráficos 
que, progressivamente, desenvolvem temas, aproximam conteúdos e sistematizam assuntos promovendo realces para pontos relevantes e tópicos capitais das matérias.

Consideramos que eram auxiliares nas salas de aula e divulgadas nas dependências das escolas-oficinas, sendo específicas para cada matéria. Se movimentavam no Liceu formaram uma coleção instrumental.

As pranchas remanescentes no acervo, em sua grande maioria alemãs, austríacas e italianas, mas também francesas e portuguesas, têm alto grau de apuro técnico e gráfico sendo, por vezes, protegidas por carpetas requintadas e chamativas separadas por números, frequentemente compondo-se de conjuntos com mais de 100 folhas, ilustradas com gravuras policromas ou monocromas, organizadas por série e numeradas uma a uma. Ou são pranchas avulsas, montadas sobre grossos cartões, às vezes margeadas por bordas em cores, numeradas e separadas por séries tocantes a assuntos específicos, formando conjuntos 'desmembráveis', forma que também encontramos nos manuais de estilo sem lombada.

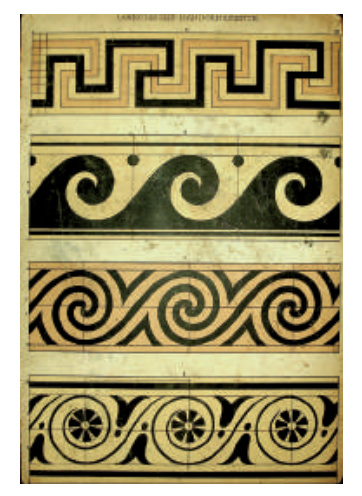

[Anton Andel Gez]. [Sem título]

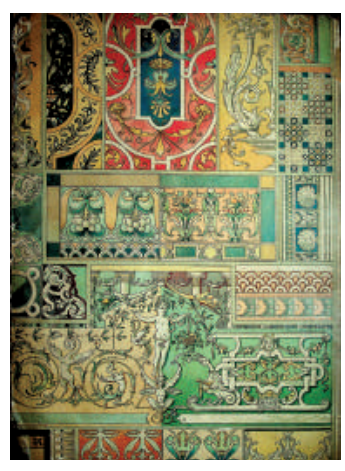

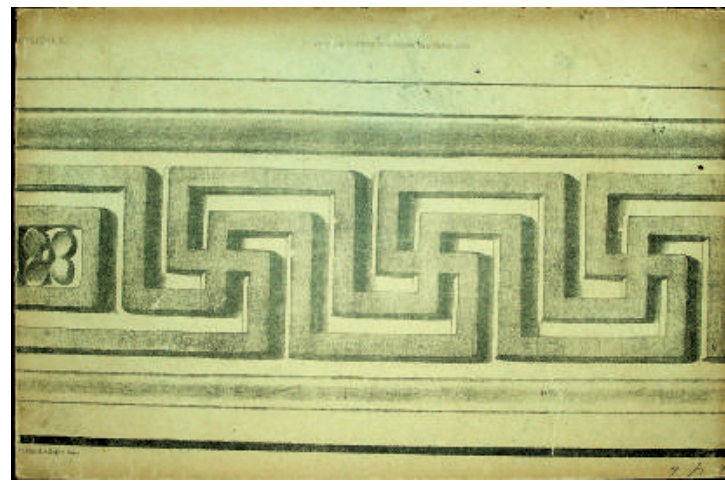

Denticules. D'Apres des Platres de l'Ecole des Beaux-Arts

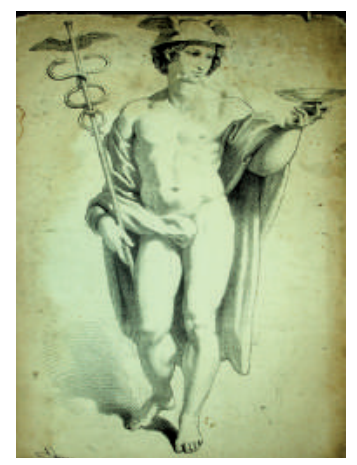

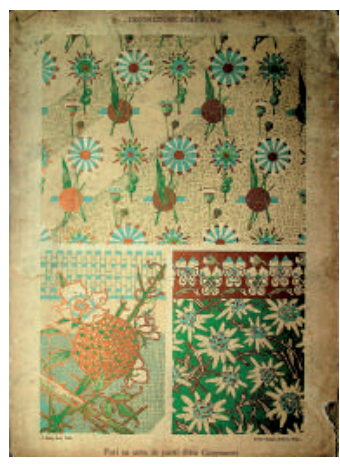




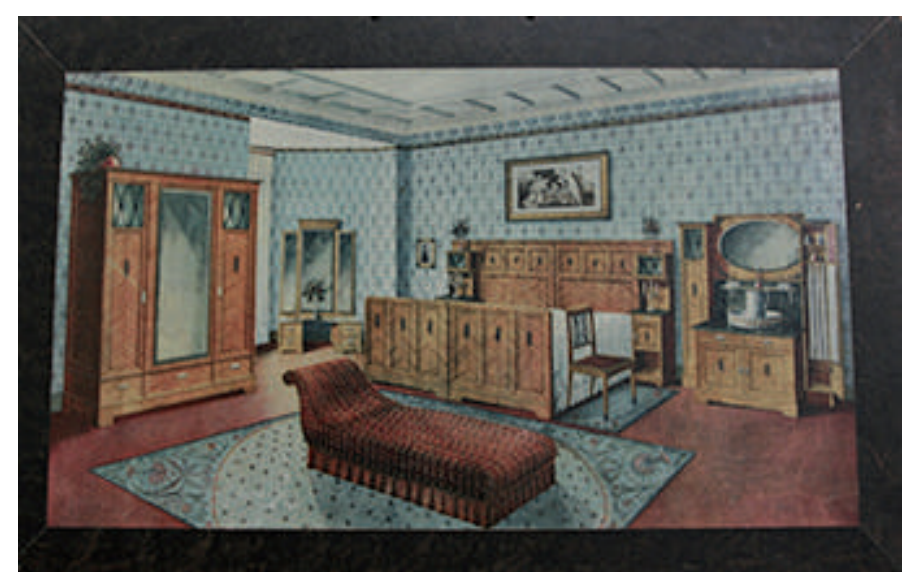

4

Ameublements complets de Tous Styles]
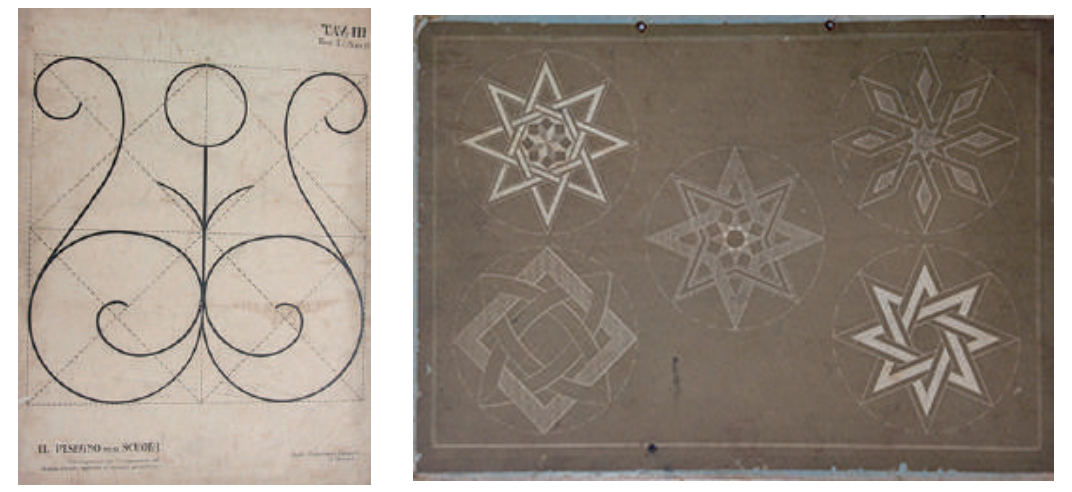

I Disegno nella scuola. Corso

progressivo per l'insegnamento del

disegno d'ornato applicato al disegno geométrico; Desenho geométrico.
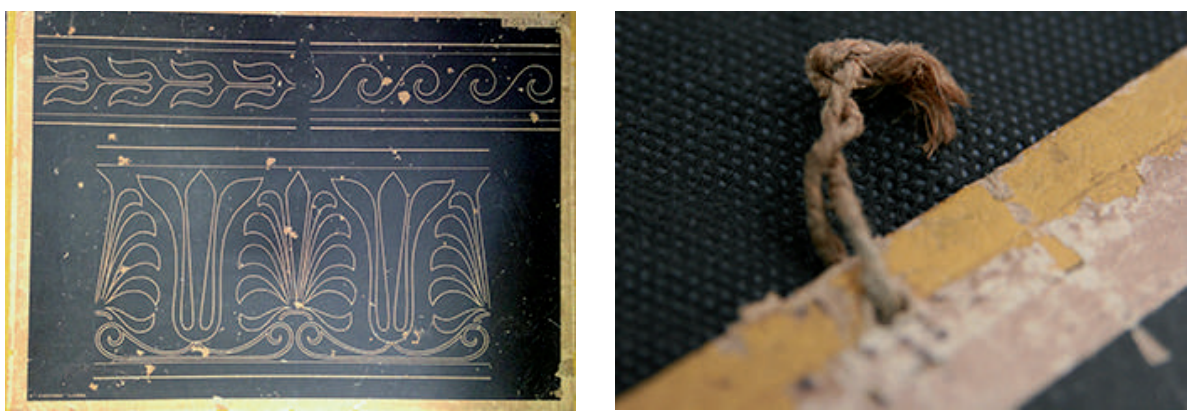

"A Editora", Lisboa,
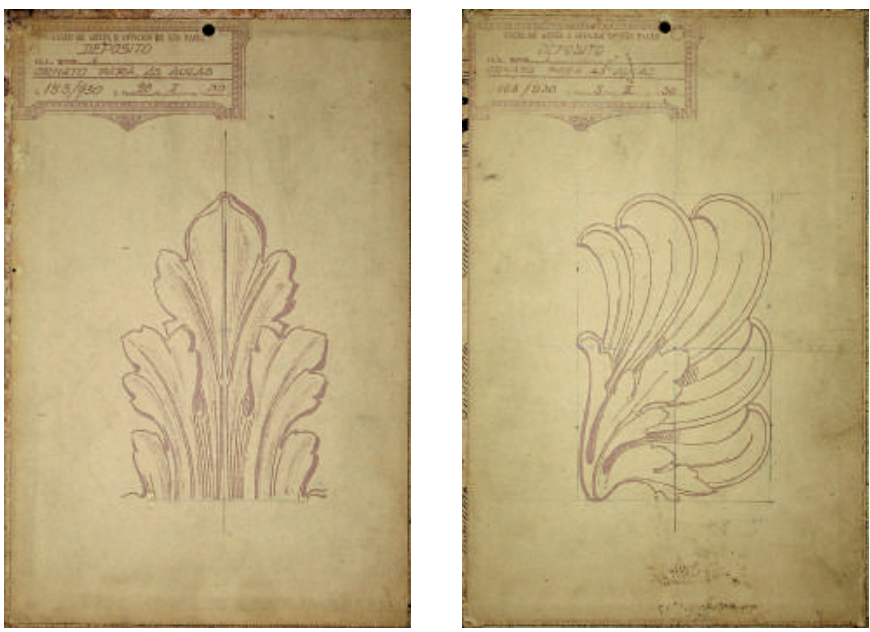

Liceu de Artes e Ofícios

Ornatos para aula, 1930 
Entre as pranchas encontra-se um conjunto de plantas de autoria do Escritório Técnico "Ramos de Azevedo" Severo \& Villares relativas à Sede do Serviço Técnico do Café, que teoricamente serviram para informar a produção de peças para decoração externa e interna do edifício encomendadas ao Liceu.

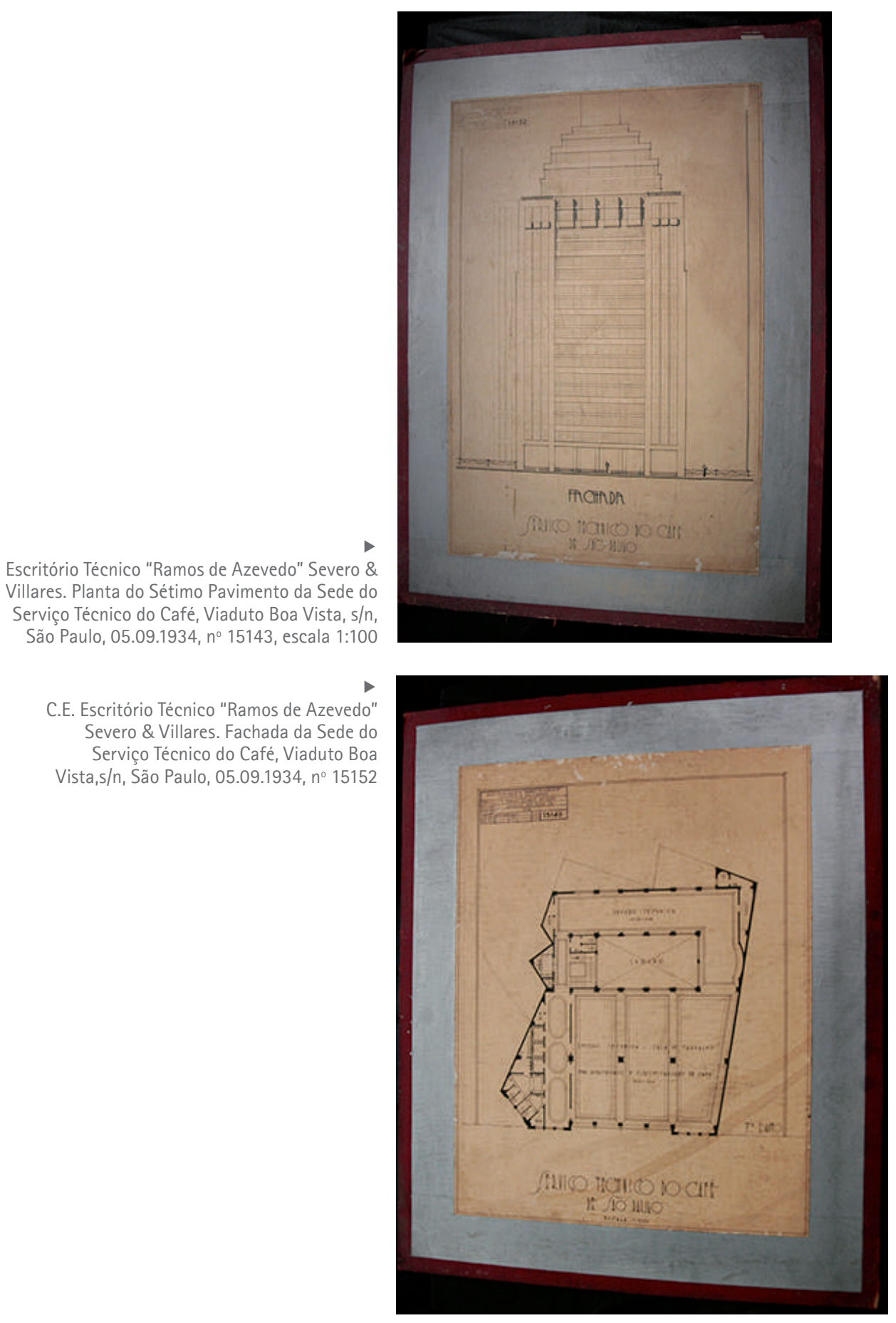




\section{Impressos}

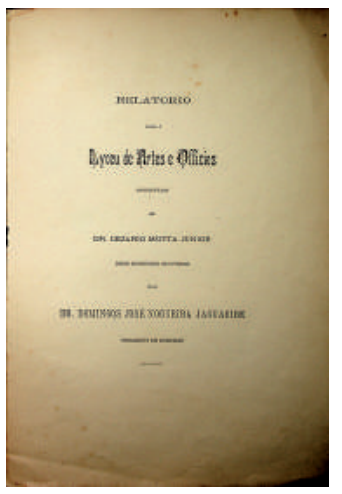

Relatório sobre o Liceu de Artes e Ofícios apresentado ao Doutor Cezário Motta Junior pelo Doutor Domingos Jose Nogueira Jaguaribe, presidente em exercício, 1895, impresso

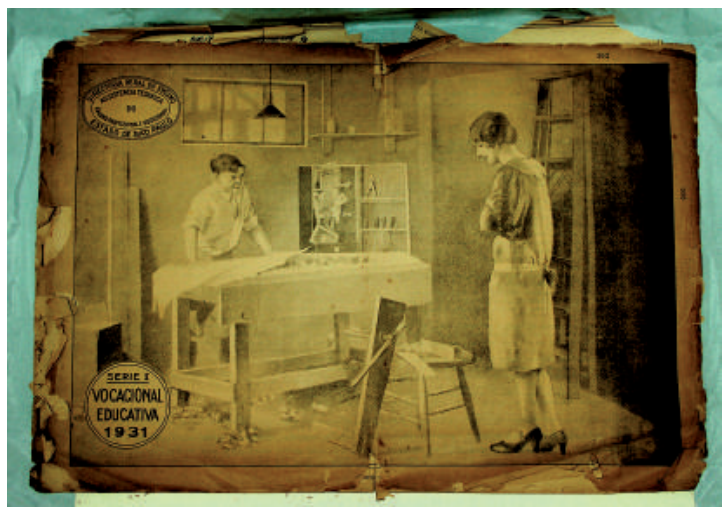

Directoria Geral Do Ensino.

Assistência técnica do Ensino

Profissional e Vocacional. Estado

de São Paulo. Série I. Vocacional

Educativa. S.I: S.n., 1931

\section{I.2 Acervo artístico}

O acervo artístico do Liceu de Artes e Ofícios merece exame especial e detalhado diante de sua história e singularidade. O mapeamento da coleção de arte e da produção artística da instituição extrapola seus muros e demanda um projeto de longo prazo e amplo espectro capaz de aglutinar a colaboração de especialistas de distintas áreas de conhecimento. Não sendo o objeto direto deste trabalho, os exemplos de escultura e pintura aqui indicados são meros indicativos de suporte.

Acerca da Gipsoteca, coleção de cópias em gesso adquirida em 1906-1908 considerada recurso pedagógico excepcional, foi catalogada no Extrato anteriormente mencionado. Embora os exemplares remanescentes tenham comparecido sinteticamente identificados no arrolamento que realizamos em 2011, eram em número diminuto se comparados com a profusão das peças catalogadas em 1934, carecendo de nova aproximação desde que seus exemplares mais importantes foram destruídos por um incêndio em 2014. Alguns poucos foram restaurados, enquanto outros preservados aguardam entrevistas e conferência. 


\subsubsection{Mobiliário}

As peças como armários, mesas, cadeiras, criado- mudos,camas e cômodas, são em pequena quantidade.

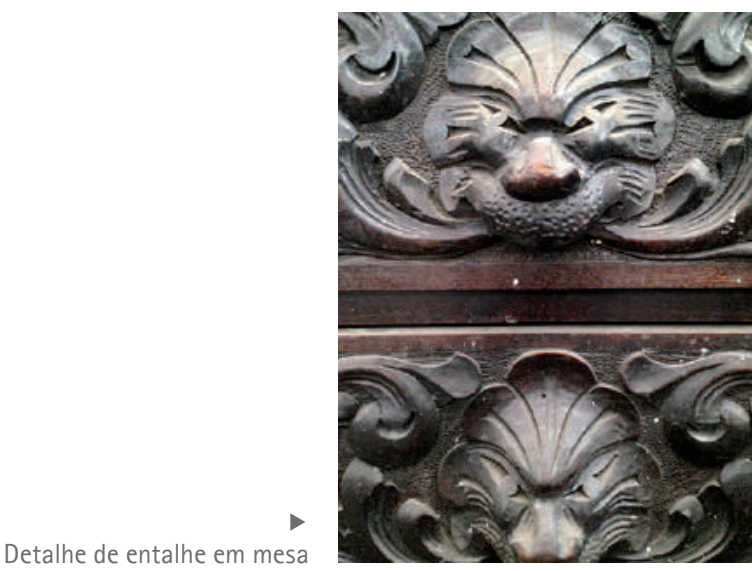

\subsubsection{Esculturas}

Há uma linda escultura em bronze, cópia da Diana de Jean Antoine Houdon nos jardins da escola, um busto de Ramos de Azevedo assinado por Ettore Ximenes e outras esculturas em bronze e em pedra sem identificação de autoria ou indicação de datação.

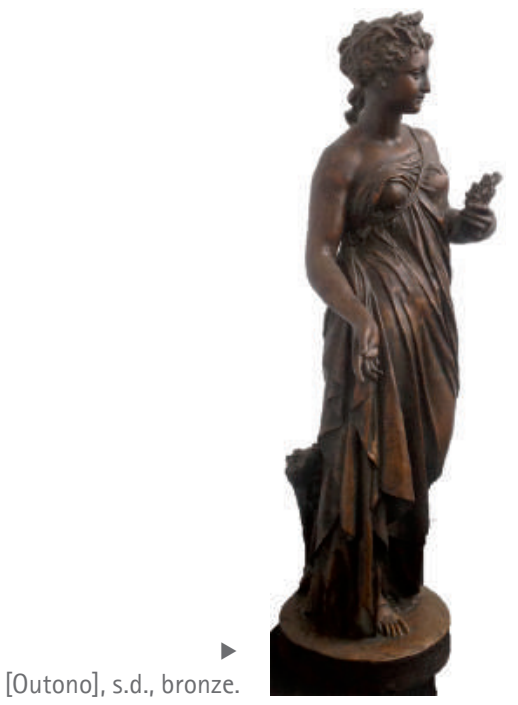

\subsection{Pinturas}

A coleção resume-se a retratos sem identificação e datação, um retrato de Azevedo Marques e um retrato de Ramos de Azevedo de autoria de Enrico Vio. 


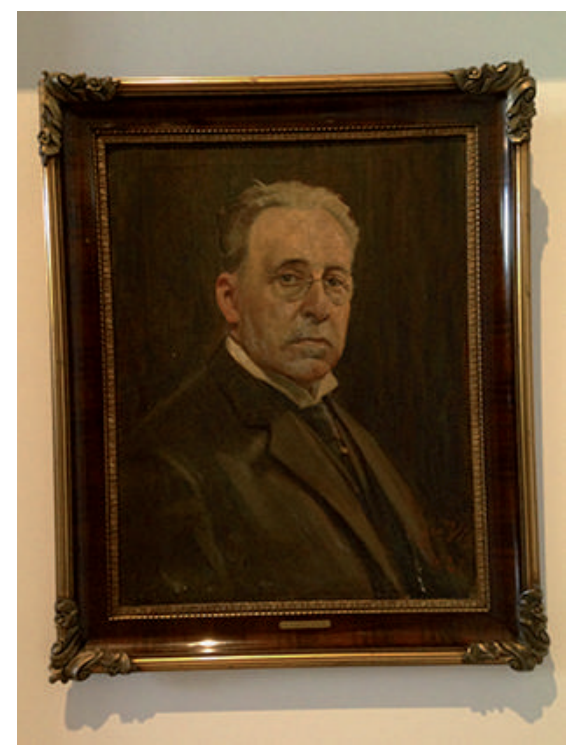

Enrico Vio, Retrato de Ramos de Azevedo

\subsubsection{Gipsoteca (galeria de reproduções em gesso)}
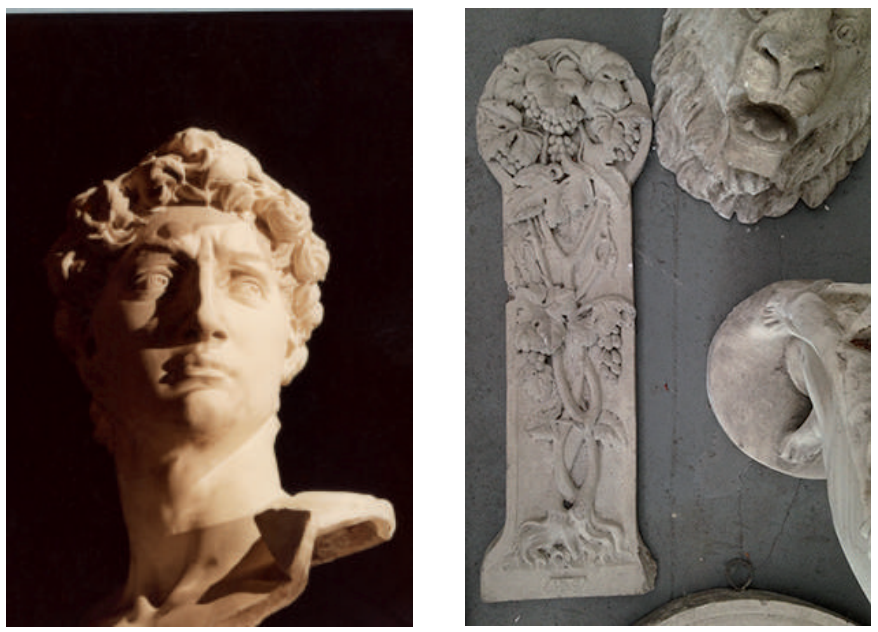

4

Cabeça de Davi, Michelangelo; Modelos de ornatos
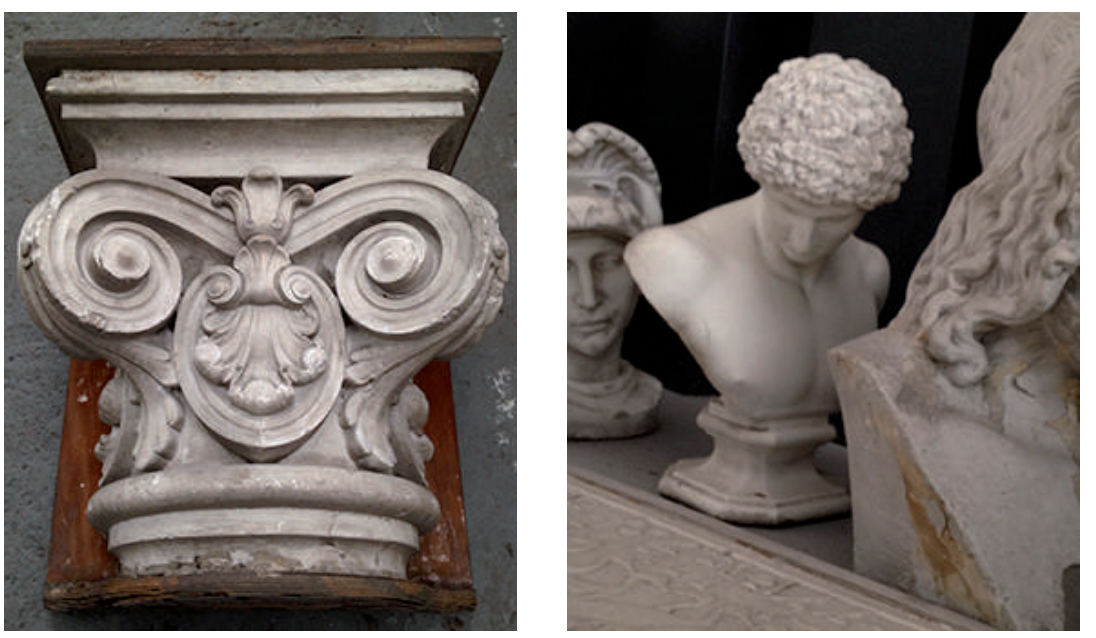

Capitel; Bustos 


\section{I.3 Fotográfico}

\section{Fotografias avulsas (modelos)}

A coleção de fotografias avulsas de modelos pode referir-se a imagens retiradas de manuais e guias ou podem ser registros avulsos, servem de modelos e referências como os dos lustres Baccarat com carimbo da companhia francesa, indicando medidas dos produtos déposés, ou presumivelmente tomada fotográfica do Pavilhão Brasileiro na Exposição Internacional de Saint Louis, 1904.

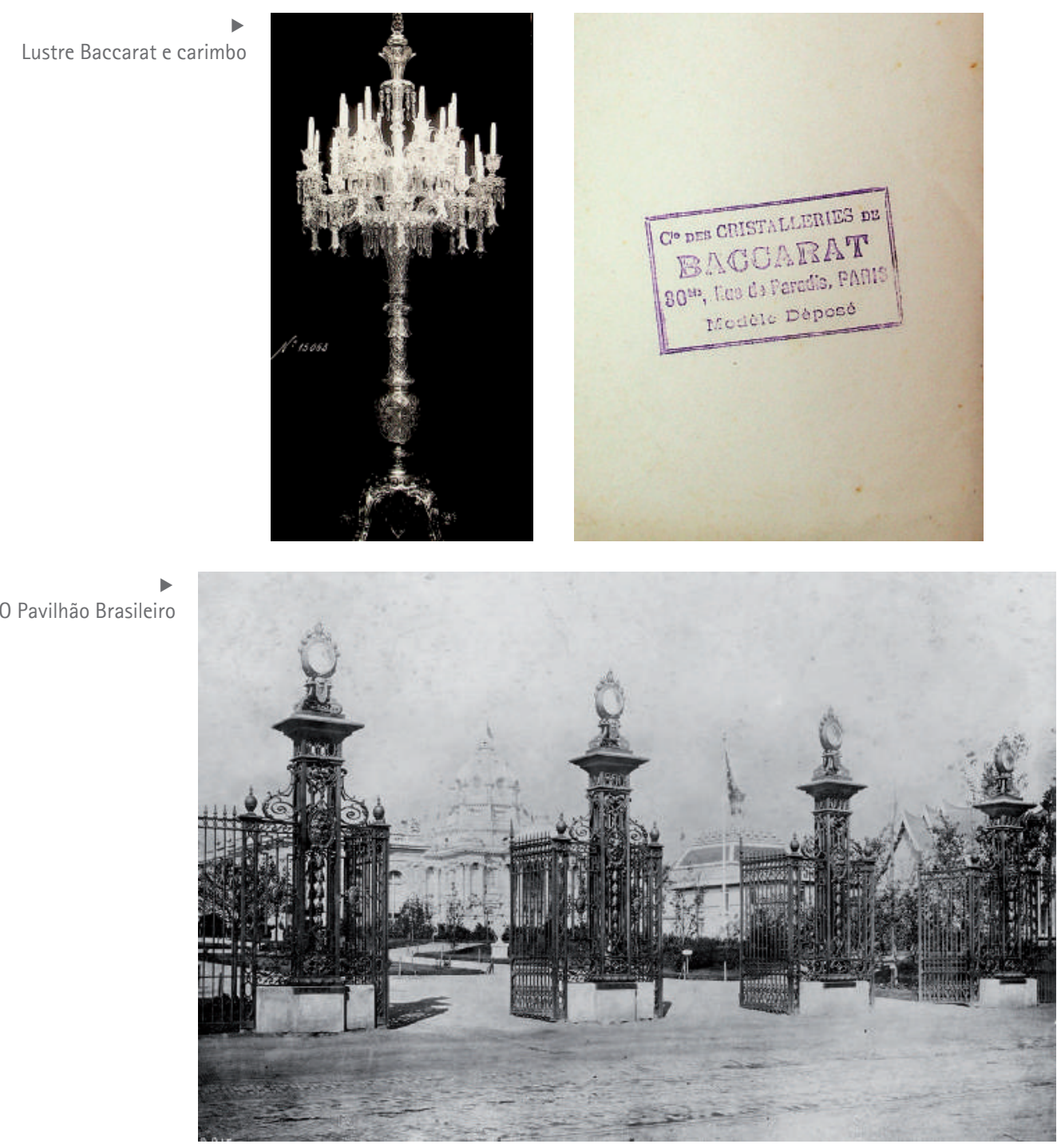




\section{Coleção Institucional}

\section{II.1 Atas e livros manuscritos}

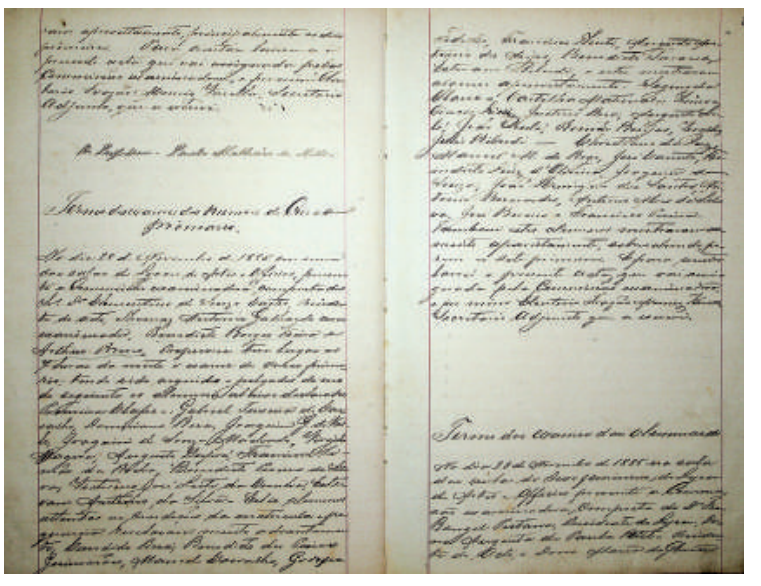

Livro de termo de exames,

1884-1940, sendo que os

resultados dos exames também

eram publicados no Correio

Paulistano até pelo menos 1917
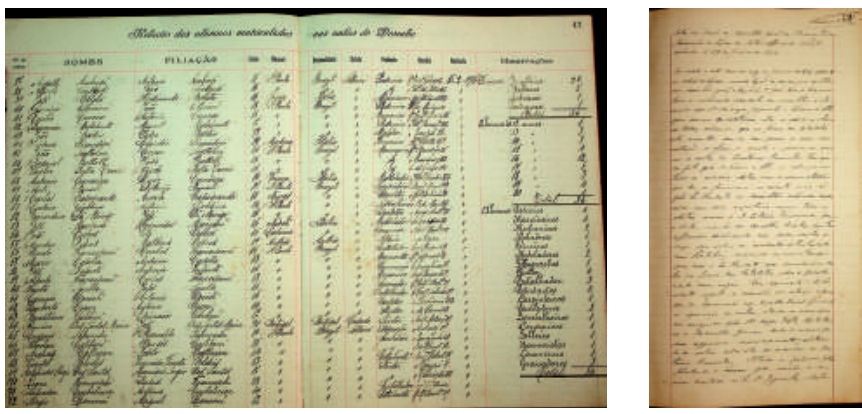

4 (esquerda)

0 Livro de matrículas na aula

de desenho 1911-1917

4 (direita)

Ata da diretoria 27 de Janeiro 1895

\section{2 Álbuns fotográficos (mostruário) e fotografias avulsas}

\section{Álbuns fotográficos}

Existem no acervo álbuns-mostruários encadernados, alguns luxuosos, de médio formato, com capa em vinhático e impressos em fototipia e outros mais simples, com fotografias coladas sobre cartão.
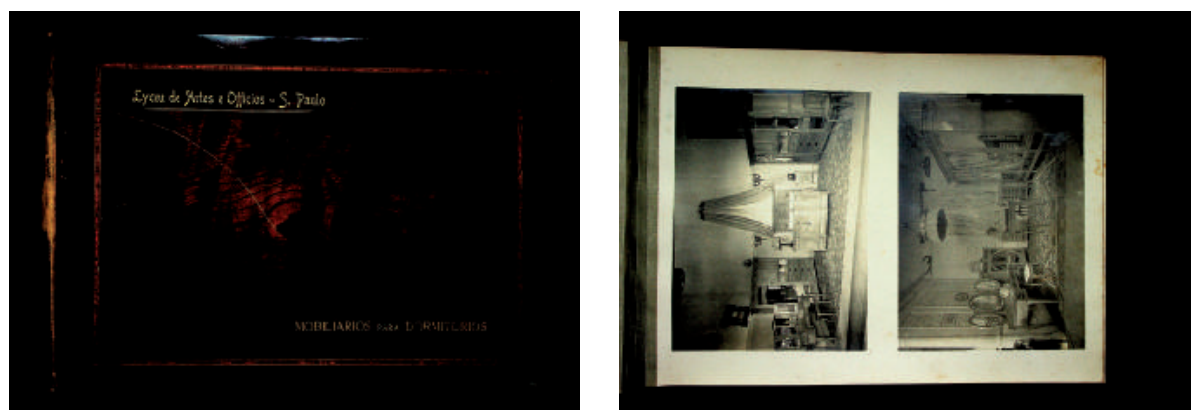
A maioria é maciça e relativa à produção de tipos de mobiliário para dormitórios, salões, salas de jantar, escritórios, boudoirs, por vezes indicando o estilo dos móveis, estilo que nem sempre perfaz todas as imagens integrantes dos álbuns. Há ainda os relacionados à produção de banquetes, cadeiras, poltronas, sofás, buffets e étagères, além dos relativos à produção de pratas repuxadas e cinzeladas, cerâmicas, maiólica, lustres e arandelas, ferro batido, paraventos, floreiras, vitrinas e porcelanas. Um único é dedicado à modelagem. Quase todos numeram os produtos e via de regra não trazem índices ou listas remissivas para os preços.
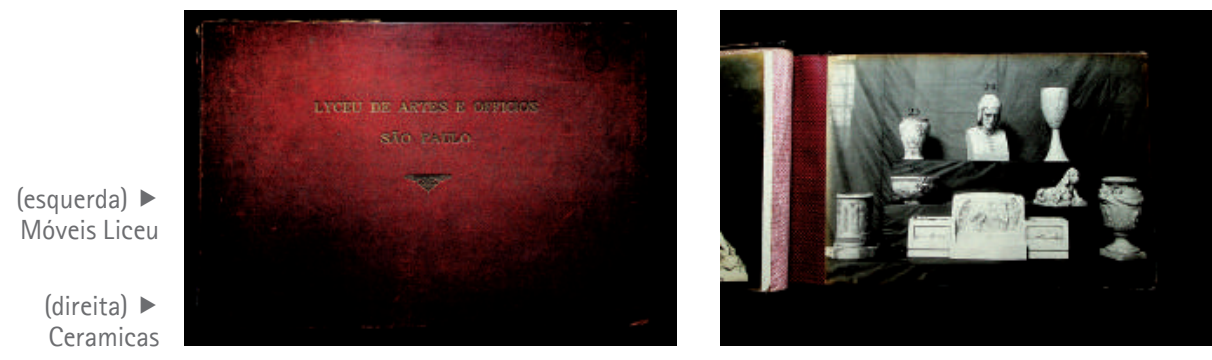

Outros álbuns trazem registros fotográficos de mobiliário feito sob encomenda para clientes públicos e privados, como nos titulados Alfândega de Santos, este com a grafia da data na capa, 1938, Novas termas de Poços de Caldas e Carro leito.
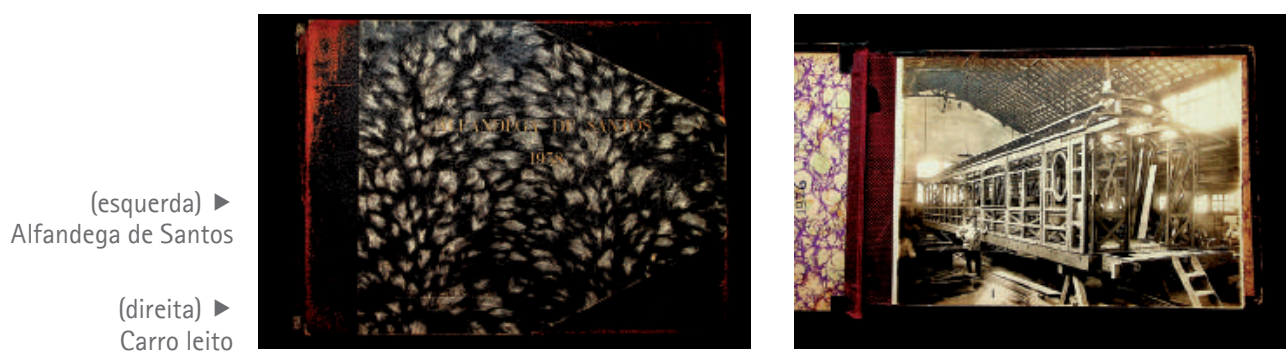

O álbum correspondente às obras feitas para a Banca Italiana di Sconto, com capa de couro e fragilizado, apresenta obras de decoração externa e interna, com indicações de vistas de fachadas e portadas, além do décor interno contendo mobiliário e demais itens feitos sob encomenda para a instituição. Deste tipo existem ainda os que registram obras realizadas para o Palácio dos Campos Elíseos e Palace Hotel Rio de Janeiro. 

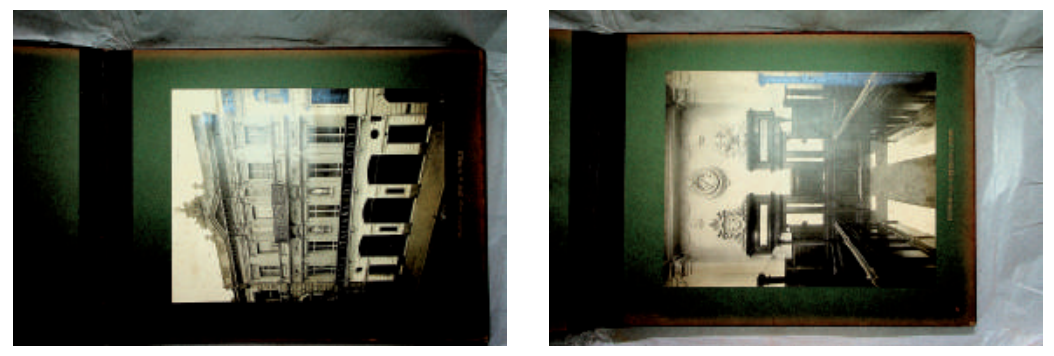

\section{Fotografias avulsas}

Dentre as centenas de fotografias avulsas constantes do acervo existem pacotes numerados com registros aparentemente descolados de álbuns ou em via de compor um, reunindo fotografias referentes às fachadas, decoração interna e mobiliário de obras paulistas como o Banco Ítalo Belga, Bolsa de São Paulo, London and Brazilian Bank, Casa Guinle, Teatro Municipal, Teatro Santana, Club Comercial, Jockey Clube, Banco do Brasil, Banco do Comércio e Indústria de São Paulo, Banco Hipotecário Agrícola, Banco Português do Brasil, Banco Nacional do Comércio de São Paulo, Caixa Econômica Federal, Casa Palmares, Catedral Sé, Companhia Paulista de Estradas de Ferro, Companhia Predial Alvares Penteado, Correios e Telégrafos, Faculdade de Direito, Igreja Ordem 3a do Carmo e Santa Casa de Misericórdia.
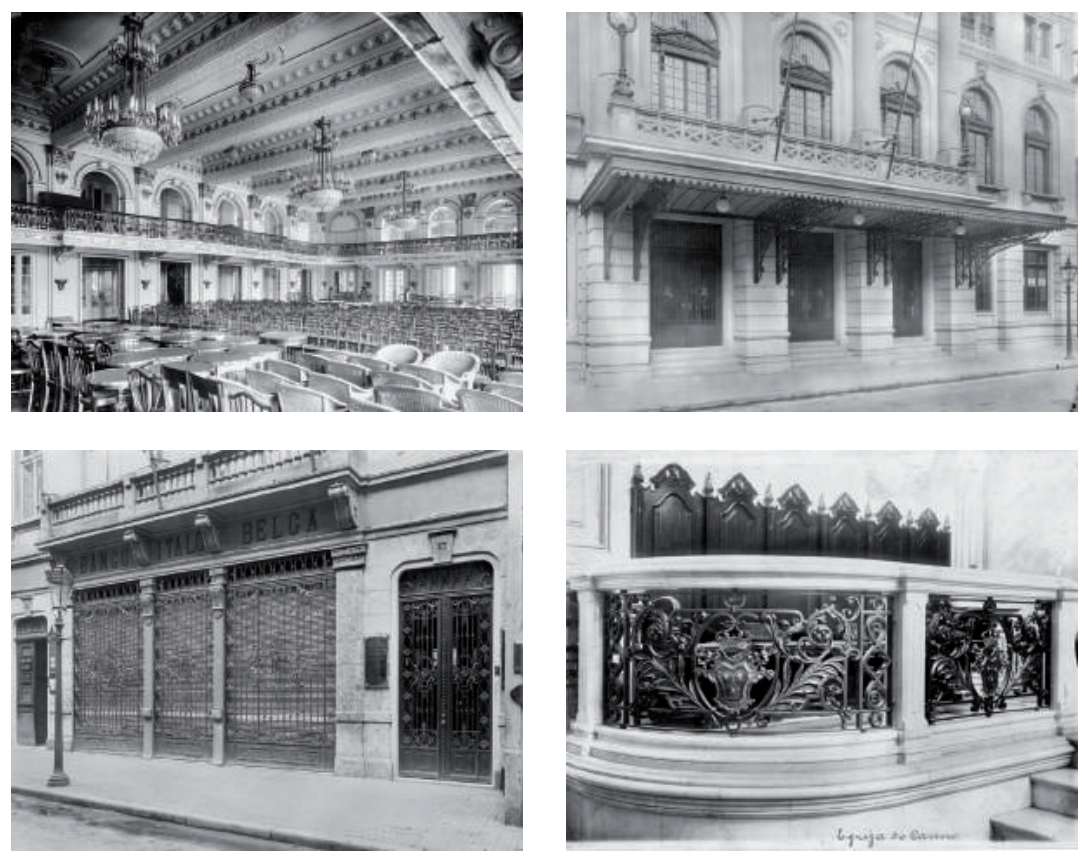

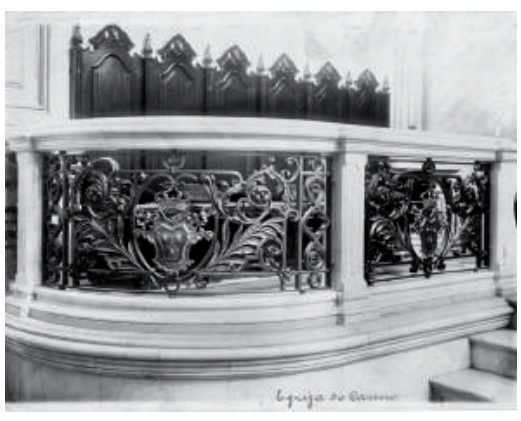

4 (esquerda)

Club Comercial

4 (direita) Teatro Santana

4 (esquerda) Banco İtalo Belga

4 (direita) Igreja Ordem $3^{\text {a }}$ do Carmo 
Também há registros fotográficos avulsos e obras realizadas fora da cidade como Grand Hotel La Plage, Guarujá, Ministério da Fazenda, Rio de Janeiro, Paço Municipal de Santos e Banco do Comércio e Indústria de Santos.

Há ainda um pacote intitulado Decorações e mobiliário da Colônia no Brasil, que inferimos sejam registros de repertório tomados em eventuais viagens de estudos.

Outras séries referem-se a registros de atividades nas oficinas e na escola sendo datadas entre 1912 e 2010.
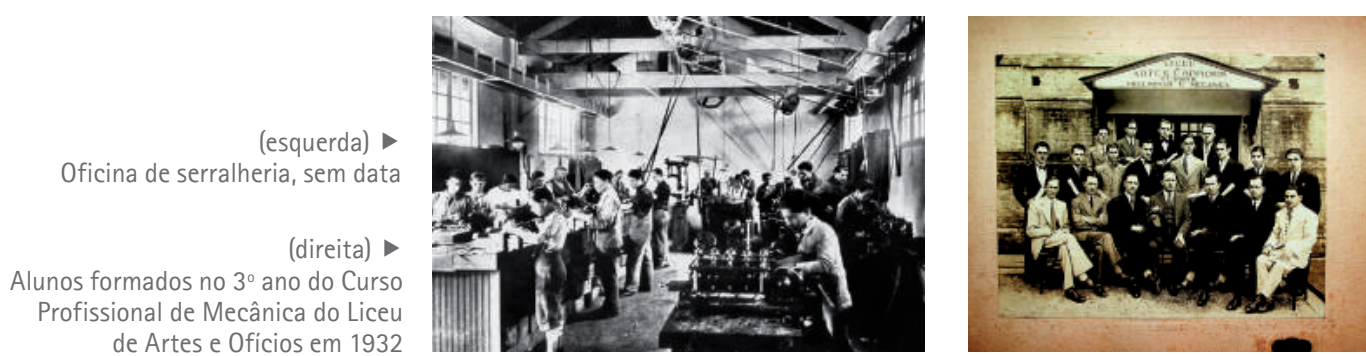

\section{II.3 Desenhos, projetos, estudos e esboços originais}

A coleção de desenhos e projetos originais é modesta diante da profusão dos registros fotográficos e referenciais da produção institucional ao longo da história do Liceu. Os originais datados até 1940 formam um conjunto diminuto, mas rico. As peças são avulsas e referem-se a composições de ambiências ou de objetos isolados.

Eventualmente trazem o nome dos comitentes, assinalando o número, o arquivo, o estilo, o desenhista, a data e eventuais observações e notas de trabalho. Ou podem pertencer aos dois únicos álbuns encadernados: Companhia Itaquerê, datado de 1934 e um sem título com desenhos de lustres e luminárias.
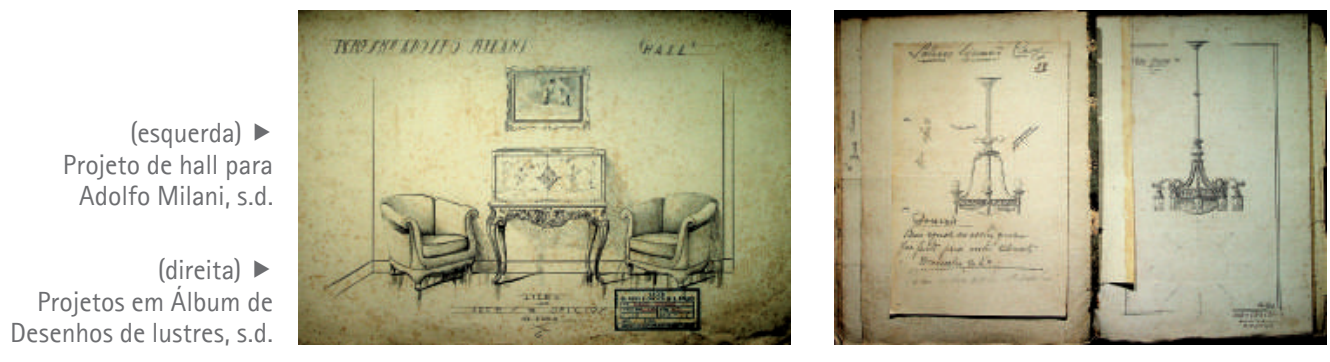
Dos projetos elaborados para instutições públicas, privadas e pessoas físicas existem cópias impressas ao modo de desenhos arquitetônicos, talvez em diazotipo, geralmente um conjunto de folhas encadernado sob um título. Outras vezes há cópias fotográficas dos ambientes com indicativo do nome do cliente e mais nenhum outro dado.

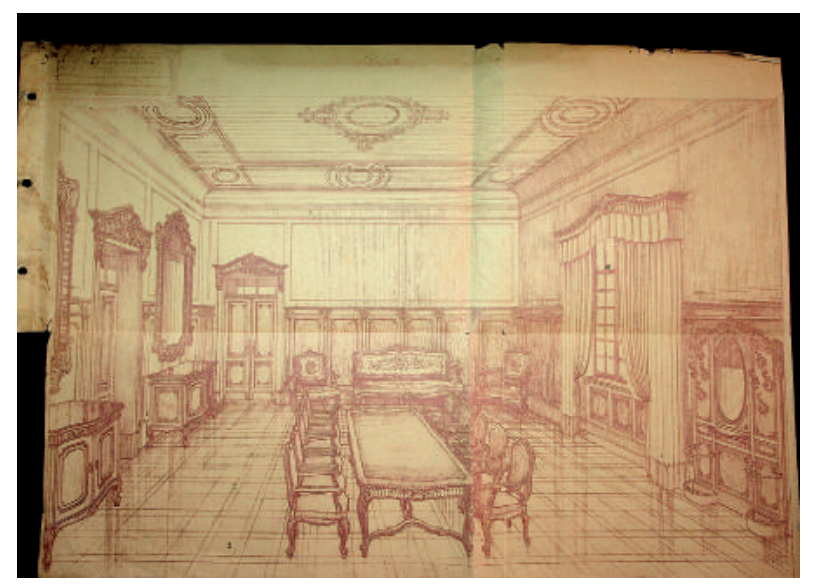

Sala do Palácio da Justiça

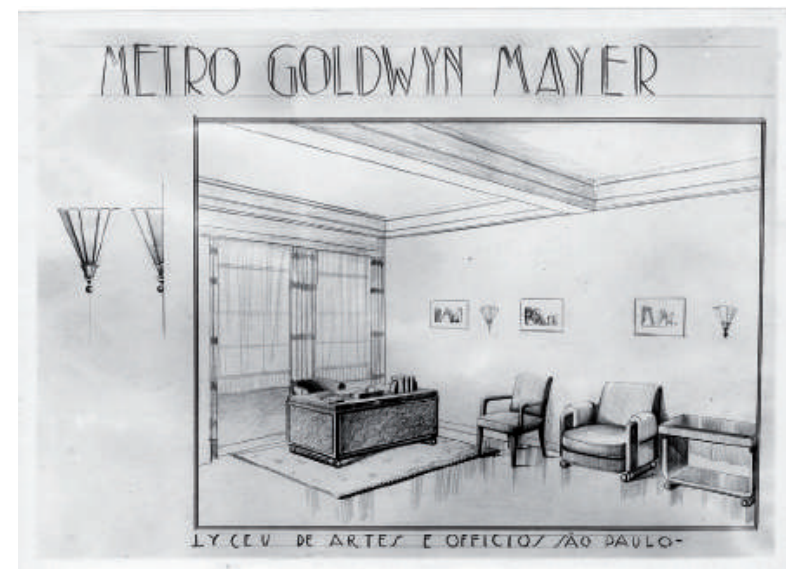

4

Departamento da Metro Goldwyn Mayer

Existem ainda cópias em álbuns reunindo diferentes tipos de objetos ou relativos a um tipo único como cerâmicas, por exemplo.
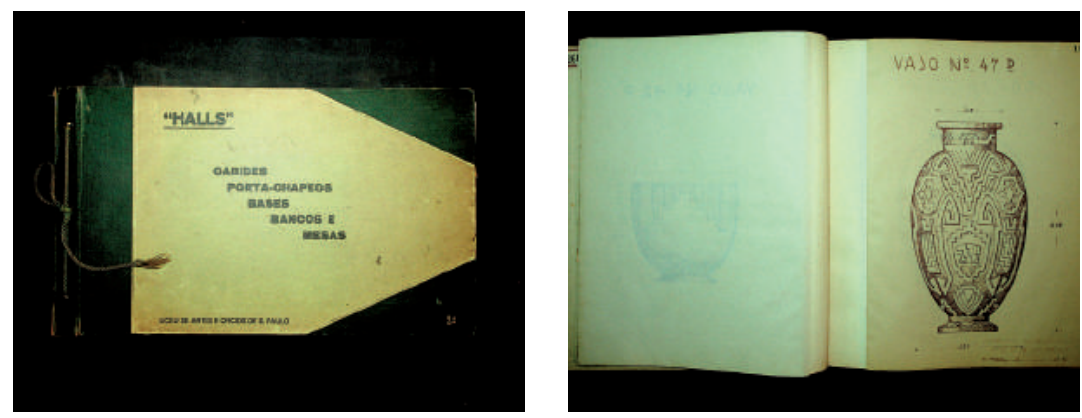

4 (esquerda)

Halls, Cabides, porta chapeos, bases, bancos e mesas, s.d.

4 (direita)

Cerâmicas, s.d. 


\section{4 Diplomas, prêmios, documentos e impressos}

Diplomas de 1957 e 1965 que mesmo fora de nosso alcance cronológico demonstram os nomes que o Liceu adotou ao longo de sua

história: Liceu de Artes e Oficios e Liceu de Artes e Oficios Escola Técnica Ramos de Azevedo
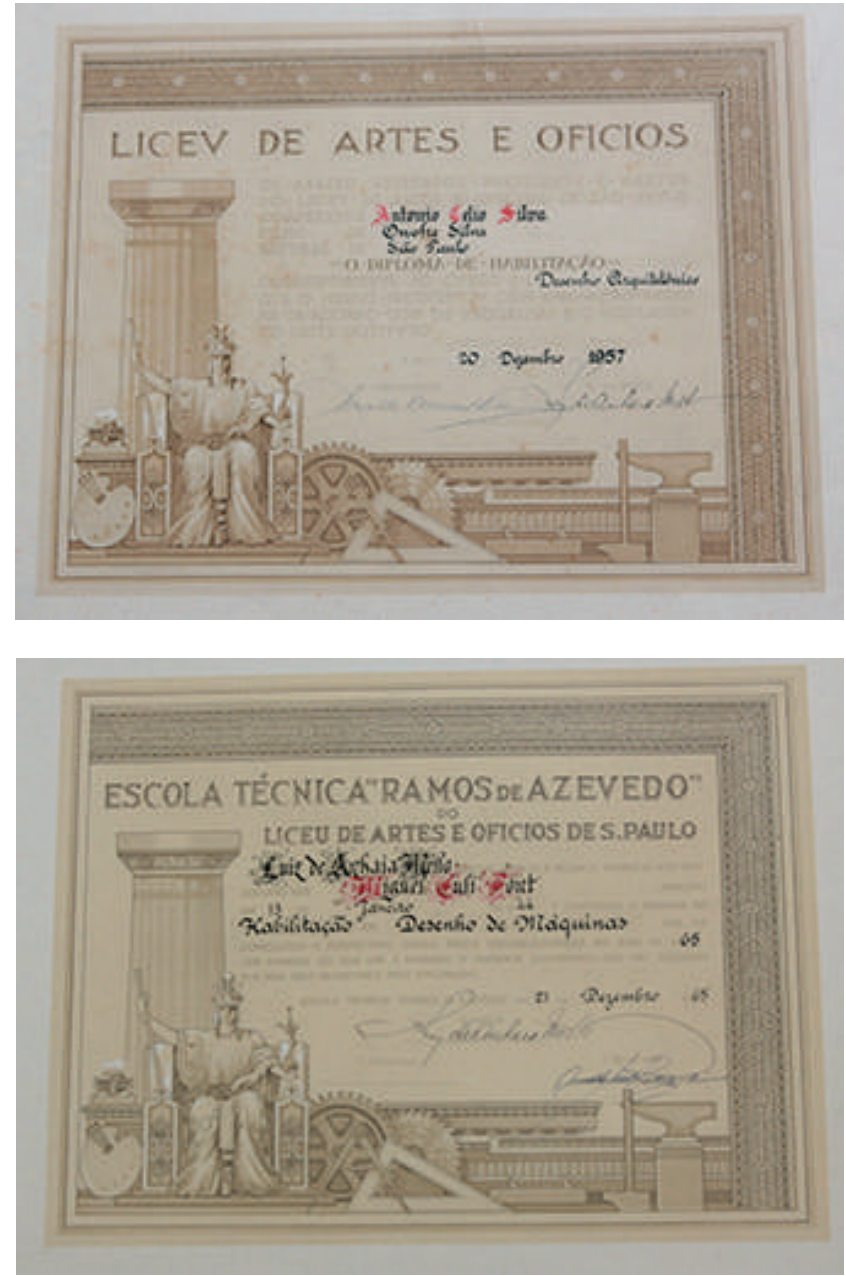

Dyplome de Médaille d'or Exposition Universelle de Bruxeles, 1910. Sous le Haute Patronage de S.M. Le Roi des Belges, 1910

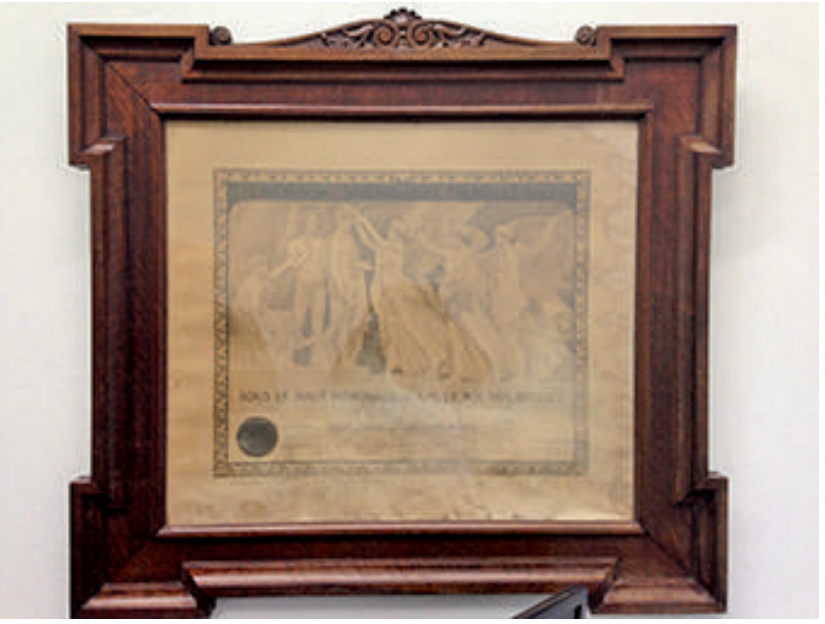



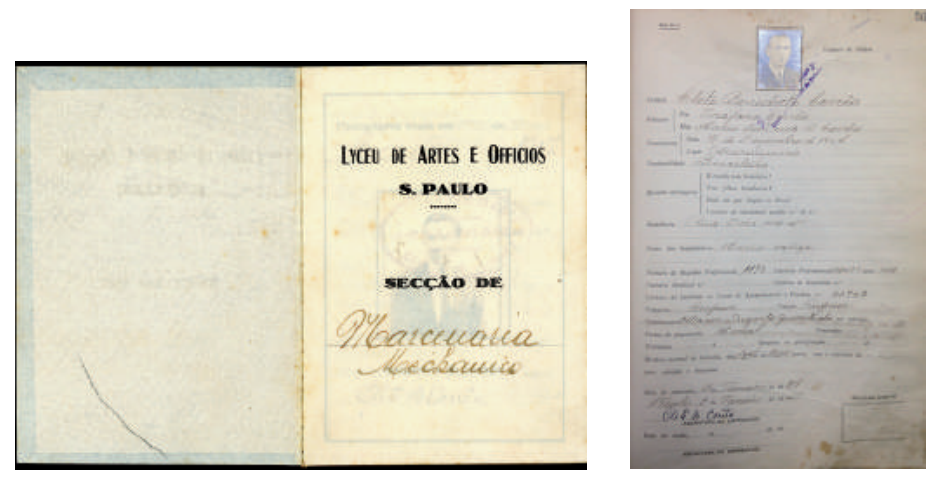

4

Carteira de trabalho e registro de empregado de Cleto Benedito Correa

Como pudemos observar, as publicações podem ser relacionadas a exposições e eventos, patrocinadas por associações, empresas, instituições públicas e privadas ou mesmo ser complemento às atividades editorais e curatoriais de seus editores. Deixam transparecer entrecruzamentos e redes de sociabilidade forjadas nas relações entre inovações técnicas e artísticas e cultura material.

As peças bibliográficas e certos itens ao acervo artístico reuniram repertórios de formas, vocabulários e sintaxes diversas, compondo coleções de arte, elementos de arquitetura, decoração e politécnica entre outros assuntos relacionados às artes e ofícios. Veicularam tanto a produção corrente quanto modelos próprios da cultura artística e arquitetônica e elementos relativos a criações técnicas, industriais e comerciais de sua época. De certo modo, as peças nos mostram como convergiram as referências do passado, as liberdades de composição eclética, as experimentações da modernidade assim como códigos que definem o gosto.

Embora algumas tragam diversos números e carimbos interpretáveis como sinais de seus registros e eventualmente indícios de suas procedências, sabemos muito pouco ou quase nada sobre os circuitos que percorreram até serem depositadas na biblioteca. Podem ter sido incorporadas ao acervo logo em seguida ou muito depois de suas edições.

Não obstante, elegemos como emblemático o exemplar bibliográfico Mercier Frères, para o qual atribuímos o título. Trata-se de um catálogo de mobiliário estilo Luís XV-XVII da empresa francesa Mercier Frères, especializada na fabricação de móveis de estilo e tapeçaria, fundada em 1828 e situada no número 100 do faubourg Saint-Antoine em Paris. Sem datação, a obra traz o autógrafo do Gerente Geral Luiz Scattolini, contratado pela Escola em 1895 e o carimbo das 
Oficinas de Carpintaria e Marcenaria do Liceu de Artes e Ofícios no Largo do Jardim da Luz.
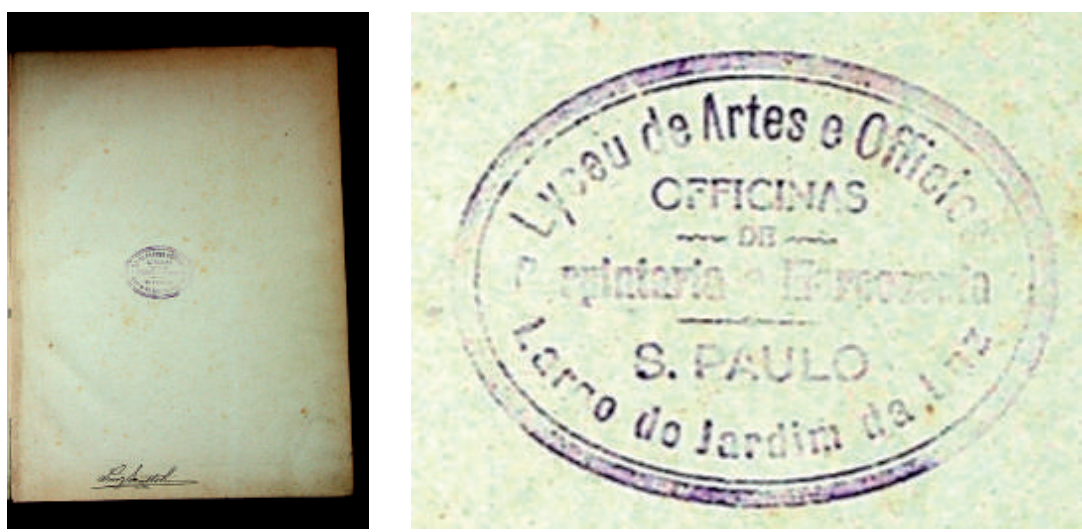

Catálogo Mercier Frères, 100 Faubourg Saint Antoine, Paris

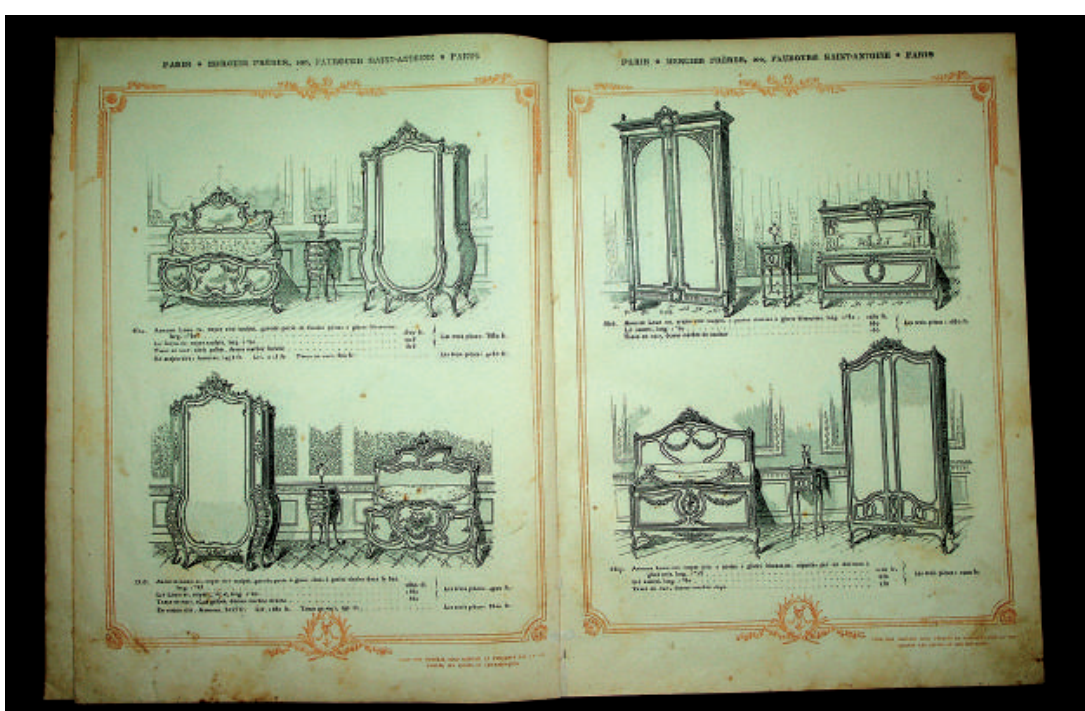

Prova de que nos espaços das oficinas, onde o trabalho coletivo realizava obras sob encomenda, conjuntos de motivos reconhecíveis em movimento achavam seu verdadeiro lugar. 


\section{Capítulo 2. Saberes em trânsito (1873-1885)}

\subsection{Modernidade enciclopédica}

As revoluções industriais geraram novas necessidades de coordenação da produção e da organização do trabalho originando novas paisagens urbanas e socioculturais. As metrópoles manufatureiras e industriais, fruto da racionalização dos processos produtivos e a especialização do trabalho, conheceram crescimento econômico acelerado. ${ }^{7}$ A cidade, tomada como símbolo exterior da sociedade industrial, centro de produção e comércio, administração, serviços, transportes e lugar da democracia política, torna-se locus de experiências coletivas e individuais.

Instruir-se e aprender a trabalhar parece ter sido o leitmotiv da "cidade moderna". O treinamento prático e moral dos autores anônimos do espaço urbano, entendido como lugar de trocas e inovações relativas à produção social, exigiu novos padrões estéticos. A virtuosidade do antigo artífice e as habilidades técnicas do novo trabalhador qualificado estavam amalgamando a conformação do artesão moderno.

O século XIX, historicista e eclético, celebrador do triunfo da arte e da técnica, adepto fervoroso da exposição e acesso aos objetos, instaurou um novo ciclo de inovações tecnológicas e consequentemente de novas formas de sociabilidade cosmopolitas. Ciência, educação, arte e indústria, inscritas no contexto de expansão do capital industrial, andaram de mãos dadas projetando diferentes desejos de "perfectibilidade".

7. Segundo E. P Thompson (1998, p. 267-304), a revolução industrial promoveu uma nova divisão de trabalho e o "uso econômico do tempo", contrapondo o "ritmo natural do trabalho humano com suas alternâncias necessárias" à supervisão e sincronização disciplinadas. O shock desta medida na vida social e doméstica, com a internalização da disciplina e dos "relógios morais", teve grande impacto nos costumes. 
Segundo Chantal Georgel, o século herdeiro do Iluminismo, curioso sobre tudo, ansioso por abraçar o universo, ordenar, classificar, explicar e apropriar, desenvolveu enciclopédias extensas, verdadeiras acumulações, através de obras e objetos de todos os tipos: históricos, literários, científicos ou artísticos, melhor ainda, universais. ${ }^{8}$

Marcos importantes para o comércio mundial e lugares privilegiados para as trocas de informações científicas e tecnológicas, as Exposições Universais, símbolos da modernidade triunfante, promoveram intensos fluxos de capital intelectual em uma rede que conectava inúmeros agentes sociais, tornando-se, inclusive, um terreno fértil para indivíduos engajados em educação. Martin Lawn, em seu estudo acerca da materialidade da educação no período, considera as exposições como vetores das relações entre as nações emergentes e a modernidade, onde o progresso poderia ser projetado, produzido e garantido. Nelas, mercado, invenção, produção e inovação tornam-se visíveis às massas locais revelando a produção artesanal para audiências maiores. As próprias nações transformam-se em sinônimos de mercadorias e as ideias apertam as tramas do tecido internacional. ${ }^{9}$

Não por acaso a Great Exhibition of the Works of Industry of All Nations, primeira exposição universal ocorrida em Londres em 1851, originou o núcleo central da coleção do museu de arte decorativa e de ciências da Inglaterra, o Victoria and Albert Museum chamado, em 1854, de South Kensington Museum. Suas coleções iniciais de arte decorativa, ciências naturais e maquinismos foram utilizadas como recursos educacionais para impulsionar a produção industrial inglesa. ${ }^{10}$

As coleções formadas durante esta época, muitas delas enciclopédicas, tornaram-se suportes de instrução, meios de estudos artísticos e científicos e de investigação prática. Para Georgel, os museus foram inventados e percebidos desde sua origem como lugares de ensinamento e espaços de aperfeiçoamento e aprendizagem como a recebida na École de beaux-arts francesa onde triunfava o princípio da cópia a partir do

8. cf. Chantal Georgel (1994, p. 52), trad. da A.

9. Ver Martin Lawn (2009, p. 15-30), trad. da A.

10. A Grande Exposição, como ficou conhecida, foi precedida pela Exposition des produits de l'industrie française, um evento público com várias edições organizado pelo governo francês entre 1798 a 1849, que oferecia um panorama da produção dos diferentes ramos da indústria francesa. 


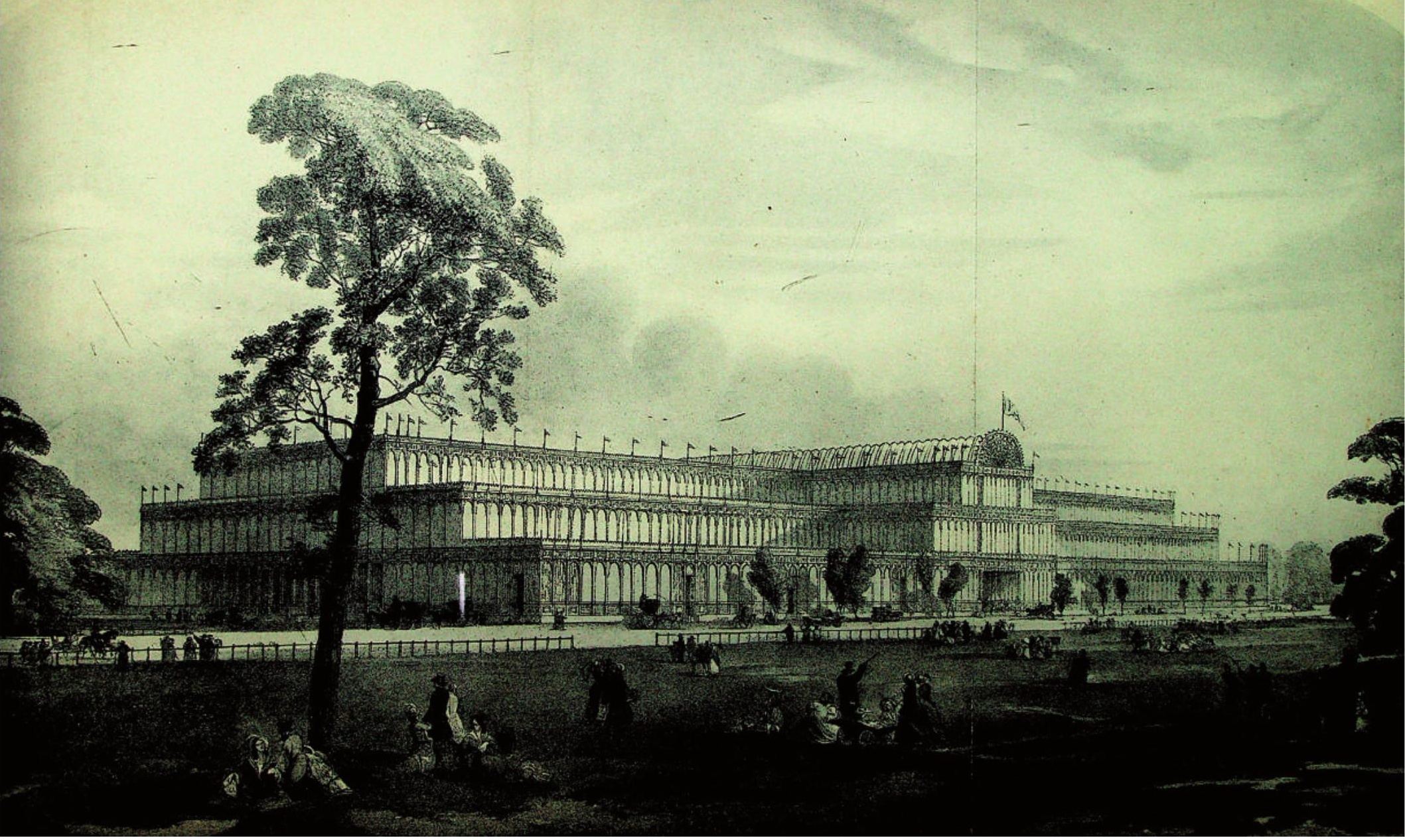

modelo. A autora, demonstra as ligações do museu com a instrução de desenho e pintura indicando que o ensinamento artístico se organizou a partir das coleções museais.

Para Georgel, na França a indústria e o que chamamos hoje de métiers d'art conheceram pleno florescimento depois do começo do século XIX. Como objeto de numerosas atenções, favoreceram o nascimento de escolas e museus "d'Art industriel", "d'Art et d'Industrie" ou "d'Art décoratifs" com o propósito de formar e instruir trabalhadores.

Em Paris o Conservatoire national des arts et métiers ${ }^{11}$ providenciava máquinas, modelos, ferramentas, desenhos, descrições e livros de todos os gêneros de artes e ofícios com o propósito de suprir conhecimentos úteis à indústria e aos diversos ramos de artesanato franceses. Onde se instalava a indústria abriam-se cursos públicos e gratuitos de desenho para adultos.

11. Segundo Roland Schaer: le Conservatoire des arts et métiers, a partir de la reforme de 1819, qui, autour des trois mille modèles recensés à cette date, met en place les cours gratuits de mécanique, de chimie appliquée aux arts, d'économie industrielle, puis de physique expérimentale, traite également sa collection comme support de l'étude par le moyen des "démonstrations". cf. Roland Schaer. In Chantal Georgel (1994, p. 440), O Conservatório fora criado em 1789 e reorganizado entre 1845-72 pelo arquiteto francês Léon Vaudoyer. 
Em seu apanhando histórico sobre a educação artística na Europa, o arqueólogo e pedagogo alemão Ludwig Pallat ${ }^{12}$ indica que a abertura das coleções de arte e ciências para os curiosos em prol do renascimento da arte industrial ocorreu também na Alemanha e na Inglaterra, facultando aos cidadãos e trabalhadores instrução profissional e cultura artística. Desenho, trabalho manual, dicção, música, teatro e ginástica passaram a ser integrados à formação das almas e dos corpos. Para Pallat, esta conjuntura ajudou enormemente a recuperação da importância da arte para a indústria, fornecendo também uma base para a prática da reprodução de modelos de todos os estilos históricos, além de incentivar o debate sobre as artes aplicadas.

Escola e museu tiveram papel fundamental no aprendizado dos ofícios artísticos, onde o ensino do desenho tornou-se a base exigente para a cópia e o exercício da memória, o apoio didático de uma "gramática do ornamento" constituída por reproduções de espécimes das artes decorativas ${ }^{13}$. Os modelos de estudo forneciam aos artistas um imenso repertório de formas acompanhado de indicações práticas, promovendo assim o surgimento de novas expressões artísticas que integram o útil ao belo.
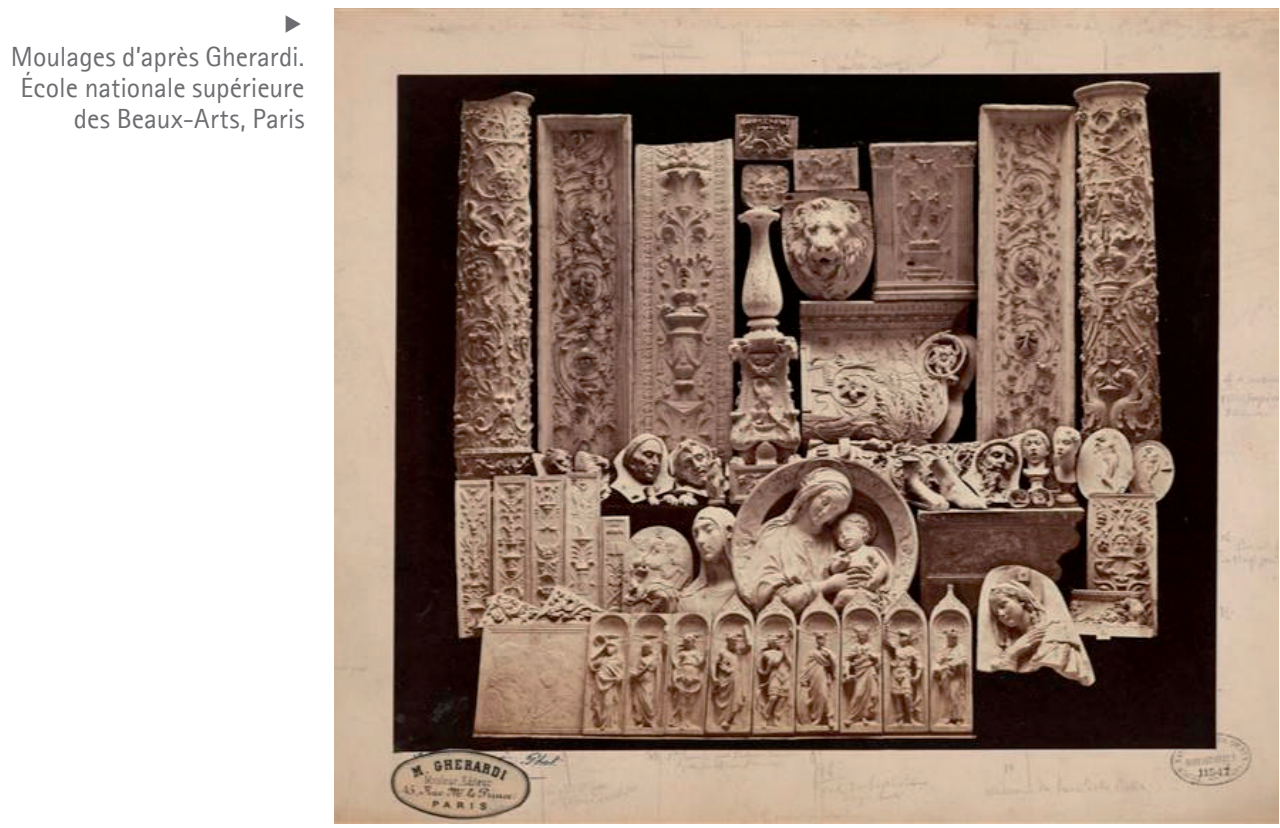

12. Ver Ludwig Pallat. Le Musée et l’Ecole. In Mouseion, n 9, dez. 1929, p. 236-243. 13. Para as questões desenvolvidas nesta seção e sobre a função educativa dos museus relacionada ao aprendizado dos ofícios artísticos, ver Chantal Georgel (1994, p. 58 a 65 e p. 85), trad. da A. 
Desde o Iluminismo, escola, museu e biblioteca são dispositivos didáticos interligados que têm garantido papel fundamental na produção e transmissão de conhecimentos e do saber-fazer.

Roland Schaer define o museu como uma "enciclopédia material com vocação didática”. Para o filósofo a aliança entre museu e biblioteca coloca em paralelo duas fontes de saber, as palavras e as coisas, configurando "un encyclopédisme du lisible et un encyclopédisme du visible, discours et figure". O que o autor define como "enciclopedismo didático", ao mesmo tempo especializado e vulgarizador, encontra sua forma pura no "enciclopedismo técnico", promotor de repertórios completos de modelos de referência, ou seja, criações do passado que servem de substrato na aquisição do saber-fazer em todos os ramos da atividade produtiva. Segundo Schaer, o enciclopedismo retrospectivo, ao substituir a vocação didática e técnica dos repertórios fez com que os museus se tornassem locais de memória. ${ }^{14}$

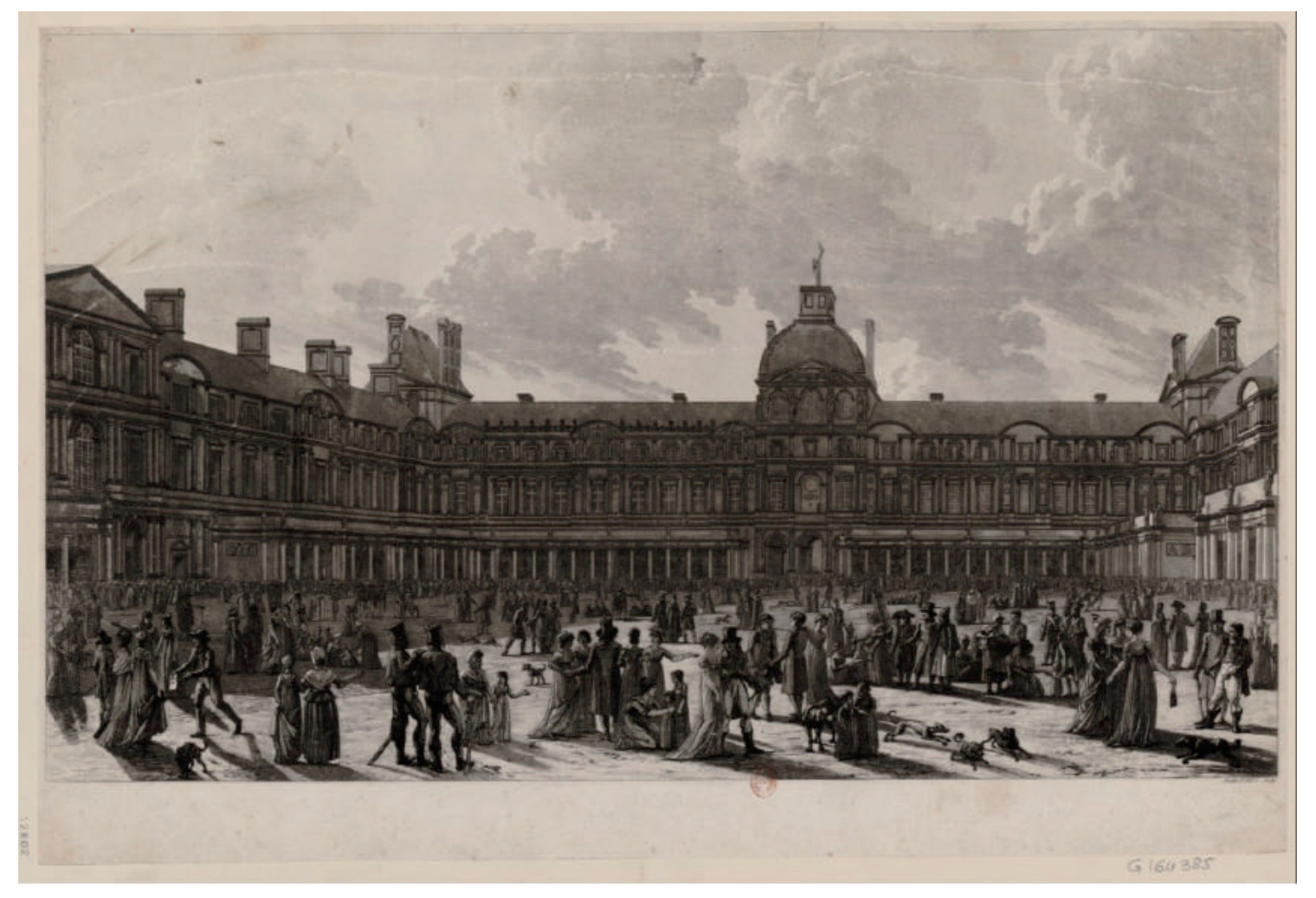

Baltard. Graveur. Vue de la Cour du Louvre prise pendant l'exposition des produits de l'industrie française dans les jours complémentaires de I'an IX : [estampe]. [s.n.][s.n.]. Bibliothèque nationale de France, département Estampes et photographie, Paris

14. Ver Roland Schaer. Des encyclopédies superposées. In Chantal Georgel, (1994, p. 38 e ss.). 


\subsection{A "metrópole do café"}

Assim como na Europa, o Brasil imperial e republicano apostou na instrução como locus de transformação social e adequação do sistema de educação à produção. ${ }^{15}$ Os modelos, padrões e objetos europeus em circulação no período, apropriados pela Sociedade Propagadora de Instrução Popular, mais tarde Liceu de Artes e Ofícios de São Paulo, no contexto da aprendizagem e da produção artesanal de objetos artísticos e técnicos, denotam o papel da indústria na disseminação de repertórios civilizatórios. Iluminando fluxos de transferência de práticas artísticas, científicas e educativas compartilhadas.

Emulada pelo desejo de progresso e simpática à atração do capital cultural e simbólico da Europa, a elite paulista, conduzida pelo "positivismo filosófico"16, acreditava na instrução pública gratuita como alavanca do desenvolvimento da nação.

Entre 1870-1940, os processos de internacionalização das sociedades e das culturas ocidentais agenciados pela elite progressista brasileira, frequentadora assídua das capitais e cidades europeias e norte-americanas, tiveram impacto na capital paulista, mudando a configuração dos ambientes culturais da cidade e criando novos usos e espaços.

No processo de metropolização, a São Paulo das três últimas décadas do século XIX, aglomerando funções econômicas e sociais complexas, trazendo em seu bojo a interação de mudanças tecnológicas, institucionais e econômicas traduzíveis em padrões espaciais, não esteve infensa às exigências da modernidade.

Na passagem da Monarquia para a República, as modificações dos usos e espaços da "metrópole do café", denotam as inter-relações entre o ambiente construído da cidade e o espaço social onde circularam e foram consumidos tanto bens materiais quanto práticas, ideias, valores e padrões culturais.

A paisagem urbana modificava-se gradativa, mas inexoravelmente. Entre 1860 e 1890, instalaram-se no meio urbano paulista

15. Anotações de aula da disciplina Museus pedagógicos e escolares no final do século XIX: aspectos de uma história transnacional da educação, ministrada pela profa. Dra. Diana Gonçalves Vidal no 2. ${ }^{\circ}$ semestre de 2017 na Faculdade de Educação da Universidade de São Paulo.

16. cf. Ricardo Severo, (1934, p. 8). 
companhias ferroviárias, casas de negócios, importadoras, oficinas, bancos, livrarias, hotéis, casas de moda, restaurantes, lojas de departamento, entre outros ramos comerciais de produtos industrializados, dinamizando hábitos de consumo civilizatório:

Em São Paulo, enquanto cidade periférica no sistema econômico mundial, o comércio não constituiu um sistema para circulação apenas de produtos locais, sejam artesanais ou industriais, mas também - e intensamente a partir do final do século XIX - de produtos estrangeiros. ${ }^{17}$

Engenheiros, arquitetos, artistas e artesãos estiveram galvanizados na transformação de objetos artísticos em objetos técnicos e no manejo de signos em busca de formas artísticas originais. Nas últimas décadas do século XIX e início do século XX o mercado imobiliário, onde atuavam escritórios e construtoras operando em bases empresariais, valeu-se do uso dos saberes especializados pela tradição e com "veleidades artísticas" para a construção por encomenda de edifícios públicos e privados, assim como de residências de luxo ${ }^{18}$. Verificaremos alguns exemplares que tiveram a colaboração do Liceu de Artes e Ofícios no próximo capítulo.

A influência estrangeira (autóctone ou de artífices e comerciantes fixados na cidade através da imigração subvencionada em massa) e a interação cultural geravam "mudanças inovadoras", as feições da cidade se transformavam pouco a pouco, fachadas e interiores eram reformados com novas técnicas, materiais e estilos. $\mathrm{Na}$ composição de sua própria materialidade, a capital da província tomava a forma de cidade moderna.

O Liceu recrutou mestres imigrados para suas tendas de trabalho, praticando técnicas tradicionais vis-à-vis os esforços de absorção dos repertórios e adaptação das 'receitas'19 para a produção encomendada pela burguesia enriquecida com investimentos na ferrovia e na produção cafeeira. Unindo arte e produção coletiva, a escola-indústria foi capaz de estimular o progresso artístico e cultural da cidade.

17. Ver BARBUY, Heloisa. Cidade-exposição. Comércio e Cosmopolitismo em São Paulo 1860-1914. Estudo de história urbana e cultura material. 2001, 298. Tese de Doutorado, Faculdade de Arquitetura e Urbanismo da Universidade de São Paulo. São Paulo, Setembro de 2001. Datiloscrito.

18. Ver Maria Lucia Caira Gitahy (1997, p.118-132).

19. Ver Ana Maria de Moraes Belluzo (1988). 


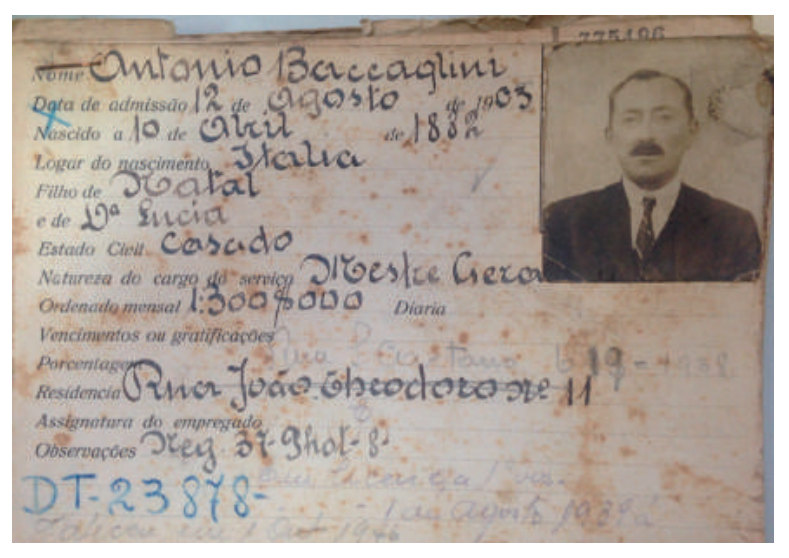

Ficha de admissão de Antonio Baccaglini Mestre geral admitido 1903, italiano

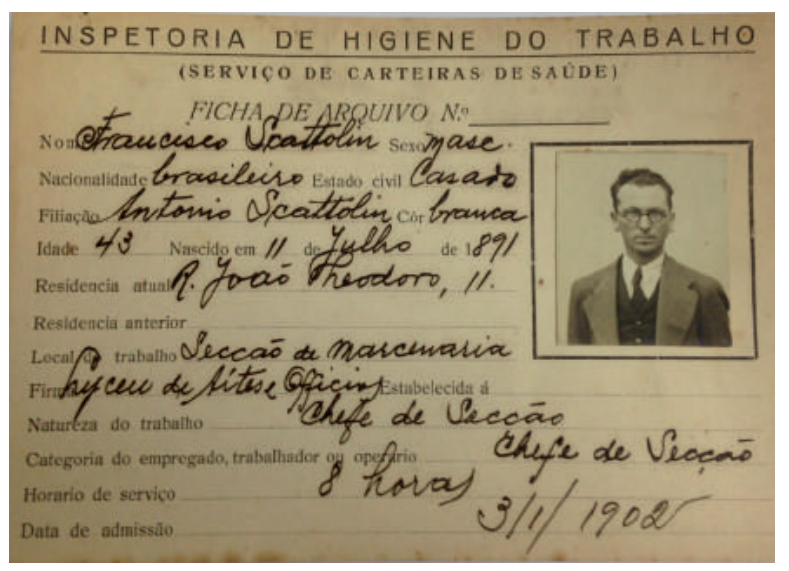

Ficha de admissão de Francisco Scattolin, Chefe da seção de marcenaria, admitido em 1902, brasileiro

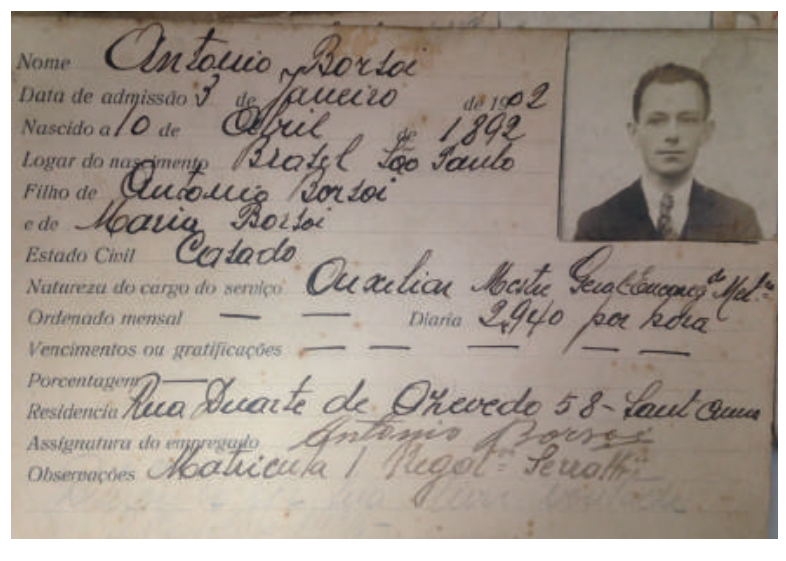

Ficha de admissão de Antonio Borsoi, Auxiliar do mestre geral, admitido em 1902, brasileiro

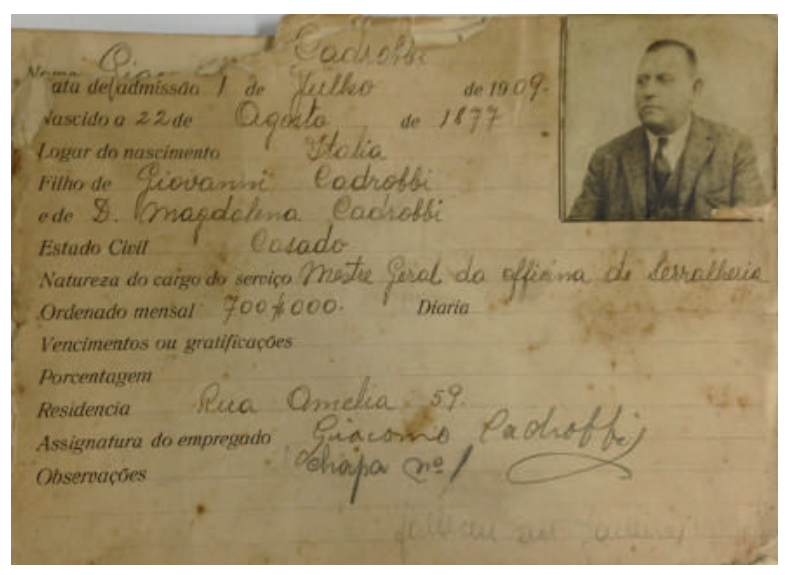

Ficha da Inspetoria de Higiene do Trabalho de Giacomo Cadrobbi, mestre geral da oficina de serralheria, admitido 1909, italiano

Operando as relações entre a circulação de repertórios europeus em São Paulo e as práticas relacionadas à composição da materialidade da cidade, o Liceu de Artes de Ofícios cumpriu o papel de receptor, produtor e difusor de saber-fazer no âmbito das transferências de modelos culturais.

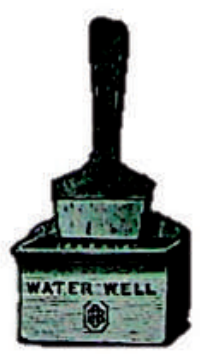

\subsection{Lápis, papel, tinta e compassos}

A Sociedade Propagadora de Instrução Popular, constituída em São Paulo em 1873 como organismo privado de instrução popular e gratuita, foi reorganizada em 1882 como Liceu de Artes e Ofícios, idealizada, fundada e dirigida pelo Conselheiro Carlos Leôncio de Carvalho. Seus pares nesta iniciativa foram, o Conselheiro Vicente Pires da Motta, 
Bernardino Gavião Peixoto, Raphael de Barros e o Marquês de Três Rios, Joaquim Egídio de Sousa Aranha.

Instalada num prédio da rua São José, atual rua Líbero Badaró, a Sociedade benemérita tinha o objetivo de fundar uma escola noturna e gratuita para ministrar os 'conhecimentos necessários ao cidadão e ao operário'. Seu capital era constituído por joias e mensalidades dos sócios e 'pelas dádivas que lhes fossem feitas', como rezavam seus estatutos publicados no jornal Correio Paulistano.

A cidade de taipa passava a dispor em seu centro de um instituto de educação popular que se propunha formar bons cidadãos com 'resgate do passado e garantia do futuro.' ${ }^{20}$

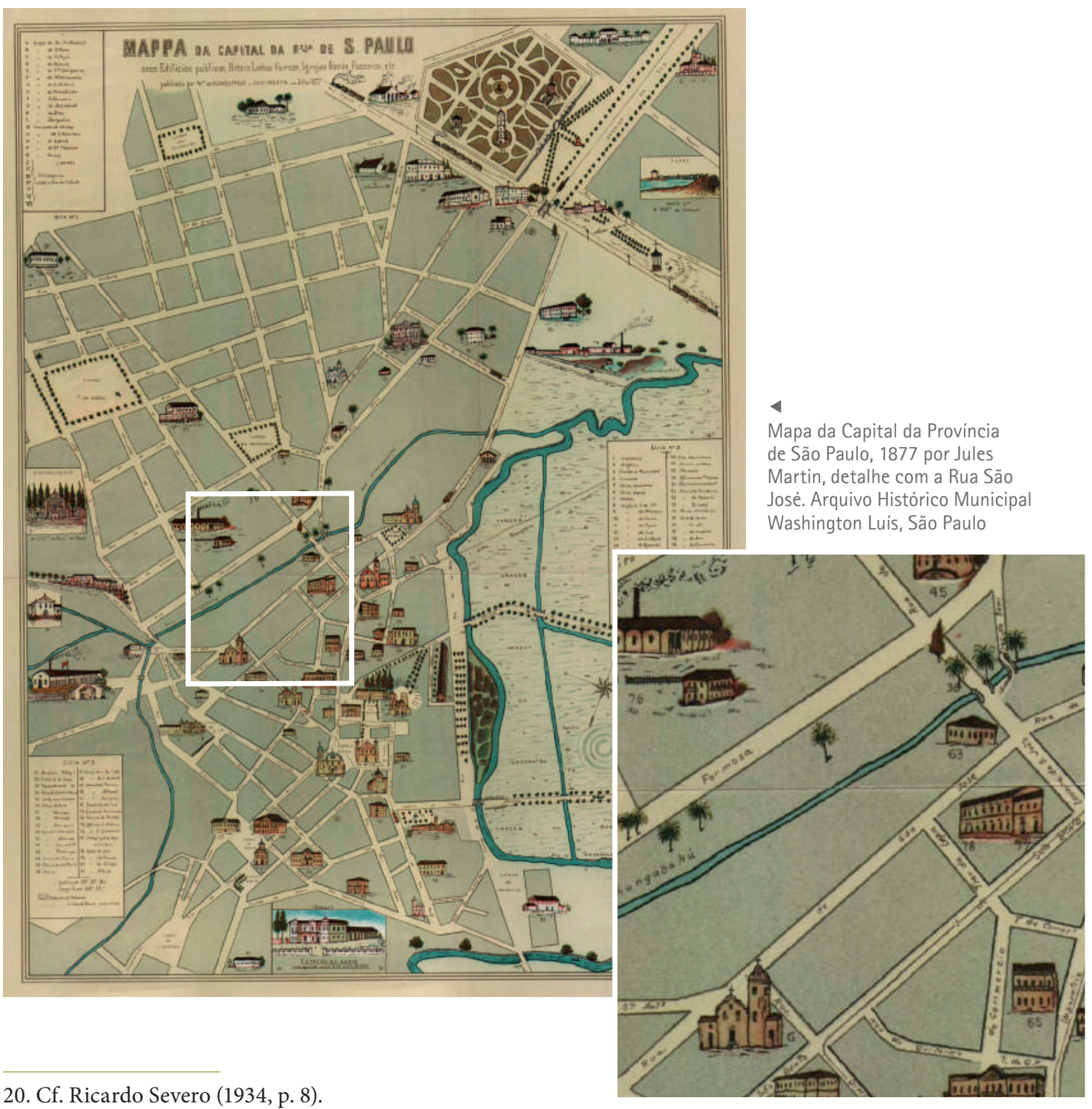


Entre os primeiros sócios da Propagadora destacamos os nomes de José Maria Correia de Sá e Benevides, Luiz Gama, Francisco Rangel Pestana, Antonio Carlos Ribeiro de Andrada, Francisco Antônio de Souza Queiroz, José Bonifácio, Anatole L. Garraux, Elias Pacheco Chaves, Luís de Oliveira Lins de Vasconcellos, Victor Nothmann, Antônio da Silva Prado, Barão de Iguape e Lebre, Irmão e Comp., Antônio Proost Rodovalho e os reverendos Emmanuel Vanorden e George Chamberlain. ${ }^{21}$

Desde o dia 29 de novembro de 1873 eram oferecidas aulas de leitura e caligrafia, elementos de aritmética, elementos de geometria, desenho linear, língua portuguesa, língua francesa, sistema métrico, história pátria, geografia com especialidade da América, noções de moral e análise da Constituição do Império. Ainda sem biblioteca, a Sociedade previa, como versado no artigo $3^{\circ}$ de seus estatutos, a oferta de cursos com aulas de mecânica, física, química e ciências naturais. ${ }^{22}$

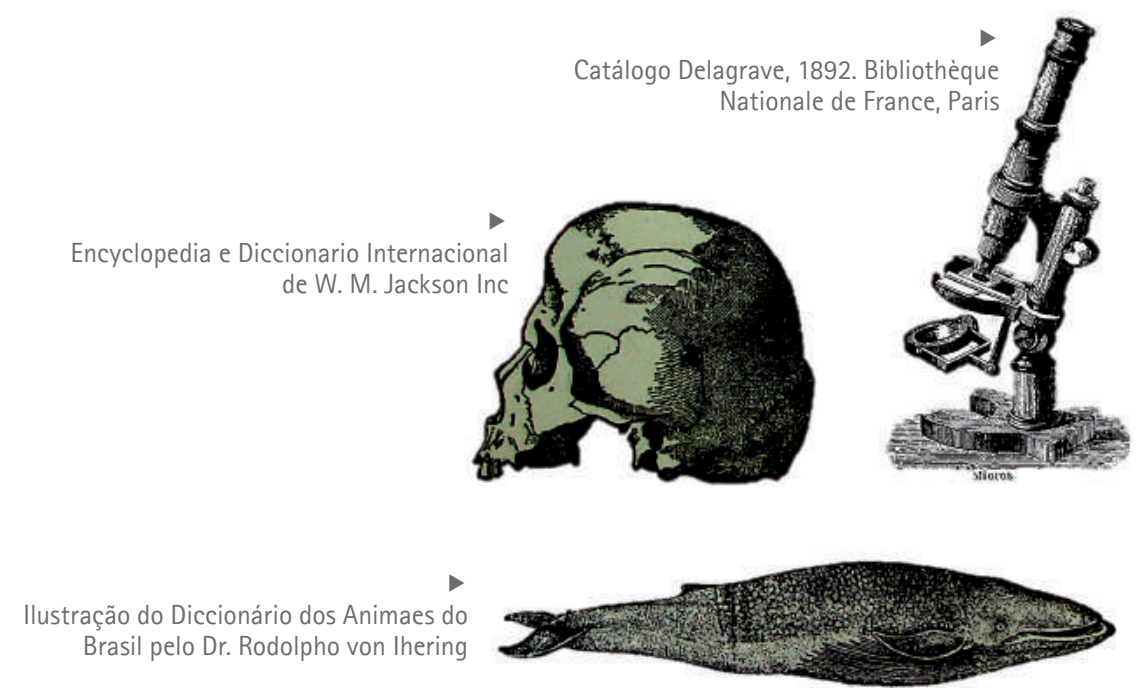

A Loja maçônica América que há tempos possuía, mantinha e custeava na cidade uma escola popular noturna e uma biblioteca com mais de três mil exemplares - dentre eles "muitas obras de subido (sic) valor literário e cientifico"- doou sua coleção de livros à Sociedade Propagadora, conforme noticiado pelo Correio Paulistano

21. cf. Correio Paulistano, São Paulo, 2 a 28 dez. 1873.

22. cf. Estatutos da Sociedade Propagadora de Instrução Popular, Correio Popular, São Paulo, p. 1, 29 nov. 1873. 
em $1^{\circ}$ dezembro de $1873 .{ }^{23} \mathrm{~A}$ doção foi um presente recebido de bom grado por Leôncio de Carvalho, antes mesmo de a Propagadora ocupar em fevereiro de 1874 as duas casas na Rua São José, onde seriam instaladas a escola e a biblioteca.

Apesar das buscas intensivas por registros e documentos referentes aos exemplares doados, nada sabemos sobre esse acervo. Entretanto, consideramos que tenha sido o núcleo inicial da biblioteca do Liceu. Quais teriam sido os títulos 'científicos' transferidos por doação para as casas da rua São José? Haveria outros títulos? A Loja doara sua biblioteca integralmente ou teria mantido exemplares para sua própria escola? Como e quando teria sido formada a coleção da Loja América?

O então Presidente da Província João Theodoro Xavier aprovara os Estatutos da Propagadora em 5 de janeiro de 1874, tornando-se sócio da instituição. Sabe-se pelo Correio de 21 janeiro de 1874 que a partir de $1^{\circ}$ de fevereiro e 9 de março daquele ano, cinco salas espaçosas abrigariam as aulas e a biblioteca, de modo a executarem o programa gratuito e franco da 'eschola', composto por cursos primário, secundário e superiores. As aulas noturnas de instrução elementar para adultos eram ministradas pelos professores Carlos A. Ferreira, Silveira Caldeira e Antônio Gabriel Franzen.

Segundo os estatutos o curso primário seria composto pelas matérias de leitura de Português, caligrafia, princípio gerais de gramática, conhecimentos úteis, geografia, noções elementares de cosmografia e aritmética prática até os decimais. O secundário, por leitura de clássicos portugueses, composição, gramática portuguesa, geografia, matemática e física, história do Brasil, língua francesa, escrituração mercantil e música vocal. Os cursos superiores de arquitetura e construção, agrimensura e mecânica industrial, a serem cumpridos em dois anos, teriam as classes de aritmética, sistema métrico e álgebra, geometria, trigonometria e desenho respectivos. $\mathrm{O}$ de agrimensura teria aulas de topografia, desenho topográfico, uso e prática de instrumentos. O de agricultura contaria com as cadeiras de física, química e ciências naturais. Havia ainda os cursos de higiene e moral, além do de direito natural e público.

23. cf Correio Paulistano 5 dez. 1873, 20 fev. 1874, p. 2 e 26 mai. 1874. 
Um dos exemplares
mais antigos do acervo
do Liceu. BOURDON, M.
Élements D’Arithmétique
par M. Bourdon, Paris:
Gauthier-Villars,
1878,. Édition redigée
conformément aux
nouveaux Programmes
de enseignement dans les
Lycées. Paris, Gauthier-
Villars, Imprimeur -
Librairie du Bureau de
Longitudes, de L'École
Polytechnique, Succeseur
de Mallet-Bachelier.
Carimbo- autógrafo e
assinatura manuscrita de
Alexandre M. Rodrigues,
São Paulo, Setembro
de 1888, timbre da
Livraria Garnier, Rio de
Janeiro e carimbo Casa
Gazeau, São Paulo

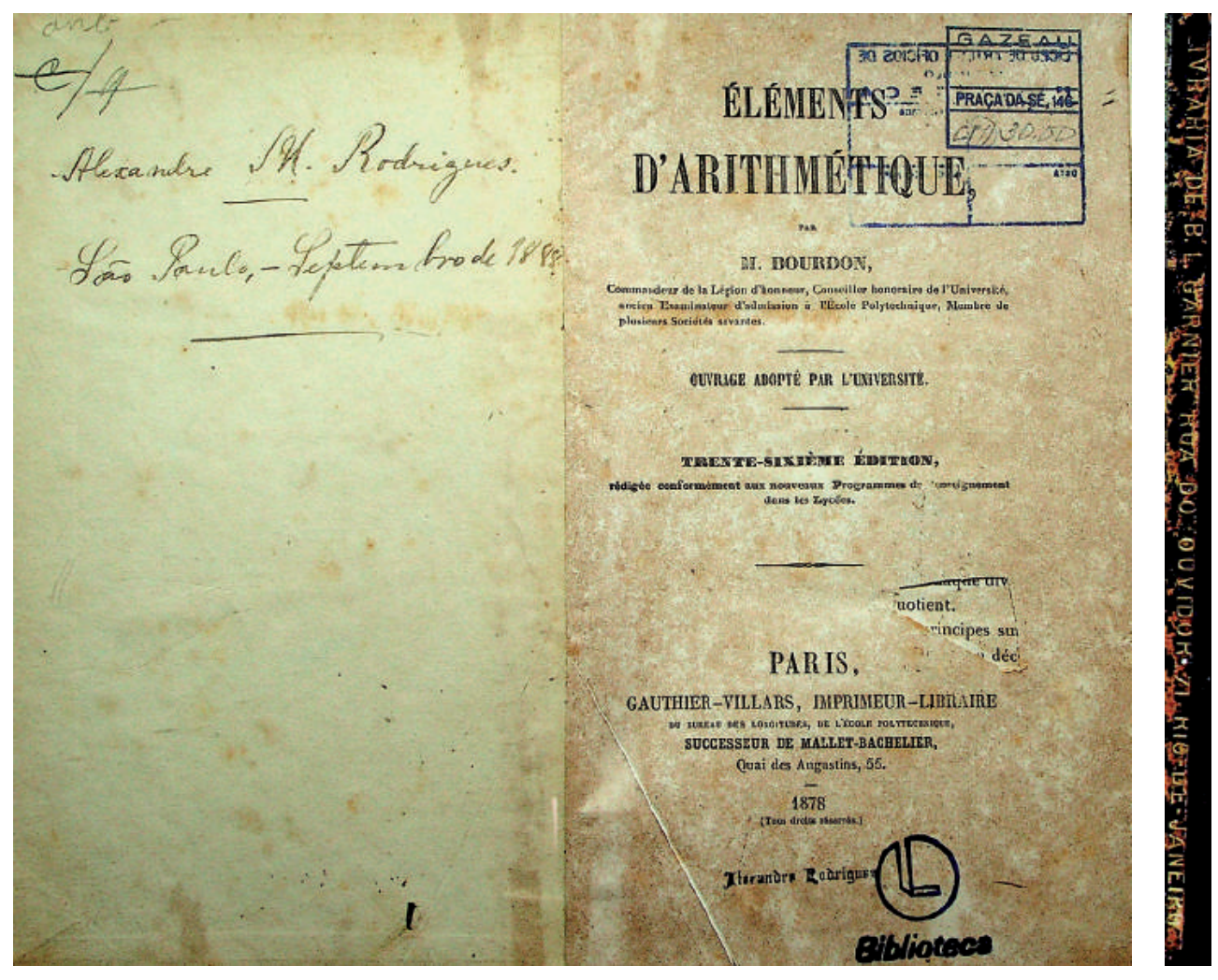

Naquela ocasião foram nomeados o diretor da biblioteca José Maria Vaz Pinho Coelho e para o posto de bibliotecário Joaquim Rodrigues Goulart. Consultando as fontes disponíveis sobre as personalidades que ocuparam estes cargos, sabemos que entre 1884 e 1893 os bibliotecários, que também eram membros da diretoria, foram Américo de Campos, Antônio Moraes Cordeiro, Brigadeiro José Vieira Couto de Magalhães, Paulo Malheiros de Melo, José Joaquim Vieira de Carvalho e Augusto de Souza Queiroz. ${ }^{24}$

No dia 24 de janeiro de 1874 um festejo literário musical beneficente comemorou o início das aulas do curso primário gratuito noturno oferecidas para crianças e adultos. Em proveito da "instrução social", música e poesia celebraram "as artes, o gosto e o estudo". Na segunda parte do programa, entre outras composições, estavam trechos de $O$ Guarani, de Antônio Carlos Gomes que estreara em Milão em 1870 e de Fantaisie sur des motifs de Weber de Ferdinand Beyer, conhecido em sua época por suas composições leves, arranjos de obras populares e

24. cf. Correio Paulistano, São Paulo, p. 2, 21 jan. 1874 e Ricardo Severo (1934). 
pelo influente método pedagógico Elementary Instruction Book for the Piano, de $1851 . .^{25}$

Uma leitura distraída do título da fantasia executada no programa nos faria pensar no sociólogo Max Weber, cuja noção de individualidade, influenciada pelo debate na educação está presente em sua Teoria da Personalidade que, aparentemente, teve pouca ressonância entre os clubes não orientalistas da América Católica. Os verdadeiros 'motivos' eram os de Carl Maria von Weber, crítico musical romântico, autor em 1811 de Ruler of the Spirits, composta como uma revisão da abertura da ópera incompleta Rübezahl que, em conjunto com outras peças e sonatas de sua autoria, influenciou músicos como Richard Wagner e Gustav Mahler. ${ }^{26}$

Depois de celebrada, a escola foi inaugurada com utensílios, mobiliário e livros próprios sendo a biblioteca aberta ao público inclusive à noite ${ }^{27}$, rivalizando com a da Faculdade de Direito. Logo em seguida o secretário da Propagadora, Joaquim Roberto de Azevedo Marques, também proprietário do jornal Correio Paulistano, publica as regras de conduta para os visitantes dentro do edifício: não portar chapéu, nem fumar ou fazer barulho e solicitar ao bibliotecário os livros e jornais a serem consultados. Somente ao diretor e aos empregados da biblioteca era lícito colocar ou retirar das estantes qualquer livro ou papel..$^{28}$

A escola da Sociedade Propagadora funcionava diariamente, cuidando da 'educação popular de fim profissional', cumprindo sua função social e habilitando mais de 800 alunos em primeiras letras.

Através de sua biblioteca proporcionava leituras públicas franqueadas aos professores, alunos e cidadãos, das 16 às 21 horas, acrescidas de conferências populares aos moldes das realizadas na corte.

Parte do projeto de desenvolvimento da instrução pública e de reformas educacionais promovidas pelo estado brasileiro em benefício dos saberes científicos e da modernidade, as Conferências Populares da Glória, realizadas no Rio de Janeiro entre 1873-1889, foram lições

25. cf. Correio Paulistano, São Paulo, p. 3, 24 jan.1874 e p.2, 27 jan.1874 para programa do evento e comentários sobre o "cultivo artístico" paulista, respectivamente.

26. cf. International Music Score Library Project, verbete Weber, Carl Maria von.

27. cf. Domingos Jaguaribe (1889).

28. cf. Correio Paulistano, São Paulo, 12 fev. 1874. 
independentes que pretendiam popularizar o conhecimento. Dirigidas pelo Conselheiro Manuel Francisco Correa, estudante de direito no Largo São Francisco em 1854, senador do Império, sócio do Instituto Histórico e Geográfico Brasileiro e autor de Ensino obrigatório, conf. populares, as conferências foram publicadas em 1876 pela Typographia Imperial e Constitucional de J. de Villeneuve \& Cia. ${ }^{29}$ As palestras foram frequentadas pelo imperador, sua família e por público seleto, acolhendo em seu calendário uma série de preleções públicas feitas por professores e por afiliados de lojas maçônicas, divulgando, de fato, conhecimentos relacionados às ciências naturais e sociais, à política e à cultura, mas apenas entre as camadas letradas.

Educação, instrução e beneficência eram entendidas como móveis de esclarecimento e alavancas para a modernidade quando formassem trabalhadores especializados cujas necessidades profissionais não poderiam ser atendidas pela educação profissional ou secundária. A eles eram oferecidos ensinamentos de ciências naturais, industriais e outras formas de conhecimento útil.

A escola e a biblioteca da Propagadora recebiam donativos de diferentes naturezas. Em 1874, logo depois de começar a funcionar a Propagadora recebeu montantes em réis, oito frascos de tinta americana preparados por José Francisco de Almeida, catálogos como o da Exposição Universal de Viena (1873), exemplares da Revista Instrução Nacional, assinatura da revista Correspondência de Coimbra, cem exemplares do Silabário Português, os livros de leitura e gramática portuguesa de Abílio Cesar Borges, o Barão de Macaúbas, os doze volumes do curso de Direito Civil por Alexandre Duranton doados sem nomeação do benfeitor e cem volumes não especificados ofertados pelo vigário da cidade de Bananal. ${ }^{30}$

Encontra-se na coleção bibliográfica um exemplar de grande formato com fac-símiles de escritos e autógrafos de americanos notáveis nas ciências, letras, artes e política publicado em 1874. Não se conhece sua procedência e data de entrada no acervo da instituição.

29. Ver Karoline Carula (2009, p. 27-77). A mesma tipografia imprimia o Jornal do Commércio.

30. cf. Correio Paulistano, São Paulo, 7 fev.1874. 

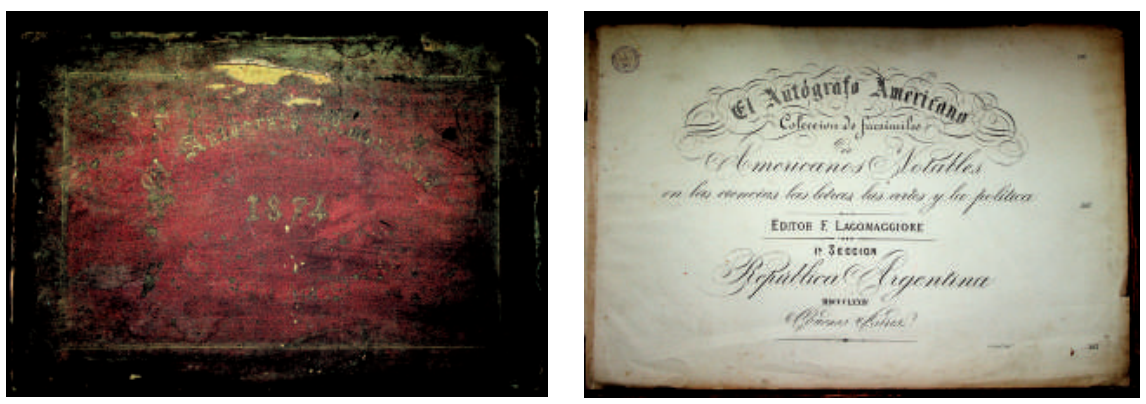

Capa e frontispicio

de El Autografo

Americano, 1874

\subsubsection{Diagramas}

Muito provavelmente os compêndios da biblioteca também se relacionavam à nova cultura técnica exigida por novos processos produtivos, complementados por livros, dicionários e material clássico. O boom industrial da segunda metade do século XIX viu o rápido crescimento das estradas de ferro, das indústrias metalúrgicas e da construção de máquinas. Os processos de produção nestas indústrias eram baseados em tecnologias cada vez mais complexas, estimulando a procura por trabalhadores que pudessem ler e decodificar as instruções, diagramas e desenhos técnicos nomeados pelos americanos como blueprints ${ }^{31}$. Na França, as écoles manuelles d'apprentissage, depois renomeadas écoles pratiques de commerce et d'industrie ensinavam, como no Liceu, ciências aplicadas e naturais, artes manuais e instrução fabril. ${ }^{32}$

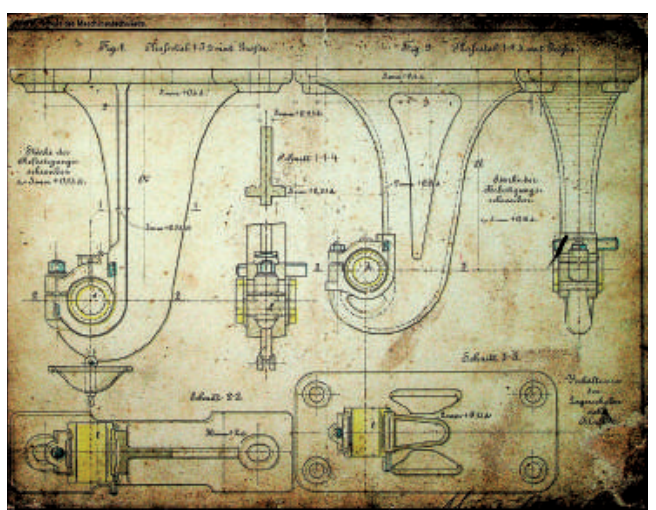

Karl Georg Weitzel. Die Schule des Maschinentechnikers. Band 9. Die Mechanik. Leipzig: Verlag Moritz Schäfer, [1894-1907]

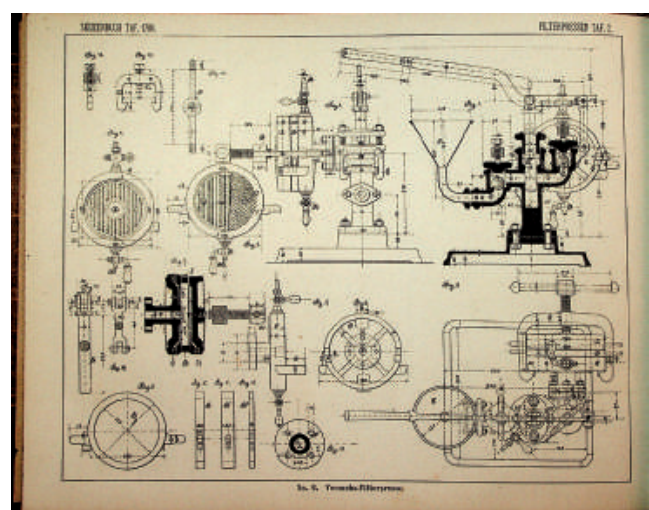

Uhland Pressen. Leipzig: Verlag von H. A. Ludwig Degene, [1920]

31. Para o aprofundamento desta questão ver Siegfried Giedion (2014).

32. Para aprofundamento das particularidades dos sistemas de ensino das artes anuais e industriais na Inglaterra, Alemanha, Suécia, Finlândia, Rússia e América do Norte, ver Charles Alpheus Bennett (2015). 


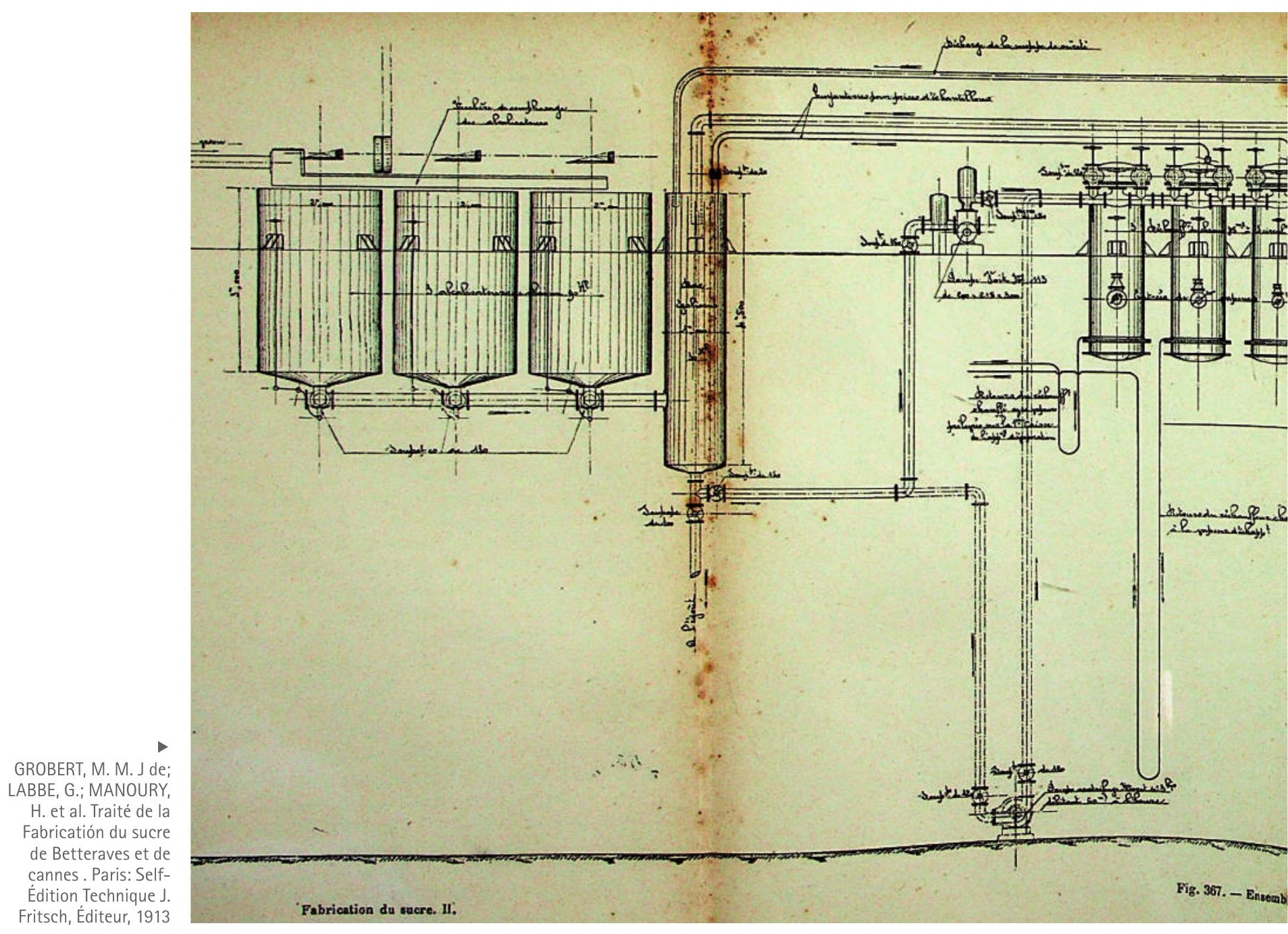

Em função destas demandas, o estado e a iniciativa privada em nível internacional, envolveram-se na organização e ativação de amplos circuitos relacionados à produção de publicações e materiais para o ensino do saber-fazer. Segundo Solange Lima, as atividades envolvendo a transmissão e aprendizado de modelos se beneficiaram das novas possibilidades de reprodutibilidade, empregando a fotografia e as técnicas subsidiárias, deram impulso à edição de variada tipologia de publicações:

[...] a intensificação editorial crescente ao longo da segunda metade do século XIX e até as primeiras décadas do século XX [...] é atestada por tiragens cada vez maiores e pela diversidade de perfis das publicações. Do século XIX em diante, além dos tradicionais manuais e repertórios, surgem enciclopédias, intensificam-se os 
Giocondo Albertolli dis. G. Merc inc. Foglia d'acanto di un capitello Corintio trata dall'antico [1782] XXIV e Ornamento di uma Metopa, per in Fregio Dorico. Ultima tavola. XXVIII.Corso elementare d ornamenti architettonichi. A Milano: Si trova presso I Autore, 1805
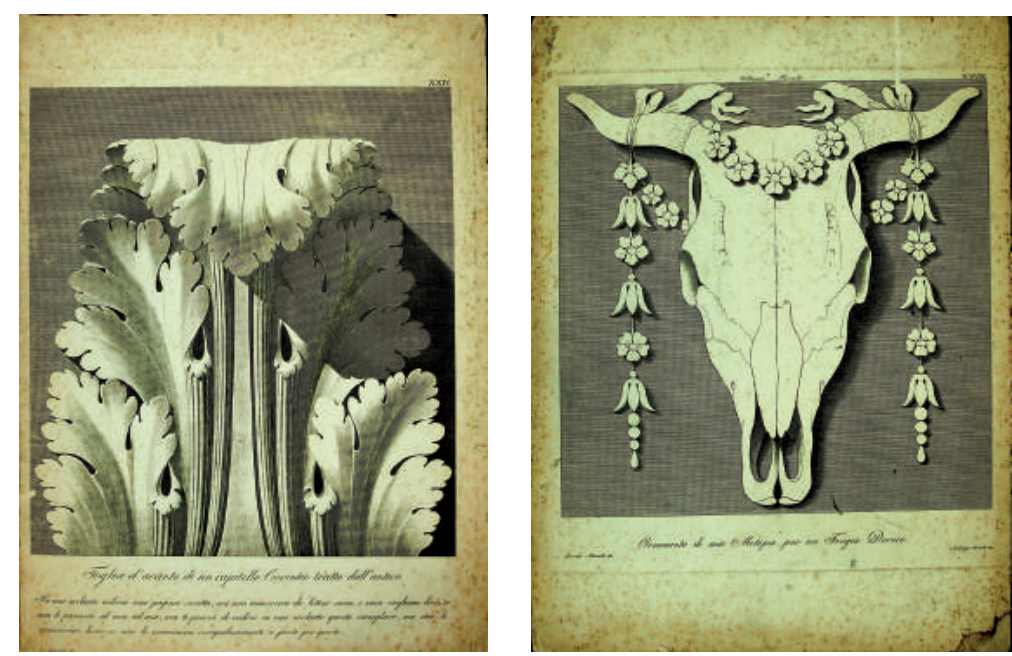

[Elementos arquitetônicos]. T_XV
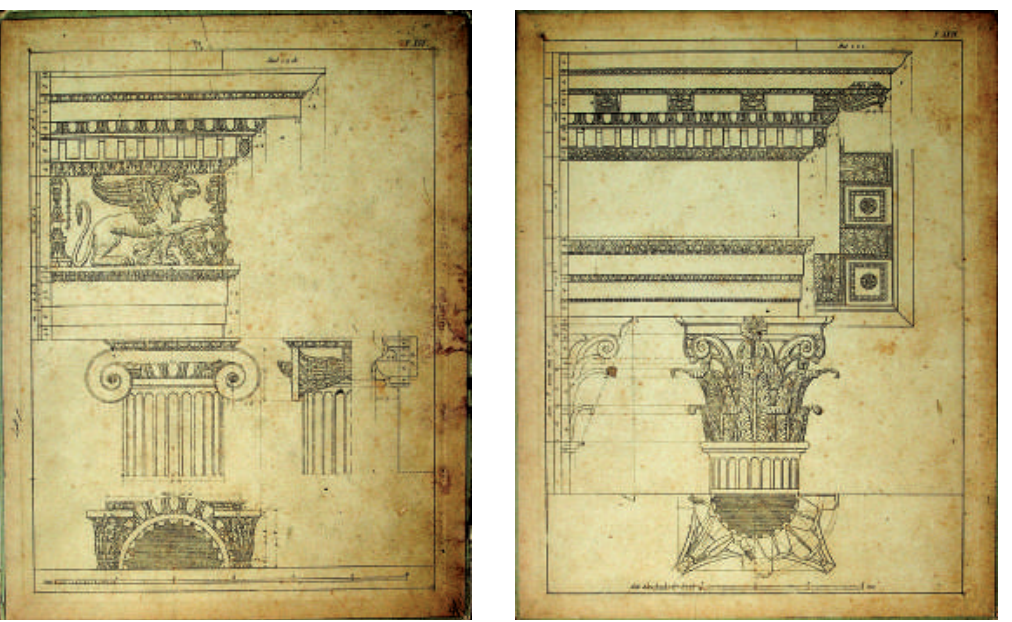

Ornamento para fachada

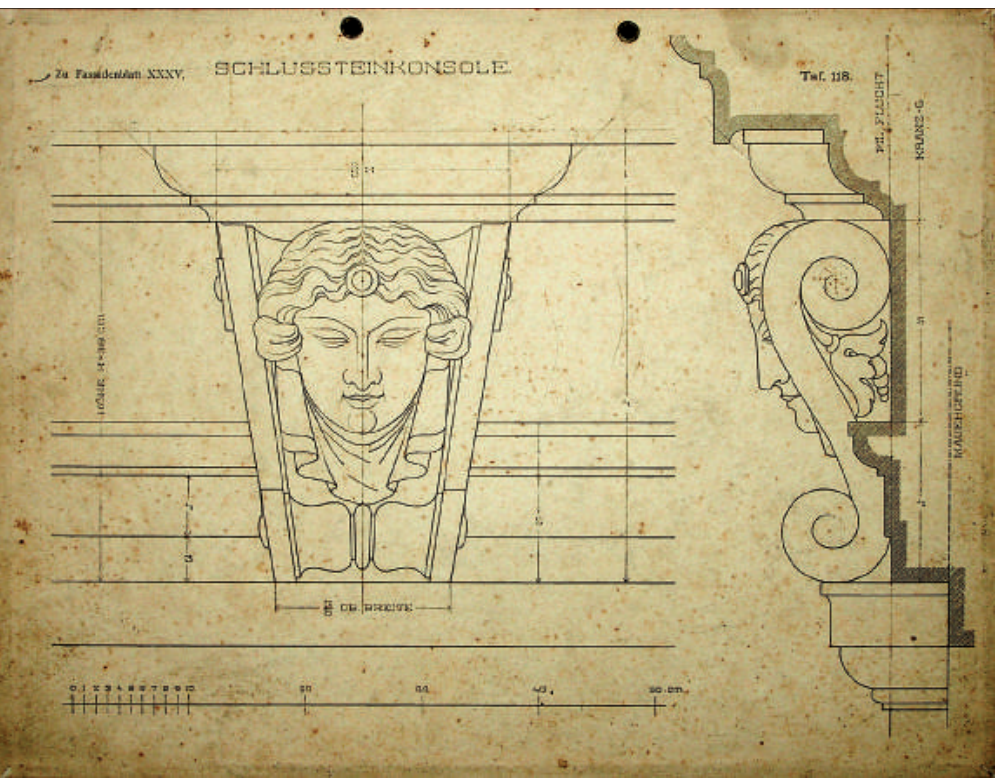


$\mathrm{O}$ positivismo ilustrado animava as reformas no ensino. $\mathrm{Na}$ Europa e no Brasil, o trabalho manual fora inserido na educação e formou uma elite orientada para o domínio do desenho e da construção de máquinas, atraindo o apoio de industrialistas, mecânicos e artesãos habilidosos. E mesmo não contando com oficinas e laboratórios próprios para o ensino das artes, as escolas treinavam as mentes, as mãos e os olhos com ensinamentos e aplicações práticas.

A monarquia constitucional dirigida por Dom Pedro II a partir do Rio de Janeiro assentava sua autoimagem virtuosa, erudita e liberal num vocabulário reformador onde razão, ciência e educação eram garantias de progresso. Reflexo positivo desta imagem pode ser encontrado, por exemplo, na tradução para o português e publicação no Diário Oficial do Império entre 1871 e 1874 dos relatórios de Hippeau sobre a instrução nos Estados Unidos da América e na Inglaterra. ${ }^{34}$ Entretanto, a imagem era ambivalente desde que em si trazia oculta a odiosa ordem escravocrata sustentada por elementos políticos conservadores. ${ }^{35}$

O Conselheiro Carlos Leôncio de Carvalho, advogado formado pela Faculdade de Direito do Largo São Francisco, o mesmo fundador da Sociedade Propagadora, Ministro do Império durante o Gabinete de João Lins Vieira Cansanção de Sinimbu (05 de janeiro de 1878 a 28 de março de 1880), explicita sua noção de modernidade no Relatório da Secretaria de Negócios do Império apresentado à Assembleia Geral compreendendo o ano de 1877 até o final de 1878. Não por acaso, seu ponto de vista está assentado no capítulo que trata da instrução pública:

Primeira condição de todo progresso material e moral, a instrução constitui o elemento vital das sociedades modernas, porque é a sua luz, como a liberdade é o seu ar. Dela dependem, para o jogo regular de seu mecanismo, todas as instituições a que está ligada imediata e essencialmente a vida política e social das nações, que, à medida que aumentam o seu cabedal científico,

34. Ver Diana Gonçalves Vidal (2012 p. 1-15). Sobre a influência de Célestin Hippeau, escritor e pedagogo francês que publicou descrições do sistema educacional de vários países, ver Maria Helena C. Bastos (2002, p. 67-112).

35. Um dos desdobramentos deste reflexo edificante da monarquia brasileira foi o comparecimento pessoal de Sua Majestade na Exposição Universal da Filadélfia em 15 de abril de 1876. Nada obstante, d. Pedro II e sua comitiva desembarcaram em Nova Iorque, estando indicados nas notas de viagem do imperador apontamentos sobre visitas a escolas, bibliotecas, museus e instituições públicas. 
descortinam sucessivamente novos horizontes e caminham mais seguras em busca de seu ideal de perfectibilidade, reformando o presente, preparando o futuro e melhorando de dia em dia as suas condições de existência. ${ }^{36}$

O Conselheiro-fundador, defendendo a difusão do ensino livre, obrigatório e gratuito diretamente do centro do Império, expressava um desejo de 'perfectibilidade' atrelado aos avanços da civilização mecanicista. Leôncio de Carvalho elaborou o Decreto no 7.247 de 19 de abril de 1879 reformando o "Ensino Primário e Secundário do Município da Corte e o Superior em todo o Império", instituindo o "ensino pratico das artes e officios" (Art. $8^{\circ}$, parágrafo $9^{\circ}$ ) a "Pratica do ensino intuitivo ou lições de cousas" (Art. $9^{\circ}$ ) e atribuindo aos governos central e municipais a responsabilidade de "Fundar ou auxiliar bibliothecas e museus pedagogicos nos logares onde houver Escolas Normaes" (Art. 10²)

O Decreto do Ensino Livre, instituindo o método intuitivo para as escolas primárias públicas no Império, apostava também nos benefícios da percepção intuitiva. Naquele mesmo ano Jules Ferry, ministro da Instruction Publique francesa e reformador do sistema de ensino francês, criava o Museu Pedagógico de Paris. ${ }^{38} \mathrm{~A}$ leçon de choses (object lessons para os norte-americanos), adotada nas escolas primárias da Europa e dos Estados Unidos, propugnava aplicações reiteradas e diversificadas da intuição.

Os objetos deveriam ser observados em sua concretude, para a partir dela, adquirir-se uma ideia abstrata sobre a coisa, ensinando-se essencialmente pelo aspecto. As lições serviam, sobretudo, para que se aprendesse a observar, perseverar na observação, saber olhar, analisar, comparar e descrever metodicamente o mundo para compreendê-lo, mantendo contato com a variedade atraente da realidade ao invés de catalogá-la maquinalmente.

Pregando que a aprendizagem deveria partir dos sentidos para chegar à intelecção, privilegiar o conhecimento do que era próximo para atingir o distante, o concreto para alcançar o abstrato, o método

36. cf. Brasil, Carlos Leôncio de Carvalho (1878, p. 23).

37. cf. Brasil (1879, Art. $8^{\circ}$, Art. $9^{\circ}$ Art. $10^{\circ}$ ), grifo nosso.

38. Musée pédagogique de l’État. cf. Ferdinand Edouard Buisson (1911, verbete museu pedagógico). 
intuitivo, também posto em prática no Liceu, "abria as portas da escola para a introdução de um grande conjunto de objetos a serem experimentados pelos alunos em seu processo de aquisição de conhecimentos"39.

De modo a adequar-se ao Decreto e a perseguir o objetivo de "ministrar gratuitamente ao povo os conhecimentos necessários às artes e ofícios, ao comércio, à lavoura e às indústrias, através de cursos profissionalizantes", em $1^{\circ}$ de setembro de 1882 a Propagadora foi reorganizada com o nome de Liceu de Artes e Ofícios dilatando seu programa. A ele foram acrescentadas aulas de francês e inglês, geografia, história pátria, história universal, cosmografia, filosofia, história da arte e dos ofícios, anatomia, estética, higiene, anatomia e fisiologia das paixões, psicologia, elementos de direito natural e direito constitucional e economia política. Criava-se o 'curso especial de artes e ofícios' e outros, de comércio e agricultura e ciências, pretendia-se publicar revista dedicada a questões do ensino primário e profissional, ampliava-se a biblioteca. ${ }^{40}$

O novo programa dividia-se em duas seções visando suas 'aplicações elementares e práticas': Ciências Aplicadas e Artes. O primeiro abrangia aritmética, álgebra, geometria plana e descritiva, geologia, botânica, física, química, mecânica, agrimensura e estereometria. O segundo agrupava desenho linear, de ornato, de figura, flores e paisagens, de máquinas, de arquitetura, modelação, escultura de ornatos e arte, estatuária, caligrafia, gravura, pintura, fotografia e música.

As aulas de desenho linear e de figuras começaram a funcionar no dia 5 de setembro. Para elas o Liceu se comprometia a fornecer gratuitamente aos alunos lápis, papel e tinta exigindo, porém, que os inscritos no curso de desenho linear forneçam às suas custas "uma caixa de compassos e tira-linhas, um transportador, uma esquadria, uma régua, um plantilho de curvas e um canivete". Os do curso de desenho de figuras deveriam fornecer apenas o canivete. A chamada acrescenta que "o estudo do desenho é "hoje um elemento essencial em todas as indústrias e ofícios" ${ }^{” 11}$.

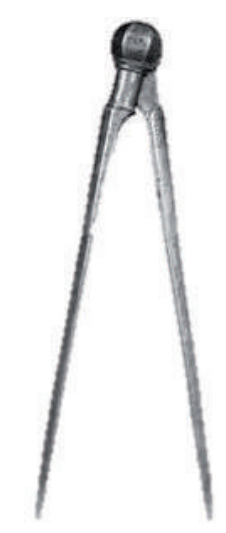

39. cf. Diana Gonçalves Vidal (2012, p.9).

40. cf. Almanach Administativo, Commercial e Industrial da Província de São Paulo para o Anno de 1884, São Paulo, p. 114-115.

41. Cf. Correio Paulistano, São Paulo, p. 2, 5 set. 1882. 
No ano seguinte o Liceu 'mudou-se do seu primeiro habitat' para um prédio na Rua da Boa Morte, 17, atual rua do Carmo, repartindo salas com a Escola Normal e permanecendo neste endereço entre 1883 e 1886. No Relatório dirigido à Assembleia Provincial pelo Conselheiro Soares Brandão, transcrito no Almanaque Administrativo, Comercial e Industrial da Província de São Paulo para o Ano de 1884, o Liceu autodenomina-se 'escola industrial', contando mais de 600 alunos atendidos por com um corpo docente do qual destacamos Clementino de Souza e Castro, lecionando geometria e álgebra; George Le Barbier, desenho geométrico; George Le Barbier e Guilherme Kraemer, desenho linear, de figura, de flores, de ornatos, de paisagem e pintura; Emilio Ascagne e Jules Martin, modelação; Paulo Bourroul, química; Teófilo Dias Antônio, estética; Gabriel Franzen e Eugenio Motta Paes, responsáveis pelas aulas do curso primário ${ }^{42}$.

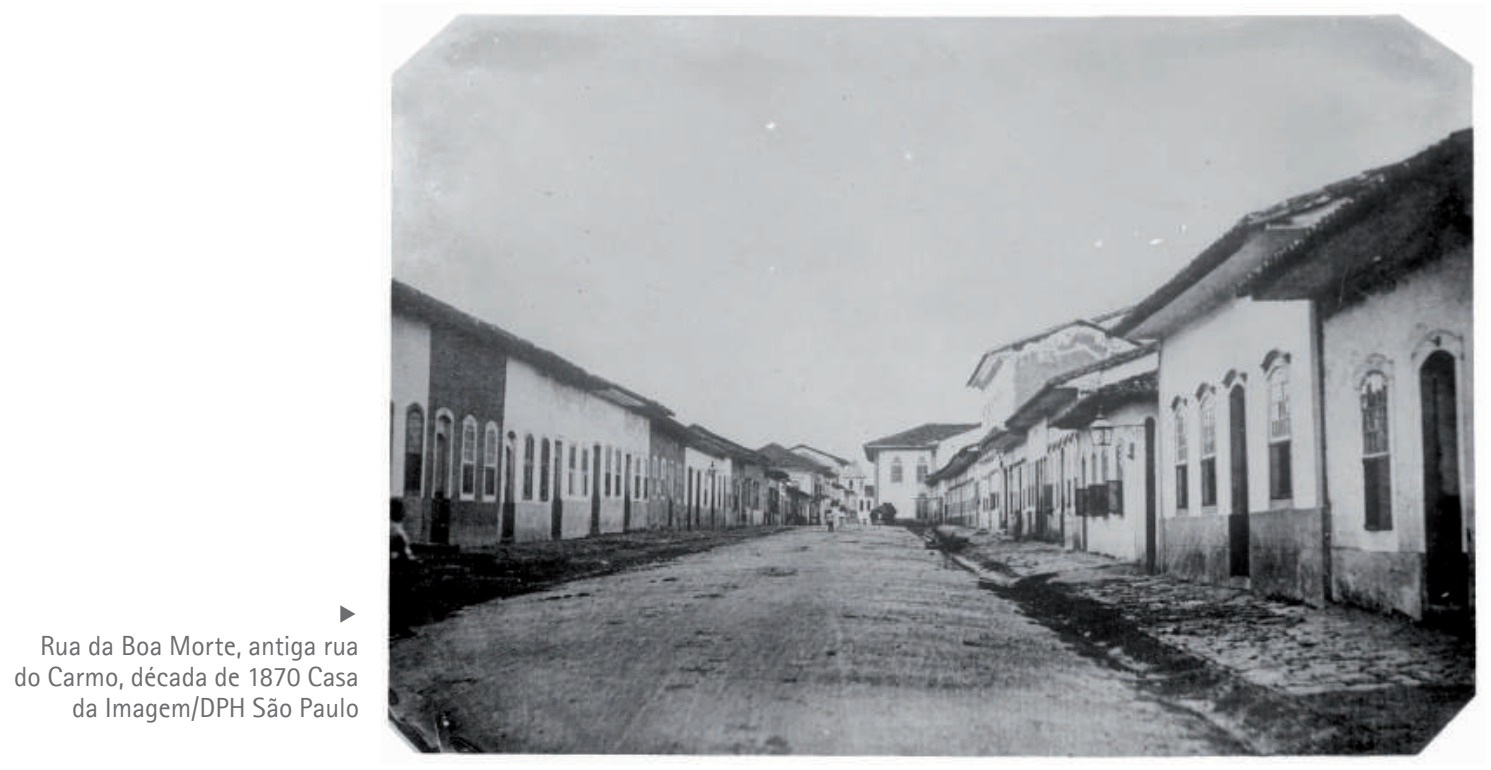

Como o Liceu teria aumentado sua biblioteca quando reorganizara seu programa? Anatole L. Garraux, o maior livreiro da cidade, associado à Propagadora em 1873 e à Casa Garnier no Rio de Janeiro teria colaborado com a biblioteca de algum modo? ${ }^{43}$ Não sabemos quais,

42. Cf. Ricardo Severo (1934, p.13-18) e Almanach Administativo, Commercial e Industrial da Provincia de São Paulo para o Anno de 1884, São Paulo, pág. 114-115, 1884.

43. Ver Marisa Midori Deaecto (2005). 
mas é possível que tenha adquirido ou recebido outros títulos relativos às artes e às ciências, talvez até aqueles apresentados no Congresso Internacional Pedagógico ocorrido em Buenos Aires em 1882, evento comentado pelo Barão de Macaúbas. ${ }^{44}$

As conquistas da escola alinhadas aos pilares da 'ilustração e educação' e ao ideal de 'cultura geral e popular' puderam ser conferidas na $1^{a}$ Exposição de trabalhos dos alunos, realizada em 21 de novembro de 1884. A ocasião foi descrita como uma "festa popular" irresistível, na qual estiveram presentes a Princesa Isabel e o Conde D'Eu, junto com uma multidão de curiosos que lotou as salas acanhadas.

Todos puderam admirar os desenhos expostos, que segundo a resenha de Don Gigadas, el Chico para A Província de São Paulo, eram "cópias feitas de desenhos litógrafos e de cópias de modelos de gesso". Para el Chico, os estudos da Vênus de Milo, uma cabeça de mulher e de estudos de extremidades de autoria de Manoel Santiago Peres, mais um estudo de perfil da Vênus de autoria de Aníbal Pires de Albuquerque mereceram ser assinalados, assim como os estudos de modelos litografados de João R. de Siqueira. ${ }^{45}$ Terminada a visita, os representantes da família real ofertaram ao Liceu "a quantia de 500 mil réis para ser distribuída em prêmios". ${ }^{46}$

Interessante notar que, segundo a crônica do jornal, o Liceu não expunha produtos e sim desenhos de modelos. Isto é, instruía a desenhar. Embora já dotado de um programa de ensino profissional, com ênfase em ciências, e artes aplicadas, matemáticas e medida dos sólidos (estereometria), processos inovadores como fotografia, desenhos e exercícios manuais de modelação e escultura de ornatos e arte, o Liceu não possuía oficinas próprias e provavelmente não contava com matérias para o treinamento de professores. A Escola Normal, que funcionou ao lado do Liceu e intermitentemente até o final da década de 1880, lutava contra falta de materiais didáticos e a evasão de alunos não era muito efetiva na formação de docentes para a cidade.

Desde a criação da Sociedade Propagadora prêmios eram oferecidos aos alunos exemplares que também recebiam diplomas por boa conduta e merecimento intelectual. Houve quem, como a Livraria Faro

44. Ver Demerval Saviani (2007).

45. cf, A Província de São Paulo, p.1, 3 dez 1884.

46. cf. Ricardo Severo, (1934, p. 16). 
\& Lino se propusesse a subsidiar as distinções aos alunos instituindo um prêmio anual denominado Leôncio de Carvalho "para ser oferecido ao aluno que mais se distinguir nas aulas de Desenho do Liceu de Artes e Ofícios de São Paulo. O prêmio de 1884 consistiu no livro 'O Curso de Desenho de Eugene Ciceri, ricamente impresso e encadernado, com finíssimas pinturas e tendo gravado sobre a capa em letras de ouro" ${ }^{47}$

A Casa Faro participara da Exposição Pedagógica em 1883, organizada no Rio de Janeiro por Leôncio de Carvalho em conjunto com a Associação Protetora da Infância Desamparada, dirigida pelo Conde d'Eu. Compartilhando do circuito alargado das exposições mundiais, participaram do evento:

“(...) colégios brasileiros e fabricantes e distribuidores nacionais ou estrangeiros de móveis e materiais didáticos. Carteiras, livros, mapas, objetos de laboratório de física, química e história natural, quadros de história, globos, material de ginástica, além de relatórios e documentos de várias nações, como Bélgica, França, Estados Unidos, Alemanha, Holanda, Portugal e Argentina distribuíram-se pelos ambientes." ${ }^{38}$

Durante a Exposição nosso conselheiro-fundador realizou a Conferência sobre Educação da Infância, mandada publicar juntamente com as conferências de Antônio de Paula Freitas, Amaro Cavalcanti, Joaquim Abílio Borges e do barão de Macaúbas, anotadas por Júlio de Lima Franco, autor do Catalogo da bibliotheca do Museu Escolar Nacional Rio de Janeiro, editado por G. Leuzinger em 1885. ${ }^{49}$

Segundo Vidal, o Guia para os visitantes mencionava como expositores franceses as empresas "Guillard, Aillaud e Cie., Charles Delagrave, Hachette \& Comp., E. Bertaux, Ludovic Baschet, Dellain Frère, Carue, Victor Palmé, Charavay Frères, Paulo Ollendorf, Ducher \& Comp., P. Garcet \& Nisius, W. Walcker, Calman Lévy, Firmin -Didot 7 Comp., A Ghio, Armand Colin, Furne, Juvet \& Comp., Gaspar, Charles Fouraut \& Fils, Monneq Frères, Victor Sarlit \& Cia., W. Henrischsen, Rousseau e Ract \& Falquet. Dos museus escolares havia somente os editados por Saffray Faiquet". ${ }^{0}$

47. cf, A Província de São Paulo, São Paulo, 17 fev. 1884.

48. cf. Diana Gonçalves Vidal (2012, p.1-2).

49. Ver Brasil (1884, p. 5-23).

50. cf. Diana Gonçalves Vidal (2009, p.47). 
Consultando o Guia, sabemos que os expositores foram divididos em diferentes grupos e ambientes sendo que a Librairie Delagrave e Hachette \& Comp. dividiram a sala de número dez. Nesta sala a Maison Delagrave expôs cerca de 160 livros, o Museu das Famílias (espécie de fascículo ilustrado mensal para leitura noturna), duas caixinhas de lições de coisas, contadores mecânicos de Chaumell e Leroy, claraboia indicando ao lado do item que se referia a geografia em 10 polegadas, uma caixinha de dominó geográfico, dez globos terrestres e dois celestes e dois cosmógrafos ${ }^{51}$. Em outro setor da exposição exibiu o museu industrial Dorangeon ${ }^{52}$.

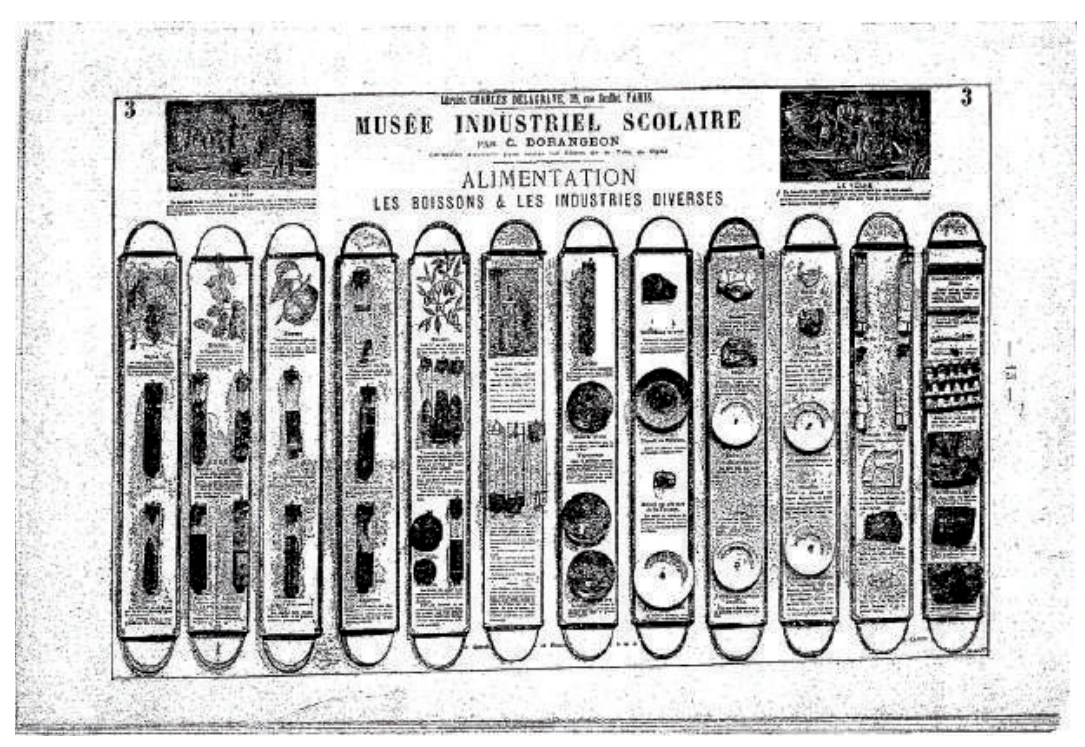

4

Museu Industrial Dorageon. Catálogo Delagrave, 1892. Bibliothèque nationale de France, Paris

51. cf. Brasil. GUIA para os visitantes da Exposição Pedagógica (1883, pp. 62; 69; 73; 177). 52. O Musée Industriel Dorangeon, exposto pela Librairie Delagrave e mencionado nas atas do júri da exposição pedagógica de 1883, era acompanhado pela monografia Leçons de choses: d'après le musée industriel scolaire / de C. Dorangeon, impressa pela Librairie, com conteúdos explicativos para cada curso. Composto por 12 pranchas que ilustram as produções de 75 indústrias com 1200 amostras, desde matérias-primas até produtos artesanais, não possibilitava qualquer manipulação por parte dos alunos. Os museus dependiam de contribuições ou fornecedores comerciais para aumentar seu estoque de espécimes e objetos. Havia fornecedores-chave de conjuntos de lições de coisas com amostras respectivas como Oliver e Boyd de Edimburgo, Museu Dorangeon e Cox \& Co. Um museu colonial, como o Museu Industrial Sanitário e Tecnológico de New South Wales (precursor do Sidney Powerhouse Museum), comprou em 1885 um armário de conchas, minério de prata e ouro, modelos de olho, orelha e nariz, modelos em madeira de cristais, um grande número de cartões de lição de coisas e 56 modelos de frutas de cera. Foram comprados quadros de parede, diagramas e tabelas, às vezes em francês ou alemão, e um grande número de 'artigos' chineses, moldes de gesso de Paris e modelos mecânicos e industriais em escala plena. Cf. Martin Lawn (p. 23), trad. da A. 
A Casa Faro e Lino e o Doutor Joaquim Viegas de Menezes Vieira expuseram museus escolares e grande diversidade de objetos educativos, além do Museu Caixa Saffray destinado ao emprego do método intuitivo e, segundo os julgadores, bem conhecido no país. ${ }^{53}$

As comissões julgadoras da exposição foram organizadas em distintas categorias que incluíam, entre outros, planos e arquitetura dos edifícios escolares, planos de bibliotecas e museus escolares, mobília escolar, alfabetos, silabários, livros e quadros de leitura, instrumentos e aparelhos para as aplicações elementares de física, química e mecânica e livros de ensino destas matérias, música, ensino dos cegos, ensino dos surdos-mudos, produtos naturais e publicações referentes à história natural, instrumentos próprios para ofícios, trabalhos dos alunos e coleções destinadas às lições de coisas e à ornamentação escolar, relacionadas ao método intuitivo. ${ }^{54}$

Muito provavelmente foi nesta ocasião que Leôncio de Carvalho conheceu a Librairie Charles Delagrave, a quem encomendou um museu pedagógico para o Liceu de São Paulo pagando por ele a quantia de 2: $617 \$ 500$ (dois milhões, seiscentos e dezessete mil réis e 500 mirréis). ${ }^{55}$

A Librairie Delagrave é assim apresentada no Bulletin de l'Union Centrale. Revue mensuelle des beaux-arts appliqués à l'industrie de 1876:

"La maison Delagrave, fondée en 1839 par MM. Dezobry et Magdeleine, exposait sa collection très-nombreuse d'ouvrages et de tableaux pour les asiles et les écoles primaires, ses dictionnaires, dictionnaire de biographie et d'histoire, dictionnaire des sciences morales et politiques, dictionnaire des sciences, les éditions annotées des classiques grecs et latins, sa collection de livres pour l'enseignement secondaire spécial et pour l'enseignement scientifique des lycées, ses nombreuses publications géographiques, cartes en relief, cartes murales, atlas et livres

53. Ver BRASIL. ACTAS e pareceres do Congresso da Instrucção (1882-1883, p. 62, 123). Curioso sabermos pela leitura das atas que H. Laemmert \& Comp. recebeu diploma de segunda classe pela impressão e publicação da história natural de C.F. Ph. Martius e menção honrosa por um alfabeto pitoresco.

54. Ver Brasil. ACTAS e pareceres do Congresso da Instrucção, 1882-1883.

55. Segundo o Almanaque da Província de 1887, o próprio conselheiro escolheu e comprou as coleções do museu para o Liceu, instituição dedicada a "ministrar gratuitamente ao povo os conhecimentos necessários aos ofícios, artes, ao comércio, à lavoura e às indústrias". Cf. Ricardo Severo (1934, p.173). 
d'enseignement. [...] édite des modèles en plâtre qui atteignent le même but pour la géométrie descriptive que ceux de $M$. Forestier pour la perspective; nous ne saurions trop insister sur l'importance qu'il $y$ a à encourager de semblables travaux au point de vue de la facilité de l'enseignement." ${ }^{56}$

O Journal des chambres de commerce et d'industrie, commerce françaises et étrangères d'Europe, dedica uma página inteira à apresentação da editora destacando o cuidado, o bom gosto, a elegância e o luxo de suas publicações. A editora publicou em 1899 o livro Le Brésil en 1889: avec une carte de l'empire en chromolithographie com artigo de Frederico Santa Anna Nery, do Barão de Saboia, L. Cruls e do contra -almirante Barão de Tefé sobre a instrução pública no Brasil. ${ }^{57}$

Encerrada a Exposição Pedagógica, os objetos exibidos ficaram no Rio de Janeiro e constituíram o primeiro núcleo do acervo do Museu Escolar Nacional, criado pela Sociedade Mantenedora do Museu Escolar Nacional (1883), cuja diretoria contava com muitos membros, alguns filiados à maçonaria. Faziam parte da diretoria o Conde D'Eu, Luís Pedreira do Couto Ferraz, Senador Visconde de Bom Retiro e o próprio Leôncio, primeiro secretário. O museu escolar foi estabelecido em 1883 e mantido pela Associação Promotora de Instrução do Rio de Janeiro. ${ }^{58}$ Acompanhando a revolução educacional fomentada pela corte que seguia de perto os modelos de instrução internacionais, o ensino no Liceu contava, então, com recursos pedagógicos magníficos: uma biblioteca de mais de três mil volumes acrescida então pelo museu pedagógico "sob orientação do método intuitivo, adotado com sucesso nas escolas primárias da Europa e dos Estados Unidos". 59

56. cf.Union Centrale (1874/08/01-1876/07/0, p. 12, p. 11).

57. Agradeço à professora doutora Diana Gonçalves Vidal a indicação desta obra, assim como de fontes essenciais para o entendimento da história da educação no século XIX. 58. Ver Milena Aparecida Almeida Candiá (s.d, s.p.). A Diretoria da Sociedade Mantenedora do Museu Escolar Nacional contava ainda com a presença de Manuel Francisco Lisboa, a quem Benjamin Franklin Ramiz Galvão, Inspetor Geral da Instrução Primária e Secundária solicita material clássico e biblioteca para que integrem o Pedagogium. O estabelecimento de ensino profissional assim denominado criado em 1890 por Benjamin Constant, centro de pesquisas e capacitador de professores, era "flor exótica" do projeto educacional vigente. Havia ainda, no Rio de Janeiro, a Associação Propagadora de Cursos Noturnos, presidida por Leôncio de Carvalho e cujo presidente honorário era o Barão Homem de Mello.

59. cf. Ricardo Severo (1934, p. 16). 
O museu pedagógico do Liceu foi inaugurado por Dom Pedro II em $1885^{60}$ e franqueado às escolas públicas da cidade, conforme informado à Assembleia Provincial em 1889 tendo sido considerado item precioso no conjunto de melhorias pedagógicas como a diversificação do material escolar, mudanças nos espaços e nas condições higiênicas dos colégios. A diretoria da escola,

"Para dar ao povo a instrução profissional de que tanto carece, hoje uma das principais preocupações das nações civilizadas, ensinar-lhes os princípios de ciências naturais, como zoologia, botânica, mineralogia e outras, [...] foi obrigada a mandar vir da Europa um pequeno museu de ensino aplicado àqueles ramos de conhecimentos humanos, e que na Bélgica, Suiça e outros países tem dado resultado admirável". ${ }^{61}$

Nossa fonte preferencial afirma que o museu era composto de "quadros, mapas, modelos, exemplares, amostras, aparelhos, maquinismos, reproduções, etc., próprios para o ensino e exercício práticos", o museu abrangia diferentes seções sendo integrado às matérias das aulas. Os itens usados no Curso Preparatório eram mapas de leitura, lições de coisas, história natural, geografia e cosmografia; no de Desenho de Ornato, estampas e modelos ornamentais em gesso e madeira; no Desenho de Figura, anatomia artística, estátuas e composições em gesso; no de Desenho e pintura decorativa, painéis ornamentais e quadros; no de Mecânica, modelos a aparelhos para o estudo da cinemática e dinâmica, órgãos de máquinas, ferramentas. Havia ainda usos para os cursos de Física, Química e Eletrotécnica. ${ }^{62}$

Ainda que não específicas, estas informações sobre o museu ajudam-nos a entender a inserção de seus recursos pedagógicos no sistema de ensino do Liceu, onde as experiências de aprendizado

60. O imperador que se fez acompanhar do Presidente da Província, João Alfredo Correia de Oliveira, do Ministro da Agricultura, Antônio da Silva Prado, de João Lustosa da Cunha Paranaguá, Visconde de Paranaguá, de Vicente Cândido Figueira de Saboia, Barão de Saboia, de Francisco Pereira Pinto, Barão de Ivinhema e outros dignitários tendo sido introduzido pelos diretores Leôncio de Carvalho, Rangel Pestana, Antônio Carlos de Andrada e Vieira de Carvalho. O imperador assistiu as aulas dos professores Roso Lagoa, Gabriel Franzen, Antonio Aymoré e Galdino Bittencourt.

61. cf. Ricardo Severo (1934, p. 175).

62. cf. Ricardo Severo (1934). 
pressupunham a conexão entre o aprender e o fazer. É extremamente difícil afirmar quais exatamente eram os painéis, quadros, reproduções, modelos de vários tipos, incluindo modelos anatômicos, maquinismos e ferramentas.

Aparentemente o que seja relativo a qualquer tipo de objetos, maquinismos relativos a um museu pedagógico não remanesceu no acervo da instituição. Sem acesso à documentação que comprove a aquisição comercial e a descrição original das peças, as aproximações ao museu podem ser conduzidas através da análise das ofertas de conjuntos pedagógicos constantes nos catálogos do seu fabricante, existentes na Biblioteca Nacional de Paris.

Os catálogos ilustrados publicados por Delagrave, partilhando dos predicados apontados nas apresentações referidas acima, trazem ofertas primorosas de mobiliário escolar, aparelhos de ginástica, livros e dicionários, material de ensino e de desenho de acordo com os programas oficiais franceses.

Para as práticas de desenho de imitação e perfil (ronde bosse) apresentavam móveis e acessórios como mesas, suportes, baús-porta modelo, apoios fixos, tamboretes, prateleiras de apoio, porta-modelos avulsos e porta-papelão, entre outros. Para o desenho de perspectiva havia uma solução ágil e clara: regra de precisão e tabuletas demonstrativas de perspectiva.

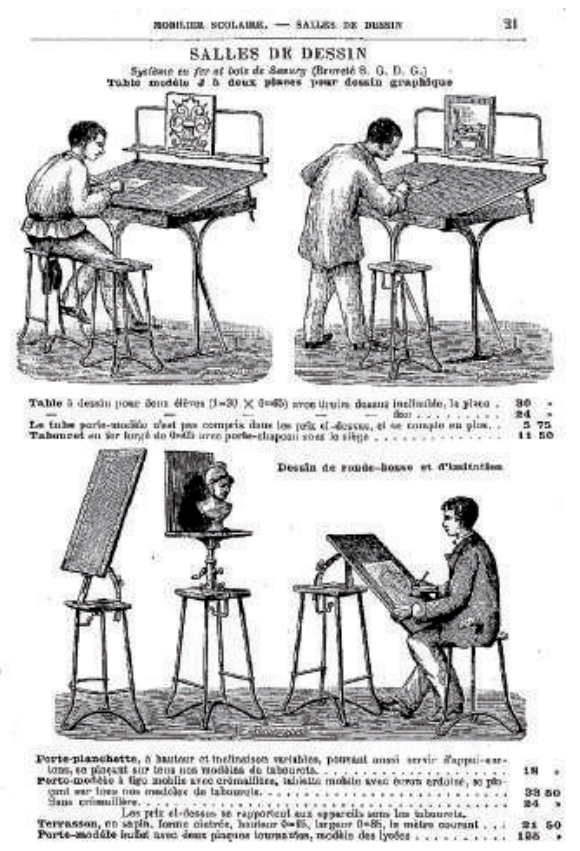

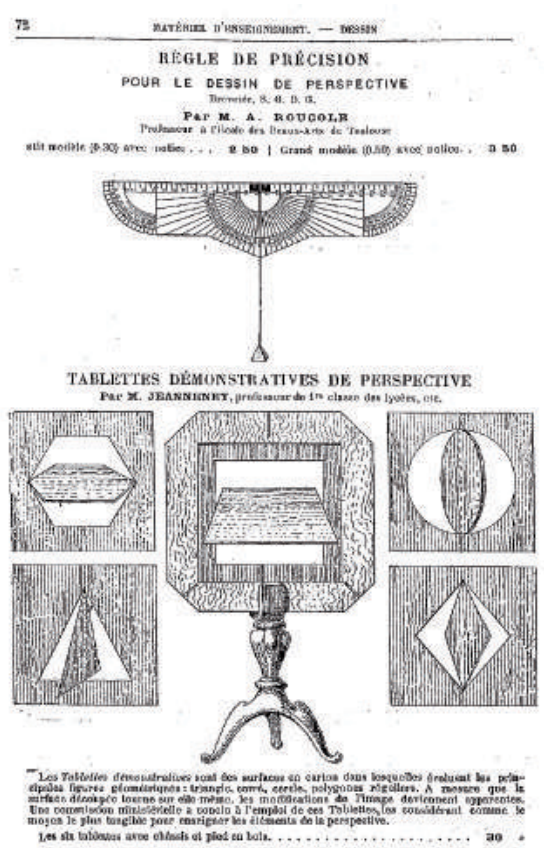

4 (esquerda) Móveis para salas de desenho. Catálogo Delagrave, 1892. Bibliothèque nationale de France, Paris

4 (direita) Regras de precisão para 0 desenho em perspectiva. Catálogo Delagrave, 1892. Bibliothèque nationale de France, Paris 
Na seção de material de ensino ofereciam-se porta lápis Froebel para crayons de mina, ardósias fictícias e naturais nuas, com réguas ou quadriculadas, barômetro, varas de monitor, bússola escolar, mostradores para ensinar as horas, diapasão e apitos e muitos outros objetos. Sólidos geométricos niquelados eram fabricados em várias cores para uso nas aulas de geometria prática.

Para as classes de ciências eram oferecidos gabinetes-vitrines para instrumentos e coleções, relógios geográficos, bustos em gesso individuais ou em consoles. Globos terrestres podiam ser montados em português e espanhol.

Para o cálculo havia o sistema métrico com contador de ábaco sobre pés ou vertical, horizontal de mão e vários outros tipos de contadores numéricos. O quadro de pesos e medidas do sistema métrico de Linares era publicado em francês e também em língua espanhola e portuguesa.

O material especial de Madame Pape Carpentier usado na lição de coisas era composto por brochura da Notice sur l'éducation des sens et quelques instruments pédagogiques; instrumentos pedagógicos como porta-cores móveis, polífono (coleção de brinquedos em matérias sonoras); demonstrações aritméticas e métricas; execução de traços geométricos com o gerador mecânico de formas planas Polygonaire e progressões de formas sólidas através dos três reinos da natureza (seções cônicas e grandes curvas).

Diante do elenco dos compêndios métricos oferecidos no catálogo percebemos, na materialidade da escola, a incorporação de objetos diferenciados baseados em pressupostos pedagógicos (método intuitivo, ensino simultâneo, escola graduada), administrativos, econômicos e políticos. A interpenetração entre ciência, educação e museologia fica evidente. ${ }^{63}$

O Musée des Leçons de Choses era dividido em três compartimentos principais, contendo amostras 'classicamente' classificadas no estado bruto e no estado processado de diferentes materiais usados para a alimentação, vestimenta e habitação, era explicado "como

63. Anotações de aula da disciplina Museus pedagógicos e escolares no final do século XIX: aspectos de uma história transnacional da educação, ministrada pela profa. Dra. Diana Gonçalves Vidal no segundo semestre de 2017, na Faculdade de Educação da Universidade de São Paulo. 
uma biblioteca de coisas, uma ferramenta valiosa para lições sobre a origem, história e fabricação das principais coisas de uso comum nos usos da vida. Há muitas maneiras de atingir os sentidos, cativar a atenção das crianças e comentar de forma impressionante, o livro de leitura atual". ${ }^{64}$

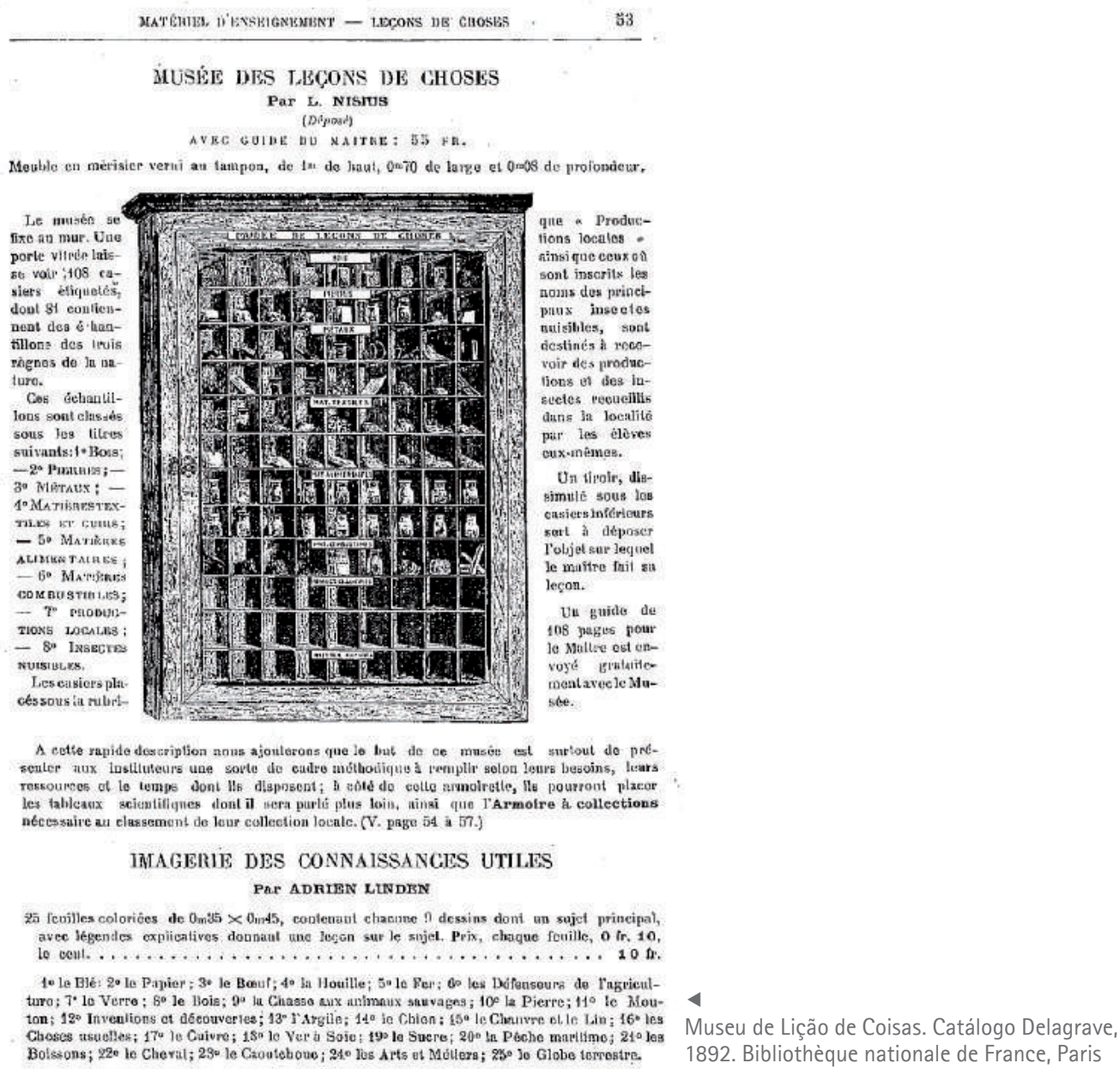

Inovações como a Lampadorama, uma espécie de lanterna mágica, podiam ser montadas em ferro ornamentado em branco ou acaju. A própria asssemblage destes mecanismos delicados exigia habilidade e conhecimento dos processos, o entendimento do funcionamento das coisas, mesclando atitudes criativas e promovendo a aliança entre artesanato e belas-artes mediada pela ciência.

64. cf. Librairie Charles Delagrave (1892, p.53), Trad. da A. 
Na introdução ao catálogo de 1892, a Librairie Delagrave indica a importância da fabricação de seus produtos e dos processos mecânicos relacionados à produção, afirmando que os procedimentos empregados lhes permitia entregar móveis higiênicos, sólidos e elegantes, a preços inferiores aos dos industriais locais. Informa ainda que em 1890 e 1891 fabricou instalações para Argélia, México, Brasil, não se incomodando, portanto, com a distância entre suas fábricas e seus comitentes. ${ }^{65}$ Além do mais, todos os itens podiam ser solicitados por encomenda telegráfica e levados até as gares para seguirem aos portos onde seriam embarcados para chegarem aos seus destinos.

Os itens componentes do catálogo fizeram parte do museu encomendado para o Liceu? Fora acompanhado de materiais escolares e outros objetos de ensino? Quais percursos percorreu desde a rue Soufflot até a Várzea do Carmo? A negociação para a compra do museu para o Liceu foi direta ou teria sido intermediada por alguma instância dos poderes central ou provincial paulista?

Se o museu pedagógico era, como definiu Ferdinand Buisson, reformador da instrução pública francesa em 1879 sob o ministério de Jules Ferry elaborando leis de 1880, relativas à escola pública, secular e obrigatória e professor de pedagogia na Sorbonne:

Por um lado, uma biblioteca de livros educacionais, legislação e administração escolar, bem como livros clássicos próprios; por outro lado, coleções de materiais didáticos e mobiliário escola. ${ }^{66}$

Quais teriam sido os títulos que acompanharam o museu adquirido para o Liceu? Os livros foram integrados aos da biblioteca da escola, numa seção particular? Ainda são muitas as perguntas sem resposta.

Em 1885 a Assembleia Provincial votou a subvenção de 12 contos de réis sancionada pelo governador José Luiz de Almeida Couto que, retirando a autorização para o Liceu funcionar contiguamente à Escola Normal, impõe à escola nova mudança de endereço. Instala-se, então, com sua biblioteca e seu museu pedagógico, num sobrado na Rua do Imperador esquina com rua de Santa Teresa, atual Roberto Simonsen.

65. Ver Librairie Charles Delagrave (1892, p. 1).

66. cf. Ferdinand Edouard Buisson (1911, verbete museu pedagógico): Trad. de A. 

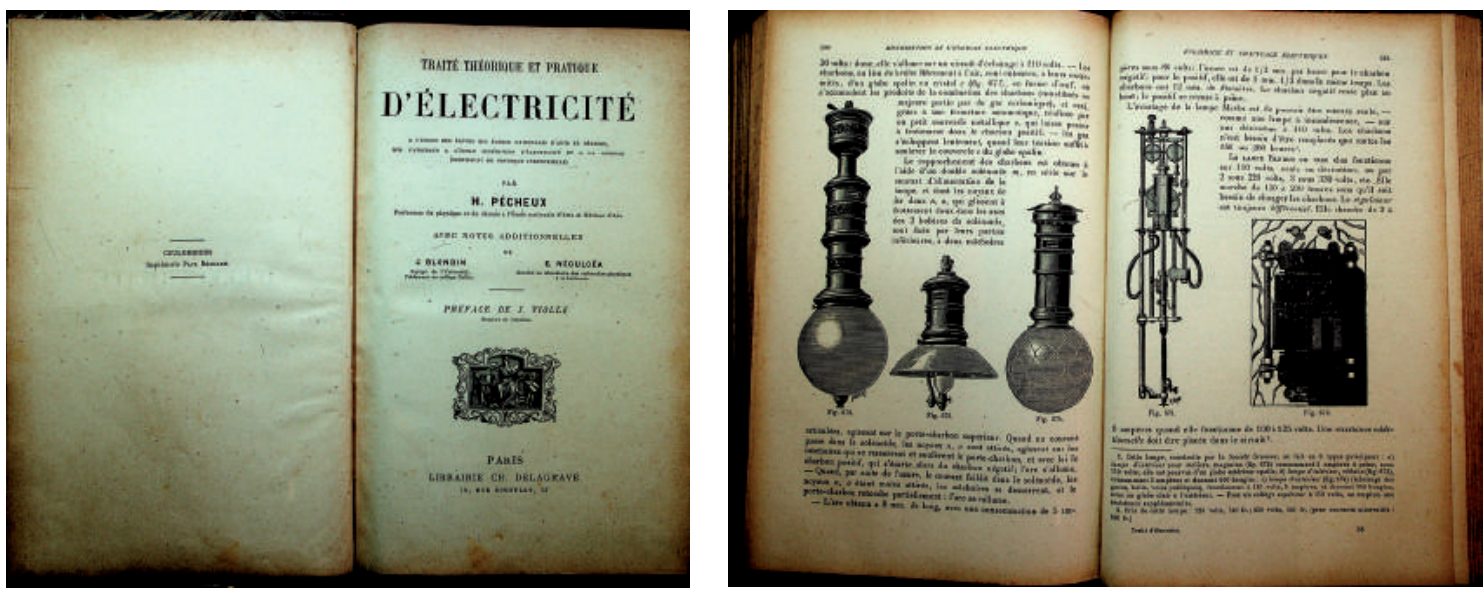

Neste período algumas cadeiras eram regidas pelos diretores, outras pelos professores Azarias de Azevedo, Roso Lagoa, Isaias Vilaça, Carlos Muller, Teófilo Dias, Clementino de Souza e Castro, Eleutério Muniz Varella, Emilio Ascagne e Frederico Rosencrantz. Era porteiro procurador Josaphat Soares Filho. ${ }^{67}$

Como seus congêneres internacionais e nacionais na Bahia, Pernambuco, Minas Gerais e Rio de Janeiro ${ }^{68}$ assim como as escolas normais pelo país, o Liceu estava então equipado como organismo polímata.

Referente à Librairie Charles Delagrave, encontramos no acervo apenas o Traité théorique et pratique d'Élétricité à l 'usage des élèves des écoles nationales d'art et métiers, des candidats à l'École Supérieure d'Élétricité et à la licence (certificat de Physique Industrielle) por H. Pécheux publicado pela editora francesa em 1904

67. Segundo Ricardo Severo (1934) a diretoria desde 1884 até 1887 compunha-se do Conselheiro Leôncio de Carvalho que presidia o Liceu, ajudado pelo $1^{\circ}$ vice-presidente Francisco Rangel Pestana e pelo $2^{\circ}$ vice-presidente Antônio Carlos Ribeiro Machado e Silva. Eram secretário Antônio Bueno de Andrada, tesoureiro Francisco de Almeida Nobre, diretores José Vieira do Couto Magalhães, J. Vieira de Carvalho, Vicente Mamede de Freitas, Antônio Candido Rodrigues. O conselho diretor era formado por Luis Pereira Barreto, Manuel Lopes de Oliveira, Paulo de Souza Queiroz, Rafael de Barros, José Duarte Rodrigues, Domingos Correa de Moraes, Frederico de Araújo Abranches, Antonio Caetano de Campos, Gabriel Franzen, Francisco Nicolau Baruel, Paulo Malheiros de Mello. Augusto Cesar Miranda de Azevedo, M.J. da Lapa Trancoso e Carlos Garcia Ferreira.

68. Para aprofundamento das questões relativas ao ensino artístico no Brasil desde a colônia, incluindo a constituição em tese de uma Escola Real das Ciências Artes e Ofícios, a chegada da Missão Francesa e a criação a Academia Imperial de Belas Artes, liceus e afins, cf. Ana Maria de Moraes Belluzzo, (1988, p. 69-80). 



\section{Capítulo 3. Laboratórios de vocações (1895-1928)}

\subsection{Ecletismo e beaux-arts}

Como abordado rapidamente no capítulo anterior, o desenvolvimento das sociedades modernas e das potências industriais foi acompanhado por profundas transformações políticas, econômicas e sociais. Os estados organizaram seus códigos civis, ordenaram o ensino laico e civil e adotaram o sistema métrico decimal.

A industrialização acelerada promoveu o desenvolvimento de novos materiais construtivos como o ferro e o concreto e métodos de construção inovadores agenciando proezas técnicas e novas formas. A tecnologia do aço viabilizou novos programas e novas tipologias arquitetônicas. Gares, apartamentos, museus, teatros, casas, escolas, boulevards, mercados, tribunais, maisons, coretos, bibliotecas, cabarés, quiosques, affiches viraram motivo de orgulho para realizadores e usuários, tornando-se até mesmo temas para obras de arte como a Gare Saint-Lazare em Paris para Claude Monet.

As cidades capitais na Europa e nas Américas foram remodeladas e urbanizadas com recursos públicos e privados, tornando-se lugares da cultura oficial. Os equipamentos modernos se multiplicaram e a arquitetura foi tomada como conhecimento técnico e experimental.

A cultura arquitetônica de Paris conformada ao longo de séculos e através de diferentes escolas conheceu novas aproximações a partir de 1830. O ensino das profissões de engenheiros, arquitetos, desenhistas e outras artes tinha diferença de escopo, métodos e podia diferir no material de apoio e em equipamentos típicos, mas convergia no cenário moderno em busca "do Belo, do Verdadeiro e do Útil". ${ }^{6}$

69. Para as considerações expostas nesta seção ver Jean-Pierre Épron, (1997, 34-112), trad. da A. 
Como nos mostra Épron, o ecletismo foi uma atitude pragmática, eficaz e moderna que promoveu debates acerca das profissões e suas práticas visando modernizá-las. Na França, a École des beaux-arts por sua estrutura, história e método singular torna-se a escola do ecletismo, reajustando constantemente o discurso arquitetural. Organizados como um corpo de sábios, os arquitetos franceses discutiam a história da arquitetura organizando publicações, conferências e comissões que alcançassem seus pares intelectuais admitindo em sua organização sindical não arquitetos, ditos membros auxiliares, engenheiros verificadores e colaboradores oriundos de outras escolas, como a École régionale des Arts industriels e a École des Arts décoratifs.

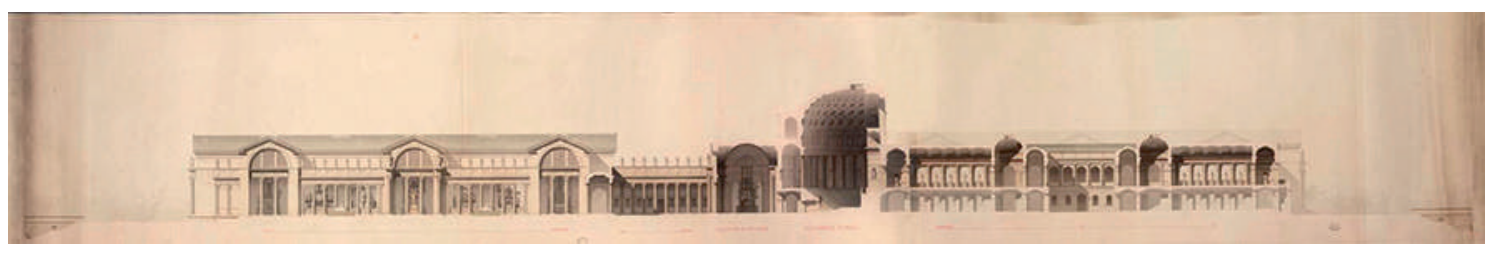

Antoine-Isidore-Eugène Godeboeuf. Palais pour l'exposition d'objets d'art et des produits de l'industrie [Corte longitudinal]. Trabalho de aluno, Prix de Rome de Arquitetura, 1836, pluma e aquarela sobre papel $55,8 \times 330 \mathrm{~cm}$. Acervo l'école nationale supérieure Beaux-arts de Paris
Entretanto, na década de 1870 a escola, pretendendo dirigir seu sistema educativo e resistindo ao controle do ensino pelo estado, perdeu sua unidade subdividindo-se em ateliers oficiais e livres dando espaço ao surgimento em Paris de escolas rivais e independentes.

Para Épron o ambiente na École des beaux-arts - laboratório de nova ideias, lugar de discussão institucional, de confrontação e competição onde os arquitetos "compõem livremente, cada um segundo sua tendência e temperamento" servindo-se de um enorme corpus referencial - propiciou a construção e desenvolvimento do ecletismo.

Le succès de la formule pédagogique de l'École des beaux-arts est attesté par sa renommée dans le monde entier. [...]. L'École n'a pas exporté le classicisme français ni un style architectural mais l'écletisme en architecture, c'est-à-dire une atitude, une démarche, une méthode toujours particulière à certaines situations et à certaines circonstances. C'est pourquoi l'écletisme a pu prendre, dans le monde, des expressions diverses ${ }^{70}$. 
O estudo das obras do passado formou um repertório de questões técnicas dispostas aos arquitetos relativamente ao emprego de materiais e ao conhecimento das estruturas da arquitetura, mais do que pela referência ao gosto. Eugène Viollet-de-Duc, arquiteto, teórico, restaurador da Sainte-Chapelle e da Catedral de Notre-Dame em Paris, autor do Dictionnaire raisonné de l'architecture française du XI au XVI siècle com edição definitiva de 1875, sugeria que os arquitetos aprendessem com os construtores princípios aplicáveis em todas as ocasiões, além da ciência prática do emprego de materiais.

Para Épron, Viollet -de-Duc fazia conhecer o passado para preparar o futuro e compreender o espírito que anima os hommes de métier desde que o arquiteto não dirige apenas o trabalho de todos, mas trabalha com eles. Épron conclui daí, e a partir de uma citação de Viollet-de-Duc, que a lição construtiva contém um ensinamento social e o ecletismo técnico repousa sobre uma moral:

[...] la classe laborieuse [...] veut des difficultés à résourdre, car son intelligence est encore plus active que se bras. [...] elle veut compreende ce qu'elle fait, pourquoi elle le fait, et qu'on lui sache gré de ce qu'elle a fait. Maçons, tailleurs de pierre, chaufourniers, charpentiers, menuisiers, serruriers, couvreurs, peintres, sculpteurs, ébénistes, tapissiers, et les subdivisions de ces divers états, forment une armée innombrable d'ouvriers et d'artisans agissant sous une direction unique [...].71

As lições construtivas do ecletismo foram desenvolvidas no ensino da École des beaux-arts. E para garantir seu lugar entre a técnica os arquitetos dominarão as informações, descrições e comparações entre diferentes sistemas, materiais e procedimentos disponibilizando-as na Revue de l'architecture et des travaux publics. ${ }^{72}$

As informações técnicas essenciais à profissão foram acompanhadas pelo debate estilístico ou profissional e criou-se um corpus de referências que viajou através da história das civilizações a fim de coletar e desenhar os elementos da arquitetura, revisitando grandes mestres da arte da construção, estabelecendo também uma coleção de

71. cf. Jean-Pierre Épron, (1997, p.111), citando o verbete construction do dicionário de Viollet-le-Duc.

72. cf. Jean-Pierre Épron, (1997, p.151). 
ornamentos cujo campo de pesquisa não se limitava à história se estendendo à natureza.
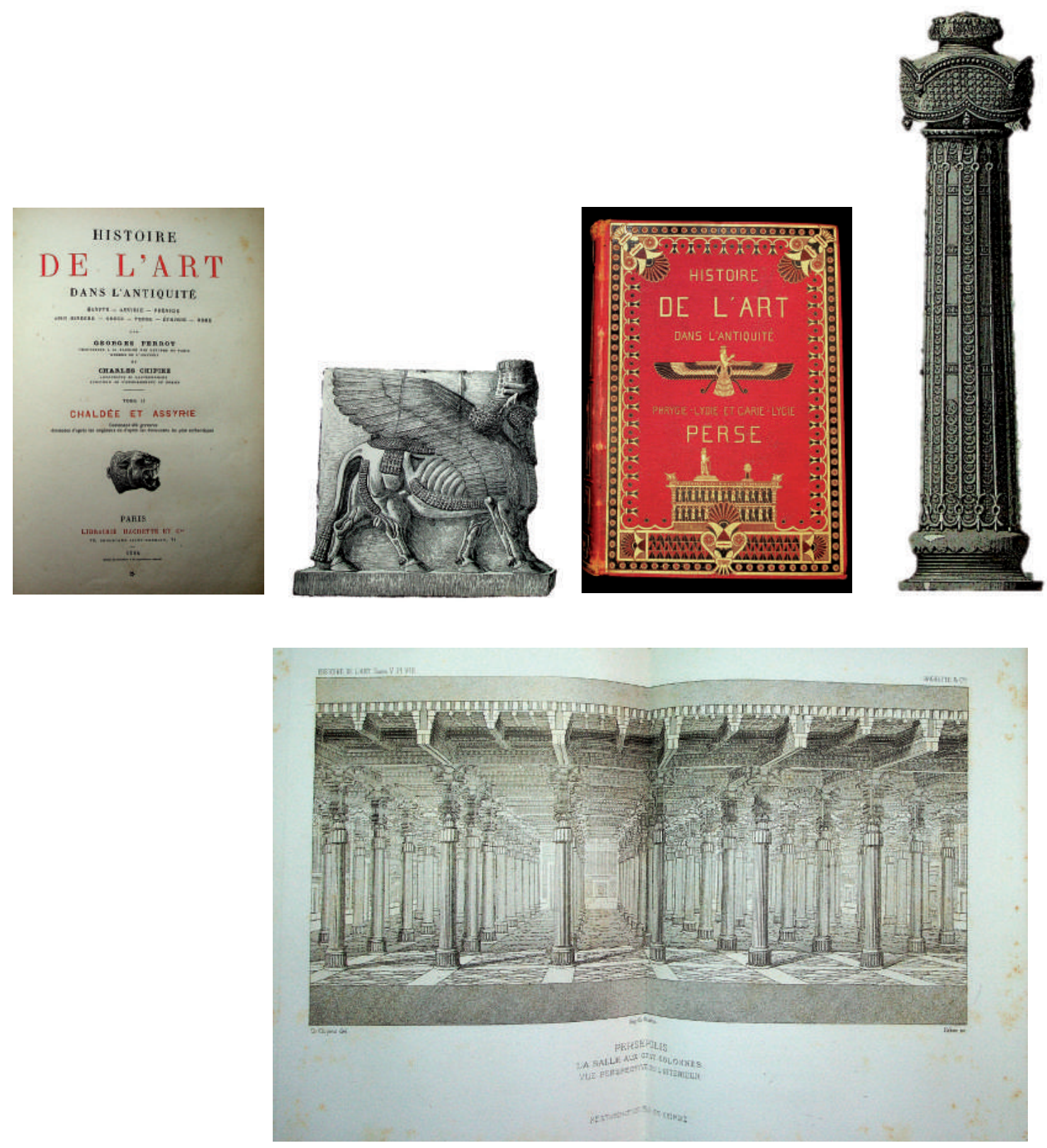

Dentre os exemplares raros do acervo os soberbos volumes da Histoire de l'Art dans Antiquité Égypte, Assyrie, Phénicie, Judée Asie Mineure, Perse, Gréce organizados por par Georges Perrot e Charles Chipiez e publicados e impressos entre 1884 em Paris pela Libraire Hachette et Cie., são ricamente ilustrados, trazendo, entre outros gêneros, exemplos de cidades como Persópolis e elementos arquitetônicos como a Coluna de Bronze do templo descrito na Bíblia e o touro alado do palácio de Sargon, habitante do Museu do Louvre. Os autores são apresentados no frontispício como Perrot, Professeur a la Faculté des Lettres de Paris, Membre de I'Institut e Chipiez, Architecte du Gouvernement, Inspecteur de I'Enseignement du dessin. 0 exemplar de Historia general del arte, maciço e luxuoso e onde consta a etiqueta da biblioteca de Ramos de Azevedo foi publicado em 1893 podendo ser considerado uma oferta do mestre à biblioteca da escola.

Os desenhos de Andrea de Vico reproduzindo ornamentos gregos e romanos que o artista restaurou saltam à vista. [De Vico Andrea, Trenta tavole di ornamenti architettonici greci, romani e italiani nelle loro più classiche epoche disegnati e restaurati per Andrea De Vico. Roma: Danesi, 1862], monocromia, impresso, carimbo Lyceo de Artes e Officios, 7 abril [19]30

Os dois volumes de Les arts Décoratifs A Toutes les Époques de Édouard Lièvre, publicados em Paris pela Vve. A. Morel e Cie. Librairies-Éditeurs em 1870 e impressos por Claye, talvez incompletos, são admiráveis. 

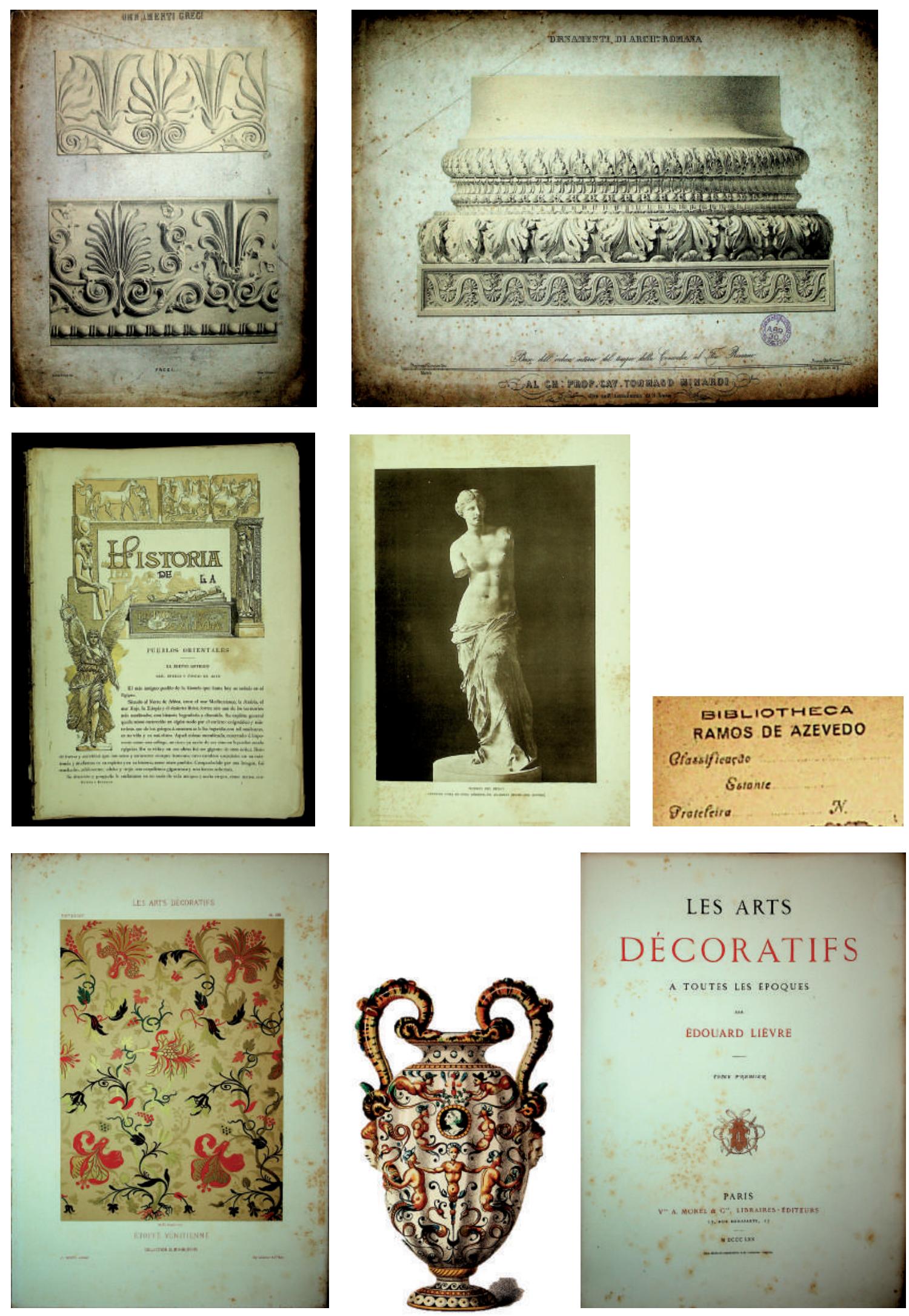
Épron comenta que a cultura construtiva não pode ser contrastada com a cultura arquitetônica, nem a cultura arquitetônica pode ser contrastada com a cultura decorativa, que era ensinada desde 1848 na École nationale et spéciale de dessin, de mathématiques, d'architecture et de sculpture d'ornament appliqués aux arts industriels, depois École impériale e mais tarde École des arts décoratifs.

Segundo o autor, a pedagogia do desenho que instruía a ver, compreender ou ler os objetos ensinava o desenhista a escolher o ponto de vista para o exame. A prática do desenho foi o meio de análise privilegiado para os arquitetos do século XIX dadas as características analíticas e construtivas da disciplina.

O ornamento feito objeto de análise do edifício necessitava da mesma decomposição e trabalho de découpage em conjuntos e subconjuntos, podendo ser aprendido e integrado ao projeto tornando o conceito de composição coerente à construção, estrutura, disposição e aos ornamentos. No ecletismo a decoração é integrada ao edifício e não apenas reportada a ele sendo o arquiteto o sujeito que, dominando o vocabulário arquitetural (ordens e molduras), estabelece o ornamento indicando através do desenho a estrutura e o estilo do ornamento.

A história da arquitetura propicia o estudo de décors de todos os tipos sendo que os exercícios específicos na École des beaux-arts eram concernentes à integração das artes. Deste modo, eram associadas na mesma busca a ciência da construção, o conhecimento do material, o desenho de ornamento e o partido arquitetural. Segundo Épron, não se deve confundir este exercício com um exercício de estilo já que o objetivo era conciliar e combinar seus elementos e inventar o novo. ${ }^{73}$

Faltam registros capazes de elucidar as circunstâncias históricas de aquisição do repertório de cultura arquitetônica e decorativa produzido no período e apropriado pelo Liceu, mas os exemplares do acervo são eloquentes mesmo quando incompletos ou segmentados em suas séries. Demonstram que ao longo da trajetória da escola procurou-se

73. cf. Jean-Pierre Épron, (1997, p.169), trad. da A. 
manter a biblioteca, em conjunto com outros recursos pedagógicos inovadores, farta e atualizada.

À disposição dos alunos e professores havia exemplares que mostravam e instruíam o modo de conceber e fazer o novo, modelos que poderiam ser transpostos, apreendidos e traduzidos deste lado do Atlântico.
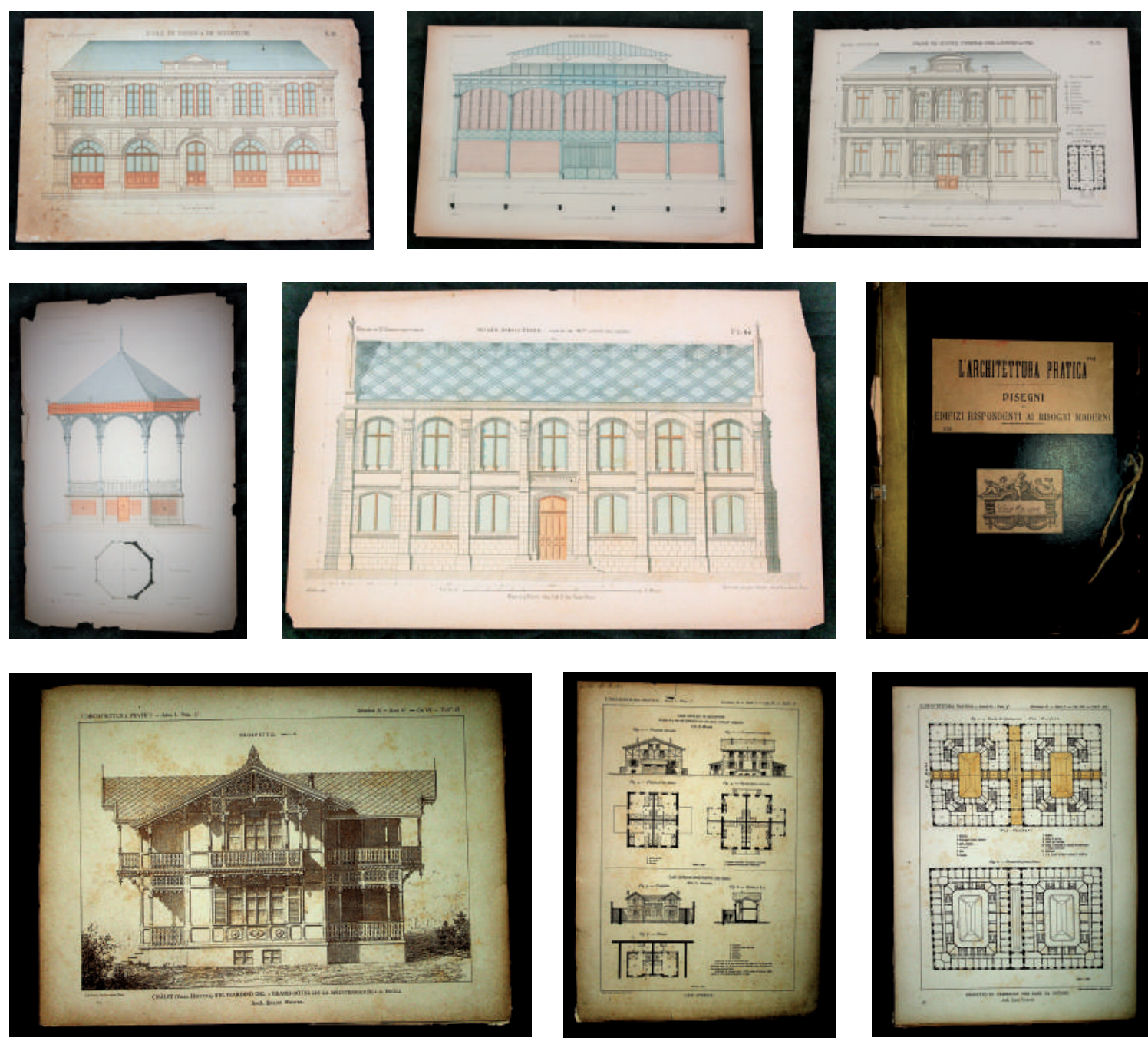

Escola de desenho e escultura; Mercado coberto; Palácio de Justiça, Tribunal Civil e Justiça de Paz, Quiosque para concertos e Museu Industrial em Dessins D'Architecture. Paris: Monroq Frères Imp. Edit., s.d.

Capa de L'Architettura Pratica Disegni di Edifizzi Rispondenti ai Bisogni Moderne, s.d.

Projetos de casa operária em L'Architettura Pratica Disegni di Edifizzi Rispondenti ai Bisogni s.d. 


\subsection{Organizador: Chef dos chefs d'atelier}

$\mathrm{Na}$ era do industrialismo, a ciência andava de braços dados com a indústria e a arte. Durante a mecanização da cultura artística a tecnologia se fundiu com os estilos, a instrução com a história e a eficiência com a criatividade. No ofício do belo, para usarmos a expressão de Paul Valéry evocada em uma apresentação do clássico ensaio de Walter Benjamin sobre a era da reprodução mecânica, importava ser hábil, conhecer as técnicas e produzir objetos peculiares. Ao promover a possibilidade da duplicação de objetos únicos em série, o mundo da reprodutibilidade mecânica exacerbou a questão da autenticidade e da singularidade ao mesmo tempo que passou a enfatizar a qualidade dos objetos comuns.

Considerando o ecletismo, o historicismo e a pluralidade de estilos como a confirmação da expansão do industrialismo, as práticas compartilhadas - relacionadas ao modelo beaux-arts francês e ao uso de repertórios europeus - efetivadas pelo Liceu de Artes e Ofícios de São Paulo influenciaram a feitura de formas modernas em pleno século XIX. Colaborando na conformação de um gosto dominante, o Liceu motivou a inovação gramatical dos estilos e a construção de novas formas artísticas. Reforçando sem oposição os modelos dos estilos históricos denotou uma vontade estética, visível nas composições do décor externo e interno, realizadas por alguns dos mais importantes escritórios de arquitetura estabelecidos na cidade e que contrataram a perícia dos artesãos formados na escola.

Ponderando que estilo é marca, unidade de princípios ligada a uma geografia e a uma história e que cada época propõe ao mundo um gosto ao determinar a formas das coisas, o Liceu parece ter colaborado amplamente na especificidade do ecletismo paulista. Se mundanismo caipira transido de engenho, transgressão ou originalidade é coisa a ser averiguada com mais propriedade em futuras ocasiões.

Como apontado no capítulo anterior, a cidade de São Paulo crescera a gabaritos largos com investimentos privados e estatais tanto nacionais quanto estrangeiros na esteira da riqueza gerada pela economia do café.

Além dos bancos, hotéis, estações de trem, empresas do ramo têxtil, habitações, lojas, importadoras e muitos ramos de negócios que 
agitavam a capital, até o final do Império a cidade contou com pequenas fábricas industriais relacionadas a gêneros alimentícios e bebidas, artigos do vestuário, veículos de tração animal ou humana, livros em branco, sabão, bilhares, velas, órgãos e harmônios e artefatos de barro. ${ }^{74}$

No domínio do artesanato orbitavam em torno do Liceu uma miríade de lojas, oficinas e fabriquetas operadas por mão de obra imigrante profissional e que ofertava produtos e serviços para a construção durante a Primeira República. ${ }^{75}$

Para Carlos Lemos grande parte dos materiais de acabamento arquitetural neste período era importada. A Azevedo Bueno e Companhia, com sede na rua do Rosário, empresa importadora da qual era associado Ramos de Azevedo desde $1891^{76}$, transformada mais tarde na Casa Dias de Castro, talvez fosse responsável por parte do fornecimento de móveis, lustres, revestimentos, bronzes, cerâmicas, mármore, peças de serralheria artística importados usados nos projetos de decoração encomendados por escritórios de arquitetura, pelo Escritório Técnico Ramos de Azevedo e ao Liceu. As peças também poderiam ser compradas de comerciantes principalmente estrangeiros ou suas agências e representantes estabelecidos na cidade antes do início das vendas dos produtos das oficinas do Liceu em 1902 ou mesmo depois.

Supomos que alguns produtos de luxo oferecidos por empresas francesas, alemãs e austríacas podem ter integrado o décor interno de ambientes em conjunto com peças produzidas pelo Liceu. Os chandeliers de cristal do salão e o lustre do cassino do Grand Hotel La Plage no Guarujá, empreendido por Percival Farquhar e projetado por Ramos de Azevedo em 1893 e terminado em 1911, servem de apoio para esta conjectura. As peças são bastante parecidas aos tipos impressos em folhas avulsas de um catálogo alemão sem título e sem data.

74. Ver Nelson Nozoe (2004, p.101-112).

75. Ver Ana Maria Belluzzo (1988). Em seu trabalho lapidar sobre o Liceu, Belluzzo realizou um levantamento inédito sobre estes estabelecimentos indicando serralherias e fundições artísticas, empresas de metalurgia, indústrias mecânicas, serralherias e carpintarias, carpintarias e marcenarias especializadas em decoração e mobiliário, componentes fixos em edifícios e objetos decorativos; lojas de materiais de construção, olarias e cerâmicas, vidrarias e cristaleiras, marmorarias, lojas de pedras artificiais, estuques e de decoração e empórios e lojas de materiais para a indústria da construção. 76. cf. Jacques Marcovitch (2006, p. 139 e ss.). 

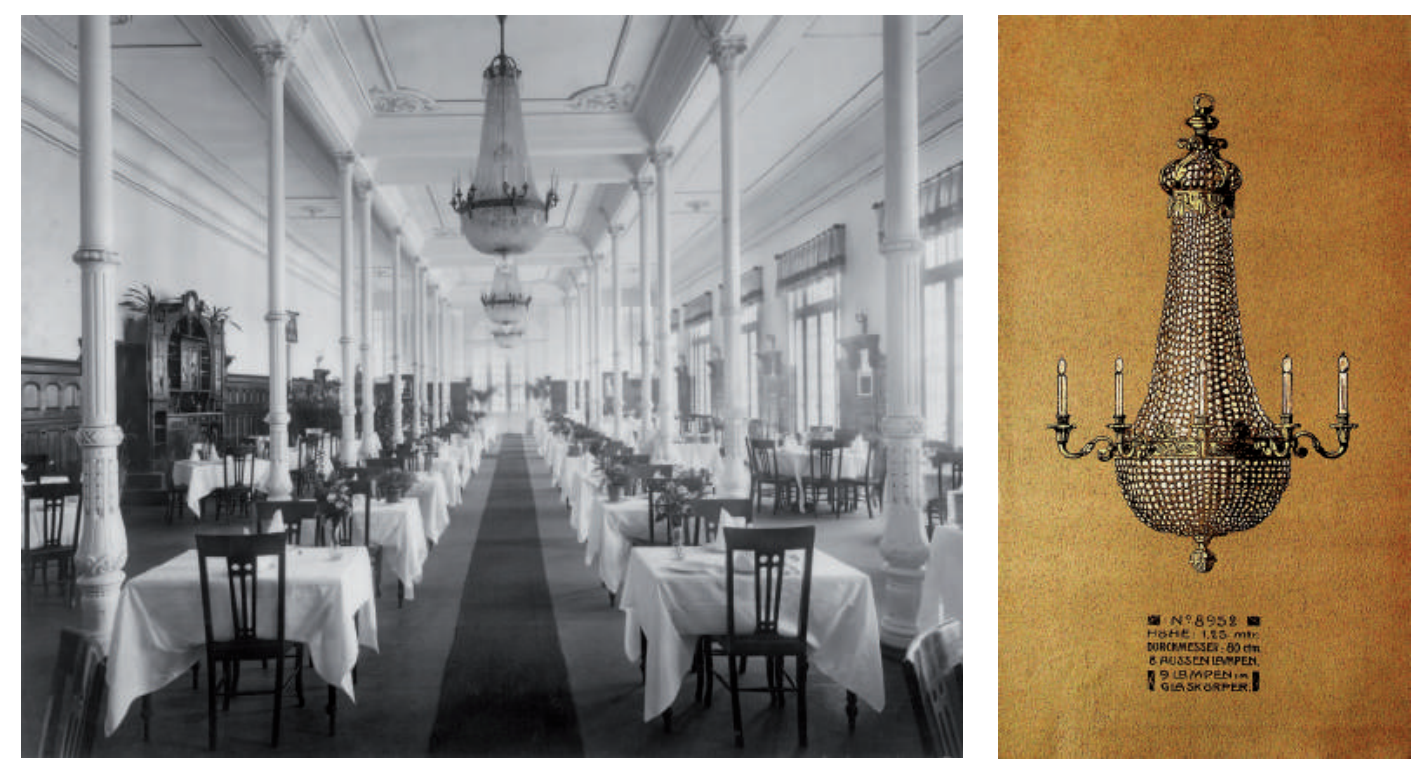

Salão do Grand Hotel La Plage Guarujá terminado em 1911. Chandelier de Cristal em catálogo alemão sem título e sem data
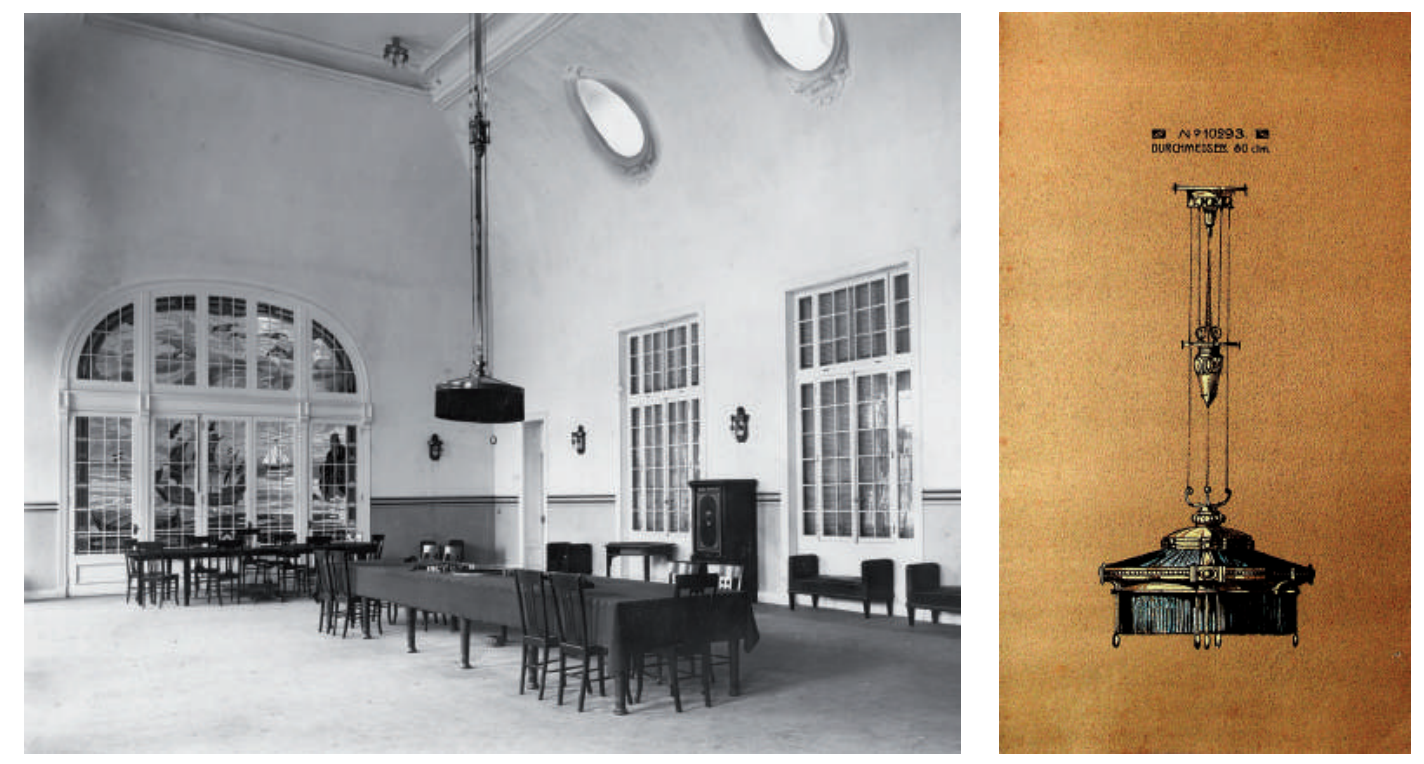

Cassino do Grand Hotel La Plage Guarujá terminado em 1911. Lustre em catálogo alemão sem título e sem data

No acervo existem catálogos marcados com o carimbo Ernesto de Castro e com o carimbo do Liceu. É possível que depois de analisados na loja os catálogos fossem depositados na biblioteca do Liceu para servir de modelo ou inspiração. 

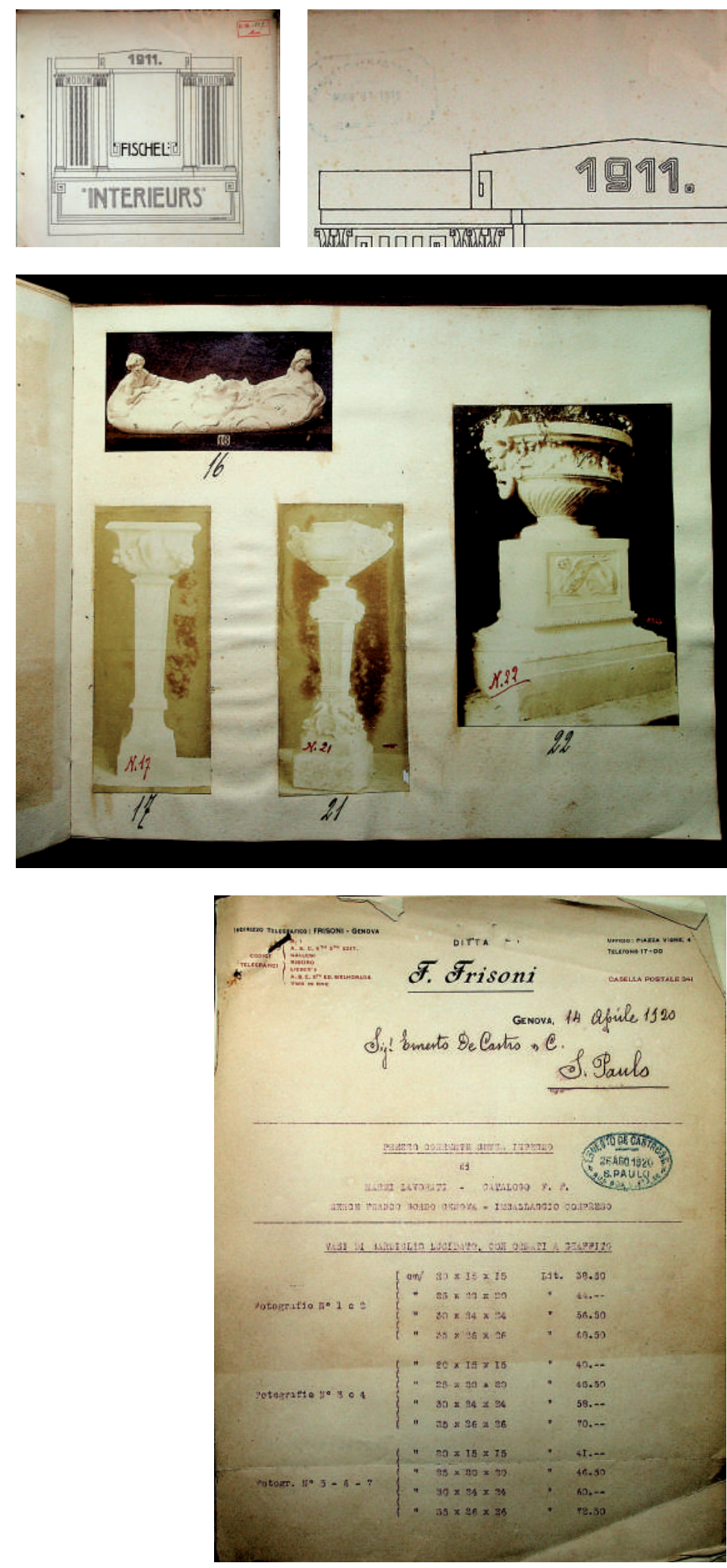

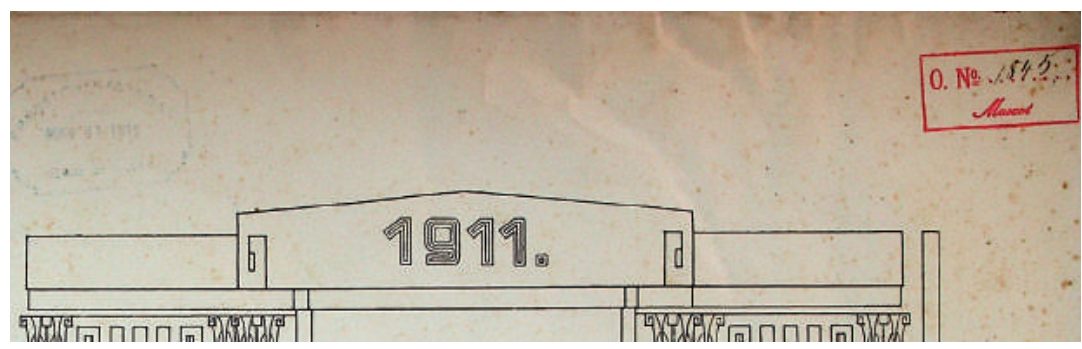

$\Delta$

Frontispício do catálogo Interieurs. D. G. Fischel Söhne, fabricante de armários, cadeiras, sofás, espelhos e camas. 0 projeto gráfico é cuidadoso contendo elementos ornamentais, prefácio em alemão, inglês, francês e espanhol. Na página constam carimbos Ernesto de Castro e Mascot, que pensamos ser agenciadora de fábricas alemãs, eslovena e austriacas

0 catálogo "FF", etiquetado e guardado junto aos álbuns mostruários do Liceu, trata-se de fato de um catalogo de empresa (ditta) genovesa F. Frisoni. Na lista de preços endereçada à casa importadora Dias de Castro consta carimbo da própria empresa e carimbo de Ernesto de Castro datado de 1920. A simplicidade do catálogo contrasta com os trabalhos em mármore que apresenta em fotografias coladas sobre papelão 


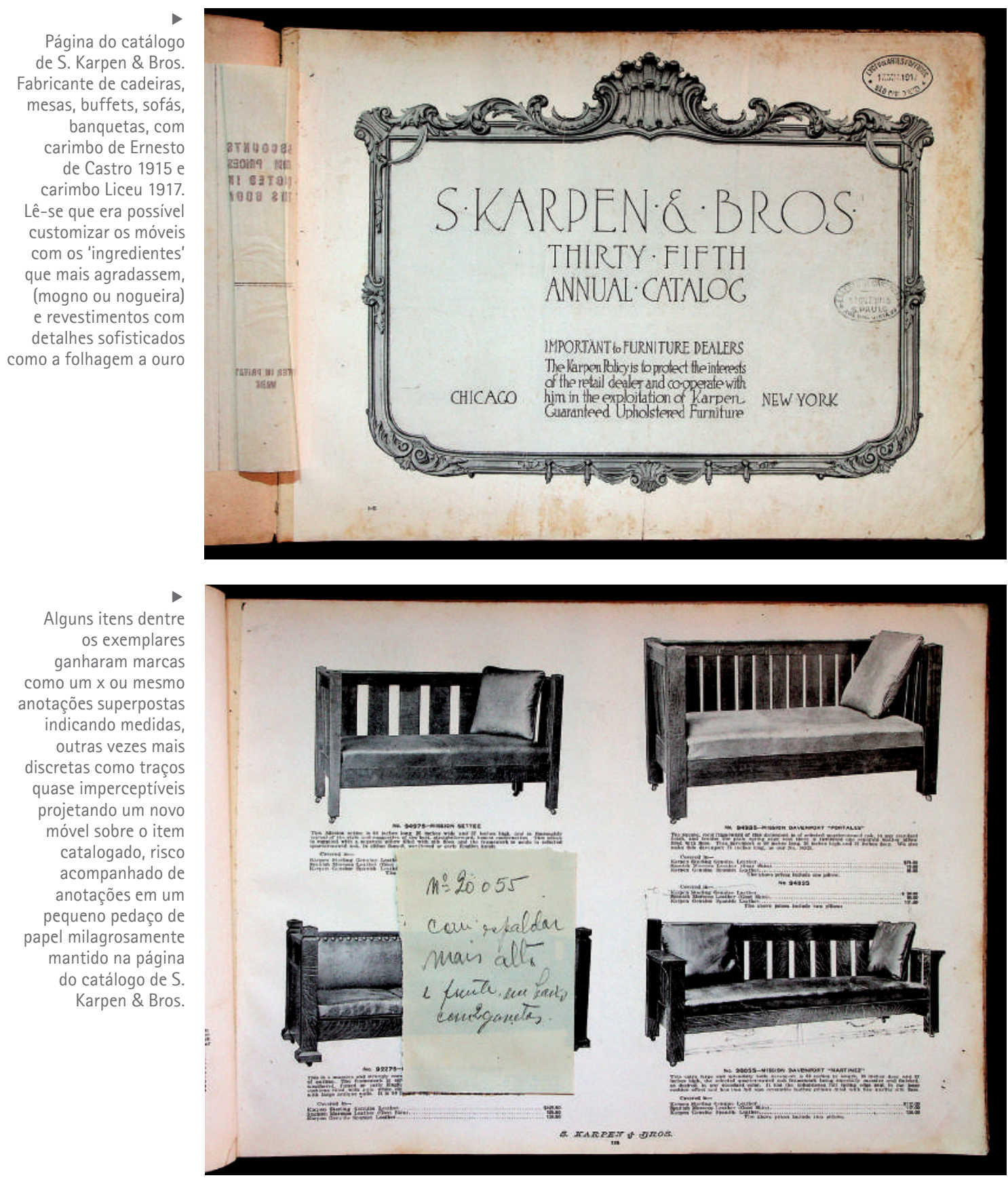

Residências de luxo e prédios públicos monumentais como o Palácio da Presidência (projeto de Eusébio Stevaux executado entre 1881-1886), a Secretaria da Agricultura (projeto de Ramos de Azevedo executado entre 1886-1896) indicavam que novos padrões de consumo colaboravam na substituição da feição neoclássica por outra eclética. Aos vários serviços públicos organizados na década anterior, como o 
transporte coletivo (1872), a rede de água e esgotos (1883), o telefone (1884), a luz a gás (1872) somou-se a luz elétrica (1888).

A capital se aparatava. Em fins do século XIX e meados do XX as edificações, assinadas pelos escritórios de arquitetura de maior prestígio na cidade eram projetadas do geral ao pormenor, desde sua estrutura até os artefatos que as decoravam interna e externamente, contavam com o engenho e a perícia de artesãos e artistas, muitas deles formados no Liceu de Artes e Ofícios.

Dentre as inúmeras obras realizadas na primeira metade do século XX em São Paulo com a colaboração do Liceu apontamos a Casa Palmares, a Residência Chedid Jafet, o Edifício [Germaine Burchard], Banco da Indústria e Comércio de São Paulo, interiores não identificados, Banco Italiano de Desconto e a Biblioteca Jayme Loureiro. No próximo capítulo retomaremos os exemplos de obras feitas pelo Liceu.

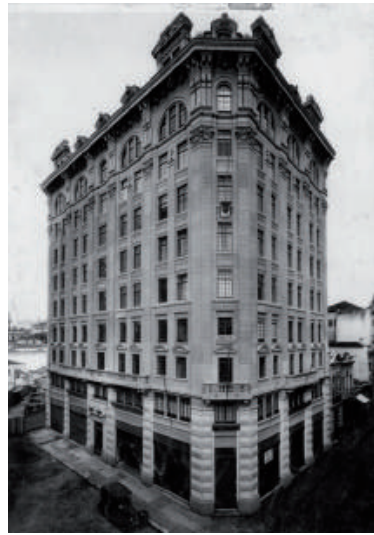

$\Delta$

Casa Palmares, São Paulo

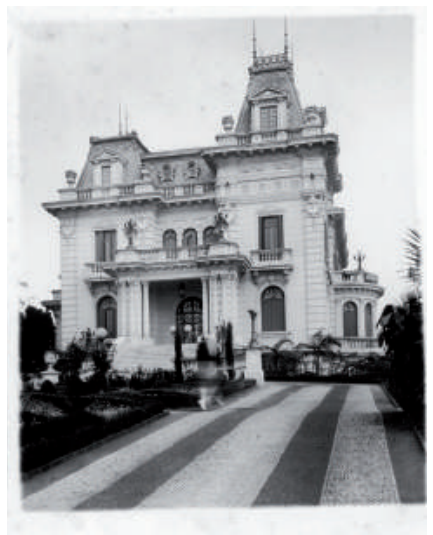

$\Delta$

Residência Chedid Jafet, São Paulo

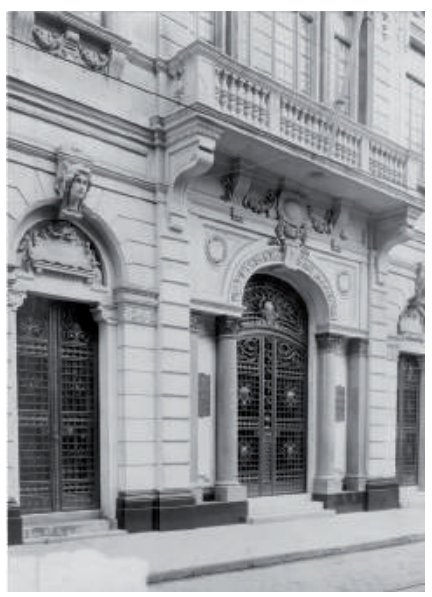

Fachada do Banco da Indústria e Comércio de São Paulo

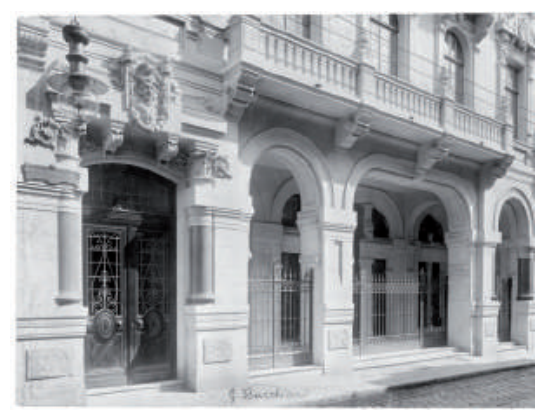

Edíficio [Germaine Burchard], São Paulo 


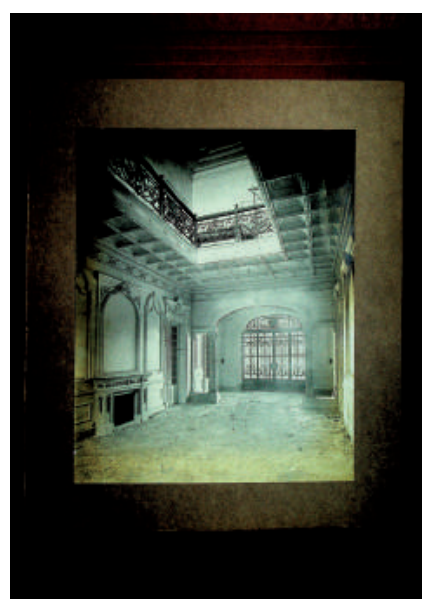

Exemplo de modelagem, sem identificação, São Paulo

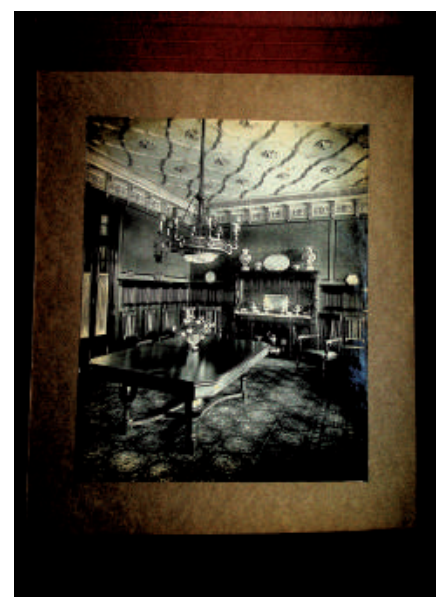

Exemplo de modelagem, sem identificação, São Paulo

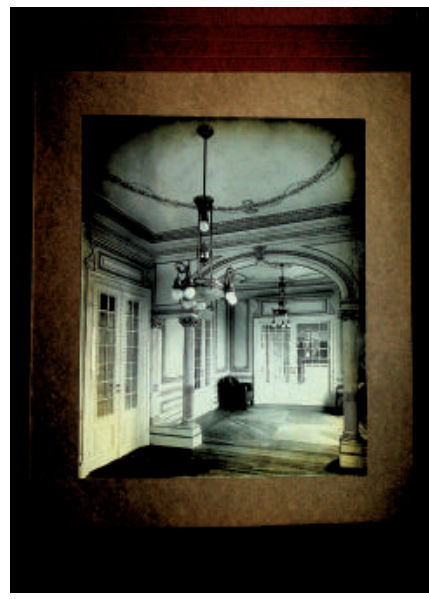

Exemplo de modelagem, sem identificação, São Paulo

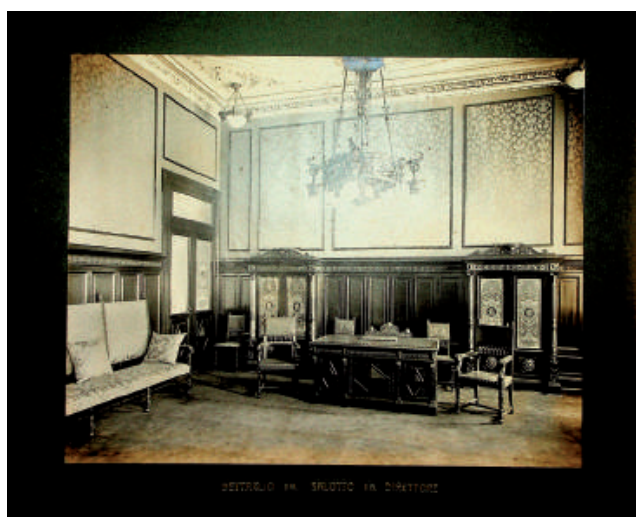

Banco Italiano de Desconto, São Paulo

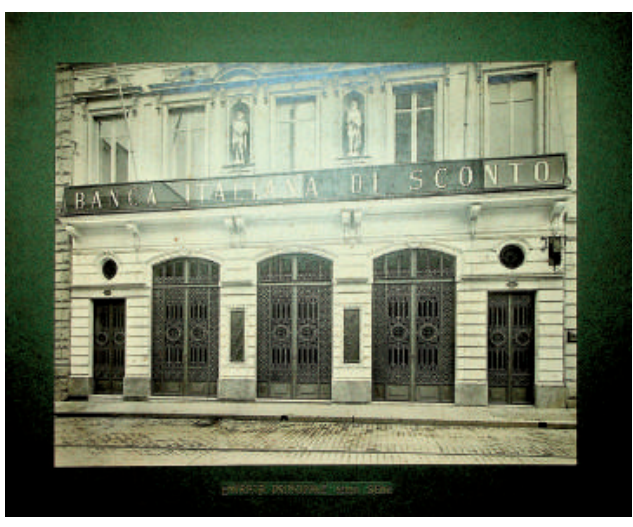

Banco Italiano de Desconto, São Paulo

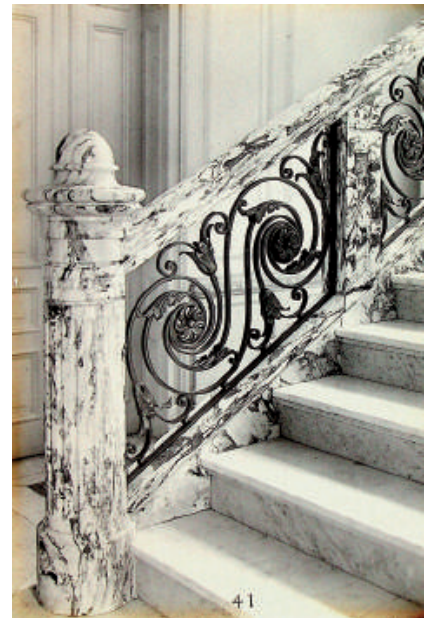

Interior de residência, São Paulo

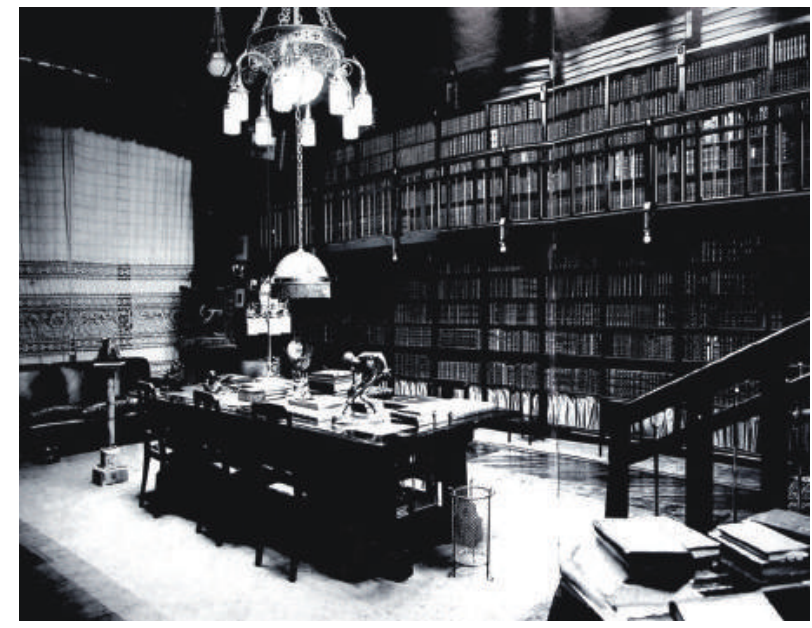

Biblioteca Jayme Loureiro, São Paulo 
Com 738 alunos matriculados nos diferentes cursos do programa escolar estabelecido em 1882, o Liceu recebera em 1888 uma loteria de benefício do valor de 120 contos de réis que, juntamente com as mensalidades dos sócios nem sempre pagas com regularidade, amparava sua missão de dar cultura profissional e artística ao povo.

Instaurada a República em 1889 e ultrapassada a instabilidade política, o Liceu deparou-se com uma crise. Sem apoio dos auxílios oficiais, suspensos com a mudança do regime político, a escola passou por "ligeiros distúrbios funcionais" que, contudo, não abalaram o "esqueleto moral" da sociedade benemérita. ${ }^{77}$

Entre 1890 e 1893, a diretoria foi composta por Leôncio de Carvalho, presidente, Domingos José Nogueira Jaguaribe, vice-presidente, Antônio Teixeira da Silva e Reynaldo Porchat, secretários, Antônio Moraes Cordeiro, acompanhados de Rangel Pestana, Américo de Campos, Bueno de Andrada, Gabriel Franzen, Antônio Candido Rodrigues, Rafael de Barros, Luiz Pereira Barreto, Martinho Prado Junior, Paulo Malheiro, entre outros.

Devido a antagonismos com o governo do Estado, em 1893 o Conselheiro Carlos Leôncio de Carvalho afastou-se da presidência do Liceu, seguido por Rangel Pestana e outros membros da diretoria que deixaram seus cargos para compor comissões e comitês, deixando a instituição sob a responsabilidade do secretário Antônio Teixeira da Silva durante a estada de Domingos Jaguaribe na Europa.

A revolta da Armada de 6 de setembro daquele ano recrutou os alunos esvaziando completamente as aulas e obrigando o fechamento da escola. Aos alunos que tinham salvo conduto foram oferecidas aulas irregularmente. A escola só voltou à normalidade no ano seguinte.

As adversidades se avolumavam e vencido o contrato da casa onde o Liceu funcionava, vizinho ao Pátio do Colégio, a escola foi despejada e o mobiliário e demais bens provisoriamente depositados na Igreja de São Gonçalo, no largo Municipal, atual praça João Mendes. $\mathrm{Na}$ mudança, alguns objetos foram roubados, outros perdidos, tendo desaparecido documentos administrativos e muitos volumes componentes da biblioteca. ${ }^{78}$

77. cf. Ricardo Severo, (1934, p.19).

78. cf. Ricardo Severo (1934, p. 22). 
A Assembleia Geral do Liceu reuniu-se em 24 de dezembro de 1893 reelegendo a mesma diretoria, agora sobre a presidência meramente honorária de Leôncio de Carvalho, incluindo no conselho Antônio Francisco de Aguiar e Castro, José Alves de Cerqueira Cesar, Martinho Prado Júnior, Clementino de Souza e Castro, Arthur Cezar Guimarães, Augusto Souza Queiroz, João Pedro da Veiga Filho, Victor Marques da Silva Ayrosa, Antônio Bento de Rego Freitas.

Domingos Jaguaribe voltando da Europa retoma a diretoria do Liceu em 1894. Em relatório de 1895 dirigido a Cesário Mota, secretário de Estado do Interior no governo de Bernardi José de Campos Júnior, o presidente apresentava o Liceu confiando na cooperação do governo para uma reforma e fornecimento de uma casa, mais os meios para o estabelecimento de novas oficinas. ${ }^{79}$ Jaguaribe esperava a reintegração do subsídio de 12 contos de réis, valor acrescido em 1888 com loteria de benefício do valor de 120 contos de réis.

O Liceu ainda não possuía oficinas particulares utilizando outros espaços para o ensino prático, como as oficinas do Instituto de Educandos e Artífices, fundado em São Paulo por iniciativa pública em 1844 como entidade assistencial para abrigo de órfãos e expostos e ensino de ofícios como os de carpinteiro de machado, calafate, marceneiro, pedreiro, serralheiro, sapateiro, entre outros.

No relatório Jaguaribe indica que a biblioteca, "poderoso auxiliar do ensino" na instituição, tinha 2.950 volumes brochados, 1.630 volumes encadernados e 740 folhetos, somando 5.320 itens. ${ }^{80}$

Em 1890, conforme anunciado pelo Correio, a biblioteca recebeu entre livros encadernados e brochuras os títulos La Sociologie, de Letourneau oferecido por Eduardo Chaves que também entregara dois volumes de Fagulhas, de sua autoria; Fábulas de La Fontaine vertidas e anotadas pelo Barão de Paranapiacaba, oferecido por Júlio Cesar da Silveira; Notas a lápis, por Patrick, oferecido por Luiz Gonzaga de Oliveira e Costa; Visita à Nympha da Parahyba de Jose Palmella; Ascenção ao Paraiso do Itatiaya; Vida de Pedro Alvares Cabral; Geographia, História e Estatística da província de São Paulo e mais os

79. cf. Domingos José Nogueira Jaguaribe (1895, p. 10). 80. Para este assunto Ver Luiz Antonio Cunha (1983). 
19 volumes da Collecção das leis da Provincia de São Paulo, ambos oferecidos pelo secretário Antônio Teixeira da Silva. ${ }^{81}$

Nem o diretor, nem o jornal mencionam nenhum título relacionado ao ensino e à prática das artes e ofícios como tampouco fazem referência à existência de livros técnicos, catálogos, periódicos, exemplares em carpetas, álbuns seriados ou outros recursos impressos avulsos.

Dentre os exemplares anteriores a 1894 sublinhamos os seguintes:

\section{Manuais de estilo}
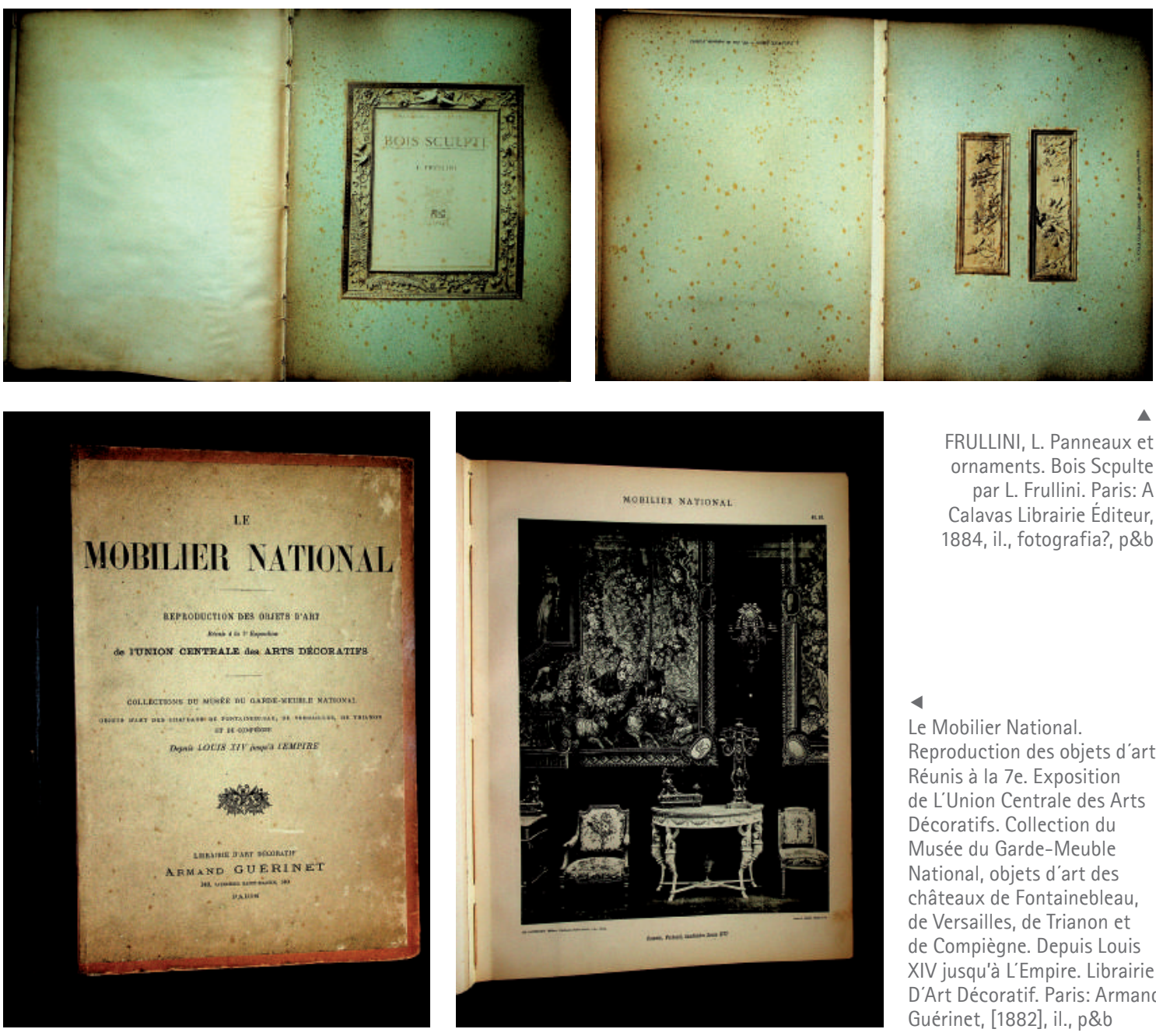

FRULLINI, L. Panneaux et ornaments. Bois Scpulte par L. Frullini. Paris: A Calavas Librairie Éditeur 1884, il., fotografia?, p\&b

Le Mobilier National.

Reproduction des objets d'art. Réunis à la 7e. Exposition de L'Union Centrale des Arts Décoratifs. Collection du

Musée du Garde-Meuble

National, objets d'art des châteaux de Fontainebleau de Versailles, de Trianon et de Compiègne. Depuis Louis XIV jusqu'à L'Empire. Librairie D’Art Décoratif. Paris: Armand Guérinet, [1882], il., p\&b

81. cf. Correio Paulistano, São Paulo, p.2, 3 set. 1890. 
Periódico

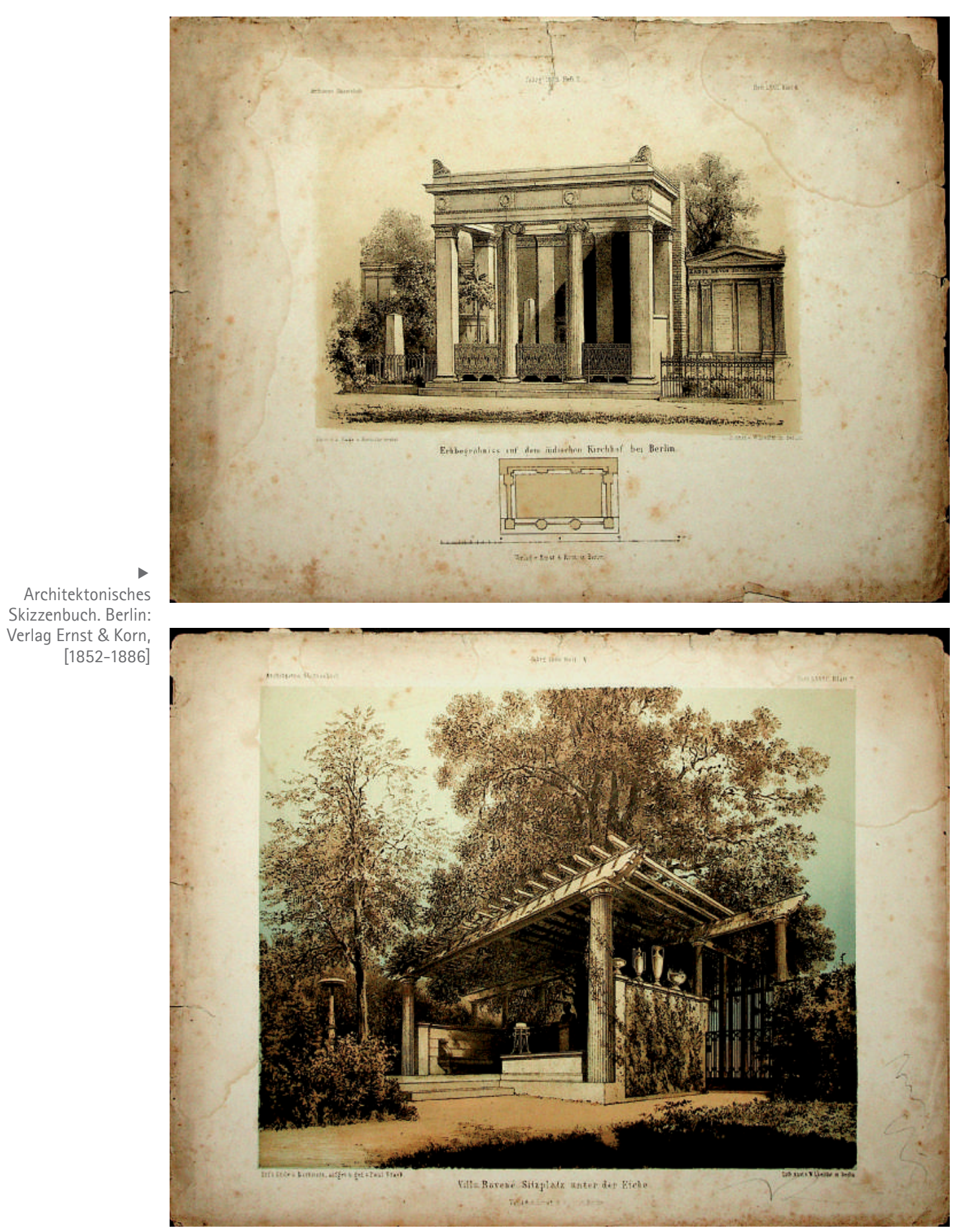


Pranchas impressas/álbuns seriados
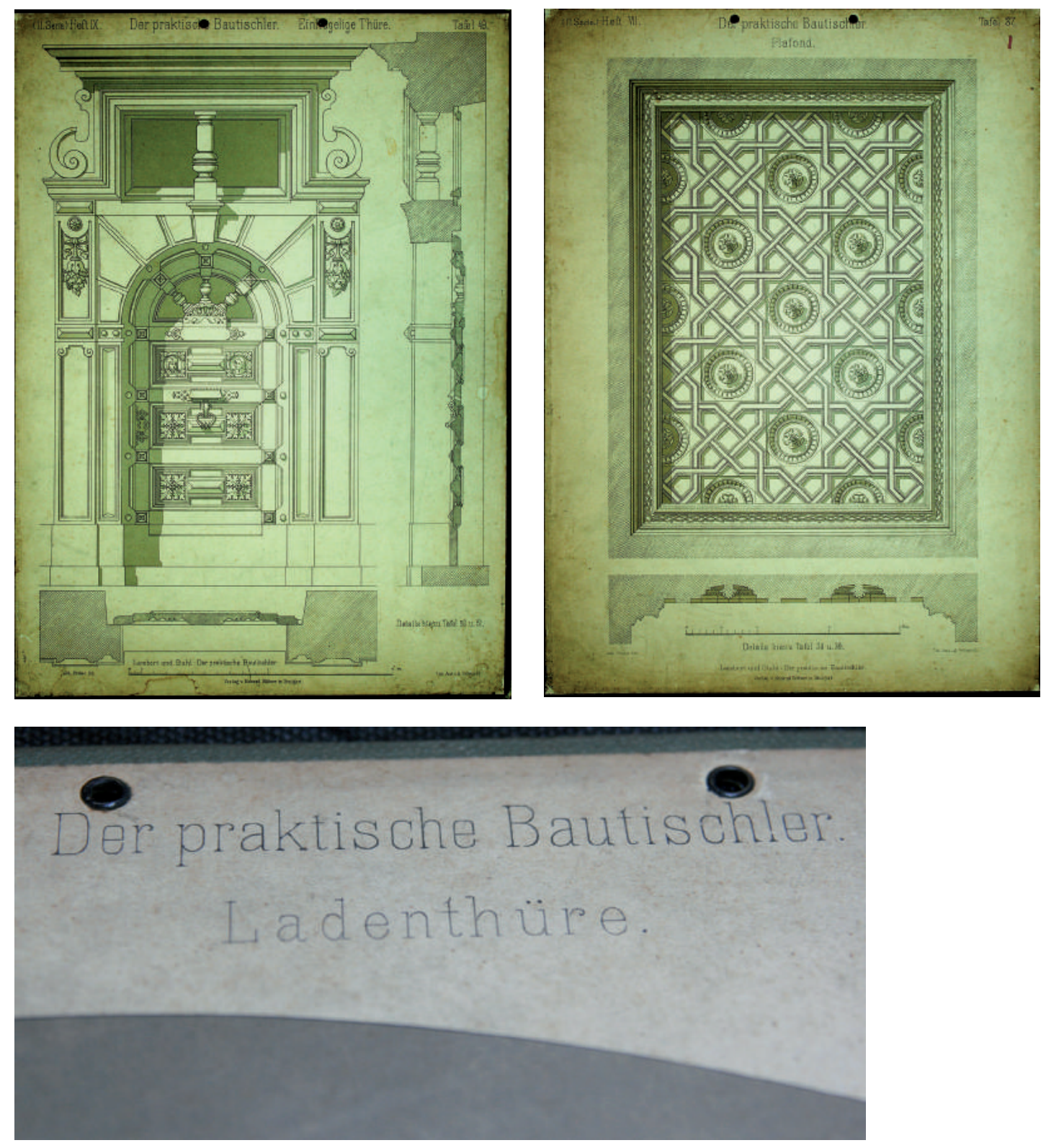

\section{Lith. Anst.v. A. Gatternicht.}

Lambert und Stahl: Der Praktische Bautischiler. John Bruker lith. Ladenfenster. (II

Serie). Heft I. Tafel 4. Details hiezu Tafel 5 u 6. Lith. Anst v.A. Gatternicht. Impresso.

Stuttgart: Verlag von Konrad Wittwer, [1890], color., p\&b, impresso 


\section{Catálogos comerciais}
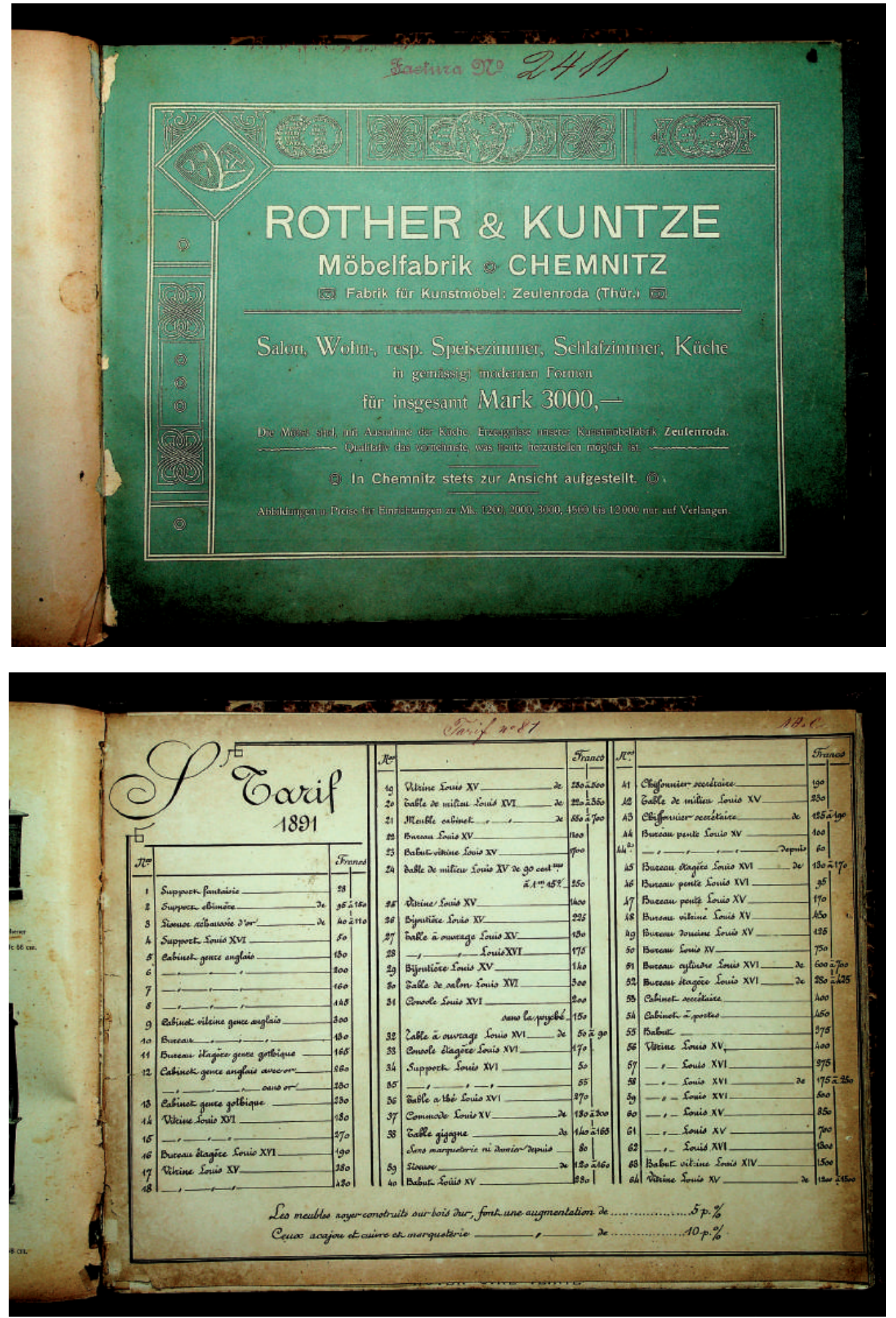

Rother \& Kuntze, Mobiliário em Geral incluindo móveis para lavanderia com tarifa praticada em 1891 grafada em francês 

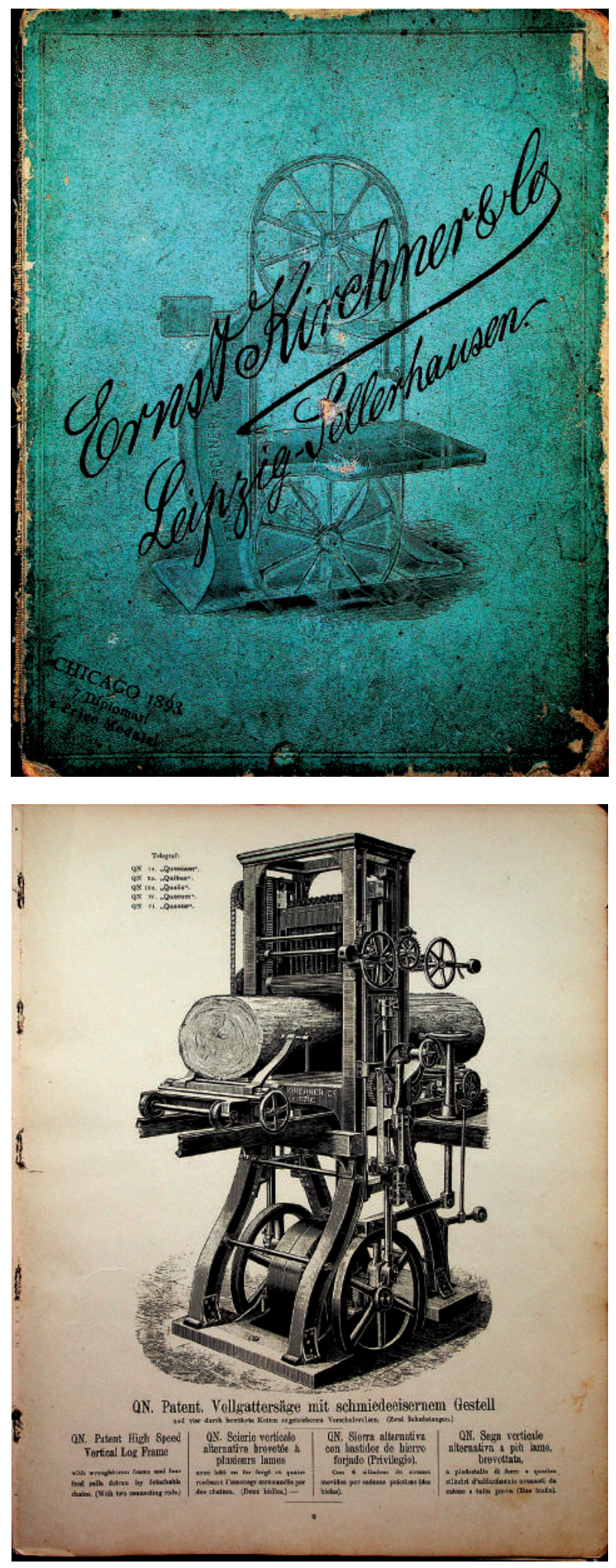

Ernst Kirchner \& Co. Leipzig Sellerhausen. Sage und holzbearbeitungs-maschinen. Leipzig: S.n., [1894], apresentando máquinas para o trato com a madeira incluindo tornos ornamentais 

holzbearbeitungs-maschinen.

Leipzig: S.n., [1894]

apresentando máquinas

para o trato com a madeira incluindo tornos ornamentais

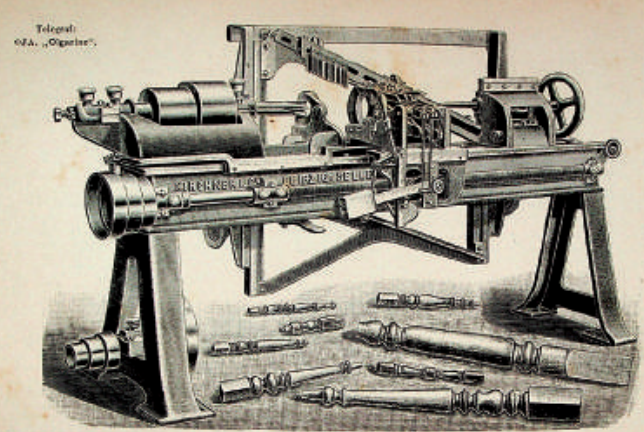

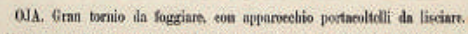

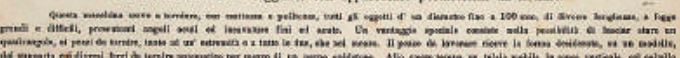

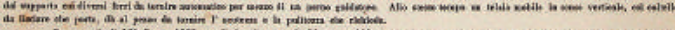

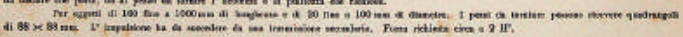

0H. Grasse Façon-Drehbank für ornamentale Arbeiten.
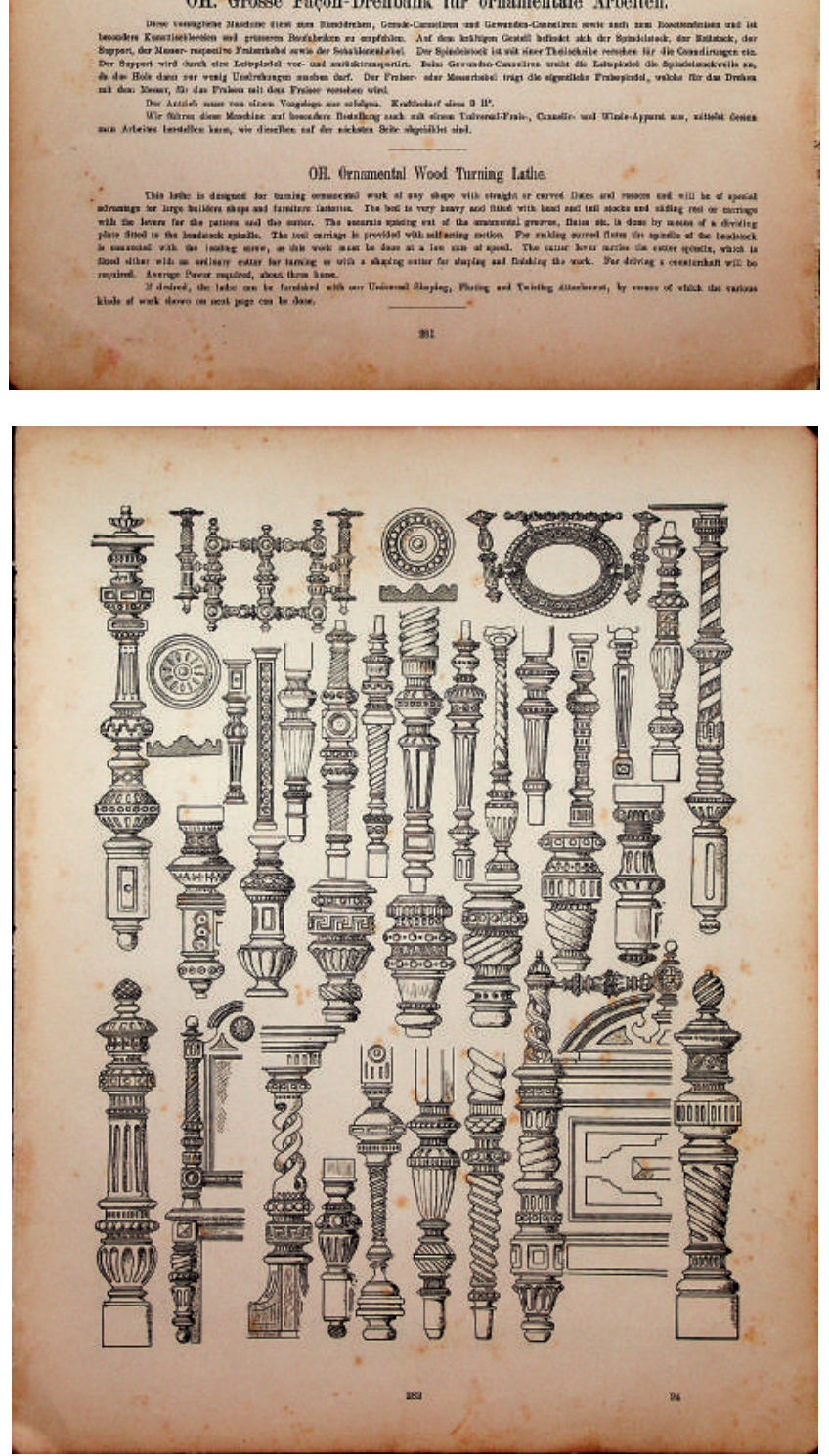
Embora nada garanta que os exemplares sejam anteriores ou contemporâneos ao relatório de Jaguaribe, as peças denotam escolhas precisas relacionadas diretamente aos centros difusores dos modelos como a Union Centrale des Arts Décoratifs na França e seus confrades europeus, editores de revistas sobre arquitetura, kits práticos de construção, catálogos de máquinas talentosas, algumas movidas a vapor, por vezes publicados pelos próprios fabricantes.

Pode ser que se as peças estivessem incorporadas ao acervo em 1894, os professores Gabriel Franzen, Álvaro Guimaraes, J. Antonio de Sant'Ana, Tertuliano Delfim, José Ferraz de Almeida Junior, substituído por Rosalbino Santoro e Fernando Martins Bonilha Júnior, decano de corpo docente, tenham tido contato com os exemplares. ${ }^{82}$

Em 20 de Janeiro de 1895, o Liceu elegeu nova diretoria composta por Cerqueira Cesar, presidente, Francisco de Paula Ramos de Azevedo, $1^{\circ}$ vice-presidente, José Ferraz de Almeida Junior, 20 vice-presidente, Antônio Teixeira da Silva, $1^{\circ}$ secretário, Reynaldo Porchat, $2^{\circ}$ secretário e Pedro de Mello e Souza tesoureiro. Sete dias depois Ramos de Azevedo propõe que se reforme os estatutos da escola passando a partir deste dia a assinar as atas do conselho diretor e os diplomas dos alunos. ${ }^{83}$

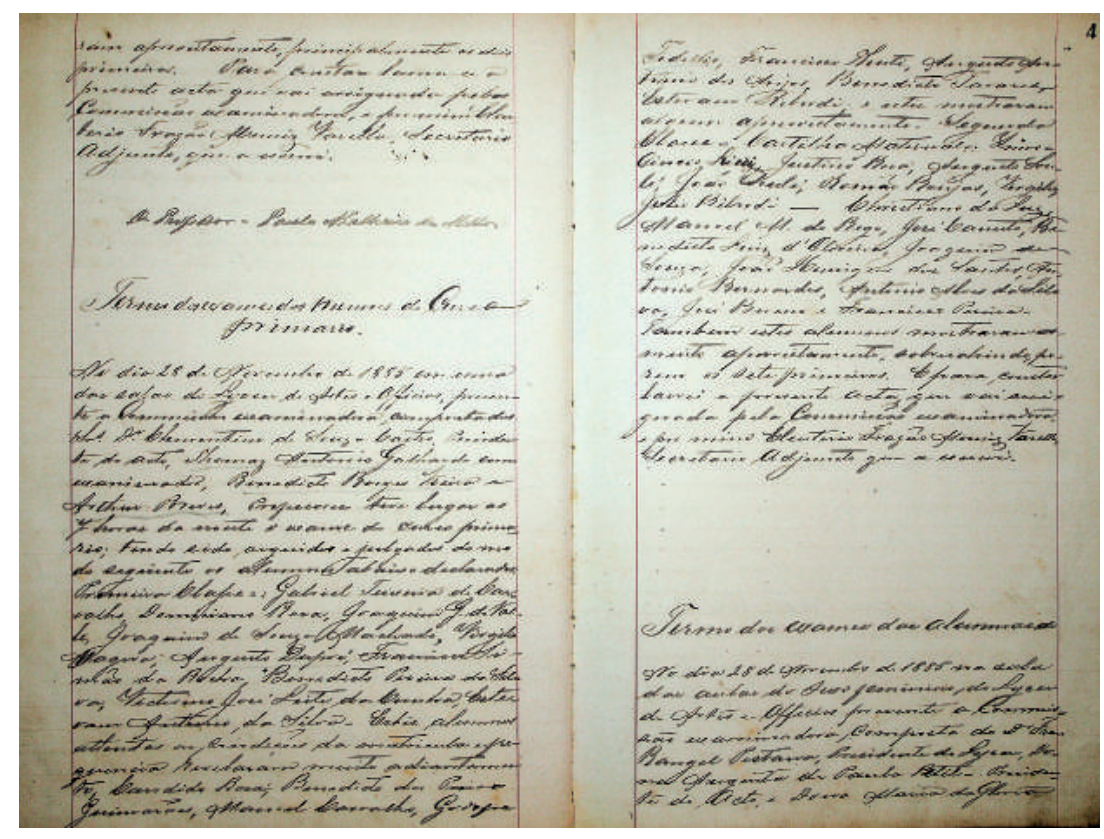




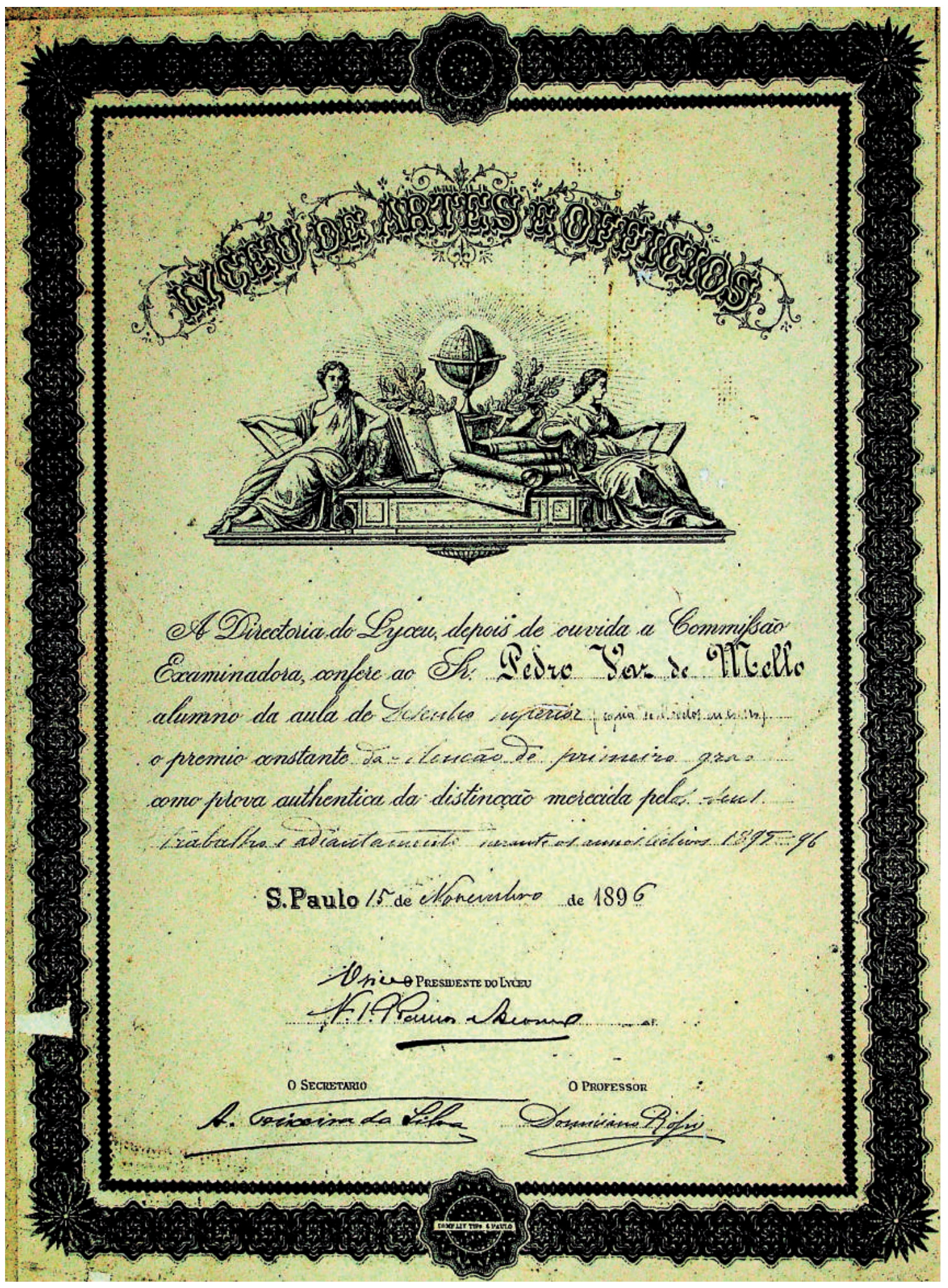

Prêmio de Pedro Vaz de Mello em desenho superior, 1895 
Francisco de Paula Ramos de Azevedo, com estudos na Escola Militar do Rio de Janeiro e formado em 1878 na École Speciale du Génie Civil et des Arts et Manufactures Annescée da Universidade de Gand, na Bélgica, foi colaborador nos trabalhos dos caminhos de ferro paulistas, tendo sido chamado à capital pelo presidente da província, Antônio de Queirós Teles, Visconde de Parnaíba. Nesta época, Ramos chefiava a Carteira Imobiliária do Banco União tornando-se responsável por obras públicas importantes na cidade.

Fundou em 1894 junto com Antonio Francisco de Paula Souza a Escola Politécnica de São Paulo para oferecer cursos de engenharia industrial, agrícola, civil e o curso anexo de artes mecânicas, tendo como colaboradores Adolfo Lutz, Vital Brasil, Luiz de Anhaia Mello, Maximiliano Hehl, Luiz Cintra do Prado, Telêmaco Van Langendock, entre outros. ${ }^{84}$

Ramos de Azevedo já deixara de ser apenas um engenheiro- arquiteto. Tornara-se um homem de negócios capaz de tirar proveito de uma ampla rede de sociabilidade de modo a qualificar artisticamente a mão de obra ligada à construção, preparando o terreno para que o conhecimento útil e o espírito da invenção das artes mecânicas progredissem entre os artistas industriais partícipes da escola profissional que dirigia.

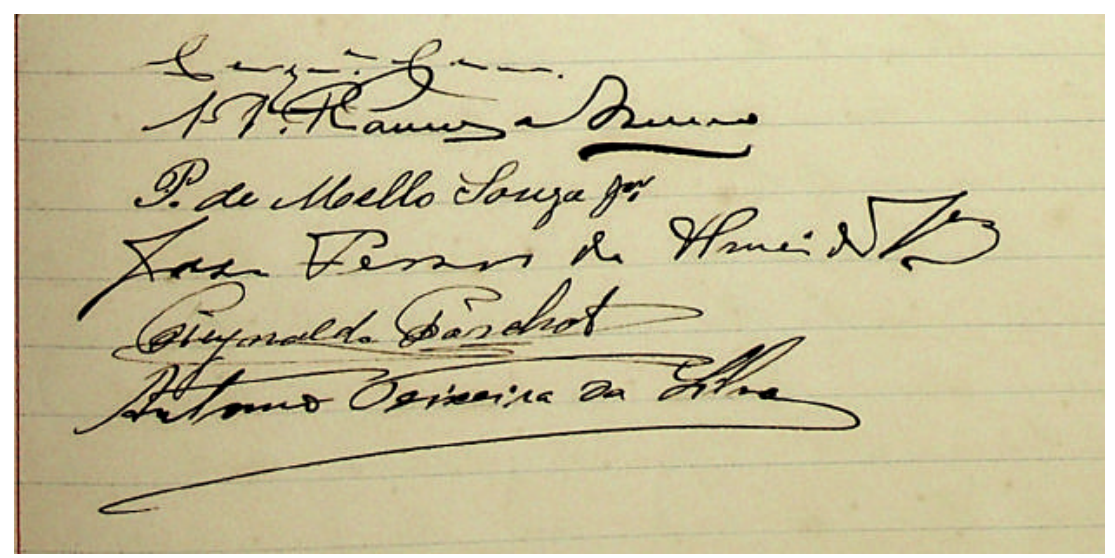

A partir de 1896 Ramos reorganiza também seu escritório técnico de arquitetura, inaugurado na década anterior. O escritório passou

84. Para a formação dos arquitetos da Escola Politécnica de São Paulo ver Sylvia Ficher (2005). 
a chamar-se, em 1907, F.P. Ramos de Azevedo e Cia. e mais tarde Escritório F. P. Ramos de Azevedo, Severo \& Villares contando com Ricardo Severo e Arnaldo Dumont Villares como sócios; entre os colaboradores, com Victor Dubugras e Domiziano Rossi, responsável pela seção de projetos.

Entre 1896 e 1928 o escritório construiu um conjunto de obras basilares no cenário urbano da capital paulista e no interior. Erigiu escolas, residências e palacetes como os de José Paulino Nogueira, Antônio Carlos da Silva Telles, Jose Sampaio Moreira, Martinho da Silva Prado, Numa de Oliveira, Lauro Cardoso de Almeida e muitas outras personalidades da elite paulistana. Dentre as obras públicas do escritório em São Paulo destacam-se o Teatro Municipal, a sede dos Correios e Telégrafos, a Faculdade de Medicina, o Palácio das Indústrias, a Secretaria da Agricultura, o Palácio da Justiça e Mercado Municipal. Além destas projetou sedes de bancos como a sede do Banco ÍtaloBelga, um edifício para o Banco Comércio e Industria de São Paulo, o London \& River Plate Bank e o Clube Comercial. As firmas Escritório Técnico Ramos de Azevedo e F.P. Ramos de Azevedo e Cia. realizaram mais de 200 projetos. ${ }^{85}$

O novo programa proposto por Ramos para o Liceu intitulou-se Reforma do Ensino e fez mudanças radicais nos regulamentos da escola, introduzindo novas disciplinas no ensino secundário e especialmente no curso de artes e ofícios. $\mathrm{O}$ engenheiro-arquiteto amplificou as matérias de desenho esperando que escola popular viesse a tornar-se a futura Escola de Belas Artes de São Paulo. ${ }^{86} \mathrm{~A}$ reestruturação consistiu em plano técnico e administrativo que conformou o caráter definitivo da escola com destaque para o ensino do desenho.

A importância deste curso gráfico corresponde justamente à orientação principal que compete a esta escola, de começo destinada a alunos operários, para aos quais o ensino do desenho é equivalente ao ensino basilar das primeiras letras. ${ }^{87}$

85. cf. Beatriz Piccolotto Siqueira Bueno, (2015).

86. cf. Ricardo Severo (1934, p. 12 e p. 32).

87. cf. Liceu de Artes e Ofícios, ([1913], p. 6). 
Tomando conhecimento das carências da escola, Ramos de Azevedo aponta em fevereiro de 1895 a necessidade de construção de um novo prédio além da precisão de compra de mais modelos para as aulas de desenho. Estando ausente o professor Rosalbino Santoro (professor de desenho da seção feminina que substituíra Almeida Júnior), Ramos de Azevedo nomeia Domiziano Rossi para ministrar as aulas da matéria que seriam, então, acrescidas das classes de desenho geométrico, desenho de perspectiva, desenho de ornamento e desenho de figuras e paisagens, estas últimas ministradas por Pedro Alexandrino.

Rossi, arquiteto italiano radicado na cidade fora contratado em 1894 para dar aulas de Projetos de Composição, Desenho de Mão Livre e Trabalhos Gráficos na Escola Politécnica de São Paulo, sendo mais tarde inspetor e diretor do curso de artes do Liceu, com status de sócio no escritório de Técnico Ramos de Azevedo. Domiziano foi responsável por projetos assinados pelo Escritório, entre eles o próprio edifício do Liceu de Artes e Ofícios, o Palácio das Indústrias, o prédio dos Correios, fazendo inclusive o detalhamento do projeto do Teatro Municipal de São Paulo.

Do corpo docente do Liceu também faziam parte em 1895 Fernando Martins Bonilha, responsável pelo curso preliminar de adultos, Tertuliano de Moraes e Justiniano Viana, do curso preliminar de menores, Horácio Berlink, de escrituração mercantil, José Vicente de Azevedo, de geografia e história pátria e Adolfo Borione, de modelação e escultura.

A escola fizera, em janeiro de 1896, nova exposição dos trabalhos dos alunos, organizada pelo Professor Claudio Rossi, arquiteto, cenógrafo e decorador e associado do escritório de Ramos de Azevedo. Como a seção experimental e de aprendizagem era incompleta, realizada em oficinas de outras escolas de artífices e mesmo por estabelecimentos industriais da capital ${ }^{88}$, é possível que a exposição tenha apresentado apenas os trabalhos gráficos dos alunos. As fontes disponíveis não esclarecem mais sobre o evento.

Ramos de Azevedo e Reynaldo Porchat ficaram incumbidos de representar solicitação ao Congresso Estadual relativamente à

88. cf. Ricardo Severo (1934, p. 26). 
concessão de terreno para a construção de uma sede para o Liceu, temporariamente instalado na Rua de Santa Tereza, perto do Largo Sete de Setembro, de modo a continuar favorecendo a instrução pública profissional e tornar-se propriamente uma escola de artes e ofícios.

Em meio às ações da diretoria e dos sócios ${ }^{89}$ para proteger o Liceu e mantê-lo como escola de 'instrução profissional para o ensino de artes, ofícios e técnicas' de reconhecida utilidade pública, foi sancionada lei em 1895 que concedia 100 contos de réis e um terreno como auxílio para edificação de um edifício-sede que servisse tanto ao Liceu quanto ao Ginásio de São Paulo. A diretoria propôs em reunião do dia 12 de setembro que metade do auxílio fosse empregado de imediato na construção do prédio, ficando Ramos de Azevedo encarregado em demarcar a área em frente ao seminário Diocesano, próximo ao Jardim Público da Luz e de frente para a "Inglesa" decidindo sobre a implantação e organização do prédio.

Nesta mesma reunião Ramos de Azevedo propõe que os secretários Teixeira da Silva e Porchat formem uma comissão para avaliar se a diretoria poderia ou não doar a biblioteca do Liceu para a Biblioteca Pública que o governo tratava de organizar. Ramos teceu considerações sobre este assunto, todavia não foram transcritas em ata. ${ }^{90}$

O que, além da extensão de seus volumes, teria a biblioteca de excepcional para chamar a atenção do governo? O governo trocaria a biblioteca por algum favorecimento ao Liceu ou estaria tentando organizar a biblioteca pública do estado cujo acervo foi incorporado em 1937 à Biblioteca Municipal?

Talvez pretendesse integrar a biblioteca do Liceu e seus exemplares específicos para a prática das artes e ofícios às aulas e oficinas da Escola Normal Caetano de Campos cuja sede, com projeto do Escritório Ramos de Azevedo, fora inaugurada no local do antigo largo das Milícias, em 1894. Ou talvez para uso nas dependências da Escola Normal do Brás.

89. Os sócios protetores, relacionados em Livro de Sócios datado de 1895 eram, entre outros, Arthur Prado de Queiroz Telles, Júlio de Mesquita, Martinho Buchard, major Domingos Sertório, cônego Eugênio Dias Leite, Victor Nothman, Ana Guilhermina Pompeu do Amaral, Viscondessa de Indaiatuba e Jorge Tibiriçá, todos pessoas de prestígio ligadas, direta ou indiretamente, ao poder imperial e depois republicano. 90. cf. Atas da Diretoria, 12 de setembro de 1895. 
A Escola Normal no centro da cidade já tinha à sua disposição um notável museu pedagógico além de peças de anatomia humana e anatomia comparada e mais modelos de flores e frutos adquiridas pela Secretaria do Estado dos Negócios do Interior junto à Maison Deyrolles, em Paris. ${ }^{91}$

Antes do parecer dos secretários, a Loja maçônica América encaminhou ofício à diretoria do Liceu reclamando informações sobre a biblioteca ofertada à Sociedade Propagadora em 1873, dizendo constar-lhe que a mesma estava abandonada. A diretoria concluiu pela manutenção da biblioteca no Liceu, oficiando a loja América com a informação de que a biblioteca estava guardada, esperando para ser instalada no novo prédio. ${ }^{92}$ No ano seguinte, Teixeira da Silva faz notar a necessidade da catalogação das obras, ação aparentemente não levada a cabo.

Como mencionado na introdução deste trabalho as fontes são omissas quanto à composição da biblioteca. O que dela restou é amostra de que foi exclusiva, potente e preciosa. Objeto de orgulho da Loja Maçônica e objeto de cobiça do Estado ao ser considerada possível peça de barganha política era, antes de mais nada, lugar de estudos e de construção de conhecimento no Liceu.

Em contato com os exemplares remanescentes mais longevos, percebemos que foi depositária de uma coleção de modelos clássicos e modernos, repertório compósito de manuais com princípios práticos e regras aplicáveis, catálogos comerciais e de politécnica, revistas especializadas e outros, todos apropriados nas esferas da instrução e da inspiração para fabricação de objetos artísticos carregados de expressividade.

91. Ver Diana Gonçalves Vidal, (2009).

92. cf. Atas da Diretoria, 21 de outubro de 1895. 

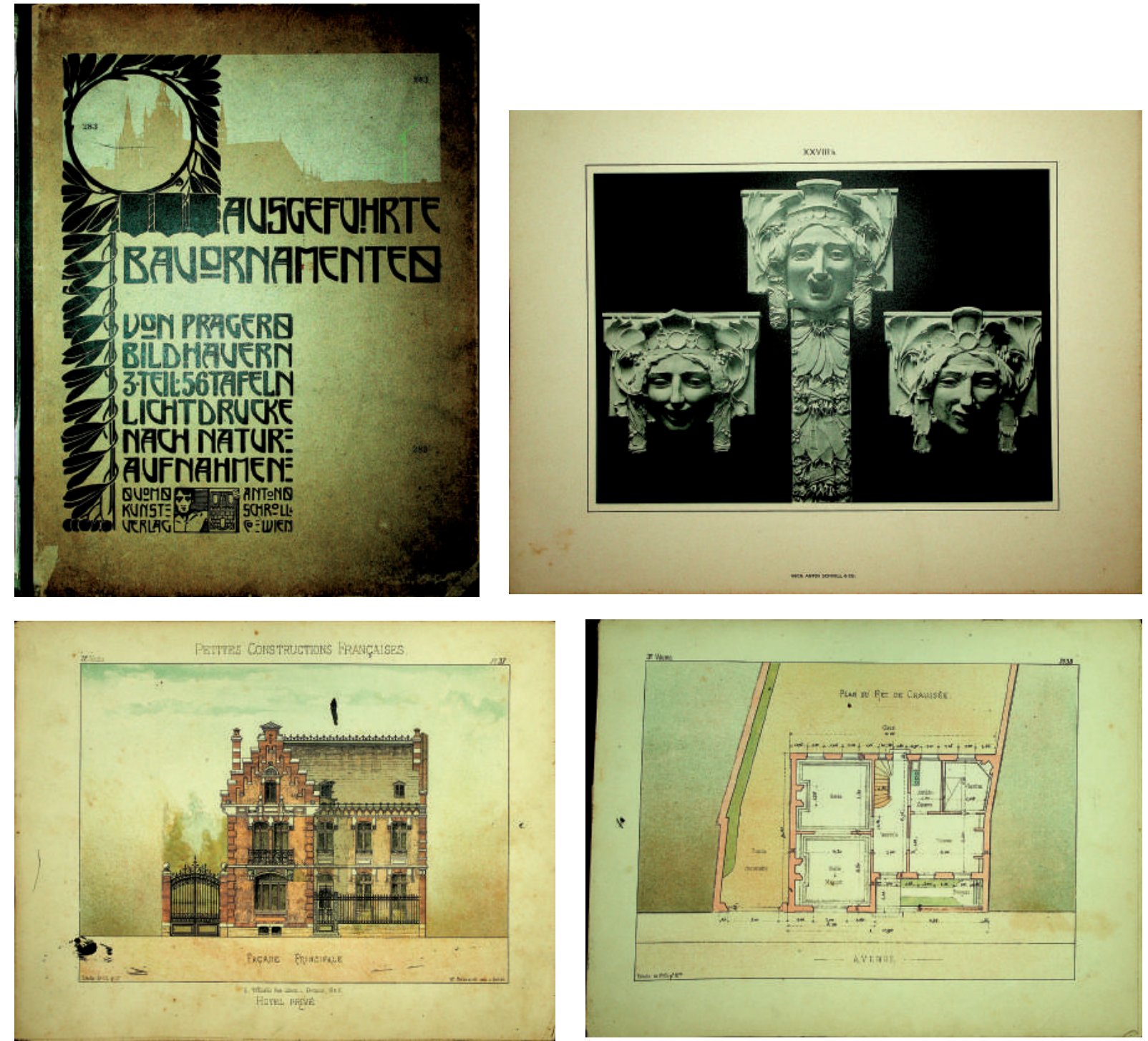

Há exemplares italianos, alemães e franceses como Ausgeführte Bau Ornamente; e Petites Constructions Francaises par un comite D’Architectes, com data atribuida em 1896, que trazem exemplos de sistemas construtivos e decorativos para hotéis particulares, sarcófagos e residências. Outros, também de procedência variada, representam objetos e motivos decorativos e ornamentais, mobiliário e exemplos de arranjos de ambientes internos. Particolari di Architettura Classica; Serie Entwürfe du modern; Documents d'Atelier. Art Décoratif Moderne; Styl. Salon Wohn; Choix d' Intérieurs Belges; Argentor; Anton Andel Gez Ornament; Arte Italiana Decorativa e Industriale 

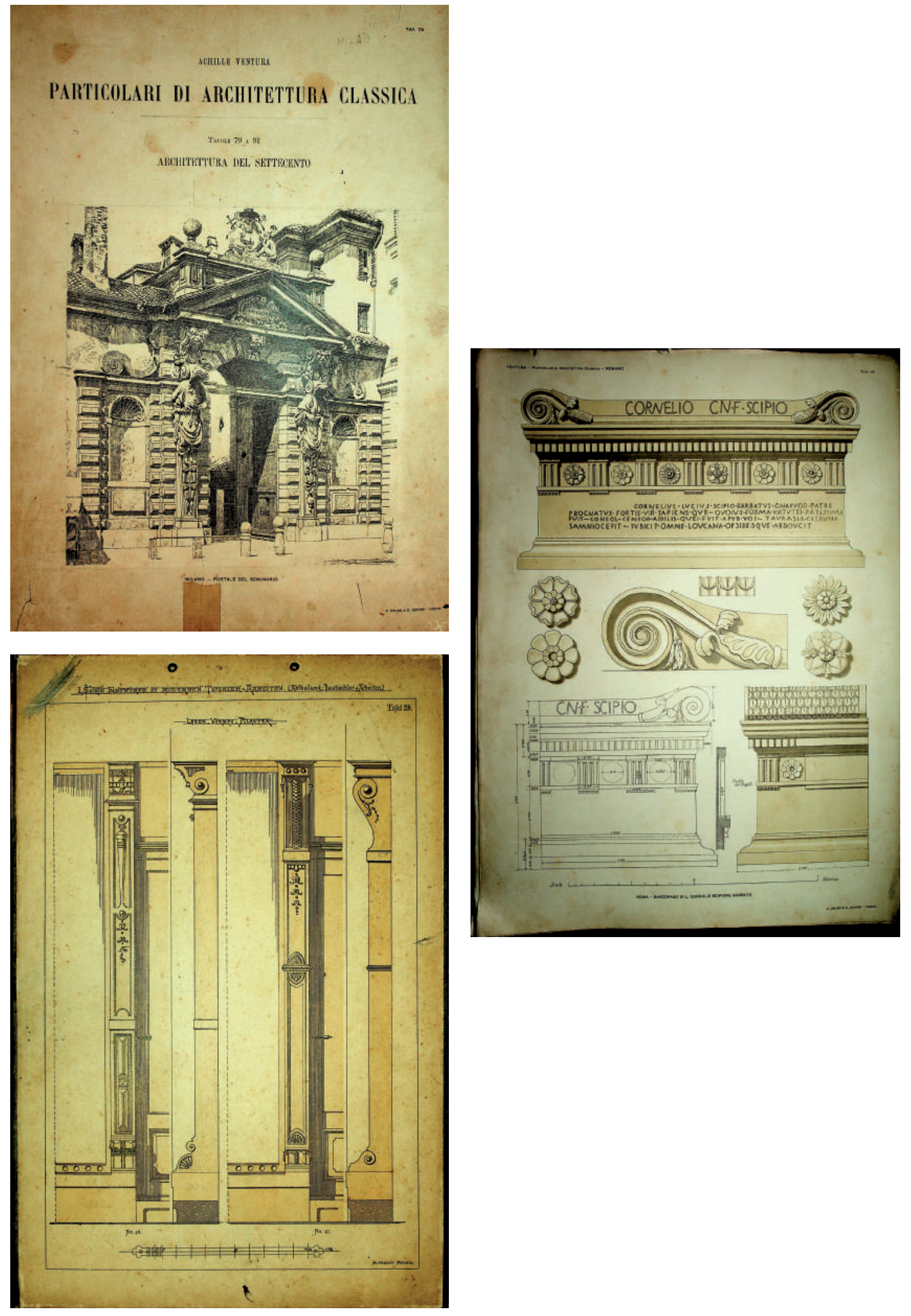

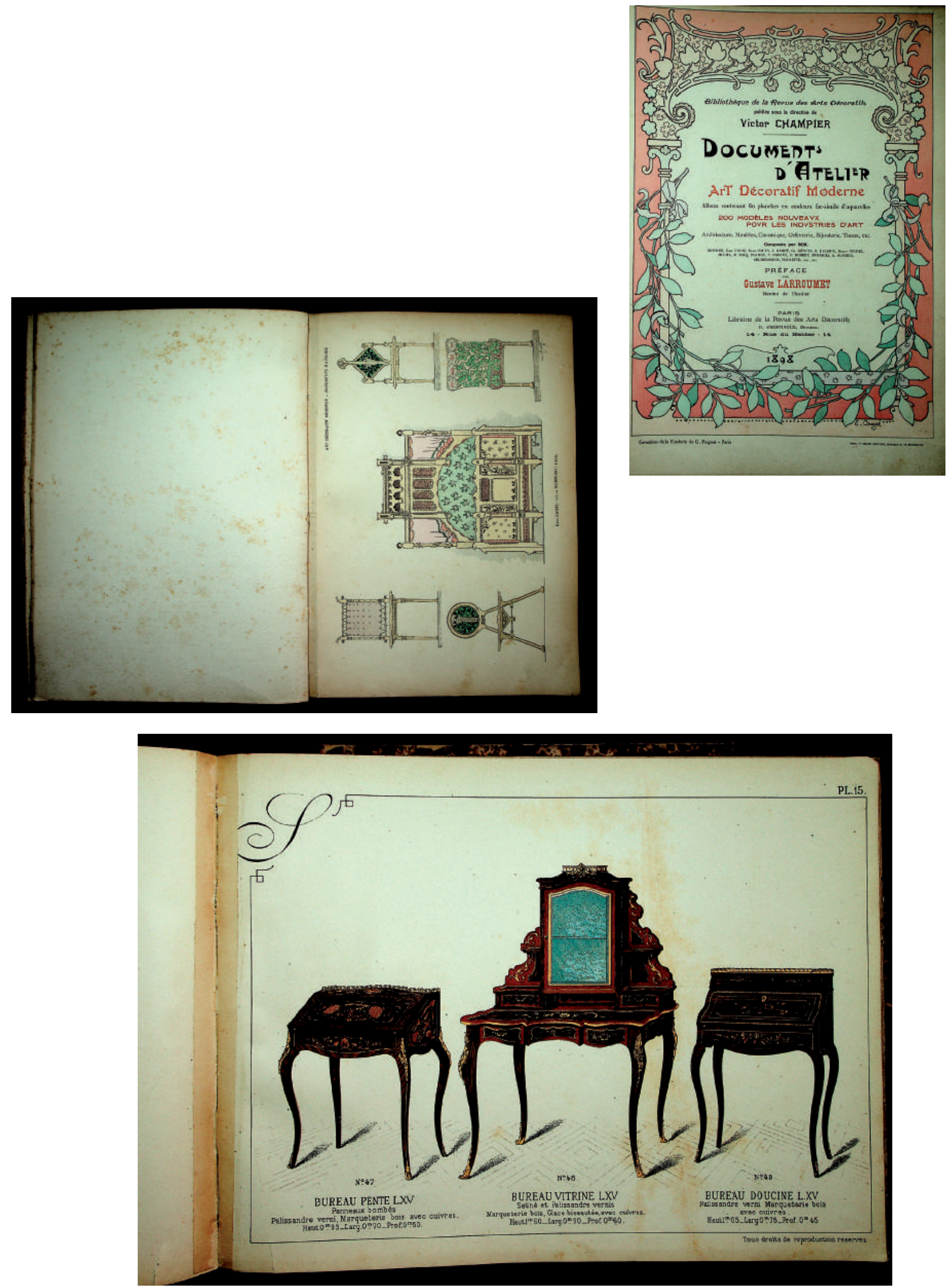

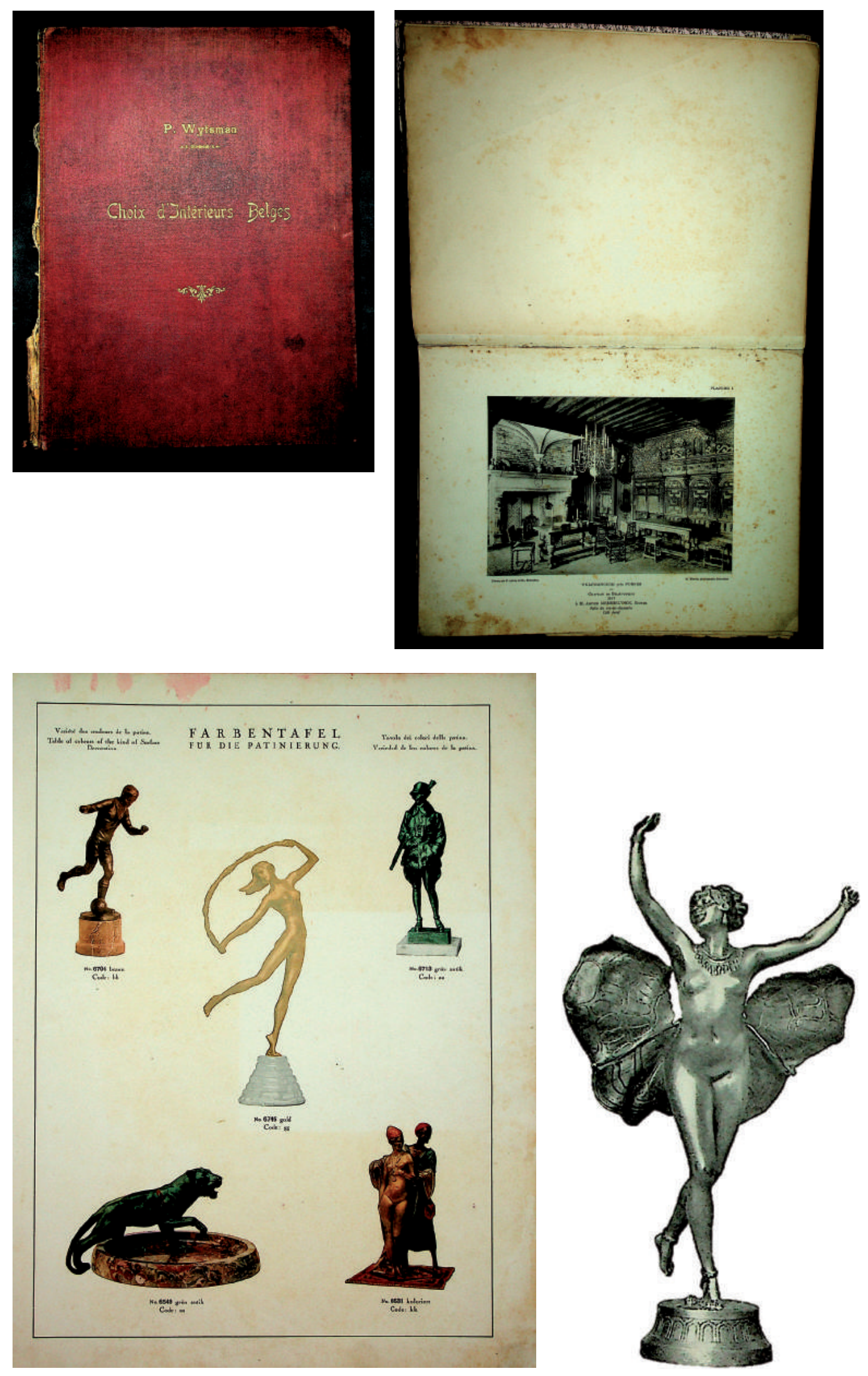

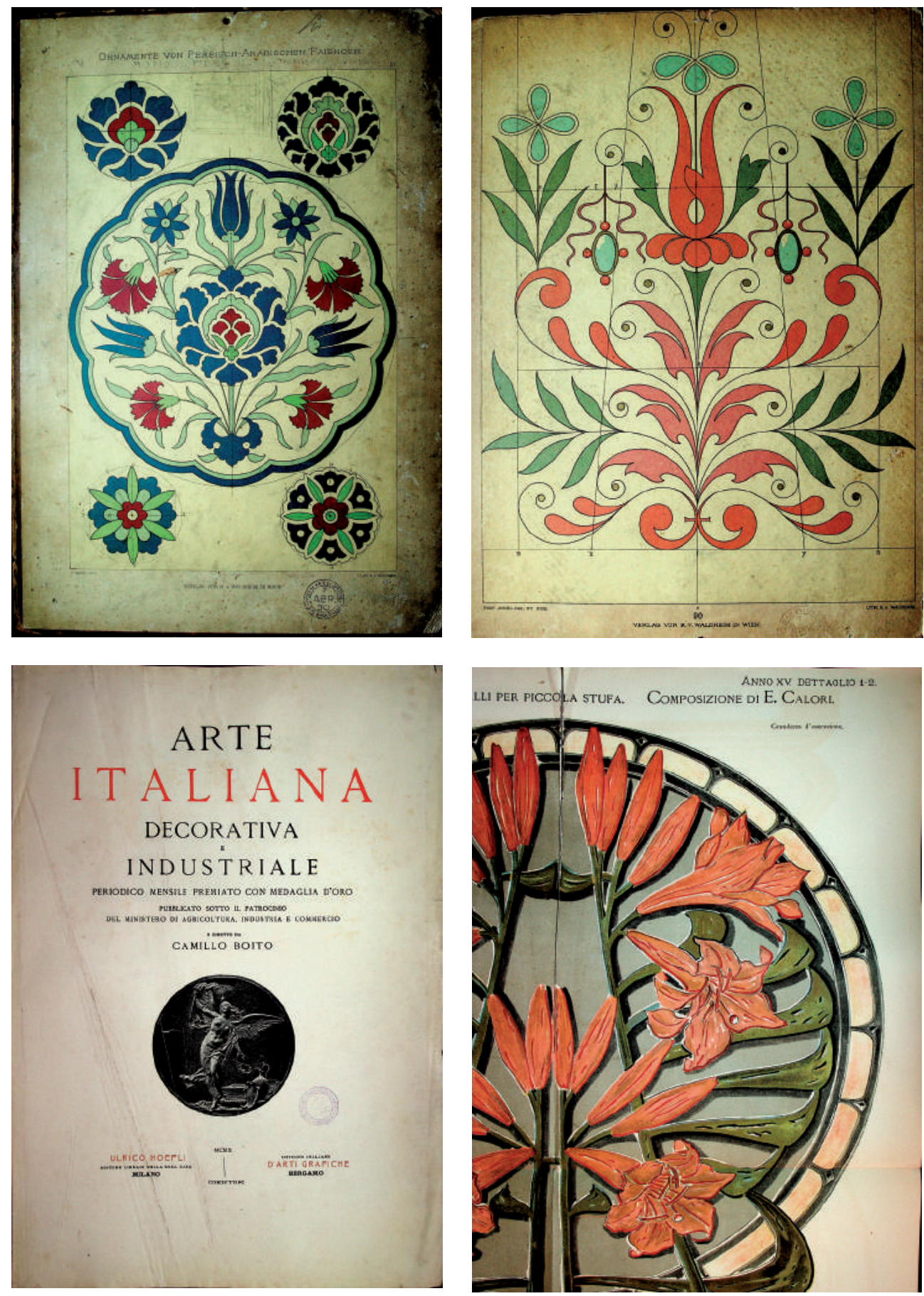


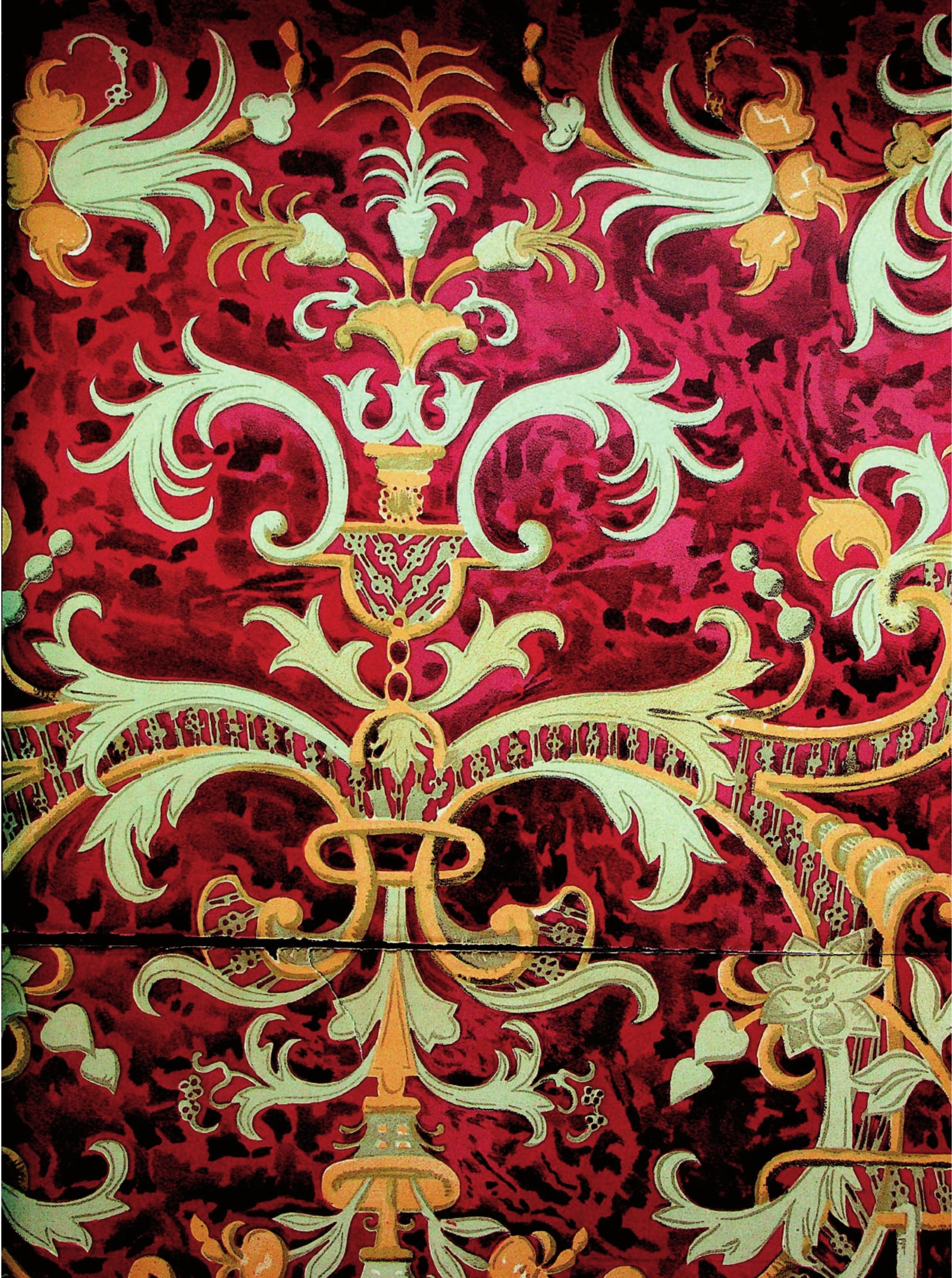




\subsection{A alegria séria das artes}

Reunida no salão de frente do Banco União de São Paulo, empreendimento ainda não liquidado do qual também participava como dirigente Ramos de Azevedo, a diretoria foi oficialmente informada em 26 de setembro de 1896 que o Estado doara ao Liceu, por título de 10 de março, o terreno para construção da sede a ser erigida com os recursos garantidos pela Assembleia Legislativa. Em 1897 o terreno foi retificado e a área deslocada 25 metros para o norte, tendo o Liceu recebido da São Paulo Railway Company a indenização correspondente ao valor dos alicerces e embasamento já iniciados. ${ }^{93}$

Ramos de Azevedo foi o responsável por preparar a planta do palácio monumental. A nova sede da escola na avenida Tiradentes foi projetada pelo arquiteto italiano Domiziano Rossi e realizada pelo Escritório Técnico Ramos de Azevedo.

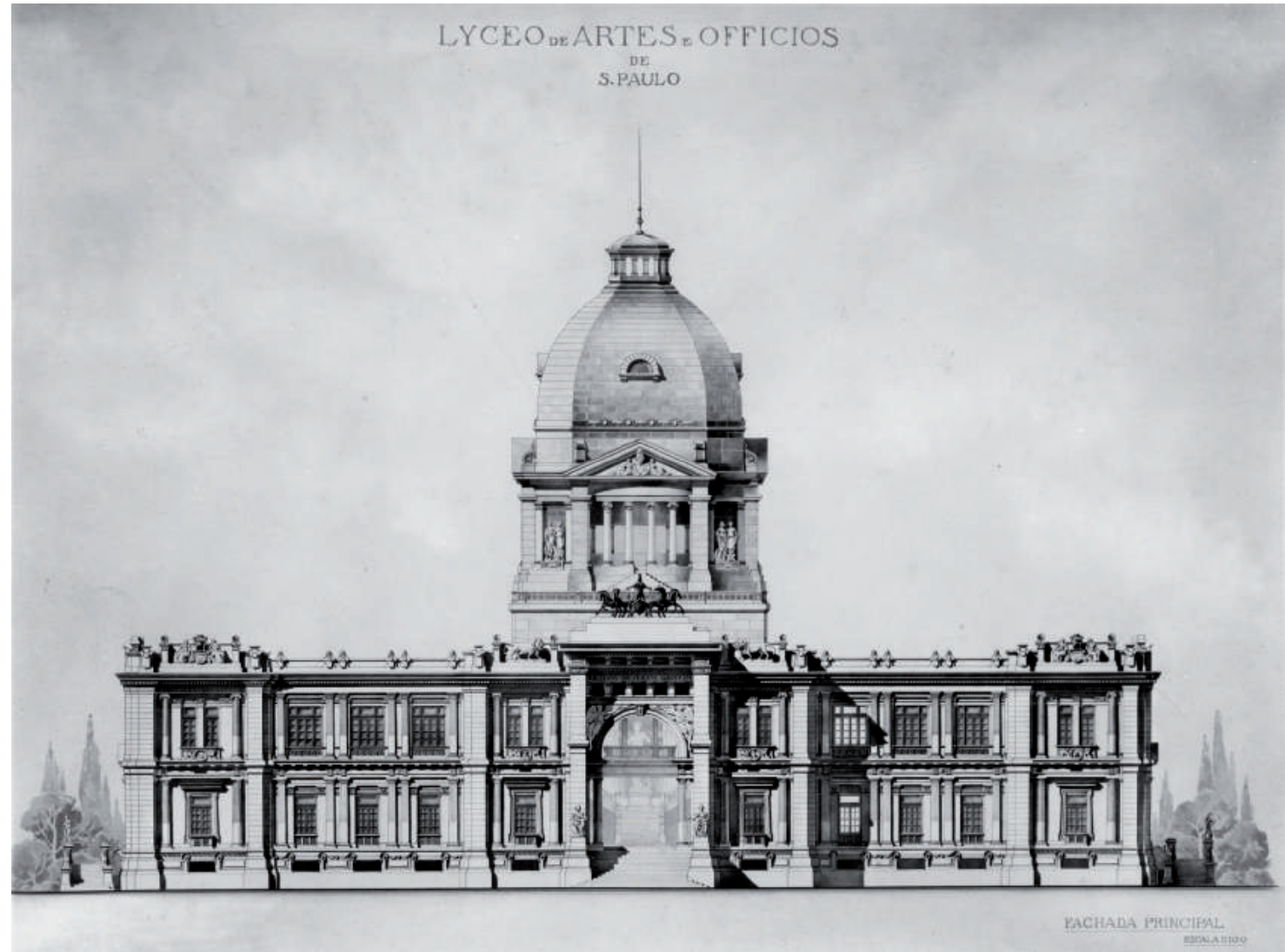

93. cf. Ricardo Severo (1934, p. 33). 


\section{Segundo Carlos Lemos,}

O prédio, projetado por Ramos de Azevedo e Domiciano Rossi, seu principal colaborador, tem estilo monumental em forte consonância com os princípios do ecletismo italiano, formado por três pavimentos, com dois pátios internos de modo a garantir ventilação e iluminação. No centro, primeiro piso, localiza-se o saguão central, com altíssimo pé-direito e janelas voltadas para o interior, que prevê uma cúpula, nunca concluída. Na construção são empregados materiais importados como pinho-de-riga e cerâmica francesa. No projeto, os engenheiros idealizam a integração entre o edifício e o Jardim da Luz, pelo recurso às varandas laterais e às janelas que dão para o parque. ${ }^{94}$

Olhando o desenho do projeto mais de perto, descobrimos que o autor incluiu no pórtico a seguinte frase em latim: Artium Severum Gaudium (A alegria séria das artes) quem sabe referindo-se à sentença de Sêneca. ${ }^{95} \mathrm{~A}$ frase não foi inscrita no edifício, mas decerto foi lá praticada. A cópia da estátua de Davi de Michelangelo, por outro lado, habitou o palácio por longo tempo senão no centro do átrio em outros lugares.

Obra prima colossal emblemática da redescoberta da cultura greco -romana na Renascença, a estátua de Davi foi concebida por Michelangelo entre 1501-1504 e realizada em puro mármore. Ocupou a Piazza della Signoria em Florença estando ao lado do Pallazo Vecchio até 1873, quando foi movida para a Galleria dell'Academia. Medindo 5.17 metros, representa um nu masculino e parece imbuída de plenitude e poder.

Domiziano Rossi, antecipando a possibilidade de a réplica da obra em gesso ocupar a centralidade do palácio que projetara, talvez tenha deixado claro que o programa do edifício era dirigido para a acomodação de uma escola de belas artes.

94. Ver A PINACOTECA do Estado. Texto Carlos Alberto Cerqueira Lemos, Paulo Mendes da Rocha, Maria Cecília França Lourenço. São Paulo: Banco Safra, 1994. 319 p., il.

95. Mihi crede, verum gaudium res severa est. Cf. Seneca, Epístola 23.4, que traduzimos como Creia-me, a verdadeira alegria é séria. Segundo o filósofo italiano Remo Bodei, a frase também denota a colaboração e os conflitos paradoxais entre paixão e razão ao longo da história como demonstrado em seu brilhante estudo intitulado Geometria das Paixões. 
A cópia em gesso pertencente ao acervo do Liceu consta da seção Arte da Renascença do Extrato e Resumo do Catálogo Geral da Galeria

Domiziano Rossi. Projeto da sede do Liceu de Artes e Ofícios de São Paulo, detalhe de Arte publicado em 1934. A réplica está relacionada sob o número 302 e é dita Davi, Michelangelo, estátua de $5 \mathrm{mts}$ - Academia de Florença. ${ }^{96}$

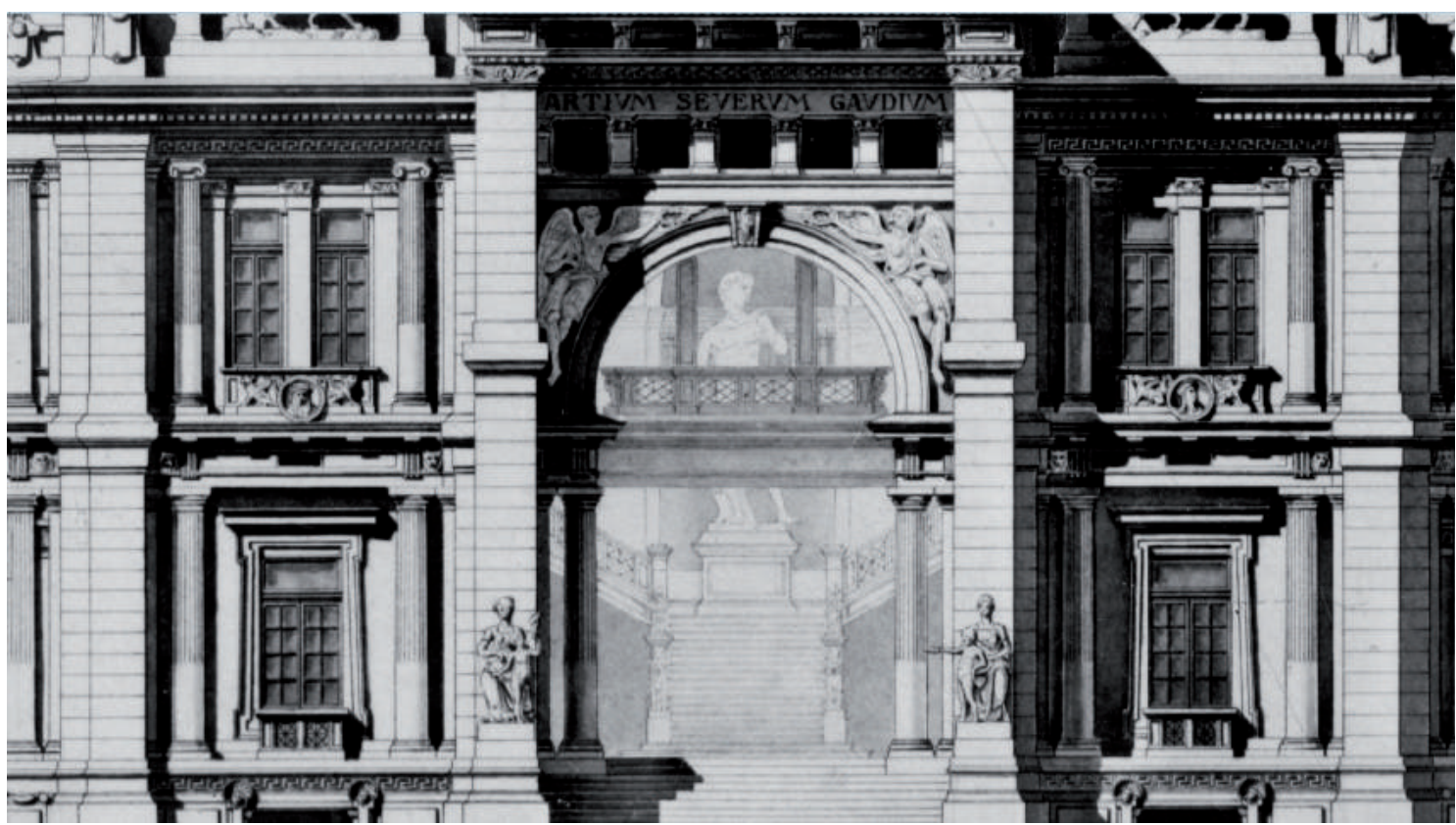

As obras do edifício começaram em 1897 e custaram 1 mil e 200 contos de réis. ${ }^{97}$ As caraterísticas únicas do edifício com seus vazios internos conformados por uma rotunda central octogonal, seus dois pátios laterais, suas molduras, colunas e robustas paredes em alvenaria de barro lhe conferem beleza e majestade, mesmo estando inconcluso. ${ }^{98}$ Como sede do Liceu, e depois, o palácio conheceu ao longo dos anos mudanças na ocupação e usos de seus espaços.

Em 1900 o Liceu mudou-se com 576 alunos, 6 professores do curso primário, 5 dos cursos gráficos e 2 dos cursos de arte para o prédio em construção. Em 1903, o Palácio da Avenida Tiradentes ainda estava inacabado. A iluminação, consistindo em 117 lâmpadas de 16 velas vendidas

96. cf. Ricardo Severo (1934, p. 245). Hoje a cópia encontra-se guardada na sede da instituição havendo uma réplica em cimento exposta na entrada do Centro Cultural do Liceu de Artes e Ofícios de São Paulo.

97. cf. Liceu de Artes e Ofícios. Instituto de Ensinos Profissionais, [1913], p. 7.

98. O prédio foi readequado mais de cem anos depois pelo arquiteto Paulo Mendes da Rocha para abrigar definitivamente a Pinacoteca do Estado. 
pela Light, Power e Co., que também fornecia a energia, era deficiente. Mesmo assim, uma turma de 53 aprendizes remunerados trabalhava desde 1902 nas oficinas de marcenaria e serralheria instaladas ao résdo-chão do edifício. Começava, de fato, o ensino artístico e industrial na escola.

Em 1903, com a saída de Cerqueira Cesar da presidência, o Liceu recompõe a diretoria elegendo Manuel Pessoa Siqueira Campos para presidente, Ramos de Azevedo para vice-presidente, Reynaldo Porchat $1^{\circ}$ Secretário, Victor da Silva Freire, $2^{\circ}$. Secretário, Augusto Cezar do Nascimento, $1^{\circ}$. Tesoureiro e Luiz Gonzaga de Azevedo $2^{\circ}$. Tesoureiro. Faziam parte do conselho Administrativo Cerqueira Cesar, Antônio Teixeira da Silva, Domingos Jaguaribe, João Alves Rubião Junior, Antônio Vieira de Carvalho, João Maurício Sampaio Vianna, Alfredo Pujol, Antônio de Pádua Salles, José Cardoso de Almeida, Ricardo Gray, Christiano Peregrino Vianna, Francisco Ferreira Ramos, William Speers, James Mitchell, Daniel Monteiro de Abreu, Horácio Espindola, Carlos de Campos, Albuquerque Lins e José Paulino Nogueira.

O Liceu fora constituído como pessoa jurídica com novos estatutos registrados no Cartório de Registro Geral e de Hipotecas da comarca da capital. Neste ano Josephine Gualco doou ao Liceu 40.000\$00 reis em memória do marido Francisco Antônio Gualco, fundador da Light \& Power Company em São Paulo. A quantia deu início ao fundo patrimonial do Liceu, mais tarde acrescido com outros donativos. ${ }^{99} \mathrm{~A}$ instituição fora considerada de utilidade pública. Contudo, para enfrentar as dificuldades financeiras fazendo frente às despesas da escola a diretoria sugere o emprego de fundos em ações da Companhia Mogiana de Estradas de Ferro e Navegação, fundada em 1872 e dirigida por Ramos de Azevedo. ${ }^{100}$

O organizador, diretor e mestre, em reunião da diretoria colocou sobre a mesa um compêndio de desenho linear geométrico que mandara adaptar às nececessidades da escola, trabalho do professor J. Esteves Ribeiro da Silva e do qual imprimiu-se 500 exemplares.

99. Como os 2 contos doados por José Weisson em 1904, os 12 contos doados por Ignacio Penteado e Olivia Penteado em 1910 e 1916, os 2,5 contos por Celestino Silva em 1911, 20,5 contos da Comissão de Monumento Feijó em 1915, 50 contos de Bento Quirino em 1916, 8,7 contos de Hermann Sielk em 1919, entre outros. cf. Severo (1934, p.33-34). 100. cf. Atas da Diretoria 14 março de 1903, 5 e 10 de março de 1904. 

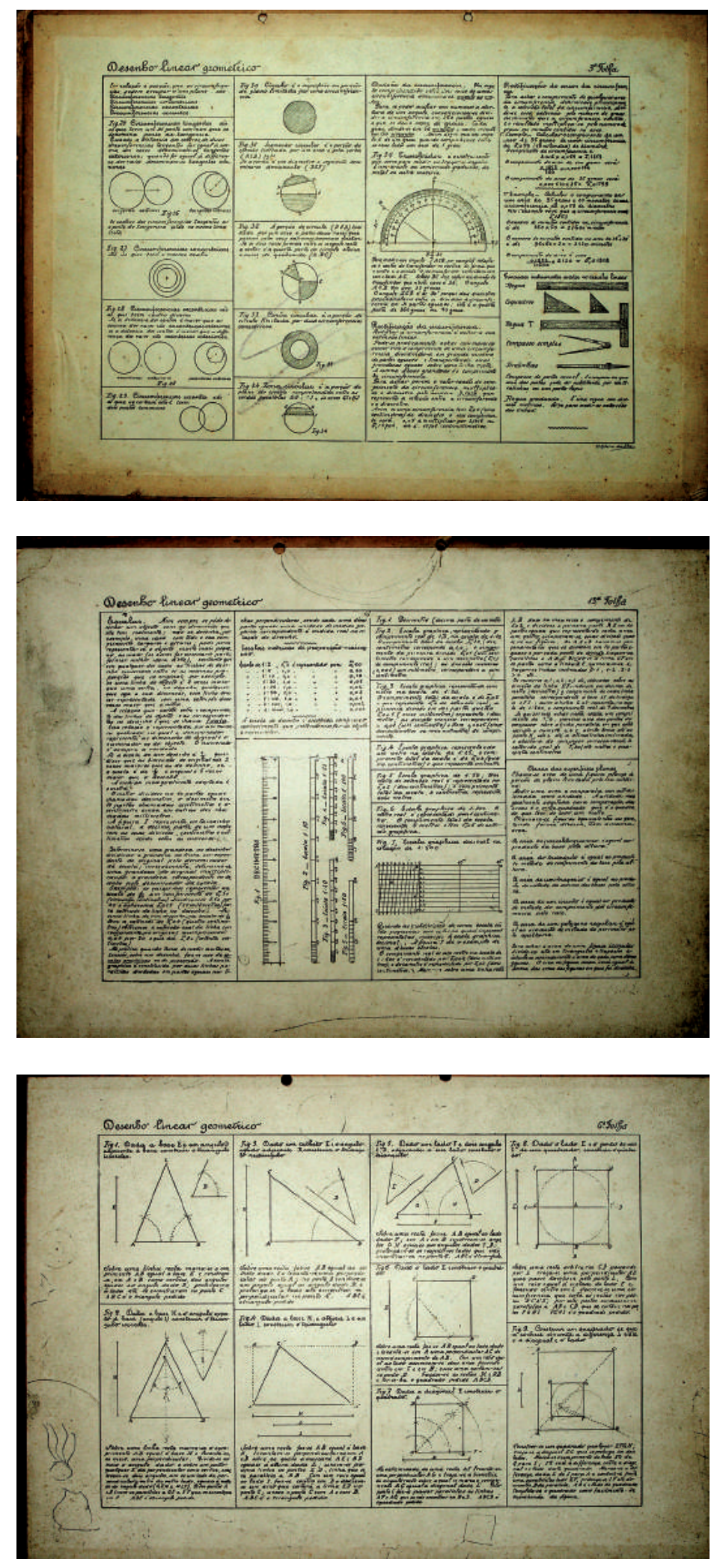

$\Delta$

J. Esteves Ribeiro da Silva. [Curso de ] Desenho linear geométrico, S.I., s.d. 

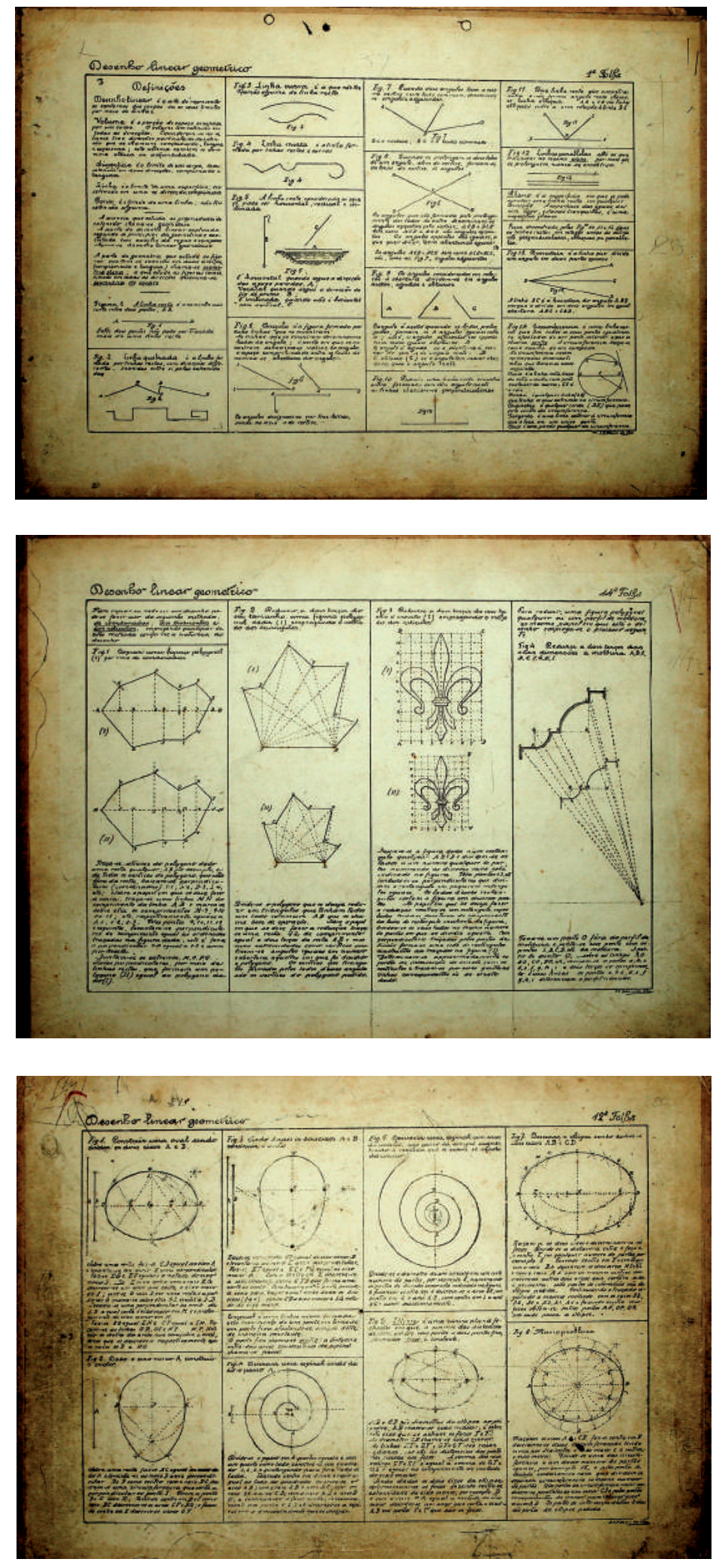
O material foi adotado na sala A da aula de Geometria I do professor C. Nogueira, conforme carimbo no verso de uma prancha.

Os cursos práticos de fundição, escultura e marcenaria instalados no palácio progrediam, especialmente o de marcenaria que requeria escritório próprio para a escrituração das cobranças e dos recibos. Participando da Exposição Internacional de Saint Louis em 1904, o Liceu recebeu a medalha de ouro na categoria Mobiliário Artístico por uma estante giratória em estilo art-nouveau. Este foi o primeiro de uma série de prêmios e diplomas internacionais recebidos pela instituição.

A abertura de novas oficinas e a contratação de novos mestres habilitados aguardava a conclusão da ala onde seriam instalados 'aparelhos trepidantes' de modo a não atrapalhar as aulas no Liceu e no Ginásio do Estado que funcionou no prédio, entre 1901 e 1910, em troca da concessão de terreno para a instalação apropriada das oficinas. Ramos de Azevedo reconhecia a necessidade de instalação de uma pequena oficina de fundição e da transferência do local da oficina de serralharia localizada na frente da rua da Estação, atual Rua Mauá. ${ }^{101}$

O prédio foi ocupado em toda sua extensão. As cópias dos planos do edifício ainda que sem datação, mas provavelmente elaboradas entre 1908 e 1930 para fins que desconhecemos, trazem indicações interessantes sobre os usos dos espaços no palácio. Nelas não aparecem as oficinas nem referimentos explícitos à biblioteca. Talvez ambas tivessem se mudado quando o prédio não comportou mais seu organismo industrial propulsionado pela reforma de Ramos de Azevedo. Segundo Severo, apenas entre 1910 e 1912 o Liceu começou a levantar barracões para as oficinas das mais variadas profissões, as quais aumentou em dimensões e especialidades preenchendo em pouco tempo a capacidade total do quarteirão entre as ruas João Teodoro, Cantareira e Jorge Miranda. ${ }^{102}$

Mas, vejamos o que mostram.

Ao rés-do-chão, na parte fronteiriça ficavam a sala da aula de costura, quatro salas de tapeçaria, uma para o porteiro, outra para a tipografia, uma para a encadernação, outra para a expedição e mais um depósito ao centro. Na lateral direita havia dois depósitos, uma sala de aula e um almoxarifado; na esquerda salas de aula, uma sala para o fotógrafo,

101. Cf. Atas da Diretoria, 5 e 10 março 1904.

102. cf. Ricardo Severo (1934,p. 36). 
um depósito de cerâmica e um water closet. Ao redor do octógono havia salas para quatro pintores perto do sanitário e de outro water closet, uma sala para o dourador, perto do elevador. Ao fundo uma galeria ficava na frente de oito salas de aula, sendo no canto esquerdo uma de química e físicas e no outro uma sala para montagem de móveis. Ao fundo, na mesma extensão ocupada pelas classes do pavimento acima arrendadas ao ginásio, ficava um grande depósito de móveis. Do lado externo direito havia uma área retangular com water closet logo depois da moradia do porteiro. Na frente, do lado esquerdo, ficava a garagem.

$\mathrm{Na}$ parte fronteira do segundo pavimento ficavam quatro classes, três salas de exposição de frente para a rua. Na lateral direita ficavam uma sala de exposição e duas de depósitos um deles dando para uma pequena galeria. No centro, ao redor da rotunda, um depósito, ao redor corredores com galerias e exposição e water closets, com espaço para o elevador. Na lateral esquerda uma galeria e três classes. Ao fundo um corredor galeria dava frente para nove classes arrendadas ao Grupo.

No primeiro pavimento, na frente, ficavam duas classes, três escritórios, um almoxarifado e duas grandes salas de exposição de frente para a rua. Nas laterais ficavam as classes, os depósitos e galerias. No centro, ao redor da rotunda central, uma grande sala de exposição, corredores de exposição e uma galeria. Neste pavimento vê-se a indicação do pátio e da passagem para o Jardim. Ao fundo ficavam nove classes arrendadas ao Grupo Escolar Prudente de Moraes.

Ricardo Severo publicou em 1934, uma planta do primeiro pavimento melhor acabada do que a apresentada acima e provavelmente de fatura anterior, na qual os espaços têm outra disposição. Embora de leitura difícil, a planta indica ao fundo seis salas e talvez um depósito, sem menção ao ginásio do estado. Na frente, onde a planta anterior marcava duas classes e três escritórios, a planta indica no lado esquerdo o que lemos, ou queremos ler, bibliotecário ladeado por um amplo salão para a biblioteca! Onde ao centro se viam escritórios, nesta planta se lêa diretoria e do outro lado, em oposição a esta, um escritório. 


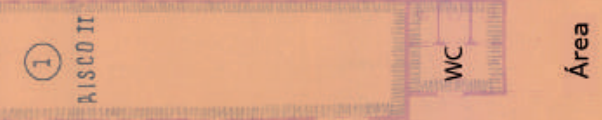

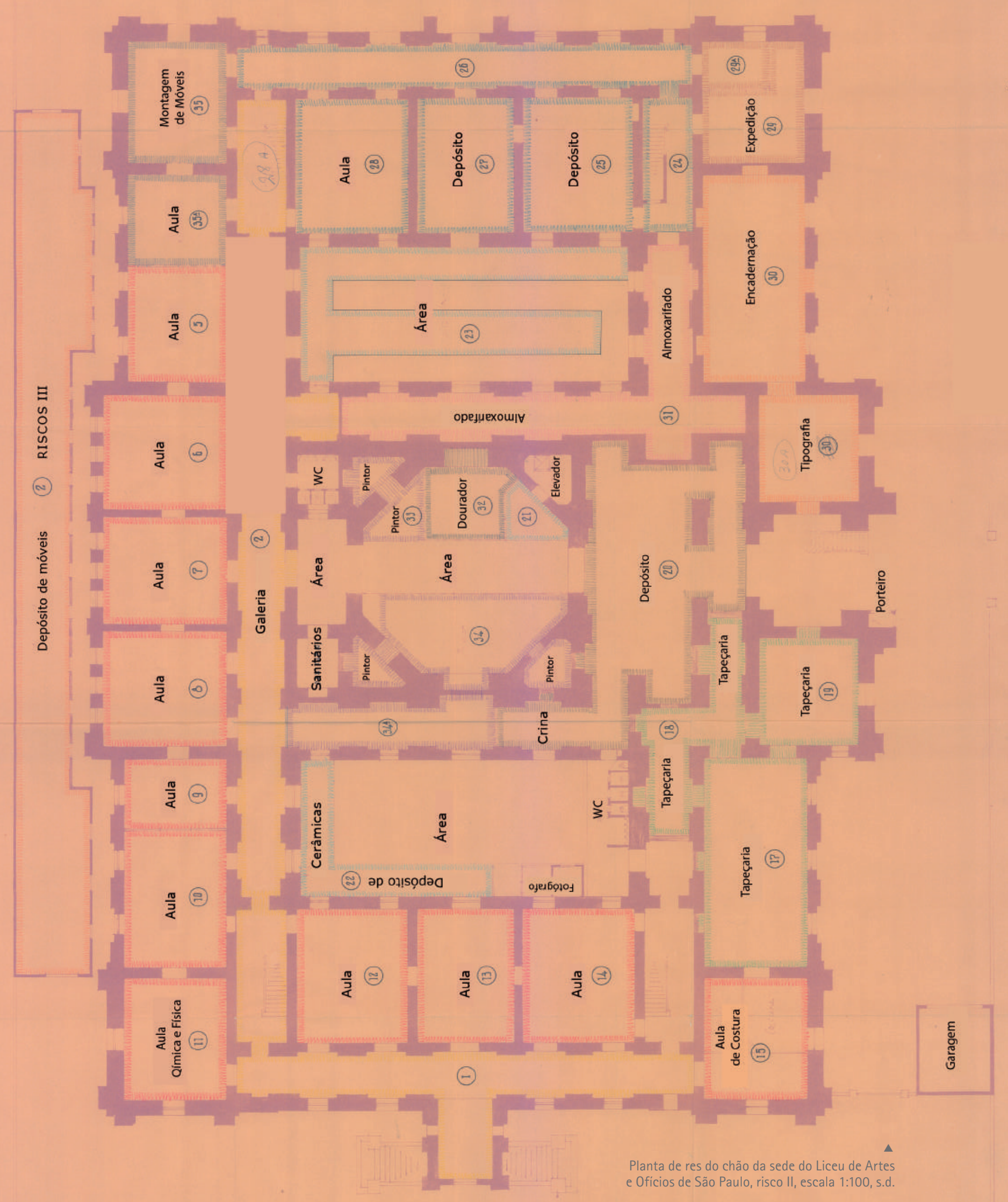




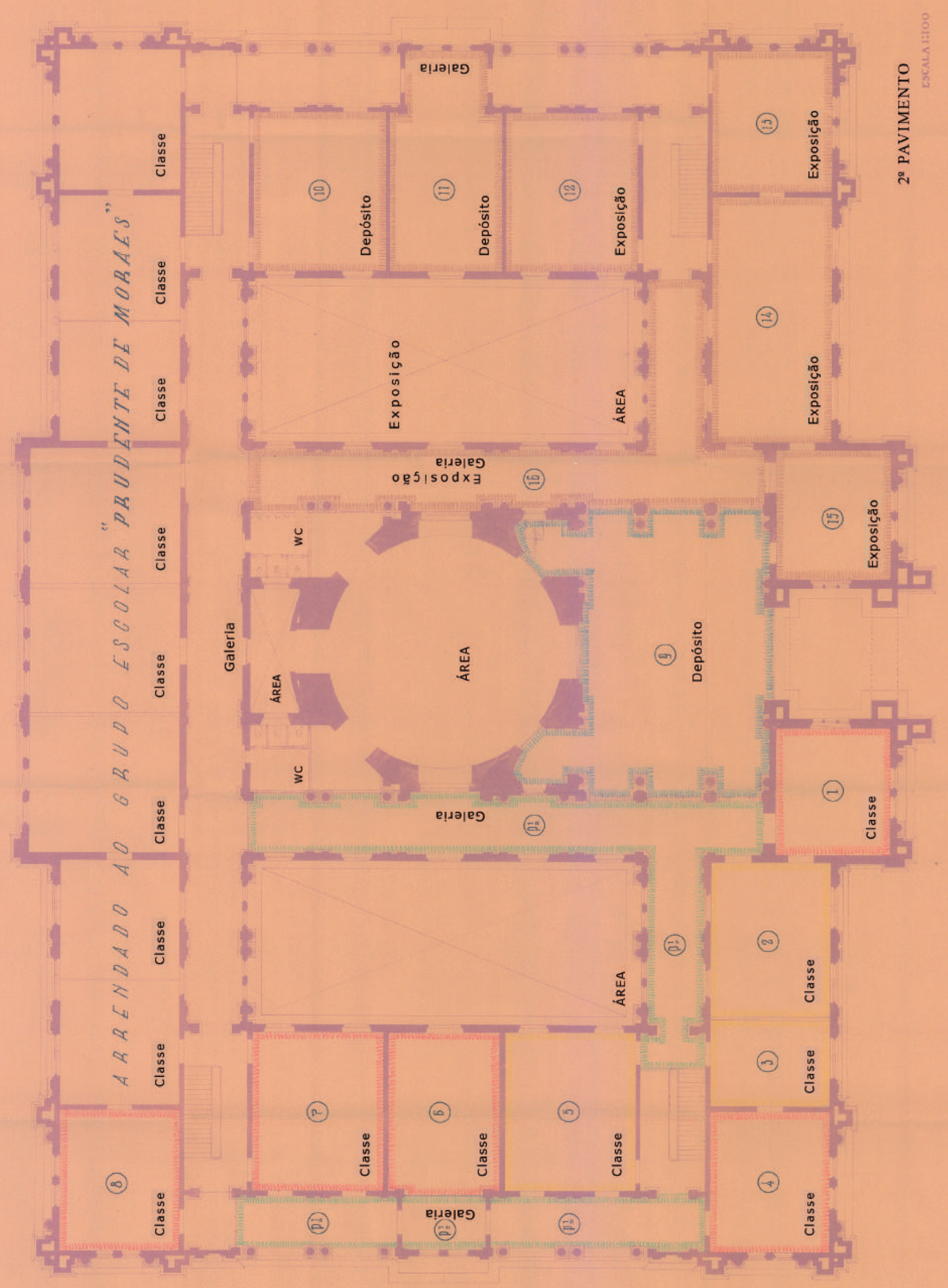

$\Delta$

Planta do segundo pavimento da sede do Liceu de Artes e Oficios de São Paulo, escala 1:100, s.d. 


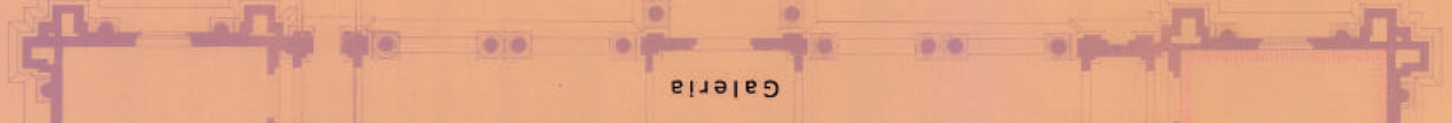

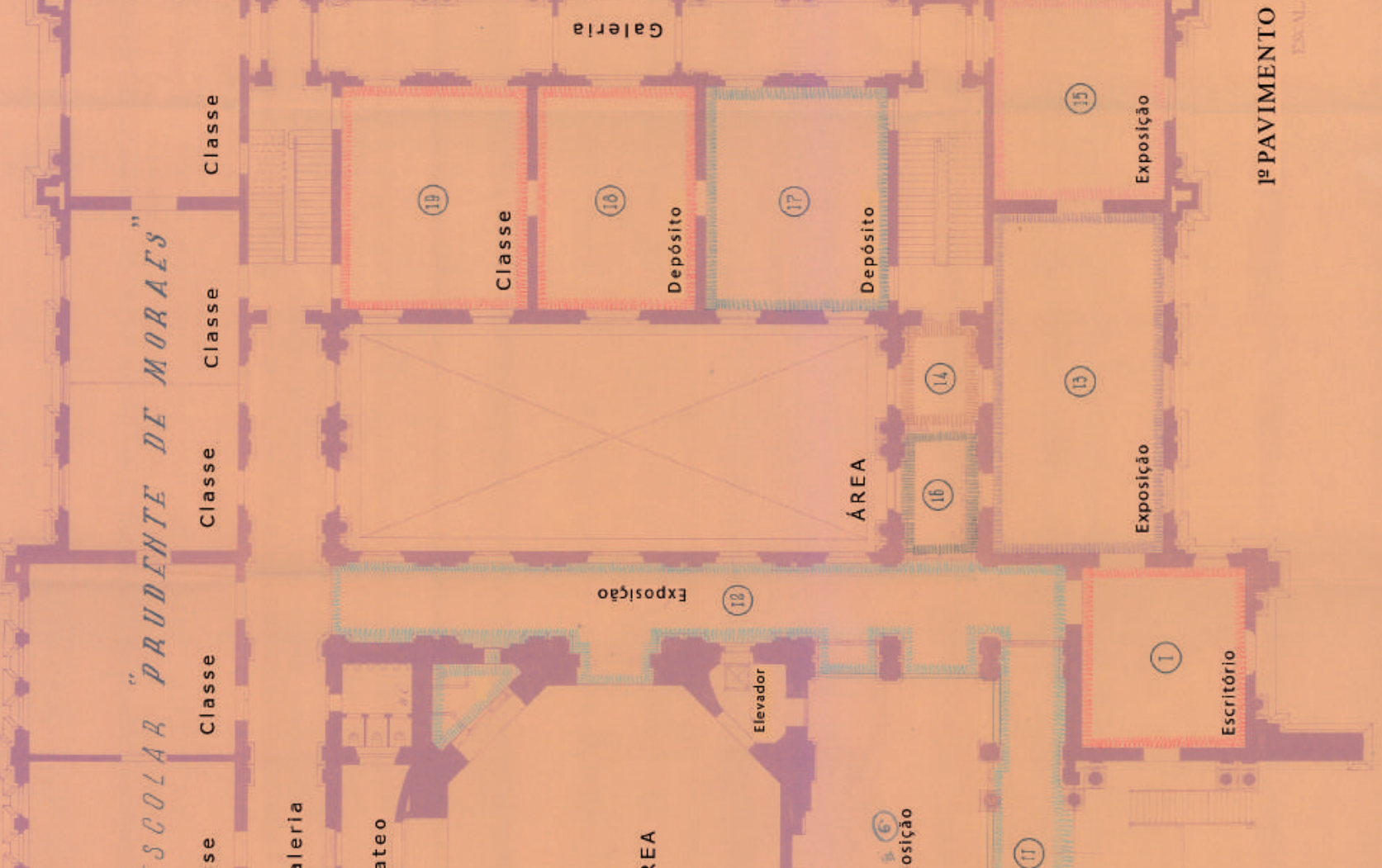

11

(4)

Q

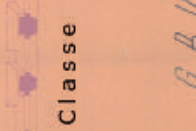

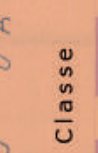

$\frac{1}{4}+\frac{\pi}{u}$
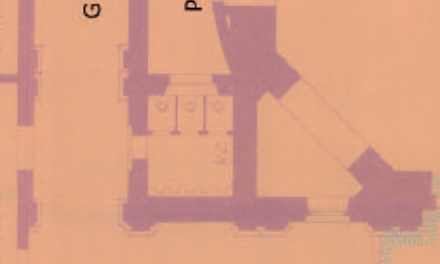

$1+\begin{array}{ll}0 & 0 \\ \theta & \vdots \\ \nabla & 0 \\ \nabla & \frac{\pi}{u}\end{array}$

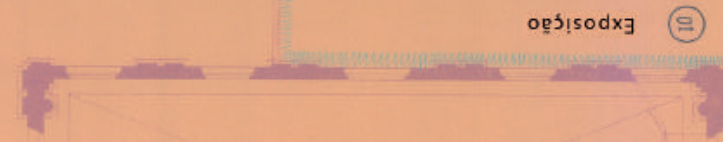

12

(1)
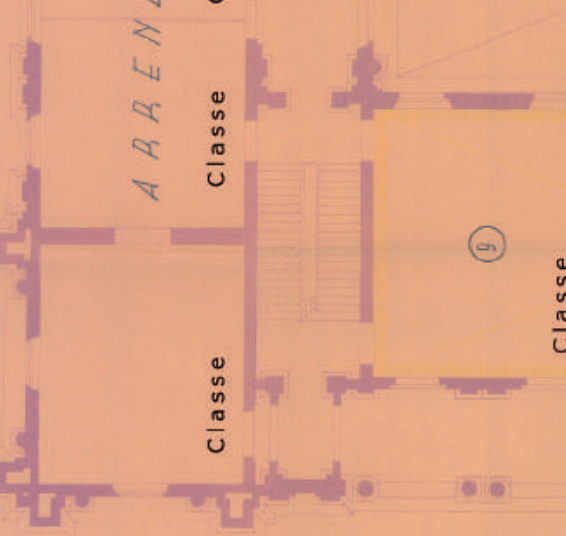

(6)
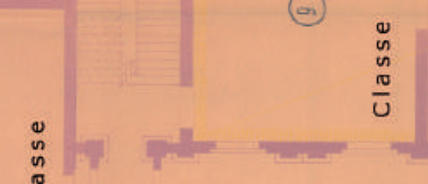

(๐)

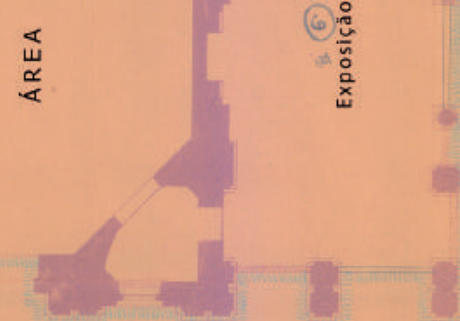

$\ominus$

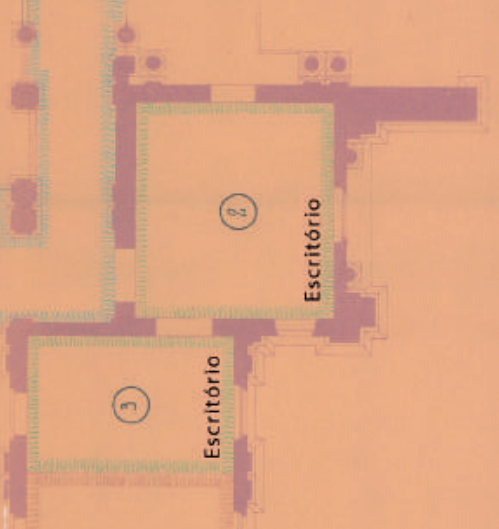

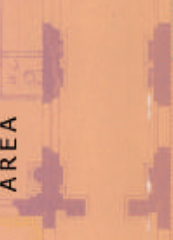

(4)

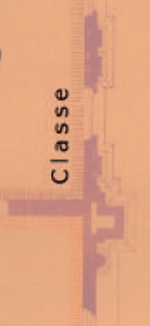

(4)

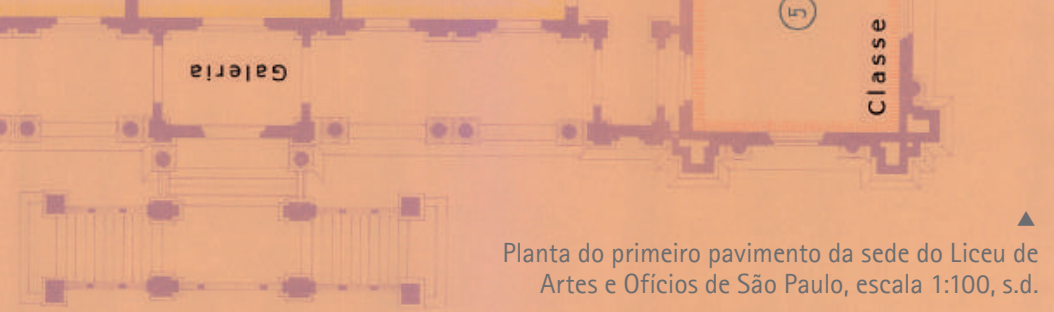




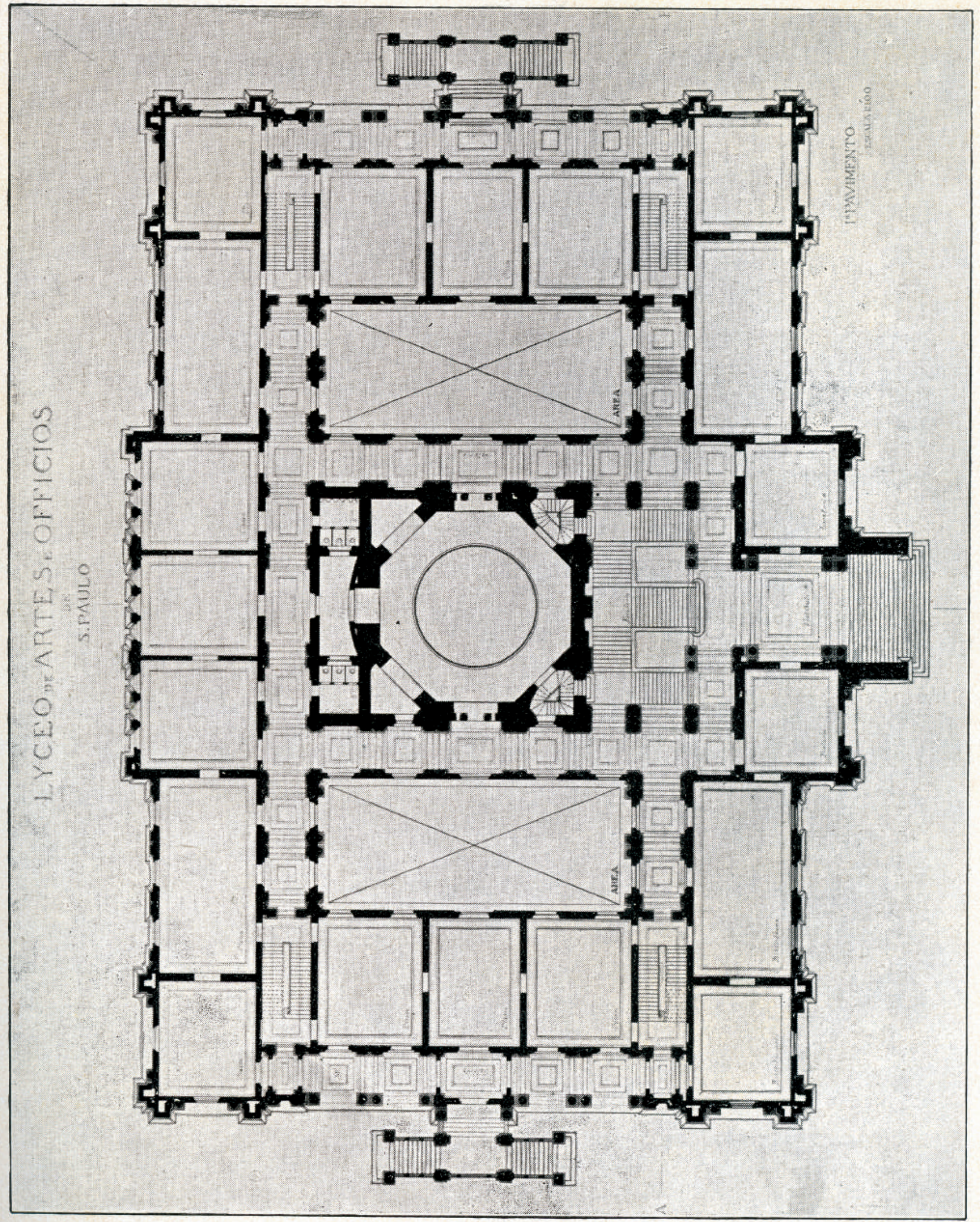

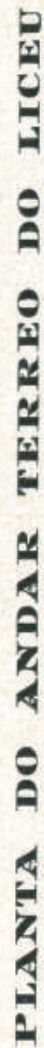

Planta do primeiro pavimento da sede do Liceu de Artes e Ofícios de São Paulo conforme publicada por Severo, 1934 
Em 1905, com o aumento das matrículas e com 807 alunos, passaram a funcionar as oficinas de ebanisteria, escultura em madeira, caldeiraria, forja artística de fundição de bronze e metais finos de modelação, iniciando-se a produção de artigos para a venda ao público, a fim de ajudar na manutenção da escola. ${ }^{103}$

Liceu de Artes e Ofícios. Álbuns mostruários Salões. Mesas, consolos, floreiras e vitrinas Luiz XVI e Império; Pratas repuxadas e cinzeladas Época Dom João V e Salões. Sofás, poltronas, cadeiras s.d.
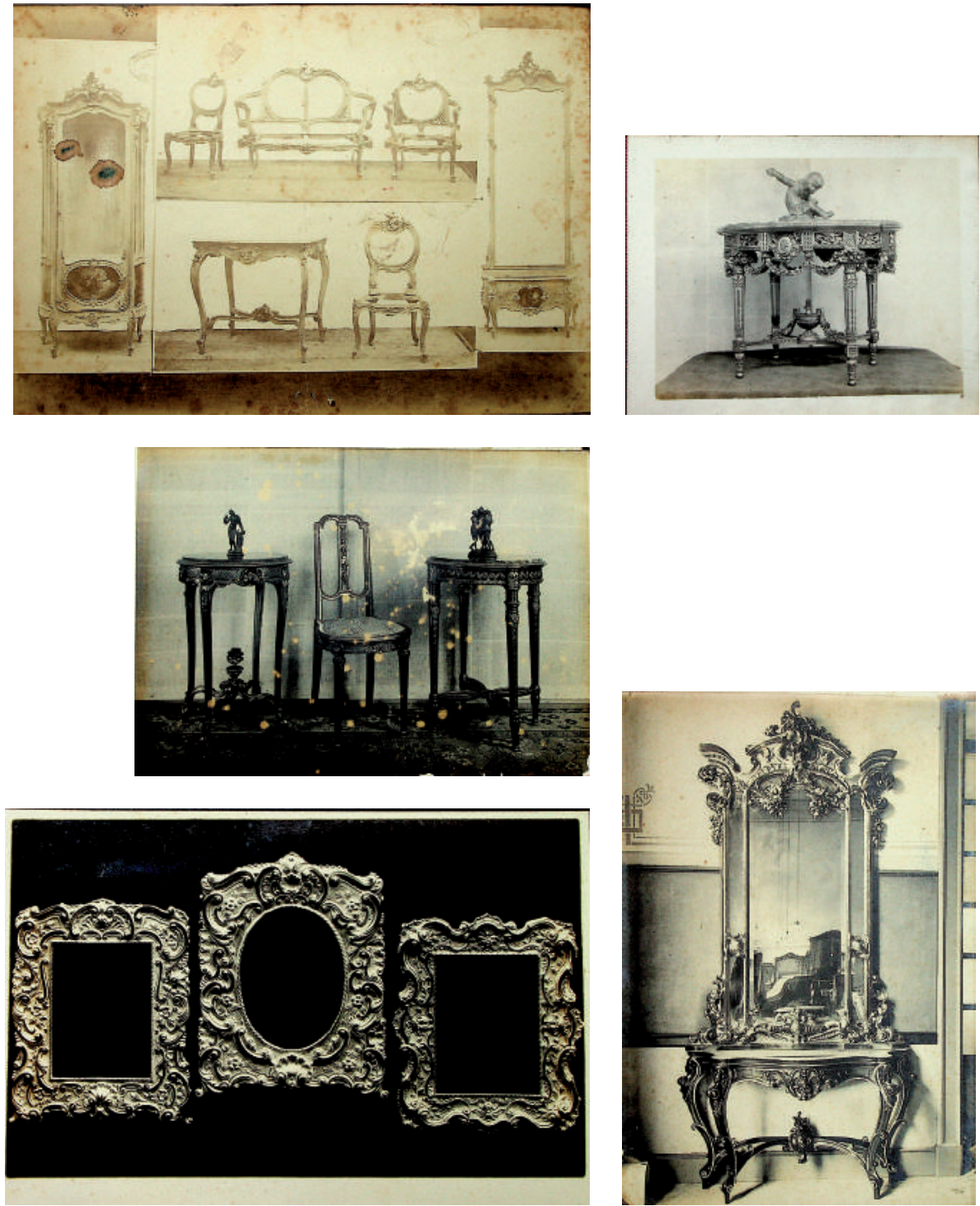

103. cf. Liceu de Artes e Ofícios de São Paulo (1958, p. 1). Como noticiado em primeira página pelo Correio Paulistano de São Paulo em 12 fev. de 1906, o Conselheiro Leôncio de Carvalho acompanhando da Diretoria do Liceu percorreu todo o edifício, observando com muito interesse e atenção todas as oficinas que possuíam os mais modernos aparelhos, modelos e máquinas, movidas por eletricidade, e cujos excelentes artefatos que eram vendidos por bons preços atestavam a proficiência dos mestres e o aproveitamento dos aprendizes. 



\section{Capítulo 4. Práticas do saber (1906-1940)}

\subsection{As belas artes}

Conforme comentado no capítulo três deste estudo, o "Organizador" incumbiu-se de configurar definitivamente o Liceu como instituição que ministrava às classes pobres educação técnica e de caráter prático, expressão que Joséphine Gualco usou ao dirigir uma carta a Ramos de Azevedo informando sua doação à escola em 1903.

A reforma de Ramos seguia sua via. Junto dos cursos de instrução primária e artística foram introduzidas novas disciplinas nos cursos secundários e especialmente nos cursos profissionais, ditos "cursos práticos de belas artes" ou de artes e ofícios, organizados em vasta "oficina de aperfeiçoamento do operariado e ensino dos aprendizes para todas artes subsidiárias da arquitetura" ${ }^{106}$.

Em 1906 a escola tinha mais de 800 alunos matriculados sendo 219 no curso de desenho. Neste ano o Liceu abriria seus salões de mostruário permanente, espalhados pelas galerias e áreas expositivas do primeiro e segundo pavimentos, exibindo suas manufaturas artísticas. Ganhara medalha de prata na exposição anual da Academia de Belas Artes do Rio de Janeiro pela "perfeição artística e técnica" de seus produtos. ${ }^{107}$

106. cf. Ricardo Severo (1934, p. 196 -197).

107. cf. Ricardo Severo (1934, p. 36). 


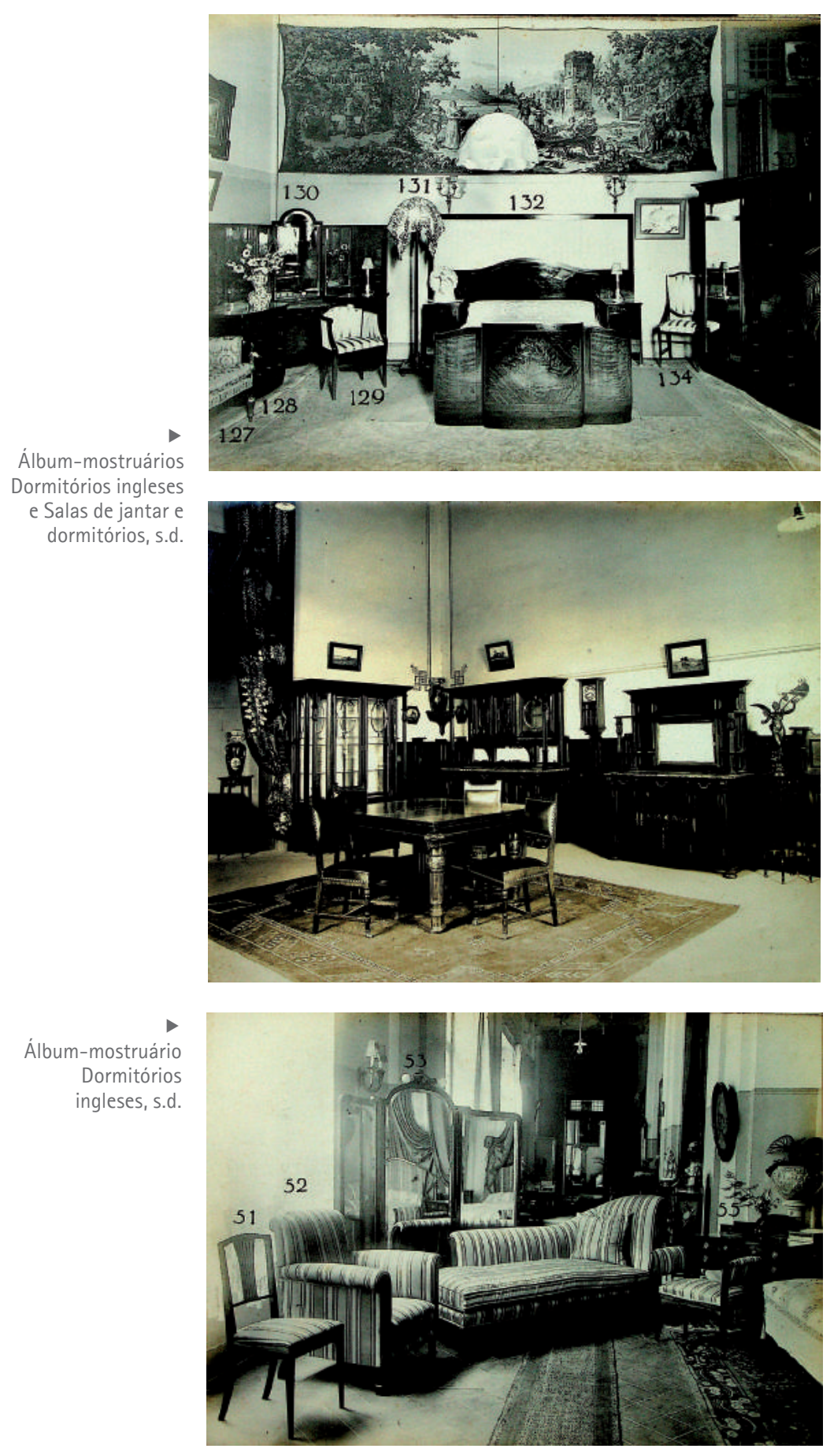

Mais tarde o Liceu apresentaria seus produtos em outros locais como galerias, feiras, congressos e exposições nacionais e internacionais, tendo ganho um diploma de honra, oito grandes prêmios, dez medalhas de ouro, com destaque para o Diploma de Grande Prêmio e Medalha de Ouro na Exposição Universal de Bruxelas em 1910 e 
Medalha de Ouro na Esposizione Internazionale Delle Industrie e del Lavoro em Torino em 1911.

É provável que em certas ocasiões, além de exibir sua produção, o Liceu colaborasse na confecção de estantes, vitrinas e mostruários para outros expositores.

Aliás, o Liceu sediou exposições nacionais e estrangeiras. Acolheu a I Exposição Geral de Belas Artes em 1911-1912, exibindo 83 concorrentes com 461 produções de pintura, escultura, arquitetura, desenhos e fotografias, alguns adquiridos pelo governo para a Pinacoteca.

O Liceu tornava-se também Casa da arte, na definição de Ricardo Severo.

Em 1913, conforme proposta do médico e colecionador Bettencourt Rodrigues e do diretor do Liceu Ricardo Severo, sob o patrocínio do governo francês e com o concurso do governo do Estado, um dos pavilhões do prédio abrigou a Exposição da Arte Francesa em São Paulo, promovida pelo Comité France Amérique de São Paulo.

A comissão organizadora foi constituída por Ramos de Azevedo (vice-presidente do Comité), Victor da Silva Freire, M. Quoniam de Schompré, cônsul da França e M. Montgolfier, Tesoureiro do Comitê. A exposição ficou aberta de 7 de setembro a 9 de outubro de 1913, sendo inaugurada pelo Presidente do Estado, Rodrigues Alves e pelo Secretário do Interior, Altino Arantes.

O comissário geral da exposição e inspetor de Belas Artes de Paris Louis Hourticq contou com material e pessoal do Liceu, segundo ordens de Ramos de Azevedo, tendo organizado juntamente com Maupas o catálogo da mostra sob o título Exposition d'Art Français de São Paulo, com prefácio de Gabriel Hanotaux, além do breviário Histoire-Guide de L'Art Français. Un musèe-type d'enseignement de l'art français à l'étranger - le Musèe d'art français de São Paulo. ${ }^{108}$

A exposição foi dividida em três seções principais: arte retrospectiva, com 1.025 obras, sendo 930 cópias fotográficas, gravuras, sanguíneas, águas-fortes, litogravuras, estampas e fotografias, e 94 modelagens, algumas provenientes do ateliê de modelagem do Louvre, além de cerâmicas e medalhas; Belas Artes com 255 obras de pintores, escultores e arquitetos franceses contemporâneos e Artes Decorativas

108. Ver Ricardo Severo (1934). 
reunindo um conjunto de 786 produtos de arte, das manufaturas nacionais francesas dos Gobelins, da Savonnerie e Sèvres e de casas comerciais como Daum, Lalique, Galle, Baccarat e muitas outras. Nesta última sessão os objetos estiveram à venda.

A mostra contou com a reconstituição de ambientes decorativos em estilo Luís XVI, Segundo Império, dentre outros.

Segundo Ana Paula Nascimento:

toda a sessão de arte retrospectiva foi comprada pelo governo do estado de São Paulo para que permanecesse em São Paulo a fim de que desse origem a um museu da história da arte francesa na cidade. ${ }^{109}$

A autora indica que o material adquirido através da mostra foi incorporado ao acervo artístico da Pinacoteca do Estado, embora sugira que o mesmo tenha sido deixado à margem da coleção principal, provavelmente sendo integrando à biblioteca do Liceu. Objetos como medalhas e algumas cópias em gesso permaneceram no acervo, ainda que um outro conjunto tenha sido transferido para o Liceu de Artes e Ofícios na gestão de Fábio Magalhães (1979-1982). ${ }^{110}$
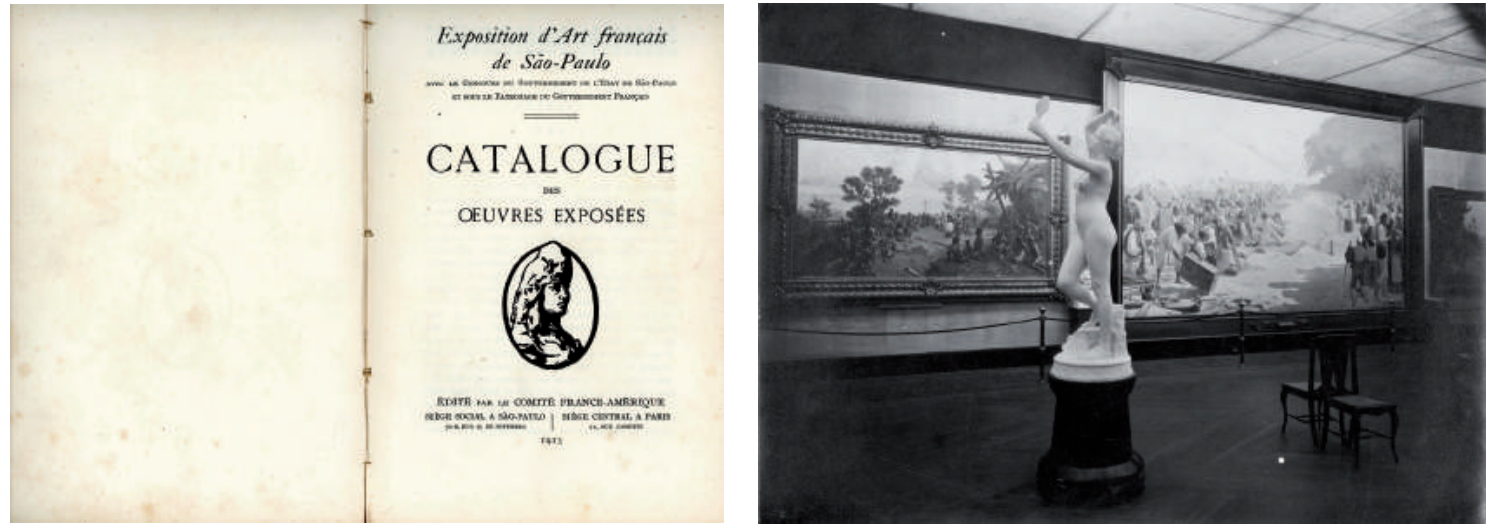

O material transferido pode ter sido acrescido à Gipsoteca do Liceu que já ocupava os espaços do edifício e tinha uso didático-pedagógico. Teria integrado a relação do catálogo geral da galeria de arte?

109. Ver Ana Paula Nascimento (2014).

110. Ver Ana Paula Nascimento (2014). 
Como comentado na introdução deste estudo, a escola adquiriu uma Gipsoteca, coleção de cópias de esculturas em gesso que Ricardo Severo nomeia como a Galeria de Arte do Liceu. Ao publicar o extrato e resumo do catálogo da galeria onde os principais modelos são sumarizados e classificados em diversas épocas e estilos, ${ }^{111}$ o diretor a descreve nestes termos:

reproduções em gesso provenientes dos principais museus das Europa, e de muitas esculturas contemporâneas nacionais e estrangeiras, com originais e modelos de tamanho natural ou reproduções, compreendendo 380 exemplares de estatuas, grupos de estatuária, altos e baixos relevos, 83 de elementos arquitetônicos, 109 de motivos ornamentais, 65 de elementos de anatomia artística, 130 de elementos naturais e ornatos de fauna e flora, estilizações para modelos escolares, 7 maquetas de monumentos cívicos e 1060 modelos de ornamentação arquitetural que compõem a gipsoteca especial da Oficina de Artes Plásticas.

Os modelos estrangeiros reproduziam em gesso obras de arte originais localizadas em museus como o Louvre em Paris, Vaticano em Roma, Britânico em Londres e a Galeria dos Uffizi em Florença. Não se sabe ao certo como e quando a coleção foi adquirida, mas pode ser que tenha sido comprada entre 1906 e 1908 com recursos advindos de donativos feitos pela Condessa Álvares Penteado. ${ }^{112}$

A coleção ficava disponível para o uso de alunos e professores durante as aulas de diversos cursos, sendo que parte ficava exposta no Palácio-sede.
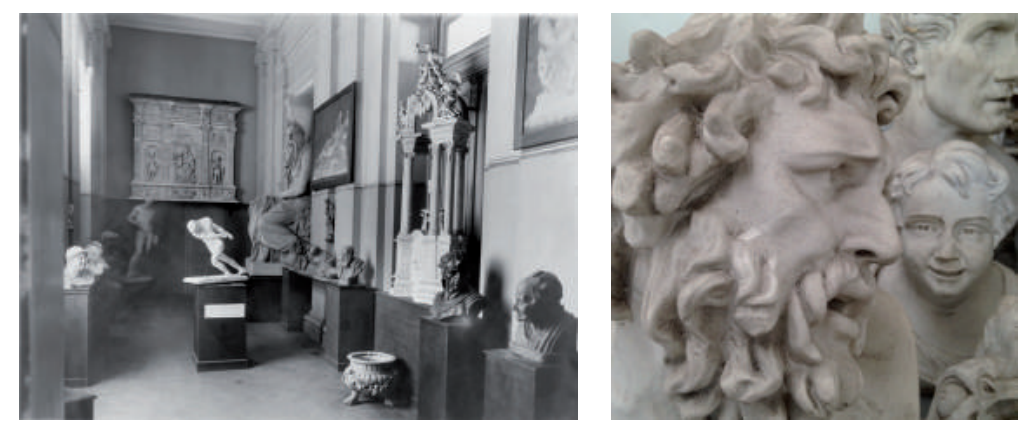

A coleção de gessos nos corredores do Palácio da Avenida Tiradentes, São Paulo, s.d.

111. Os modelos são classificados como sendo de estatuária antiga, oriental, da idade média, bizantina, renascentista, moderna e contemporânea, numerados e titulados, a maioria seguida de indicações de autoria, data e procedência. Ver Ricardo Severo (1934). 112. cf. Atas da Diretoria, 1 de março de 1908. 

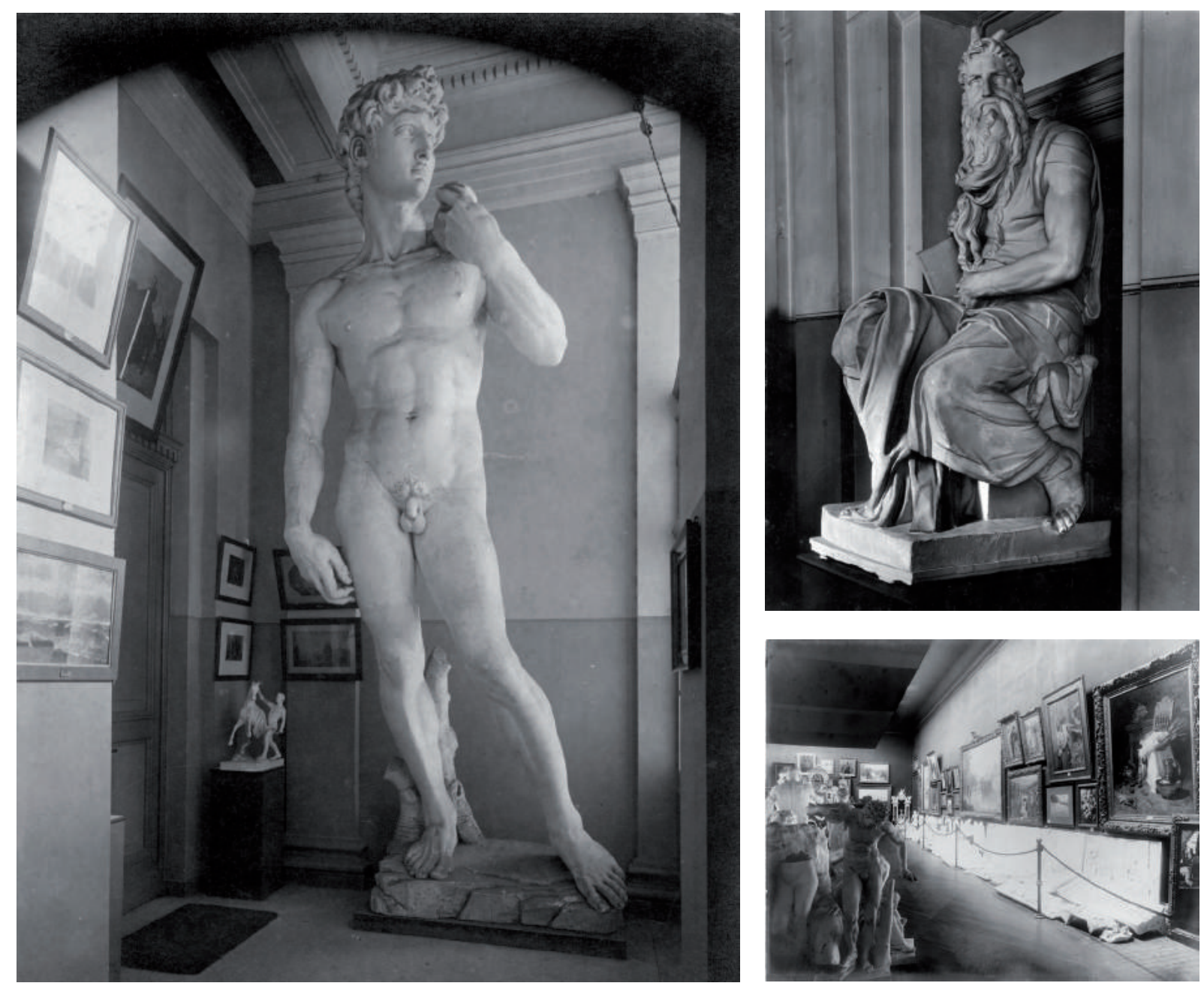

Réplicas em gesso de Davi e Moisés de Michelangelo e outras peças da coleção

A partir deste momento o Liceu estava equipado com um museu pedagógico, uma biblioteca e uma significativa coleção de modelagens (moulages) e cópias, séries que, ao replicarem originais raros e preciosos seriam consideradas na França 'a base de uma escola profissional de escultura de ornamento' ou, melhor ainda, um museu de arte decorativa. ${ }^{113}$

Contudo, no Brasil, como bem nos adverte Ana Maria Belluzzo:

[...] [n]a coleção de modelos do Liceu (...) as obras não revelam uma orientação para as artes decorativas: são tributárias do sistema de Belas Artes e compõem as referências das três artes

113. Ver Chantal Georgel para a discussão acerca do museu de arte decorativa e de museus industriais na França, assim como o papel desempenhado pela Union Centrale des arts décoratifs no incentivo das cópias para o uso de artistas industriais (1994, p. 67,77 e ss.). 
figurativas ou artes do desenho visando a formação de um repertório mais compatível com uma futura escola superior de Belas Artes efetivamente almejada por Ramos de Azevedo. ${ }^{114}$

Discorrendo sobre a gipsoteca e sobre os modelos disponíveis no Liceu, a autora considera que a galeria, ao promover o contato direto com a estatuária tradicional e as coleções de catálogos e revistas, ao difundirem e atualizarem as questões relativas às artes decorativas, eram cadinhos de simultaneidade, criando uma "injunção eclética". ${ }^{115}$ Assim, na aprendizagem do desenho para as artes industriais os recursos pedagógicos existentes no Liceu, sendo complementares e operados em conjunto, estimularam substancialmente a produção do belo no útil.

Buscaremos compreender como os recursos aparecem integrados ao programa do Liceu desde que a instrução e a aprendizagem nas oficinas eram práticas e o aporte de conhecimento teórico somado à habilidade técnica fundamentava o processo de produção.

\section{2. 'Agentes de produtividade'}

O Liceu, dito em 1934 Instituto de Ensinos Profissionais, era dotado de um programa que abrangia uma Escola de Cultura Geral e Profissional, e uma Escola Prática de Artes e Ofícios instalada nas oficinas. Lembremos que as oficinas só foram plenamente instaladas entre 1910-1912, alcançando seu apogeu em 1922, sendo ali o lugar "onde o trabalho prático passa a ser o núcleo da formação oferecida". ${ }^{116}$ Severo detalha o programa de cada curso das escolas, sendo que salientaremos aspectos dos cursos de desenho da Escola de Cultura Geral e Profissional, assim como o programa e organização da Escola Prática de Artes e Ofícios.

O programa da Escola de Cultura Geral e Profissional oferecia aulas noturnas dos cursos gerais divididos em preliminar, preparatório e complementar, além do curso geral de arte e dos cursos especiais. ${ }^{117}$

No curso preliminar as classes eram de leitura, linguagem oral e escrita, aritmética elementar e lição de coisas e fatos. No preparatório,

114. cf. Ana Maria de Moraes Belluzzo (1988, p. 135-136).

115. cf. Ana Maria de Moraes Belluzzo (1988, p. 136).

116. cf. Maria Lucia Gitahy (1986, p. 45).

117. Para esta seção e todas as descrições dos programas ver Ricardo Severo (1934). 
aritmética pura e aplicada, português com gramática expositiva. A classe complementar tinha as matérias de geografia, cosmografia, geografia geral e do Brasil, história universal e do Brasil, história natural e lições cívicas.

O curso geral de artes era composto pelas matérias de desenho linear e geométrico, desenho linear a mão livre, desenho arquitetônico, artes plásticas e artes decorativas. Nas aulas de desenho linear e geométrico aprendia-se geometria plana, no espaço (estereometria) e descritiva (estereografia, perspectiva e aplicações). Nas de desenho linear a mão livre, desenho de estampa, de ornato e figura. Em desenho arquitetônico estudava-se rudimentos da arquitetura e desenho profissional. Para as artes plásticas, havia aulas de modelação e para as artes decorativas aulas de desenho e pintura.

Conforme nos ensina Ana Maria Belluzzo, professores e alunos, todos dominavam o desenho porque:

[...] como se sabe, sendo uma razão construtiva da forma, a geometria constitui um nexo interno, uma ordem lógica, pela qual a forma parece existir em si mesma. Enfatizá-la é subordinar a forma à construção, à medida. ${ }^{118}$

Nestes cursos os alunos manuseavam instrumentos e utensílios de desenho, faziam exercícios e resolviam problemas de construção de formas geométricas treinando aplicações como, por exemplo, as superfícies helicoidais às escadas e parafusos. Aos alfabetos da esfera e dos pontos e aos cálculos juntavam-se ensinamentos de representações.

No curso de geometria descritiva ensinava-se a perspectiva geométrica e suas aplicações a elementos simples de arquitetura e de máquinas. Para a penetração dos sólidos estudava-se os perfis e juntas usando-se exemplificação e demonstração com "elementos fornecidos pelas oficinas". ${ }^{119}$ Para o corte e ensamblagem das madeiras instruía-se o desenho de tipos e aplicações usuais à carpintaria, marcenaria e serralharia com o uso de modelos escolares e trabalhos das oficinas.

Muito provavelmente o tratado de carpintaria de Louis Mazerolle foi utilizado nestas e em outras aulas.

118. cf. Ana Maria de Moraes Belluzzo (1988, p. 127).

119. cf. Ricardo Severo (1934, p. 116). 


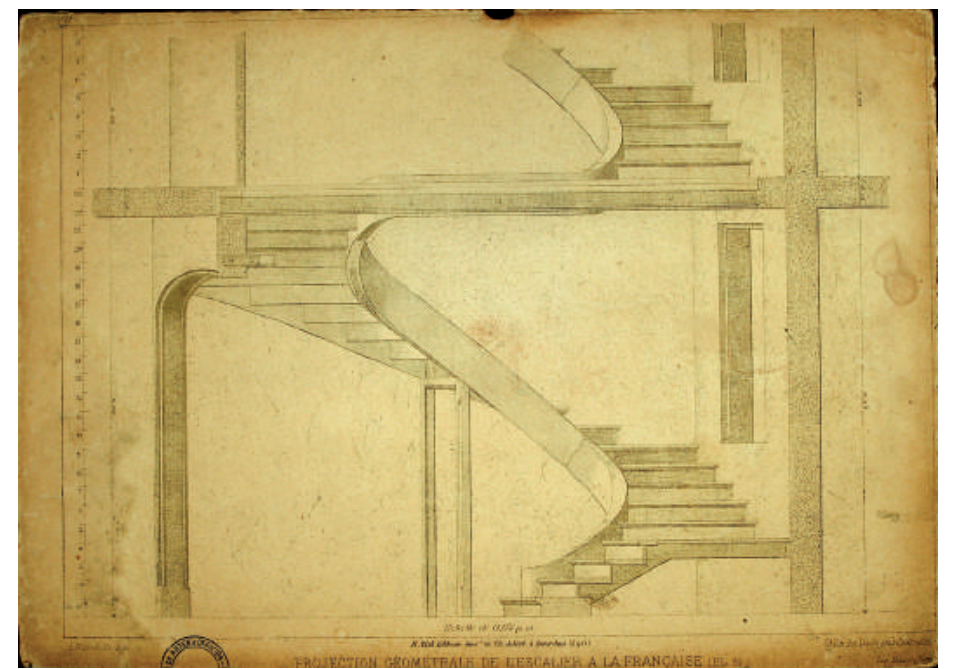

Projeção geometral de escada francesa, do Traité Théorique et Pratique de Charpente, 1900

Para o desenho de estampas era ensinado desenho de contorno com técnica do traço, cópia de estampas com figuras planas representando objetos de uso comum e doméstico, mais cópias de composições ornamentais em alto e baixo relevo e série de perfis de combinações florais e elementos arquitetônicos. Aprendia-se também o desenho dos alfabetos.

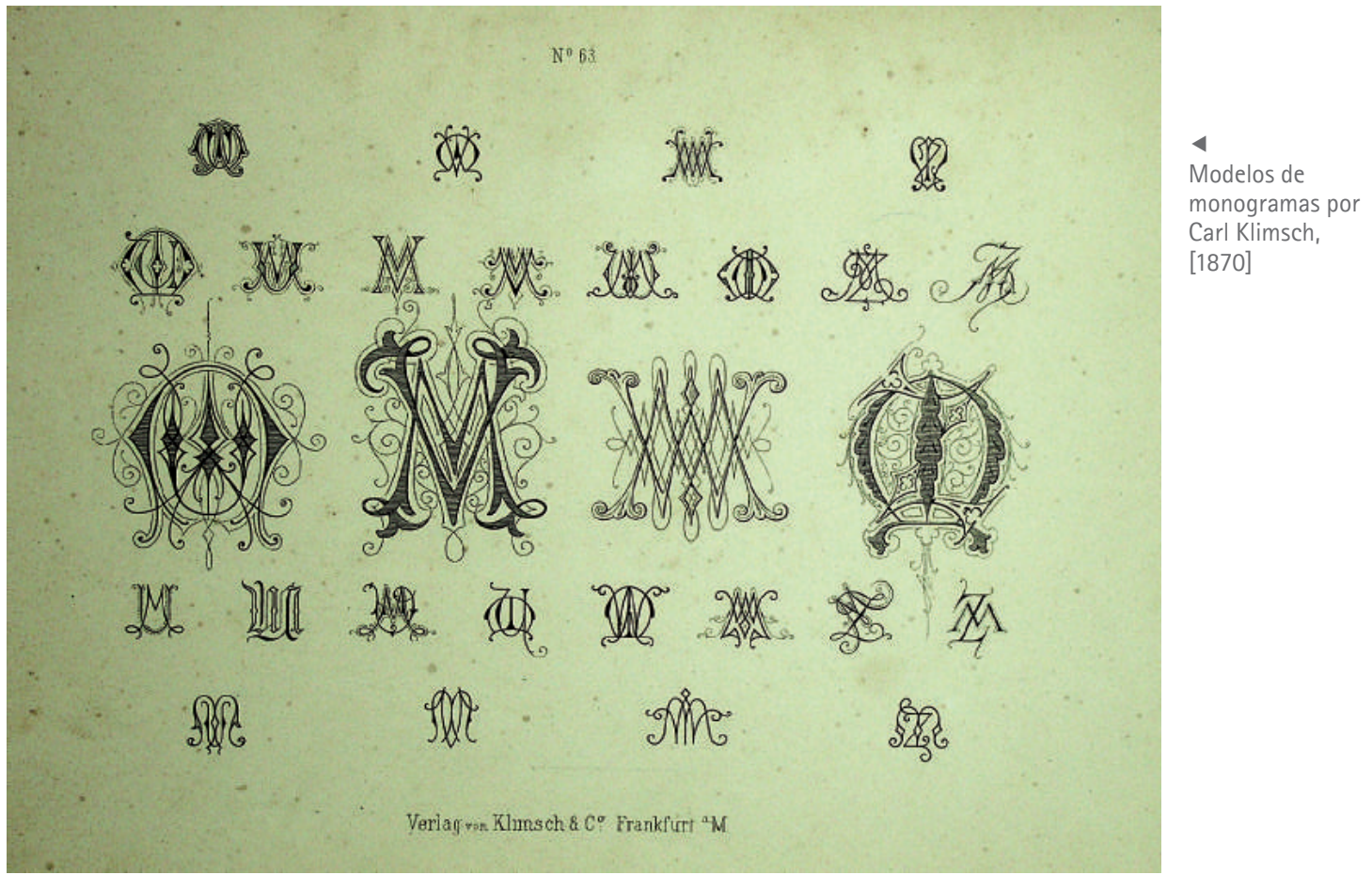


Nas aulas de desenho de ornato era lecionado o desenho de ornatos modelados em gesso para ornamentos simples, elementos arquitetônicos dos principais estilos clássicos e desenho de composições ornamentais e desenho arquitetônico.

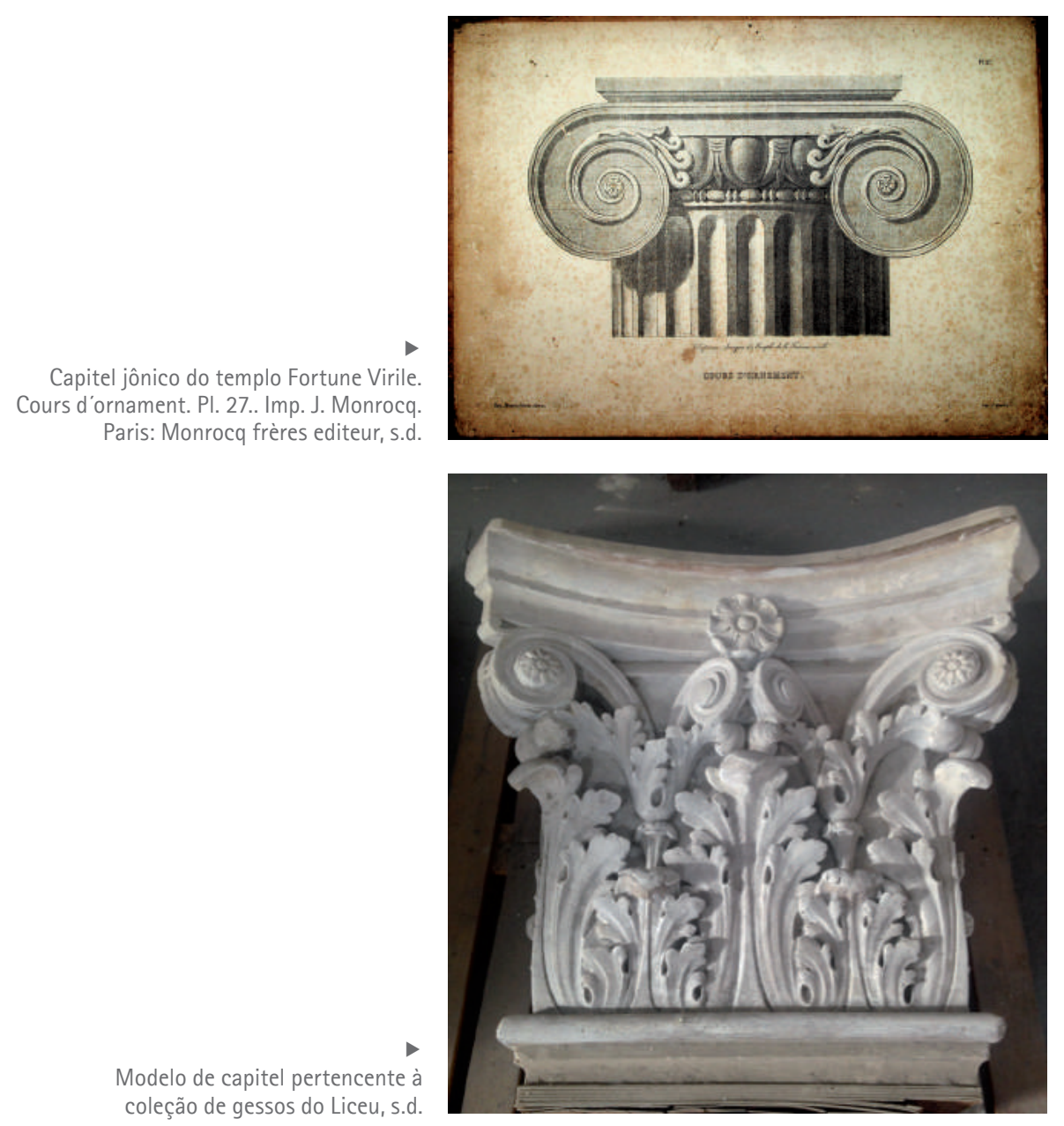

Segundo Ana Maria Belluzzo, o desenho de representação respeitava a concepção mimética e "[na] disciplina de desenho de ornato, além da reprodução ou cópia de estampas, eram representados modelos sólidos, elementos dos estilos e composições ornamentais. A autora indica que, no Liceu, as ordens arquitetônicas eram estudadas via Vignola e que o elemento arquitetônico era entendido como um componente construtivo e decorativo ao mesmo tempo". ${ }^{120}$ 
Havia ainda os cursos de desenho profissional, aplicado às especialidades dos alunos, marceneiro, serralheiro e outros e o cursos de desenho e pintura decorativa com aplicações da geometria projetiva às construções civis, mais teoria das cores e tecnologia e pintura. Em pintura aprendia-se o preparo das tintas e técnicas especiais de pintura a cal e a fresco, esgrafiada e a encáustico, pintura a seco, a têmpera, com colas, a óleo e aplicação de vernizes.

Ensinava-se a pintura ornamental e seus estilos, ornatos geométricos e outros com aplicações em mobiliário, tapeçaria e outras industrias ornamentais além de pintura de imitação de madeiras, mármores e rochas decorativas e cenografia. Estudava-se elementos decorativos das artes aborígenes americanas e da etnografia brasileira.

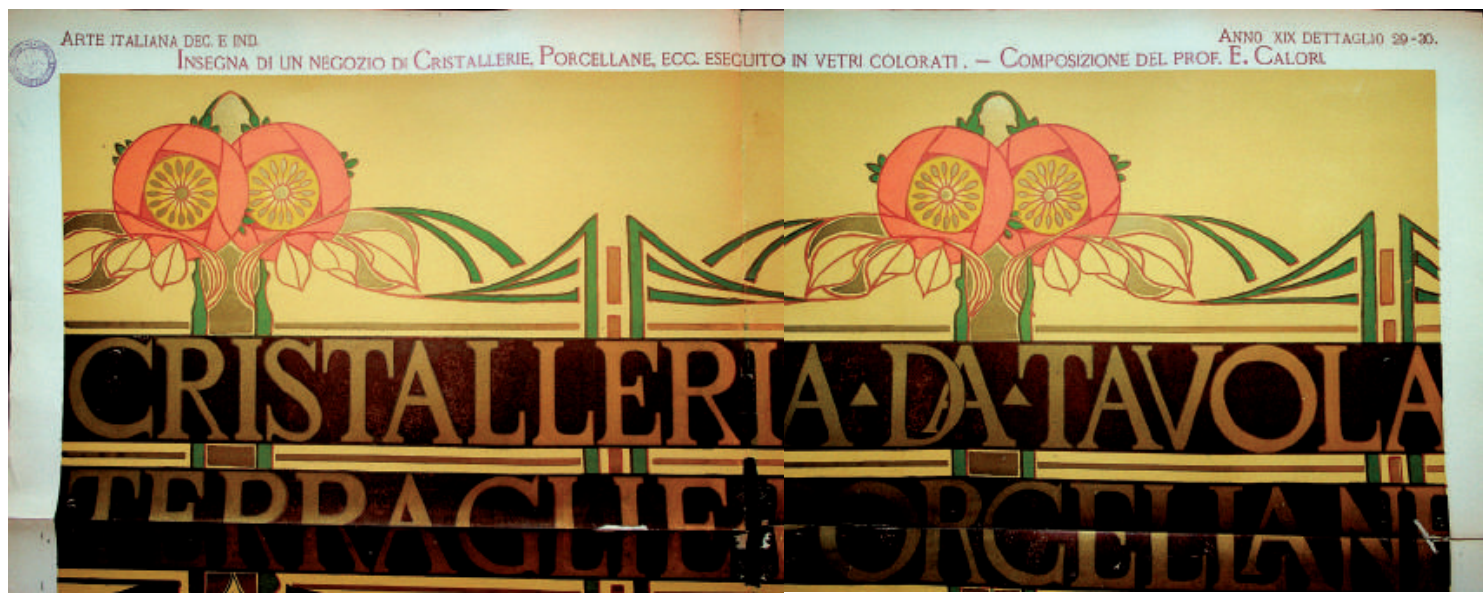

Uma aula de história da arte e estética obrigatória para os três cursos de aperfeiçoamento e para a última classe do curso geral de artes era dada uma vez por semana e versava sobre a definição de obra de arte, imaginação, inspiração e técnica, entre outros assuntos, história da arte americana, colonial e moderna no Brasil e história geral das belas artes incluindo as escolas contemporâneas dos românticos, impressionistas, expressionistas, cubistas, futuristas, etc.

Os cursos especiais referiam-se a cursos de aperfeiçoamento em desenho e pintura, desenho de arquitetura e escultura que desenvolviam os programas do curso geral do desenho arquitetônico e escultura, aprimorando neste último a modelação e as artes plásticas. Além dos cursos de contabilidade, profissional de tecnologia e mecânica, com oficina de aplicação e aprendizagem e desenho de máquinas, e eletrotécnica. 
No curso profissional de tecnologia e mecânica aprendia-se a tecnologia das ferramentas e dos utensílios assim como as características das matérias primas como ferro, aço, cobre, estanho e outros metais além de materiais complementares. Ademais, noções preliminares de máquinas, elementos de cinemática e dinâmica e resistência dos materiais.

Sobre as máquinas eram ensinadas suas formas de energia, seus geradores, motores e transmissões, havendo exemplificação prática com modelos de máquinas e visitas à diversas oficinas.

Para o desenho de máquinas aplicava-se o desenho geométrico aos elementos da máquina, desenho a mão livre de peças de máquinas, de conjuntos e detalhes de máquinas e organização de um projeto de máquina incluindo cálculos e orçamentos.
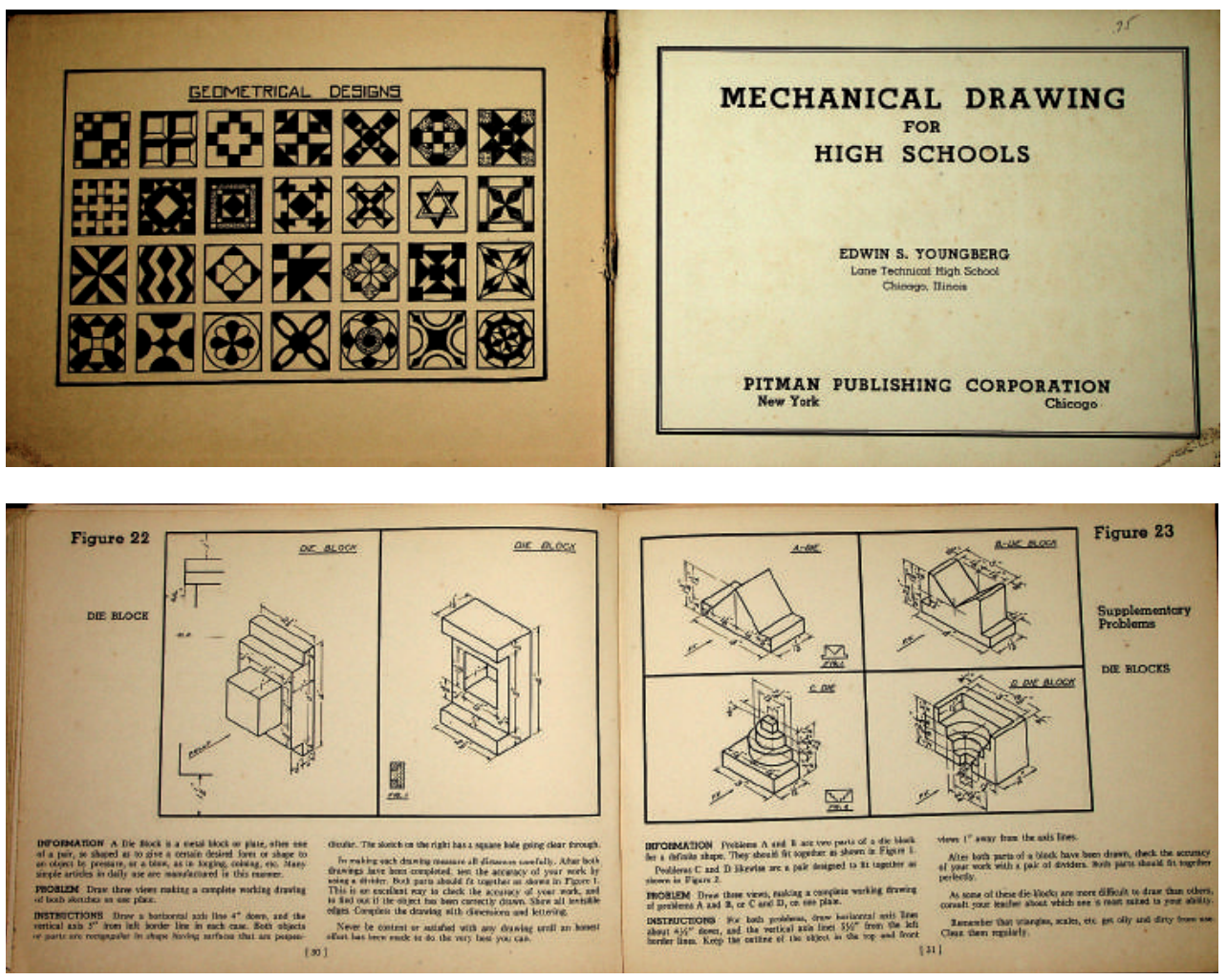

Desenho mecânico para escolas, por Edwin S. Youngberg, [1938]

O Curso de Mecânica Prática, implantado em 1923 pelo engenheiro Robert Manges era inovador porque além ensinar a construção de máquinas capazes de aumentar a produtividade utilizava os fundamentos da psicotécnica. 

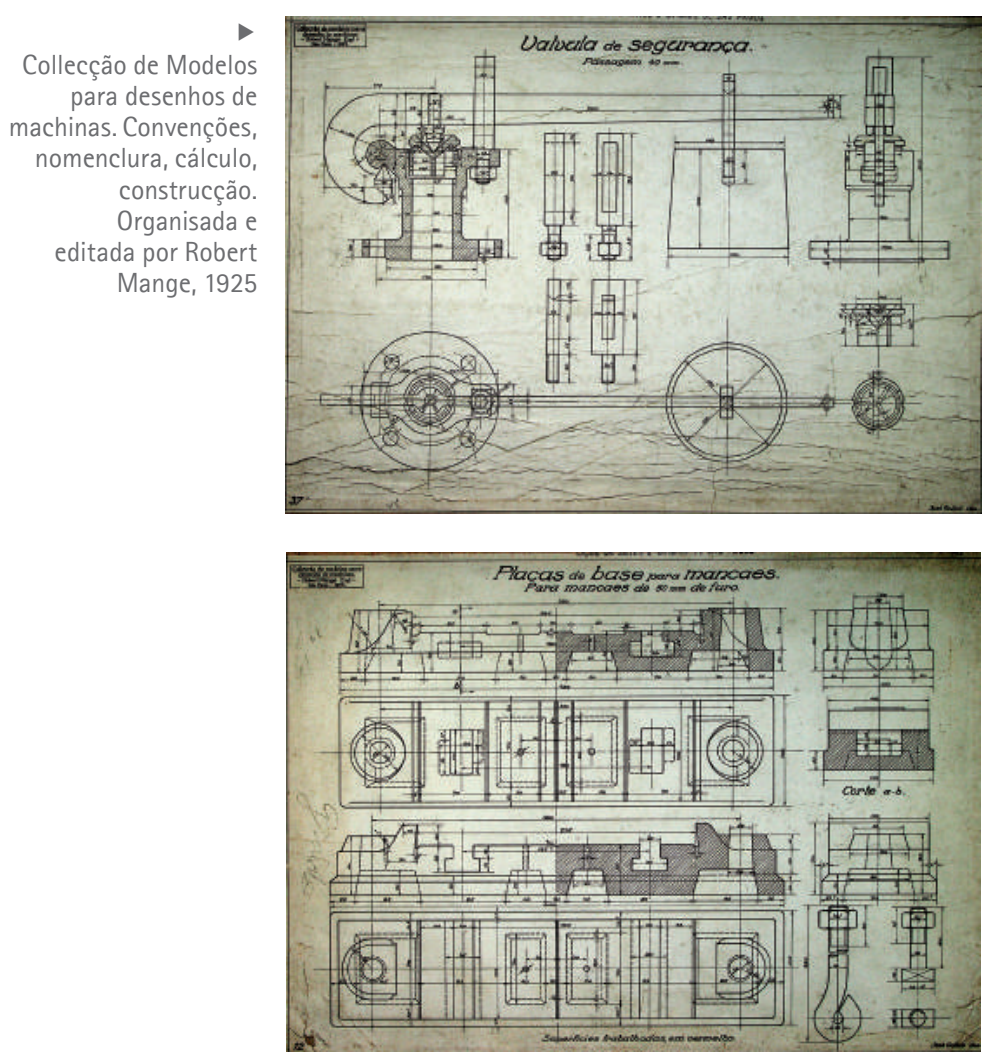

O curso profissional de mecânica ou mecânica prática era uma oficina-escola onde eram ensinados trabalhos práticos relativos ao programa da Cadeira de Tecnologia e Mecânica Racional e aplicações de seus princípios. Lá aprendia-se o ofício de mecânico em forja, fundição, caldeamento, solda, serralheria manual e mecânica, especialidades do traçador, ajustador, montador e execução e organização técnica de projetos dos trabalhos e das oficinas.

Ali, os alunos aprendizes eram considerados operários. Portanto, sujeitos à disciplina e regime de trabalho conforme o regulamento. Em 1934 só eram admitidos aprendizes com idade igual ou superior a 14 anos de idade. O que não era regra nos primeiros tempos da escola quando foram admitidas crianças de 8 a 11 anos e adultos frequentando o curso primário e secundário, a maioria sendo imigrante ou filho de imigrantes, alunos e operários que trabalhavam obedecendo à disciplina e hierarquia rígidas. Trabalhava-se "como aprendiz, como auxiliar, como operário, com utensílios próprios ou dirigindo diversos maquinismos (...)”. ${ }^{121}$

121. Cf. Maria Lucia Gitahy (1986, p. 28). 


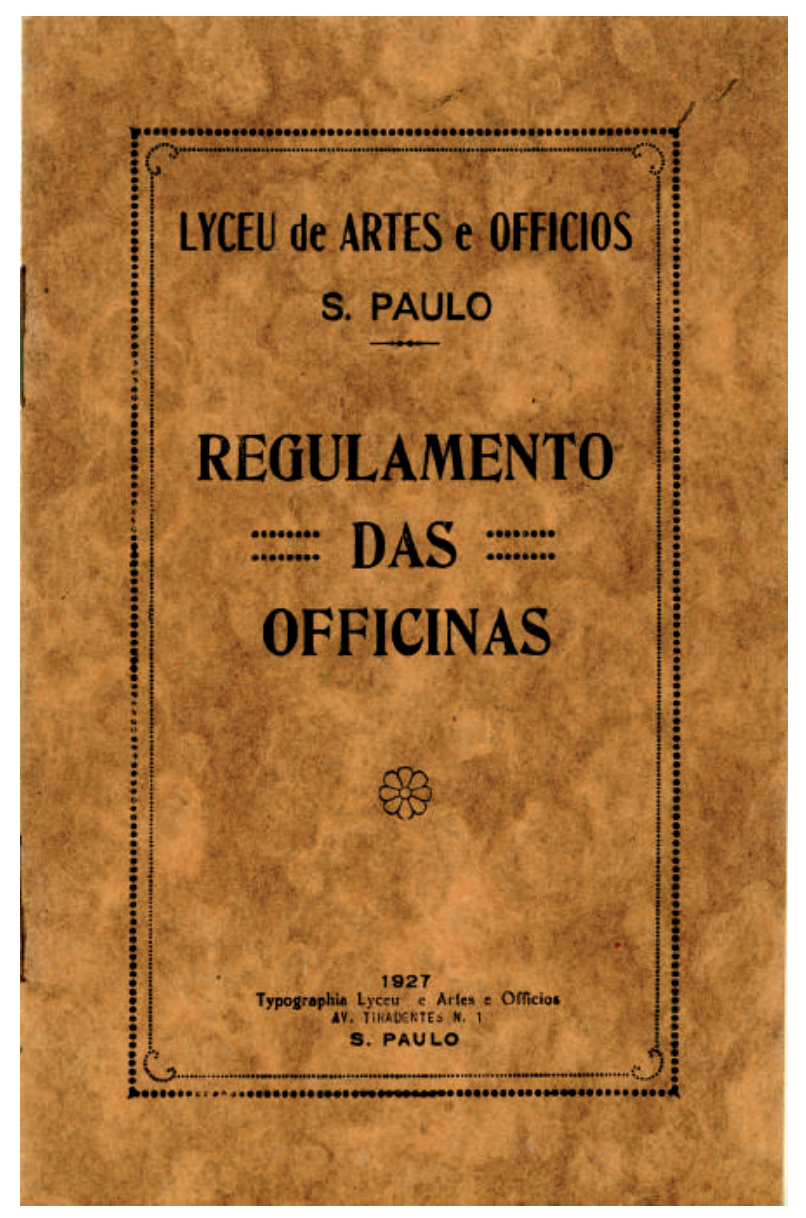

Regulamento das

oficinas do Liceu de

Artes e Ofícios, 1927

Fichas de admissão

Cataldo Rocco, aprendiz da sala

brinquedos, admitido em 1927

Henrique Cegove Moreno Filho,

aprendiz, admitido em 1928, brasileiro

Geraldo de Souza, aprendiz

de marceneiro, admitido

em 1929, brasileiro

Francisco Nascimento, aprendiz de

lampadários, admitido em 1924
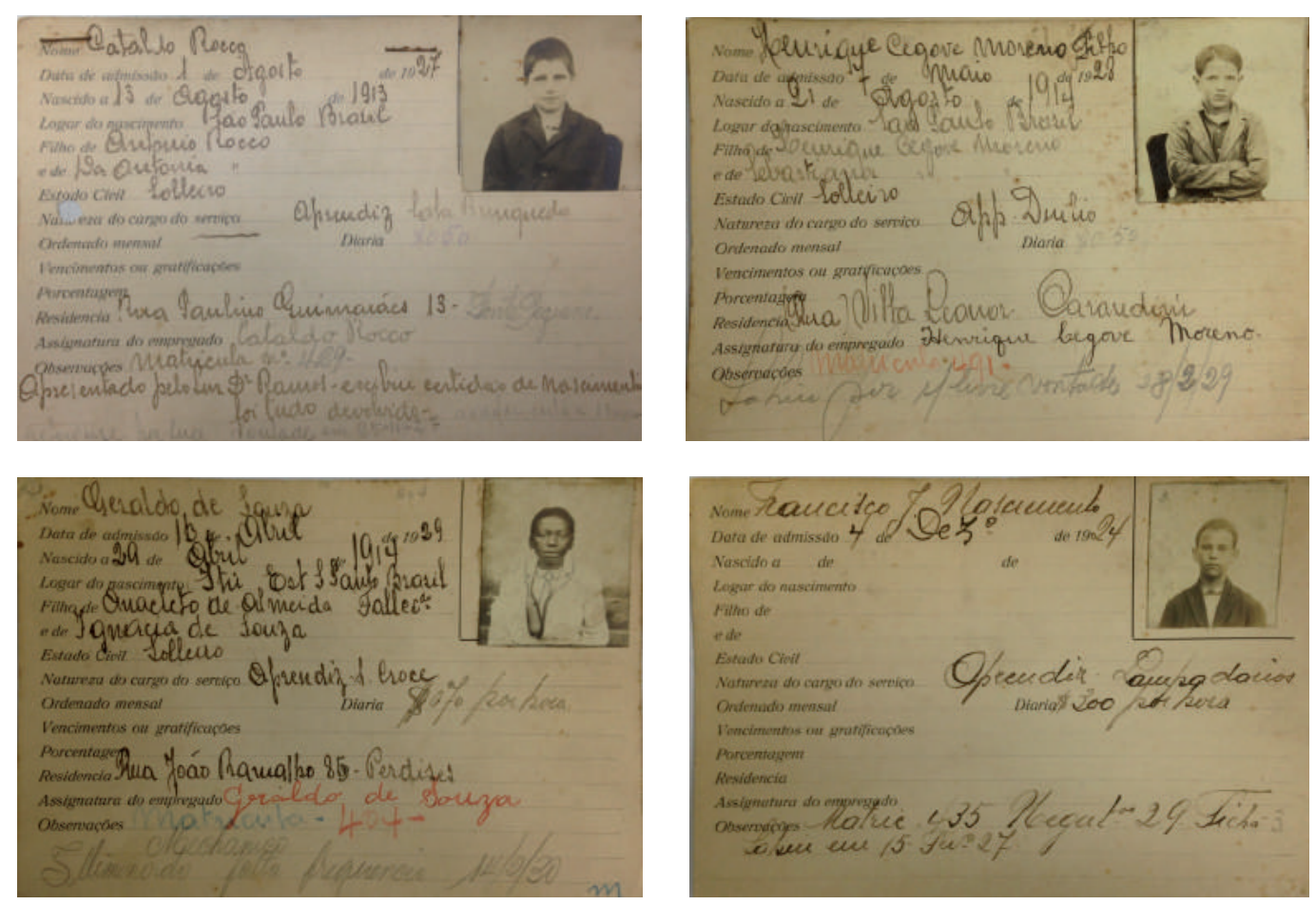


\subsection{1 'Núcleo gerador de realidades'}

O Liceu de Artes e Ofícios de São Paulo, nomeadamente, foi administrado por um Conselho Administrativo composto por membros notáveis que se reunia uma vez por semestre. Este Conselho se reportava à Diretoria composta pelo presidente, vice-presidente, secretários, tesoureiros e o superintendente, de acordo com os estatutos. Depois das mudanças dos estatutos de 1903 visando tornar o Liceu a futura Escola de Belas Artes da cidade ${ }^{122}$, só conhecemos os aprovados na Assembleia Geral Extraordinária de 18 de julho de 1934 e registrados no $1^{\circ}$ Oficio de Registros de Títulos e Documentos de São Paulo.

Em 1909 o prédio da Avenida Tiradentes não comportava o crescimento de seu organismo industrial. Como vimos anteriormente, em 1904 Ramos de Azevedo já trabalhava para garantir espaços onde a produção industrial se completasse devidamente. Em 1906, o diretor conseguira junto ao governo do Estado a cessão do terreno situado no quarteirão entre as ruas João Teodoro, Cantareira e Doutor Jorge Miranda, onde o Liceu assentou suas tendas de trabalho.

Salões e galerias expositivas do Liceu de Artes e Ofícios de São Paulo, década de 1920

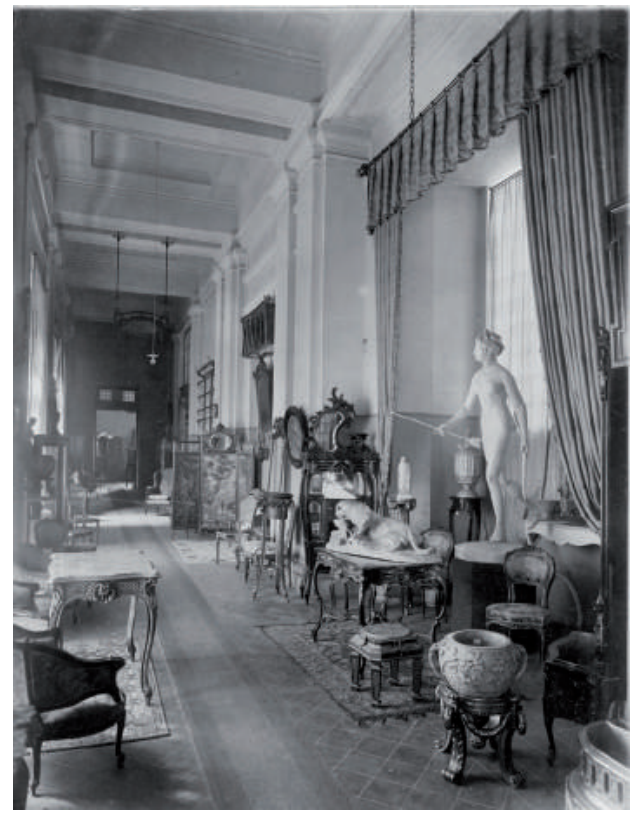

122. Naquela época Ramos de Azevedo ainda advogava junto ao governo a criação de exposições de belas-artes, de prêmios aos artistas, pensões, bolsas e aquisições de obras de arte. Como vimos, as aspirações do diretor se concretizaram ao menos quanto às exposições. Cf. Ricardo Severo (1934, p. 33). 

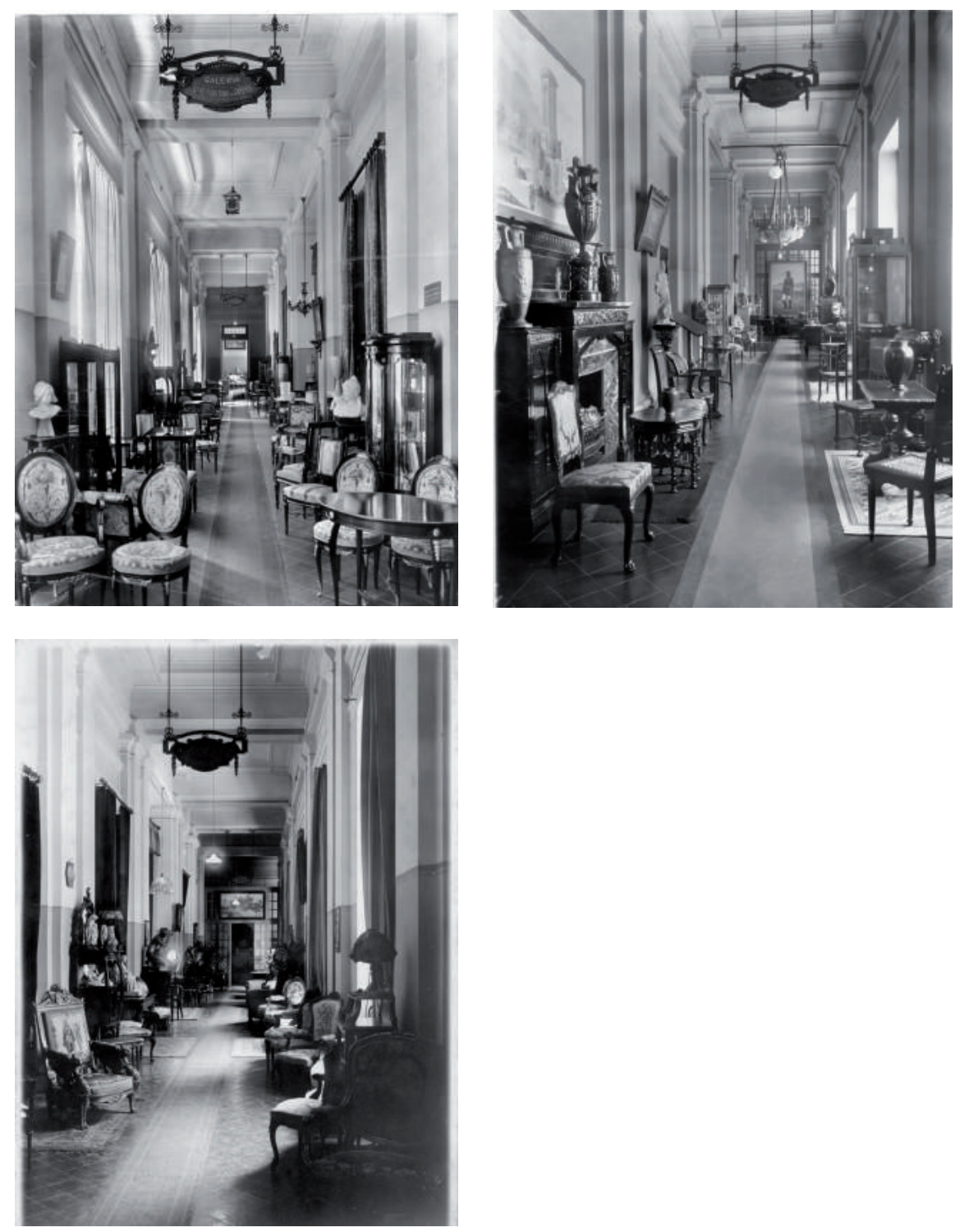

No Palácio permaneceram os escritórios, algumas aulas e cursos e o salão de exposições e vendas "com perfeitos modelos de arte decorativa de todos os estilos que ornamenta o interior dos mais luxuosos edifícios particulares e públicos de São Paulo e outras cidades do país". ${ }^{123}$ Nada se diz sobre a biblioteca, mas imaginamos que tenha permanecido no Palácio para uso nas aulas do programa da Escola de Cultura Geral e Profissional, sendo complementada ao longo das décadas de 1920 e 1930.

123. cf. Ricardo Severo (1934, p. 60). 


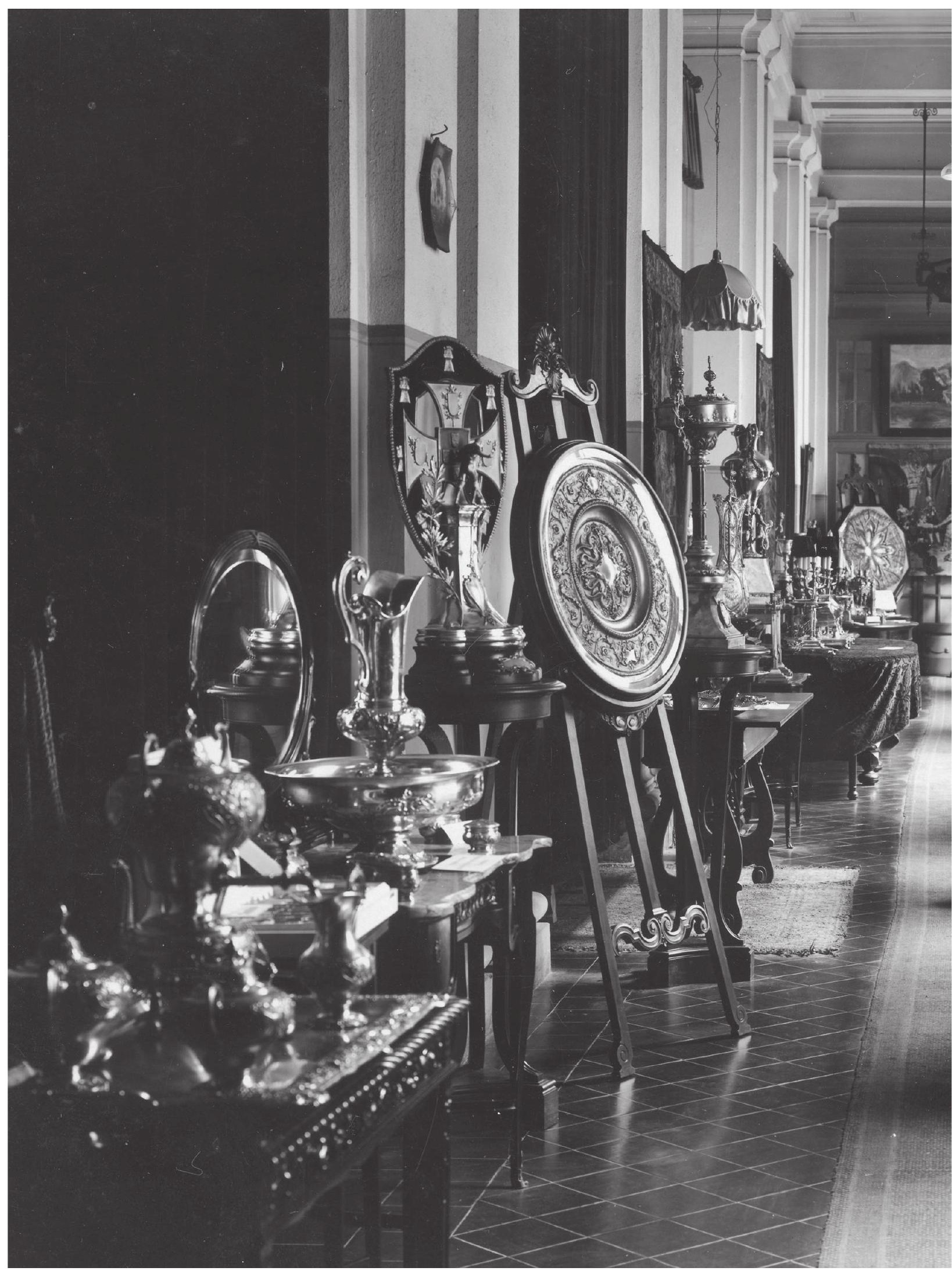




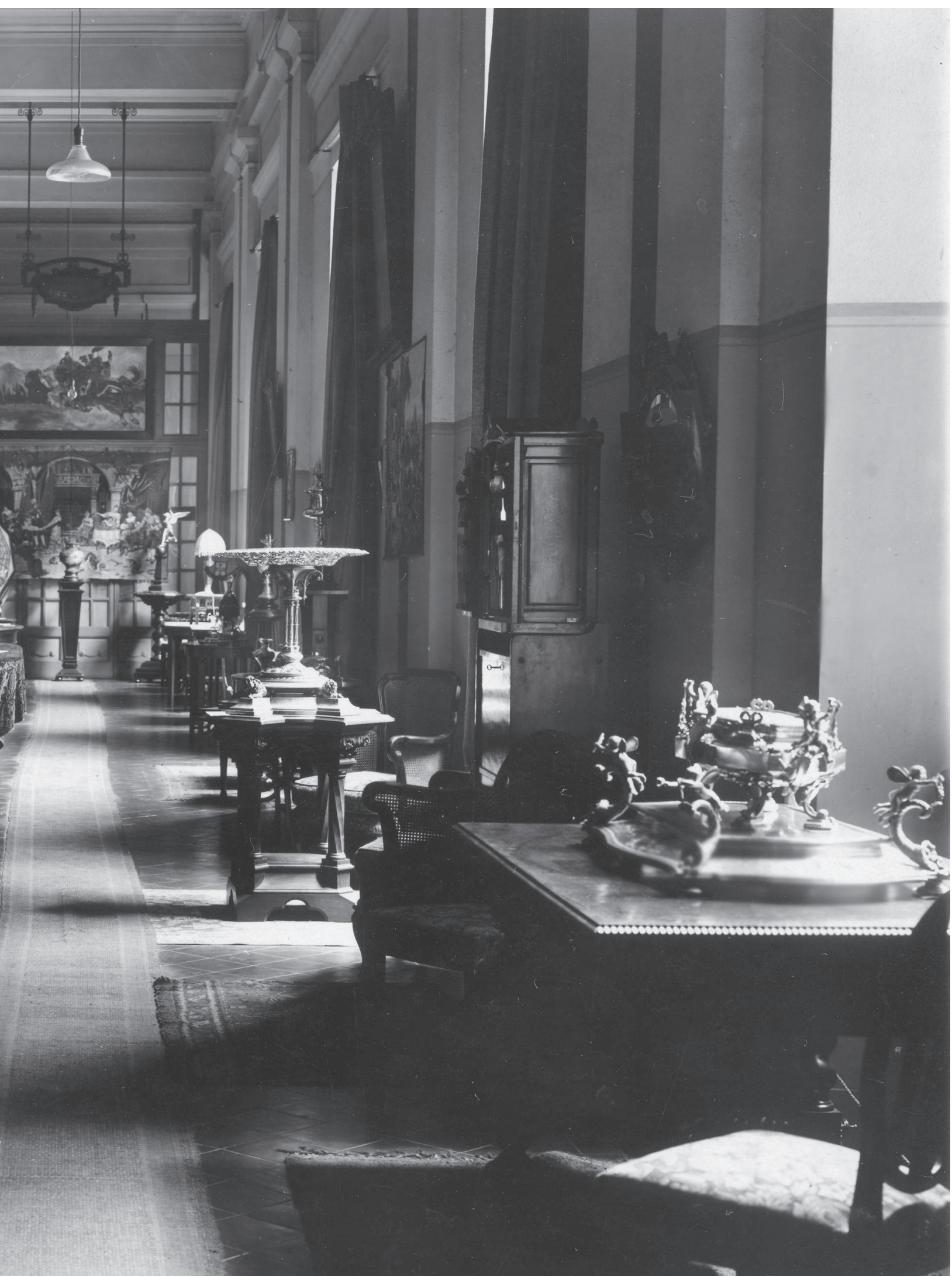


Desde 1910 o Liceu ministrava dois cursos, um teórico elementar e outro prático ${ }^{124}$. A Escola Prática de Artes e Ofícios ou as oficinas propriamente ditas, conduzidas pelo Conselho contava com o curso de aprendizagem e o trabalho diário dos alunos aprendizes, operários e artífices nas oficinas especializadas. Cada operário deveria possuir as ferramentas de seu mister, o Liceu fornecendo apenas o armário ou banco para a guarda. Desde 1910 o Liceu tinha um Curso Teórico elementar e outro Prático, de artes e ofícios.

Ao Gerente Geral e a superintendência do diretor estava subordinado o Escritório Central Técnico e Artístico dotado de uma Gerência Geral responsável pela secretaria das escolas e pela administração industrial e comercial. Posto de confiança, o gerente organizava o dia-a-dia das escolas e todo o expediente incluindo o do salão de exposição e vendas. ${ }^{125}$ A gerência das oficinas era diretamente subordinada à Gerência Geral e Artística.

Havia um Conselho Técnico, de caráter consultivo composto pelo Gerente Geral, Gerente Técnico e Artístico, e dos chefes e mestres das oficinas, assistido pelo Professor de Tecnologia e mecânica e presidido pelo Diretor geral.

Ao Escritório Central Técnico e Artístico competia a organização dos projetos, os desenhos de conjuntos, de detalhe, de perspectiva, cópias, confecção de modelos, amostras, mostruários, orçamentos, planos e contabilidade geral.

Supomos que o organograma da instituição tenha sido determinado por Ramos de Azevedo quando fez a grande reforma afiançando ainda o acréscimo de novas instalações e a adoção de nova organização para a marcenaria e serralheira em 1915, tendo a estrutura formal sofrido muito poucas mudanças até a gestão de Ricardo Severo, que assumiu as responsabilidades de dirigir o Escritório Técnico e o Liceu quando da morte do "Organizador", em 1928.

Ramos de Azevedo, dono de uma personalidade marcante capaz de atrair a estima pública, modificou o perfil arquitetônico da cidade instituindo padrões de excelência comparáveis aos das metrópoles europeias. Em seu funeral recebeu honras de chefe de Estado ganhando

124. Ver Liceu de Artes e Ofícios (1958).

125. Para estes dados e para a organização das oficinas ver Ricardo Severo (1934). 


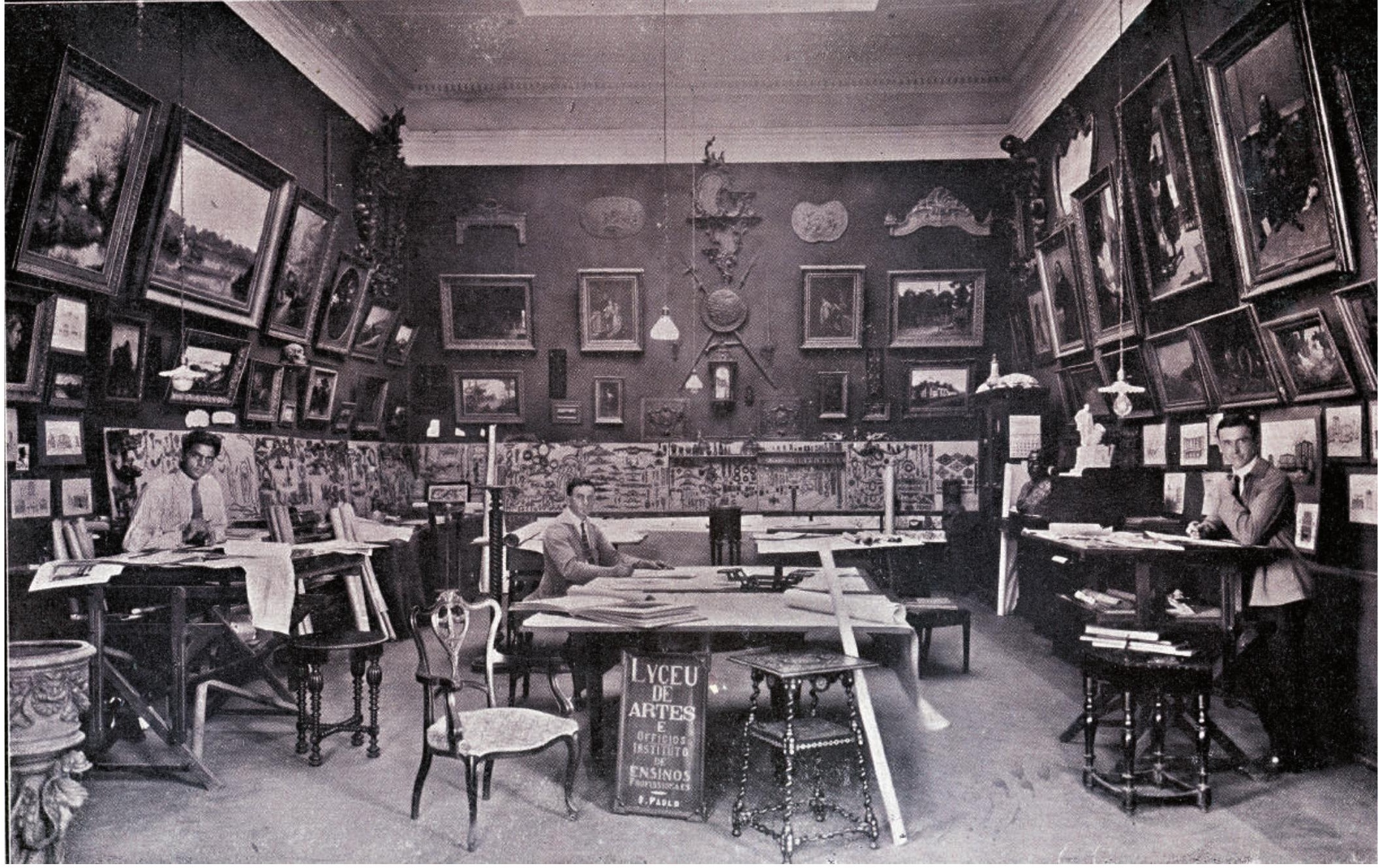

homenagens de companheiros e dos alunos da Escola Politécnica e do Liceu. Em sua memória foi construído em frente ao Liceu o Monumento Escritório Central Técnico e Artístico do Liceu de Artes e Ofícios de São Paulo, s.d.

a Ramos de Azevedo, projetado por Galileo Emendabili e erigido por subscrição popular. Mais tarde o monumento foi transferido para a Cidade Universitária.

\subsubsection{Pulsos de aço}

A Escola Prática, tendo o Escritório Central como espécie de quartel general, ministrava diariamente os cursos de aprendizagem em Oficinas-Escolas estabelecidas na Rua João Teodoro 11.

A Escola organizava-se em classes profissionais relacionadas às obras e as classes se dividiam em seções refletindo seu próprio programa de ensino.

Mesmo fora do escopo cronológico de nosso estudo, uma planta de 1945 nos dá a dimensão dos galpões instalados na diagonal do rio Tamanduateí e indicações sobre a implantação das oficinas. 


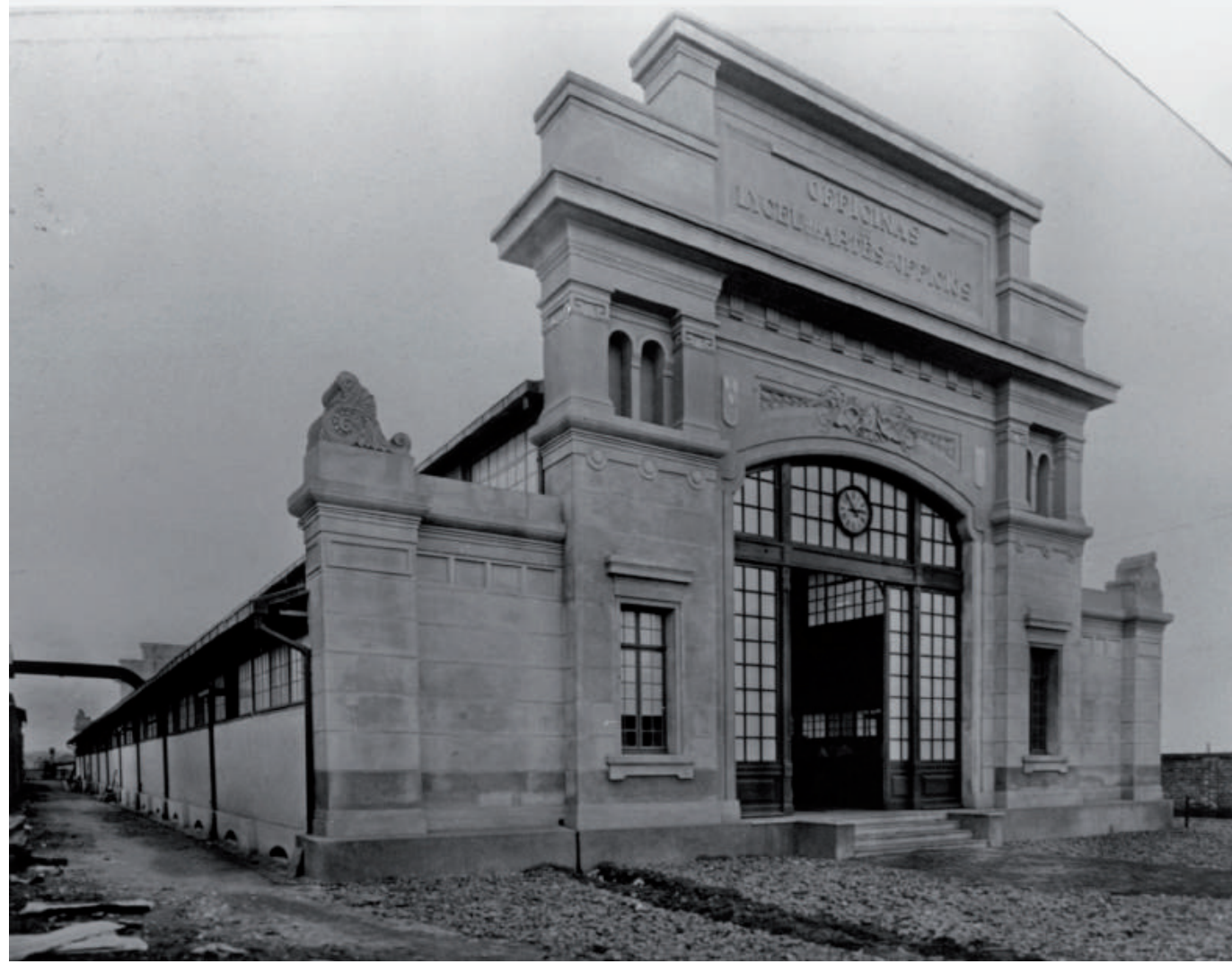

Fachada das Oficinas do Liceu na rua João Theodoro, São Paulo, s.d.
A organização das Oficinas era a seguinte:

Classe A Obras de madeira com Almoxarifado geral provido de completo e variado sortimento de matéria-prima, ferragens e materiais para confecção e acabamento de móveis e outras obras de madeira.

Seção I) Preparação mecânica com Chefe Geral, Mestre especializado, operário prático, ajudantes, escriturário e vários aprendizes;

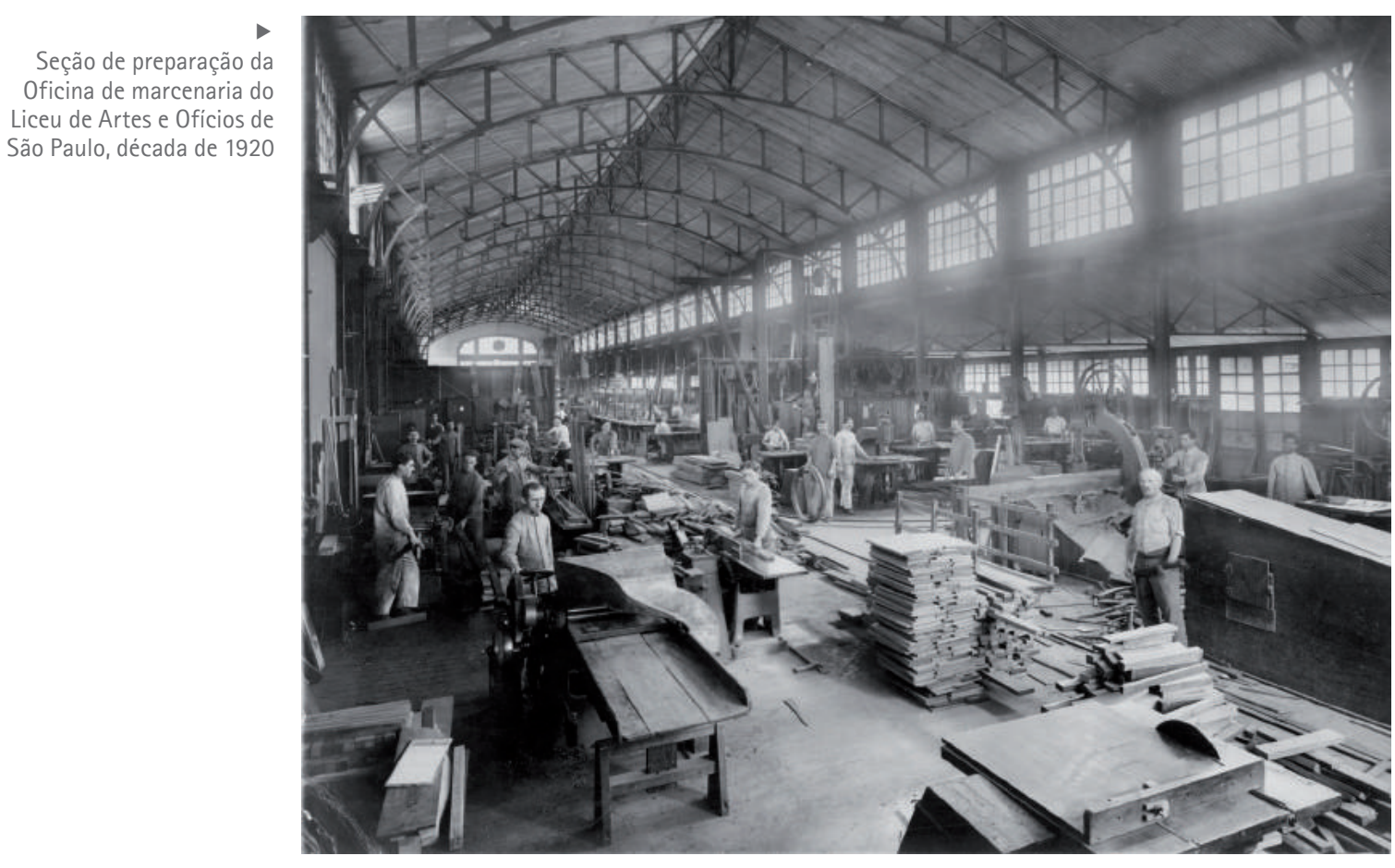



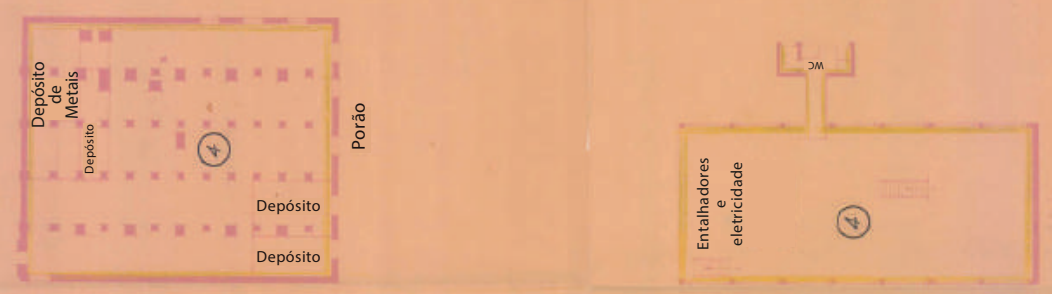

จงูำ

upuarly efrof and

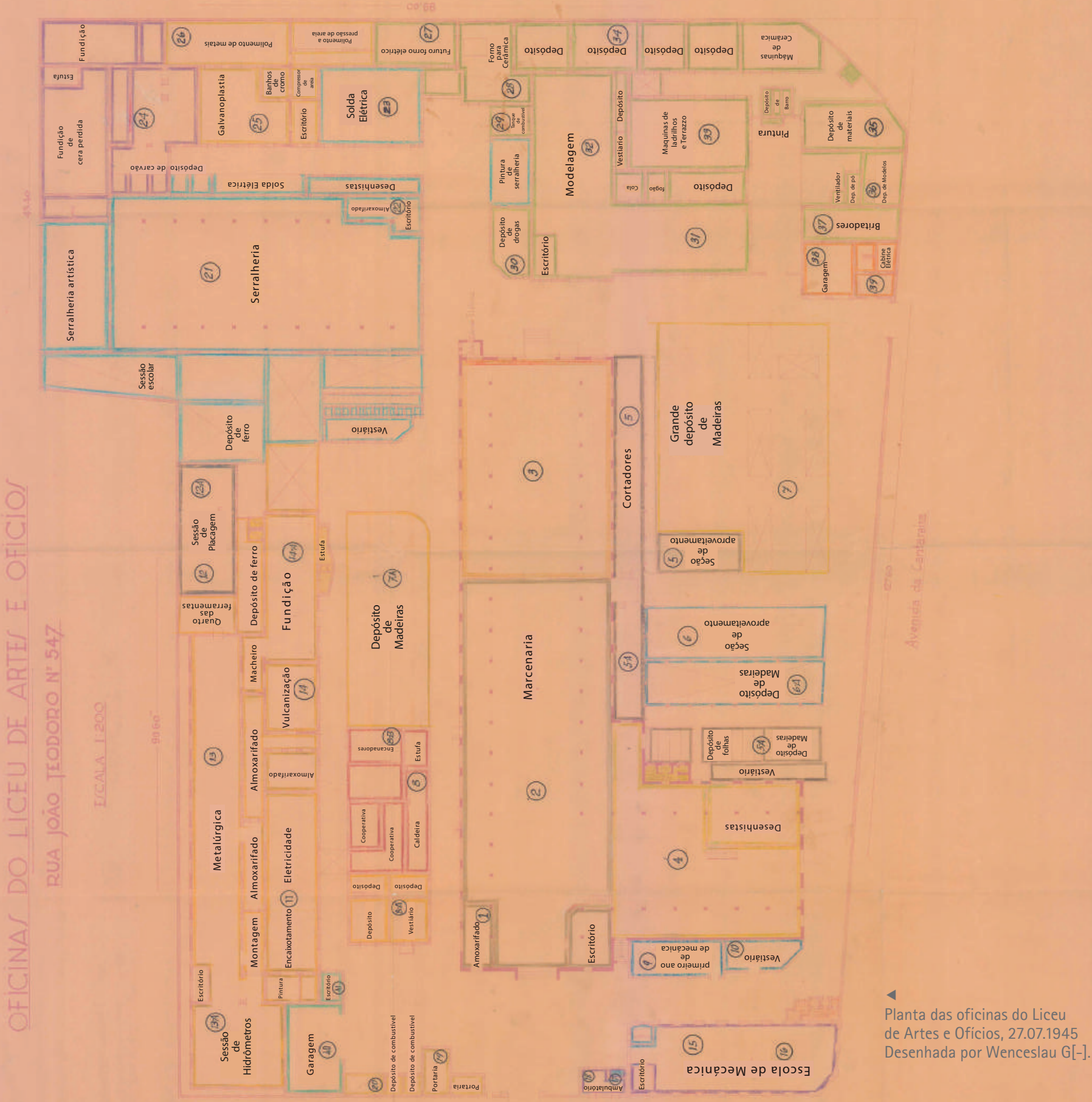


Seção II) Folheados e compensados com máquinas movidas a eletricidade e acessórios.

Seção III) Marcenaria com sala de planejadores que ampliavam e detalhavam os projetos com desenhos construtivos e arquivo geral dos desenhos e moldes. Com 1 mestre geral, 1 mestre ajudante, 15 contramestres, 150 operários e 150 aprendizes. Com oficinas de trabalhos mecânicos e de trabalhos manuais com acessórios próprios e muitos maquinismos. Possuía escritório de contabilidade próprio assim como um escritório técnico para projetos e desenhos.

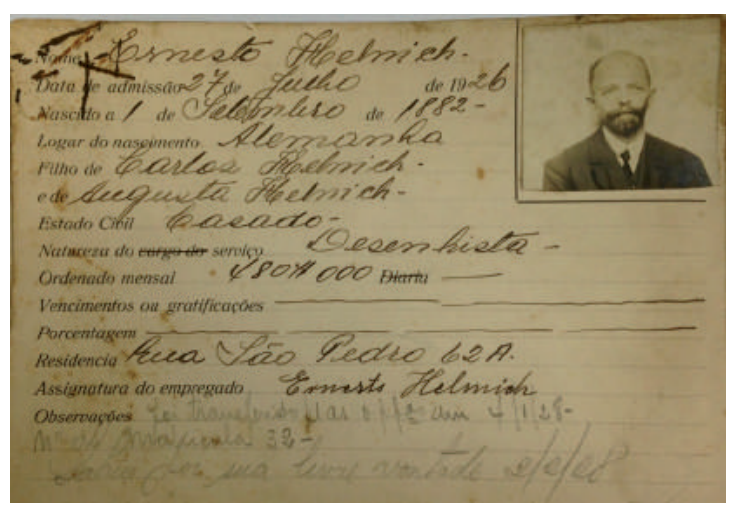

Ficha de admissão do desenhista Ernesto Helmich, admitido em 1926

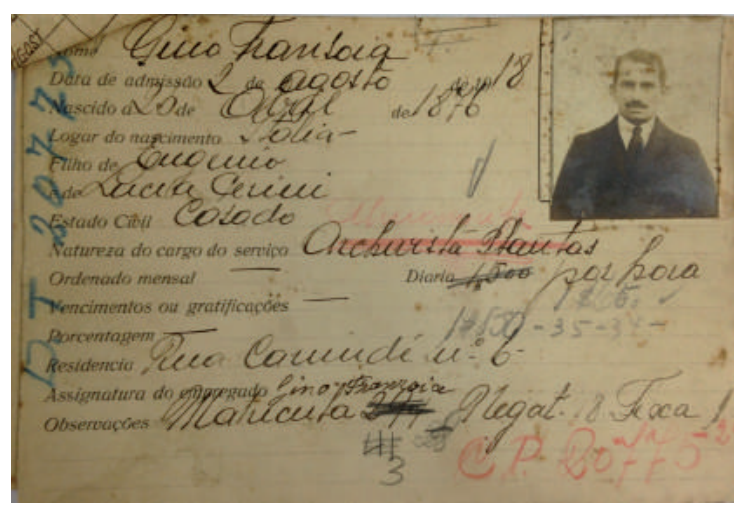

Ficha de admissão do arquivista de plantas e almoxarife Gino Franroia, admitido em 1918

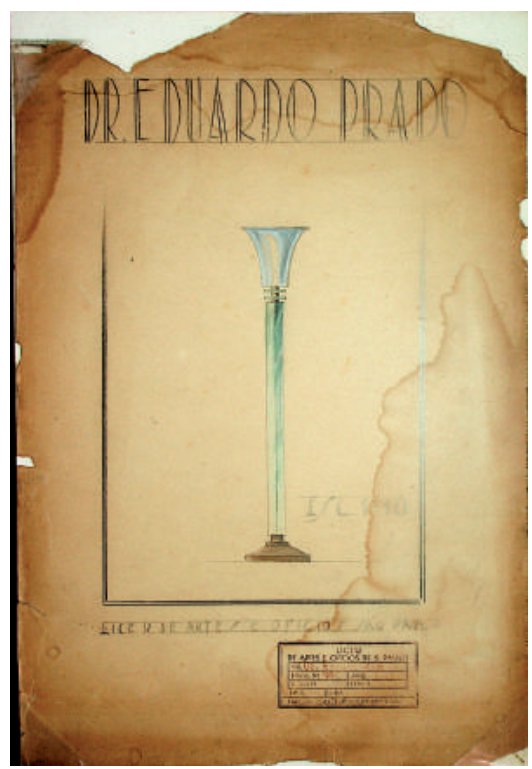

Seção IV) Escultura e entalhe com sala de risco, transporte e adaptação de desenhos com modelos de execução. Com oficina de 
entalhadores, composta de 1 mestre, 1 desenhista especializado, 15 entalhadores e 40 aprendizes. Contava com uma máquina para reprodução mecânica de peças em série, 4 mesas para estudos e modelos, e sortimento variado de modelos e desenhos do gênero.

Seção V) Ebanistaria (sic) Marchetaria para trabalhos em ébano, pau-santo e jacarandá por ser marcenaria especializada em aplicações metálicas e incrustações. Com mestre especializado, desenhista, 8 operários mestres e 25 aprendizes e máquinas e acessórios.

Seção VI) Acabamentos com oficinas de pintura a esmalte, de envernizamento e enceramento com 4 mestres especializados, 30 operários e 35 aprendizes. Com estufa.

Secção VIII) (sic) Encaixotamento com um mestre especializado e 2 operários práticos. Com bancos de madeira, balança e outros acessórios.

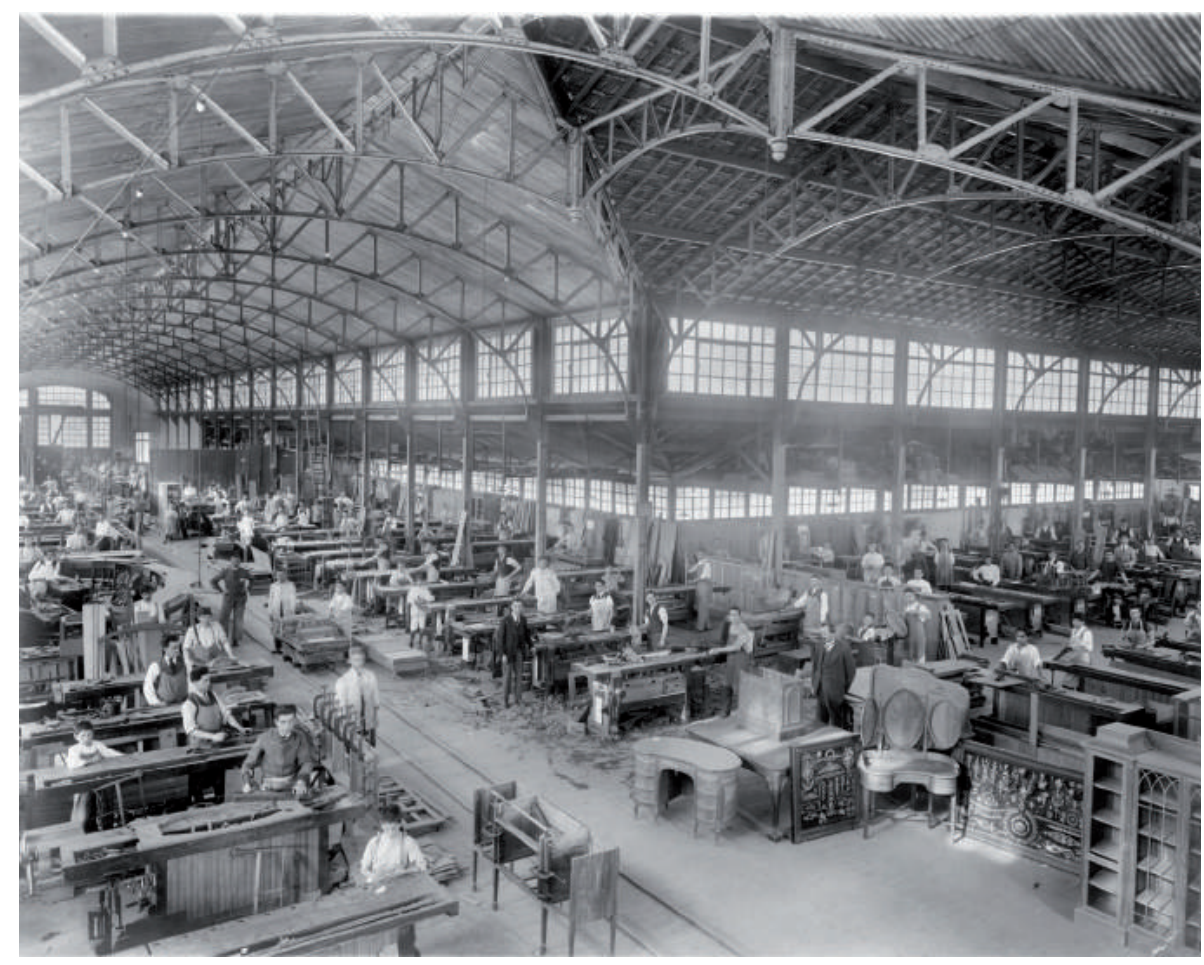

Oficina de marcenaria do Liceu de Artes e Ofícios de São Paulo, década de 1920

O estoque de madeiras do Liceu era enorme. A marcenaria, assim como a serralheria e a estuqueria, foram responsáveis por obras de grande porte solicitadas pelo mercado das indústrias de construção civil e mobiliário. 


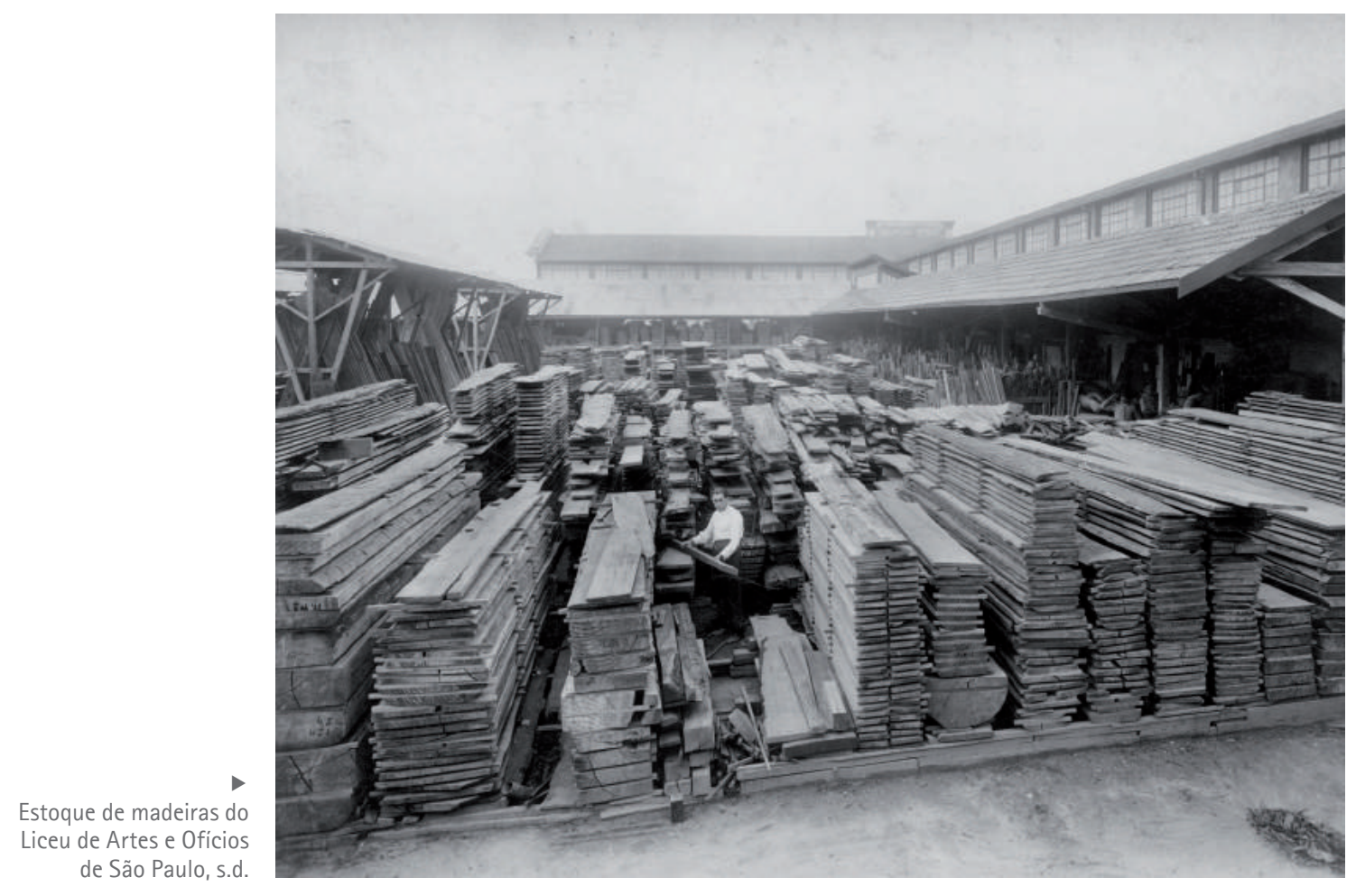

Classe B) Obras de ferro

Seção I.a) Serralheria mecânica com sala de risco para ampliação dos desenhos e confecção de modelos e moldes e almoxarifado.

Seção II.a) Serralheria civil para trabalho de ferros em aplicações civis.

Seção III.a) Serralheria artística com preparo dos modelos e matrizes em relevo, em trasforo (sic) e trabalhos de ferro batido, repuxado, cinzelado, esculpido, etc.

Seção IV) Forjamento e soldadura com trabalhos de forja, soldadura pelo processo de maçarico oxídrico e elétrico.

Estas quatro secções ocupavam uma oficina geral para os trabalhos da classe com capacidade para 150 lugares e superfície de $1.370 \mathrm{~m}$. Compunha-se de 1 mestre geral, 1 mestre auxiliar, 4 mestres de seção, 2 desenhistas especializados, 1 escriturário e 2 ajudantes, 1 almoxarife, 1 encarregado dos armazéns de ferro, operários mestres e 75 aprendizes. Tinha máquinas e acessórios modernos. 


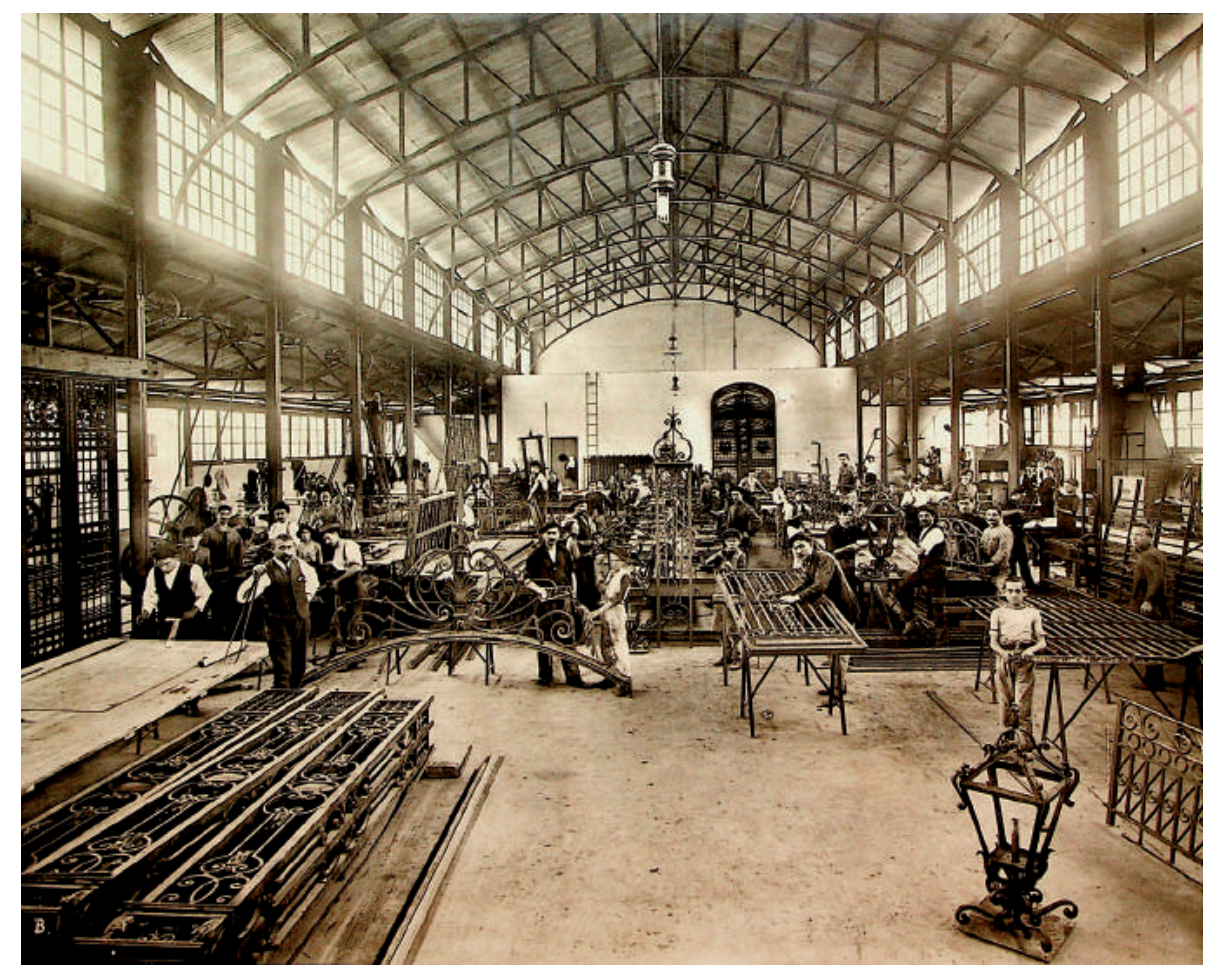

Classe C) Artefatos metálicos

Seção I.a) Metalurgia. Oficina de fundição de metais à pressão e preparo de ligas de cobre e alumínio. Com 1 mestre geral especializado, 4 operários mestres, 4 mecânicos e 10 aprendizes. Contava com máquinas para fundir o bronze e fornos e cadinhos para fundição de metais, além de aparelhagem para fabricar e fundir peças de "Baquelite" para uso nas oficinas do Liceu e seção mecânica de precisão.

Seção II.a) Mecânica de precisão e especialidades. Com 1 mestre geral, 2 mestres ajudantes, 15 operários mestres e 35 aprendizes. Maquinismos e aparelhagem. Apta à fabricação de aparelhos de iluminação direta e indireta de todos os estilos. A parte principal estava montada para a fabricação de hidrômetros. ${ }^{126}$

Seção III.a) Galvanoplastia com seção mecânica, seção química com laboratório químico, máquinas e acessórios. Com 1 mestre geral,
Oficina de serralheria do Liceu de Artes e Ofícios de São Paulo, década de 1920

126. Em 1931 fez-se o teste do hidrômetro Paulista fabricado pelo Liceu. O instrumento de precisão cuja produção começou em 1929 atendendo as demandas da crescente urbanização no país. A produção de hidrômetros e medidores de gás passaria mais tarde a ser o foco dos investimentos da instituição tornando-se o principal suporte de recursos para manutenção da escola. 
1 mestre especializado, 1 mestre da seção de politrizes, 1 escriturário, 4 operários e 6 aprendizes. Com máquinas e acessórios modernos e instalação para banhos de metais, além de aparelhos de um laboratório de galvanoplastia.

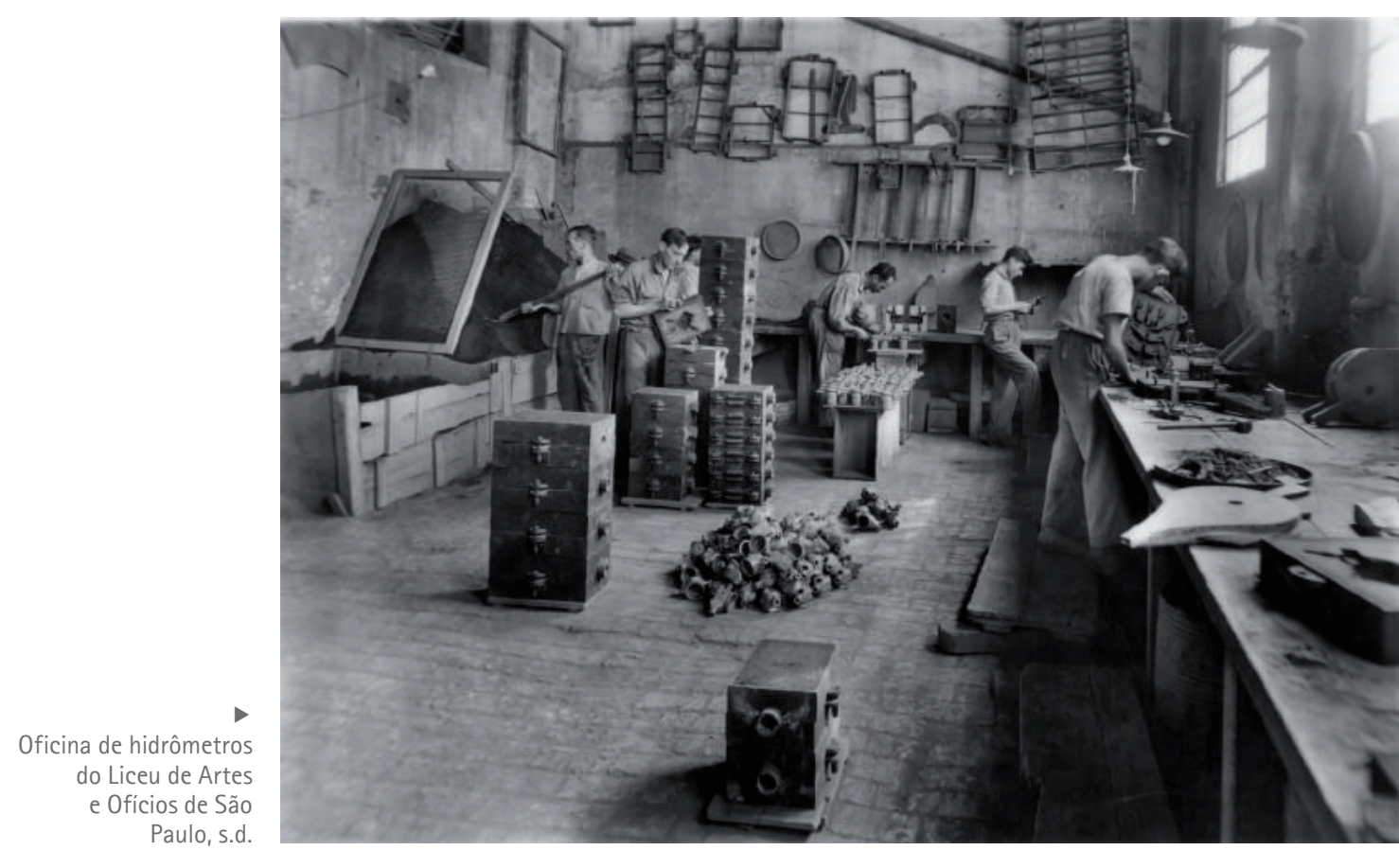

Classe D) Fundição metálica

Seção I.a) Modelagem e formação. Com ateliê para confecção de modelos e formas. Preparos dos moldes a barro, areia, gesso e cera.Com 1 mestre geral, 1 mestre de fundição, 1 mestre de moldes e ceras, 4 operários mestres e 8 aprendizes;

Seção II.a) Fundição. Com 1 mestre geral, 1 mestre fundidor, 4 operários especializados e 6 aprendizes. Com fornos, cadinhos e caixas de ferro para modelagem e fundição pelo processo comum;

Seção III.a) Estatuária monumental. Acabamentos, limpeza de peças, retoques, cinzelamento, polimento e patinação. 


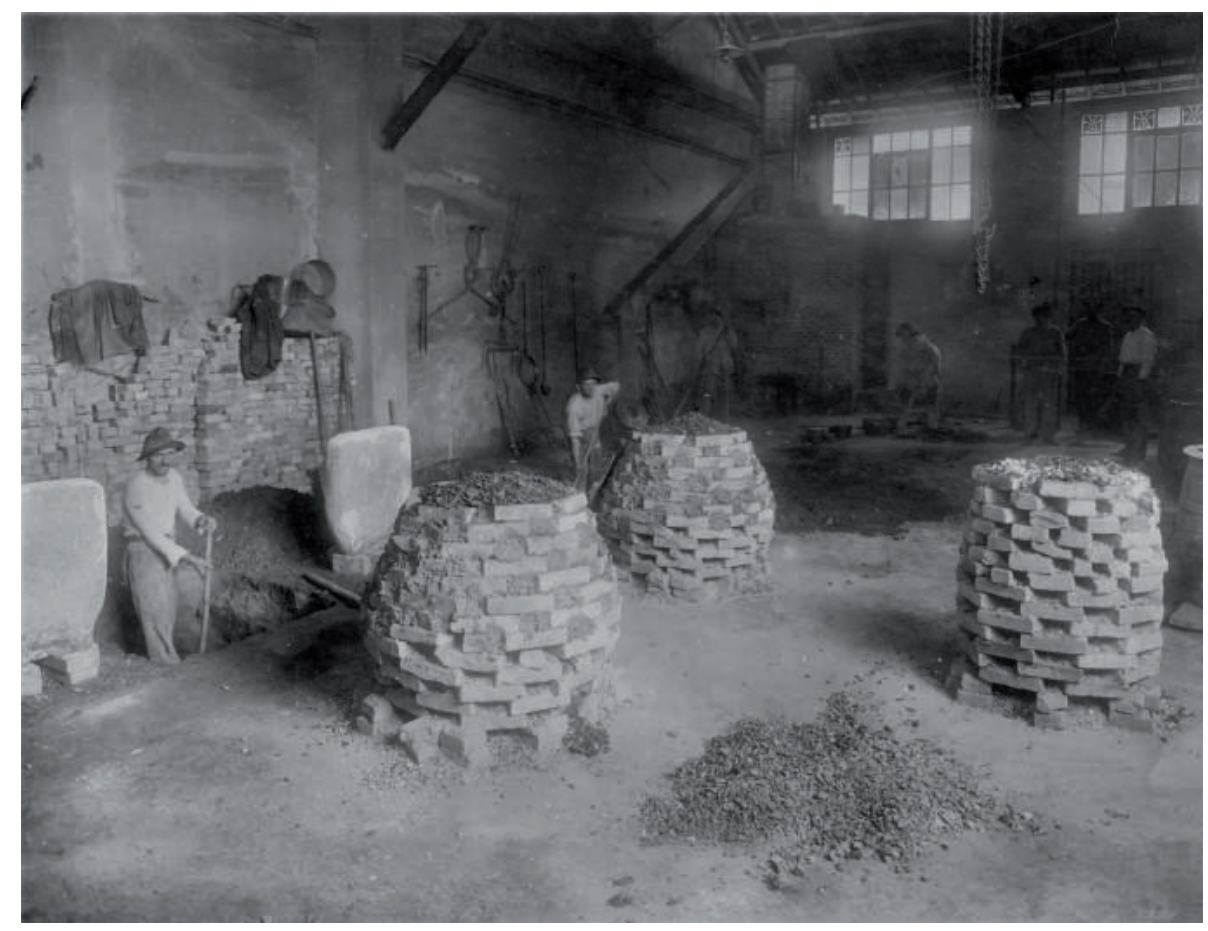

Oficina de fundição do Liceu de Artes e Ofícios de São Paulo, s.d.

Classe E) Aprendizes mecânicos. Oficina especial e complementar ao curso de tecnologia, mecânica e eletrotécnica.

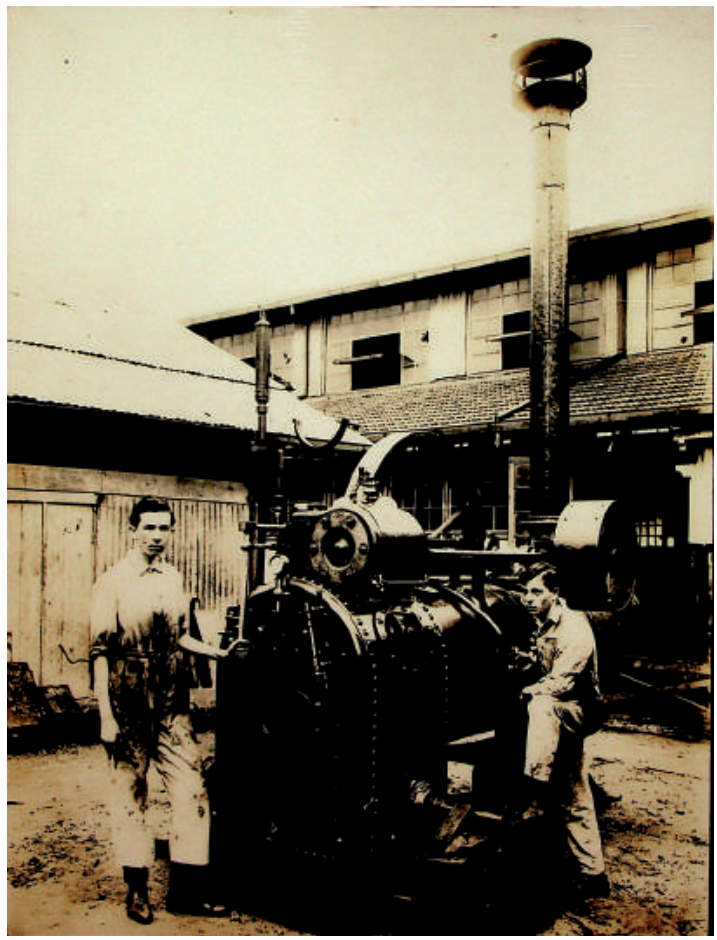

Aprendizes mecânicos

no Liceu de Artes

e Ofícios, s.d. 


\section{Classe F) Artes plásticas}

Seção I.a) Preparação da matéria prima. Depósito e tanques para preparo das argilas. Oficina de maxalagem. Possuía fornos e muflas especiais, maquinaria para mistura, decantação, moendas, seleção e refinação do barro, tanques para depósitos, estacionamento e secagem do barro.

Seção II.a) Modelação e formação. Com sala de risco para desenhos de preparação, ampliações e detalhes de execução. Ateliê de modelação, escultura em plastilina para modelos. Modelação do barro. Oficina de formação e fundição de gesso, cimento e geleias artificiais.

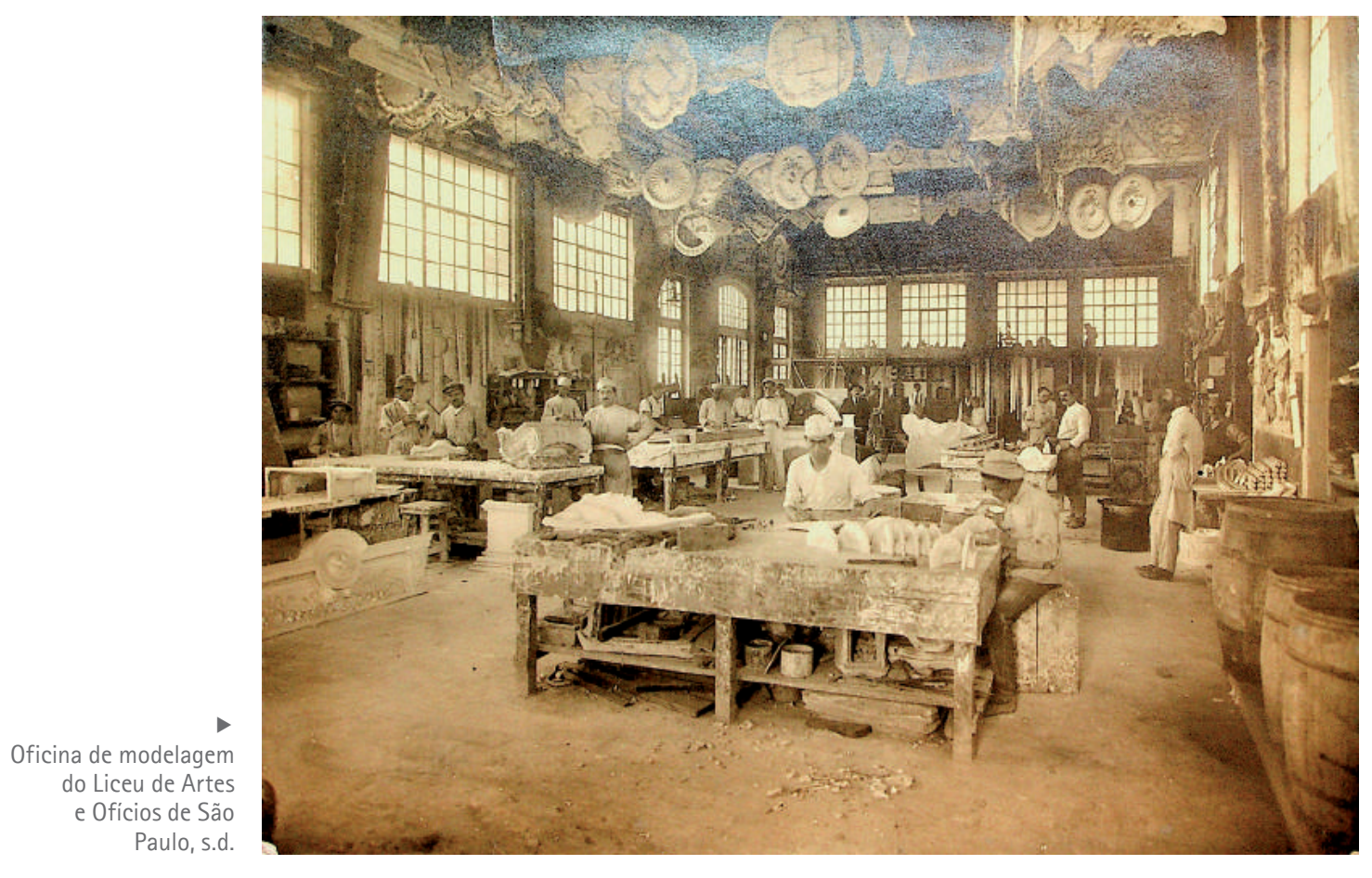

Seção III.a) Cerâmica (terracota) e esmaltes. Modelação e formação para execução de terracotas. Formas, numeroso e variado sortimento de modelos e formas de vasos e objetos de arte em todos os estilos. Laboratório para preparo das ligas de barro e esmalte. Com Mestre geral, 2 desenhistas, 3 escultores- modeladores, 1 mestre de seção, 2 mestres de colocação, 15 operários e 20 aprendizes. Maquinismos e fornos de material refratário.

Seção IV) “Terrazzo" - Pedras artificiais. Anexa à oficina de modelagem, especializada em ladrilhos de granilite, "terrazzos" de 
mosaico e decorações murais com painéis e placas ornamentais. Com máquinas e material apropriado.

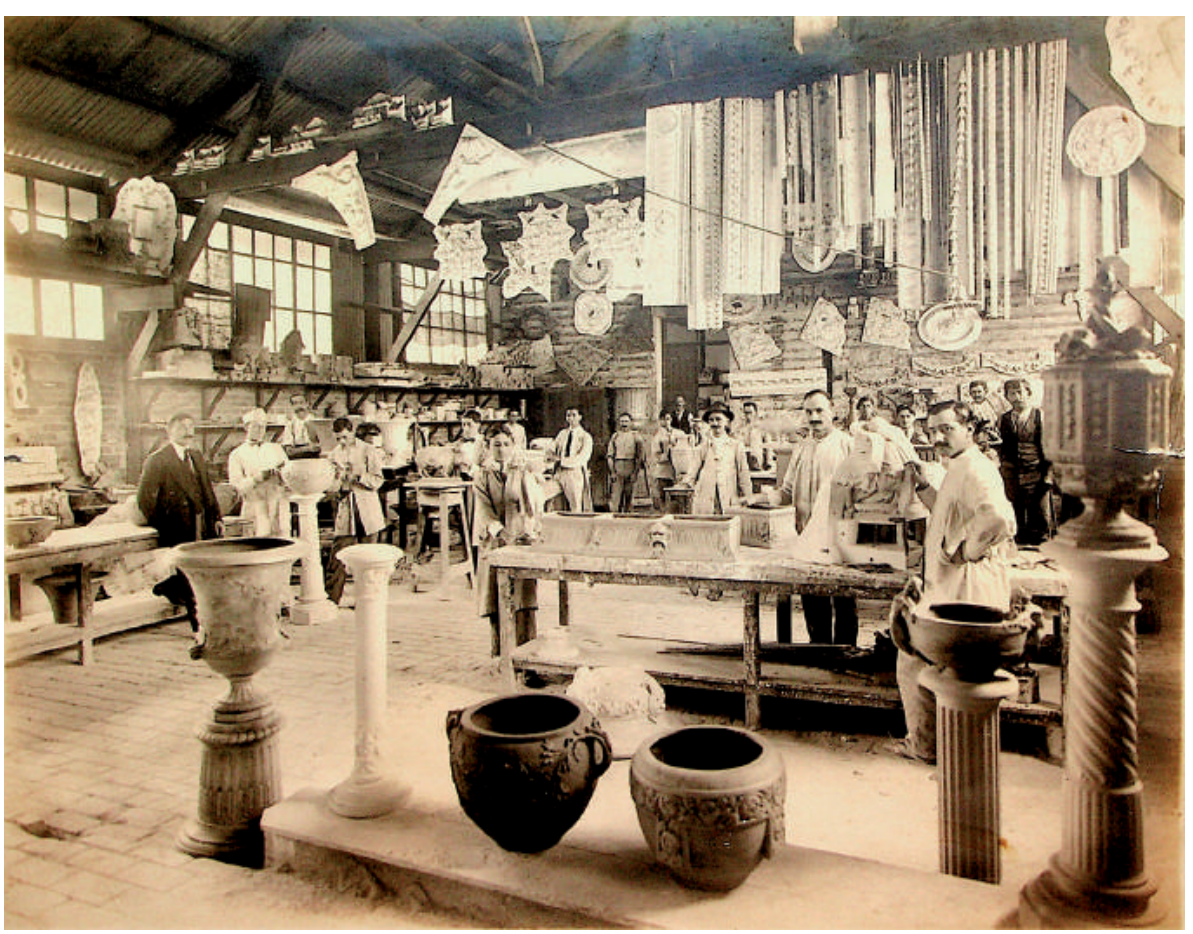

Classe G) Artes complementares

Seção I.a) Ornamentista ornamentações internas em gesso, estofos ou tapeçarias, pinturas, esmaltes e douração. Aplicação de papéis pintados, painéis de tela, de tecido de juta, algodão, seda, etc., em decorações murais, pavimentos, guarnições de portas e janelas etc. Estofos para mobiliários a crina e molas, acolchoados, forrações de peles, couros e marroquins. 1 Mestre decorador, 1 mestre tapeceiro, 8 operários, 15 aprendizes e 1 costureira.

Seção II.a) Artes gráficas. Tipografia, encadernação e gravura. Com máquinas e acessórios próprias para cada especialidade. Com 1 tipógrafo, 1 impressor e 4 aprendizes para a tipografia, 1 mestre geral, 1 mestre de seção 4 encadernadores e 6 aprendizes para a encadernação e gravura. Com sortido estoque de couros, camurça, papéis fantasia e em branco, chagrins (couros corrugados), etc. Contava com ateliê fotográfico aparelhado com laboratório químico, material complementar, variados aparelhos fotográficos; e capacidade para 10 lugares. Tinha 1 fotógrafo e um ajudante. de cerâmica do Liceu de Artes e Ofícios de São Paulo, s.d. 
Seção III.a) Eletrotécnica anexa à metalurgia, reparava e fazia instalações elétricas para uso das oficinas e escolas do Liceu.

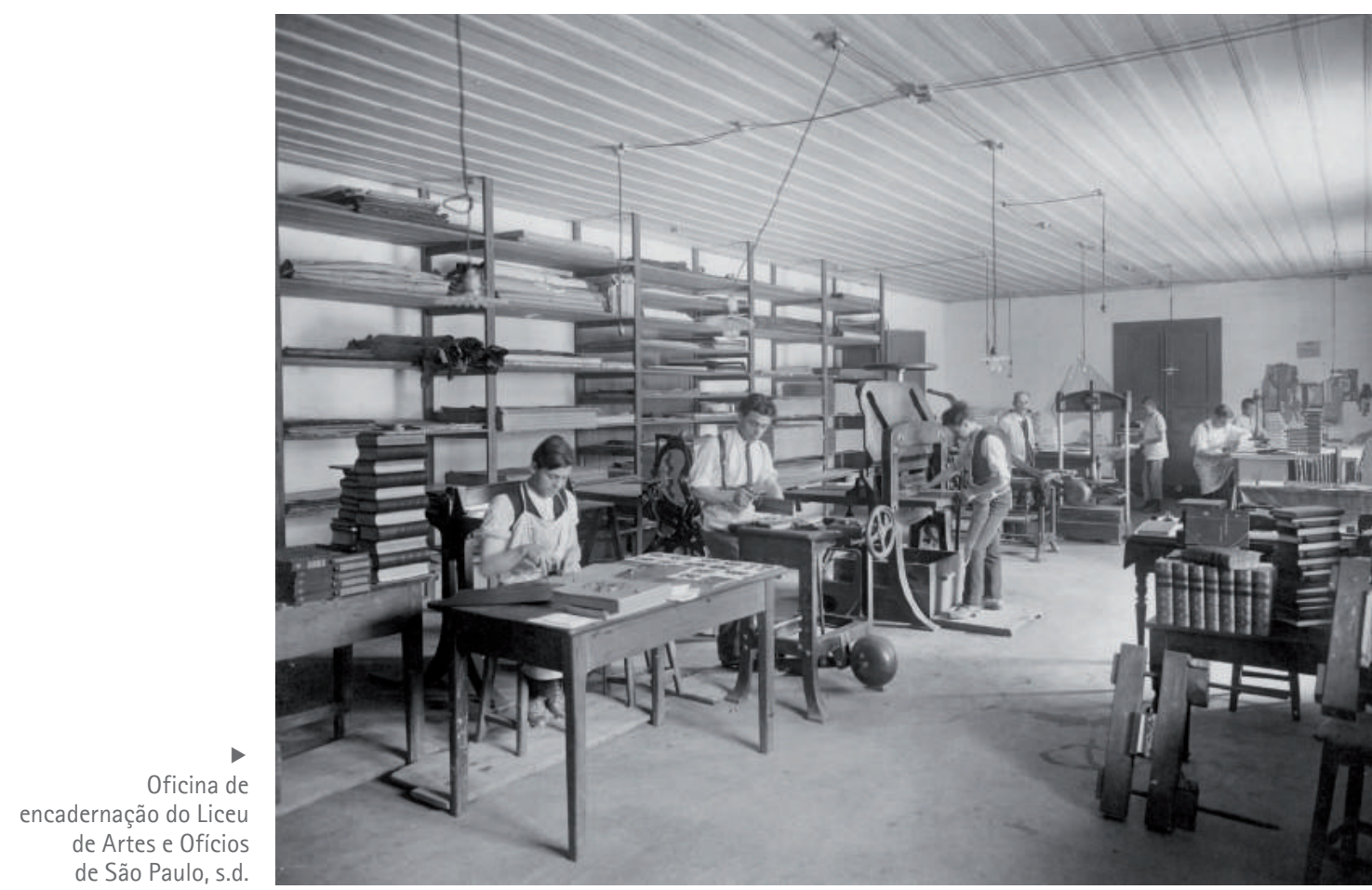

Classe H) Caldeiraria e canalização

Seção I. a) Oficina de caldeiraria. Com salas de risco, modelação e corte.Com um mestre geral. 4 operários e 15 aprendizes.

Seção II.a) Canalização e instalações sanitárias. Com 1 mestre geral, 5 operários e 10 aprendizes.

Depois de explicar minuciosamente os arranjos e aparelhamento das oficinas-escolas sobre sua direção, Ricardo Severo resume o móvel de todas elas:

O método adotado nas oficinas é completamente empírico. As oficinas são montadas como verdadeiros estabelecimentos industriais, destinados a produzir os artefatos utilizáveis no mercado: contratam obras, aceitam encomendas e fabricam manufaturas de comércio corrente. ${ }^{127}$ 
Ao transcrever uma matéria sobre o Liceu publicada pelo Jornal do Comercio de São Paulo em 28 de janeiro de 1917, Severo nos oferece um resumo poético acerca das práticas produtivas da escola:

Objetos preciosos, manuseados a cada instante por pulsos de aço, disciplinados pelo acerto e conhecimento exato da sua utilidade. ${ }^{128}$

Nas oficinas do Liceu, como em todas as manufaturas, o trabalho especializado era executado por artesãos cuja perícia, instinto e capacidade produtiva vivificavam o talento. Os artífices são trabalhadores privilegiados, embebidos em uma herança pré-industrial, dotados de tradição e experiência prática e capazes de manter suas posições mesmo com o deslocamento do campo artesanal para a indústria e a fabricação em série.

Ao contrário da grande indústria, nas oficinas ocorrem procedimentos peculiares a ocupações determinadas, a técnica e o improviso compensando falhas de ferramentas primitivas. ${ }^{129}$

Segundo Maria Lucia Githay no Liceu:

Os ofícios não aparecem como atividades fixas ou tradicionais, mas como habilidades a serem oferecidas num mercado em constante transformação. ${ }^{130}$

Os aprendizes, auxiliares e operários alfabetizados nas aulas noturnas e trabalhando nas oficinas passavam a oficiais, mestres, contramestres e gerentes, recebendo pequeno salário que aumentava ao longo de sua habilitação que durava cerca de quatro anos. ${ }^{131}$

Dentro das oficinas da escola a hierarquia era própria das organizações industriais e rigorosa. Estavam a postos e, nesta ordem, Gerente Geral, Gerente técnico-Artístico, Chefe de Oficina, Mestre Geral, Contramestre. Cada qual com as seguintes atribuições específicas:

128. cf. Ricardo Severo (1934, p. 190).

129. Para o detalhamento dos contextos e especificidades sobre as manufaturas em contraposição à grande indústria, cf. HOBSBAWM, E. Mundos do Trabalho. Rio de Janeiro, Paz e Terra, 1984, p.349-377.

130. cf. Maria Lucia Gitahy (1986, p. 65).

131. Ver Maria Lucia Gitahy (1986). 
- Gerente Geral organizava orçamentos e contratos das obras, compras e vendas, pagamentos, recebimentos e liquidações; era encarregado de admitir e demitir pessoal auxiliar e operário das seções.

- Gerente técnico-artístico colaborava com decisões do Gerente Geral e dirigia as seções de organização, projetos, composição, desenho e modelação, acompanhando o funcionamento e realizações das diversas seções sob o ponto de vista da técnica e arte profissionais, orientando o aperfeiçoamento das manufaturas e o progresso das oficinas-escolas. A ele competiam os estudos, cálculos, desenhos, modelos e metodização técnica do respectivo trabalho.

- Chefes de Oficina eram responsáveis pela execução do trabalho e do ensino repartido entre vários mestres e contramestres. Organizavam plano de execução, distribuíam e administravam os serviços, promoviam o ensino técnico da profissão artística ou industrial a todos os operários e aprendizes, dirigiam as oficinas mantendo a ordem, higiene e disciplina, fiscalizando o regulamento, zelavam pelos prédios, materiais, máquinas e utensílios sob sua guarda, ordenavam e fiscalizavam os mestres e contramestres da oficina.

- Mestres obedeciam, auxiliavam e substituíam chefes das oficinas, permanecendo na oficina durante o período de trabalho e acompanhavam o trabalho manual de cada aprendiz sob o ponto de vista da técnica profissional, seu ensino e aperfeiçoamento individual.

- Os Contramestres eram auxiliares e substitutos dos Mestres. ${ }^{132}$

Como podemos perceber, as oficinas do Liceu tinham equipamentos modernos enquanto a escola dispunha de recursos pedagógicos de ponta incluindo uma biblioteca especializada, um museu pedagógico e uma galeria de arte.

Ao constituir e operar saberes, ensinando o desenho e o projeto, o Liceu instruía a composição, com ênfase no projeto de acordo com

132. Para esta seção ver Maria Lucia Gitahy (1986). 
a especialização dos usos. Como empresa dotada de estrutura administrativa industrial fordista, conhecendo o gosto de seus clientes e trabalhando sob encomenda, fazia rodar as engrenagens projeto- manufatura- venda - usuário.

A combinação da perícia no saber-fazer, a precisão dos modelos, das formas e da qualidade dos materiais trabalhados garantiu alto grau de desenvolvimento técnico na produção de objetos arquitetônicos e artísticos.

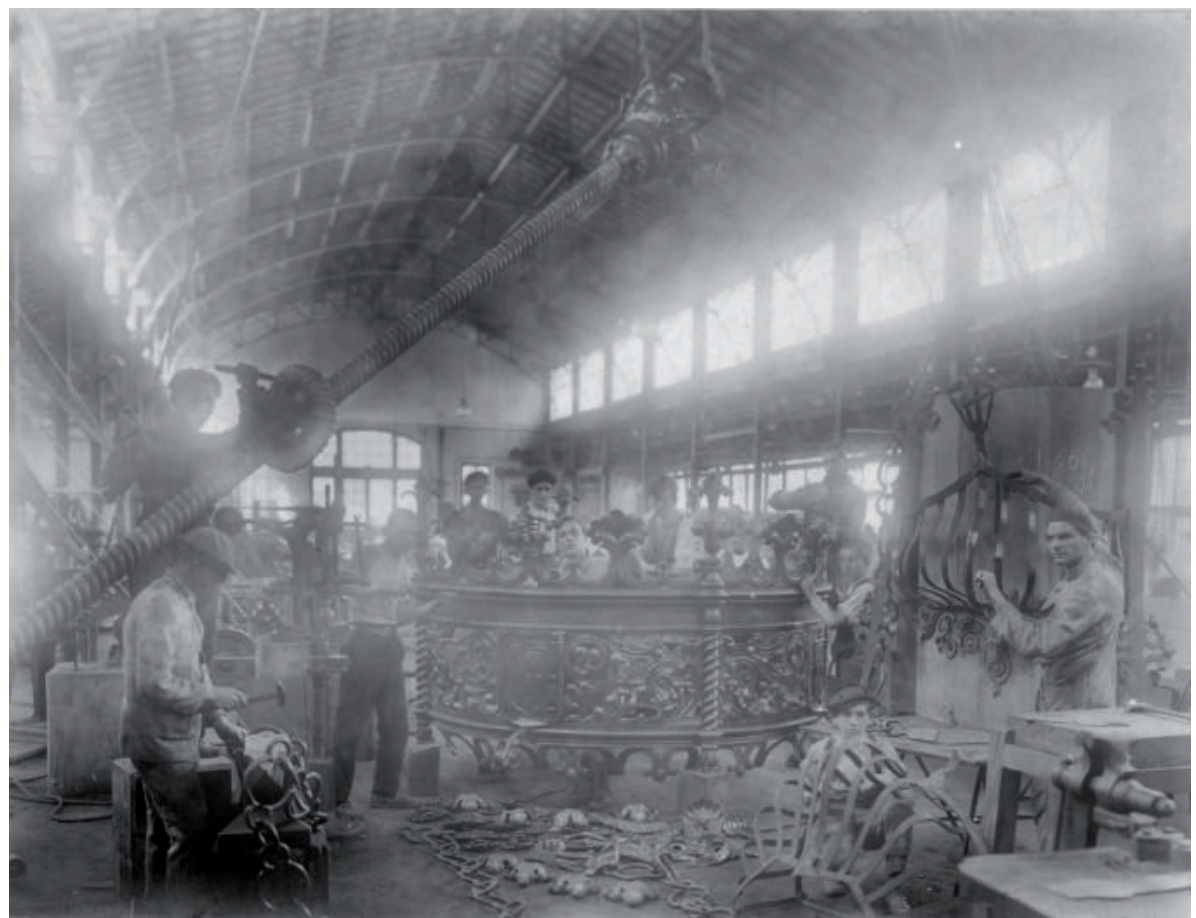

Oficina de metais do Liceu de Artes e Ofícios de São Paulo, s.d.

\subsection{Entre mudança e tradição}

Acontecimentos determinantes nos cenários político e econômico nacional e internacional, como o crack da Bolsa de Nova Iorque, as revoluções de 1930 e a de 1932 juntamente com a perda de Ramos de Azevedo interromperam o ritmo das atividades do Liceu e causaram prejuízos materiais; mas as escolas e oficinas, mesmo funcionando precariamente, mantiveram-se produtivas e abertas. Eram os lucros das vendas de seus produtos e suas especialidades que faziam a manutenção da instituição. 
As oficinas foram capazes da "ompetência eclética" para usarmos a expressão de Ana Maria Belluzzo. Dispondo de uma enorme gama de repertórios, elegendo modelos e estilos, dominando o desenho, produzindo obras de arte e modelos contratados por escritórios de arquitetura e notadamente o Escritório Técnico Ramos de Azevedo, o Liceu gravou seu nome como marca de excelência na execução, conhecendo seu apogeu durante as décadas de 1920 e 1930. Instrumentos de propagação de gostos, suas obras coletivas transformaram a fisionomia dos ambientes da cidade.

$\mathrm{Na}$ confluência entre mudança e tradição, a forma paulista de cidade - expressa nas decorações externas e internas de incontáveis edifícios públicos e residências de luxo, ornamentados em estilos históricos e modernos - percebe-se em alguns exemplares certas inovações carregadas de originalidade, distantes da forma rígida e padronizada requerida pela produção da máquina.

Sem nos propormos a investigações teóricas sobre a natureza prática e ou filosófica das artes arquitetônicas e decorativas, elegemos como exemplos emblemáticos da 'personalidade' coletiva do Liceu as realizações referentes ao Teatro Municipal, 1910-1911, Banco Português do Brasil, 1919, Palácio dos Campos Elíseos, 1936 e ambientes internos de residências sem identificação e data.
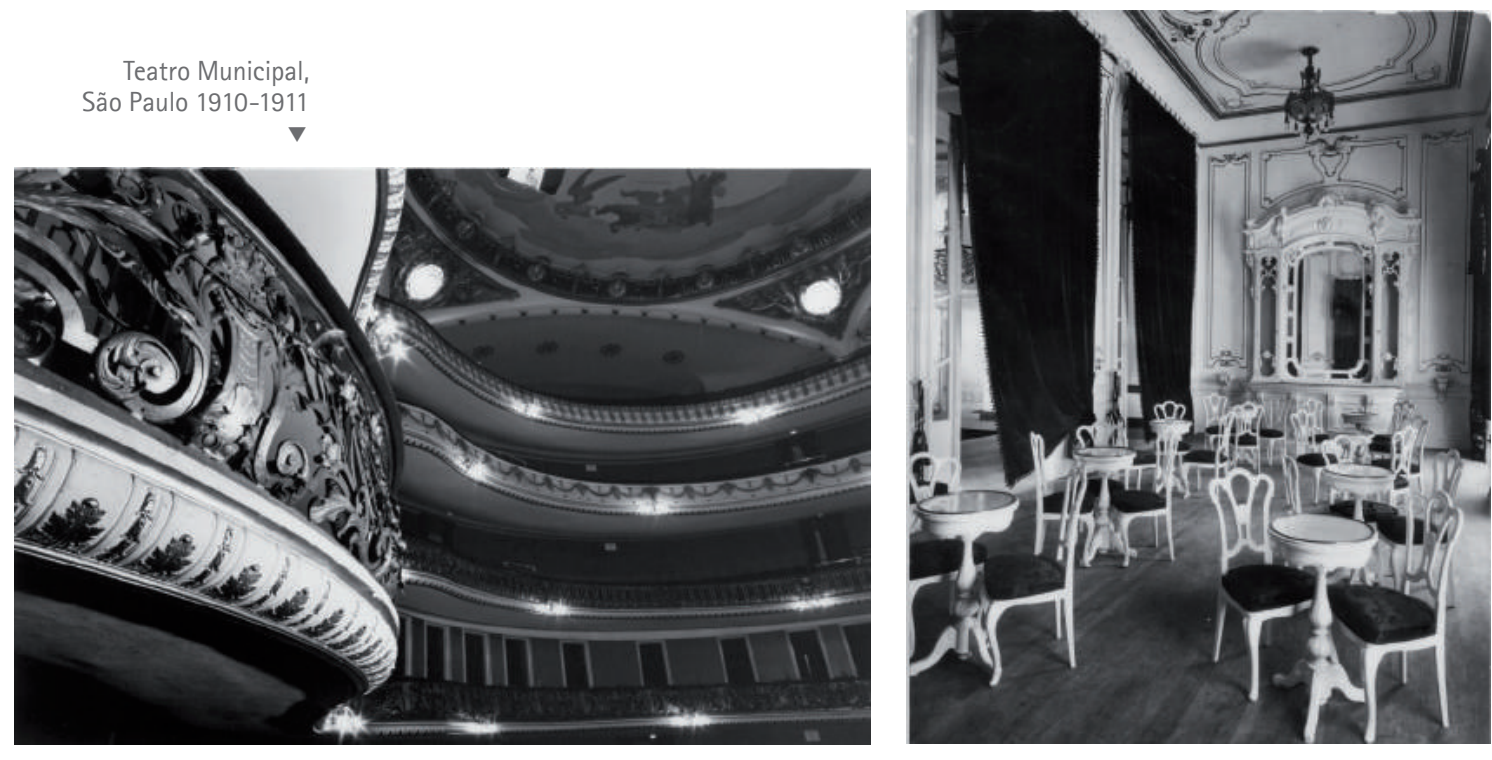

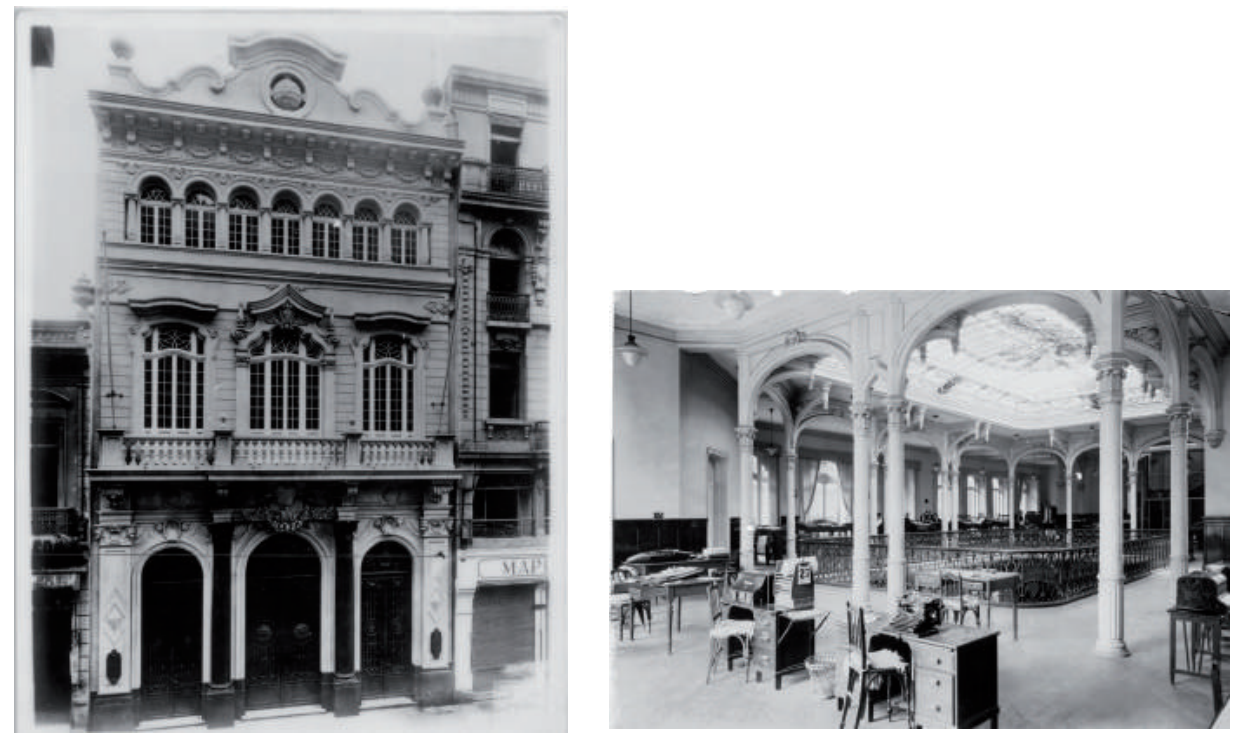

Banco Português do Brasil, São Paulo, 1919
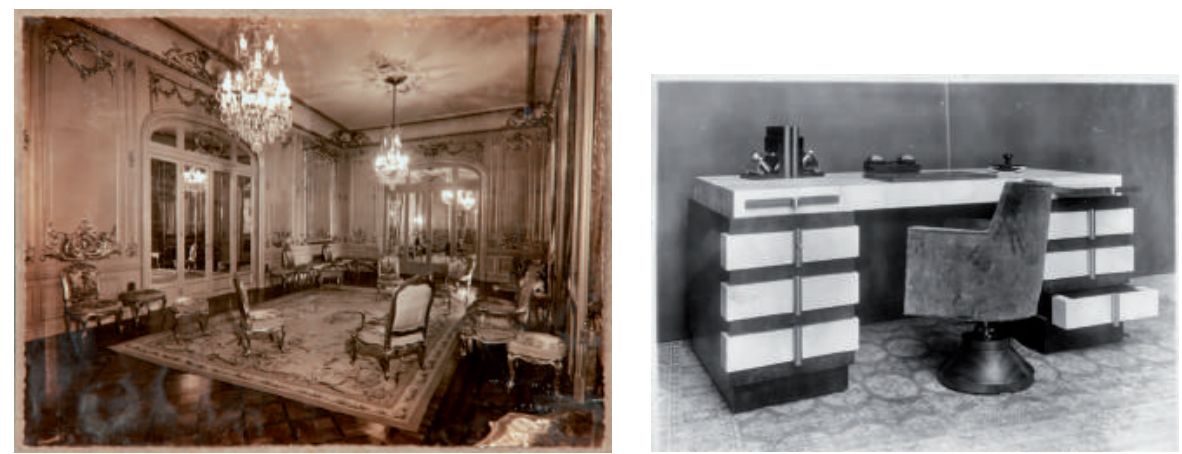

Mobiliário do Palácio dos Campos Elíseos, São Paulo, 1936

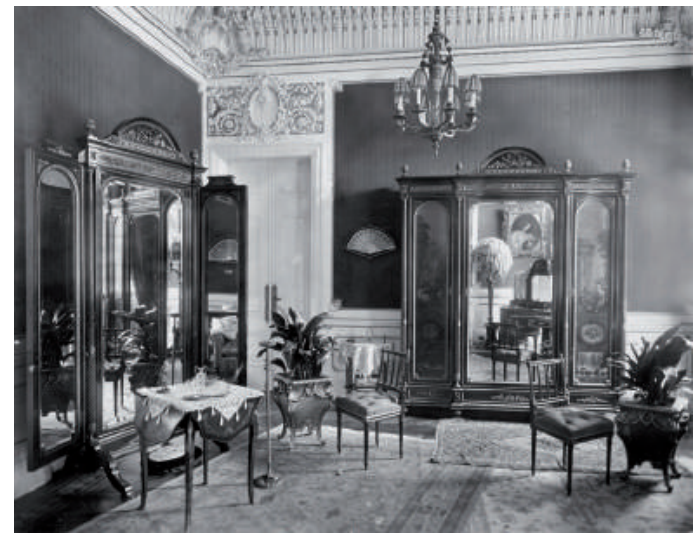

Foi apenas na década seguinte, com o surto industrial do pós-

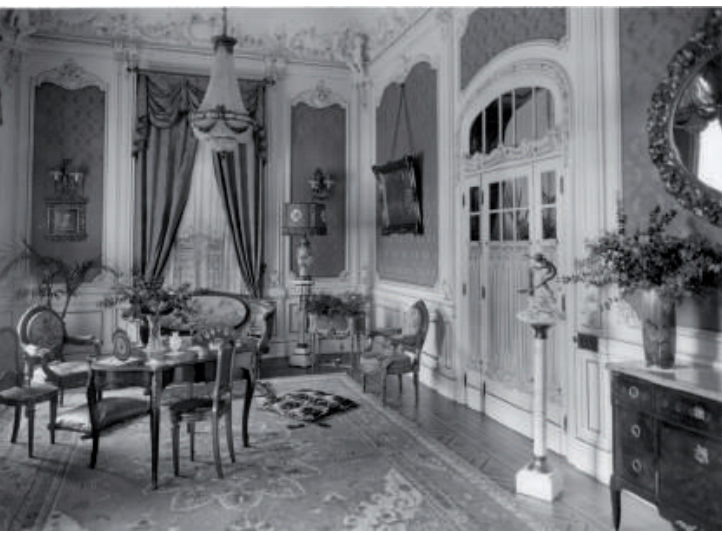

Ambientes internos de residências, São Paulo, s.d. guerra e as exigências de mão de obra qualificada e para obedecer a lei orgânica do ensino industrial promulgada em 1941 que o Liceu deixou de oferecer ensino gratuito aos cidadãos e operários. Os cursos noturnos puderam manter seu currículo e organização enquanto os cursos 
diurnos, que deveriam equivaler ao curso ginasial da época, não ofereciam as matérias exigidas por lei. ${ }^{133}$

Até aquele momento, “a preocupação com a formação do 'operário completo' caminhou lado a lado com a produção do 'artefato perfeito". ${ }^{134}$ A partir de então, e quando arte e técnica parecem se dissociar, a História elegeu outras formas e medidas para construir o mundo.

133. Mais tarde o Liceu desoficializa seus cursos diurnos passando novamente a cumprir seu objetivo inicial de oferecer instrução técnica e gratuita. Ver Liceu de Artes e Ofícios de São Paulo (1958).

134. cf. Maria Lucia Gitahy (1986, p, 46). 


\section{Ensaios de seriação visual}

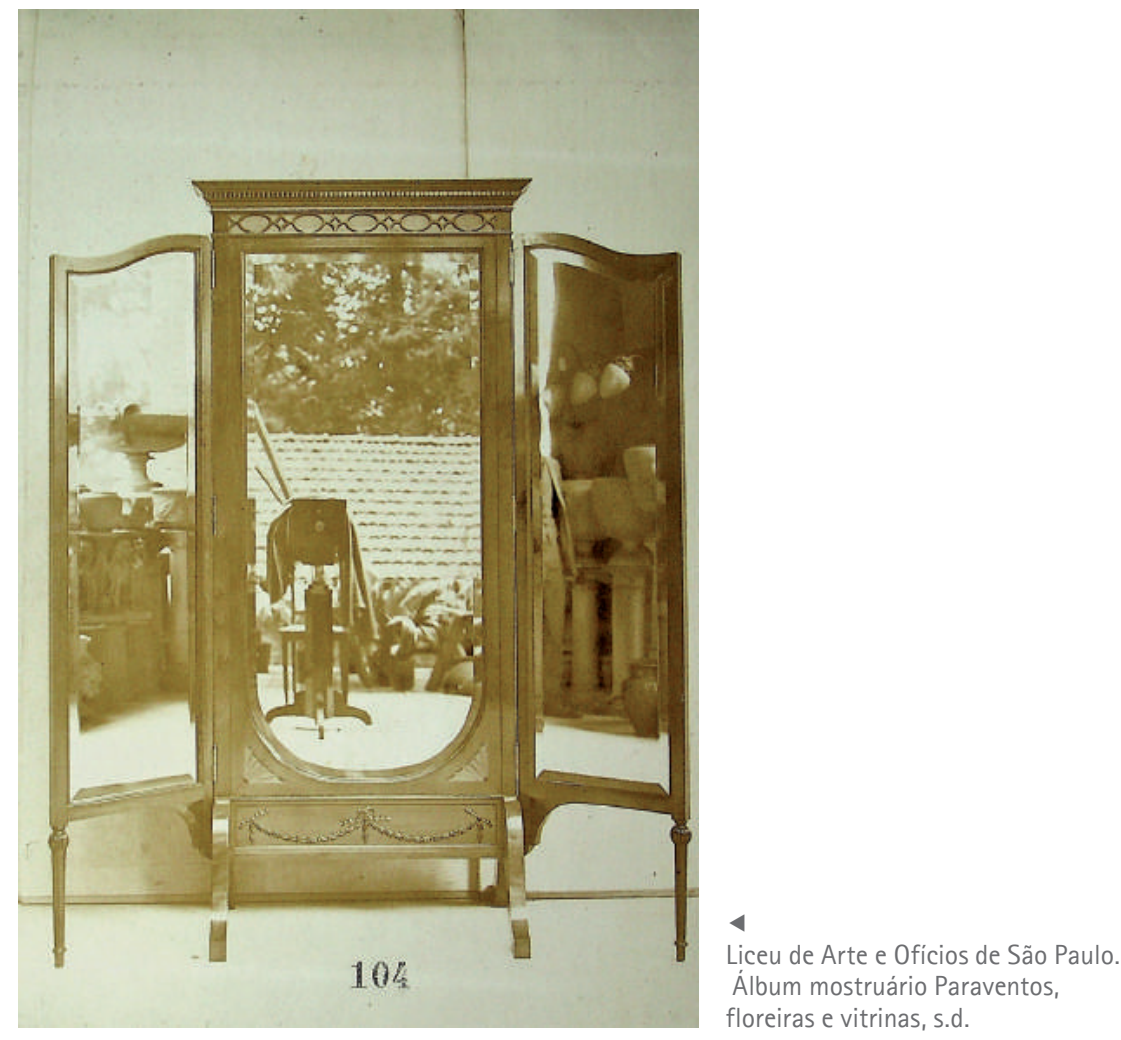

À maneira da lição de coisas empregada nas escolas do Liceu de Artes e Ofícios de São Paulo abordamos empiricamente os exemplares bibliográficos remanescentes no acervo institucional. Como nos exercices d'intuition aprendemos a observá-los em sua concretude, folheando, adivinhando, descobrindo, desvendando para compreender tanto suas qualidades físicas quanto seus predicados de objetos culturais.

As peças que estudamos são por si mesmas representações notáveis da vida cultural das ideias e das formas artísticas ecléticas e, no limite, modernas. Nos revelam aspectos multifacetados da produção 
material e simbólica de diferentes épocas históricas e nos convidam a cruzar diferentes camadas do tempo em busca de idiossincrasias e simultaneidades.

Apresentamos aqui o resultado de nossas primeiras aproximações a este entrelaçamento.

\section{Entre projeto e objetificação}

Com a advertência de que o projeto não foi executado e assinalando remissão para um outro desenho não disponível, conhecemos a versão descartada e a versão objetivada da encomenda.

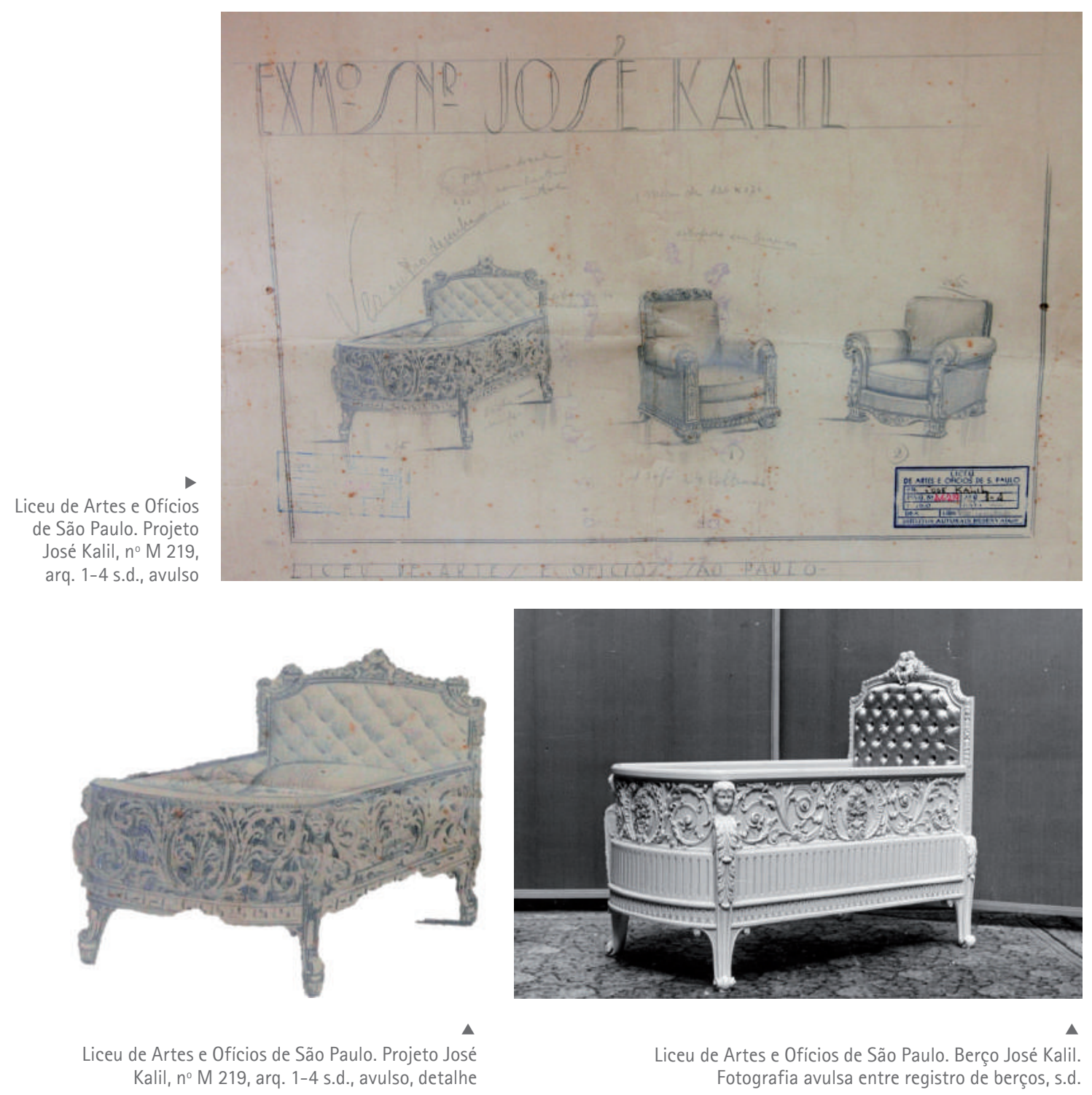


Adaptações para diferentes clientes. O ambiente decorado para o hall da residência de Lauro Cardoso de Almeida traz pequenas alterações em relação ao projeto de espaço semelhante para a residência de Adolfo Milani.
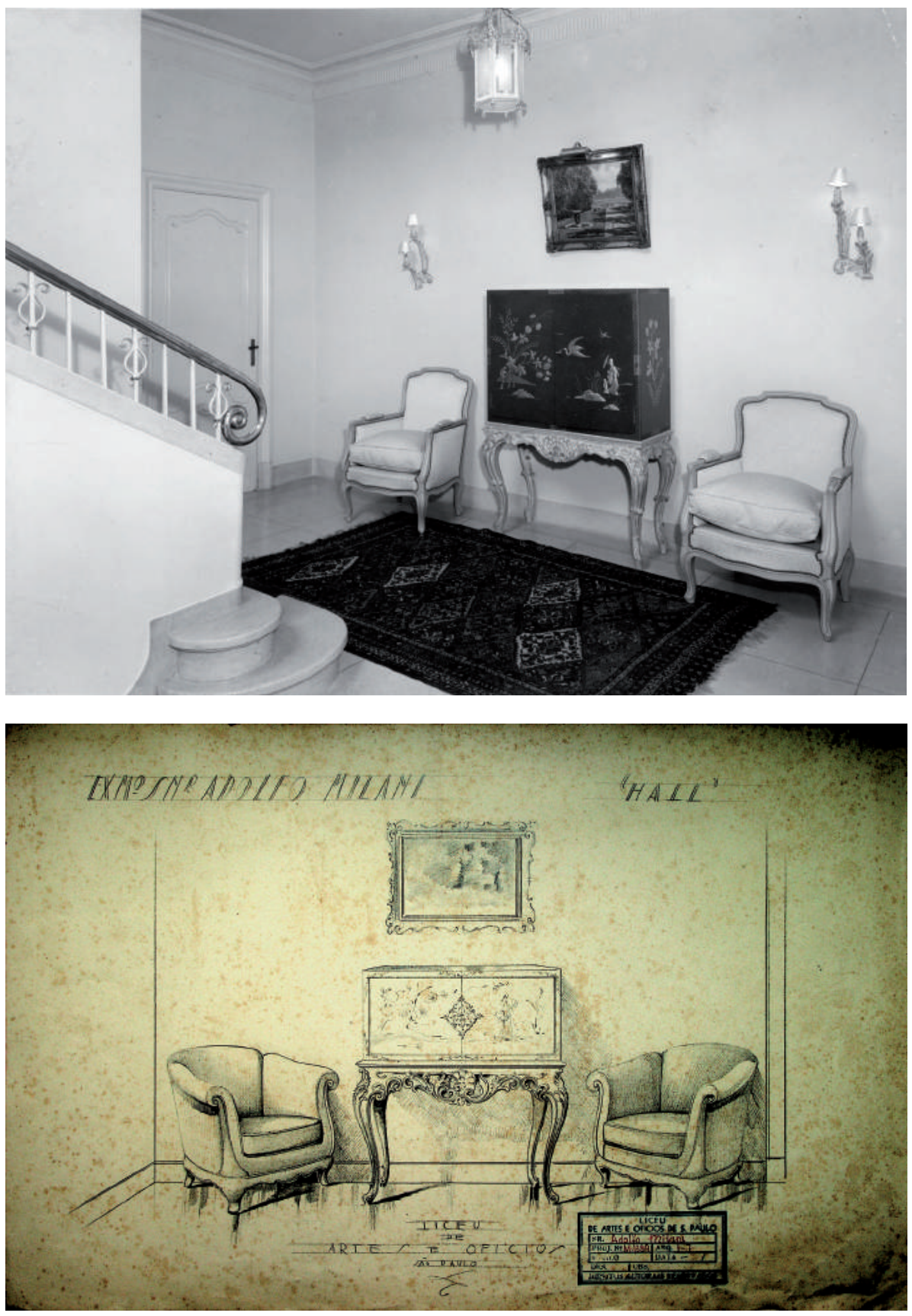

Liceu de Artes e Oficios de São Paulo. Residência Lauro Cardoso de Almeida. Fotografia avulsa entre registros de ambientes internos, s.d.

Liceu de Artes e Ofícios de São Paulo. Projeto Adolfo Milani, no M 1389, arq. 1-7, s.d., avulso 


\section{Mostruários}

Mostruários em forma de desenho diazotipo, desenho a cores e em formato fotográfico exibem tipos feitos tal e qual o projeto ou carregam indicações para modificações, mostrando procedimentos de trabalho diante do projeto/modelo submetido à clientela.

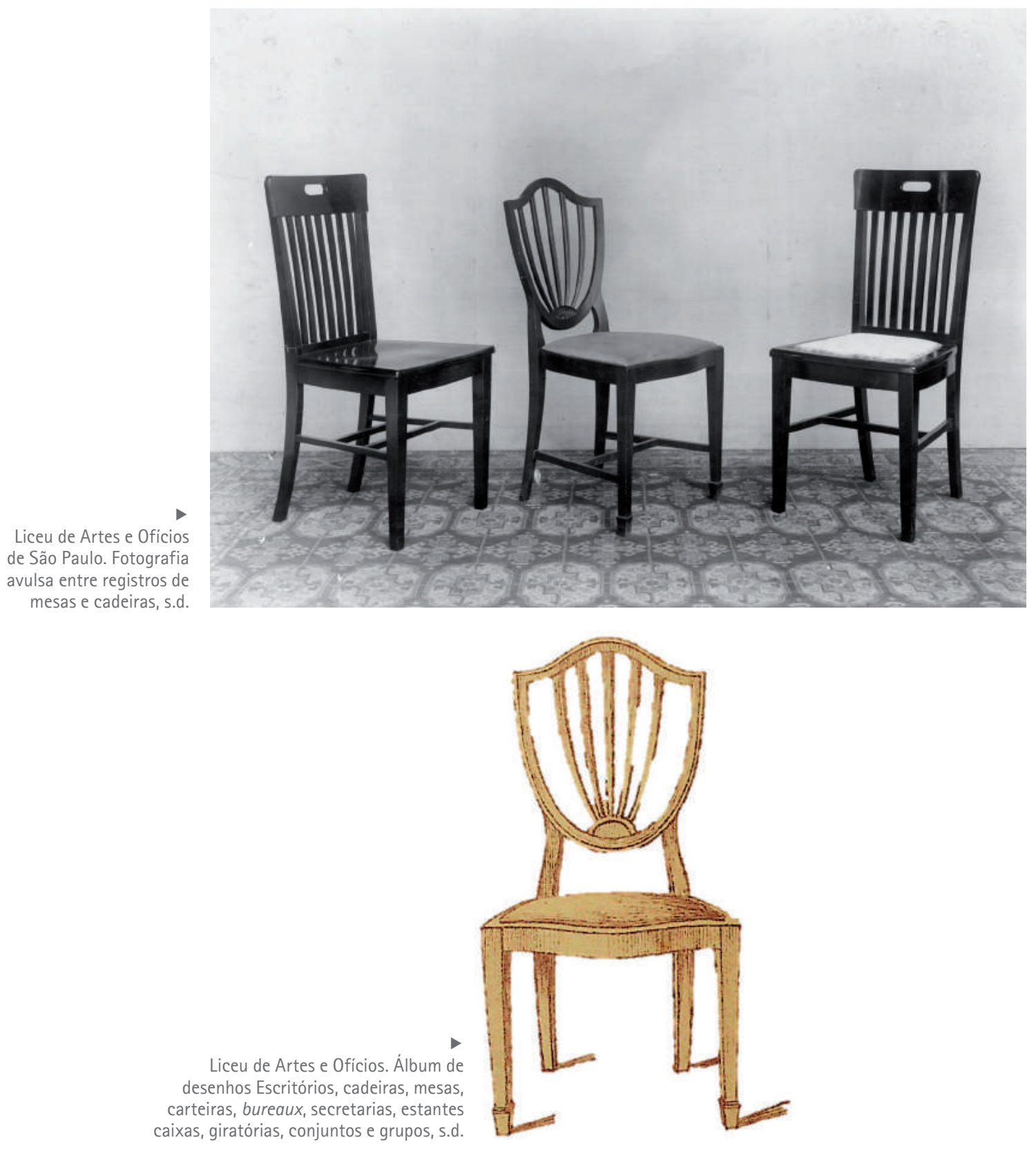




\section{Referências e transposições}

Repertórios e manuais de estilo exibem tipos tomados como modelos, padrões e guias.

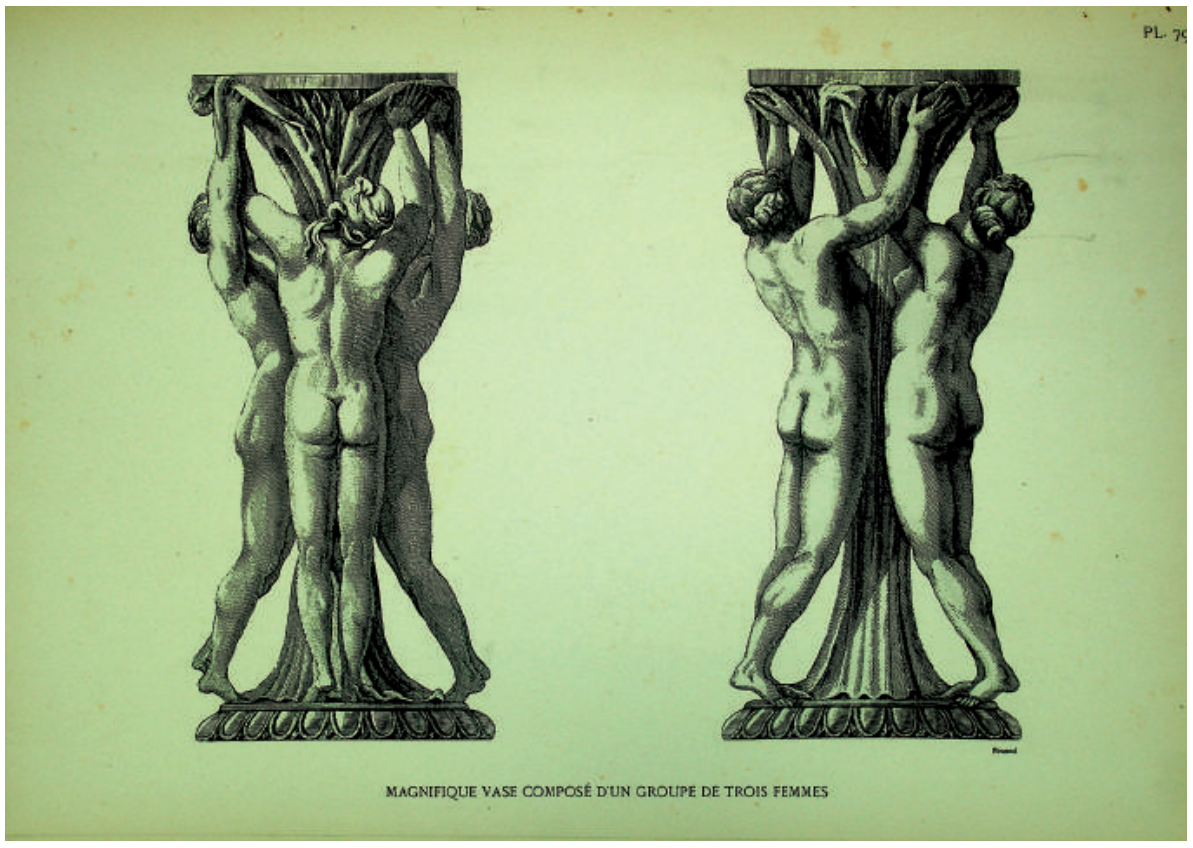

Vaso composto de três mulheres. In Coupes, Vases, Candélabres (...) déssinés et gravés par J.B. Piranesi. Paris: Auguste

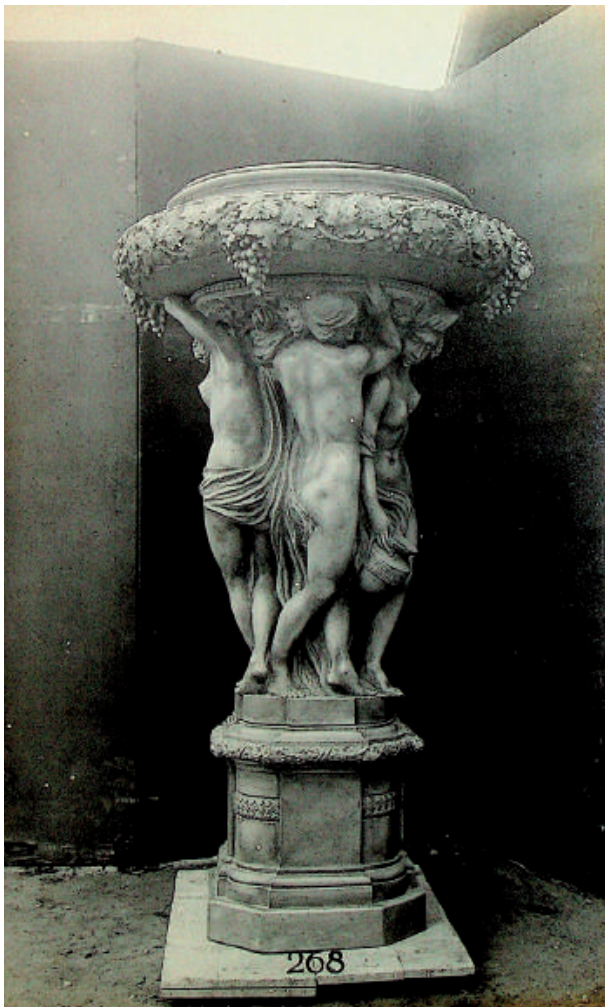

Vincent Éditeur, 1905

Liceu de Artes e Ofícios de São Paulo. Vaso. Álbum mostruário Cerâmicas, s.d. 


\section{Simultaneidades}

O modo de exibir os produtos evidencia similaridades na composição dos conjuntos em estilos históricos, demonstrando arranjos análogos, evidenciando a preocupação com a ambiência e incluindo peças escultóricas dentre os itens.

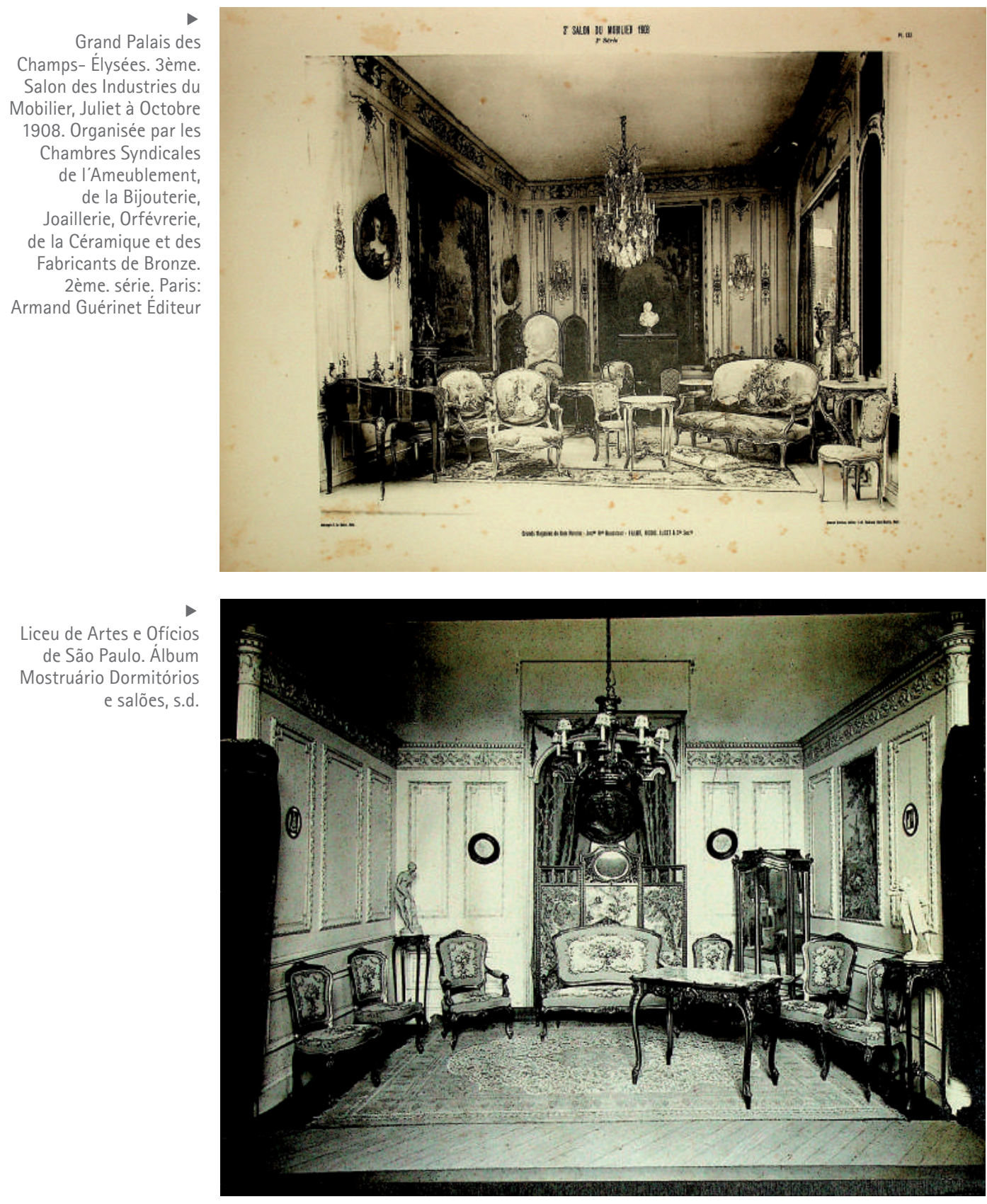


E em peças com linhas Art Deco.

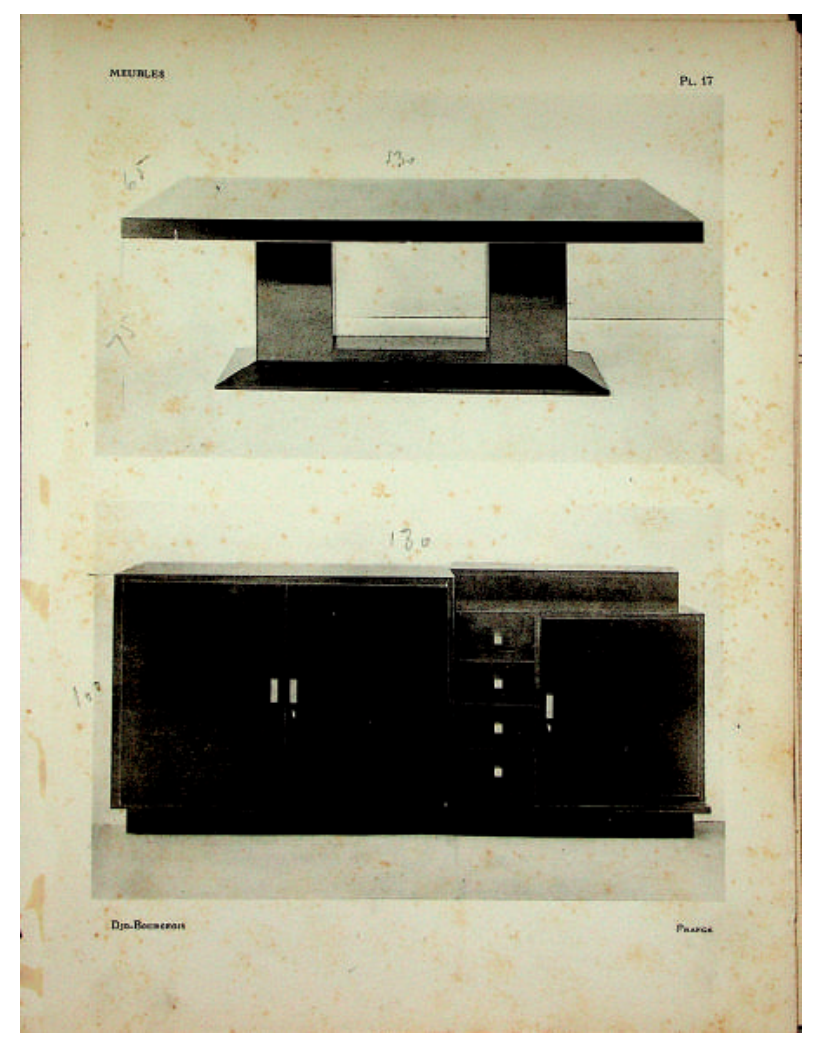

Meubles. L'Art International D'Aujourd'hui.

Présenté par Pierre Chareau Paris:

Éditions D'Art Charles Moreau, [1920]

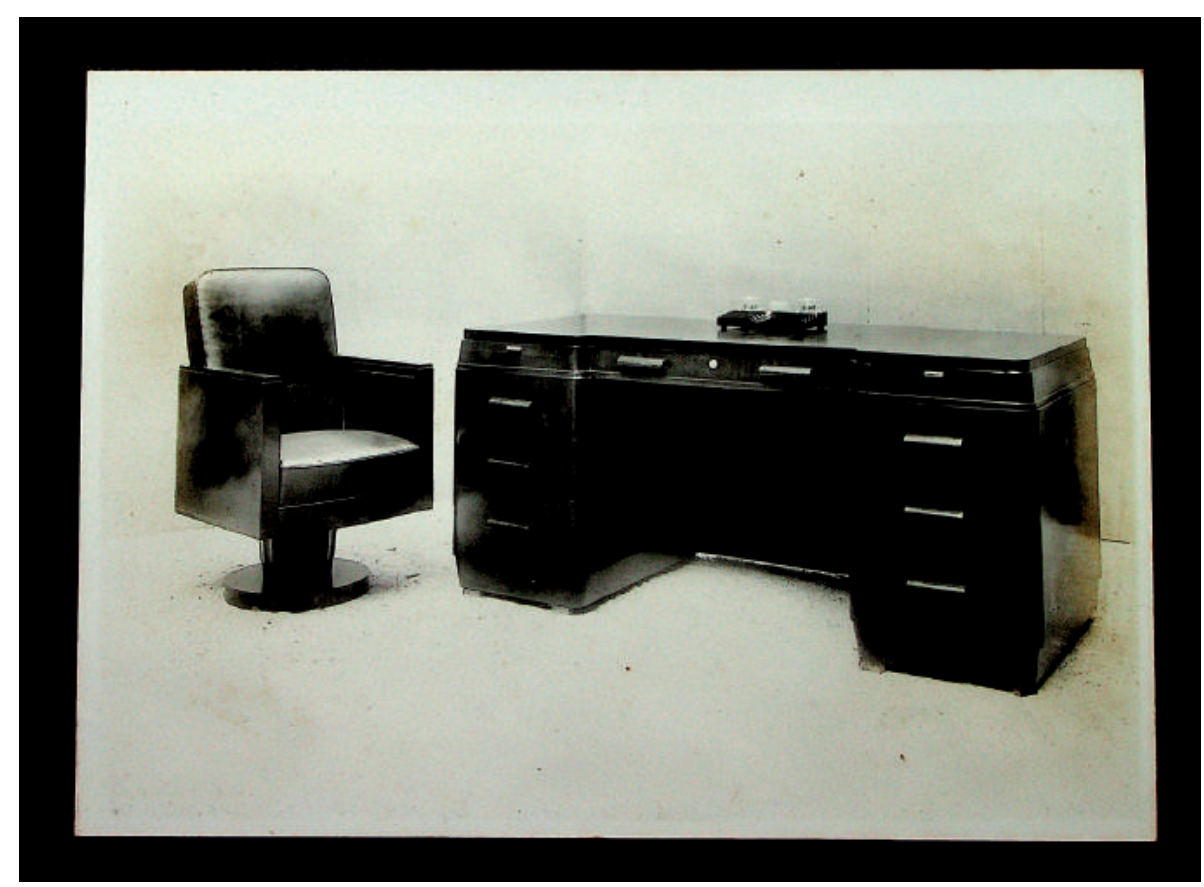

Liceu de Artes e Ofícios de São Paulo. Album

Mostruário Alfândega de Santos, 1938 


\section{Variações}

Se variações de modelos ou originais, algumas representações, quando isoladas de seus suportes e identificações, aparecem como sendo da mesma linhagem.

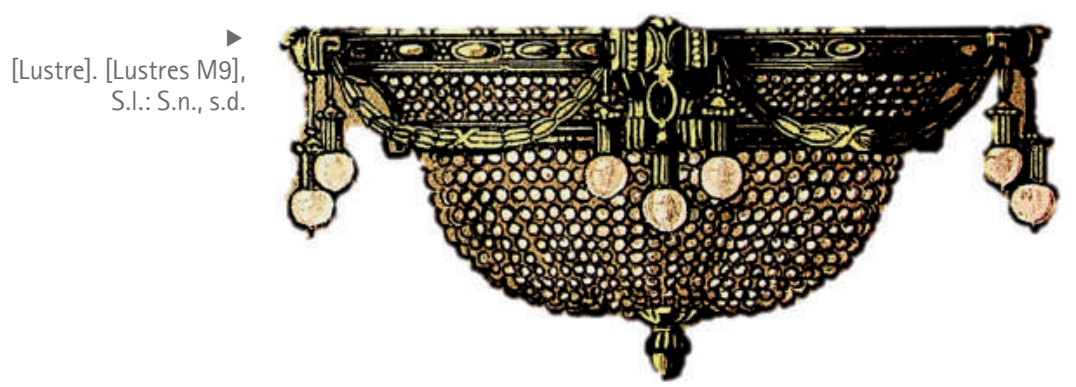

Liceu de Artes e Ofícios

de São Paulo. Desenho

de lustre [tipo plafond].

[Álbum de desenhos de lustres], s.d.
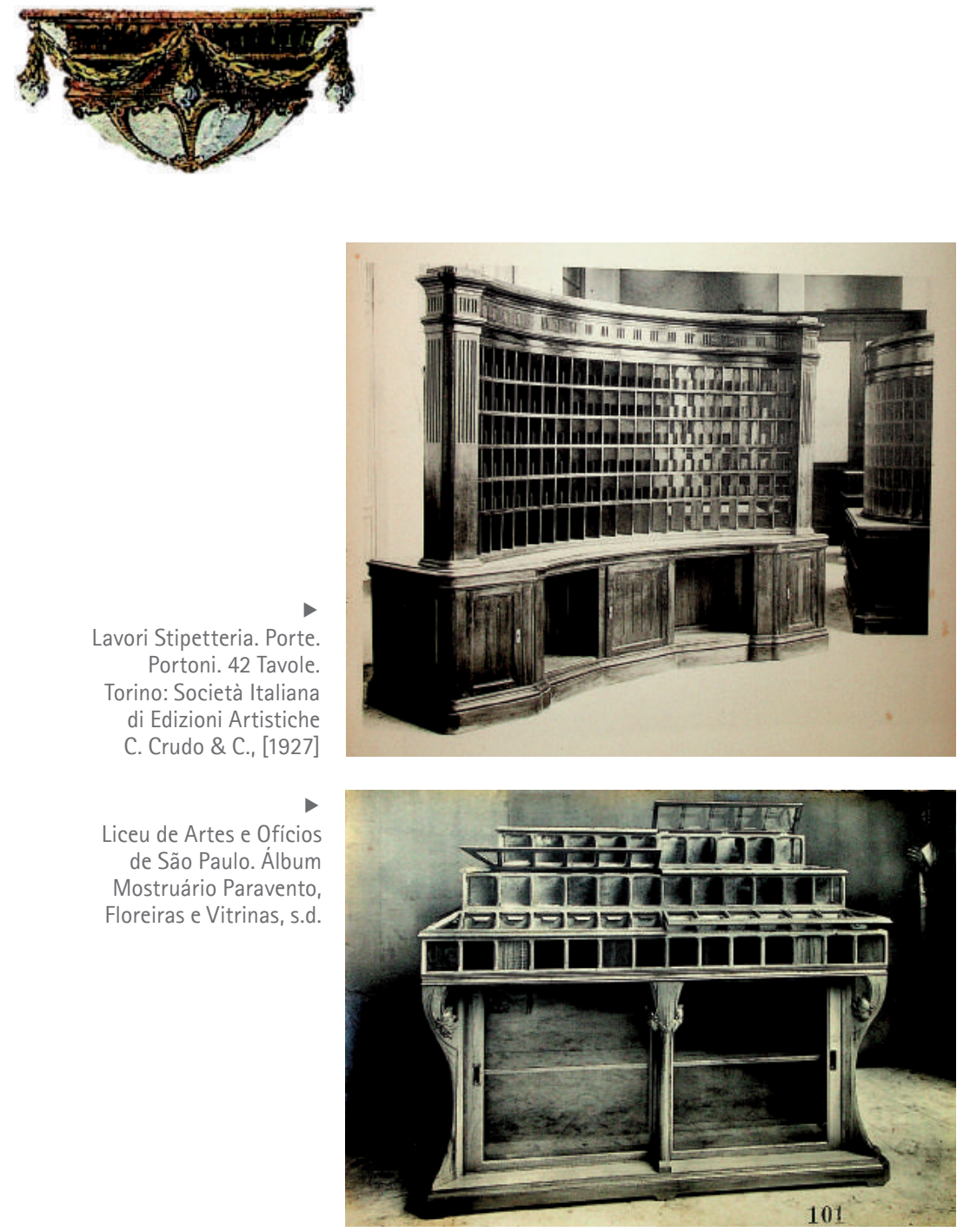


\section{Encontros}

Itens da biblioteca da escola foram mobilizados para integrar a composição de arranjos de exibição da produção feita por artífices que colaboraram em educar.
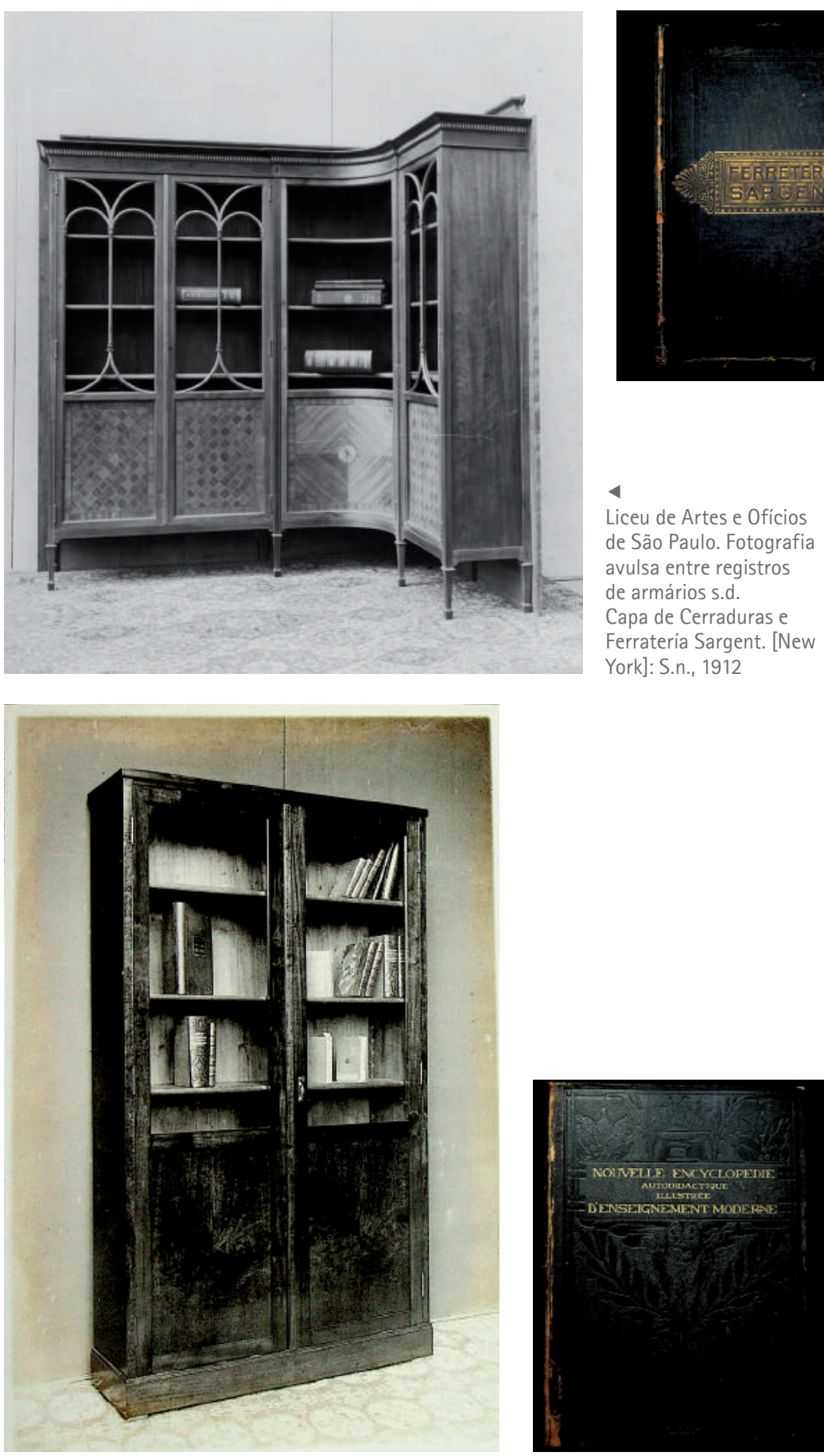

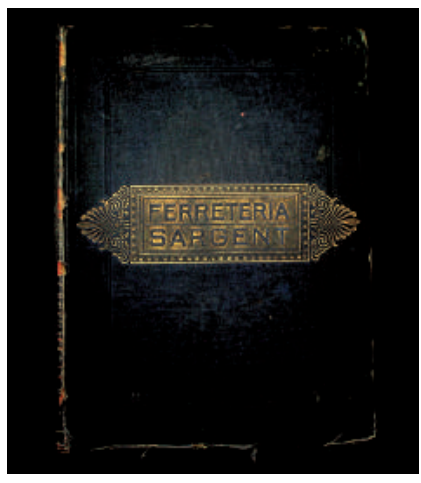

Liceu de Artes e Ofícios de São Paulo. Fotografia avulsa entre registros de armários s.d.

Capa de Cerraduras e Ferratería Sargent. [New York]: S.n., 1912
Liceu de Artes e Ofícios de São Paulo. Álbum Mostruário Alfândega de Santos, 1938.

Capa de Nouvelle Encyclopédie Autodidactique Illustrée, 1922 



\section{Considerações finais}

A busca por simultaneidades compartilhadas no manejo de saberes e fazeres relativamente a formas artísticas originais é tarefa das mais estimulantes. No âmbito das transferências de modelos culturais é possível investigar o modo como receptores, produtores e difusores do saber-fazer determinaram certas objetivações artísticas ou melhor, a maneira como os gestos de artesãos e artistas organizaram a forma na matéria sensível tornando-a objetos únicos.

Ao longo deste estudo procuramos demonstrar que os exemplares bibliográficos conservados no Liceu de Artes e Ofícios de São Paulo foram, aliados a outros recursos pedagógicos, artefatos fundamentais na transformação de objetos artísticos em objetos técnicos durante o manejo - por arquitetos, artistas e artesãos- de signos em busca de singularidades.

Muito embora não tenhamos determinado exatamente quais exemplares compuseram a biblioteca original do Liceu, tendo nos baseado em amostragens e em séries incompletas remanescentes no acervo da instituição, sabemos que a apropriação, uso e interpretações de modelos e fontes importadas operadas na escola impactou a construção de originalidades e/ou avivou os padrões de estilos históricos.

No período que estudamos a forma escolar e seus artefatos, incluindo os exemplares bibliográficos, estavam homogeneizados. Os mesmos títulos que circulavam em Paris circulavam em São Paulo e alhures. Tentamos, através de tímidas aproximações, conferir se quando apropriados, interpretados e traduzidos no âmbito do ensino das artes e ofícios do Liceu, os exemplares foram capazes de evidenciar a contraposição da tradição à inovação, ou ainda se a relativizaram, fizeram variar e mesmo a transformaram. 
As coisas que nos rodeiam são árbitros de nossas relações com a realidade. A tarefa de conhecer e aproximar os exemplares bibliográficos do Liceu, juntamente com outros tipos documentais, das práticas escolares considerando as curvas temporais de sua história, contou com achegas intuitivas mais do que com certezas históricas.

Desde a formação de seu núcleo inicial em 1873 até deixar de ser diretamente mencionada pelas fontes correntes, a biblioteca do Liceu foi objeto de orgulho, contou com doações esparsas sofreu perdas talvez compensadas com as ampliações vinculadas à aquisição do museu pedagógico em 1885 e às reformas dos programas da escola em $1882 \mathrm{e}$ 1895. Tornou-se objeto de cobiça, conheceu novos aliados ocos, mas potentes, em 1906-1908, e talvez tenha ganho influxos franceses em 1913 e mais entradas gálicas até 1940 .

Entretanto, revendo os exemplos selecionados para ilustrar nossas incursões no Liceu entre 1873-1940, as linhas de força da biblioteca parecem diluir-se. As informações sobre os conjuntos são demasiado amplas, nem sempre decifráveis, por vezes escapando ao alcance imediato. A reunião de alguns exemplares por editoras e bibliotecas especializadas nos abriu horizontes e nos convida a novos estudos que contem com recortes melhor definidos, de modo a isolarmos exemplares individuais em busca dos vestígios preciosos de suas carreiras como veículos de conhecimento.

No trato com as peças e em sua sistematização numerosas questões ficaram latentes aguardando o tempo de serem retomadas. A própria relação das peças entre si e com os exemplares artísticos componentes da gipsoteca, a coleção de gessos e sua história; as circunstâncias e os contatos com as livrarias e casas editoras assim como a 'biografia' das bibliotecas especializadas que publicaram obras na tentativa de remontar a lógica dos circuitos por onde transitaram; a indagação sobre seus eventuais congêneres em outras intuições brasileiras e internacionais para verificação do alcance da disseminação de seus conteúdos no tempo e no espaço; o impacto que tiveram sobre os modos expositivos no Liceu e fora dele, estudos comparativos, entre muitos outros temas.

O que sabemos até aqui é que os exemplares foram coadjuvantes essenciais para a eficácia do programa técnico das escolas-oficinas que qualificou artística e magistralmente a mão-de-obra para a indústria das artes decorativas e da construção arquitetural em São Paulo. 
Nas oficinas-escolas do Liceu foi ensinada a composição, o know-how da doutrina nas artes aplicadas, combinado com conhecimentos úteis, formando o artesão apto ao fazer e ao pensar, ou, se preferirmos, o trabalhador especializado pela tradição, com certezas técnicas, capacidade de projetar e perícia tecnológica.

A extroversão daquela virtuosidade esteve intimamente ligada às práticas de composição das ambiências da cidade, a própria cidade entendida como artefato, restando nela os traços dos homens. 



\title{
Fontes e Bibliografia
}

\author{
Fontes \\ Jornais \\ A PROVINCIA DE SÃO PAULO, 17 fev. 1884 \\ ALMANACH Administativo, Commercial e Industrial da Provincia de \\ São Paulo para o Anno de 1884, III, pág. 114-115, Parte II, Seção IV, \\ Jorge Seckler, 1884, São Paulo \\ CORREIO PAULISTANO, São Paulo, 29 nov. 1873 \\ CORREIO PAULISTANO, São Paulo, 2 dez. 1873 \\ CORREIO PAULISTANO, São Paulo, 5 dez. 1873 \\ CORREIO PAULISTANO, São Paulo, 25 dez. 1873 \\ CORREIO PAULISTANO, São Paulo, 28 dez. 1873 \\ CORREIO PAULISTANO, São Paulo, 21 jan. 1874 \\ CORREIO PAULISTANO, São Paulo, 24 jan. 1874 \\ CORREIO PAULISTANO, São Paulo, 27 jan.1874 \\ CORREIO PAULISTANO, São Paulo, 7 fev. 1874 \\ CORREIO PAULISTANO, São Paulo, 12 fev. 1874 \\ CORREIO PAULISTANO, São Paulo, 20 fev. 1874 \\ CORREIO PAULISTANO, São Paulo, 11 mar. 1874 \\ CORREIO PAULISTANO, São Paulo, 26 mai. 1874 \\ CORREIO PAULISTANO, São Paulo, 5 set. 1882
}


CORREIO PAULISTANO, São Paulo, 3 set. 1890

CORREIO PAULISTANO, São Paulo, 12 fev. 1906

CORREIO POPULAR, São Paulo, 10 fev. 1874

JORNAL DO COMÉRCIO, São Paulo, 28 jan. 1917.

REFORMADOR (PERIÓDICO) - RIO DE JANEIRO (RJ) - 10_1883 ANO 1, NÚMERO 21

O ESTADO DE S. PAULO, São Paulo, 1 jan. 1917

O ESTADO DE S. PAULO, São Paulo, 6 jan. 1917

O ESTADO DE S. PAULO, São Paulo, 9 dez. 1919

[ARROLAMENTO dos tipos documentais constantes do acervo do Liceu de Artes e Ofícios de São Paulo]. In ARAÙJO, MARCELO et alii. Proposta de Novo Programa Museológico para o Centro Cultural do Liceu de Artes e Ofícios de São Paulo, Pinacoteca do Estado de São Paulo, 2011.

AUTORIA INDETERMINADA Album Photografico [Escola Normal de São Paulo]. São Paulo: P. Doumet, 1895.

AUTORIA INDETERMINADA. Almanach da provincia de SãoPaulo, administrativo, commercial e industrial para 1887. São Paulo: Jorge Seckler, 1887.

AUTORIA INDETERMINADA. [Desenho de carteira escolar, São Paulo], 1894, pertencente ao conjunto do projeto da Escola Normal Caetano de Campos. Coleção Ramos de Azevedo. Acervo da Biblioteca Faculdade de Arquitetura e Urbanismo de Universidade de São Paulo.

BIENAL DE SÃO PAUlO, 6á, 1961, Museu de Arte Moderna, São Paulo. Catálogo da 6a. Bienal de São Paulo. São Paulo: Museu de Arte Moderna, 1961, 720 p. Disponivel em http://bienal.org.br/publicacao.php?i=4395 Acesso em 11.02.2018.

BRASIL. ACTAS e pareceres do Congresso da Instrucção, 1882-1883. Rio de Janeiro: Typographia Nacional, 1884, vol. I a IV.

BRASIL. Comissão Brasileira na Exposição Universal de Philadelphia; Centennial Exhibition (1876 : Philadelphia, Pa.). The Empire of Brazil at the Universal Exhibition of 1876 in Philadelphia $\underline{\text { Rio }}$ de Janeiro : Typ. e Lithographia do Imperial Instituto Artistico, 1876. Disponivel em https://archive.org/details/empireofbrazilat00comi Acesso em 18.02.2018. 
BRASIL. CONFERENCIAS effectuadas na Exposição Pedagogica. Carlos Leoncio de Carvalho, Antonio de Paula Freitas, Joaquim Abilio Borges, Barão de Macahubas. Rio de Janeiro: Typographia Nacional 1884, 210 p.

BRASIL. COLLECÇÃO DE LEIS DO IMPÉRIO DO BRAZIL DE 1879. Decreto n. 7217, 19 de abril de 1879. tomo XXVI, parte I, tomo XLII, parte II.

BRASIL. DECRETO No 667, DE 16 DE AGOSTO DE 1890. Disponível em http://www2.camara.leg.br/legin/fed/decret/1824-1899/decreto667-16-agosto-1890-552093-publicacaooriginal-69096-pe.html Acesso em 18.02.2018.

BRASIL. Exposição Universal de Antuérpia. Relatório apresentado a S. Ex. Sr. Conselheiro A. da Silva Prado. Ministro e Secretário de Estado dos Negócios da Agricultura, Comercio e Obras Publicas pelo Conde de Villeneuve. Ri o de Janeiro: Imprensa Nacional,1885.

BRASIL. GUIA para os visitantes da Exposição Pedagógica. Rio de Janeiro: Imprensa Oficial, 1883.

BRASIL. Ministério do Império. Ministro (Carlos Leôncio de Carvalho). Relatório do anno de 1877 apresentado à Assembleia Geral Legislativa na $1^{\text {a. }}$ Sessão da $17^{\text {a }}$. Legislatura. Publicado em 1878. Disponivel em http://brazil.crl.edu/bsd/bsd/u1744/000001.html Acesso em 30.10.2017.

BRASIL. Museu Imperial. Apresentação do Diário da Viagem de d. Pedro II aos Estados Unidos, s.p.

CHAMBRE DE COMMERCE. Journal des chambres de commerce ["puis" de commerce et d'industrie; de commerce françaises ; de commerce françaises et étrangères d'Europe] [s.n.?] (Paris): 1888-12, p. 383. Bibliothèque nationale de France, Paris. Disponivel em: http://gallica. bnf.fr/ark:/12148/bpt6k5761299g.r=bpt6k5761299g?rk=21459;2

Acessso em 30.10.2017.

COMITÉ FRANCE-AMERIQUE. Expo Inter de Art Decoratif, Paris, 1925. Exposition d'Art français de São Paulo avec le concurs du gouvernement de l'Etat de São Paulo et sous le patronage du gouvernement français. Catalogue des oeuvres exposées. Édite par le Comité France -Amerique. Paris: Comité France -Amerique, 1913, il., 98 p.

DELAGRAVE, Librairie Charles. Catalogue Spéciel de Mobilier, Matériel Scolaires et Accessoires de Classes. Paris, 1890. In [Mobilier scolaire. Matériel d'enseignement. Catalogues. Recueil.] 1879-1898. Bibliothèque nationale de France, Paris. Disponível em: ark:/12148/bpt6k5698630m Acesso em: 30.10.2017. 
Mobilier Scolaire et Matériel D'Enseignement. Systèmes et Modèles Brevetés (S.G.D.G.) Conformes aux Règlements et Programmes officiels . Écoles Maternelles, Enfantines, Primaires Écoles Primaires Supérieures et Écoles Normales Institutions, Collèges Lycées, Facultés, etc. Paris, 1892. In [Mobilier scolaire. Matériel d'enseignement. Catalogues. Recueil.] 1879-1898. Bibliothèque nationale de France, Paris. Disponível em: http://gallica.bnf.fr/ark:/12148/bpt6k5698628j Acesso em: 30.10.2017.

Catalogue de Livres de Fondes: Paris: Librairie Delagrave, 1898. Disponível em: http://hellanicus.lib.aegean.gr/handle/11610/16676 Acesso em 30.10.2017.

DORANGEON, C. Leçons de choses: d'après le musée industriel scolaire I de C. Dorangeon. Paris: Charles Delagrave, 1884. Disponível em http:// gallica.bnf.fr/ark:/12148/bpt6k5495534h Acesso em 24.02.2018.

Falla dirigida á Assembléa Legislativa Provincial de S. Paulo na abertura da 2.a sessão da 24.a legislatura em 10 de janeiro de 1883 pelo presidente, conselheiro Francisco de Carvalho Soares Brandão. S. Paulo, Typ. do Ypiranga, 1883.

International Music Score Library Project, verbete Weber, Carl Maria von.

LICEU DE ARTES E OFICIOS. Atas da Diretoria, 1893 a 1909, maço manuscrito

LICEU DE ARTES E OFICIOS. Escola Pratica de Artes e Ofícios. Programa e organização das classes profissionais e oficinas. São Paulo, MCMXXXIV, 14 p., impresso

LICEU DE ARTES E OFICIOS. Estatutos do Liceu de Artes e Ofícios, 1934, impresso.

LICEU DE ARTES E OFICIOS. Estatutos do Liceu de Artes e Ofícios, 1939, impresso.

LICEU DE ARTES E OFICIOS. Estatutos do Liceu de Artes e Ofícios, 1942, impresso.

LICEU DE ARTES E OFICIOS. Excerto do Regulamento Geral do Liceu de Artes e Ofícios e Regimento interno. Regime disciplinar. S.l.: Werner e Lima, 1948, 14p., impresso

LICEU DE ARTES E OFICIOS. Extrato e resumo do Catalogo Geral da Galeria de Arte, 1934, impresso.

LICEU DE ARTES E OFICIOS Instituto de Ensinos Profissionais, [1913]. 12 p., impresso 
LICEU DE ARTES E OFICIOS Regulamento das oficinas do Liceu de Artes e Ofícios, 1934, impresso

PÉCHEX, $\mathrm{H}$. Traité théorique et Pratique D'Éléctricité al 'usage des élèves des écoles nationales d'art et métiers, des candidats a l'École Supérieure D'Élétricité et à la licence (certificat de Physique Industrielle) par $H$. Péchex. Paris : Librairie Ch. Delagrave, 1904.

RIO DE JANEIRO. Exposição Pedagógica, 1883. Conferências effectuadas na exposição pedagógica. Rio de Janeiro: Imprensa Nacional, 1884.

SÃO PAULO. Relatório apresentado á Assembléa Legislativa Provincial de S. Paulo pelo Presidente da Provincia o Exm. Sr. Dr. João Theodoro Xavier em 5 de fevereiro de 1874. S. Paulo: Typographia Americana, 1874.

SÃO PAULO. Relatório com que o exm. monsenhor dr. Joaquim Manoel Gonçalves de Andrade 5o. Vice-presidente passou a administração da provincia de S. Paulo ao exm. sr. dr. Sebastião José Pereira presidente da mesma no dia 8 de junho de 1875. S. Paulo: Typographia do Diário, 1875.

SÃO PAULO. Relatório apresentado á Assembléa Legislativa Provincial de São Paulo pelo presidente da provincia, Barão do Parnahyba, no dia 17 de janeiro de 1887. São Paulo: Typ. a Vapor de Jorge Seckler \& Comp., 1887.

SÃO PAULO. Relatório apresentado á Assembléa Legislativa Provincial de São Paulo pelo presidente da provincia, dr. Pedro Vicente de Azevedo, no dia 11 de janeiro de 1889. São Paulo: Typ. a Vapor de Jorge Seckler \& Comp., 1889.

SÃO PAULO. Relatório sobre o Liceu de Artes e Ofícios apresentado ao Doutor Cezário Motta Junior pelo Doutor Domingos Jose Nogueira Jaguaribe, presidente em exercício, 1895, impresso

SEVERO, Ricardo. O Liceu de Artes e Ofícios de São Paulo. São Paulo: Liceu de Artes e Ofícios, 1934, 276 p.

SOUTH Kensington Museum. Catalogue of the Educational division of the South kensington Museum. London: G.E. Eyre and W. Spottiswoode, for H.M. Stationery Off., 1876. Disponível em https://archive.org/ details/catalogueeducat01musegoog Acesso em 16.02.2018.

UNION CENTRALE. Bulletin de l'Union centrale. Revue mensuelle des beaux-arts appliqués à l'industrie. Paris: Bureaux Administration et Ré daction.1874/08/01-1876/07/01. Disponivel em: Acessado em 30.10.2017. 


\section{Bibliografia}

100 anos da Pinacoteca: a formação de um acervo / curadoria Marcelo Mattos Araujo, Ana Paula Nascimento, Regina Teixeira de Barros; cronologia Marcia Camargos, Maria Luiza Moraes. São Paulo: FIESP: Pinacoteca do Estado, 2005, 136 p.

A PINACOTECA do Estado. Texto Carlos Alberto Cerqueira Lemos, Paulo Mendes da Rocha, Maria Cecília França Lourenço. São Paulo: Banco Safra, 1994. 319 p., il

ALCANTARA, Wiara. A transnacionalização de objetos escolares no fim do século XIX. An. mus. paul., São Paulo, v. 24, n. 2, p. 115-159, ago. 2016 . Disponível em $<$ http://www.scielo.br/scielo.php?script=sci_arttext\&pid $=S 0101-47142016000200115 \& \operatorname{lng}=\mathrm{pt} \& \mathrm{nrm}=\mathrm{iso}>$. Acesso em: 11 fev. 2018. http://dx.doi.org/10.1590/1982-02672016v24n0204

ALVES, Claudia. Santa-Anna Nery e a educação: um olhar brasileiro no estrangeiro (Brasil-França, século XIX)/ Claudia Alves, Diana Gonçalves Vidal, Elizabeth Figueiredo de Sá. Cuiabá : Edufmt, 2015, 101 p.

AMARAL, Aracy A. O mecenato em São Paulo de 1890 a 1920: Freitas Valle, o magnífico. In Arte e meio artístico: entre a feijoada e o x-burguer (1961-1981) / Aracy A. Amaral. São Paulo, SP: Nobel, 1982, p. 34-43.

AMARAL, Cláudio Silveira. A cidade como obra de arte. O Liceu de Artes e Ofícios do Rio de Janeiro, Rui Barbosa e John Ruskin. In Arquitextos, São Paulo, ano 09, n. 099.07, Vitruvius, ago. 2008 <http://www.vitruvius.com.br/revistas/read/arquitextos/09.099/122>.

John Ruskin e o Desenho no Brasil. São Paulo: Editora UNESP, 2011, $144 \mathrm{p}$.

Um projeto de industrialização para o Brasil a partir do ensino do desenho (o Liceu de Artes e Ofícios do Rio de Janeiro), Rui Barbosa e John Ruskin. In Revista Pós n. 19 (2006). Disponível em http://www.revistas.usp.br/posfau/search/search?simpleQuery=Silveira+Claudio\%5B\&searchField=query Acesso em 27.02.2018

ARGAN, Giulio Carlo. Arte moderna: do iluminismo aos movimentos contemporâneos. /Giulio Carlo Argan; tradução Denise Bottmann e Federico Carotti; prefácio Rodrigo Naves; projeto gráfico M.A.S. São Paulo: Companhia das Letras,1992, 709 p.

"O espaço visual da cidade". In História da Arte como História da cidade. São Paulo: Martins Fontes, 1993: 223-241. 
História da arte como história da cidade. São Paulo: Martins

Fontes, 2005.

- Projeto e destino/ Giulio Carlo Argan; tradução Marcos Bagno. São Paulo: Editora Ática 2000, 334 p.

ARRUDA, Maria Arminda do Nascimento. Metrópole e Cultura. São Paulo no meio do século XX. Bauru: EDUSC, 2001.

AUSLANDER, Leora. Taste and power, furnishing Modern France. Leora Auslander.

Berkeley University of California Press c1996. xv, 495 p. ; ill. : 24 cm

AVILA, Ana Carolina Xavier. A Gênese dos Museus Históricos e Pedagógicos do Estado de São Paulo. In Museus Históricos e Pedagógicos no século XXI: processo de musealização e novas perspectivas. Dissertação de Mestrado - Programa de Pós-Graduação Interunidades em Museologia/Universidade de São Paulo, 2014, p. 31-69.

AZEVEDO, Ricardo Marques de. Metrópole e Abstração. São Paulo: Editora Perspectiva, 2006.

Antigos modernos. Estudos das doutrinas arquitetônicas nos séculos XVII e XVIII. 1 $1^{\text {a }}$ edição. São Paulo: Faculdade de Arquitetura e Urbanismo da Universidade de São Paulo, 2009, 96 p.

BACHELARD. Gaston. La formation de l'esprit scientifique. Paris: Vrin, 2004, 301 p.

La poétique de l'espace. Paris: Les Presses universitaires de France, 3e édition, 1961, 215 pp. Première édition, 1957. Collection: Bibliothèque de philosophie contemporaine.

BANNATYNE, Mark W. McK. Current Trends in Technology Education and Vocational Training in the Former Republics of the Soviet Union, 1995. Paper presented at the Jerusalem International Technology Education Conference (2nd, Jerusalem, Israel, January 8-11, 1996), 34 p.

BARBOSA, Rui. Reforma do ensino primário e várias instituições complementares da instrução pública. Rio de Janeiro: Ministério da Educação e Saúde, 1947, vol. X, tomos I a IV.

O desenho e a arte industrial. Rio de Janeiro: Rodrigues \& Cia, 1949

BARBUY, Heloisa. A cidade-exposição comércio e cosmopolitismo em São Paulo, 1860-1914. Heloisa Barbuy; [prefácio de Benedito Lima de Toledo]. São Paulo: EDUSP, 2006, 303 p. 
A exposição universal de 1889: visão e representação na sociedade industrial / Heloisa Maria Silveira Barbuy. São Paulo: Fflch/ usp, 1995. 170p. Dissertacao de mestrado em historia social.

Comércio francês e cultura material em São Paulo na passagem do século XIX para o XX. In: Vidal, Laurent; Luca, Tânia Regina de. Franceses no Brasil, séculos XIX e XX. São Paulo: Editora UNESP, 2009, p. 193-208.

Dos gabinetes de curiosidades aos museus do século XIX. São Paulo : Via Lettera: Rio de Janeiro: MAST, 2008, p. 245-255.

O Brasil vai a Paris em 1889: um lugar na Exposição Universal. An. mus. paul., São Paulo, v. 4, n. 1, p. 211-261, 1996. Disponível em <http://www.scielo.br/scielo.php?script=sci_arttext\&pid $=$ S0101-47141996000100017\&lng $=$ pt\&nrm=iso $>$. Acesso em 15 fev. 2018. http://dx.doi.org/10.1590/S0101-47141996000100017

BARROS, A. P. O Liceu de Artes e Ofícios e seu fundador. Rio de Janeiro: Typographia do Liceu de Artes e Ofícios do Rio de Janeiro, 1956.

BASTOS, Maria Helena Camera Bastos. Journée d'études sur Ferdinand Buisson: Ferdinand Buisson au Bresil. Pistes. vestiges et signaux de ses idées pédagogiques (1870-1900). Service d'histoire de l' éducation. INRP. Paris/França. 30 de maio de 2000.

Leituras da Ilustração Brasileira: Célestin Hippeau (18031883). In revista brasileira de história da educação n³ jan./jun. 2002,p. 67-112. Disponível em http://www.rbhe.sbhe.org.br/index.php/rbhe/ article/view/258 Acesso em 23.02.2018.

Método intuitivo e lições de coisas por Ferdinand Buisson. Hist. Educ., Santa Maria, v. 17, n. 39, p. 231-253, Apr. 2013. Available from <http://www.scielo.br/scielo.php?script=sci_arttext\&pid=S223634592013000100013\&lng=en\&nrm=iso > Acesso em: 11 Feb. 2018. http:// dx.doi.org/10.1590/S2236-34592013000100013

BELlUZZO, Ana Maria de Moraes. Artesanato, Arte e Indústria. Tese (Doutorado em Arquitetura e Urbanismo) Universidade de São Paulo, São Paulo, 1988.

BENJAMIN, Walter. "A obra de arte na época de sua reprodutibilidade técnica". In Magia e técnica, arte e política: ensaios sobre literatura e história da cultura. São Paulo: Brasiliense, 1994.

BENJAMIN, Walter. The Work of Art in the Age of Mechanical Reproduction. In Benjamin, Walter. lluminations, edited by Hannah Arendt, translated by Harry Zohn, from the 1935 essay. New York: Schocken Books, 1969, 278 p. 
BENNETT, Charles Alpheus. História da educação em artes manuais e industriais - 1870 a 1917. Charles Alpheus Bennett; tradução Paulo Sérgio Bonagura. São Paulo: SENAI, 2015, 598 p.

BENNET, Tony. “The Exhibitionary Complex". In Culture, Power, History, ed. N. Dirks, G. Eley, and S. Ortner. Princeton: Princeton University Press, 1994, 123p.

BENTON, Tim. Form and function, a source book for the History of architecture and design 1890-1939, edited by Tim and Charlotte Benton, with Dennis Sharp. London : Crosby Lockwood Staples 1975. xxiii, 252 p., [6] leaves of plates. ; ill. : 26

BLAKE, Augusto Victorino Alves Sacramento. Diccionario bibliographico brazileiro pelo doutor Augusto Victorino Alves Sacramento Blake. Rio de Janeiro: Typographia Nacional, 1883, 7 v. Disponível em http://bd. camara.gov.br/bd/handle/bdcamara/14856 Acesso em 16.02.2018

BODEI, Remo. Geometry of the Passions: Fear, Hope, And Happiness: Philosophy and Political Use. Translated by Gianpiero W. Doebler. Toronto: University of Toronto Press, 2018, 520 p.

BOURDIEU, Pierre. Distinction. A Social Critique of the Judgement of Taste. Trasl. By Richard Nice. Cambridge: Harvard University Press, 1994, $613 \mathrm{p}$.

BRADLEY. F. H. Appearance and reality. A Metaphysical Essay. Second Edition (Revised), with an Appendix, LONDON: GEORGE ALLEN \& UNWIN LTD., 1897

BRESCIANI, Maria Stella. Londres e Paris no Século XIX: o Espetáculo da Pobreza; São Paulo: Brasiliense, 1982, 127 p.

BUENO, Beatriz Piccolotto Siqueira. Arqueologia da paisagem urbana: lógicas, ritmos e atores na construção do centro histórico de São Paulo (1809-1942). Rev. Inst. Estud. Bras., São Paulo, n. 64, p. 99-130, Aug. 2016. Available from <http://www.scielo.br/scielo.php?script=sci_ arttext\&pid=S0020-38742016000200099\&lng $=$ en\&nrm $=$ iso $>. \quad$ ac cess on 18 Feb. 2018. http://dx.doi.org/10.11606/isnn.2316-901X. voi64p99-130

Desenho e Desígnio. O Brasil dos Engenheiros Militares (15001822). São Paulo: Edusp, 2010.

Escritório Ramos de Azevedo. Arquitetura e a Cidade. (Catálogo exposição). São Paulo, 2015.

BUISSON, Ferdinand Edouard. Nouveau dictionnaire de pedagogie et d'instruction primaire./ Ferdinand Edouard Buisson. Paris: Hachette, 1911. 
BUISSON, Nathalie. Le cour de Voltaire: un secret bien gardé. In Actualités de la conservation [en ligne], n³2, 2012, 7 p. Disponível em http://www. bnf.fr/documents/lettre cons 32 art2.pdf Acesso em 15.02.2018

BURKE, Peter. BURKE, Peter. Hibridismo Cultural. São Leopoldo: Ed. Unisinos, 2006 p. 39-54.

CABRERA, Leoncio López-Ocón . "La exhibición del poder de la ciencia. La América Latina en el escenario de las exposiciones universales del siglo XIX”. In O mundo ibero-americano nas grandes exposições. ed. José Augusto Mourao, Ana Maria Cardoso de Matos, and Maria Estela Guedes. Lisboa: Vega Ed., 1998, p. 67-90.

CACCIARI, Massimo. A Cidade. São Paulo: Gustavo Gili, 2010, 80 p.

. Dialética de lo negativo en las épocas de la metropoli. In TAFURI, Manfredo et alii. De Ia Vanguardia a Ia Metropoli: Crítica Radical a Ia Arquitectura, Barcelona: Gustavo Gili, 1972 (Arquitectura y Crítica).

Metropolis. In TAFURI, Manfredo et alii. De Ia Vanguardia a Ia Metropoli: Crítica Radical a Ia Arquitectura, Barcelona: Gustavo Gili, 1972 (Arquitectura y Crítica).

CALKINS, Norman A. Primary object lessons, for training the senses and developing the faculties of children. 18th ed.New York: Harper \& Brother, 1875,xiv, [15]-442 p.

Primeiras lições de coisas, manual de ensino elementar para uso dos paes e professores. Tradução de Rui Barbosa. Obras Completas, v. XIII, tomo 1, Rio de Janeiro, 1950. 573 p.

CANDIÁ, Maria Aparecida. Maçonaria e Educação Popular. Espaços de Circulação do ideário educacional maçônico (1870-1889). Universidade Federal Fluminense, s.d.

CARAMORI, Leonardo Capelossi. A biblioteca da Escola Politécnica de São Paulo e seus acervos de engenharia civil e arquitetura entre $1894 e$ 1928. São Paulo: FFLCH/USP 2015, 297 p. (Tese).

CARVALHO, Carlos Leôncio de. Primeira exposição pedagogica do Rio de Janeiro: Relatorio. Rio de janeiro: Typographia Nacional, 1884.

CARVAlho, Maria Cristina Wolff de. Ramos de Azevedo. São Paulo: EDUSP, 2000.

CARVALHO, Marta Maria Chagas de. "School and Modernity Representations as Pedagogical Models: A Study on their Circulation and Uses in Brazil (1889-1940)" In Paedagogica Historica, 41, no. 1 (2005), p. 259. 
CARULA, Karoline. A tribuna da ciência. As conferencias populares da Gloria e as discussões do darwinismo a imprensa carioca (1873-1880). São Paulo: Annablume, 2009, p. 27-77.

CASSIN, Barbara, ed. Vocabulaire européen des philosophies: dictionnaire des intraduisibles sous la direction de Barbara Cassin. Paris Le Robert c2004 Seuil. xxiv, 1531 p.,27 cm

CASSIRER, Ernst. The philosophy of the Enlightenment. Ernst Cassirer; translated by Fritz C.A. Koelln and James P. Pettegrove; with a new foreword by Peter Gay. Princeton: Princeton University Press 2009, xviii, $366 \mathrm{p}$.

CASTRO, César Castro, ed., Cultura material escolar: a escola e seus artefatos (MA, SP, PR, SC e RS, 1870-1925). São Luis: EDUFMA, Café \& Lápis, 2011, 153p.

CERTEAU, Michel de. A invenção do cotidiano 1: artes de fazer. Michel de Certeau; nova edição, estabelecida e apresentada por Luce Giard; tradução Ephraim Ferreira Alves. Petrópolis: Vozes 2012, 316 p.

CHARTIER, Roger. A história Cultural: entre práticas e representações. Lisboa: Difel, s/d| Roger Chartier, Lydia G. Cochrane. Cultural History: Between Practices and Representations. Cornell University Press, 1988.

CIÊNCIA, história e historiografia / [Marta de Almeida, Moema de Rezende Vergara, organizadoras]. São Paulo, Rio de Janeiro: Via Lettera: Museu de Astronomia e Ciências Afins, 2008. 397 p. ; ill. : 23 cm.

COLLICHIO, Terezinha Alves F. Dois eventos importantes para a História da Educação Brasileira: a Exposição Pedagógica de 1883 e as Conferências Populares da Freguesia da Glória. Revista da Faculdade de Educação, vol. 13, nr. 2, jul. dez. 1987, p. 5-14.

Primeira Exposição Pedagógica realizada no Rio de Janeiro em 1883 e um importante Congresso da Instrução cancelado. Resultados de uma pesquisa. Cadernos de História \& Filosofia da Educação, vol. 4, nr. 6, 2001, p. 149-194.

COSTA, Cacilda Teixeira da. O sonho e a técnica: a arquitetura de ferro no Brasil / Cacilda Teixeira da Costa. 2a. ed, São Paulo, SP : Edusp, 2001.

CUNHA, Luiz Antônio. Aspectos sociais da aprendizagem de ofícios manufatureiros no Brasil colônia. Fórum Educacional. Rio de Janeiro, v. 2, n. 4, out./dez. (1978)

. As raízes das escolas de ofícios manufatureiros no Brasil 1808/1820. Fórum Educacional. Rio de Janeiro, ano 3, n. 2, abr./jun. 1979 
As escolas de aprendizes artífices e a produção manufatureira. Revista da Faculdade de Educação da UFF. Niterói, ano 10, n. 1-2, jan./dez. 1983

O ensino industrial - manufatureiro no Brasil: origem e desenvolvimento. Faculdade Latino-americana de Ciências Sociais - FLACSO. Disponível em: [http://www.flacso.org.br/data/ biblioteca/392.pdf] Acesso em Agosto 2006

DEAECTO, Marisa Midori. Anatole Louis Garraux e o comércio da livraria francesa em São Paulo (1860- 1890). V Encontro dos Núcleos de Pesquisa da Intercom. Sociedade Brasileira de Estudos Interdisciplinares da Comunicação. XXVIII Congresso Brasileiro de Ciências da Comunicação. Universidade Estadual do Rio de Janeiro, 2005 Disponível em http://www.intercom.org.br/papers/ nacionais/2005/resumos/R0168-1.pdf Acesso em 05.02.2018

D'ANGELO Márcia. Caminhos para o advento da Escola de aprendizes artífices de São Paulo (1910-1930): um projeto das elites para uma sociedade assalariada / Márcia D’Angelo; orientador Benedicto. Dissertação (Mestrado)-- Faculdade de Filosofia e Ciências Humanas da Universid ade de São Paulo. São Paulo : s.n., 2000, 350 p.

D'ELBOUX, José Roberto. Tipografia como elemento arquitetônico no Art Déco paulistano: uma investigação acerca do papel da tipografia como elemento ornamental e comunicativo na arquitetura da cidade de São Paulo entre os anos de 1928 a 1954. Dissertação de Mestrado. FAUUSP. São Paulo, 2013.

DELLA VOS, Victor. Description of the Collections of Scientific Appliances Instituted for the Study of Mechanical Art in the workshops pf the Imperial Technical School of Moscow. Moscow: W. Gautier, 1876.

DESVALLÉES, André; MAIRESSE, François (Eds.). Conceitos-chave de museologia. Tradução e comentários de Bruno Brulon Soares e Marília Xavier Cury. São Paulo: Comitê Brasileiro do Conselho Internacional de Museus; Pinacoteca do Estado de São Paulo; Secretaria de Estado da Cultura, 2013, p. 32. Disponível em: http://www.icom.org.br/wpcontent/uploads/2014/03/PDF Conceitos-Chave-de-Museologia.pdf Acesso em 03.01.2018

DEWEY, John. Arte como experiência. John Dewey; organização Jo Ann Boydston ; editora de texto Harriet Furst Simon ; introdução Abraham Kaplan ; tradução Vera Ribeiro. São Paulo: Martins Fontes, 2012, 646 p.

DURAND, José Carlos Garcia. Arte, privilégio e distinção: artes plásticas, arquitetura e classe dirigente no Brasil, 1855/1985. José Carlos Durand. São Paulo: Perspectiva 2009, 1989 xxv, 307 p. 
DUSSEL, Ines. 'Between Exoticism and universalism: Educational sections in Latin American participation at international Exhibitions, 1860-1900', Pedagogica Historica 47, no. 5, 2011, p. 601-617.

EPRON, Jean Pierre. Comprendre l`éclectisme / par Jean-Pierre Epron; Institut français d'architecture. Paris: Norma, 1997, 357 p.: ill.

FERRO, Sérgio. O Canteiro e o Desenho. São Paulo: Projeto Editores Associados: Instituto de Arquitetos do Brasil, 1979, 112 p.

FIGUEIREDO, B. G. (Org.); VIDAL, Diana Gonçalves (Org.). Museus: dos Gabinetes de Curiosidades à Museologia Moderna. 2a. ed. Belo Horizonte: Fino Traço, 2013. v. 1.250p

FINDLEN, Paula. Possessing Nature: Museums, Collecting, and Scientific Culture in Early Modern Italy. Berkeley, Ca.: University of California Press, 1994.

FICHER, Sylvia. Os Arquitetos da Poli. Ensino e Profissão em São Paulo. São Paulo: Edusp, 2005, 416 p..

FORTUNÉ, Isabelle. Man Ray et les objets mathématiques. In Études photographiques, 6 | Mai 1999, Disponível em http://journals.openedition.org/etudesphotographiques/190. Acesso em 24 fev 2018.

FOSTER, Hal. Design and Crime. New York: Verso, 2002.

The archive without museum. OCTOBER 77, Summer 1996, p. 97-119.

FRAGOSO, João Luís Ribeiro. Homens de Grossa Aventura. Acumulação e hierarquia na praça mercantil do Rio de Janeiro (1790-1830). 2a ed. Rio de Janeiro: Civilização Brasileira, 1998.

FRAMPTON, Kenneth. História Crítica de la Arquitectura moderna. Barcelona/Madrid/Buenos Aires, Gustavo Gilli, 1991.

FRANK, Isabelle (org). The theory of decorative art : an anthology of European \& American writings, 1750-1940 / edited by Isabelle Frank; with translations by David Britt. New Haven, Conn. : Published for The Bard Graduate Center for Studies in the Decorative Ars, New York, by Yale Univ., c2000.

FURTADO. Janaína Lacerda. Um museu desaparecido do século XIX: uma discussão acerca do Museu Agrícola e Industrial do Jardim Botânico do Rio de Janeiro (1871-1886). In Revista do Arquivo Nacional, v. 26, n. 2 jul-dez, 2013, p. 146-159. Disponivel em http://revista.arquivonacional.gov.br/index.php/revistaacervo/article/view/521 Acesso em: 18.02 .2018 
GARRAUX, Anatole Louis. Bibliographie brésilienne: catalogue des ouvrages français \& latins relatifs au Brésil 1500-1898 / A. L. Garraux. Paris: Ch. Chadenat /Jablonski, Vogt et Cie., 1898. Disponivel em ark:/12148/ bpt6k57240437 Acesso em 16.02.2018

GEBAUER, Gunter. Mimesis: culture, art, society/ Gunter Gebauer, Christoph Wulf; translated by Don Reneau. Berkeley: University of California Press, c1995, 400 p.

GEORGEL, Chantal (org.). La jeunesse des musées: les musees de France au XIXe siecle . Paris, Musee d'Orsay, 7 fevrier- 8 mai 1994 / sous la direction de Chantal Georgel. Paris : Musee d'Orsay : Reunion des musees nationaux, c1994, 403p. : il.

GIEDION, Siegfried. Espaço, tempo e arquitetura: o desenvolvimento de uma nova tradição. Sigfried Giedion; tradução de Alvamar Lamparelli ; revisão técnica e da tradução Ana Luiza Nobre e Denise Chini Solot. São Paulo: Martins Fontes 2004, xxviii, 949 p.

Mechanization Takes Command. A Contribution to Anonymous History. Univ Of Minnesota Press; 1 edition (March 1, 2014), $608 \mathrm{p}$.

GINZBURG, Carlo. Mitos, emblemas, sinais : morfologia e historia / Carlo Ginzburg ; tradução: Federico Carotti. São Paulo, SP : Companhia das Letras, 1989, $281 \mathrm{p}$.

GITAHY, Leda. A New Paradigm of Industrial Organization. The Diffusion of Technological and Managerial Innovations in the Brazilian Industry. Uppsala, Uppsala University, 2000.

GITAHY, Maria Lúcia C. "Qualificação e Urbanização em São Paulo: A experiência do Liceu de Artes e Ofícios (1873-1934)" In Ribeiro, Maria Alice Rosa (org). Trabalhadores Urbanos e Ensino Profissional. Campinas, Ed. UNICAMP, 1986.

"Os trabalhadores da construção civil na belle époque, 1889-1914". In Anais do II Congresso Brasileiro de História Econômica, vol. II, 1997:118-132.

GREENBERG, Clement. Estética doméstica: observações sobre a arte e o gosto/ Clement Greenberg ; tradução André Carone. São Paulo Cosac \& Naify 2013, 410 p.

GOMBRICH, Ernst Hans. Meditações sobre um cavalinho de pau e outros ensaios sobre a teoria da arte/ Ernst Hans Gombrich; tradução de Geraldo Gerson de Souza. São Paulo EDUSP 1999, x, 182p.. ; il. : 25 cm 
GORELIK, Adrián. Das Vanguardas a Brasília. Cultura urbana e Arquitetura na América Latina. Belo Horizonte: Editora UFMG, 2005.

GROLA, Diego Amorim. Coleções de história natural no Museu Paulista, 1894-1916. São Paulo, 2014. 190 p. +apêndices. Dissertação (Mestrado).

Carvalho, Paula Carolina de Andrade; Barbuy, Heloisa. Nuttruring collection and the trade in objects: the formation of the Museu Paulista, 1850s-1910s. London: Taylor \& Francis, 2016, p. 93107. In: Museum History Journal, London, v. 9, n. 1, p. 93-107, jan. 2016, ISSN: 1936-9816

GROSVENOR, Ian. "Pleasing the Eye and at the Same Time Useful in Purpose': A Historical Exploration of Educational Exhibitions". In Materialities of Schooling. Design, Technology, Objects, Routines, ed. Martin Lawn and Ian Grosvenor. Oxford: Symposium Books, 2005, p. $163-176$

. MACNAB, Natasha. 'Seeing through touch': the material world of visually impaired children. Educ. rev., Curitiba, n. 49, p. 39-57, Sept. 2013. Available from $<$ http://www.scielo.br/scielo.php?script=sci_arttext $\&$ pid $=$ S0104 $=40602013000300004-\& \operatorname{lng}=$ en $\& n r m-$ iso >. http://dx.doi.org/10.1590/S0104-40602013000300004 Acesso em 15.02.2018.

GUILLEMOTEAU, René. Du Musée pédagogique à l'Institut pédagogique national : 1879-1956, Paris, CNDP [Centre national de documentation pédagogique], 1979. n: Histoire de l'éducation, nº 5, 1979. p. 44

HARVEY, D. ACondição Pós-Moderna. Uma pesquisa sobre as origens da mudança cultural. São Paulo, Loyola, 1992, cap.7, 8 e 9, p.117-162.

HEIDEGGER, Martin. The Basic Problems of Phenomenology. Translation, Introduction and Lexicon by. Albert Hofstadter Bloomington: Indiana University Press.

HOBSBAWN, Eric J. A invenção das tradições. Eric Hobsbawn com Terence Ranger, organização, tradução Celina Cardim Cavalcanti. São Paulo: Paz e Terra 2012,395 p.

"Uma Economia Mudando de Marcha". In A Era dos Impérios. Rio de Janeiro:Paz e Terra, 1988.

. Mundos do Trabalho. Rio de Janeiro: Paz e Terra, 1984, p.349-377.

KANDINSKY, Wassili. Do espiritual na arte e na pintura em particular. Wassily Kandinsky; tradução Álvaro Cabral, Antonio de Pádua Danesi. 2a. Ed. São Paulo: Martins Fontes 2009, 1996,284 p. 
KAHN, Pierre. Lições de coisas e ensino das ciências na França no fim do século 19: contribuição a uma história da cultura. História da Educação, Porto Alegre, v. 18, n. 43, p. 183-201, maio/ago. 2014.

KAUFMANN, Emil. De Ledoux a Le Corbusier: Origen y Desarollo de Ia Arquitectura Autónoma; Barcelona: Gustavo Gili, 1982 (Punto y Línea).

KUHLMANN JUNIOR, Moyses. As grandes festas didáticas: a educação brasileira e as exposições internacionais (1862-1922). Bragança Paulista: São Francisco, 2001, 262 p.

LAWN, Martin. Sites of the future: comparing and ordering new education actualities. In: LAWN, Martin (ed.). Modelling the Future: exhibitions and the materiality of education. London: Symposium books, 2009, p. 15-30.

\& GROSVENOR, I. (2005). Materiality of Schooling. London: Symposium Books. Lawn, M [Ed] (2008). Modelling the Future - Changing Education through World Exhibitions. Oxford: Symposium Books, 2009.

Disponível em https://books.google.com.br/books?id=UUhwCQAAQBAI\&pg=PA153\&lpg=PA153\&dq=Modelling+the+Future+\%E2\%80\%93+Changing+Education+through+World+Exhibitions. \&source=bl\&ots=qUKvjg88qv\&sig=vtbmBXu8Lv2biZJksUWGfWfm aM\&hl=en\&$\underline{\mathrm{sa}=X \& v e d=0 \mathrm{ahUKEwj0} \text { ues1cbZAhUB7FMKHQZ4CVAQ6AEIODA- }}$

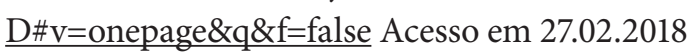

LE CORBUSIER. A Arquitetura e as Belas Artes. In Revista do Patrimônio Histórico e Artístico Nacional n.19, 1984.

A Arte decorativa. São Paulo: Martins Fontes, 1996.

LEAL, Maria das Graças de Andrade. A Arte de ter um ofício (18721996): Liceu de Artes e Ofício da Bahia. Salvador: Liceu de Artes e Ofícios da Bahia, 1996. 402 p., il.

LEMOS, Carlos Alberto Cerqueira. Alvenaria burguesa. São Paulo: Studio Nobel, 1989, 206 p.

LEROI-GOURHAN, Andre. Evolução e técnicas: o homem e a matéria I Andre Leroi-Gourhan. Lisboa : Perspectivas do Homem, 1986, 239 p. ( Perspectivas do Homem ; 22)

Le geste et la parolel André Leroi-Gourhan. Paris: Albin Michel 1965-.v. - ill., 285 p.

LICEU de Artes e Ofícios de São Paulo: missão excelência. Coordenação Margarida Cintra Gordinho; Marília Fontana Garcia; projeto gráfico Sylvia Monteiro. São Paulo: Marca d’Água, 2000, 119p. 
LIMA, Solange Ferraz de. Les ornements dans l'architecturecomment préserver la mémoire du travail des artisans et des artistes. Paris: TICCIH Koinetwork geie, 2012, p. 38-46.

. Ornamento e cidade: ferro, estuque e pintura mural em São Paulo (1870-1930). São Paulo 2001. 136 p. +anexos. Tese (Doutorado)

. São Paulo: os estrangeiros e a construção da cidade [banco de dados]. São Paulo: FAU/USP; MP/USP; FFLCH/USP; IAU/USP 2011.

O trânsito dos ornatos: modelos ornamentais da Europa para o Brasil, seus usos (e abusos?). Anais do Museu Paulista: História e Cultura Material, 16 (1), 2008, 151- 199. https://dx.doi.org/10.1590/ $\underline{\text { S0101-47142008000100005 }}$

LOOS, Adolf. Ornamento y Delito y Otros Escritos. Barcelona, Gustavo Gili, 1972, 276 p.

LOPES, João Marcos; LIRA, José (orgs). Memória, Trabalho e Arquitetura. São Paulo: Edusp, 2013, 368 p.

LOPES, Maria Margaret. O Brasil descobre a pesquisa científica: os museus e as ciências naturais no século XIX. São Paulo: Hucitec, 1997. 369 p.

LOURENÇO, Maria Cecília F. Operários da Modernidade. São Paulo, EDUSP/HUCITEC, 1995, $322 \mathrm{p}$.

LUNDAHL, Christian. The Swedish Schoolhouse at the Centennial exposition in Philadelphia 1876 - World's Fairs and innovation in Policy and practice. Paper presented at AERA 2014, Philadelphia. Disponível em http://www.skoloverstyrelsen.se/wp-content/uploads/2014/03/ssh paper-aera final.pdf Acesso em 27.02.2018

MAJAULT, Joseph. Le Musée Pédagogique: origines et foundation (18721979). Paris: CNDP, 1979.

MANTOUX, P. “Introdução”. In A Revolução Industrial no século XVIII. São Paulo: Martins Fontes, 1980.

MARCOVITCH, Jacques. Pioneiros e Empreendedores: a saga do desenvolvimento no Brasil, v.1/ Jacques Marcovitch. - 2.ed. rev. São Paulo: Editora da Universidade de São Paulo: Editorsa Saraiva, 2006, 321 p.

MARGLIN, S. “Origens e funções do parcelamento das tarefas." In Gorz, A. (org.) Crítica da Divisão do Trabalho. São Paulo: Martins Fontes, 1980

MARX, Karl. O Capital. Rio de Janeiro: Civilização Brasileira, 1971,579 p. 
MATOS, Ana Maria Cardoso de . Sociedades e associações industriais oitocentistas: projectos e acções de divulgação técnica e incentivos à actividade empresarial. In Análise Social, vol. xxxi (136-137), 1996 (2.3. $)$, 397-412.

MAXWELL, Nicholas. "Karl Popper and the Enlightenment Programme." In Karl Popper, Science and Enlightenment. London: UCL Press, 2017, 291-326, Disponível em http://www.jstor.org/stable/j.cttlvxm8p6.15 Acesso em 18.02.2018

MERLEAU-PONTY, Maurice. L'oeil et l'esprit. Paris: Gallimard, 1995, 108 p. O visivel e o invisível. M. Merleau-Ponty ; tradução de José Artur Gianotti, Armando Mora d'Oliveira ; revisão de Pérola de Carvalho, Luiz Henrique Lopes dos Santos e Ricardo Terra. São Paulo: Perspectiva. 2014, 271 p.

MISAN, Simona. A implantação dos museus históricos e pedagógicos do estado de São Paulo (1956- 1973). São Paulo, 2005, 274 p. Tese (Doutorado). Faculdade de Letras e ciências Humanas da Universidade de São Paulo, 2005.

MOACYR, Primitivo. A instrução e a república. Vol. I. Reformas Benjamin Constant (1890-1892). Rio de Janeiro: Imprensa Nacional, 1941.

MONTAIGNE, Michel de. Da educação das crianças. Os Ensaios: livro I/ Michel de Montaigne; tradução Rosemary Costhek Abílio. 2a ${ }^{\text {a }}$ Ed. São Paulo: Martins Fontes, 2002, p. 217-265.

MONTEIRO, Ana Carla de Castro Alves. Hotéis da Metrópole. O contexto histórico e urbano da cidade de São Paulo através da produção arquitetônica hoteleira ( 1940-1960). Dissertação de mestrado. Universidade de São Paulo. Faculdade de Arquitetura e Urbanismo da Universidade de São Paulo. São Paulo: 2006, 250 p.: il.

MONTOIA, Ana. "O ideal de cidade: a reforma dos costumes e a gênese do cidadão em São Paulo no século XIX”. In, PORTA, Paula (org.) História da Cidade de São Paulo, v. 2: a cidade no Império. São Paulo: Paz e Terra, 2004: 153-185.

MOTTA, Flávio. Contribuição ao estudo do Art Nouveau no Brasil. São Paulo, 1957, $83 \mathrm{p}$.

NASCIMENTO, Ana Paula. 1913 - A Exposição de Arte Francesa no Liceu de Artes e Ofícios de São Paulo: o que fazer com o que restou? Anais Comunicações Colóquio Histórias da Arte em Exposições. Campinas: Unicamp, 2014.0000000 
NEVES, Margarida de Souza. Vitrines do progresso: o conceito de trabalho na sociedade brasileira na passagem do seculo xix ao seculo xx: a formacao do mercadodetrabalhonacidadedoriodejaneiro/MargaridadeSouzaNeves. Rio de Janeiro : S N, 1986.

NOZOE, Nelson. Vida econômica e finanças municipais da capital paulista na época imperial. In História da Cidade de São Paulo, v. 2: a cidade do Império/organização Paula Porta. São Paulo: Paz e Terra, 2004, p.101-112

PAIM, Gilberto. A beleza sob suspeita: o ornamento em Ruskin, Lloyd Wright, Loss, Le Corbusier e outros/Gilberto Paim. Rio de Janeiro: Jorge Zahar 2000. 147 p.

PALLAT, Ludwig. Le Musée et l'Ecole. In Mouseion, nº 9, décembre 1929, p. $236-243$

PEDAGOGIUM: símbolo da modernidade educacional republicanal. Organizadora Ana Chrystina Venancio Mignot. Rio de Janeiro: Quartet: Faperj, 2013, 368 p.

PEDROSA, Mário. Modulações entre a sensação e a ideia. In Arantes, Otília Beatriz Fiori. Modernidade cá e lá: textos escolhidos IV. São Paulo: EDUSP, 2000, p. 123-129.

PERROT, Michelle. Os Excluídos da História. Rio de Janeiro: Paz e Terra, $1988,332 \mathrm{p}$.

PEVSNER, Nikolaus. Os Pioneiros do Desenho Moderno. Lisboa - Editora Ulisséia, 1975, $235 \mathrm{p}$.

PICON, Antoine. Architectes et ingénieurs au siècle des Lumières/Antoine Picon. Marseille: Parenthèses, c1988, 317 p.

POSSAMAI, Zita. Exposição, Coleção, Museu Escolar: ideias preliminares de um museu imaginado ${ }^{\text {.In }}$ Educar em Revista, Curitiba, Brasil, n. 58, p. 103-119, out./dez. 2015, p. 107.

"Lição de Coisas" no museu: o método intuitivo e o Museu do Estado do Rio Grande do Sul, Brasil, nas primeiras décadas do século XX. Arquivos Analíticos de Políticas Educativas, v. 20, n. 43, 2012.

POULOT, Dominique. Une histoire des musées de France, XVIII-XX siècles. Paris: La

Decouverte, coll. « L'espace de l'Histoire », 2005, 198 p

READ, Herbert. Art and Industry. The Principles of Industrial Design. New York: Harcourt, Brace and Company, 1935, 143p. 
REIS, Nestor Goulart. 100_anos_de_ensino_de_arquitetura_e urbanismo_em_São_Paulo: catálogo da exposição, realizada no Museu da Casa Brasileira, Secretaria de Estado da Cultura, setembro de 1996 / [coordenador, Nestor Goulart Reis]. [São Paulo, Brazil] : Comissão de Cultura e Extensão Universitária, Faculdade de Arquitetura e Urbanismo, Univ ersidade de São Paulo, [1996]. 97 p.

RENÉ-BAZIN, P. Musée pédagogique Répertoire numérique détaillé (AJ/71/1-AJ/71/90) Par P. René-Bazin . Archives nationales (France) Pierrefitte-sur-Seine 1983. Disponível em https://www.siv.archivesnationales.culture.gouv.fr/siv/rechercheconsultation/consultation/ir/ pdfIR.action?irId=FRAN IR 000897 Acesso em 27.02.2018

RIBEIRO, Maria Alice Rosa. Trabalhadores urbanos e ensino profissional / Maria Alice Rosa Ribeiro (coord.), Coraly Gará Caetano, Maria Lucia Caira Gitahy. Campinas : Editora da UNICAMP, 1986, 308 p.

ROUSSEAU, Jean-Jacques. Discurso Sobre as Ciências e as Artes, 2a ed. - São Paulo: Abril Cultural, 1978 (Os Pensadores).

SALGUEIRO. Heliana Angotti. La casaque d'Arlequin: Belo Horizonte, une capitale éclectique au $19^{\text {eme }}$ siècle; préf. de François Loyer. Paris: Éd. De l'École des Hautes Études en Sciences Sociales, 1997- XIV- 474p. (Civilisations et sociétés).

SAINT-JEAN. Ximena Gallardo. Museo de Copias. El principio imitativo como proyecto modernizador. Chile, siglo XIX y XX. Serie Documentos para la comprensión de la historia del arte en Chile. Santiago de Chile: Ediciones Universidad Alberto Hurtado, 2015, 136 págs.

SANTA-ANNA NERY, Frederico José de. Aux États-Unis du Brésil; voyages de M. T. Durand ... par M. F.-J. de Santa-Anna Néry. Paris: C. Delagrave [1890?], viii, $340 \mathrm{p}$.

. et alii. Instruction Public. In Le Brésil en 1889: avec une carte de l'empire en chromolithographie. [S.1.]: Delagrave. 1889. Disponível em http://www.manioc.org/patrimon/HASH010d08988893e8073dlea073 Acesso em: 20.10.2017

A instrução pública no Brasil. In: ALVES, Claudia; VIDAL, Diana Gonçalves; SÀ, Elizabeth Figueiredo de. (Org.) Santa-Ana Nery e a educação: um olhar brasileiro no estrangeiro. (Brasil-França, século XIX. Cuiabá: EdUFMT, 2014, p. 61-77.

SAVIANI, Demerval Saviani. História das idéias pedagógicas no Brasil. Campinas: Autores Associados, 2007. 473p. 
SCHWARTZMAN, Simon. Um espaço para a ciência: A formação da comunidade científica no Brasil. (2a edição brasileira, revista) Brasília: Ministério de Ciência e Tecnologia, 2001

SCHWARTZ, JOAN M. and COOK, TERRY. Archives, Records, and Power: The Making of Modern Memory. Archival Science 2: 1 - 19, 2002. Kluwer Academic Publishers. Netherlands.

SCHELBAUER, Analete Regina. A constituição do método de ensino intuitivo na Província de São Paulo (1870-1889). Tese (Doutorado). Faculdade de Educação da Universidade de São Paulo, 2003, 350 p.

. Em exposição as coleções de objetos para o ensino intuitivo: a Exposição Pedagógica do Rio de Janeiro. In: V Congresso Brasileiro de História da Educação, 2008, Aracajú. Anais do V Congresso Brasileiro de História da Educação. O ensino e a pesquisa em História da Educação. Aracajú: SBHE, UFS, UNIT, 2008. p. 1-13.

. Araújo, José Carlos de Souza (Org.). História da Educação pela Imprensa. 1. ed. Campinas: Editora Alínea, 2007. v. 1. 268p.

O método intuitivo e lições de coisas no Brasil do século XIX. In: Maria Stephanou; Maria Helena Camara Bastos. (Org.). Histórias e Memórias da Educação no Brasil. 3ed.Petrópolis-RJ: Editora Vozes, 2010, v. 2, p. 132-149.

SCHORSKE, Carl. Pensando com a História. Indagações na passagem para o modernismo. São Paulo: Companhia das Letras, 2000, 282 p.

SENECA, Lucius Annaeus. Lucilium epistulae Morales. Cambridge: Harvard University Press, 1917-1925 . Disponível em https://archive. org/details/adluciliumepistu01sene/page/n9

SENNETT, Richard. O Artífice. Tradução de Clóvis Marques. 2a. edição. Rio de Janeiro: Editora Record, 2009, p.319-328.

SILVA, Joana Mello de Carvalho e. Ricardo Severo da Lusitânia ao Piratininga. Da arqueologia portuguesa à arquitectura brasileira. Porto: Dafne Editora, 2007, 247 p., il.

SIMMEL, Georg. A metrópole e a vida mental. In VELHO, Otávio G. (org.) O Fenômeno Urbano. Rio de Janeiro: Zahar, 1976.

SILVA, Lucílio Luís Silva. Educação e trabalho para o progresso da nação: $o$ Liceu de artes e ofícios de Ouro Preto (1886 -1946). Dissertação de mestraDo apresentada ao Curso de Mestrado em Educação Tecnológica do Centro Federal de. Educação Tecnológica de Minas Gerais -. CEFET-MG, 2009 Disponível em http://www2.et.cefetmg.br/permalink/a50c934f-14cd-11df-b95f-00188be4f822.pdf Acesso em 27.02.2018 
SILVEIRA, Paulo César da. O Liceu de Artes e Ofícios de SP: arte e indústria em São Paulo. São Paulo, 1983. Trabalho de Graduação Interdisciplinar. Faculdade de Arquitetura e Urbanismo da Universidade de São Paulo, São Paulo, 1983, datiloscrito

SOUKEF, Junior, Antonio. Cem anos Luz. $2^{\text {a }}$ ed. São Paulo: Dialeto Latin American Documentary 2000

SOUZA, Ludmila Érica Cambusano de. A seção de brinquedos da metalúrgica Matarazzo S.A. - Metalma -, anos de 1930-1950 em São Paulo: estudo sobre industrialização e cultura material. São Paulo, 2012., 317 p. ; il +anexos. Dissertação (Mestrado) Fac. Fi. Let. C. Humanas USP

STAROBINSKI, Jean. L'Eil vivant. Corneille, Racine, La Bruyère, Rousseau, Stendhal. Paris: Gallimard, coll. « Tel », 1999 [1961].

SUMMERSON. John. A linguagem clássica da arquitetura, John Summerson ; [Trad] Sylvia Fischer ; [Rev] Monica Stahel. São Paulo: Martins Fontes 1994, 148 p.

TAFURI, Manfredo et alii. De Ia Vanguardia a Ia Metropoli: Crítica Radical a Ia Arquitectura, Barcelona: Gustavo Gili, 1972 (Arquitectura y Crítica), 553 p.

THEODORO, Janice. São Paulo de Ramos de Azevedo: da cidade colonial à cidade romântica. Anais do Museu Paulista. São Paulo. N. Sér. v.4 p.201-8 jan./dez. 1996, 10 p. Disponível em http://www.scielo.br/pdf/ anaismp/v4n1/a16v4n1.pdf Acesso em 27.02.218

TORRES, Acrísio. Esclarecimentos necessários. In VOLTAIRE. (FrançoisMarie Arouet). A filosofia da história. Voltaire. São Paulo: Martins Fontes, 2007, p.vii-xiii.

TREVIÑO, A. Javier Treviño. The Development of Sociological Theory: Readings from the Enlightenment to the Present. Thousand Oaks: SAGE Publications, Inc; 1 edition (February 15, 2017), 535 p.

VALDEMARIN, Vera T. Método intuitivo: os sentidos como janelas e portas que se abrem para um mundo interpretado. In: SOUZA, R. F.; VALDEMARIN, V. T.;

ALMEIDA, J. S. O legado educacional do século XIX. Araraquara: UNESP, 1998.

VAN DE VELDE, Henry. Fundamentos do estilo moderno / Faculdade de Arquitetura e Urbanismo, Universidade de São Paulo. São Paulo: FAU/USP, 1962. 
VARIOT, Gaston. Le cerveau de Voltaire. Ce qu'il en reste dans le musée de la Comédie Française. In Bulletin de la Société française d'histoire de la médecine, no 21, 1927, pp. 260-276. Disponível em http://www.biusante.parisdescartes.fr/histmed/medica/page?bsfhmx1927x21\&p=274 Acesso em 15.02.2018

VIDAL, Diana. Por uma pedagogia do olhar: os museus escolares no fim do século XIX. In: VIDAL, D. \& SOUZA, M.C.C.C. A memória e a sombra. Belo Horizonte: Autêntica, 1999, p. 107-116.

. O Museu Escolar Brasileiro: Brasil, Portugal e França no âmbito de uma história conectada (final do século XIX). In: LOPES, FARIA FILHO, FERNANDES. (Org.). Para a compreensão histórica da infância. Belo Horizonte: Autêntica, 2007, p. 199-220.

A invenção da modernidade educativa: circulação internacional de modelos pedagógicos, sujeitos e objetos no Oitocentos. In: CURY, Claudia \& MARIANO, Serioja (org). Múltiplas visóes: cultura histórica no Oitocentos. João Pessoa: Ed. UFPB, 2009, p. 37-58.

Museus pedagógicos e escolares: inovação pedagógica e cultura material escolar no Império Brasileiro. In: ALVES, Claudia; MIGNOT, Ana Chrystina.(Org.). História e historiografia da educação ibero-americana: projetos, sujeitos e práticas. 1ed. Rio de Janeiro: Quartet/Faperj/SBHE, 2012, p. 197-211.

VOLTAIRE. (François-Marie Arouet). Candide, ou l'Optimisme, par M. de Voltaire. Première [-Deuxième] partie. Édition revue, corrigée et ornée de figures en tailles-douces ["sic"], dessinées et gravées par M. Daniel Chodowiecky. chez Chrétien Frédéric Himbourg (À Berlin), 1778. 2 parties en 1 vol. petit in- $8^{\circ}$. (Bengesco, $n$ 1452.). Bibliothèque nationale de France, ZBEUCHOT-133, Disponivel em ark:/12148/btvlb8626474n Acesso em : 18.02.2018

La Philosophie de l'Histoire, par feu l'abbé Bazin. chez Changuion (À Amsterdam). Cramer) ((Genève), 1765. In- $8^{\circ}$, VIII [-II]$336 \mathrm{p}$. (Bengesco, n 1164, p. 333-334, note, 2.). Bibliothèque nationale de France, département Arsenal, 8-BL-34173. Disponivel em ark:/12148/ btv1b8618430t Acesso em : 18.02.2018

. Philosophical Dictionary. Edited and translated by Theodore Besterman. London: Penguin Books, 2004,403 p.

WAISMAN, Marina. O interior da História. Historiografia arquitetônica para uso de latinoamericanos. São Paulo: Editora Perspectiva, 2013, 206 p.

WILLIAMS, Raymond. Cultura e sociedade, 1780-1950 / Raymond Williams; traducão de Leônidas H. B. Hegenberg, Octanny Silveira da Mota e Anísio Teixeira. São Paulo: Nacional, [1969], 355 p. 



\title{
Apêndice - Liceu de Artes Ofícios: rol de cultura material 1870-1940
}

\author{
Índice \\ I. Coleção Pedagógica \\ I.1 Acervo bibliográfico \\ I.1.1 Enciclopédias \\ I.1.2 Tratados \\ I.1.3 Dicionários \\ I.1.4 Livros, livros técnicos e metodologias \\ I.1.5 Manuais, repertórios, enciclopédias e guias de estilos \\ I.1.6 Manuais de politecnia \\ I.1.7 Catálogos comerciais \\ I.1.8 Catálogos de politecnia \\ I.1.9 Periódicos \\ I.1.9.1 Anais e anuários \\ I.1.9.2 Revistas especializadas em artes e decoração \\ I.1.9.2 Revistas especializadas em tecnologia \\ I.1.10 Pranchas impressas/álbuns seriados \\ I.1.11 Impressos \\ I.2 Acervo artístico \\ I.2.1 Mobiliário \\ I.2.2 Esculturas \\ I.2.3 Pinturas \\ I.2.4 Gipsoteca (galeria de reproduções em gesso) \\ I.3 Fotográfico \\ I.3.1 Fotografias avulsas (modelos)
}


II. Coleção Institucional

II.1 Acervo de manuscritos

II.1.1 Atas e livros manuscritos

II.2 Acervo fotográfico

II.2.1 Álbuns fotográficos (mostruário) e fotografias avulsas

II.3 Acervo de projetos (desenhos)

II.3.1 Desenhos, projetos, estudos e esboços originais

II.4 Outros

II.4.1 Diplomas, prêmios, documentos e impressos

Rol

\section{Coleção Pedagógica}

\section{I.1 Acervo bibliográfico}

\section{I.1.1 Enciclopédias}

- Cars Builder's Cyclopedia of American Practice. New York: SimmonsBoardman Pub. Corp., [1903], il., p\&b, etiqueta 5E.

- CASTILlO, Don Joaquín Fontanals del. Historia general del arte. Historia de la pintura y escultura. Em Todas las épocas y escuelas, com noticias biográficas de los artistas más ilustres desde da antiguëdad à nuestros dias por Don Joaquín Fontanals del Castillo. Ilustrada con variedade de láminas y com 1157 grabados intercalados en el texto que reproducen las obras más famosas de la Pintura y Escultura. Barcelona: Montaner y Simon, Editores, 1893, il., color.

- Enciclopedia delle Moderne Arti Decorative. Diretta da Guido Marangoni. II. Il Ferro Battuto. Milano: Casa Editrice Ceschina, 1936, il.

- Encyclopedia e Diccionario Internacional organizado e redigido com a collaboração de distinctos homens da sciencia e de lettras brasileiros e portugueses. Edição ricamente illustrada com milhares de gravuras, muitas em cor. Rio de Janeiro, Nova Iorque: W. M. Jackson Inc., [1935], 20 volumes, il., color.

- Nouvelle Encyclopédie Autodidactique Illustrée D’Enseignement Moderne. Publié en collaboration par un Comité D’ Universitaires. Paris: [Librairie Aristide Quillet], 1922, tomo 1, il., color.

- Nouvelle Encyclopédie Autodidactique Illustrée D’Enseignement Moderne. Publié en collaboration par un Comité D’ Universitaires. Paris: [Librairie Aristide Quillet], 1922, tomo 2, il., color. 
- Nouvelle Encyclopédie Autodidactique Illustrée D'Enseignement Moderne. Publié en collaboration par un Comité D' Universitaires. Paris: [Librairie Aristide Quillet], 1922, tomo 3, il., color.

- PERROT, Georges (1832-1914); CHIPIEZ, Charles. Histoire de l'Art dans Antiquité Égypte, Assyrie, Phénicie, Judée, Asie Mineure, Perse, Gréce par Georges Perrot, Membre de l'Institut et Charles Chipiez, architecte du Gouvernement. Égypte. Paris: Libraire Hachette et Cie., 1903, Égypte, il., color.,tomo 1.

- PERROT, Georges (1832-1914); CHIPIEZ, Charles. Histoire de l'Art dans Antiquité Égypte, Assyrie, Phénicie, Judée, Asie Mineure, Perse, Gréce par Georges Perrot, Membre de l'Institut et Charles Chipiez, architecte du Gouvernement. Égypte. Paris: Libraire Hachette et Cie., 1903, Assyrie, il., color., tomo 2.

- PERROT, Georges (1832-1914); CHIPIEZ, Charles. Histoire de l'Art dans Antiquité Égypte, Assyrie, Phénicie, Judée, Asie Mineure, Perse, Gréce par Georges Perrot, Membre de l'Institut et Charles Chipiez, architecte du Gouvernement. Égypte. Paris: Libraire Hachette et Cie., 1903, Phénicie- Cypre, il., color., tomo 3.

- PERROT, Georges (1832-1914); CHIPIEZ, Charles. Histoire de l'Art dans Antiquité Égypte, Assyrie, Phénicie, Judée, Asie Mineure, Perse, Gréce par Georges Perrot, Membre de l'Institut et Charles Chipiez, architecte du Gouvernement. Égypte. Paris: Libraire Hachette et Cie., 1903, Sardaigne, Judée, Syrie, Cappadoce, il., color., tomo 4.

- PERROT, Georges (1832-1914); CHIPIEZ, Charles. Histoire de l'Art dans Antiquité Égypte, Assyrie, Phénicie, Judée, Asie Mineure, Perse, Gréce par Georges Perrot, Membre de l'Institut et Charles Chipiez, architecte du Gouvernement. Égypte. Paris: Libraire Hachette et Cie., 1903, Phrysie, Lydie et Carie Lycie, Perse, il., color., tomo 5.

- PERROT, Georges (1832-1914); CHIPIEZ, Charles. Histoire de l'Art dans Antiquité Égypte, Assyrie, Phénicie, Judée, Asie Mineure, Perse, Gréce par Georges Perrot, Membre de 1'Institut et Charles Chipiez, architecte du Gouvernement. Égypte. Paris: Libraire Hachette et Cie., 1903, Gréce Archaïque, il., color.

\section{I.1.2 Tratados}

- CINCINATTI PLANER COMPANY. Planer Company Treatise on Planers. Practical and suggestions for economically producing Flat 
Surfaces. Second edition. Cincinatti: Cincinatti Planer Company, 1940, etiqueta $12 \mathrm{E}$.

- DEITE, C. Tratado de Jabonería por el Dr. C. Deite ampliado por el Dr.Walther Schrauth, professor de la Universidad de Berlin, director de la "Tretalin Gessellschaft". Traducido por la Quinta Edición Alemana por el Dr. José Estalella, catedrático del Instituto de Tarragona. Barcelona: Gustavo Gili, Editor, 1923, il., p\&b, etiqueta 15 E.

- GROBERT, M.M. J de; LABBE, G.; MANOURY, H. et al. Traité de la Fabricatión du sucre de Betteraves et de cannes par M.M. J de Grobert; G. Labbé; H. Manoury; O. de Vreese. Ouvrage publié par les soins de J. Fritsch, Chimiste. Tome Ier. avec 238 figures et planches. Paris: SelfÉdition Technique J. Fritsch, Éditeur, 1913, tomo 1, il., p\&b, etiqueta 67 E. - GROBERT, M.M. J de; LABBE, G.; MANOURY, H. et al. Traité de la Fabricatión du sucre de Betteraves et de cannes par M.M. J de Grobert; G. Labbé; H. Manoury; O. de Vreese. Ouvrage publié par les soins de J. Fritsch, Chimiste. Tome Deuxième avec 165 figures et planches 239 a 403. Paris: Self- Édition Technique J. Fritsch, Éditeur, 1913, tomo 2, il., p\&b, etiqueta $67 \mathrm{E}$.

- MAZEROLlE, Louis Mazerolle. Traité Théorique et Pratique de Charpente. Dourdan: H. Vial, éditeur, successeur de Ch. Juliot, 1900, policromia, impresso, 25 pranchas avulsas.

- PECHEUX, H. Traité théorique et Pratique D'Éléctricité a l 'usage des élèves des écoles nationales d'art et métiers, des candidats a l'École Supérieure D'Élétricité et à la licence (certificat de Physique Industrielle) par H. Pécheux. Professeur de physique et de Chimie à l'École Nationale D'Arts et Métiers d'Aix, avec notes de J. Blondin, Agrégé de 1 'Université, Professeur au Colllège Rollim. E. Néculcéa attaché au laboratoire de recherches physiques à la Sorbonee. Préface de J. Violle. Membre de l'Institut. Paris: Libraire Ch.[arles] Delagrave, 1904.

- PILLET, Jules. Cours de Sciences Appliquées aux Arts. Traité de Stéréotomie. Charpente et Coupe des Pierres. Texte et dessins par Jules Pillet, ancien professeur de Géométrie descriptive à L'École des BeauxArts [...]. Nouveau tirage. Paris: Libraire Scientifique Albert Blanchard, 1923, il., p\&b.

- VERGA, Giuseppe. Trattato di Litografia e Moderne applicazioni. Studio pratico e teorico con appunti scientifici di Giuseppe Verga. Litografia, fotolitografia, eliotipia, fotografia, zincografia, Algrafia. 
Milano: Gli tipi della Raimondi \& Granata e cromolitografia Sucessori Parini Varoni \& C., 1923, il., 24 pranchas.

\section{I.1.3 Dicionários}

- Dictionnaire Pratique de Menuiserie - Ebénisterie - Charpente Par J. Justin Storck Editeur J. Justin Storck. Paris: Lardy, circa 1910. Imp. Dubos? il., p\&b.

- Pitman's Technical Dictionary of Engineering and Industrial Science in seven languages [...] arranged on an English alphabetical base and including the principal words and phrases compiled by Ernest Slater, M.I.E.E, M.I, Mech. E. London: Sir Isaac Pitman \& Sons Ltd., 1928, vol. 1.

- Pitman's Technical Dictionary of Engineering and Industrial Science in seven languages [...] arranged on an English alphabetical base and including the principal words and phrases compiled by Ernest Slater, M.I.E.E, M.I, Mech. E. London: Sir Isaac Pitman \& Sons Ltd., 1928, vol.2.

- Pitman's Technical Dictionary of Engineering and Industrial Science in seven languages [...] arranged on an English alphabetical base and including the principal words and phrases ...compiled by Ernest Slater, M.I.E.E, M.I, Mech. E. London: Sir Isaac Pitman \& Sons Ltd., 1928, vol.3.

- Pitman's Technical Dictionary of Engineering and Industrial Science in seven languages [...] arranged on an English alphabetical base and including the principal words and phrases compiled by Ernest Slater, M.I.E.E, M.I, Mech. E. London: Sir Isaac Pitman \& Sons Ltd., 1928, vol.5.

- VON IHERING, Rodolpho. Diccionário dos Animaes do Brasil pelo Dr. Rodolpho von Ihering (original para o "Boletim de Agricultura"). S.l: S.n., [1940], il., p\&b.

\section{I.1.4 Livros, livros técnicos e metodologias}

- ADAMS, John. The Evolution of Educational Theory by John Adams, M. A., B. S.C., LL.D., Professor of Education in the University of London. London: MacMillan and Co. Ltd., 1938, selo British Council, etiqueta $5 \mathrm{~B}$.

- ALLEN, G. C. British Industries and their organization by G. C. Allen, PhD, M. Com., Brunner Professor of Economic Science University of Liverpool. London: Longmans, Green and Co., 1939. 
- BONCI, E. Teoria delle Ombre e del Chiaroscuro. Quarta Edizione. Milano: Ulrico Hoepli Editore Libraio della Real Casa, 1923, Manuali Hoepli, il.,p\&b.

- BOURDON, M. Élements D'Arithmétique par M. Bourdon, Commandeur de la Légion d'honeur, conseiller honoraire de L'Université, ancien Examinateur d'admission à L'École Polytechnique, membre de plusiers Societés savantes. Ouvrage adopté par L'Université. Trente-Sixième Édition redigée conformément aux nouveaux Programmes de enseignement dans les Lycées. Paris, GauthierVillars, Imprimeur - Libraire du Bureau de Longitudes, de L'École Polytechnique, Succeseur de Mallet-Bachelier. Paris: Gauthier-Villars, 1878, Trente-Sixième Édition, carimbo e assinatura Alexandre M. Rodrigues, Sao Paulo, Septembro de 1888, etiqueta 13 D.

- BURGESS, M. W. Warships to-day, by M. W. Burgess, A.M.I, Mech. E., A.M.I.N.A. London: Oxford University Press, 1940, (The Pageant of Progress), il., p\&b.

- BRUZZONE, Tomaso. Il calcolo dei Tempi nelle lavorazioni meccaniche [...] con 19 figure e 7 Tavole fuori testo. Milano: Ulrico Hoepli Editore Libraio della Real Casa, 1922, il., p\&b, etiqueta 7D.

- Buehler Ltd. presents The Metal Analyst. A Review of Selected Apparatus and equipment for the Metallurgical and Mineralogical Testing. Evanston: Buehler Ltd. and Adolph I. Bruehler Inc., 1962, etiqueta $9 \mathrm{E}$.

- BULLENS, D.K. Steel and its Heat Treatment. Principles, processes, control, by D.K. Bullens and the Metallurgical Staff of the Battelle Memorial Institutte. Fourth Edition, rewritten and reset. New York: John Wiley \& Sons Inc.; London, Chapman \& Hall Limited, [1938], Fourth Edition, vol.1, etiqueta 3D.

- BULLENS, D.K. Steel and its Heat Treatment. Engineering and special purpose steels, by D.K. Bullens and the Metallurgical Staff of the Battelle Memorial Institute. Fourth Edition, rewritten and reset, New York: John Willey \& Sons Inc.; London: Chapman \& Hall Limited, [1938], Fourth Edition, vol. 2, etiqueta 4D.

- CARVALHEIRO, Luiz. Matemática comercial e financeira. Contendo noções de cálculo diferencial e integral. De acordo com os programas oficiais. Para uso dos alunos de todos os cursos técnicos de Comércio. Rio de Janeiro: Irmãos Pongetti Editores, 1939, (Biblioteca de Iniciação Econômica), etiqueta $17 \mathrm{D}$. 
- CARVALHO, Joaquim Bertino de Moraes. A Indústria de óleos vegetais e seus problemas. Questões techino industriaes e de ensino. Por Joaquim Bertino de Moraes Carvalho. E. A. Ex director e Prof. Catedrático do Instituto de Óleos (extincto) [...]. Rio de Janeiro: [Instituto de Óleos Diretoria de Estatística da Producção. Secção de Publicidade], 1936, vol. 1, il., fotografia, p\&b.

- CARVALHO, Joaquim Bertino de Moraes. A Indústria de óleos vegetais e seus problemas. Questões techino industriaes e de ensino. Por Joaquim Bertino de Moraes Carvalho. E. A. Ex director e Prof. Catedrático do Instituto de Óleos (extincto)[...]. Rio de Janeiro: [Instituto de Óleos Diretoria de Estatística da Producção. Secção de Publicidade], 1936, vol. 2, il., fotografia, p\&b.

- Cimento Armado. Compilado por Alberto de Mendonça Moreira, engenheiro civil. Membro Honorário da Congregação da Escola Polytechnica de S. Paulo. Ex-Chefe da Linha da Cia. Paulista de Estrada de Ferro. 3a . Edição revista e ampliada. São Paulo: Casa Vanorden, 1925, il., des., 411p., exemplar numerado 0996, etiqueta 20 D.

- Coletânea sobre arte I. S.I.: S.n., s.d., il, p\&b.

- Coletânea sobre arte no. 1. S.l.: S.n., s.d., il, p\&b.

- [Conversión de milimetros y fracción de milimetros en pulgadas e fraccion decimal de pulgadas]. S.1.: S.n., s.d., impresso, ex. 1, etiqueta 6 D.

- [Conversión de milimetros y fracción de milimetros en pulgadas e fraccion decimal de pulgadas]. S.l.: S.n., s.d., impresso, ex. 2, etiqueta 21 D.

- CRANE, E.V. Plastic working of metals and power-press operations by E.V. Crane, Ph.B, M.E. Second edition. New York: John Willey \& Sons Inc.; London: Chapman \& Hall Limited, 1939, Second edition, etiqueta $66 \mathrm{E}$.

- CREMONA, Luigi. Elementos de Geometria Projetiva de Luigi Cremona. Versão portuguesa por C.G.S. Shaders, outrora lente dessa matéria na Escola Polytechnica de S. Paulo. São Paulo: Casa Duprat, 1918, capa descolada, etiqueta 11 D.

- Crouse - hinds products. Condulets, Groundulets Plugs and Receptacles. Catalog 2200. Issued and Effective november 1, 1929. Supersedes all previous listings. Unless otherwise specified, all listings in this catalogue take regular condulet discounters. Crouse- Hinds Company. Established 1897. Syracuse, New York, U.S.A, Sales Offices New York, Boston. Chicago. S.l: S.n., 1929, il., etiqueta 42 E. 
- DEARDEN, John. Iron and Steel to-day, by John Dearden, B. S.C, A. M. I, Mech. E. London: Oxford University Press, 1939, (The Pageant of Progress), il., p\&b, etiqueta 61 E.

- DIRINGER, David. L'Alfabeto nella Storia della civiltà. Firenze: S. A. G Barbèra Editore, 1937, il.

- DOURADO, Mecenas. Erasmo e a Revolução Humanista. São Paulo: Companhia Editora Nacional, 1939.

- École Spéciale des Travaux Publics du Batiment et de L'Industrie. Cours de Machines-Outils. Livre I. La Machine, L'Outils e les méchanismes. Professeur M. Le Général L. Gages. Paris: [École Spéciale des Travaux Publics du Batiment et de L'Industrie], 1925.

- Escuelas Intenacionales. Cursos de Engeniero Constructor Eletricista, traduzido por International Educational Publishing Company. S.l.: S.n., s.d., vol. 1.

- Escuelas Intenacionales. Cursos de Engeniero Constructor Eletricista, traduzido por International Educational Publishing Company. S.l.: S.n., s.d., vol. 2.

- Escuelas Intenacionales. Cursos de Engeniero Constructor Eletricista, traduzido por International Educational Publishing Company. S.l.: S.n., s.d., vol. 3 .

- Escuelas Intenacionales. Cursos de Engeniero Constructor Eletricista, traduzido por International Educational Publishing Company. S.l.: S.n., s.d., vol. 4.

- Escuelas Intenacionales. Cursos de Engeniero Constructor Eletricista, traduzido por International Educational Publishing Company. S.l.: S.n., s.d., vol. 5 .

- Escuelas Intenacionales. Cursos de Engeniero Constructor Eletricista, traduzido por International Educational Publishing Company. S.l.: S.n., s.d., vol. 6 .

- Escuelas Intenacionales. Cursos de Engeniero Constructor Eletricista, traduzido por International Educational Publishing Company. S.l.: S.n., s.d., vol. 7.

- Escuelas Intenacionales. Cursos de Engeniero Constructor Eletricista, traduzido por International Educational Publishing Company. S.l.: S.n., s.d., vol. 8.

- Escritório Técnico do Engenheiro e Arquiteto F. P. Ramos d'Azevedo. Álbum de Construções. São Paulo: S.n., 1900. 
- Exposition d'Art français de São Paulo avec le concurs du gouvernement de l'Etat de São Paulo et sous le patronage du gouvernement français. Catalogue des oeuvres exposées. Édite par le Comité France -Amerique. Paris: Comité France -Amerique, 1913, il., fotografia, p\&b.

- FINDLAY. Alexander. Chemistry in the service of Man by Alexander Findlay, Prof. of Chemistry, University of Aberdeen, with portraits, diagrams and illustrations. Fifth Edition. London: Longmans, Green and Co., 1939, il., p\&b, selo British Council, etiqueta 40 E.

- GSELL, Paul. Auguste Rodin. Die Kunst. Gespräche des meisters gesammelt von Paul Gsell. MIT 87 abbildungen. Berlin: Kurst Wolff Verlag, 1913, il., color., sem contracapa.

- GILLESPIE, Cecil Merle. Introdución a la Contabilidad de Costos. Practicas de Contabilidad Costos. Por M.B.A. Professor Adjunto de Contabilidad em la North Western University y George A. Neff, C.P.A. Secretario y Tesorero de Birtman Electric CO., Tesorero de Modern Laundry Machine Manufacturing Co., para ser usado con el texto de Introducción a la Contabilidad de Costos. Traducido al español por el Lic. Sealtiel Alatriste. México, DR: C. P. T. Union Tipográfica Editorial Hispano - Americana, 1939, carpeta vazia.

- GOODYEAR, Frederick. Printing and Books Crafts for Schools. By Frederick Goodyear, member of The College of Handcraft, Handcraft master Catham House (county) School Ramsgate. London: George G. Harrap \& Co., Ltd., 1930, etiqueta 4 B.

- GUILLET, Léon. La Cimentación des Produits Métalurgiques et sa Génération. Cémentation des Aciers par le carbone par Léon Guillet. Membre de L'Institut. Directeur de L'École Centrale des Arts et Manufactures, Professeur au Conservatoire National des Arts et Métiers. Paris: Dunod, 1935, tomo 1.

- Homenagem a Ramos de Azevedo. Monimentv, Hoc acre populi collato amici ollegaeqve posvere anno domini MCMXXXIV. S.l.: S.n., 1924, il., p \&b, c. 75 p., ex.1.

- Homenagem a Ramos de Azevedo. Monimentv, Hoc acre populi collato amici ollegaeqve posvere anno domini MCMXXXIV. S.l.: S.n., 1924, il., p\&b, c. 75 p., ex.2.

- Homenagem a Ricardo Severo. Centenário de sei nascimento 18691969. S.1., S.n., [1969], brochura, ex.1.

- Homenagem a Ricardo Severo. Centenário de sei nascimento 18691969. S.l., S.n., [1969], brochura, ex.2. 
- HÜLLE, F.W. I Principi Fondamentali delle Macchine Utensili e della lavorazione dei metalli. Traduzione italiana sulla sesta edizidione tedesca con appendice originale a cura dell'Ing. Prof. Egidio Gáruffa della Scuola di Ingegneria di Milano. Primo. La Costruzione delle macchine utensili con 584 figure nel texto. Torino. Unione TipográficoEditrice Torinese già Fratelli Pomba Libraj in Principio della Contrada di Po, 1929, vol.1, il., p\&b.

- HÜLLE, F.W. I Principi Fondamentali delle Macchine Utensili e della lavorazione dei metalli. Traduzione italiana sulla sesta edizidione tedesca con appendice originale a cura dell'Ing. Prof. Egidio Gáruffa della Scuola di Ingegneria di Milano. Volume Secondo. L'impiego industriale delle macchine utensili. Calcoli e diagrami per il migliote impiego delle operatrici la valutazione dei temoi e dei costi...con 580 figure nel texto. Torino: Unione Tipográfico-Editrice Torinese già Fratelli Pomba Libraj in Principio della Contrada di Po, 1929, vol. 2, il., p\&b.

- Istituto Elettrotecnico Italiano. Roma. Lezioni di Elettrotecnica Superiori Svolte dall'Ing. G. Chierchia. Roma: Libreria Della Sapienza di A. Sampadesi, s.d.

- Istituto Elettrotecnico Italiano. Roma. Lezioni di Macchine Elettriche del Dott. Ing. G. Chierchia, Direttore dell'Istituto. IV Edizione. Roma: [Stab. Tipo-Litografico Attilio Sampaolesi], s.d, IV Edizione.

- Istituto Elettrotecnico Italiano. Roma. G. Chierchia. Corso di Calcolo e Progetto delle Macchine Elettriche. Roma: Stab. Tipo-Litografico Attilio Sampaolesi, s.d.

- Istituto Elettrotecnico Italiano. Roma. G. Chierchia. Corso preparatorio di Matematica e Física. Roma: Stab. Tipo-Litografico Attilio Sampaolesi, s.d.

- Istituto Elettrotecnico Italiano. Roma. G. Chierchia. Lezioni di costruzione, montaggio e bobinaggio delle Macchine Elettriche. Roma: Stab. Tipo-Litografico Attilio Sampaolesi, s.d.

- Istituto Elettrotecnico Italiano. Roma. Lezioni di Matemática Superiore e Cenni di Mecânica Razionale svolte dal Dott. Carlo Lamoglie. Roma: Stab. Tipo-Litografico Attilio Sampaolesi, s.d.

- Istituto Elettrotecnico Italiano. Roma. Dott. Ing. G. Chierchia, Direttore dell'Istituto. Complementi ao Corso di Impianti Elettrici. Roma: Officina di Arti Grafiche, s.d.

- Istituto Elettrotecnico Italiano. Roma. Lezioni di Impianti Elettriche svolte dal Dott. Ing. G. Chierchia, Direttore dell'Istituto. S.I.: S.n., s.d. 
- JERVIS, T. La resistenza dei materiali spiegata con esempi. Nozioni e esercizi elementari di resiatenza dei materiali e calcolo di parti di costruzioni e di macchine. Ad uso dei capimastri, costrutori meccanici e capi d'Arte Torino: G. Lavagnolo Editore, s.d, etiqueta 11 E.

- KRETZSCHMAR, F. E. Les Maladies de L'Accumulateur du Plomb. Causes, Diagnostic.Traitement.Préventions. Par F.E. Kretzschmar, Ingénieur, Professeur d'électricité à L'École mécanique industrielle de Leipzig. Traduit sur la deuxième édition allemand par M. Walter, Ingénieur à la Societé Parisienne pour l'Industrie des Chemins de fer et Tramways éléctriques, Paris: Dunod, 1924, etiqueta 71 E.

- L'État de São Paulo (Brésil). Renseignements utiles. Troisème Édition. Commissariat Général du Gouvernement de L'État de São Paulo. Anvers: Caport \& Dosse, 1914, il., fotografia, p\&b.

- LERY, Jean de. Historia de uma viagem feita à Terra do Brasil. Traduccção ordenada literariamente por Monteiro Lobato. Rio de Janeiro: Companhia Editora Nacional, 1926.

- Livro do Centenário da Câmara dos Deputados 1826-1926. Rio de Janeiro: Empreza Brasil Editora Ltda., 1926, il., p\&b.

- Livro do Centenário da Câmara dos Deputados 1826-1926. Rio de Janeiro: Empreza Brasil Editora Ltda., 1926, vol. 2, il., p\&b.

- Livro do Centenário da Câmara dos Deputados 1826-1926. Volume Especial. Rio de Janeiro: Empreza Brasil Editora Ltda., 1926, il., fotografia, p\&b

- LOON, Hendrick van. O mundo em que vivemos. Tradução de Álvaro Franco. Porto Alegre: Edição da Livraria do Globo, 1934, il., p\&b, 503 p.

- MANGE, Robert. Texto da Collecção de modelos para desenhos de machinas. Convenções. Nomenclatura. Cálculo. Construção. Organizada e editada por Robert Mange, engenheiro mecânico, lente de Máquinas da Escola Polytechnica de S. Paulo, com a collaboração dos engenheiros Paulo do Amaral, José Gollub e Moysés Marx. São Paulo, Typograhia Brasil de Rohschild \&Co., 1925, impresso.

- MARSHALL, Alfred. Industry and Trade. A Study of Industrial Technique and business organization and of their influences on the conditions of various classes and nations by Alfred Marshall. London: MacMillan and Co. Ltd., 1932.

- MERCANTE, Victor. Metodologia Especial de la enseñanza primaria. Leyes. Leciones. Enseñanza de la Escritura, Lectura, Ortografia, ejercicios intuitivos, composión y aritmética por Victor Mercante. Segunda 
Parte. Segunda Edición, corregida. Buenos Aires: Cabaut e Cia. Editores. Libreria del Colégio Alsina y Bolívar, 1912, assinatura Cássio de Mello, Itapetininga, 4 de out 1914, etiqueta 3 B.

- MERCANTE, Victor. Metodologia Especial de la enseñanza primaria. Leyes. Leciones. Enseñanza de la Escritura, Lectura, Ortografia, ejercicios intuitivos, composión y aritmética por Victor Mercante. Segunda Edición, corregida. Buenos Aires: Cabaut e Cia. Editores. Libreria del Colégio Alsina y Bolívar, 1913, assinatura Cássio de Mello, Itapetininga, 4 de out 1914, etiqueta 2 B.

- México. One Hundred and Seventy - Eight Photographs by Pierre Verger. Introduction by Jacques Soustelle. Paris: Paul Hartmann, 1938, il., fotografia, $\mathrm{p} \& \mathrm{~b}$, sem capa.

- Ministério da Agricultura. O Governo e a Producção. Discursos e entrevistas do Ministro Odilon Braga. I. Directoria de Estatística da Produção. Secção de Publicidade. Rio de Janeiro: S.n., 1935, etiqueta 9 C.

- Ministério da Fazenda. Tarifas das Alfândegas mandada executar pelo decreto no 24.343 de 5 de junho de 1934, acompanhada de Índice Alfabético e remissivo, de relação de países [...]. Rio de Janeiro: Imprensa Nacional, 1934, etiqueta 4 C.

- MITOLDI, S. Ferreri. Elementi di Agrimensura de Mitoldi. Milão: Ulrico Hoepli, 1914.

- Modern schoolshop. Booklet no 55 Y. South Bend Lathe Works. South Bend, Indiana, U.S.A. [South Bend], [1935], il, fotografia, p\&b, etiqueta $28 \mathrm{E}$.

- MORRISH, Reginald. The Police and Crime Detection to-day, by Reginald Morrish, Ex-chief Inspector, Metropolitan Police. London: Oxford University Press, 1940, (The Pageant of Progress).

- Noções de Perspectiva exacta. Para alumnos das escolas secundárias e admissão às escolas superiores civis e militares. Rio de Janeiro: Livraria Paulo de Azevedo e Cia., s.d., il., Nihil obstat. Pe. João Kulay, São Paulo 9 de março de 1936. Imprimatur. São Paulo, 9 de dezembro. Mons. Ernesto de Paula, vig. geral.

- O'BRIEN, J.J.;. O'BRIEN, M.W. How to run a Lathe. The Care and operation of a Screw cutting Lathe by J.J. O'Brien; M.W. O'Brien. Editon 43. Indiana: The South Bend Lathe Works, [1940], vol. 1, etiqueta 30 I.

- PALMER, Frank R. Tool steel simplified a handbook of modern practice for the man who makes tools by Franck R. Palmer, Vice President The 
Carpenter Steel Company. First Edition. Pennsylvania: The Carpenter Steel Company Reading, 1937, etiqueta 16 E.

- PASSOS, Francisco Pereira. Caderneta de campo para uso dos engenheiros incumbidos de trabalhos de Estrada de Ferro contendo explicações[...] seguidas de todas as tabellas indispensáveis para as explicações, marcações de curvas e construcção de plantas e finalmente uma tabella de jornaes de operários ... por Francisco Pereira Passos. 5ª edição. Rio de Janeiro: Typ. e Lith. de Olympio de Campos e C., 1920.

- PENNA, Leonam de Azevedo. A Meteorologia, o solo e a planta pelo engenheiro agrônomo Leonam de Azevedo Penna. Ministério da Agricultura. Diretoria Geral de Pesquisas Científicas. Instituto de Metereologia, Hidrometria e Ecologia Agrícola. Rio de Janeiro: Imprensa Nacional, 1934, il., fotografia, p\&b.

- Perspectiva de observação. Para uso dos professores e alumnos das escolas primárias, secundárias, normais e profissionais. Rio de Janeiro, São Paulo: Livraria Paulo de Azevedo e Cia., s.d., (Colleção F. T. D), il., Nihil obstat. Pe. João Kulay, São Paulo 9 de dezembro de 1936. Imprimatur. São Paulo, 9 de dezembro. Mons. Ernesto de Paula, vig. geral.

- POLETTINI, Aldo. Impianti Elletrici di produzione. Trasformazione, trasporto e utilizzazione. Seconda Edizione riveduta e ampliata. 513 illustrazione. 9 Tavole fuori testo. Milano: Ulrico Hoepli Editore, 1933, il., p\&b.

- POMINI, Ottorino. Costruzione di Macchine I. Elasticita e Resistenza dei Materiali [...]. Teorie e richerche moderne. Calcoli Ed esempi pratici. Applicazione Tecniche. Disegni Costruttivi. Seconda Edizione completamente rifatta e aumentata con 646 illustrazioni nel testo. Milano: Ulrico Hoepli Editore Libraio della Real Casa, 1921, il., p\&b.

- POMINI, Ottorino. Costruzione di Macchine II. Organi per il moto rotatório [...]. Seconda Edizione accuratamente riveduta con 748 illustrazioni nel testo. Milano: Ulrico Hoepli Editore Libraio della Real Casa, 1922, il., p\&b.

- POMINI, Ottorino. Costruzione di Macchine III. Macchine a stantuffo e Loro Elementi [...]. Seconda Edizione accuratamente riveduta con 714 illustrazioni nel texto. Milano: Ulrico Hoepli Editore Libraio della Real Casa, 1922, il., p\&b.

- POMINI, Ottorino. Costruzione di Macchine IV. Ingranaggi [...]. Seconda Edizione riveduta e molto ampliata con 500 illustrazioni nel testo. Milano: Ulrico Hoepli Editore Libraio della Real Casa, 1922, il., p\&b. 
- PORTWAY, Donald. Military Science to-day, by Donald Porway, Lieut. Colonel, R.E., Senior Tutor of Sr. Catharine's College. Cambridge and University Lecturer in Engineering, author of Science and Mechanization in Land Warfare and Talks to Future Officers. Foreword by Major-General J. H. Beith, C. B. E., M.C. (Ian Hay). London: Oxford University Press, s.d., (The Pageant of Progress), il., p\&b.

- REES, J. F. A Survey of Economic Development with Special reference to Great Britain by J. F. Rees. London: Sir Isaac Pitman \& Sons, Ltd., 1933, selo do British Council, etiqueta 13C.

- REILE, Adolf. Nuevo trazado de Perspectiva para Architectos. Solución de todos los problemas sin líneas auxiliares por Adolf Reile. Fachschulrat an der Staatlichen Kunstgewerbeschule zu Sttugart, Würtemberg. Traducido del alemán por el Arq. E Canosa, professor de la Escuela Superior de Arquitectura de Barcelona. 36 láminas. Barcelona: Casa Editorial Canosa, 1928, il.

- Ricordo di Roma. 32 Vedute. S.l.: s.d., parte I A, fotografia, p\&b.

- Ricordo di Roma. 32 Vedute. S.l.: s.d., parte II A, fotografia, p\&b.

- RINALDI, Emilio. Formulario Tecnico di Meccanica generale con numerosi problemi risolti e note di Elettrotecnica. Torino: G. Lavagnolo Editore, s.d., etiqueta $38 \mathrm{E}$.

- ROGGERO, Egisto. Come devo educare la mia memoria?. In sostizione del Manuale B. Plebani “L'Arte della Memoria”. Milano: Ulrico Hoepli Editore, 1929.

- ROLL, Erich. Elements of Economic Theory by Erich Roll. London: Oxford University Press, 1938, selo British Council, etiqueta 14 C.

- ROYSTON, George. Brazilian Marriage. London: Thornton Butterworth, Ltd., 1936.

- SENELFEDER, Alois. The Invention of Litography by Alois Senelfeder. Translated from the original german by J. W. Muller. New York: The Fuchs and Lang Manufacturing Company, 1911, il., etiqueta 47 E.

- SEVERO, Ricardo. O Liceu de Artes e Ofícios de São Paulo Histórico, Estatutos, Regulamentos, Programas, Diplomas. MDCCCLXXIIIMCMXXXXIV. S.l.: S.n., s.d. il., fotografia, p\&b, ex 1.

- SEVERO, Ricardo. O Liceu de Artes e Ofícios de São Paulo Histórico, Estatutos, Regulamentos, Programas, Diplomas. MDCCCLXXIIIMCMXXXXIV. S.l.: S.n., s.d. il., fotografia, p\&b, ex 2. 
- SEVERO, Ricardo. O Liceu de Artes e Ofícios de São Paulo Histórico, Estatutos, Regulamentos, Programas, Diplomas. MDCCCLXXIIIMCMXXXXIV. S.l.: S.n., s.d. il., fotografia, p\&b, ex 3.

- SHANNON, R.W. Sheet Steel and Tinplate by R.W. Shannon, Associate Member American Institute of Mining and Metallurgical Engineers. New York: The Chemical Catalogue Company Inc., 1930, etiqueta 70 E.

- SOMONTE, Ignácio Suarez. Aritmética. Por Ignácio Suarez Somonte. Catedrático de matemáticas en el Instituto del Cardenal Cisneros. Madrid: Imprenta Viuda e Hijos de Jaime Ratés, 1930, etiqueta 1D.

- STAMP, L. Dudley; CASSEL, Ernest. Chisholm's Handbook of Commercial Geography. Entirely Re-Written by L. Dudley Stamp, D. Sc, B.A. (Lond.), Sir Ernest Cassell [...] with maps and diagrams. London: Longmans, Green and Co., 1937, il., p\&b, selo British Council, etiqueta 2C.

- STOREZ. M. M.Storez caractères Typographiques. Paris: VincentFreál Éditis, s.d., il.,p\&b.

- STRANGE, Thomas. English furniture decoration woodwork and allied arts. From the last half of the Seventeenth Century to the early part of the Nineteenth century. New York: Bonanza Books, primeira metade do século XX, il., del., p\&b.

- STURT, Mary; OAKDEN, E.C. Modern psychology and Education. A text book of Psychology for Students in Training Colleges and Adult Evening Classes by Mary Sturt, M.A. and E.C. Oakden, M.A. Eight Edition revised. London: Kegan Paul, Trench, Trubner \& Co. Ltd., 1937, selo British Council, etiqueta 7 B.

- Systema de contabilidade. Controle- Estatística Hollerith. Metodização. Analyse e fiscalização. International Business Machines Co. of Delaware. S.l.: S.n., s.d., il., fotografia, p\&b, etiqueta 15 D.

. - TÁVORA, Juarez. O Ministério da Agricultura em 1933-1934. Diretoria de Estatística da Produção. Secção de Publicidade, Rio de Janeiro. [Rio de Janeiro]: S.n, [1933-1934].

- Teses sobre Arte. S.I.: S.n., s.d., [miscellanea ], il.

- Trabalhos Manuaes. Cartonagem. Traduzido do Allemão. Rio de Janeiro: Papelaria Americana, 1926, il.

- VENN, J. A. The Foundations of Agricultural Economics together with an Economic History of British Agriculture during and after the Great War by J.A. Venn, Litt. D. Cambridge: Cambridge University Press, 1933, il., fotografia, p\&b selo British Council, etiqueta 15 C 
- VIEWEGER, H. Elettrotecnica Generale e Applicata. Riassunti Teorici e Esercizi Pratici. Completamente svolti com esempi di calcolo delle macchine ad uso degli Istituti Tecnici Superiori delle Scuole Industrialli e di chi studia Dave. Prima Edizione Italiana com note e aggiunte di G. Sorarú [...] com 209 figure intercalate nel testo e 2 tavole. Milano: Ulrico Hoepli Editore Libraio della Real Casa, 1926, il., p\&b.

- VINYCOMB, T. B. Electricity to-day, by T. B Vinycomb, M.C., M.A., F. Inst. P. London: Oxford University Press, 1939, (The Pageant of Progress), il., p\&b.

- VIVES, Juan Luís (1492-1540). Causa de la decadencia de las Artes. Buenos Aires: Emecé Editores S. A., 1948, (Biblioteca Emecé de Obras Universales. Sección IV. Ensayo y Crítica).

- YOUNGBERG, Edwin S. Mechanical Drawing for High Schools. Edwin S. Youngberg, Lane Techical High School Chicago, Illinois. New York: Pitman Publishing Corporation, [1938], etiqueta 29 E.

\section{I.1.5 Manuais, repertórios, enciclopédias e guias de estilos}

- [Art nouveau 1]. S.l., s.n., s.d., 10 pranchas coloridas avulsas.

- [Art nouveau]. S.l., s.n., s.d., 12 pranchas coloridas avulsas.

- [Wohnungskultur]. S.l: S.n, s.d., il., p\&b.

- 120 Intérieurs en couleurs. Paris: Librairie D'Architecture R. Ducher, Imprimerie J. Hoffmann Stuttgart, [1902].

- A Arte e a Natureza em Portugal. Álbum de photographias com descripções, clichês originaes; cópias em phototypia inalterável; monumentos, obras d'arte, costumes, paisagens. [Porto]: Emilio Biel e Cia. Editores, 1903, il., fototipia, p\&b.

- Architecture Internationale Moderne. Expositions Internationales D’Anvers et de Liége. Paris: Éditions D’Art Charles Moreau, Paris, [1930], il., heliotipia?, p\&b.

- Arte Funeraria Italiana. Serie V. XXX Tavole. Milano - Roma: Casa Editrice Bestetti e Tumminelli, [1920], fotografia?, il., p\&b.

- Arte Funeraria Italiana. Serie VI. XXX Tavole. Milano - Roma: Casa Editrice Bestetti e Tumminelli, 1920], fotografia?, il., p\&b.

- Ausgeführte Bau Ornamente von Prager Bildhavern. 56 Tafeln. Licht Drucke nach Nature Aufnahmen. Dritter Teil. Wien: Verlag von Anton Schroll \& Co., 1900, il., p\&b, carpeta incluindo 3 pranchas. 
- Ausgeführte Bau Ornamente von Prager Bildhavern. 3. Dritter Teil. 56 Tafeln. Licht Drucke nach nature aufnahmene. Wien: Kunst Verlag Anton Schroll \& Co., 1900, il., p\&b, 3 pranchas avulsas, desencadernado, sem capa.

- AZEVEDO, Francisco de Paula Ramos de. Álbum de Construccões do Escriptorio Technico Engenheiro Architecto F. P. Ramos d'Azevedo. São Paulo: S.n., 1904, litogravura?, p\&b, com capa, sem contracapa.

- BADOVICI, Jean. Intérieurs Français, présentés par Jean Badovici, Architecte. Documents D’Architecture. Art Français Contemporain. Ornements graphiques de Raoul Dufy. Paris: Éditions Albert Morancé, Paris, 1925, il.,color., p\&b.

- BADOVICI, Jean. Intérieurs Süe et Mare présentés par Jean Badovici, Architecte. Documents D'Architecture. Art Français Contemporain. Illutrations de Paul Véra, graphiques de Raoul Dufy. Paris: Éditions Albert Morancé, 1924, il., color., p\&b.

- BAJOT, Édouard. Motifs Louis XVI. Paris: Charles Schmid Éditeur, [1890], il., p\&b.

- BAJOT, Édouard. Profils et Tournages. Recueil de Documents de Styles. Gothique-François Ier -Henri II - Henri III - Henri IV - Louis XIII - Louis XIV - Louis XV - Louis XVI - Empire - Moderne. Tirés des principauxs musées, palais, châteaux, grandes collections, etc. (sic) 1680 motifs. Relevès et dessinés sous la Direction de Ed. Bajot. Librairie Gènerale D'Architecture et des Arts Décoratifs. Paris: Charles Schmid Éditeur, [1899], il., p\&b, desencadernado.

- BALDIZZI, Leonardo Patterna. Gradus ad Parnassum. Disegni varii \& Progetti Architettonici com 233 incisioni in 103 tavole. Leonardo Patterna Baldizzi, professore di Disegno Architettonico nella R. Universitá di Napoli. Torino: Società Italiana di Edizioni Artistiche. C. Crudo \& C., 1908, il., color., p\&b.

- BANEAT, Paul. Le Mobilier Bressan. Ensembles et Détails. Paris: Charles Massin, Éditeurs, 1925, (Collection D’Art Régional en France), il., heliotipia?, p\&b.

- BARREZ, Alphonse. Maisons D'Habitation présenté par Alphonse Barrez. L'Art international d'aujourd'hui. Paris: Éditions D'Art Charles Moreau, [1920], il., fotografia?, p\&b.

- Bars, Cafes, Dancing, Restaurants. Nouvelle serie. Paris: Éditions D’Art Charles Moreau, 1930, il., heliotipia, p\&b. 
- BERTET, Gabriel. La tenture Moderne et son application technique par Gabriel Bertet. Préface de Geo. Rémon. Paris: Éditions Eugène Moreau, 1928, il., color., p\&b.

- BÉRTIN, Léon. Bibliothèque de L'Ameublement. Documents pratiques d'Ameublement. Ébénisterie, Sculpture, Tournage par Bértin et L. Compagnion. Deuxième série. Bertin et Compagnion del. Librairie Spéciale D'Architecture. Dourdan: Émile Thézard Éditeur, [1899-1900], il., del., fototipia, p\&b, ex.1.

-BÉRTIN, Léon. Bibliothèque de L'Ameublement. Documents pratiques d'Ameublement. Ébénisterie, Sculpture, Tournage par Bértin et L. Compagnion. Deuxième série. Bertin et Compagnion del. Librairie Spéciale D'Architecture. Dourdan: Émile Thézard Éditeur, [1899-1900], il., fototipia, p\&b, ex. 2

- BOLTON, Arthur T. The Architecture of Robert and James Adam (1758-1794) by Arthur T. Bolton, F.S.A, F.R.I.B.A, curator of the Sir John Soane Museum. Volume I. London at the Offices of Country Life, Tavistock St., Covent Garden, and George Newnes Ltd. New York: Charles Scribner's Sons, 1922, 2 vol., il., p\&b.

- BOUTILlON, M. Cosy-Corners et Lits de Repos par M. Boutillon. 1re série. Paris: Éditions Eugène Moreau, 1931, il., p\&b.

- Boutiques et Magasins. Présenté par René Herbst. L'Art International D'Aujourd'hui, 8. Paris: Éditions D'Art Charles Moreau, [circa 1920], il., fotografia?, p\&b.

- BRANDON, Raoul. Nouveau Modeles de Tombeaux par Raoul Brandon, Architecte Professeur de la Ville a Paris, 1er. Prix en Concours Public [...]. Delrieu, Déssinateur avec le concours de divers architetctes Déssinateurs, Sculpteurs er entrepreneurs[...]. Dourdan: Ch. Juliot Éditeur, [1905], il., color. e p\&b.

- BRAUN, A. Le Louvre et le Luxembourg: photographies de la Maison Ad. Braun, Clément et cie. Paris: Librairie D’Art Ludovic Baschet èditeur. Imprimerie Générale Lahure Collection “Le Panorama”: nos musées nationaux, [18--].

- BRUN, Charles. Intérieurs rustiques. Paris: Éditions D'Art Charles Moreau, 1927, il., fotografia?, p\&b.

- Cafes. Bars. Restaurants. II. Soixante planches. Paris: Librairie de la Construction Moderne Éditeur, [circa 1930], il., fototipia, del., p\&b.

- Case e Palazzi in Itália. Milano: Casa Editrice D’Arte Bestetti e Tumminelli, s.d., il., heliocromia, em carpeta. 
- CHAMPIER, Victor. Documents d'Atelier: Art Décoratif Moderne. Album contenant 60 planches en couleurs fac-simile d'aquarelles. 200 modéles nouveaux pour les industries d'art. Architecture, Meubles, Céramique, Orfèvrerie, Bijouterie, Tissus, etc. Composés par MM. Bonnier, Emil Causé, Edme Couty, J. Dampt, Ch. Génuys, R. Lalique, Marius Michel, Mucha, H. Nocq, Plumet, V. Prouvé, E. Robert, Rudnicki, A. Sandier, Selmersheim, Tourette, etc., etc. Préface par Gustave Latroument. Membre de l'Institut. Paris, Bibliothèque de la Revue des Arts Décoratifs publiés sous la direction de Victor Champier. G. d Hostingue, Dirécteur. Paris: Grande Imprimerie Centrale, 1899, il., color.

- CHAMPIER, Victor. Le Mobilier Flamande. Paris: Charles Massin \& Cie. Éditeurs, 1930, (Collection D’Art Régional en France), il., heliotipia?, p\&b.

- CHAREAU, Pierre. Meubles. L'Art International D'Aujourd'hui. Présenté par Pierre Chareau Paris: Éditions D’Art Charles Moreau, [1920], il., p\&b.

- CIZALETTI, Maxime. Halls et Bureaux Modernes. Libraire Profissionnelle de l'Architecture et des Beaux-Arts. Paris Éditions: Alexis Sinjon, [1920], il.,fototipia, clichês, p\&b,

- CLOUZOT, Henri. La Ferronnerie Moderne. 3éme. Série. Paris: Éditions D’Art Charles Moreau, [1925], il., fotografia?, p\&b,

- ClOUZOT, Henri. La Ferronnerie Moderne. 4éme. série. Paris: Éditions D'Art Charles Moreau, [1925], il., fotografia?, p\&b,

- CLOUZOT, Henry. La Ferronnerie Moderne présenté par H. Clouzot. La Ferronnerie Moderne à L'Exposition Internationale [des arts décoratifs]. Paris: Éditions D’Art Charles Moreau, [1939], il., heliotipia, p\&b, ex.1.

- CLOUZOT, Henry. La Ferronnerie Moderne présenté par H. Clouzot. La Ferronnerie Moderne à L'Exposition Internationale [des arts décoratifs]. Paris: Éditions D’Art Charles Moreau, [1939], il., heliotipia, p\&b, ex.2.

- CLOUZOT, Henry. La Ferronnerie Moderne présenté par H. Clouzot. La Ferronnerie Moderne à L'Exposition Internationale [des arts décoratifs]. Paris: Éditions D'Art Charles Moreau, [1939], il., heliotipia, p\&b, ex.3.

- COLASANTI, Arduino. Tesori D’Arte Italiana. Volte e soffitti italiani. Milano: Casa Editrice D’Art Bestetti e Tumminelli, 1915, (serie Tesori D’Arte Italiana), il., fotografia, p\&b.

- Concours d'Installations de Chambres de Hotels organisé par L'Automobile Club de France. Chambres a coucher et cabinets de toilette. 24 planches. Librairie Générale de L'Architecture et des Arts Décoratifs. Paris: Charles Schmid Éditeur, [1910], il., fotografia?, p\&b, ex.1. 
- Concours d'Installations de Chambres de Hotels organisé par L'Automobile Club de France. Chambres a coucher et cabinets de toilette. 24 planches. Libraire Générale de L'Architecture et des Arts Décoratifs. Paris: Charles Schmid Éditeur, [1910], il., fotografia?, p\&b, ex.2.

- CORNETTO, F. [Modelos de ferro batido para grades e portões e guarda corpos]. S.l., L. Avalle Editore: s.d., pranchas avulsas em escala 1:10, em carpeta.

- Coupes, Vases, Candélabres, Sarcophages, Trépieds, Campes et Ornements divers déssinés et gravés par J.B. Piranesi. Reproduction de l'Édition originale. Paris: Auguste Vincent Éditeur, 1905, il., p\&b.

- Croquis de Ruhlmann présentés par Léon Moussinac. 53 planches publiées sous la Direction et avec une introduction de Léon Moussinac. Librairie Centrale des Beaux- Arts. Paris: Éditions Albert Lévy, 1924, (Collection Documentaire d'Art Moderne), il., croquis, color., p\&b.

- Das Haus Neue Folge. Verlagsbuchhandlung, für architektur und Kunstgewerbe. Düsseldorf: Verlag von FriedrichWolfrum, Hofbuchhan dlung, 1900, fotografias acompanhadas por plantas baixas, p\&b, fora de carpeta.

- Décorations Intérieurs et Meubles. Des Époques Louis XV, Louis XVI et Empire. Paris: Ch[arles] Foulard, 1907-1909 il., fotografia?, p\&b.

- Décorations Intérieurs et Meubles. Des Époques Louis XV, Louis XVI et Empire. Iere. année. Paris: Ch[arles] Foulard, 1907-1908, ano 1, il., fotografia?, p\&b.

- Décorations Intérieurs et Meubles. Des Époques Louis XV, Louis XVI et Empire. Revue d'Art Décoratif, 2me. anné. Paris: Librairie Charles Foulard, 1908-1909, ano 2, il., fotografia?, p\&b.

- DELACROIX, Henry. Répertoire de L'Architecture Moderne. Intérieurs modernes. Henry Delacroix, architecte. 3. Librairie Nouvelle de L'Architecture et des Beaux- Arts. Paris: Éditions S. de Bonadona, s.d., il., fototipia, cliché, p\&b, color., ex.1

- DELACROIX, Henry. Répertoire de L'Architecture Moderne. Intérieurs modernes. Henry Delacroix, architecte. 3. Librairie Nouvelle de L'Architecture et des Beaux- Arts. Paris: Éditions S. de Bonadona, s.d., il., fototipia, cliché, p\&b, color., ex.2

- Der Ausbau des Hauses. Neue Entwürfe für die moderne ausgestung von Wohn und Geschaftsräumen. Serie I. 48 Tafeln. Wien und Leipzig: Friedr. Wolfrum \& Co., Verlag für Architektur und Kunstgewerbe, 1900, il., color. 
- Der Drechsler Eine Sammlung von Musterblätlein moderner Holzdreherein für brechsler. Bau-um Möbelschreiner fowie zum gebrauch für gewerbliche Schulen herausgegeben von fr. Dör um $\mathrm{H}$. Müller. Eiferung. Ravensburg: Verlag von Otto Maier, [1896], il., p\&b, selo Laemmert, São Paulo, 2 pranchas, incompleto?

- Der Moderne Baustichler. Tore und Türen. Verlag für Architektur und Kunstgewerbe. Wien und Leipzig: Verlag Friedrich Wolfrum \& Co. Wien und Leipzig, [1900], color., impresso, pranchas avulsas.

- Der Moderne Schlosser. Praktische Musterbücher in Taschenformat. II Band. 50 Türen und Tore. Herausgegeben von W. Ehlerding. Ravensburg: Verlag Otto Maier, [1910], vol.2, il., p\&b, com logotipo da Livraria de Edições Artísticas A. Cattani e Filho.

- Der Moderne Schlosser. Praktische Musterbücher in Taschenformat. III Band. 100 Füllungsgitter von Josef Feller. Herausgegeben von Josef Feller. Ravensburg: Verlag Otto Maier, [1910], vol.3, il., p\&b, com logotipo da Livraria de Edições Artísticas A. Cattani e Filho.

- Der Moderne Schlosser. Praktische Musterbücher in Taschenformat. IV Band. 100 Brüstungs und Balkongitter von W. Herding. Herausgegeben von W. Ehlerding. Ravensburg: Verlag Otto Maier, [1910], vol.4, il., p\&b, com logotipo da Livraria de Edições Artisticas A. Cattani e Filho.

- Der Moderne Schlosser. Praktische Musterbücher in Taschenformat. V Band. 100 Treppengelander. Herausgegeben von W. Ehlerding. Ravensburg: Verlag Otto Maier, [1910], vol.5, il., p\&b, com logotipo da Livraria de Edições Artísticas A. Cattani e Filho.

- Der Moderne Schlosser. Praktische Musterbücher in Taschenformat. VI Band. 100 Grabgitter und Kreuse von W. Ehlerding. Herausgegeben von von W. Ehlerding. Ravensburg: Verlag Otto Maier, [1910], vol.6, il., p\&b, com logotipo da Livraria de Edicoes Artisticas A. Cattani e Filho.

- [Desenhos]. [Eigenthum und Verlag Keltz \& Meiners], Berlin, Anterman. [Berlin]?: Verlag Keltz \& Meiners, s.d., il., pranchas dobradas com desenhos impressos em sépia .

- DESHAIRS, Léon. Intérieurs en couleurs, France. Exposition des Arts Décoratifs Paris 1925. Cinquante planches en couleurs, accompagnées d'une préface par Léon Deshairs, consérvateur de la Bibliothèque des Arts Décoratatifs, rédacteur en chef D’Art et Décoration. Paris: Éditions Albert Lévy, 1925, il.,color.

- Dessins D'Architecture. Paris: Monroq Frères Imp. Edit., s.d., il. color., desencadernado. 
- Devantures de Boutiques et Installations de Magasins. Façades et Détails. Intérieurs. Détails de Construction. Coupes. Plans. Assemblages. 90 planches en phototypie et lithographie. Librairie D'Art et D'Architecture. 2ème. Édition. Paris: Librairie D’Architeture Ducher et Fils, [1900], il., fototipia, litografia, $\mathrm{p} \& \mathrm{~b}$.

- Devantures et installations de Magasins. Paris: Éditions D'Art Charles Moreau, [1930], il., fotografia?, p\&b.

- Die Deutsche Villa. I. Serie, 50 Tafeln. Entwürfe und Bauausführungen von C. Schick, Avanzo \& Lange, G. Hauberrisser, Kayser \& von Groszheim, H. Grisebach, E. Bischoff u. A. Berlin: Verlag von C.H. Claesen \& Cie. [ Hessling \& Spielmeyer, o.J., 1900], plantas baixas atribuídas a diversos arquitetos, heliotipia ? incompleto?

- Die Entwicklung Der modernen friedhofsanlagen und der Verschiedenen Bestattungsarten vom standpunkte der technik und Hygiene. Nebst anhang: Idealprojekt einer Zentralfriedhofs - Anlage für die Stadt Warschau. Mit Zwölf Tafeln in lichdruck von Dr. Techn. Stefan Fayans, Ingenieur, Architekt. Wien: Verlag Anton Schroll \& Co., 1905, il., p\&b.

- Die Neuzeit. Leipzig: Verlag Baumgärtner s Buchhandlung, [1900], fotografias?, folhas avulsas.

- DUMONTHIER, E. Bois de Siège par E. Dumonthier. Paris: Éditions Charles Massin, s.d., il., p\&b, sem capa.

- École Spéciale des Travaux Publics de Batiment et de l'Industrie. M. Léon Eyrolles C, I. Ingénieur-Director. Enseignement par correspondence. (L'École chez boi). A e D. Garnitures cuivre Louis XVI e XV Style Empire de Fenêtres, ébénisterie, bois plint, bois doré, baldaquins et couronnes, baldaquins et décor de lits. S.l: S.n., 1926?, il., p\&b, desencadernado.

- El autógrafo Americano. Coleción de fac-símiles Americanos notables en las ciências, las letras, las artes e la política. Buenos Aires: Editor F. Lagomaggiore, 1874, carimbo LAO 2 maio [19]30

- Ensembles nouveaux. Paris: Éditions D'Art Charles Moreau, [circa 1930], il., fototipia, p\&b.

- Fábrica de Móveis de Antonio Demosso, São Paulo. Meubles de Style Moderne. Exposition Universelle de 1900. Sections Française et Étrangères, publié sous la Direction de TH. Lambert Architecte. Charles Schmid Éditeur/ Wierner Vorlagen für moderne Bautischrerei. Haus Thore Zimmer und Salon Thüren, Plafonds wandverkleidungen, Lademvorbauten, Glasverschläge und berge.Zumeist im 
barockstyl. Entworfen und Gezeichret von Anton Novak architekt, 36 Blatt Lithographie Wien. Kunstverlag Anton Schroll \& C. S.l.: s.d., il., color., p\&b, carimbo Marcenaria e carpintaria de Demosso Antonio. Rua Brigadeiro Tobias, 100, antiga Alegre, São Paulo; algumas pranchas referentes a Gerlach és Schenk Budapest Bécs, Mibr talapok.

- Farbige Raumkunst Auswahl land MIT 80 Farbigen Rautmentwürfern Moderner Künsteller aus den Vergriffenen Banden I-IV der "Farbige Raumkunst”. Stuttgart: Julius Hoffmann Verlag, 1930, (Bauformen Bibliotethek), vol. 28, il., p\&b

- FERRARI, Giulio. Gli Stili nella Forma e nel colore. Rassegna dell'arte ântica e moderna di tutti il Paesi. Volume I. Egiziano, Caldeo-assiro, Fenício, Egeo, Greco, Etrusco, Romano, Estremo Oriente. 48 Tavole. Torino: Società Italiana Di Edizioni Artistiche C. Crudo \& C., [1925], vol. 1, il., color.

- FERRARI, Giulio. Gli Stili nella Forma e nel colore. Rassegna dell'arte ântica e moderna di tutti il Paesi. Volume III. Românico Gótico. 50 Tavole Torino: Società Italiana Di Edizioni Artistiche C. Crudo \& C., [1925], vol. 2, il., color.

- FERRARI, Giulio. Gli Stili nella Forma e nel colore. Rassegna dell'arte ântica e moderna di tutti il Paesi. Volume III. Cristiano, Primitivo, Bizantino, Arabo. 40 Tavole. Torino: Società Italiana Di Edizioni Artistiche C. Crudo \& C., [1925], vol. 3, il., color.

- FERRARI, Giulio. Gli Stili nella Forma e nel colore. Rassegna dell'arte ântica e moderna di tutti il Paesi. Volume IV. Rinascimento in Itália. Il Quatrocento. 48 Tavole Torino: Società Italiana Di Edizioni Artistiche C. Crudo \& C., [1925], vol.4, il., color.

- Ferronnerie de Style Moderne. Motifs Éxécutes en France et a l'étranger. Paris: Charles Schmid Éditeur, [circa 1910], il., heliotipia, p\&b

- Ferronnerie de Style Moderne. Motifs Éxécutes en France et a l'étranger. 2e. série. Paris: Charles Schmid Éditeur, [circa 1910], il., heliotipia, p\&b.

- FLEURY, Gaston. Le Fer Forgé dans la Décoration Moderne. Extérieurs et Intérieurs. Paris: Charles Massin, Éditeurs, 1925, il., heliotipia? p\&b, ex.1.

- FLEURY, Gaston. Le Fer Forgé dans la Décoration Moderne. Extérieurs et Intérieurs. Paris: Charles Massin \& Cie., 1925, heliotipia?, p\&b, ex.2, incompleto, desencadernado.

- FRULlinI, L. Panneaux et ornements. Bois Scpulte par L. Frullini. Paris: A Calavas Librairie Éditeur, 1884, il., fotografia?, p\&b. 
- Furniture in England. Preface by Francis Lenyson. London. September, 1914, il., p\&b, impresso, sem capa. Edinburgh: The Darien Press?, il., $\mathrm{p} \& \mathrm{~b}$.

- GUÉDY, Henry. La Decoration Picturale au XX Siècle. [Henry Guédy del. Et direx. ] Paris: A. Guérinet, 1905, pranchas avulsas col., com carimbo Liceu 1930

- GÉLIS, Paul. Le Mobilier Alsacien. Paris: Charles Massin, Éditeurs, 1926, il., heliotipia?, p\&b.

- GERMAIN, Alphonse. Le Mobilier Breton. Ensembles et Détails. Paris: Charles Massin, Éditeurs, 1925, (Collection D'Art Régional en France), il., heliotipia?, p\&b.

- Grabdenkmäler. Aufnahmen und Entwürfe von leicht ausfürbaren, Modernern und stilgerechten. Grabmonumenten. Für Bildhauer und Steinmetzen herausgegeben von Max Schlosser, architekt in Ravensburg und Eugene Zink, architekt und lehrer ander Königi. Baugewerkschule in München. 2 Auflage. Ravensburg: Verlag Otto Maier, s.d., 2a Auf., il., p\&b.

- GUÉVREKIAN, Gabriel. Batiments Industriels présenté par G. Guévrekian. L'Art International D'Aujourd'hui, 19. Paris: Éditions D’Art Charles Moreau, [1920], il., fotografia?, p\&b.

- Habitations à bon marché. Concours de 1901. Blocs ou maisons collectives a étages. Petites maisons familiales. Librairie Spéciale D'Architecture. Médaille d'or à l'Exposition Universelle de Paris 1900. Dourdan: E [mile] Thézard Fils. Éditeur, [1901], il.,fotografia?, plantas baixas, p\&b, desencadernado.

- Handzeichnungen alter meister aus der Albertina und Anderen Sammlungen. Erster Band. Herausgegeben von Ios Schönbrunner, Galerie Inspector \& Ios Meder. Seiner Kaiserlichen und Königlichen Horeit Dem Hernn Erzherzog Friedrich in Tiefster Ehrfurcht Zuggeeignet I. Wien: Gerlach \& Ferdinand Schenk Verlag für Kunst und Kunstgewerbe, 1896, 8 vol. il., color., carimbo LAO 13 JUN [19]30. - Holländische Möbel und Raumkunst von 1650 - 1780. Herausgegeben von Dr. C. H. de Tonge. Eingeleitet von Dr. W. Volgelgang mit 434 Abbildungen. Band XIII. Stuttgart: Julius Hoffmann Verlag, [1922], (Bauformen Bibliotethek), vol. 13, il., p\&b.

- Hôtels de Voyageurs. Paris: Éditions D’Art Charles Moreau, [1925], vol.2, il., fotografia?, p\&b. 
- HUNTER, George Leland. Italian Furniture and Interiors with text by George Leland Hunter. 200 plates. Volume I. London: B. T. Batsford Ltd., [1920], il., p\&b.

- [Il Disegnatori italiano. Studi progressivi. Carlos Aliprandi Editore [Milano: [Carlos Aliprandi Editore, [1898], 1 fl., s.l., p\&b, impresso, não planificado.

- Inside 100 homes by Mary Fanton Roberts. Thanks to Art and Decoration. New York: Robert M. Mc Bride \& Company, 1936, il., fotografia, p\&b.

- Intérieurs I. Pierre Chareau, Francis Jourdain, J. Ruhlmann, Süe et Mare. 58 planches publiées sous la Direction et avec une introduction de Léon Moussinac. Librairie Centrale des Beaux- Arts. Paris: Éditions Albert Lévy. 1924, (Collection Documentaire d'Art Moderne), vol. 1, il., fotografia, $\mathrm{p} \& \mathrm{~b}$.

- Intérieurs II. Dominique, Dufréne, René Gabriel, André Groult, Foubert et Petit, Rob. Mallet-Stevens, F. Nathan. 52 planches publiées sous la Direction et avec une introduction de Léon Moussinac. Librairie Centrale des Beaux- Arts. Paris: Éditions Albert Lévy, 1924, (Collection Documentaire d'Art Moderne), vol. 2, il., fotografia, p\&b.

- Intérieurs III. Djo Bourgeois, Mme. Chauchet, Guilleré, Fréchet, M. Guillermard, René Herbst, E. Kohlmann, M. Matet, Lucie Renaudot. 53 planches publiées sous la Direction et avec une introduction de Léon Moussinac. Librairie Centrale des Beaux- Arts. Paris: Éditions Albert Lévy, 1924, (Collection Documentaire d'Art Moderne), vol. 3, il., fotografia, p\&b.

- Intérieurs et Ameublements Modernes. Préface de Waldemar George. Paris: Éditions Eugène Moreau, 1927, il., p\&b.

- Intérieurs Français au Salon des Artistes Décorateurs en 1926. Présentés par Maurice Dufréne. Paris: Charles Moreau, 1926, il., heliotipia, p\&b.

- Intérieurs Français au Salon des Artistes Décorateurs. Presenté par Paul Follot. Paris: Charles Moureau Éditeur, 1927, il., fototipia, p\&b.

- Intérieurs au Salon des Artistes Décorateurs en 1928. Présentés par René Prou. Paris: Éditions D’Art Charles Moreau, 1928, il., color., fotografia?, p\&b.

- Intérieurs au Salon des Artistes Décorateurs en 1929. Présentés par Léon Bouchet aux Éditions D'Art Charles Moreau. Paris: Charles Moreau, 1929, il., color., fotografia?, p\&b. 
- Intérieurs présenté au Salon des Artistes Décorateurs. Paris: Éditions D'Art Charles Moreau, 1930, il., fotografia, color.

- Intérieurs au Salon des Artistes Décorateurs en 1931. J. Hiriart. Paris: Éditions D’Art Charles Moreau, 1931, il., fotografia?, p\&b.

- Intérieurs au Salon des Artistes Décorateurs en 1932. Présentés par P. Montagnac. Paris: Éditions D'Art Charles Moreau, 1932, il., color., des., fotografia?, p\&b.

- JANNEAU, Guillaume. Le Luminaire et les moyens D'Éclairages Nouveaux. Exposition Internationale des Arts Décoratifs et Industriels Modernes, Paris, 1925. 1ere. série. Paris: Éditions D'Art Charles Moreau, 1925, il., color., ex. 1.

- JANNEAU, Guillaume. Le Luminaire et les moyens D'Éclairages Nouveaux. Exposition Internationale des Arts Décoratifs et Industriels Modernes, Paris, 1925. 1ere. série. Paris: Éditions D’Art Charles Moreau, 1925, il., color., ex. 2.

- JANNEAU, Guillaume. Le Luminaire. Procedes D'Éclairages nouveaux. Paris: Éditions D’Art Charles Moreau, 1925, il., fotografia?, p\&b.

- JOURDAIN, M. English Decoration and Furniture of the Early Renaissance 1500-1650. The Library of Decorative Art. An account of its development and characteristics by M. Jourdain. London: B. T. Batsford Ltd., [1924], il., p\&b.

- JOURDAIN, Francis. Intérieurs. Présenté par Francis Jourdain. L'Art International D'Aujourd'hui, 6. Paris: Éditions D'Art Charles Moreau, [1920], il., color., fotografia, p\&b.

- JOURDAIN, M. English Decoration and Furniture of the later XVIII Century 1760-1820. The Library of Decorative Art. An account of its development and characteristics by M. Jourdain. London: B. T. Batsford Ltd., [1924], il., p\&b.

- JOURDAIN, M. English Interiors in Smaller Houses. From the Restoration to the Regency 1660-1830 by M. Jourdain. London: B. T. Batsford Ltd., [1924], il., p\&b.

- KLIMSCH, Carl. Monogramme, entworfen und ausgeführt von Carl Klimsch. Frankfurt A/M: Kunst Verlag von Klimsch \& Co., [1870], il., p\&b.

- KOCH, Alexander. Das Haus eines Kunst- Freundes. Architektur Immerraüme gemälde- Plastiken. Haus Alexander Kock. Darmstadt. Verlagsanstalt alle rechte vorbehalten. Darmstadt: Alexander Koch, G.M.B.H, 1926, il., fotografia?, p\&b, del., color. 
- L'Architettura Arabo-Normanna e il Rinascimento in Sicilia Milano: Casa Editrice D’Arte Bestetti e Tumminelli, 1913, il., heliocromia, em carpeta.

- L'Architettura degli Edifizi Moderni in Itália. 40 tavole e 38 plante. Torino: Editrice D'Opere Tecniche Gerardo Molfese, s.d., vol.1, il., em carpeta.

- L'Architettura Pratica Disegni di Edifizi Rispondenti ai Bisogni Moderne. Casa Operaie, anno II, fase 12e. Torino: Tipo. Lit. Camilla e Bertolero Editori, [1897], il., p\&b.

- L'Art Décoratif Français 1918- 1925. Récueil de Documents parus dans la Révue Art et Décoration publiées avec une introduction de M. Léon Deshairs, rédacteur en chef de Art et Décoration, conservateur de la Bibliothéque de 1'Union Centrale des Arts Décoratifs et une préface de M. Ferrand David, Comissaire générale de L'Exposition Internationale des Arts Décoratifs et Industriels Modernes. Librairie Centrale des Beaux- Arts. Paris: Éditions Albert Lévy, [1925], il., fotografia, p\&b.

- La décoration des intérieurs au XVIIIe siècle: motifs d'architecture, de sculpture et de peinture exécutés sous les époques Louis XV, Louis XVI et Empire: choix de documents inédits, recueillis dans les anciens hôtels de Paris, le Faubourg Saint-Germain. Librairie Générale de L'Architecture et des Arts Décoratifs. Paris: Charles Schmid Éditeur, 1908, il., fototipia, p\&b.

- La Décoration et L'Ameublement à L'Exposition de 1900. Série: La Peinture Décorative. Publiés par Armand Guérinet, Libraire Éditeur des Musées Nationaux. Paris: [Armand Guérinet Éditeur ], 1901] il., heliotipia, p\&b.

- Lavori Stipetteria. Porte. Portoni. 42 Tavole. Torino: Società Italiana di Edizioni Artistiche C. Crudo \& C., [1927], il., fotografia?, p\&b.

- ROUSSEL, Jules Adolphe. Le Château de Blois. Extérieures et Intérieurs. Cheminées. Détails de sculpture. Notice par J. Roussel, Sécretaire du Musée de Sculpture de Trocadéro. Publiés par Armand Guérinet, Éditeur des Musées Nationaux, Librairie a Paris. Paris: Armand Guérinet Éditeur, s.d., il., heliotipia, p\&b.

- Le Costruzioni Moderne in Italia. Facciate di Edifici in Stile Moderno. Milano. Tavole in Eliotipia. Torino: Società Italiana di Edizioni Artistiche C. Crudo \& C., 1910, vol.1-2, il., heliotipia, p\&b, em carpeta que agrupa os 2 vols. 
- Le Costruzioni Moderne in Itália. Facciate di Edifici in Stile Moderno. Genova. 60 Tavole in Eliotipia. Torino: Società Italiana di Edizioni Artistiche C. Crudo \& C., 1910., il, heliotipia?, p\&b, ex.1, em carpeta.

- Le Costruzioni Moderne in Itália. Facciate di Edifici in Stile Moderno. Genova. 60 Tavole in Eliotipia. Torino: Società Italiana di Edizioni Artistiche C. Crudo \& C., 1910, il, heliotipia?, p\&b, ex.2, em carpeta .

- Le Costruzioni Moderne in Itália. Facciate di Edifici in Stile Moderno. Torino. 60 Tavole in Eliotipia. Torino: Società Italiana di Edizioni Artistiche C. Crudo \& C., 1910, il, heliotipia?, p\&b, em carpeta.

- Le Garde- Meuble. Collection de meubles. [Par Desire Guilmard]. Publié par Vv. Maincent. Droits de reproduction reserves. Imp. Monroq à Paris. Étofjes soieries, nouveaux brochés, brvetés S.G.D.G de la Mon. Boyer et Cie., Lariche lith. Paris: Vve, Maincent Oficier d'Academie, s.d., il., p\&b, [1 ed. 1860], pranchas $\mathrm{n}^{\circ} 318,326,375,376,378,379,380$ desencadernado.

- Le Meuble D'Art dans les Collections particulières. Paris: Librairie Génèrale de L'Architecture et des Arts Décoratifs. Paris: Charles Massin, Éditeurs, s.d., il., heliotipia?, p\&b.

- Le Mobilier en France aux XVII et XVIII siècles. Paris: Armand Guérinet Éditeur, s.d., il., p\&b.

- Le Mobilier National. Reproduction des Meubles exposés dans le Salles du Mobilier des XVIIe. et XVIIIe. siècles au Musée du Louvre. Meubles des époches Louis XIV, Louis XV, Louis XVI, Ier. Empire. Nouvelle série publié par Armand Guérinet Éditeur. Librairie D'Art Décoratif. Paris: Armand Guérinet, 1920, il., p\&b.

- Le Mobilier National. Reproduction des objets d'art. Réunis à la 7e. Exposition de L'Union Centrale des Arts Décoratifs. Collection du Musée du Garde-Meuble National, objets d'art des châteaux de Fontainebleau, de Versailles, de Trianon et de Compiègne. Depuis Louis XIV jusqu'à L'Empire. Librairie D'Art Décoratif. Paris: Armand Guérinet, [1882], il., p\&b.

- LECLERC, Léon. Le Mobilier Normand. Ensemble et Détails. Paris: Charles Massin, Éditeurs, 1928, (Collection De L'Art Régional en France), il., heliotipia, p\&b.

- LEFOL, Gaston. Hotels Particuliers. Intérieurs Décoration et Ameublement. Vestibules, Chambres, Salons, Salles a manger. Bibliothèque Documentaire de L'Architect. Publiée sous la Direction de Gaston Lefol, Architecte Diplomé par le gouvernement. Librairie 
Générale de L'Architecture et des Arts Décoratifs. Paris: Charles Massin Éditeurs, [1925], il., heliotipia, p\&b.

- Les Grandes Palais de France. Le Mobilier des Palais de Versailles et des Trianons. Meubles styles Louis XIV, Louis XV, Louis XVII et Empire. Paris: Librairie Centrale D'Art et D'Architecture Ancienne Maison Morel, Ch. Eggimann Succr., [1911], il., fotografia?, p\&b.

- Le Palais de l'Élysée, Décorations Intérieurs. Les clichés de cette Monographie ont été éxécutés par la Société Ouvrière. Paris: Armand Guérinet Éditeur, s.d., il., heliotipia, p\&b

- Le Portefeuille Pratique du Tapissier Parisién, 2e. partie. Dessins de Tentures modernes avec coupes détails et texte explicatif. Publié par E. Maincent, Successeur de D. Guilmard. Paris: E. Maincent, s.d., il., p\&b, 34 pranchas.

- Le Salon du Mobilier. Exposition 1905. Paris: Armand Guérinet Éditeur, 1905, 15 vol. 1, il., heliotipia, p\&b

- Les Sièges des Palais et Musées Nationaux du Musée des Arts Décoratifs, etc., etc. (sic). Écrans, Petits meubles, XVIe, XVIIe, XVIIIe siècles et Premier Empire. Des Palais et Musées Nationaux et Collections Celébres. Librairie D’Art Décoratif. Paris: Armand Guérinet Éditeur, [19--], il., fototipia, p\&b, ex. 1.

- Les Sièges des Palais et Musées Nationaux du Musée des Arts Décoratifs, etc., etc. (sic). Écrans, Petits meubles, XVIe, XVIIe, XVIIIe siècles et Premier Empire. Des Palais et Musées Nationaux. Collections Celébres. Deuxième série. Librairie D'Art Décoratif. Paris: Armand Guérinet Éditeur, [19--], il., fototipia, p\&b, ex. 2.

- Les Sièges des Palais et Musées Nationaux du Musée des Arts Décoratifs, etc., etc. (sic). Sièges et petits meubles Anciens. Tables de planches. 1 Fauteuil époque du Directoire Des Palais et Musées Nationaux Collections Celébres. Librairie D'Art Décoratif. Paris: Armand Guérinet Éditeur, [19--], fototipia, il., p\&b.

- Les Sièges des Palais et Musées Nationaux du Musée des Arts Décoratifs, etc., etc. (sic). Écrans, Petits meubles, XVIe, XVIIe, XVIIIe siècles et Premier Empire. Des Palais et Musées Nationaux. Collections Celébres. 4ème. série. Librairie D'Art Décoratif. Paris: Armand Guérinet Éditeur, [19--], il., fototipia, p\&b.

- Les Sièges des Palais et Musées Nationaux du Musée des Arts Décoratifs, etc., etc. (sic). Petits meubles de salon. Anciens ou imités de l'Ancien. en bois sculpté. Styles Louis XIV, Louis XV, Louis XVI. Librairie D'Art Décoratif Paris: Armand Guérinet Éditeur, [19--], il., fototipia, p\&b. 
- LENYSON, Francis. Decoration in England from 1660-1770 by Francis Lenyson. [The Library of Decorative Art]. London: B. T. Batsford Ltd., [1921], il., p\&b.

- LENYSON, Francis. Furniture in England from 1660-1760 by Francis Lenyson. London: B. T. Batsford Ltd., [1921], il., p\&b.

- Les Formes Architecturales de L'Antiquité Classique. Considerées spécialment sous le rapport des ordres et des moulures et profils. Ouvrage publié avec le concours du Gouvernement ducal de BrunswickLunebourg par Constantin Uhde, ancien professeur de la "Technische Hochschuele "de Brunswick. Sélon de édition, revues et augmentée par R. Phené Spiers, F.S.A., F.R.I.B.A, correspondant de la Societé Centrale des Architectes de Paris, membre honoraire de "The American Institute of Architrects (sic)", etc. 76 planches en couleur, photo-litographie et heliotypie avec texte explicatif, 1909. Librairie D'Architecture et D'Arts Décoratifs et Industriels. Berlin: Bruno Hessling, G.M.B.H., 1909, il., foto-litografia, heliotipia, color., p\&b .

- Lieferung 83 (Tafel 553-558). Moderne Vorlagen in jugendstil. 6 Tafeln in Folio. Entworfen von Konrad Wiederhold, Leipzig: Verlag von E. Haberland, [1930], il., p\&b, 6 pranchas, incompleto?

- LIĖVRE, Édouard. Les arts Décoratifs A Toutes les Époques par Édouard Lièvre. Tome Premier. Paris: Vve. A. Morel e Cie. LibrairiesÉditeurs, 1870, il., color., desencadernado.

- LIĖVRE, Édouard. Les arts Décoratifs A Toutes les Époques par Édouard Lièvre. Tome Deuxième. Paris: Vve. A. Morel e Cie. LibrairiesÉditeurs, 1870, il., color., desencadernado.

- LOCKWOOD, Luke Vincent. Colonial Furniture in America by Luke Vincent Lockwood. New and greatly enlarged edition with eight hundred and sixty-seven illustrations of representative pieces. Volume I. New York: Charles Scribner's Sons, 1911, vol.1, il., p\&b.

- LOCKWOOD, Luke Vincent. Colonial Furniture in America by Luke Vincent Lockwood. New and greatly enlarged edition with eight hundred and sixty-seven illustrations of representative pieces. Volume II. New York: Charles Scribner's Sons, 1911, vol.2, il., p\&b.

- Louis XIV und Régence Raumkunst und mobiliar. Herausgegeben von Seymour de Ricci mit 414 Albbildungen. Band XXIV. Stuttgart: Julius Hoffmann Verlag, 1929, (Bauformen Bibliotethek), vol. 24, il., fotografia, $p \& b$. 
- MALLET-STEVENS, Robert. Grandes Constructions 1. Présenté par Rob[ert] Mallet-Stevens. L'Art International D'Aujourd'hui. Paris: Éditions D'Art Charles Moreau, [1920], 2 vol., il., fotografia?, p\&b.

- MARX, M. Roger. Les Médailleurs Modernes en France et à l' étranger. Les Médailleurs Modernes à L'Exposition Universelle de 1900. Récueil de 327 médailles françaises et étrangères publié sous la direction et avec une préface de Roger Marx, Inspecteur Général du Ministère des Beaux-Arts, Paris. Bibliothèque des Peintres et des Décorateurs (tirage a 500 exemplaires numérotés). Paris: Librairie Renouard. Henri Laurens Éditeurs, [1900], exemplaire no 36, p\&b.

- MAZZUCOTELlI, Alessandro. I Ferri Battuti di Allesandro Mazzucotelli. Prefazione di Ugo Ojetti. Milano: Casa Editrice Bestetti e Tumminelli, [19--]., il., heliocromia, p\&b

- MELANI, Alfredo. [Desenhos] Milano: Ulrico Hoepli Editore, s.d., il., desenhos, p\&b, impresso, desencadernado, sem capa.

- MELANI, Alfredo. L'Arte Nell'Industria. Indici per la collocazione delle Tavole e dei particolari nel volume Primo, Atlante. Milano: Casa Editrice Dott. Francesco Vallardi, [1902-1912], vol.1, il., color., p\&b.

- MELANI, Alfredo. L'Arte Nell'Industria. Lavori di Legno e pastiglia. Lavori di metallo. Lavori di Pietra, marmo, alabastro, cerâmica, mosaico, vetro. Lavoro di osso e avorio. Lavore Tessili. Carte da Pasati e cuoi decorati. Ricami, Pizzi, Cartelloni, Stampe, ecc. (sic). Volume I (testo) com 410 figure nel texto 160 tavole in Nero e in colori e 7 particolari grandi Milano: Casa Editrice Dott. Francesco Vallardi, Stablimenti Riuniti d'Arte Grafiche, [1902-1912], vol.1, il., color., p\&b.

- MELANI, Alfredo. L'Arte Nell'Industria. Lavori di Legno e pastiglia. Lavori di metallo. Lavori di Pietra, marmo, alabastro, cerâmica, mosaico, vetro. Lavoro di osso e avorio. Lavore Tessili. Carte da Pasati e cuoi decorati. Ricami, Pizzi, Cartelloni, Stampe, ecc. (sic). Volume II (testo) com 405 figure nel texto 73 tavole in Nero e in colori e 13 particolari grandi. Milano: Casa Editrice Dott. Fransceco Vallardi, Stablimenti Riuniti d'Arte Grafiche, [1902-1912], vol.2, il., color., p\&b.

- MELANI, [Alfredo]. L'Arte nell'Industria. Volume I. Milano: Casa Editrice Dr. Francisco Vallardi, Proprietá Artística, [1902-1912], il., desenho, p\&b, 18 pranchas, desencadernado, incompleto?

- MELANI, [Alfredo]. L'Arte nell'Industria. Volume II. Milano: Casa Editrice Dr. Francisco Vallardi, Proprietá Artística, [1902-1912], il., desenho, p\&b, 9 pranchas numeradas, incompleto? 
- MELANI, Alfredo. Raccolta di mobili Moderni D'Arte Italiana. 100 tavole com circa 300 Modelli. Ambienti e mobili, Isolati, Eseguiti. O no. Sviluppi, Geometrici, in Iscala com piante. Sezioni particulari. Milano: Ulrico Hoepli, [1913], (Collezione Artistica Hoelpli), il., fotografia, p\&b.

- MESTICA, A. Motivi Ornamentali. N. 20 Tavole a lápis a pena e a due colori. Firenze: Giuseppe Giotti Editore, 1910.

- Meubles de Style Moderne. Fábrica de Móveis de Antonio Demosso, São Paulo, carimbo Marcenaria e carpintaria de Demosso Antonio, Rua Brigadeiro Tobias, 100, antiga Alegre, São Paulo.

- Meubles du jour. 6ème série. Paris: Éditions Eugène Moreau, [1920], il., $\mathrm{p} \& \mathrm{~b}$.

- Meubles du Temps présent. Présenté par Maurice Dufréne chez Eugène Moreau. Paris: Éditions Eugène Moreau, 1930, il., fotografia?, p\&b, ex. 1.

- Meubles du Temps présent. Présenté par Maurice Dufréne chez Eugène Moreau. Paris: Éditions Eugène Moreau, 1930, il., fotografia?, p\&b, ex. 2.

- Meubles et Ameublements de Style Moderne publiés sous la direction de Théodore Lambert, Architecte. Paris: Charles Schmid Éditeur, [1900], il., p\&b.

- Meubles de goût moderne. Première série. Chambres a coucher. Salons de manger par un groupe de Dessinateurs Parisiens. Librairie Industrielle et D'Ameublement. Paris: Charles Moreau Éditeur, [1925], il., heliotipia, p\&b.

- Meubles Flamands du XIVème au XVIIIème siècle, lère série. Bruxelles: Louis Le Blanc Éditeur, s.d., il., fotografia?, p\&b.

- Meubles Flamands du XIVème au XVIIIème siècle, 2ème série. Bruxelles: Louis Le Blanc Éditeur, s.d., il., fotografia?, p\&b.

- Meubles Flamands du XIVème au XVIIIème siècle, 3ème série. Bruxelles: Louis Le Blanc Éditeur, s.d., il., fotografia?, p\&b.

- Meubles. L'Art International D’Aujourd'hui. Présenté par Pierre Chareau Paris: Éditions D'Art Charle Moreau [1920].

- Meubles modernes de Bon Goût. Paris: Éditions D’Art Charles Moreau, [1925], il., p\&b.

- Meubles modernes. 7ème. Série. Paris: Éditions D'Art Charles Moreau, [1930], il., p\&b.

- MINNUCI, Gaetano. Scuole. Asili d'Infanzia, Scuole All Aperto Elementari e Medie, Case del Balilla. Palestre e Impianti Sportivi. Prefazione di S.E. L' Architetto Marcelo Piacentini. Criteri, dati, esempi per la progettazione per la costruzione e l' arredamento. 
Quattrocentocinquantasei figure e piante. Milano: Ulrico Hoepli Editore, 1936, il., p\&b, 277 p., desencadernado.

- Möbel und Raumkusnt in England 1680-1800. Herausgegeben von G.M. Elwood. Zweiter Band. Stuttgart: Julius Hoffmann Verlag, 1929, (Bauformen Bibliotethek), il., p\&b.

- Modern American Sculpture. Edited by Sadakichi Hartmann; 60 plates. Published by Paul Wenzel, Publisher of Architectural and Art Industrial books. New York: The Architectural Book Publishing Company, [década de 1920].

- Monographie du Musée de Cluny. Époques Gothique, Renaissance, Louis XIII a Louis XV. 1er. partie. Meubles e Bois Sculptés. Publié par Armand Guérinet Éditeur, Paris: Armand Guérinet Éditeur, s.d., il., p\&b.

- Monographie du Palais de Compiège 2ème série. Meubles, Bronzes, Décorations. Librairie de Armand Guérinet Éditeur. Paris: Armand Guérinet Éditeur, s.d., il., heliotipia, p\&b.

- Monographie du Palais de Fontainebleau. Décorations Intérieurs et Extérieures. Notice par Jules Roussel, Conservateur- Adjoint du Musée de Sculpture Comparée du Trocadéro. Aile Louis XV, Appartements réservés, 5e. série. Décorations Intérieurs, Mobilier. Époques Louis XV, Louis XVI, Premier Empire. Librairie D'Architecture et D'Art Décoratif. Paris: Armand Guérinet Éditeur, s.d., il., heliotipia, p\&b.

- Monographie du Palais de Fontainebleau. Décorations Intérieurs et Extérieures. Troisième partie. Le Mobilier. Époches Premier Empire, Louis XVI, Louis XV, Louis XIV, Louis XII. Librairie D'Architecture et D’Art Décoratif. Paris: Armand Guérinet Éditeur, s.d., il., p\&b.

- Monographie du Palais de Fontainebleau. Décorations Intérieurs et Extérieures. Meubles d'art des époches, Louis XIV, Louis XV, Louis XVI et Premier Empire des Collection Richard Wallace à Londres. De la Collection Dutuit au Petit Palais des Beaux-Arts à la Ville de Paris. Des Collection du Musée des Arts Décoratifs. Exposées au Pavillon de Marsan. Librairie D'Architecture et D'Art Décoratif. Paris: Armand Guérinet Éditeur, s.d., il., p\&b.

- Monographie des Palais de Versailles et des Trianons Paris: Armand Guérinet Éditeur, [1899-1910], il., p\&b, pranchas avulsas, desencadernado.

- MORETTI, Bruno. Ospedali. 91 Esempi illustrati in 292 Tavole con 300 piante e disegno. Milano: Ulrico Hoelpi, 1935. 
- Município di Genova. Ufficio di Belle Arti. Gli Affreschi nei Palazzi di Genova. 50 Tavole. Raccolte e ordinate con testo esplicativo da Orlando Grosso. Milano: Preiss, Bestetti e C. Editore, [1910], il., p\&b.

- Nouveaux intérieurs Français. lère série. Paris: Éditions D'Art Charles Moreau, [1933], il., heliotipia, p\&b.

- Nouveaux intérieurs Français, 2ème série. Paris: Éditions D'Art Charles Moreau, [1934], il., heliotipia?, p\&b.

- Nouveaux intérieurs Français, 3ème série Paris: Éditions D’Art Charles Moreau, 1935, il., heliotipia?, p\&b.

- Nouveaux intérieurs Français. 4ème série Paris: Éditions D’Art Charles Moreau, 1936, il., heliotipia?, p\&b.

- Nouvelles Constructions de Nancy: Recueil de façades de Style Moderne édifiées a Nancy par MM. André, Bentz, Biet, Bourgon, César, Gutton, Hermann, Hornecker, Lanternier, Sauvage, Vallin, Weissenberger. Librairie Générale de L'Architecture et des Arts Décoratifs. Paris: Charles Schmid Éditeur, [1900], il., fototipia, p\&b.

- NOVI, A. Détails D’Architecture Intérieure. Présenté par A. Novi. L'Art International D'Aujourd 'hui, 5. Paris: Éditions D'Art Charles Moreau, [1920], il., fotografia?, p\&b.

- PEDRINI, Augusto. L'Ambiente, Il Mobílio et la Decorazioni del Rinascimento in Itália. Prefazione del Prof. Mario Ceradini, presidente della R. Accademia di Belle Arti, Torino. 645 Illustrazioni. Torino: Casa Editrice Ítala Ars, 1925, il., p\&b.

- PERNIER, Luigi. Il Palazzo Minoico di Festos. R. Istituto D'Archeologia e Storia Dell'Arte. Luigi Pernier. Il Palazzo Minóico di Festòs. Scavi e studi della Missione Archeologica italiana a Creta dal 1900 al 1934. Volume I. Gli Strati più antichi et el Primo Palazzo. Roma: La Libreria Dello Stato, 1935, il., fotografia, color., p\&b.

- PERNIER, Luigi. Il Palazzo Minoico di Festòs. R. Istituto D’Archeologia e Storia Dell'Arte. Il Palazzo Minóico di Festos. Tavole. Questo volume à stato impresso in Roma nel mese di ottobre dell'anno XIII E. F. nelle Officine dell'Istituto Poligrafico Dello Stato in 600 esemplari numerati da I a 600. Roma: La Libreria Dello Stato, 1935, anno XIII, il., color., p\&b, exemplar numerado 208.

- Petites Constructions Françaises par un comité D'Architectes. Librairie Spéciale D'Architecture. Dourdan: Émile Thézard, Éditeur, [1893], il., color. e p\&b, ex.1. 
- Petites Constructions Françaises par un comité D'Architectes. Librairie Spéciale D'Architecture. Dourdan: Émile Thézard, Éditeur, [1893], il., color. e p\&b, ex. 2.

- Petites Constructions Françaises, 2ème volume. Dourdan: E. Thezard Fils. Éditeur, [1893], il., color., desencadernado, sem capa, imcompleto.

- Petites maisons modernes de ville et de campagne récemment construites publiées sous la direction de E. Rivoalen, ancien architecte Départamental. Publication faire d'apres les plans, devis et règlements communiqués par les Architectes suivants Amiard (Clovis) [...] Paris: George Fanchon, Éditeur, [1900], il., color., p\&b, sem capa.

- Petits meubles du jour. Paris: Éditions D’Art Charles Moreau, s.d., il., fototipia, $\mathrm{p} \& \mathrm{~b}$.

- PETTORELli, A. Il Bronzo e il Rame nell'arte Decorativa Italiana. Duecentoventi cinque tavole (400 soggetti). Riproduzioni in parte inedite di opere dal período etrusco all'Epoca Moderna. Texto esplicativo, Studio sulla técnica fusoria e saggio bibliografico di Arthur Pettorelli. Milano: Ulrico Hoepli, 1926, (Collezione Artistica Hoelpli), il., fotografia, $p \& b$.

- RAGUENET, A. Extraits des Monographies de Batiments Modernes par A. Raguenet, architecte. Série Hotel privés. Paris. Librairie D’Art et D’Architecture. Paris: R. Ducher, [1900], il., litografia, p\&b.

- RAGUENET, A. Extraits des Monographies de Batiments Modernes par A. Raguenet, architecte. Série Villas. Librairie D'Art et D'Architecture. Paris: R. Ducher, [1900], il., litografia, p\&b.

- Restaurants, Dancings, Cafes, Bars. Librairie des arts du bâtiment. Paris: Éditions D'Art Charles Moreau, [década de 1930], vol. 1, il., fototipia, p\&b.

- ROBERTS, Mary Fanton. Inside 100 homes by Mary Fanton Roberts. Thanks to Art and Decoration. New York: Robert M. Mc Bride \& Company, 1936, il., fotografia, p\&b, 113 p.

- [RUHLMANN], Émile-Jacques; BADOVICI, Jean. Harmonies. Intérieurs de Ruhlmann. Collection $\diamond$ Documents d rarchitecture». Arts français contemporain. Paris: Éditions Albert Morancé, 1924, il.,color.

- RUSTIA, Giuseppe. El Legno nella pratica moderna. Costruzione di Mobili e Infissi di uso comune e artistico per artigiani e scuole Industriali Professionali e di Avviamento. Texto Weissesplicativo e sessantasette Tavole di Disegni Costrutivi. [Milano]: Editore Ulrico Hoepli, [1930], il., des., p\&b. 
- SADOUL, Charles. Le Mobilier Lorrain. Ensembles et Détails. Paris: Charles Massin, Éditeurs, [1920], (Collection D’Art Régional en France), il., heliotipia?, p\&b.

- Salon des Industries du Mobilier: 3ème salon au Grand Palais des Champs- Élysées. Organisée par les Chambres Syndicales de l'Ameublement, de la Bijouterie, Joaillerie, Orfévrerie, de la Céramique et des Fabricants de Bronze. Paris: Armand Guérinet Éditeur, 1908, il., fototipia, p\&b.

- Salon des Industries du Mobilier: 3ème salon au Grand Palais des Champs- Élysées. Exposition Organisée par les Chambres Syndicales de l'Ameublement au Grand Palais des Champs- Élysées. Reproduction en phototypie des Oeuvres des Principaux Exposants. Meubles D'Art de Époque Louis XIV, Louis XV, Louis XVI et Premier Empire, ler. série. Collections Richard Wallace à Londres. Paris: Armand Guérinet Éditeur, 1908, il., fototipia, p\&b.

- Salon des Industries du Mobilier: 3ème salon au Grand Palais des Champs- Élysées. Juliet à Octobre 1908. Organisée par les Chambres Syndicales de l'Ameublement, de la Bijouterie, Joaillerie, Orfévrerie, de la Céramique et des Fabricants de Bronze. 2ème. série. Paris: Armand Guérinet Éditeur, 1908, il., fototipia, p\&b.

- Salon des Industries du Mobilier: 3ème salon au Grand Palais des Champs- Élysées; Juliet à Octobre 1908. Exposition rétrospective organisée par la Chambre Syndicale des Négociants en Objets D'Art. 3ème. série. Paris: Armand Guérinet Éditeur, s.d., il., p\&b.

- SAUVEUR, Hector. La Décoration Intérieure en France. Intérieurs éxécutés dans le goût moderne. Recueillis et mis en ordre par Hector Sauveur. Paris: Charles Massin, Éditeurs, [192-], il., heliotipia?, p\&b.

- SAUVEUR, Hector. La Décoration Intérieure en France. Intérieurs de Style. Recueillis et mis en ordre par Hector Sauveur. Paris: Charles Massin, Éditeurs, [1910], il., heliotipia?, p\&b.

- SCHOTTMÜLLER, Frida. Wohnungskultur und Möbel der Itallianischen Renaissance von Frida Schottmüller. Band XI. Zweite ungearbeitete auflage mit 590 Abbildungen. Stuttgart: Julius Hoffmann Verlag, [1928] ?, vol. 11, (Bauformen Bibliotethek), il., color.

- Serrurerie Moderne. Ferronnerie de batiment. Paris: Éditions D'Art Charles Moreau, s.d., il., heliotipia, p\&b. 
- Sièges Contemporains. Paris: Éditions D'Art Charles Moreau, [circa 1930], il., fototipia, p\&b.

- SPELTZ, Alexander. Styles of ornament. Exhibited in designs and arranged in historical order with descriptive text...by Alexander Speltz. Translated from the Word German Edition by David O'Conor. 400 full pages illustrations with illustrated descriptive text. New York: Grosset \& Dunlap Publishers, s.d., il.

- STRATTON, Arthur. The English Interior. A review of the Decoration of English homes from Tudor Times to the XIX Century. London: B.T.Batsford Ltd., 1920, il., fotografia, p\&b.

- Style Louis XV. Les Intérieurs et les Boiseries sculptées du Château du Rambouillet. Heliotypie E. LeDeley, Chiclé A. Bourdier, Versailles. Publié par A. Guérinet Éditeur. Librairie d'Art Décoratif. Paris: Armand Guérinet Éditeur, s.d., il., heliotipia, p\&b.

- Theatres Cinemas. Paris: Éditions D’Art Charles Moreau, s.d., vol. 3., il., fotografia?, p\&b.

- Une Ambassade Française. Exposition Internationale des Arts Décoratifs et Industriels Modernes, Paris, 1925. Organisée par la Société des Artistes Décorateurs. Par Paul, Vigier \& Cie., pour les planches héliotypie et par Ducros encouleurs ont été executées par Jean Saudé. Paris: Éditions D’Art Charles Moreau, 1925, il., fototipia, p\&b, des.,color.

- VENTURA, Achille. Particolari di Architettura Classica. Architettura Greca, Romana, Bizantino-Lombarda, Gotica, Cinquecento, Seiscento, Settecento. 91 Tavole. Torino: Società Italiana di Edizioni Artistiche C. Crudo \& C., [1905], il., litografia, p\&b, em carpeta.

- Ville e Villini in Itália. Milano: Casa Editrice D'Arte Bestetti e Tumminelli, [1900], il., helicromia, em carpeta.

- Ville et Villette Moderne. Torino: Società Italiana di Edizioni Artistiche C. Crudo \& C., [1910], il., desenho, color., p\&b, em carpeta.

- WEISS, Egon. The Design of Lettering by Egon Weiss. With an original method for Spacing inscriptions. New York: The Pencil Points Press, Inc., 1932, il., p\&b.

- WELLS, Perry. Design in Wood work. London: B.T. Batsforfd Ltd., [1934], il., selo British Council.

- WYTSMAN, P. Choix d' Intérieurs Belges, Styles Gothique e Renaissance. Bruxelles: S.n., 1902, il., p\&b.

- [Wohnungskultur]. S.l: S.n, s.d., il., p\&b. 


\section{I.1.6 Manuais de politecnia}

- BARNI, Edoardo. Il Montatore Elletricista. Manuale per gli Operai Elettricisti di Impianti Industriali. Ventesima Edizione. Corretta, riveduta e Illustrata com 355 illustrazioni. Milano: Ulrico Hoepli Editore, 1931, il., p\&b.

- Branchen Ausgabe des skizzenbuchs für den praktischen Maschinen constructeur. Ein Hifsbuch für Techniker, sowie für Schüler technischer Lehranstalten. Herausgegeben von W.H. Uhland, Ingenieur und Chefredacteur des «Praktischen Maschinen-Constructeur, [...] in Leipzig. Band XIV. Dach constructionen in Holz und Eisen und Eisenconstructionen wendeltreppen (84 Tafeln nebst text), Leipzig: Verlag von H.A. Ludwig Desiner. Vornort Uhland, 1889, il., desenhos esquemáticos, $\mathrm{p} \& \mathrm{~b}$, impresso, etiqueta $59 \mathrm{E}$.

- -FÁBREGUES, F.; SAAVEDRA, J. M. Manual del cajista de Imprenta. Manuales Gallach, Espasa Calpe S.A. Ilustrado con varias figuras. Primeira Edición. Madrid: Espasa Calpe S.A., 1933, il., color.

- GÖHRE, E. Werkzeuge und Pressen der Stanzerei. Von E. Göhre VDI. Teil I. Werkzeuge zun Schneiden, Biegen und Ziehen. Mit 188 abbildungen auf 62 Tafeln. Berlin: VDI Verlag G.M.B. H, 1935.

- Handbuch der heroldstunft miffenfchaftliche Beiträge zur Deutung der hausmarfer GteinmeB- Zeichnund Mappen mit fprach und fchriftgefchichtlichen Erläuterungen nbeft fulturgefchichtlichen Bilden, Betrachtungen und Forfchungen von Dr. jur. Bernhard Roerner, vorm. Regierungsrat und mitglieb des Agl. BreuBitchen heroldsamtes mit Bild-febftgezeichneten bunten Mappentafeln mit Bild-Unlagen und Ubbildugen Bierter Band Gonnenlauf-heils und Beme-Zeichen Geheime Gchlüffel, 1930. König: Drud und Verlag von. E. U. Gtarfe, 1930, vol.1.

- Handbuch der heroldstunft miffenfchaftliche Beiträge zur Deutung der hausmarfer GteinmeB- Zeichnund Mappen mit fprach und fchriftgefchichtlichen Erläuterungen nbeft fulturgefchichtlichen Bilden, Betrachtungen und Forfchungen von Dr. jur. Bernhard Roerner, vorm. Regierungsrat und mitglieb des Agl. BreuBitchen heroldsamtes mit Bild-febftgezeichneten bunten Mappentafeln mit Bild-Unlagen und Ubbildugen Bierter Band Gonnenlauf-heils und Beme-Zeichen Geheime Gchlüffel, 1930. König: Drud und Verlag von. E. U. Gtarfe, 1930, vol.2. 
- Handbuch der heroldstunft miffenfchaftliche Beiträge zur Deutung der hausmarfer GteinmeB- Zeichnund Mappen mit fprach und fchriftgefchichtlichen Erläuterungen nbeft fulturgefchichtlichen Bilden, Betrachtungen und Forfchungen von Dr. jur. Bernhard Roerner, vorm. Regierungsrat und mitglieb des Agl. BreuBitchen heroldsamtes mit Bild-febftgezeichneten bunten Mappentafeln mit Bild-Unlagen und Ubbildugen Bierter Band Gonnenlauf-heils und Beme-Zeichen Geheime Gchlüffel, 1930. König: Drud und Verlag von. E. U. Gtarfe, 1930, vol.3.

- Handbuch der heroldstunft miffenfchaftliche Beiträge zur Deutung der hausmarfer GteinmeB- Zeichnund Mappen mit fprach und fchriftgefchichtlichen Erläuterungen nbeft fulturgefchichtlichen Bilden, Betrachtungen und Forfchungen von Dr. jur. Bernhard Roerner, vorm. Regierungsrat und mitglieb des Agl. BreuBitchen heroldsamtes mit Bild-febftgezeichneten bunten Mappentafeln mit Bild-Unlagen und Ubbildugen Bierter Band Gonnenlauf-heils und Beme-Zeichen Geheime Gchlüffel, 1930. König: Drud und Verlag von. E. U. Gtarfe, 1930, vol.4.

- Manual para instalaciones electricas de Alumbrado y Fuerza Móbil. Allgemeine Elektricitäts Gesellschaf AEG, Berlin, 1933. 5a . edición. Version española por F. Walbaum según el texto alemán publicado por R. Zaudi. S.l.: S.n., 1933, il., p\&b.

- Manual de manutenção e Catálogo de Peças. Typos 58 C e 32 C. Mecânica pesada. S.l: S.n., s.d., il., p\&b.

- SCHNEIDER, Carlos. Manual del Hojalatero y Plomero por Carlos Schneider, consejero de estúdios de la Escuela de Artes e Ofícios de Stuttgart. Herman Schneider Professor Técnico. Version del aleman por Ricardo Ferrer, Ingeniero Industrial. Barcelona: Gustavo Gili Editor, 1932, etiqueta $49 \mathrm{E}$.

\section{I.1.7 Catálogos comerciais}

- Ameublements, Décorations, Installations. Chambres à coucher. Warring and Gillow Ltd. Paris: Julien Frazier Imprimeur, s.d., il.

- Ameublements, Décorations, Installations. Salles à manger. Warring and Gillow Ltd. Paris: Julien Frazier Imprimeur, s.d., il.

- Ameublements, Décorations, Installations. Salons et Boudoirs. Warring and Gillow Ltd. Paris: Julien Frazier Imprimeur, s.d., il. 
- A M. Bronzes d'art, lustrerie, serrurerie décorative. Modéles créés et édités par A. Mousson, ancien élève des arts décoratifs et de l'école Doull. Paris: S.n., s.d., il., p\&b.

- Austrian Bentwood Furniture Company Ltd. Jacob \& Josef Kohn. Erste Österreichische Aktiengesellschaft. Zur Erzeugung von Möbeln aus gebogenem Holze. Jacob e Josef Kohn. Zentralbureau, Wien. [Wien]: S.n., s.d, il., p\&b, selo Mascot 649, carimbo Ernesto Castro e Co., 1911, jun 1 São Paulo, desencadernado.

- [B. Souto e Co., New York City]. [New York]: S.n., s.d., il., p\&b, sem capa.

- Backnanger Holzwarenfabrik. G.M.B.H. Backnang, (Württbg). [Backnang]: S.n., s.d., il., desenho, p\&b, selo Mascot.

- Baker and Company. Genuine Mahogany Antique Finish. S.l.: S.n. s.d, il., p\&b.

- Batesville Cabinet Company. Dining Room Furniture. Catalogue E. Geo. M. Hillebrand, Pres't e Treas. Jno. A. Hillebrand, vice Pres't A. W. Romweber, Sec'y. Batesville, Indiana. [Batesville]: S.n., s.d., il., p\&b.

- [Beachten Sie das Vorwort]. S.l: S.n. il., p\&b, carimbo Ernesto de Castro e C., june, 11, 1911, São Paulo, desencadernado, sem capa.

- [Bronze I.B Co.]. S.1.: S.n., s.d., il., p\&b, selo Mascot 2607.

- Bronzes d'Eclairage pour L'Electricité. Paris. Mars, 1909, Charles Blanc. ${ }^{\star}$ Paris+: S.n.,1909, il., p\&b, carimbo Charles Banch S. Electricité, 6 juil. 1911, 42 Bould. Richard-Lenoir, Paris, desencadernado.

- Cerraduras e Ferratería Sargent. Herramientas para mecânicos Sargent, V. B. M, 1912. Sargent and Company. Estados Unidos de Norte- América. Officina Principal e Almacenes en New York, 94, Centre Street. [New York]: S.n., 1912, il., p\&b, etiqueta 4 E.

- Construction Décoration et Ameublement de Cottages. Warring and Gillow Ltd. Décorateurs et Fournisseurs de sa Majesté le Roi d'Anglaterre. Devis et Dessins a title grácieux. [Paris]: S.n., s.d., il., p\&b.

- Croci d'altare. S.l.: S.n., s.d., il., p\&b, sem capa.

- [Daguerre \& Cie., 15 rue Martel, Paris]. S.l.: s.d., il., p\&b, desenhos, modelos de móveis, lista remissiva manuscrita em alemão.

- Décorations D' Intérieurs. Au Confortable, 468, rue de Rome, Paris. S.l.: S.n., s.d., il., p\&b, carimbo Liceu de Artes e Ofícios Largo do Jardim da Luz.

- Éditions Nouvelles. Céramiques d'art, Marcel Guillard Vérreries d'art. Quelque Éditons Nouvelles...Editions Etling S. A., 29. rue de Paradis, Paris. S.l.: S.n., 1929., il., p\&b. 
- [Elekrifch XIV G. B\&l. Verkaufs Bedingungen]. S.l.: S.n., s.d., il., p\&b, selo Mascot 3783.

- [Fábrica de Móveis. Modelos Antonio de Mosso]. S.l.: S.n, s.d., il., color., fls. avulsas, etiqueta M6.

- Fontaine \& Cie. E. Fontaine, H. Brost, J. A. Fontaine, G. Chéron. Serrurerie Décorative. Ouvres de R. Prou, Le Bourgeois, Montagnac, A. Groult, présenté par Eric Bagge. Paris: Fontaine \& Cie., 1925, il., fotografia, $\mathrm{p} \& \mathrm{~b}$.

- [Frises et moulures ornées, XVII.e siècle, pl. 29, Ch. Shmid ed.]. S.I: [Ch. Shmid], s.d., 1 fl., s.l., p\&b, impresso, não planificado.

- F. F. F. Frisoni. [Cerâmicas, vasos, fontes, portas-flor, etc.], Genova, 1920, album encadernado, fotografia, p\&b, com lista datilografada, numerada e remissiva de preços e dimensões, etiqueta 38 .

- [G. Baleste e Co. Agente à São Paulo. Maison F. Alexandre] . [Bruxelles]: Imprimerie. J. Delacre et fils, s.d, il., p\&b.

- Hamptons Furniture. Hapmton \& Sons Ltd., Pall Mall East London. [London]: S.n., s.d., il., p\&b.

- [Gesellschaft für Beleuchtungskörper vormais Zeisser Habiger \& Comp. Wien VII. Neustiftgasse 72, 4001-7520]. [Wien], s.d., il., p\&b, selo Mascot no 4120 .

- Ilustraciones de Muebles, Tapiceiros de su majestad El Rey de Inglaterra. Maple e Cia. Londres, Paris, Buenos Aires, Montevideo, Esmirna. S.l.: S.n, s.d., il., p\&b.

- Illustrations de Meubles. Meubles pour antichambres, Bibliothëques, Bureaux et Salles de Conseils, volume I. Maple \& Co. Paris Ltd., rue Boudreau, Paris. [Paris]: S.n, s.d., il., p\&b.

- Illustrations de Meubles. Meubles de Salles ä manger, volume II. Maple \& Co. Paris Ltd., rue Boudreau, Paris. [Paris]: S.n, s.d., il., p\&b.

- Illustrations de Meubles. Appareits d'Eclairage et Articles de Cuivrerie, volume V. Maple \& Co. Paris Ltd., rue Boudreau, Paris. [Paris]: S.n, s.d., il., p\&b.

- Indústria de Tapetes Maratona Ltda. São Paulo, s.d., fotografia, p\&b, etiqueta 40.

- Inhalts Verzeichnis. Bluemenkrippen und Blumentische JardiniëresFlower stands- Mesa para flores. S.l: S.n, s.d., il., p\&b.

- Interiores Interesantes por Maple \& Co., 326, Carlos Pellegrini, Buenos Aires. S.l.: S.n, s.d., il., p\&b. 
- Interieurs. D. G. Fischel Söhne, Wien. Fischel Wien \& Niemes in Bohême, 1911. [Wien]: S.n., [1911], il., color., p\&b, selo Mascot nº 1847.

- Klein möbel zur Ergänzung und Dekoration. Export. S.l.: S.n., s.d., il., p\&b, Mascot no 816, carimbo de Ernesto de Castro e C., jun., 24, 1911, São Paulo.

- [Korbmöbel. T H R. ErsterTeil]. S.l: S.n, il., fotografia, p\&b.

- Lalande. Fabrique et Grandes Magasins D' Ameublement. Maison Lalande, Fondée en 1852. A. Aubron, Successeur, 34, rue de Charenton, Paris. Paris: E. Alix et Cie. Graveurs Imprimeurs, O. Hervé et $\mathrm{H}$. Laemmenhirt Successeurs, s.d., il., fotografia, p\&b, color., carimbo Lyceu 10 ago [19]30.

- Lincrustra- Walton. The Sunbury Wall and Ceiling Decoration. S.1.: S.n., s.d., p\&b.

- Lumières . S.l.: S.n.,s.d., heliotipia, p\&b. etiqueta M1.

- [Lustres] [M.]. S.l.: S.n., s.d., il., p\&b.

- [Lustres]. S.1.: S.n., s.d., il., color., desencadernado, etiqueta M9.

- [Lustres]. S.l.: S.n., s.d., s.l., fotografia, p\&b, desencadernado, etiqueta M11.

- [Mercier Frères, 100 Faubourg Saint Antoine, Paris. Tous nos modéles sont déposés et couverts par la loi contre les copies et contre façons. ]. S.l: S.n, s.d, il., desenho, p\&b.

- Möbelfabrik mit Dampt Detrieb. Rother \& Kunstze Chemnitz. Eine komplette. Albuns et tableaux industriels, Noyer Teinté. S.l.: S.n., s.d., il., p\&b, fotografia, desenho, color., 20 pranchas.

- [Mobiliário inglês]. S.l.: S.n., s.d., p\&b, com lista de preços, desencadernado.

- [Moderne Lampenbehänge]. S.l.: S.n., s.d., p\&b, agrupados, selo Mascot $\mathrm{n}^{\circ} 3410$.

- [Móveis.]. S.l: S.n., s.d., fotografia, p\&b, carimbo M.Cresta \& Co., Hamburg, pranchas, desencadernado, etiqueta M7.

- Mundus. Aktien - Gesellschaft der Vereinigten-Oesterreischischen Bugholzmöbel- Fabriken Wien. Fabriken in Österreich. HeinezendorfTeschen- Buczkowice Drholetz- Niemes. Bodenbach a/ E Mähr Weisskirchen. Registrierte Schtzmarke. Buch und Steindrukeri Brüder Macndl, Wien. [Wien]: S.n., s.d., il., p\&b, com índice dos desenhos, selo Mascot no 585.

- Ornamental Iron \& Bronze. [Elevators enclosures].The W.S. Tyler Company. Cleveland, Ohio. [Ohio]: S.n., s.d., il., p\&b. 
- Ornamental Iron \& Bronze. [Railings]. The W.S. Tyler Company. Cleveland, Ohio. [Ohio]: S.n., s.d., il., p\&b.

- Ornamental Iron \& Bronze. [Store fronts]. The W.S. Tyler Company. Cleveland, Ohio. [Ohio]: S.n., s.d., il., p\&b.

- [Preise ohne Glühlampen]. S.l.: S.n. s.d., il., p\&b, sem capa.

- Price list of Iron and Brass Bedsteads Mattresses, Beding, ect. (sic). Robson \& Sons House Furnishers Ltd., New Castle, Upon-Tyne. [New Castle]: S.n., s.d., il., desenho, p\&b.

- Quality furniture Co. Direct from factory, Michigan. S.l: S.n., s.d., il., p\&b, etiqueta M2.

- [Salon. Styl. Salon, Wohn...]. Modern Wohnungs- Einrichtung. Moderne Salons. Zuz Auswhal. Die gangbaesten und preiswer stenten Modernern. Schlafzimmer in passender Zusammenstellung. Salon und Empfangszimmer. [Tarif]. S.l: S.n, 1891. Möbelfabrik mit Dampt Detrieb. Rother \& Kunstze Chemnitz. Eine komplette. Albuns et tableaux industriels, Noyer Teinté. S.l.: S.n., s.d., il., p\&b, fotografia, desenho, color., 20 pranchas.

- S. Karpen \& Bros. Guaranteed Upholstered Furniture Chicago, New York. Thirty Fifth Annual Catalog. S.l: S.n. 1915, il., p\&b.

- [S.B.F. Die angesebenen Höhen beziehen sich auf die Schilder]. S.l.: S.n., s.d., il., p\&b, circa 550 p., carimbo Ernesto de Castro e C., ago, 31, 1911, São Paulo, desencadernado.

- [Speisezimmer, Berlin]. S.l., S.n, s.d., il., p\&b, em capa de Casa Editrice Ítala Ars. Publicazioni D'Art., Torino.

- Stucchi Gattino. Milano: Officine Grafiche Leopoldo Barone e Cia., 1926 il., color., p\&b.

- The Cron Kills Company. Catalog n² 26. Designer George J. Pike. Piqua, Ohio. [Ohio]: S.n., s.d., il., p\&b.

- Upholstered Living-Room Furniture. Luxurious - without Extravagance. Catalog number Forty. S.A. Cook and Company. Office and Factories, Medina, New York. [New York]: S.n., s.d, il., p\&b, desencadernado.

- [Wilhelm Knoll]. [Sttutgart]: S.n., s.d., il., fotografia, p\&b, carimbo Liceu de Artes e Ofícios de São Paulo, 22 nov. [19]28.

- [WL \& Co.]. S.1.: S.n., s.d., p\&b, desencadernado.

- [W. K. Ausgabe. Die Modelle dieses Katalogs sind gröBtenteils gesetzlich geschütz und dürfen nicht nachgebildet werden]. S.l: S.n, s.d., il., p\&b.

- [Wohnungskult]. S.l: S.n, s.d., il., p\&b. 
- [1/20 nat. Grösse tafel 89], deslocada de álbum e acondicionada junto com outros exemplares desencadernados, 1 prancha, $\mathrm{p} \& \mathrm{~b}$.

\section{I.1.8 Catálogos de politecnia}

- Ernst Kirchner \& Co. Leipzig Sellerhausen, Chicago 1893. 7 diplomas, 2 Prize medals. Sage und holzbearbeitungs-maschinen. Máquinas para aserrár y trabajar la madera. Referenz no 10923. Cable code A.B.C., s.d., il., desenhos, p\&b, desencadernado.

- Hilo. Maschinenfabrik. Hiltmann et Lorenz A G. aue (sachsen) werke in aue und niederschlema. S.l: S.n., s.d., il, impresso, etiqueta 20 E.

- Jagenberg- Werke Aktges. Tallleres de Construccion de Maquenaria. Düsseldorf (Alemania). Casa Fundada em 1878. Fábricas succursales em Siegmar (Sajonia), Roterdán (Holanda). Berlin, Dresden, Leipzig, Hamburgo, Nuremberg, Estugarda, Viena, Londres, Copenhague, Paris. Maquinas modernas para talleres de manupulación de papeles, fábricas de capas de cartón, fábricas de papel, etc., s.d., il., impresso.

- Les usines d'Aluminium viseland près vennesia en Norvége. Ateliers de Construction Oerlikon o erlikon près Zurich. [Zurich]: S.n., 1940, il. p\&b, impresso, assinatura de Lourenço Almeida Prado na primeira p., etiqueta $22 \mathrm{E}$.

- M. Hilpert e Co. Rio de Janeiro. Turbinas Hydráulicas de todos os systemas. Jacto Livre, Francis, Patente “ Kaplan”. S.l.: S.n., 1923, il.

- Guilliet Fils Et Compagnie (Auxerre). Machines à Travailler le Bois. Catalogue. Maison Fondée en 1847. Paris: Guilliet Auxerre, 1938.

- Jagenberg- Werke Aktges. Tallleres de Construccion de Maquenaria. Düsseldorf (Alemania). Casa Fundada em 1878. Fábricas succursales em Siegmar (Sajonia), Roterdán (Holanda). Berlin, Dresden, Leipzig, Hamburgo, Nuremberg, Estugarda, Viena, Londres, Copenhague, Paris. Maquinas modernas para talleres de manupulación de papeles, fábricas de capas de cartón, fábricas de papel, etc. [Düsseldorf]: S.n., s.d., il., p\&b.

- Maschinenfabrik Weingarten vorm. Hch. Schatz A.G. Weingarten Württemberg. Sonder-Preisliste I. Ausgabe, Febr. 1927, Blechscheren Profileisenscheren lochmaschinen für Handbetrieb in Stahlausführung. Buchdrukrei J. Goelz, Mengen-Würt. [Weingarten]: [1927], s.d., il., $\mathrm{p} \& \mathrm{~b}$, impresso, etiqueta $23 \mathrm{E}$.

- [Musterbuch I. Manfraed Werke, Aktien]. S.l.: S.n, s.d, il., p\&b, impresso, 2 exemplares desencadernados 
- Musterbuch II, 1912. Mannstaedt Werke Aktion Gesellschaft. Troisdorf bei-Köln. Köln: [Verlag M.]Dumont Schauberg, 1914, il., p\&b, ex.1.

- Musterbuch II, 1912. Mannstaedt Werke Aktion Gesellschaft. Troisdorf bei-Köln. Köln: [Verlag M.] Dumont Schauberg, 1914, il., p\&b ex.2.

- Musterbuch II, 1914. Mannstaedt Werke Aktion Gesellschaft. Troisdorf bei-Köln. Köln: [Verlag M.]Dumont Schauberg, 1914, il., p\&b.

- Pedro Merlini. Fabricante de Máquinas Utensiles y de todos los elementos para instalaciones de máquinas. Casa fundada em el año 1885. El fabricante más importante de maquinarias em Sud America. Por su gran sortido de modelos próprios. Premiado com dos grandes diplomas de Honor y medallas de oro, en varias exposiciones del Pais e del Extranjero. Buenos Aires, Casa Central, 124, Defensa, 126. Talleres, 530 Larrea. [Buenos Aires]: S.n., s.d. sob os endereços impressos, carimbo Peru 45058, etiqueta 27 E.

- Spindler \& Hoyer. G.M.b.H. Mechanische und optische Werkstätten. Göttingen. Liste 36. Prämilerungen. Paris 1900, St. Louis 1904. Brüssel 1910, Grand Prix und Silberne Medaille. [Göttingen]: 1926., impresso, etiqueta $25 \mathrm{E}$.

- Uhland Armaturen und Schmeierapparate. Leipzig: Verlag von H. A. Ludwig Degene, [1910], il, desenhos esquemáticos, p\&b, impresso, etiqueta $52 \mathrm{E}$.

- Uhland Zentrifugen. Leipzig: Verlag von H. A. Ludwig Degene, [1910], il, desenhos esquemáticos, p\&b, impresso, etiqueta $57 \mathrm{E}$.

- Uhland Dampfkessel und Feuerungsanlagen. Leipzig: Verlag von H. A. Ludwig Degene, [1910], il, desenhos esquemáticos, p\&b, impresso, etiqueta $53 \mathrm{E}$.

- Uhland Dampfkessel und Feuerungsanlagen. Leipzig: Verlag von H. A. Ludwig Degene, [1910], il, desenhos esquemáticos, p\&b, impresso, etiqueta $53 \mathrm{E}$.

- Uhland Hebezeuge. Leipzig: Verlag von H. A. Ludwig Degene, [1910]., il, desenhos esquemáticos, p\&b, impresso, etiqueta $58 \mathrm{E}$.

- Uhland Müllerei und Zerkleinerungs, maschinen. Leipzig: Verlag von H. A. Ludwig Degene, [1910], il, desenhos esquemáticos, p\&b, impresso, etiqueta $54 \mathrm{E}$.

- Uhland Pressen. Leipzig: Verlag von H. A. Ludwig Degene, [1920], il, desenhos esquemáticos, p\&b, impresso, etiqueta 56 E. -

Uhland Pumpen. Leipzig: Verlag von H. A. Ludwig Degene, s.d., il, desenhos esquemáticos, p\&b, impresso, etiqueta 51E. 
- Uhland Triebwerke. Leipzig: Verlag von H. A. Ludwig Degene, s.d., il, desenhos esquemáticos, p\&b, impresso, etiqueta $55 \mathrm{E}$. Catalogue du Centenaire 1847- 1947. S.l.: S.n., il. p\&b, etiqueta 6E.

- United States Steel Products Company. General Catalogue, 1916, New York. [New York]: S.n., sd., il., etiqueta 44 E.

\section{I.1.9 Periódicos}

\section{I.1.9.1 Anais, anuários, boletins e revistas}

- Anuário da Escola Polytechnica de São Paulo. São Paulo: Escola Polytechnica de São Paulo, 1932, Anno I, 2a serie, il., fotografia, p\&b, etiqueta $35 \mathrm{E}$.

- Annuario do Commercio Anglo-Sudamericano (The British South American Trade Annual), 1930-1931. Editor A. H. Godwin. Londres: Metcalfe \& Cooper Ltd., 1930-1931, ex.1, etiqueta 7 C.

- Annuario do Commercio Anglo-Sudamericano (The British South American Trade Annual), 1930-1931. Editor A. H. Godwin. Londres: Metcalfe \& Cooper Ltd., 1930-1931, ex. 2, etiqueta 8 C.

- Boletim do Ministério da Agricultura. Rio de Janeiro: Ministério da Agricultura, Diretoria de Estatística da Produção, Jan.-Março 1938, ano $27, n^{\circ} 1-3$, il., fotografia, p\&b, etiqueta $16 \mathrm{C}$.

- Comissão Geográfica e Geológica de São Paulo. Exploração do rio Grande e seus afluentes. São Paulo: Tip. Brazil de Rothschild e Cia., 1913. - Comissão Geográfica e Geológica de São Paulo. Exploração do rio do Peixe. São Paulo: Tip. Brazil de Rothschild e Cia., 1905, desencadernado. - Comissão Geográfica e Geológica de São Paulo. Exploração do litoral. Seção da cidade de Santos e fronteira do Estado do Rio de Janeiro. São Paulo: Tip. Brazil de Rothschild e Cia., 1915, desencadernado. - Comissão Geográfica e Geológica de São Paulo. Exploração dos rios Feio e Aguapehy. São Paulo: Tip. Brazil de Rothschild e Cia., 1905, desencadernado. - Comissão Geográfica e Geológica de São Paulo. Exploração do Rio Ribeira de Iguape São Paulo: Tip. Brazil de Rothschild e Cia., 1908, desencadernado.

- Instituto Brasileiro de Geografia e Estatística. Repertório Estatístico do Brasil. Situação Cultural, (Separata do Anuário Estatístico do Brasil, ano V, 1939-1940. Rio de Janeiro: Serviço Gráfico do Instituto Brasileiro de Geografia e Estatística, 1941, vol. 1. 
- Ministério da Educação e Saúde. Anuário do Museu Imperial, Petrópolis. Rio de Janeiro: S.n., il., fotografia, color., p\&b.

- Revista do Museu Paulista. São Paulo: Typ. Cardozo, Filho e Cia., 1907, vol. 7.

- Revista do Museu Paulista. São Paulo: Typ. do Diário Oficial, 1914, vol.9

- Revista Polytechnica. São Paulo: S.n, Maio-Junho 1932, nº 105, il., fotografia, p\&b.

- Revista Polytechnica. São Paulo: S.n., Nov.-Dez. 1932, nº 106, il., fotografia, p\&b.

- Revista Polytechnica. São Paulo: S.n, Março -Abr. 1933, nº 108, São Paulo, il., fotografia, p\&b.

\section{I.1.9.2 Revistas especializadas em artes e decoração}

- Architecture. S.l.: S.n, [August, 1896], il., vol. 1, fotografia, desenho, p\&b, encadernada, sem frontispício.

- Architecture. A Monthly Magazine of Architectural Art. London: [James Dudley Morgan] Harmer \& Harley Printers, Feb. - Dec. 1896, vol.1, il. p\&b, desencadernada.

- Architecture. Architecture Supplement. S.l.: S.n, June 1898, il., vol. 1, fotografia, desenho, p\&b.

- Architectural Studies. Low costs houses, store fronts and interior details, strables, sea-shore and southern houses. New York: William T. Comstock, 1886, vol. 1, il., desenho, p\&b.

- Architektonisches Skizzen-Buch. Eine Sammlung von Landhäusern, Villen, ländlichen Gebäuden, Gartenhäusern, Gartenverzierungen, Gittern, Erkern, Balkons, Blumenfenstern, Brunnen, Springbrunnen, Hofgebäuden, Einfassungsmauern, Candelabern, Grabmonumenten und andern kleinen Baulichkeiten, welche zur Verschönerung baulicher Anlagen dienen, und in Berlin, Potsdam, und an anderen Orten ausgeführt sind. Mit Details. Berlin: Verlag Ernst \& Korn, [1852-1886].

- Arte Italiana Decorativa e Industriale. Periodico pubblicato sotto il patrocinio del Ministero di Agricoltura, Industria e Commercio e diretto da Camillo Boito. Milano: Ulrico Hoepli Editore Libraio della Real Casa, Ottobre 1895, anno IV, no 10, il, fotografia, p\&b, color., carimbo Liceu de Artes e Ofícios de São Paulo, junho [19]30, incompleta?, desencadernada. 
- Arte Italiana Decorativa e Industriale. Periodico pubblicato sotto il patrocinio del Ministero di Agricoltura, Industria e Commercio e diretto da Camillo Boito. Milano: Ulrico Hoepli Editore Libraio della Real Casa, Luglio, 1897, anno VI, n 7, il., fotografia, p\&b, color., carimbo Liceu de Artes e Ofícios de São Paulo, junho [19]30, desencadernada.

- Arte Italiana Decorativa e Industriale. Periodico pubblicato sotto il patrocinio del Ministero di Agricoltura, Industria e Commercio e diretto da Camillo Boito. Milano: Ulrico Hoepli Editore Libraio della Real Casa, Settembre 1901, anno X, n 9, il., fotografia, p\&b, color., carimbo Liceu de Artes e Ofícios de São Paulo, junho [19]30, desencadernada.

- Arte Italiana Decorativa e Industriale. Periodico pubblicato sotto il patrocinio del Ministero di Agricoltura, Industria e Commercio e diretto da Camillo Boito. Milano: Ulrico Hoepli Editore Libraio della Real Casa, Ottobre 1901, anno X, n 10, il., fotografia, p\&b, color., carimbo Liceu de Artes e Ofícios de São Paulo, junho [19]30, desencadernada.

- Arte Italiana Decorativa e Industriale. Periodico pubblicato sotto il patrocinio del Ministero di Agricoltura, Industria e Commercio e diretto da Camillo Boito. Milano: Ulrico Hoepli Editore Libraio della Real Casa, Dicembre 1901, anno X, no 12, il., fotografia, p\&b, color., carimbo Liceu de Artes e Ofícios de São Paulo, junho [19]30, desencadernada.

- Arte Italiana Decorativa e Industriale. Periodico pubblicato sotto il patrocinio del Ministero di Agricoltura, Industria e Commercio e diretto da Camillo Boito. Milano: Ulrico Hoepli Editore Libraio della Real Casa, Maggio 1902, anno XI, no 5, il., fotografia, p\&b, color., carimbo Liceu de Artes e Ofícios de São Paulo, junho [19]30, desencadernada.

- Arte Italiana Decorativa e Industriale. Periodico pubblicato sotto il patrocinio del Ministero di Agricoltura, Industria e Commercio e diretto da Camillo Boito. Milano: Ulrico Hoepli Editore Libraio della Real Casa, Giugno 1902, anno XI, nº 6, il., fotografia, p\&b, color., carimbo Liceu de Artes e Ofícios de São Paulo, junho [19]30, desencadernada.

- Arte Italiana Decorativa e Industriale. Periodico pubblicato sotto il patrocinio del Ministero di Agricoltura, Industria e Commercio e diretto da Camillo Boito. Milano: Ulrico Hoepli Editore Libraio della Real Casa, Luglio 1902, anno XI, nº 7, il., fotografia, p\&b, color., carimbo Liceu de Artes e Ofícios de São Paulo, junho [19]30, desencadernada.

- Arte Italiana Decorativa e Industriale. Periodico pubblicato sotto il patrocinio del Ministero di Agricoltura, Industria e Commercio e diretto da Camillo Boito. Milano: Ulrico Hoepli Editore Libraio della Real 
Casa, Ottobre 1902, anno XI, n 10 , il., fotografia, p\&b, color., carimbo Liceu de Artes e Ofícios de São Paulo, junho [19]30, desencadernada.

- Arte Italiana Decorativa e Industriale. Periodico pubblicato sotto il patrocinio del Ministero di Agricoltura, Industria e Commercio e diretto da Camillo Boito. Milano: Ulrico Hoepli Editore Libraio della Real Casa, Gennaio 1903, anno XII, n 1, il., fotografia, p\&b, color., carimbo Liceu de Artes e Ofícios de São Paulo, junho [19]30, desencadernada.

- Arte Italiana Decorativa e Industriale. Periodico pubblicato sotto il patrocinio del Ministero di Agricoltura, Industria e Commercio e diretto da Camillo Boito. Milano: Ulrico Hoepli Editore Libraio della Real Casa, Febbraio 1903, anno XII, n² 2, il., fotografia, p\&b, color., carimbo Liceu de Artes e Ofícios de São Paulo, junho [19]30, desencadernada.

- Arte Italiana Decorativa e Industriale. Periodico pubblicato sotto il patrocinio del Ministero di Agricoltura, Industria e Commercio e diretto da Camillo Boito. Milano: Ulrico Hoepli Editore Libraio della Real Casa, Febbraio 1903, anno XII, n² 2, fotografia, p\&b, color., carimbo Liceu de Artes e Ofícios de São Paulo, junho [19]30, desencadernada.

- Arte Italiana Decorativa e Industriale. Periodico pubblicato sotto il patrocinio del Ministero di Agricoltura, Industria e Commercio e diretto da Camillo Boito. Milano: Ulrico Hoepli Editore Libraio della Real Casa, Aprile 1903, anno XII, n 4, fotografia, p\&b, color., carimbo Liceu de Artes e Ofícios de São Paulo, junho [19]30, desencadernada.

- Arte Italiana Decorativa e Industriale. Periodico pubblicato sotto il patrocinio del Ministero di Agricoltura, Industria e Commercio e diretto da Camillo Boito. Milano: Ulrico Hoepli Editore Libraio della Real Casa, Ottobre 1903, anno XII, nº 10, il., fotografia, p\&b, color., carimbo Liceu de Artes e Ofícios de São Paulo, junho [19]30, desencadernada.

- Arte Italiana Decorativa e Industriale. Periodico pubblicato sotto il patrocinio del Ministero di Agricoltura, Industria e Commercio e diretto da Camillo Boito. Milano: Ulrico Hoepli Editore Libraio della Real Casa, Dicembre 1903, anno XII, no 12, il., fotografia, p\&b, color., carimbo Liceu de Artes e Ofícios de São Paulo, junho [19]30, desencadernada.

- Arte Italiana Decorativa e Industriale. Periodico pubblicato sotto il patrocinio del Ministero di Agricoltura, Industria e Commercio e diretto da Camillo Boito. Milano: Ulrico Hoepli Editore Libraio della Real Casa, Gennaio 1904, anno XIII $1^{\circ}$ della nuova serie, $n^{\circ} 1$, il., fotografia, p\&b, color., carimbo Liceu de Artes e Ofícios de São Paulo, junho [19]30, desencadernada. 
- Arte Italiana Decorativa e Industriale. Periodico pubblicato sotto il patrocinio del Ministero di Agricoltura, Industria e Commercio e diretto da Camillo Boito. Milano: Ulrico Hoepli Editore Libraio della Real Casa, Marzo 1904, anno XIII, n 3, il., fotografia, p\&b, color., carimbo Liceu de Artes e Ofícios de São Paulo, junho [19]30, desencadernada.

- Arte Italiana Decorativa e Industriale. Periodico pubblicato sotto il patrocinio del Ministero di Agricoltura, Industria e Commercio e diretto da Camillo Boito. Milano: Ulrico Hoepli Editore Libraio della Real Casa, Maggio 1904, anno XIII, n 5, il., fotografia, p\&b, color., carimbo Liceu de Artes e Ofícios de São Paulo, junho [19]30, desencadernada.

- Arte Italiana Decorativa e Industriale. Periodico pubblicato sotto il patrocinio del Ministero di Agricoltura, Industria e Commercio e diretto da Camillo Boito. Milano: Ulrico Hoepli Editore Libraio della Real Casa, Giugno 1904, anno XIII, nº 6, il., fotografia, p\&b, color., carimbo Liceu de Artes e Ofícios de São Paulo, junho [19]30, desencadernada.

- Arte Italiana Decorativa e Industriale. Periodico pubblicato sotto il patrocinio del Ministero di Agricoltura, Industria e Commercio e diretto da Camillo Boito. Milano: Ulrico Hoepli Editore Libraio della Real Casa, Luglio 1904, anno XIII, n 7, il., fotografia, p\&b, color., carimbo Liceu de Artes e Ofícios de São Paulo, junho [19]30, desencadernada.

- Arte Italiana Decorativa e Industriale. Periodico pubblicato sotto il patrocinio del Ministero di Agricoltura, Industria e Commercio e diretto da Camillo Boito. Milano: Ulrico Hoepli Editore Libraio della Real Casa, Agosto 1904, anno XIII, no 8, il., fotografia, p\&b, color., carimbo Liceu de Artes e Ofícios de São Paulo, junho [19]30, desencadernada.

- Arte Italiana Decorativa e Industriale. Periodico pubblicato sotto il patrocinio del Ministero di Agricoltura, Industria e Commercio e diretto da Camillo Boito. Milano: Ulrico Hoepli Editore Libraio della Real Casa, Ottobre 1904, anno XIII, nº 10, il., fotografia, p\&b, color., carimbo Liceu de Artes e Ofícios de São Paulo, junho [19]30, desencadernada.

- Arte Italiana Decorativa e Industriale. Periodico pubblicato sotto il patrocinio del Ministero di Agricoltura, Industria e Commercio e diretto da Camillo Boito. Milano: Ulrico Hoepli Editore Libraio della Real Casa, Dicembre 1904, anno XIII, no 12, il., fotografia, p\&b, color., carimbo Liceu de Artes e Ofícios de São Paulo, junho [19]30, desencadernada.

- Arte Italiana Decorativa e Industriale. Periodico pubblicato sotto il patrocinio del Ministero di Agricoltura, Industria e Commercio e diretto da Camillo Boito. Milano: Ulrico Hoepli Editore Libraio della 
Real Casa, Gennaio 1905, anno XIV $2^{\circ}$ della nuova serie, $n^{\circ}$ 1, il., fotografia, p\&b, color., carimbo Liceu de Artes e Ofícios de São Paulo, junho [19]30, desencadernada.

- Arte Italiana Decorativa e Industriale. Periodico pubblicato sotto il patrocinio del Ministero di Agricoltura, Industria e Commercio e diretto da Camillo Boito. Milano: Ulrico Hoepli Editore Libraio della Real Casa, Febbraio 1905, anno XIV, n 2, il., fotografia, p\&b, color., carimbo Liceu de Artes e Ofícios de São Paulo, junho [19]30, desencadernada.

- Arte Italiana Decorativa e Industriale. Periodico pubblicato sotto il patrocinio del Ministero di Agricoltura, Industria e Commercio e diretto da Camillo Boito. Milano: Ulrico Hoepli Editore Libraio della Real Casa, Aprile 1905, anno XIV, no 4, il., fotografia, p\&b, color., carimbo LAO junho [19]30, desencadernada.

- Arte Italiana Decorativa e Industriale. Periodico pubblicato sotto il patrocinio del Ministero di Agricoltura, Industria e Commercio e diretto da Camillo Boito. Milano: Ulrico Hoepli Editore Libraio della Real Casa, Maggio 1905, anno XIV, nº 5, il., fotografia, p\&b, color., carimbo Liceu de Artes e Ofícios de São Paulo, junho [19]30, desencadernada.

- Arte Italiana Decorativa e Industriale. Periodico pubblicato sotto il patrocinio del Ministero di Agricoltura, Industria e Commercio e diretto da Camillo Boito. Milano: Ulrico Hoepli Editore Libraio della Real Casa, Giugno 1905, anno XIV, nº 6, il., fotografia, p\&b, color., carimbo Liceu de Artes e Ofícios de São Paulo, junho [19]30, desencadernada.

- Arte Italiana Decorativa e Industriale. Periodico pubblicato sotto il patrocinio del Ministero di Agricoltura, Industria e Commercio e diretto da Camillo Boito. Milano: Ulrico Hoepli Editore Libraio della Real Casa, Ottobre 1905, anno XIV, no 10, il., fotografia, p\&b, color., carimbo Liceu de Artes e Ofícios de São Paulo, junho [19]30, desencadernada.

- Arte Italiana Decorativa e Industriale. Periodico pubblicato sotto il patrocinio del Ministero di Agricoltura, Industria e Commercio e diretto da Camillo Boito. Milano: Ulrico Hoepli Editore Libraio della Real Casa, Febbraio 1906, anno XV, nº 2, il., fotografia, p\&b, color., carimbo Liceu de Artes e Ofícios de São Paulo, junho [19]30, desencadernada.

- Arte Italiana Decorativa e Industriale. Periodico pubblicato sotto il patrocinio del Ministero di Agricoltura, Industria e Commercio e diretto da Camillo Boito. Milano: Ulrico Hoepli Editore Libraio della Real Casa, Aprile 1906, anno XV, no 4, il., fotografia, p\&b, color., carimbo LAO junho [19]30, desencadernada. 
- Arte Italiana Decorativa e Industriale. Periodico pubblicato sotto il patrocinio del Ministero di Agricoltura, Industria e Commercio e diretto da Camillo Boito. Milano: Ulrico Hoepli Editore Libraio della Real Casa, Maggio 1906, anno XV, n 5, il., fotografia, p\&b, color., carimbo Liceu de Artes e Ofícios de São Paulo, junho [19]30, desencadernada.

- Arte Italiana Decorativa e Industriale. Periodico pubblicato sotto il patrocinio del Ministero di Agricoltura, Industria e Commercio e diretto da Camillo Boito. Milano: Ulrico Hoepli Editore Libraio della Real Casa, Giugno 1906, anno, XV nº 6, il., fotografia, p\&b, color., carimbo Liceu de Artes e Ofícios de São Paulo, junho [19]30, desencadernada.

- Arte Italiana Decorativa e Industriale. Periodico pubblicato sotto il patrocinio del Ministero di Agricoltura, Industria e Commercio e diretto da Camillo Boito. Milano: Ulrico Hoepli Editore Libraio della Real Casa, Agosto 1906, anno XV, no 8, il., fotografia, p\&b, color., carimbo Liceu de Artes e Ofícios de São Paulo, junho [19]30, desencadernada

- Arte Italiana Decorativa e Industriale. Periodico pubblicato sotto il patrocinio del Ministero di Agricoltura, Industria e Commercio e diretto da Camillo Boito. Milano: Ulrico Hoepli Editore Libraio della Real Casa, Ottobre 1906, anno XV, n 10, il., fotografia, p\&b, color., carimbo Liceu de Artes e Ofícios de São Paulo, junho [19]30, desencadernada.

- Arte Italiana Decorativa e Industriale. Periodico pubblicato sotto il patrocinio del Ministero di Agricoltura, Industria e Commercio e diretto da Camillo Boito. Milano: Ulrico Hoepli Editore Libraio della Real Casa, Novembre 1906, anno XV, nº 11, fotografia, p\&b, color., carimbo Liceu de Artes e Ofícios de São Paulo, junho [19]30, desencadernada.

- Arte Italiana Decorativa e Industriale. Periodico pubblicato sotto il patrocinio del Ministero di Agricoltura, Industria e Commercio e diretto da Camillo Boito. Milano: Ulrico Hoepli Editore Libraio della Real Casa, Dicembre 1906, anno XV, ${ }^{\circ} 12$, il., fotografia, p\&b, color., carimbo Liceu de Artes e Ofícios de São Paulo, junho [19]30, desencadernada.

- Arte Italiana Decorativa e Industriale. Periodico pubblicato sotto il patrocinio del Ministero di Agricoltura, Industria e Commercio e diretto da Camillo Boito. Milano: Ulrico Hoepli Editore Libraio della Real Casa, Gennaio 1907, anno XVI, no 1, il., fotografia, p\&b, color., carimbo Liceu de Artes e Ofícios de São Paulo, junho [19]30, desencadernada.

- Arte Italiana Decorativa e Industriale. Periodico pubblicato sotto il patrocinio del Ministero di Agricoltura, Industria e Commercio e diretto da Camillo Boito. Milano: Ulrico Hoepli Editore Libraio della Real 
Casa, Febbraio 1907, anno XVI, n² 2, il., fotografia, p\&b, color., carimbo Liceu de Artes e Ofícios de São Paulo, junho [19]30, desencadernada.

- Arte Italiana Decorativa e Industriale. Periodico pubblicato sotto il patrocinio del Ministero di Agricoltura, Industria e Commercio e diretto da Camillo Boito. Milano: Ulrico Hoepli Editore Libraio della Real Casa, Marzo 1907, anno XVI, no 3, il., fotografia, p\&b, color., carimbo Liceu de Artes e Ofícios de São Paulo, junho [19]30, desencadernada.

- Arte Italiana Decorativa e Industriale. Periodico pubblicato sotto il patrocinio del Ministero di Agricoltura, Industria e Commercio e diretto da Camillo Boito. Milano: Ulrico Hoepli Editore Libraio della Real Casa, Settembre 1907, anno XVI, n 9, il., fotografia, p\&b, color., carimbo Liceu de Artes e Ofícios de São Paulo, junho [19]30, desencadernada.

- Arte Italiana Decorativa e Industriale. Periodico pubblicato sotto il patrocinio del Ministero di Agricoltura, Industria e Commercio e diretto da Camillo Boito. Milano: Ulrico Hoepli Editore Libraio della Real Casa, Settembre 1909, anno XVIII, no 9, il., fotografia, p\&b, color., carimbo Liceu de Artes e Ofícios de São Paulo, junho [19]30, desencadernada.

- Arte Italiana Decorativa e Industriale. Periodico pubblicato sotto il patrocinio del Ministero di Agricoltura, Industria e Commercio e diretto da Camillo Boito. Milano: Ulrico Hoepli Editore Libraio della Real Casa, Febbraio 1910, anno XIX, nº 2, il., fotografia, p\&b, color., carimbo Liceu de Artes e Ofícios de São Paulo, junho [19]30, desencadernada.

- Arte Italiana Decorativa e Industriale. Periodico pubblicato sotto il patrocinio del Ministero di Agricoltura, Industria e Commercio e diretto da Camillo Boito. Milano: Ulrico Hoepli Editore Libraio della Real Casa, Marzo 1910, anno XIX, no 3, il., fotografia, p\&b, color., carimbo Liceu de Artes e Ofícios de São Paulo, junho [19]30, desencadernada.

- Arte Italiana Decorativa e Industriale. Periodico pubblicato sotto il patrocinio del Ministero di Agricoltura, Industria e Commercio e diretto da Camillo Boito. Milano: Ulrico Hoepli Editore Libraio della Real Casa, Luglio 1910, anno XIX, n 7, il., fotografia, p\&b, color., carimbo Liceu de Artes e Ofícios de São Paulo, junho [19]30, desencadernada.

- Arte Italiana Decorativa e Industriale. Periodico pubblicato sotto il patrocinio del Ministero di Agricoltura, Industria e Commercio e diretto da Camillo Boito. Milano: Ulrico Hoepli Editore Libraio della Real Casa, Agosto 1910, anno XIX, no 8, il., fotografia, p\&b, color., carimbo Liceu de Artes e Ofícios de São Paulo, junho [19]30, desencadernada. 
- Arte Italiana Decorativa e Industriale. Periodico pubblicato sotto il patrocinio del Ministero di Agricoltura, Industria e Commercio e diretto da Camillo Boito. Milano: Ulrico Hoepli Editore Libraio della Real Casa, Settembre, $191^{\circ}$, anno XIX, n 9, il., fotografia, p\&b, color., carimbo Liceu de Artes e Ofícios de São Paulo, junho [19]30, desencadernada.

- Arte Italiana Decorativa e Industriale. Periodico pubblicato sotto il patrocinio del Ministero di Agricoltura, Industria e Commercio e diretto da Camillo Boito. Milano: Ulrico Hoepli Editore Libraio della Real Casa, Gennaio 1911, anno XX, nº 1, il., fotografia, p\&b, color., carimbo Liceu de Artes e Ofícios de São Paulo, junho [19]30, desencadernada.

- Art et Industrie. Arts de la Maison. Industries de Luxe. VIIe. année. [Paris]: S.n., s.d., ano 8, no 8, /1931 - 1948, nº VI-XIII. [Paris]: S.n., il., fotografia, color. .

- Arts \& Decoration. New York, Paris, London: Arts and Decoration Publishing Co. Inc., January, August-Dec. 1928, il., fotografia, color.

- Arts \& Decoration. New York, Paris, London: Arts and Decoration Publishing Co. Inc., July 1929, il., fotografia, color., tomo 1.

- Arts \& Decoration. New York, Paris, London: Arts and Decoration Publishing Co. Inc., 1929, il., fotografia, color., tomo 2.

- Arts and Decoration. New York, Paris, London: Arts and Decoration Publishing Co. Inc., 1929, il., fotografia, color., tomo 3.

- Arts and Decoration. New York, Paris, London: Arts and Decoration Publishing Co. Inc., 1930, il., fotografia, color., tomo 1.

- Arts and Decoration. New York, Paris, London: Arts and Decoration Publishing Co. Inc., 1930, il., fotografia, color., tomo 2.

- Arts and Decoration. New York, Paris, London: Arts and Decoration Publishing Co. Inc., 1930, il., fotografia, color., tomo 3.

- Arts and Decoration. New York, Paris, London: Arts and Decoration Publishing Co. Inc., 1931, il., fotografia, color., tomo 1,

- Arts and Decoration. New York, Paris, London: Arts and Decoration Publishing Co. Inc., 1931, il., fotografia, color., tomo 2.

- Arts and Decoration. New York, Paris, London: Arts and Decoration Publishing Co. Inc., 1931, il., fotografia, color., tomo 3.

- Arts and Decoration. New York: Arts and Decoration Publishing Co. Inc., 1932, il., fotografia, color.

- Arts and Decoration. New York, Paris, London: Arts and Decoration Publishing Co. Inc., 1961, il., fotografia, color., tomo 1. 
- Arts and Decoration. New York, Paris, London: Arts and Decoration Publishing Co. Inc., 1961, il., fotografia, color., tomo 2.

- Domus. Architettura e Arredamento Dell'Abitazione Moderna in Cittá e in campagna. Rivista mensile diretta Arch. Gio Ponti. Anno I. Milano: Febb. - Aprille, Settembre 1928, ano 1; Dic. 1930; 1931, il., color.

- Domus. Architettura e Arredamento Dell'Abitazione Moderna in Cittá e in campagna. Rivista mensile diretta Arch. Gio Ponti. Anno II. Milano: Gennaio - Maggio 1929, ano2, il., color., tomo 1.

- Domus. Architettura e Arredamento Dell'Abitazione Moderna in Cittá e in campagna. Rivista mensile diretta Arch. Gio Ponti. Anno II Milano: Luglio - Dic. 1929, ano 2, il., color., tomo 2.

- Domus. Architettura e Arredamento Dell'Abitazione Moderna in Cittá e in campagna. Rivista mensile diretta Arch. Gio Ponti. Anno III Milano: Gennaio - Giugno 1930, ano 3, il., color., tomo 1.

- Domus. Architettura e Arredamento Dell'Abitazione Moderna in Cittá e in campagna. Rivista mensile diretta Arch. Gio Ponti. Anno III. Milano: Luglio - Dic. 1930, ano 3, il., color., tomo 2.

- Domus. Architettura e Arredamento Dell'Abitazione Moderna in Cittá e in campagna. Rivista mensile diretta Arch. Gio Ponti. Anno IV. Milano: Marzo - Giugno 1931, ano 4, il., color., tomo 1.

- Domus. Architettura e Arredamento Dell'Abitazione Moderna in Cittá e in campagna. Rivista mensile diretta Arch. Gio Ponti. Anno IV. Milano: Luglio - Agosto, Ottobre - Dic., 1931, ano 4, il., color., tomo 2.

- Domus. Architettura e Arredamento Dell'Abitazione Moderna in Cittá e in campagna. Rivista mensile diretta Arch. Gio Ponti. Anno VI. Milano: Gennaio - Giugno 1933, ano 6, il., color., tomo 1.

- Domus. Architettura e Arredamento Dell'Abitazione Moderna in Cittá e in campagna. Rivista mensile diretta Arch. Gio Ponti. Milano: Luglio - Dic. 1933, il., color., tomo 2.

- Domus. Architettura e Arredamento Dell'Abitazione Moderna in Cittá e in campagna. Rivista mensile diretta Arch. Gio Ponti. Milano: Gennaio - Giugno 1934, il., color., tomo 1.

- Domus. Architettura e Arredamento Dell'Abitazione Moderna in Cittá e in campagna. Rivista mensile diretta Arch. Gio Ponti. Milano: Luglio - Dic. 1934, il., color., tomo 2.

- Domus. Architettura e Arredamento Dell'Abitazione Moderna in Cittá e in campagna. Rivista mensile diretta Arch. Gio Ponti. Milano: Gennaio - Giugno 1935, il., color., tomo 1. 
- Domus. Architettura e Arredamento Dell'Abitazione Moderna in Cittá e in campagna. Rivista mensile diretta Arch. Gio Ponti. Milano: Luglio - Dic. 1935, il., color., tomo 2.

- Domus. Architettura e Arredamento Dell'Abitazione Moderna in Cittá e in campagna. Rivista mensile diretta Arch. Gio Ponti. Milano: Gennaio - Giugno 1936, il., color., tomo 1.

- Domus. Architettura e Arredamento Dell'Abitazione Moderna in Cittá e in campagna. Rivista mensile diretta Arch. Gio Ponti. Milano: Luglio - Dic. 1936, il. color., tomo 2.

- Domus. Architettura e Arredamento Dell'Abitazione Moderna in Cittá e in campagna. Rivista mensile diretta Arch. Gio Ponti. Milano: Gennaio - Giugno 1937, il., color., tomo 1.

- Domus. Architettura e Arredamento Dell'Abitazione Moderna in Cittá e in campagna. Rivista mensile diretta Arch. Gio Ponti. Milano: Luglio - Agosto 119-120 Ottobre - Dic. 1937, il., color., tomo 2.

- Domus. Architettura e Arredamento Dell'Abitazione Moderna in Cittá e in campagna. Rivista mensile diretta Arch. Gio Ponti. Milano: Febbraio, Aprille - Giugno 1938, il., color., tomo 1.

- Domus. Architettura e Arredamento Dell'Abitazione Moderna in Cittá e in campagna. Rivista mensile diretta Arch. Gio Ponti. Milano: Agosto - Dic. 1938, il., color., tomo 2.

- Domus. Architettura e Arredamento Dell'Abitazione Moderna in Cittá e in campagna. Rivista mensile diretta Arch. Gio Ponti. Milano: Aprille - Maggio, Agosto 1939; Gennaio 1940, il., color.

- Emporium. Rivista Mensile illustrata D’arte e Di Cultura. Bergamo: Istituto Italiano D' Arti Grafiche, Marzo, 1918, vol. LXVII, n 279; Giugno, 1923, vol. LVII, no 342; Gennaio, 1928, vol. LXVII, no 397; Ottobre, 1928, vol. LXVIII, no 406, il., encadernada em volume Arte Miscellanea.

- Estratto dal "Per LArte”. Rivista di Arti Decorativa. Serie retrate artistiche e cerâmica dipinta. 30 Tavole. S.l.: S.n., s.d., il., p\&b.

- Good Furniture. Magazine of Furnishing and Decoration. New York, Chicago: The Dean-Hicks Company Publishers, January, March - July, Sept., Dec. 1920; August 1921, il., p\&b.

- Good Furniture. Magazine of Furnishing and Decoration. New York, Chigaco: The Dean-Hicks Company Publishers, Feb., Sept. e outros meses, 1921, sem capa. 
- Good Furniture. Magazine of Furnishing and Decoration. New York, Chicago: The Dean-Hicks Company Publishers, Sept. -Nov. 1919; January 1920; Sept. 1921, i.l., p\&b.

- Good Furniture. Magazine of Furnishing and Decoration. New York, Chicago: The Dean-Hicks Company Publishers, s.d., Good Furniture and The Furniture Journal, il., p\&b.

- Good Furniture. Magazine of Furnishing and Decoration. New York, Chicago: The Dean-Hicks Company Publishers, s.d., Good Furniture and The Furniture Journal, il., p\&b,

- Good Furniture. Magazine of Furnishing and Decoration. New York, Chicago: The Dean-Hicks Company Publishers, s.d., Good Furniture and The Furniture Journal, il., p\&b.

- House and Garden. New York: The Condé Nast Publications Inc., July 1939, vol. 76, n 1, il., fotografia, color. / House and Garden. New York: The Condé Nast Publications Inc., Aug. 1939, vol. 76, no 2, il., fotografia, color./ House and Garden. New York: The Condé Nast Publications Inc., Sept. 1939, vol. 76, n 3, il., fotografia, color./ House and Garden. New York: The Condé Nast Publications Inc., October - Dec. 1939, il., fotografia, color.

- Innen Dekoration. Die Gesamte Wohnungskunst in Bild und wort. Herausgeber: Hofrat Alexander Koch. Darmstadt: Verlaganstalt Alexander Koch. Februar 1911; em capa de April, Heft, 1916.

- Innen Dekoration. Die Gesamte Wohnungskunst in Bild und wort. Herausgeber: Hofrat Alexander Koch. Darmstadt: Verlaganstalt Alexander Koch, XXII Jahrgang, Februar Heft 1911, i.l., fl. capa, fl. contracapa e fl. Februar 1911; fl. capa, fl. contracapa Marz; fl. capa, fl. contracapa e fls. Juni, XXII Jahrgang, Darmstadt 1911, incompleta.

- Innen Dekoration. Die Gesamte Wohnungskunst in Bild und wort. Herausgeber: Hofrat Alexander Koch. Darmstadt: Verlaganstalt Alexander Koch, Oct. 1921 i.l, fl. capa, fl. contracapa.

- Innen Dekoration. Die Gesamte Wohnungskunst in Bild und wort. Herausgeber: Hofrat Alexander Koch. Darmstadt: Verlaganstalt Alexander Koch, Sept. 1923, XXXIV Jahrgang, il., fl. capa, fl. contracapa.

- Innen Dekoration. Die Gesamte Wohnungskunst in Bild und wort. Herausgeber: Hofrat Alexander Koch. Darmstadt: Verlaganstalt Alexander Koch, s.d., em capa de Einfache Moderne Möbel. Eine Sammlung meist ausgefühter bürgerlicher Zimmer- Einrichfungen herausgegeben von Keiser \& Deeg Atelier für Kunstgewerbe in München, 
Verlag von...Ravensburg, selo Laemmert e Co., S. Paulo; fl. capa, fl. contracapa Innen Dekorartion Mai 1922, rasgada.

- Innen Dekoration. Die Gesamte Wohnungskunst in Bild und wort. Herausgeber: Hofrat Alexander Koch. Darmstadt: Verlaganstalt Alexander Koch, Januar- Dez. 1929, vol. 40, il., desenho, fotografia, p\&b, color.

- Innen Dekoration. Die Gesamte Wohnungskunst in Bild und wort. Herausgeber: Hofrat Alexander Koch. Darmstadt: Verlaganstalt Alexander Koch, Januar- Marz, Juli-Nov. 1930, XLI Jahrgang, Band XL, il., fotografia, desenho, p\&b, color.

- Innen Dekoration. Die Gesamte Wohnungskunst in Bild und wort. Herausgeber: Hofrat Alexander Koch. Darmstadt: Verlaganstalt Alexander Koch, Juli- Dez. 1932, fotografia, desenho, p\&b, color.

- Innen Dekoration. Die Gesamte Wohnungskunst in Bild und wort. Herausgeber: Hofrat Alexander Koch. Darmstadt: Verlaganstalt Alexander Koch, Januar- Juni 1933, fotografia, desenho, p\&b, color.

- Innen Dekoration. Die Gesamte Wohnungskunst in Bild und wort. Herausgeber: Hofrat Alexander Koch. Darmstadt: Verlaganstalt Alexander Koch, Mai 1937, fl. capa, fl. contracapa, il., sem capa, incompleta.

- Journal de L'Ameublement. 1re. année. Livraison 1. série Tenture. Nouveau Journal de l'Ameublement. L. Bertin Directeur. Dourdan: Émile Thézard, Éditeur, Fév., Avril, Juin, Août, Oct., Déc. 1913, il., color.

- L'Ambiente Moderno. Anno I. Fascicolo I. Mobili e Decorazione Interna. Milano: Preiss Bestetti e C., Editori, s.d., il., vol. 1, ano 1, fototipia, p\&b, impresso, assinatura de Luiz Scattolin.

- L'Ambiente Moderno. Rivista Mensile. Anno 2. Fascicolo 7. Mobili e Decorazione Interna. Milano: Casa Editrice Bestetti e C., Editori, s.d., vol.7, ano 2, il., fototipia, p\&b.

- L'Ambiente Moderno. Rivista Mensile. Anno 3. Fascicolo 12. Mobili e Decorazione Interna. Milano: Casa Editrice Bestetti e C., Editori, s.d., vol. 12, ano 3, il., fototipia, p\&b.

- L'Ambiente Moderno. Rivista Mensile. Mobili e Decorazione Interna. Milano: Casa Editrice Bestetti e C., Editori, s.d., il., fototipia, p\&b.

- L'Ambiente Moderno. Rivista Mensile. Mobili e Decorazione Interna. Milano: Casa Editrice Bestetti e C., Editori, s.d., il., fototipia, p\&b. 
- L'Ambiente Moderno. Rivista Mensile. Mobili e Decorazione Interna. Milano: Casa Editrice Bestetti e C., Editori, s.d., il., fototipia, p\&b.

- L'Architetto Moderno. Schizzi e Progetti Di villini, Case civili, Edifici, Monumenti Funebri, Detaggli. 1a. serie. Tavole XL. L'Artista Moderno. Rivista Illustrata di Arte Applicata. Torino: Biblioteca de L'Artista Moderno, [1912], il.,fotografia?, p\&b.

- L'Architettura Italiana. Periodico mensile di Costruzione e di Architettura pratica. Anno 1. Torino: Società Italiana di Edizioni Artistiche C. Crudo \& C., Ottobre 1905- 1906, ano 1, nº1, il., fotografia, desenho, p\&b, color., incompleta?, desencadernada.

- L'Architettura Italiana. Periodico mensile di Costruzione e di Architettura pratica Anno II. Torino: Società Italiana di Edizioni Artistiche C. Crudo \& C., Ottobre 1907, ano 2, il., fotografia, desenho, p\&b, color., desencadernada.

- L'Architettura Italiana. Periodico mensile di Costruzione e di Architettura pratica. Anno III. Torino: Società Italiana di Edizioni Artistiche C. Crudo \& C., Settembre 1908, ano 3, il., fotografia, desenho, p\&b, color., desencadernada.

- L'Architettura Italiana. Periodico mensile di Costruzione e di Architettura pratica. Anno IV. Torino: Società Italiana di Edizioni Artistiche C. Crudo \& C., 1908-1909, ano 4, il., fotografia, desenho, p\&b, color., desencadernada.

- L'Architettura Italiana. Periodico mensile di Costruzione e di Architettura pratica. Anno VI. Torino: Società Italiana di Edizioni Artistiche C. Crudo \& C., Ottobre 1910, ano 6, il., fotografia, desenho, p\&b, color., desencadernada.

- L'Architettura Italiana. Periodico mensile di Costruzione e di Architettura pratica. Anno VII. Torino: Società Italiana di Edizioni Artistiche C. Crudo \& C., 1911-12, ano 7, il., fotografia, desenho, p\&b, color., desencadernada.

- L'Architettura Italiana. Periodico mensile di Costruzione e di Architettura pratica. Anno VIII. Torino: Società Italiana di Edizioni Artistiche C. Crudo \& C., 1912-13, ano 8, il., fotografia, desenho, p\&b, color., desencadernada.

- L'Architettura Italiana. Periodico mensile di Costruzione e di Architettura pratica Anno IX. Torino: Società Italiana di Edizioni Artistiche C. Crudo \& C., 1913-14, ano 9, il., fotografia, desenho, p\&b, color., desencadernada. 
- L'Architetto Moderno. Rivista Illustrata d'arte aplicata. Schizzi e progetti di Villini, Case civili, Edifici, Monumenti Funebri, Dettagli. 1a. serie. Tavole XL. Anno XI. Torino: Biblioteca de L'Artista Moderno, [1912], ano 11, il., fotografia, p\&b.

- L'Artista Moderno. Rivista Quindicinale e Illustrata d'Arte Pura e Applicata. Anno XXV. Torino: S.n, 25 gennaio 1926, nº 2, ano 25, il., fotografia, color., direção Rocco Carlucci, carimbo Representante Papelaria S. José, Rua da Glória.

- La Casa Bella. Rivista Mensile. A. Bonfiglioli Direttore Responsabile. Esecuzione Gustavo Modiano, Milano. Foto incisioni della Ditta C. A. Volenti. Milano: S.n., s.d., il.

- La Casa Bella. Rivista Mensile. A. Bonfiglioli Direttore Responsabile. Esecuzione Gustavo Modiano, Milano. Foto incisioni della Ditta C. A. Volenti. Milano: S.n., Gennaio 1932, n 49, il., com indicações de páginas 1 a 80, sem indicação dos meses.

- La Casa Bella. Rivista Mensile. A. Bonfiglioli Direttore Responsabile. Esecuzione Gustavo Modiano, Milano. Foto incisioni della Ditta C. A. Volenti. Milano: S.n., 2 Luglio 1932, no 55, il.

- La Casa Bella. Rivista Mensile. A. Bonfiglioli Direttore Responsabile. Esecuzione Gustavo Modiano, Milano. Foto incisioni della Ditta C. A. Volent. Milano: S.n., Gennaio 1933, il. p\&b, color., tomo 3.

- La Construction moderne. Journal Hebdomadaire Illustré. Directeur E. Rumler. Fondateur P. Planat. Paris: Librairie Construction moderne, 1924-1925.

- Mobilier et Décoration. Revue Mensuelle des Arts Décoratifs Appliqués et de l'Architecture Moderne. Sévres: Éditions Edmond Honoré, Juillet 1931, il., fotografia, p\&b.

- Mobilier et Décoration. Revue Mensuelle des Arts Décoratifs Appliqués et de l'Architecture Moderne. Sévres: Éditions Edmond Honoré, 1932, il., fotografia, p\&b.

- Mobilier et Décoration. Revue Mensuelle des Arts Décoratifs Appliqués et de l'Architecture Moderne. Sévres: Éditions Edmond Honoré, 1933, il., fotografia, p\&b, tomo 1 .

- Mobilier et Décoration. Revue Mensuelle des Arts Décoratifs Appliqués et de l'Architecture Moderne. Sévres: Éditions Edmond Honoré, 1934, il., fotografia, $\mathrm{p} \& \mathrm{~b}$, tomo 1 . 
- Mobilier et Décoration. Revue Mensuelle des Arts Décoratifs Appliqués et de l'Architecture Moderne. Sévres: Éditions Edmond Honoré, 7-12 Juillet- Déc. 1934, il., fotografia, p\&b, tomo 2.

- Mobilier et Décoration. Revue Mensuelle des Arts Décoratifs Appliqués et de l'Architecture Moderne. Sévres: Éditions Edmond Honoré, 6 Jan.Juin 1935, il., fotografia, p\&b, tomo 1.

- Mobilier et Décoration. Revue Mensuelle des Arts Décoratifs Appliqués et de l'Architecture Moderne. Sévres: Éditions Edmond Honoré, Sep.Déc. 1935, il., fotografia, p\&b, tomo 2.

- Mobilier et Décoration. Revue Mensuelle des Arts Décoratifs Appliqués et de l'Architecture Moderne. Sévres: Éditions Edmond Honoré, Jan.Juin 1936, il., fotografia, p\&b, tomo 1.

- Mobilier et Décoration. Revue Mensuelle des Arts Décoratifs Appliqués et de l'Architecture Moderne. Sévres: Éditions Edmond Honoré, AoûtDéc. 1937, Exposition Internationale Paris, il., fotografia, p\&b, tomo 2.

- Mobilier et Décoration. Revue Mensuelle des Arts Décoratifs Appliqués et de l'Architecture Moderne. Sévres: Éditions Edmond Honoré, 1-3 Janvier-Mars, 5 mai, 7-11 Julliet- Novembre 1938, il., fotografia, p\&b.

- Mobilier et Décoration. Revue Mensuelle des Arts Décoratifs Appliqués et de l'Architecture Moderne. Sévres: Éditions Edmond Honoré, - 2 Jan.-Fev., 4 -7 Avril-Julliet 1939; 1-4 Jan.-Avr. 1940, il., fotografia, p\&b, tomo 1.

- Mobilier et Décoration. Revue Mensuelle des Arts Décoratifs Appliqués et de l'Architecture Moderne. Sévres: Éditions Edmond Honoré, 1961, il., fotografia, p\&b.

- Mobilier et Décoration. Revue Mensuelle des Arts Décoratifs Appliqués et de l'Architecture Moderne. Sévres: Éditions Edmond Honoré, s.d., s. $\mathrm{n}^{\circ}$, p. 309-500, il., fotografia, p\&b.

- Mobilier et Décoration. Revue Mensuelle des Arts Décoratifs Appliqués et de l'Architecture Moderne. Sévres: Éditions Edmond Honoré, s.d., s. $\mathrm{n}^{\mathrm{o}}$, até p. 552, il., fotografia, p\&b.

- Modern Architectural Designs and Details containing Eighty Finely Lithographed plates showing new and original designs in the Queen Anne, Eastlake, Elizabethian and other modernized styles giving perspective views, floor and framing plans, elevations, sections and a great variety of miscellaneous exterior and interior details of dwellings of moderate cost .... New York: William T. Comstock, 1881, vol. 1.-4, il., litografia, p\&b, tomo 1 . 
- Modern Architectural Designs and Details. A Monthly Publication Giving details of exterior and interior woodwork drawn to scale, gelatine plates of late work by prominent architects .... New York: William T. Comstock, October 1888 to march 1889, vol. 2, New series n I-VI, vol. 1 - 4., il., p\&b, tomo 2.

- Modern Architectural Designs and Details. A Monthly Publication Giving details of exterior and interior woodwork drawn to scale, gelatine plates of late work by prominent architects .... New York: William T. Comstock, 1881, vol. 7-12., il., p\&b, tomo 3.

- Modern Architectural Designs and Details. A Monthly Publication Giving details of exterior and interior woodwork drawn to scale, gelatine plates of late work by prominent architects ... New York: William T. Comstock, 1881, vol. 13-18, il., p\&b, tomo 4.

- Moderne Welt Kunst, Liretatur, Mode. Geleitet von Ludwig Hirschfeld. Österreichisches Kunstgeverbe II Jahrgang Heft Mr. 12. Heft 12, Seite I. Wien: Verlag Moderne Welt Arnold Bachwitzs, 1920-1921, Heft 12, vol.12, il., fotografia, p\&b.

- Mouseion. [Revue Internatinale de Muséographie]. Paris: [L'Office International de Musées de L'Institut International de Coopération Intelectulle], 1931, indice Cinquième Année, vol. 15, no III; Índice Sixième Année, vol. 17-18, nº s. I-II, 1932 e artigos ilustrados, p\&b, fotografia, incompleta.

- Plaisir de France. Revue mensuelle. [Paris]: S.n., 1936, Mars -Juin 1937, il., fotografia, p\&b, color.

- Plaisir de France. Revue mensuelle. [Paris]: S.n., Août - Déc. 1937. Numero spécial Exposition Paris, il., fotografia, p\&b, color.

- Plaisir de France. Revue mensuelle. [Paris]: S.n., Jan. - Juillet 1938, no 40, il., fotografia, p\&b, color.

- Plaisir de France. Revue mensuelle. [Paris]: S.n., Août - Déc. 1938, nº 41, il., fotografia, p\&b, color.

- Plaisir de France. Revue mensuelle. [Paris]: S.n., Jan.- Julliet; Sept. 1939 (Le Pavillon Français a l'Expo International de New York), il., fotografia, p\&b, color.

- Plaisir de France. Revue mensuelle. [Paris]: S.n., Jan.-Mai, Nov. 1947, il., fotografia, $\mathrm{p} \& \mathrm{~b}$, color.

- Plaisir de France. Revue mensuelle. [Paris]: S.n., Juillet - Déc. 1948, il., fotografia, $\mathrm{p} \& \mathrm{~b}$, color. 
- Plaisir de France. Revue mensuelle. [Paris]: S.n., Oct.- Déc. 1939 ; Jan.Mai 1940, il., fotografia, p\&b, color.

- Recent English Domestic Architecture, 1911. London: Offices of "The Architectural Review"], s.d, vol. 4, il., fotografia, p\&b.

- The Architectural Digest. Los Angeles: S.n, s.d., il., p\&b, sem capa.

- The Connoisseur. London: [Edward Wenham], Christmas 1937; Sep.Dec. 1946; March, June 1947, il., fotografia, p\&b.

- The Connoisseur. London: [Edward Wenham], July, OctoberNovember 1936; January 1937, il., fotografia,p\&b.

- The Connoisseur. London: [Edward Wenham], March-April, June-July 1937, vol. 1, il., fotografia, p\&b.

- The Connoisseur. London: [Edward Wenham], August-November 1937, vol. 2, il., fotografia, p\&b.

- The Connoisseur. London: [Edward Wenham], May 1935; March, MayJune 1936, il., fotografia, p\&b.

- The Furniture Journal. Chicago: S.n, 25 June 1917, vol. XLVII/- The Furniture Journal. Chicago: S.n, July 1917, vol. XLVII, il., encadernado com outros títulos.

- The Furniture Journal. Chicago: S.n, September 1917, vol. XLVI, nº 1/ The Furniture Journal. Chicago: S.n, 10 December 1917, vol. XLVII, no. 4 , il., p\&b.

- The House Beautiful. Boston: The House Beautiful Publishing Co. Inc., Dec.-May 1916-1917, vol. XLI, il., fotografia, p\&b.

- The House Beautiful. Boston: The House Beautiful Publishing Co. Inc., Jan., Feb.-June 1917, il., fotografia, p\&b.

- The House Beautiful. Boston: The House Beautiful Publishing Co. Inc., March, June-Dec. 1917, il., fotografia, p\&b, capa solta.

\section{I.1.9.2 Revistas especializadas em tecnologia}

- Machinas. Construcções. Periódico Diffusor Technico e Commercial da Indústria Mecânica Brasileira. São Paulo: S.n., Julho 1936, anno I, nº 1, il., fotografia, p\&b.

- Machinas. Construcções. Periódico Diffusor Technico e Commercial da Indústria Mecânica Brasileira. São Paulo: S.n., Jan - Junho 1937, sob título Órgão official do Syndicato dos Industriais Metalúrgicos do Estado de São Paulo, il., fotografia, p\&b, tomo 1. 
- Machinas. Construcções. Periódico Diffusor Technico e Commercial da Indústria Mecânica Brasileira. São Paulo: S.n., junho -Dez. 1937, il., fotografia, p\&b, tomo 2 .

- Machinas. Construcções. Periódico Diffusor Technico e Commercial da Indústria Mecânica Brasileira. São Paulo: S.n., Jan. - Junho 1938, il., fotografia, p\&b, tomo 1 .

- Machinas. Construcções. Periódico Diffusor Technico e Commercial da Indústria Mecânica Brasileira. São Paulo: S.n., junho -Dez. 1938, il., fotografia, $\mathrm{p} \& \mathrm{~b}$, tomo 2 .

- Machinas. Construcções. Periódico Diffusor Technico e Commercial da Indústria Mecânica Brasileira. São Paulo: S.n., Jan. - Junho 1939, il., fotografia, $\mathrm{p} \& \mathrm{~b}$, tomo 1 .

- Machinas. Construcções. Periódico Diffusor Technico e Commercial da Indústria Mecânica Brasileira. São Paulo: S.n., junho -Dez. 1939, il., fotografia, p\&b, tomo 2 .

- Machinas. Construcções. Periódico Diffusor Technico e Commercial da Indústria Mecânica Brasileira. São Paulo: S.n., Jan. - Junho 1940, il., fotografia, p\&b, tomo 1 .

- Machinas. Construcções. Periódico Diffusor Technico e Commercial da Indústria Mecânica Brasileira. São Paulo: S.n., junho -Dez. 1940, il., fotografia, $\mathrm{p} \& \mathrm{~b}$, tomo 2 .

- Machinas. Construcções. Periódico Diffusor Technico e Commercial da Indústria Mecânica Brasileira. São Paulo: S.n., Jan. - Junho 1941, il., fotografia, p\&b, tomo 1 .

- Machinas. Construcções. Periódico Diffusor Technico e Commercial da Indústria Mecânica Brasileira. São Paulo: S.n., junho -Dez. 1941, il., fotografia, p\&b, tomo 2 .

- Machinas. Construcções. Periódico Diffusor Technico e Commercial da Indústria Mecânica Brasileira. São Paulo: S.n., Jan. - Junho 1942, il., fotografia, p\&b, tomo 1 .

- Machinas. Construcções. Periódico Diffusor Technico e Commercial da Indústria Mecânica Brasileira. São Paulo: S.n., junho -Dez. 1942, il., fotografia, p\&b, tomo 2 .

- Machinas. Construcções. Periódico Diffusor Technico e Commercial da Indústria Mecânica Brasileira. São Paulo: S.n., Jan. - junho 1943, il., fotografia, p\&b, tomo 1 .

- Marelli. Rivista Mensile. Milano: Ercole Marelli e C., S.A., Jun - Dec. 1937, anno XIV, il., fotografia, p\&b. 


\section{Revista científica}

- La Science et la Vie. Magazine Mensuel des Sciencies et de leurs applications a la vie Moderne. [Paris]: S.n., 1925, nº 98, Tomo XXVIII e outros, il., fotografia, clichês, p\&b

- La Science et la Vie. Magazine Mensuel des Sciencies et de leurs applications à vie Moderne. [Paris]: S.n., Janvier 1928, nº 137 e outros, Tomo XXXIII e outros, il., fotografia, clichês, p\&b.

- La Science et la Vie. Magazine Mensuel des Sciencies et de leurs applications à la vie Moderne. [Paris]: S.n., 1929, il., fotografia, clichês, p\&b.

- La Science et la Vie. Magazine Mensuel des Sciencies et de leurs applications à la vie Moderne. [Paris]: S.n., 1931, il., fotografia, clichés, p\&b.

- La Science et la Vie. Magazine Mensuel des Sciencies et de leurs applications à la vie Moderne. [Paris]: S.n., 1932, il., fotografia, e clichés, p\&b.

- La Science et la Vie. Magazine Mensuel des Sciencies et de leurs applications à la vie Moderne. [Paris]: S.n., 1934, il., fotografia, clichés, p\&b.

- La Science et la Vie. Magazine Mensuel des Sciencies et de leurs applications à la vie Moderne. [Paris]: S.n., 1937, il., fotografia, clichés, p\&b.

\section{I.1.10 Pranchas impressas/álbuns seriados}

- Albrecht Mockel. I Serie Entwürfe du modern. Tischler-Arbeiten. Abtheilung: Bautischler-Arbeitein. 14 pranchas, s.l., color., p\&b, impresso.

- [Alegoria]. S.n.; S.l.; s.d., monocromia, impresso.

- Ameublements complets de Tous Styles. L. Bertin. Emile Thézard. Editeur à Dourdan. Phototyphie Betrand. Paris / Nouveau Journal d'Ameublement. Décor de Croisée Louis XVI. Emile Thézard, pl.2], s.d., 7 pranchas, color., p\&b, impresso, carimbo Fábrica de Móveis de Antonio de Mosso, S. Paulo, Rua Brigadeiro Tobias, 77 .

- Andrea Devico des. Ornamenti dei secolo XVI. Patera nella Capella Cosi in S. Maria Della Pace e frammenti stipite. [De Vico Andrea, Trenta tavole di ornamenti architettonici greci, romani e italiani nelle loro più classiche epoche disegnati e restaurati per Andrea De Vico. Roma: Danesi, 1862], monocromia, impresso, carimbo Lyceo de Artes e Officios, 7 abril [19]30. 
- Andrea Devico des. Ornamenti di arch Greci. Fregi [De Vico Andrea, Trenta tavole di ornamenti architettonici greci, romani e italiani nelle loro più classiche epoche disegnati e restaurati per Andrea De Vico. Roma: Danesi, 1862], monocromia, impresso, carimbo Lyceo de Artes e Officios, 7 abril [19]30.

- Andrea Devico des. Ornamenti di arch Greca. Gola della porta [dell'Eielleo in Atonel]. [De Vico Andrea, Trenta tavole di ornamenti architettonici greci, romani e italiani nelle loro più classiche epoche disegnati e restaurati per Andrea De Vico. Roma: Danesi, 1862], monocromia, impresso, carimbo Lyceo de Artes e Officios, 7 abril [19]30.

- Andrea Devico des. Ornamenti di arch Greca. [M.] Della Porta [dell'Eielleo in Atonel]. [De Vico Andrea, Trenta tavole di ornamenti architettonici greci, romani e italiani nelle loro più classiche epoche disegnati e restaurati per Andrea De Vico. Roma: Danesi, 1862], monocromia, impresso, carimbo Lyceo de Artes e Officios, 7 abril [19]30.

- Andrea Devico des. Ornamenti di arch Greca. Ristauro Del Capitello nel monumento di Lisicrate in Atene. Volgarmente chiamato Lanterna di Demostenel [De Vico Andrea, Trenta tavole di ornamenti architettonici greci, romani e italiani nelle loro più classiche epoche disegnati e restaurati per Andrea De Vico. Roma: Danesi, 1862], monocromia, impresso, carimbo Lyceo de Artes e Officios, 7 abril [19]30.

- Andrea Devico des. Ornamenti di archra. Romana. AL SIGR. CAVR. FRANCO. PODESTI. Prof. Cattedratico di S. Luca famoso dipintore nel martitio di S. Lorenzo e per altre opere egregie, Andrea de Vico desiderava significare publicamente l'altissima sua stima, e lo fa ora come puo megliori com questo disegno. [De Vico Andrea, Trenta tavole di ornamenti architettonici greci, romani e italiani nelle loro più classiche epoche disegnati e restaurati per Andrea De Vico. Roma: Danesi, 1862], monocromia, impresso, carimbo Lyceo de Artes e Officios, 7 abril [19]30.

- Andrea Devico des. Ornamenti di archra. Romana. Base dell'ordine interno del tempio della Concordia al Foro Romano. AL CH: PROP. CAV.TOMMASO MINARDI. Che nell'Accademia di S. Luca. [De Vico Andrea, Trenta tavole di ornamenti architettonici greci, romani e italiani nelle loro più classiche epoche disegnati e restaurati per Andrea De Vico. Roma: Danesi, 1862], monocromia, impresso, carimbo Lyceo de Artes e Officios, 7 abril [19]30. 
- Andrea Devico des. [Ornamenti]. Fregi in terracota [De Vico Andrea, Trenta tavole di ornamenti architettonici greci, romani e italiani nelle loro più classiche epoche disegnati e restaurati per Andrea De Vico. Roma: Danesi, 1862], monocromia, impresso, carimbo Lyceo de Artes e Officios, 7 abril [19]30.

- Andrea Devico des. Ornamenti Greci. Dettagli di candeliera. [De Vico Andrea, Trenta tavole di ornamenti architettonici greci, romani e italiani nelle loro più classiche epoche disegnati e restaurati per Andrea De Vico. Roma: Danesi, 1862], monocromia, impresso, carimbo Lyceo de Artes e Officios, 7 abril [19]30.

- Andrea Devico des. Ornamenti Romani. Parte inferiore di um candelabro nel Museo Vaticano, riprodotto ala meta dell'originale. [De Vico Andrea, Trenta tavole di ornamenti architettonici greci, romani e italiani nelle loro più classiche epoche disegnati e restaurati per Andrea De Vico. Roma: Danesi, 1862], monocromia, impresso, carimbo Lyceo de Artes e Officios, 7 abril [19]30.

- [Anton Andel Gez]. Ornament von einer Mittelalterlichen Glasmalerei. 107. Litil R.V. Waldheim, Verlag von R.V. Waldheim in Wien [1878], policromia, impresso, carimbo Lyceo de Artes e Officios, 7 abril [19]30].

- [Anton Andel Gez]. Griechische bandornamente. [Litil R.V. Waldheim, Verlag von R.V. Waldheim in Wien][1878], policromia, impresso.

- [Anton Andel Gez]. [Sem título (Palmettenverzierung)] [Litil R.V. Waldheim, Verlag von R.V. Waldheim in Wien][1878], policromia, impresso.

- [Anton Andel Gez]. [Sem título] [Litil R.V. Waldheim, Verlag von R.V. Waldheim in Wien][1878], policromia, impresso.

- [Anton Andel Gez]. [Sem título 1] [Litil R.V. Waldheim, Verlag von R.V. Waldheim in Wien][1878], policromia, impresso.

- Anton Andel Gez. Blattband - und Palmettenverzierung eines antiken gefasses.26. Litil R.V. Waldheim, Verlag von R.V. Waldheim in Wien [1878], policromia, impresso, carimbo Lyceo de Artes e Officios, 7 abril [19]30].

- Anton Andel Gez. Indische Flachornamente. 68. Litil R.V. Waldheim, Verlag von R.V. Waldheim in Wien [1878], policromia, impresso, carimbo Lyceo de Artes e Officios, 7 abril [19]30.

- Anton Andel Gez. Ornamente Mittelalterlicher Fußbodenplatten. 57. Litil R.V. Waldheim, Verlag von R.V. Waldheim in Wien [1878], policromia, impresso, carimbo Lyceo de Artes e Officios, 7 abril [19]30. 
- Anton Andel Gez. Ornament von persisch arabischen faiencen. 63. Litil R.V. Waldheim, Verlag von R.V. Waldheim in Wien [1878], policromia, impresso, carimbo Lyceo de Artes e Officios, 7 abril [19]30.

- Anton Andel Gez. Ornament von persisch arabischen faiencen. 64. Litil R.V. Waldheim, Verlag von R.V. Waldheim in Wien [1878], policromia, impresso, carimbo Lyceo de Artes e Officios, 7 abril [19]30.

- Anton Andel Del. Et Pinx. [Sem título]. 90. Litil R.V. Waldheim, Verlag von R.V. Waldheim in Wien [1878], policromia, impresso, carimbo Lyceo de Artes e Officios, 7 abril [19]30.

- A. Quadrench. Método particular de perspectiva. Ponto, principal e de concurso. S.l., s.d., manuscrito.

- A. Quadrench. Método geral de perspectiva. S.l., s.d., manuscrito.

- A. Quadrench. Perspectiva simplificada. S.l., s.d., manuscrito, com apagamento do nome do autor.

- A. Quadrench. Perspectiva paralela. S.l., s.d., manuscrito, com apagamento do nome do autor.

- A. Quadrench. Método particular de perspectiva. S.l., s.d., manuscrito, com apagamento do nome do autor.

- BOITO, Camilo. [Arte Italiana Dec. e Ind. ]. Milano: Ulrico Hoepli: [1895-primeira metade do século XX], 6 pranchas, color., p\&b, impresso.

- BOITO, Camillo. Arte utile. Decorazione policroma. Tav. 13. Fiori su carta da parati (Stile Giapponese), Milano: Ulrico Hoepli, Editore, [1893], impresso.

- BOITO, Camillo. Arte utile. Decorazione policroma. Tav. 26. Vetri colorati di stile archiacuto. Milano: Ulrico Hoepli, Editore, [1893], impresso.

- BOITO, Camillo. Arte utile. Decorazione policroma. Tav. 27. Tappeti ed orli di modo copto. Milano: Ulrico Hoepli, Editore, [1893], impresso.

- BOITO, Camillo. Arte utile. Decorazione policroma. Tav. 34. Contorni e fascie imitante le maniere orientali. Milano: Ulrico Hoepli, Editore, [1893], impresso.

- BOITO, Camillo. Arte utile. Decorazione policroma. Motivos arquitetônicos. Milano: Ulrico Hoepli, Editore, [1893], impresso.

- BOITO, Camillo. Arte utile. Decorazione policroma. Motivos arquitetônicos 2. Milano: Ulrico Hoepli, Editore, [1893], impresso.

- Bonheur. S.n.; S.l.; s.d, monocromia, impresso.

- [Brahtz, Kirsch \& Kracht: Vorschule für das Maschinenzeichnen. Lithographie und Druck von Fr.Wilh. Ruhfus. Dortmund: Verlag der 
Ruhfusschen Kunst und Buchhandlung], [1897], 11 pranchas, color., p\&b, impresso.

- Chapiteau a Notre Dame de Paris. [L'Ornament. Imp. J. Monrocq. Paris: Monrocq frères editeur], s.d, impresso.

- Chapiteau de pilastre du Louvre. L'Ornament. Sous Henri IV. [Imp. J. Monrocq. Paris: Monrocq frères editeur], s.d, impresso.

- Chapiteaux (sic) jonique du temple de la Fortune Virile. Cours d'ornament. Pl. 27.. Imp. J. Monrocq. Paris: Monrocq frères editeur, s.d., impresso

- [Claro Pasinati. Disegno Applicato alla Arte e mesteri. Stah Lit. C. Pasinati dis. L. Battei] Parma: s.d., 6 pranchas, color., impresso, carimbo Liceu de Artes e Ofícios de São Paulo [19]30.

- [Classic]. S.l., S.n., s.d., 1 prancha, color., p\&b, impresso.

- Denticules. D'Apres des Platres de 1'Ecole des Beaux-Arts. L'Ornament. Imp. J. Monrocq. Paris: Monrocq frères editeur, s.d., impresso

- [Desenho Geométrico], s.d., 4 pranchas, s.l., color., p\&b, impresso.

- [Desenho Geométrico], s.d., 5 pranchas, s.l., color., p\&b, impresso.

- [Desenho Geométrico], s.d., 8 pranchas, s.l., color., p\&b, impresso.

- [Desenho Geométrico], s.d., 12 pranchas, s.l., color., p\&b, impresso.

- [Desenho Geométrico], s.d., 13 pranchas, s.l., color., p\&b, impresso, carimbo Liceu de Artes e Ofícios de São Paulo 23 abr [19]30.

- [Desenho Geométrico], s.d., 13 pranchas, s.l., color., p\&b, impresso.

- Desenho geométrico e elementos de geometria, S.n.; S.l.; s.d., impresso, 11 pranchas.

- [Desenho geométrico, motivos decorativos e Lições de perspectiva. A Editora. [Lisboa]: s.d., 36 pranchas, s.l., color., p\&b, impresso.

- [Desenho linear] s.d., circa 10 pranchas, s.l., color., p\&b, impresso.

- [Disegnos. Ornatos. Carlo Tamone], s.d., 28 pranchas, s.l., color., p\&b, impresso.

- E. Grossmann. Hausthüren und Thore. Tafel 6. Hofbuchdruckerei C. Liebich, Stuttgart. Verlag von Otto Maier, Ravensburg, [1901] e Hausthüren und Thore. Herausgegeben von E. Grossmann. Detailblatt 6. Details au tafel 6. Impresso. Ravensburg : Verlag von Otto Maier, [1901], 11 pranchas, s.l., color., p\&b, impresso.

- E. Herdtles's Vorlagenwerk. Herausgegeben im Auftrage d.k. kommifsion f.d. gewerbl. Fortbildungsschulen Württembergs. Lith. Anst. V. J.C. Henzler. Stuttgart: Verlag von Wilhelm Nitzschke, [1890], 34 pranchas, s.l., color., p\&b, impresso. 
- [Elementos arquitetônicos]. T XV. S.n.; S.l.; s.d, monocromia, impresso.

- [Elementos arquitetônicos]. T XVI. S.n.; S.l.; s.d, monocromia, impresso.

- [Elementos arquitetônicos]. T XXI. S.n.; S.l.; s.d, monocromia, impresso.

- [Elementos arquitetônicos]. T XXII. S.n.; S.l.; s.d, monocromia, impresso.

- [Elementos arquitetônicos]. T XXIV. S.n.; S.l.; s.d, monocromia, impresso.

- [Entalhe], s.d., 6 pranchas, s.l., color., p\&b, impresso.

- [Entalhe], s.d., 4 pranchas, s.l., color., p\&b, impresso.

- Escriptorio Technico 'Ramos de Azevedo', Serviço Technico do Café. Viaducto Boa Vista, s.n., Sede, 05.09.1934 15137; 05.09.1934 15139; 05.09.1934 15143; 05.09.1934 15145; 05.09.1934 15146; 05.09.1934 15149; 05.09.1934 15152; 05.09.1934 15 [...], 2 exemplares, 1934, 10 pranchas, color., impresso.

- E. [V--]. [Flores], policromia. S.l.; S.d., impresso.

- [Ferro puro] / [Weitzel Schule des machinentechnikers], s.d., 2 pranchas, s.l., color., p\&b, impresso.

- [Figuras], s.d., 36 pranchas, s.l., color., p\&b, impresso.

- Frise Grec. [D'Apres des Platres de l'Ecole des Beaux-Arts.] No du plâtre 2942. [L'Ornament. Imp. J. Monrocq. Paris: Monrocq frères editeur], s.d., impresso

- Giovan Battista Borsani. Frammenti di Ornati. Milano: Antonio Vallardi Editore, Via S.Margherita 9. S.d., impresso.

- Giocondo Albertolli dis. G. Mercoli inc. Foglia d'acanto di un capitello Corintio trata dall'antico [1782]. XXIV. Corso elementare di ornamenti architettonichi. A Milano: Si trova presso 1 Autore, 1805, impresso.

- Giocondo Albertolli dis. Ambrogio Barioli inc. Ornamento di uma Metopa, per in Fregio Dorico. Ultima tavola. XXVIII. Corso elementare di ornamenti architettonichi. A Milano: Si trova presso 1 Autore, 1805, impresso.

- Gotische Zimmerthüren. Taf 31. S.n.; S.l., s.d., impresso.

- [Herausg. U. Gez. Joseph Wildt. Verlag von A. Pichlers Witwe \& Sohn. Wien \& Leipzig: s.d., 1 prancha, color., p\&b, impresso.

- Il Disegno nella scuola. Corso progressivo per l'insegnamento del disegno d'ornato applicato al disegno geométrico. Torino: Scuole Professionali Salesiane. S.d., impresso, 7 pranchas, s.l., color., p\&b, impresso. 
- Il Piccolo Artista. [Figuras]. 85. Dispensa 22. [Album di disegni elementari. Figura, ornato, paesaggio, fiori, prospettiva, architettura. Milano: Sonzogno, 1924, 5 pranchas, color., p\&b, impresso, carimbo Lyceo de Artes e Officios, 23 abril [1930].

- [J. Carol]. Caisson (Renaissance [-]). Cours d'ornament. Pl. 36. Méthode du Grand Papa. Imp. J. Monrocq. Paris: Monrocq frères editeur, s.d., impresso

- [J. Carol]. Feuille d'angle d'um chapiteau de Notre Dame. Cours d'ornament. Imp. J. Monrocq. Paris: Monrocq frères editeur, s.d., impresso.

- [J. Carol]. Frise antique. Cours d'ornament. [Imp. J. Monrocq.] Paris: Monrocq frères editeur, s.d., impresso

- [J. Carol]. Modillon grec. Cours d'ornament. Pl. 38. Méthode du Grand Papa. Imp. J. Monrocq. Paris: Monrocq frères editeur, s.d., impresso

- [J. Carol]. Style Louis XV.[ Imp. J. Monrocq. Paris: Monrocq frères editeur], s.d.

- [J. Carol]. Tiré d'une frise antique. Cours d'ornament. Pl. 60. Imp. J. Monrocq. Paris: Monrocq frères editeur, s.d., impresso

- J. Esteves Ribeiro da Silva. [Curso de] Desenho linear geométrico, $1^{a}$ a 14 a fls. S.n.; S.l.; s.d., impresso.

- Josephine [--]. Main d'apres Michel- Ange. B. S.n.; S.l.; S.d., impresso.

- Josephine [--]. Venus de Milo. C. S.n.; S.l.; S.d., impresso.

- Karl Hesky, Einfache Objekte des Bau-und Maschinenfaches, 4 Aufl. Druck von Christoph Reisser's Sohne, Wien: V. Verlag von Karl Graeser \& Kie], [19-], 17 pranchas, color. p \&b, impresso.

- Karl Georg Weitzel. Die Schule des Maschinentechnikers. Band 9. Die Mechanik. Leipzig: Verlag Moritz Schäfer, [1894-1907], 2 pranchas, s.l., color., p\&b, impresso, com autógrafo ilegível no c.i.d.

- L'Alphabet de L'Ornement.24. Feuilles d'apres nature. S.n.; S.l.; s.d., impresso.

- Lambert und Stahl: Der Praktische Bautischiler. John Bruker lith. Ladenfenster. (II Serie). Heft I. Tafel 4. Details hiezu Tafel 5 u 6. Lith. Anst v.A. Gatternicht. Impresso. Stuttgart: Verlag von Konrad Wittwer, [1890], 18 pranchas, color., p\&b, impresso.

- L'Intaglio. Particolare dello specchio di uno stallo nel Coro della Chiesa di S. Pietro in Perugia, sec. XV. [Raccolta di 50 tavole con la riproduzione di elementi di scultura di varie opere d'arte italiane], impresso. Firenze: Casa Editrice Ars Nova, [1925] circa 29 pranchas, color., p\&b, impresso, carimbo Liceu de Artes e Ofícios de São Paulo 23 abr [19]30. 
- [Liceu de Artes e Ofícios]. Aplicação do oval, caligrafia; S.l.; s.d., impresso.

- [Liceu de Artes e Ofícios]. [Desenhos de Letras 1], caligrafia; S.l.; s.d., impresso.

- [Liceu de Artes e Ofícios]. [Desenhos de Letras 2], caligrafia; S.l.; s.d., impresso.

- [Liceu de Artes e Ofícios]. [Desenhos de Letras 3], caligrafia; S.l.; s.d., impresso.

- [Liceu de Artes e Ofícios]. [Desenhos de Letras 4], caligrafia; S.l.; s.d., impresso.

- [Liceu de Artes e Ofícios]. [Desenhos de Letras 5], caligrafia; S.l.; s.d., impresso.

- Liceu de Artes e Ofícios de São Paulo. Banco comum. Escala 1:5. Modelo corrigido pelo Professor [?]. S.n., S.l., 1935, impresso.

- Liceu de Artes e Ofícios de São Paulo. Banco com encosto. Assentos vistos por alto. Escala 1:5. Modelo corrigido pelo Professor [?]. S.n., S.l., (193-), impresso.

- Liceu de Artes e Ofícios de São Paulo. Banco com encosto. Assentos vistos por alto. Detalhes. Escala 1:5. Modelo corrigido pelo Professor [?]. S.n., S.l., 1935, impresso.

- [Liceu de Artes e Ofícios de São Paulo]. Banco de escola. Duas pessoas com assento comum. S.n.; S.l.; s.d., impresso.

- Liceu de Artes e Ofícios de São Paulo. Banco de escola de dois lugares com assento independente. Typo para crianças. Escala 1:5. Modelo corrigido pelo Professor [?]. S.n., S.l., (193- ), impresso.

- Liceu de Artes e Ofícios de São Paulo. Banco de igreja. De frente, do centro e do fundo. Cortes. Escala 1:10. Modelo corrigido pelo Professor [?]. S.n., S.l., 1935, impresso.

- Liceu de Artes e Ofícios de São Paulo. Escada helicoidal, s.d., impresso.

- Liceu de Artes e Ofícios de São Paulo. Escada helicoidal, (detalhe), s.d., impresso.

- [Liceu de Artes e Ofícios de São Paulo] Especificações de peso, temperatura, porcentagem, resistência à tração e uso em máquinas para os metais ferro puro, ferro fundido, aços siderúrgicos, aço moldado (fundido) e bronze. S.n.; S.l.; s.d., impresso.

- Liceu de Artes e Ofícios de São Paulo. Ornato para as aulas, n 148/930. Depósito. São Paulo, 29 de fevereiro de 1930, inscrito em cartela, impresso. 
- Liceu de Artes e Ofícios de São Paulo. Ornato para as aulas, no 149/930. Depósito. São Paulo, 28 de fevereiro de 1930, inscrito em cartela, impresso.

- Liceu de Artes e Ofícios de São Paulo. Ornato para as aulas, no 151/930. Depósito. São Paulo, 28 de fevereiro de 1930, inscrito em cartela, impresso.

- Liceu de Artes e Ofícios de São Paulo. Ornato para as aulas, nº 152/930. Depósito. São Paulo, 28 de fevereiro de 1930, inscrito em cartela, impresso.

- Liceu de Artes e Ofícios de São Paulo. Ornato para as aulas, no 153/930. Depósito. São Paulo, 28 de fevereiro de 1930, inscrito em cartela, impresso.

- Liceu de Artes e Ofícios de São Paulo. Ornato para as aulas, nº 168/930. Depósito. São Paulo, 5 de março de 1930, inscrito em cartela, impresso, ex.1.

- Liceu de Artes e Ofícios de São Paulo. Ornato para as aulas, no 168/930. Depósito. São Paulo, 5 de março de 1930, inscrito em cartela, impresso, ex.2.

- Liceu de Artes e Ofícios de São Paulo. Ornato para as aulas, nº 169/930. Depósito. São Paulo, 5 de março de 1930, inscrito em cartela, impresso, ex.1.

- Liceu de Artes e Ofícios de São Paulo. Ornato para as aulas, no 169/930. Depósito. São Paulo, 5 de março de 1930, inscrito em cartela, impresso, ex.2.

- Liceu de Artes e Ofícios de São Paulo. Ornato para as aulas, no 170/930. Depósito. São Paulo, 5 de março de 1930, inscrito em cartela, impresso.

- Liceu de Artes e Ofícios de São Paulo. Ornato para as aulas, no 171/930. Depósito. São Paulo, 5 de março de 1930, inscrito em cartela, impresso.

- Liceu de Artes e Ofícios de São Paulo. Ornato para as aulas, no 173/930. Depósito. São Paulo, 6 de março de 1930, inscrito em cartela, impresso

- Liceu de Artes e Ofícios de São Paulo. Ornato para as aulas, no 174/930. Depósito. São Paulo, 8 de março de 1930, inscrito em cartela, impresso.

- Liceu de Artes e Ofícios de São Paulo. [Ornato para as aulas], sem inscrição em cartela, impresso.

- Liceu de Artes e Ofícios de São Paulo. [Ornato para as aulas], sem inscrição em cartela, impresso. 
- Liceu de Artes e Ofícios de São Paulo. Tamborete. Planta vista por baixo. Escala 1:5. Modelo corrigido pelo Professor [?]. S.n., S.1., 1935, impresso.

- MANGE, Robert. Collecção de modelos para desenhos de machinas. Convenções. Nomenclatura. Cálculo. Construção. Organizada e editada por Robert Mange, engenheiro mecânico, lente de Máquinas da Escola Polytechnica de S. Paulo, com a collaboração dos engenheiros Paulo do Amaral, José Gollub e Moysés Marx. São Paulo: Typograhia Brasil de Rohschild \&Co., 1925, impresso, em carpeta.

- MANGE, Robert. Collecção de modelos para desenhos de machinas. Convenções. Nomenclatura. Cálculo. Construção. Organizada e editada por Robert Mange, engenheiro mecânico, lente de Máquinas da Escola Polytechnica de S. Paulo, com a collaboração dos engenheiros Paulo do Amaral, José Gollub e Moysés Marx. Reprodução em metade do tamanho natural. São Paulo: Typograhia Brasil de Rohschild \&Co., 1925, impresso, em carpeta, etiqueta $48 \mathrm{E}$.

- Michelangelo. [Homens nus], Veneza, 1503-1504. [Apud Fratelli Alinari. The Prints are of Miguel Angel Buonarroti 1475-1564. Andrea del Sorto 1486 -1530. Firenze: 1930- 1950s], impresso.

- Milieu d'um chapiteau. Ornament. No 89. Imp. J. Monrocq. Paris: Monrocq frères editeur], s.d., imprsso

- [Mobiliário Agathe, Jsolde, Paula, --], s.d., 4 pranchas, s.l., color., p\&b, impresso.

- [Motivos decorativos, com bucrania]. S.n.; S.l.; s.d., policromia, impresso.

- [Motivos decorativos, com putto]. S.n.; S.l.; s.d., policromia, impresso.

- [Motivos decorativos, com emblema Vrbis]. S.n.; S.l.; s.d., policromia, impresso.

- [Motivos decorativos, com pavão]. S.n.; S.l.; s.d., policromia, impresso.

- [Motivos decorativos, com rocalha]. S.n.; S.l.; s.d., policromia, impresso.

- [Motivos decorativos, cerâmica e tapeçaria]. S.n.; S.l.; s.d., monocromia, impresso.

- [Motivos decorativos, com emblema Vrbis]. S.n.; S.l.; s.d., monocromia, impresso.

- [Motivos decorativos, com bucrania]. S.n.; S.l.; s.d., monocromia, impresso.

- [Motivo ornamental]. Monrocq. Paris: Monrocq frères edit. Imp., s.d., policromia, impresso. 
- [Ornamento arquitetônico 1]. [L'Ornament. Imp. J. Monrocq. Paris: Monrocq frères editeur], s.d., impresso.

- [Ornamento arquitetônico 2]. [L'Ornament. Imp. J. Monrocq. Paris: Monrocq frères editeur], s.d., impresso.

- [Ornamento arquitetônico 3]. [L'Ornament. Imp. J. Monrocq. Paris: Monrocq frères editeur], s.d., impresso.

- [Ornamento arquitetônico 4]. D'Après des Platres de l'Ecole des Beaux-Arts L'Ornament. [Imp. J. Monrocq. Paris: Monrocq frères editeur], s.d., impresso.

- [Ornamento arquitetônico 5]. D'Apres des Platres de l'Ecole des Beaux-Arts L'Ornament. Imp. J. Monrocq. Paris: Monrocq frères editeur, s.d., impresso.

- [Ornamento arquitetônico 6, por Boisgontier]. D'Apres des Platres de l'Ecole des Beaux-Arts. No du platre [28--]. Imp. J. Monrocq. Paris: Monrocq frères editeur, s.d., impresso.

- [Ornamento arquitetônico 7]. D'Apres des Platres de l'Ecole des Beaux-Arts. L'Ornament. [Imp. J. Monrocq]. Paris: Monrocq frères editeur, s.d., impresso.

- [Ornamento arquitetônico 9]. D’Apres des Platres de l'Ecole des Beaux-Arts 1. L'Ornament. [Imp. J. Monrocq]. Paris: Monrocq frères editeur, s.d., impresso.

- [Ornamento arquitetônico 10 (Leão)]. [Sculpture Moderne]. [L'Ornament. Imp. J. Monrocq.] Paris: Monrocq frères editeur, s.d., impresso.

- [Ornamento arquitetônico 11, por J. Herbert]. [L'Ornament. Imp. J. Monrocq. Paris: Monrocq frères editeur], s.d., impresso.

- [Ornamento arquitetônico 12, por Herbert]. [L'Ornament. Imp. J. Monrocq. Paris: Monrocq frères editeur], s.d., impresso.

- [Ornamento arquitetônico 13, por J. Carol [Leão]. Sculpture Moderne. [L'Ornament. Imp. J. Monrocq. Paris: Monrocq frères editeur], s.d., impresso.

- [Ornamento arquitetônico]. [Cours d'ornament. Imp. J. Monrocq. Paris: Monrocq frères editeur], s.d., impresso.

- [Ornamentos. J. Petrillo], s.d., 3 pranchas, s.l., color., p\&b, impresso.

- [Phototypie S. A. A. E. Laussedat, Châteaudun, Paris. R. Bilard, éditeur, Le Mans], s.d., 23 pranchas, color., p\&b, impresso.

- Rinceaux imitées de l'antique. Cours d'ornament. [Imp. J. Monrocq. Paris: Monrocq frères editeur], s.d., impresso 
- Rosace imitée de l'antique. Cours d'ornament. Imp. J. Monrocq. [Paris: Monrocq frères editeur], s.d. impresso.

- Säulenkapitelle- u.Füsse. Dorisch, Korinthisch, Renaissance. Taf 3. Stockel. Schreiner. S.l.; [1890], impresso.

- Schmidt, Holzbau. Helmstangen und Gielbelblumen. Tafel 18. Impresso. Berlin: Verlag von Julius Springer, s.d., impresso.

- Schmidt, Die Verwendung der neuren formsteine. Rosetten.Tafel 20. Berlin: Verlag von Julius Springer, s.d., impresso.

- Schmidt, Quaderbau. Detailzeichnungen zu tafel 9. Tafel 11. Berlin: Verlag von Julius Springer, Berlin, s.d., impresso.

- Schmidt, Quaderbau. Moderne Säulen \& Pfeiler nach augsfürten Arbeiten der Kunst. [...] Tafel 4. Berlin: Verlag von Julius Springer, s.d., impresso.

- Schmidt, Verband der Mauersteine. Isometrische Zeichnung zu figur 101 auf Tafel 10 gehörig. Druck.von. H.S. Hermann. Berlin: Verlag von Julius Springer, s.d., impresso.

- [Sem título]. Lith par Julien. [Imp. J. Monrocq. Cours de dessin Paris: Monrocq frères editeur], s.d., impresso.

- [Sem título] Tafel 577. Moderne Vorlagen in Jugendstill. 6 Tafel in folio. Lieferung 83 (Tafel 553-558). Entworfen von Konrad Wiederhold. Leipzig: Verlag von E. Kaberland.

- Sem título, s.d., 4 pranchas, s.l., color, impresso.

- [Stickel Schreiner], s.d., 4 pranchas, s.l., color., p\&b, impresso.

- The Baldwin Locomotive Works. Tabulação das peças principais, s.d., 1 prancha, s.l., color., p\&b, impresso.

- Vacchetta e Della Sala Spada. Cinquanta modelli elementari di disegno a mano libera. Torino: Libr. Ed. Internazionale, 1914, 10 pranchas, color., p\&b, impresso.

- Vacchetta e Della Sala Spada. Arte del legno. Soc. Ed. Internazionale, Torino, 1921, 12 pranchas color., p\&b, impresso, carimbo Liceu de Artes e Ofícios de São Paulo 23 abr [19]30.

- Vacchetta e Della Sala Spada. Modelli dell'arte del ferro di epoche e tecniche diverse. Torino: Libr. Ed. Internazionale, 1917, impresso, 25 pranchas. Carimbo Liceu de Artes e Ofícios 24 Abril [19]30.

- [Vasos], s.d., 6 pranchas iguais, s.l., p\&b, impresso, carimbo Liceu de Artes e Ofícios de São Paulo 15 abr [19]29.

- [Zu Fassadenblatt \& Fassadenblatt], S.1.: [Siebe \& co zk], S.d., 44 pranchas, s.l., color., p\&b, impresso. 
- [Zu Fassadenblatt. Brausewetter, Bauformen. Leipzig: Verlag von E. A. Seemann, 1898], 29 pranchas, color., p\&b, impresso.

\section{I.1.11 Impressos}

- Directoria Geral Do Ensino. Assistência técnica do Ensino Profissional e Vocacional. Estado de São Paulo. Série I. Vocacional Educativa. S.l: S.n., 1931, textos e desenhos impressos, p\&b.

- EMENDABILI, Galileo. Projecto para o monumento commemorativo de Ramos de Azevedo. S.l.: s.d., il., fotografia, p\&b, impresso.

- Laboratório de Ensaios de Materiaes da Escola Polytechnica de S. Paulo pelo Engo. Civil Ary Frederico Torres. Director do Laboratório. S. Paulo. São Paulo: Escolas Profissionaes Salesianas do Lyceu Coração de Jesus 1929, s.d., impresso, etiqueta 24 E.

- LACCHINI, Luiz. Curso preparatório de desenho à mão livre para o uso das escolas secundárias e profissionaes pelo professor Luiz Lacchini compreendendo 16 cadernos divididos em 3 partes, sendo que os cadernos de 1 a 9 referem-se a primeira parte, compostos de "Simples contorno", de 10 a 12 "Claro Escuro" e 13 a 16 de "Figuras Claro Escuro", s.d, s.l, impresso, caderno 1.

- LACCHINI, Luiz. Curso preparatório de desenho à mão livre para o uso das escolas secundárias e profissionaes pelo professor Luiz Lacchini compreendendo 16 cadernos divididos em 3 partes, sendo que os cadernos de 1 a 9 referem-se a primeira parte, compostos de "Simples contorno", de 10 a 12 "Claro Escuro" e 13 a 16 de "Figuras Claro Escuro", s.d, s.l, impresso, caderno 2.

- LACCHINI, Luiz. Curso preparatório de desenho à mão livre para o uso das escolas secundárias e profissionaes pelo professor Luiz Lacchini compreendendo 16 cadernos divididos em 3 partes, sendo que os cadernos de 1 a 9 referem-se a primeira parte, compostos de "Simples contorno", de 10 a 12 "Claro Escuro" e 13 a 16 de "Figuras Claro Escuro", s.d, s.l, impresso, caderno 3.

- LACCHINI, Luiz. Curso preparatório de desenho à mão livre para o uso das escolas secundárias e profissionaes pelo professor Luiz Lacchini compreendendo 16 cadernos divididos em 3 partes, sendo que os cadernos de 1 a 9 referem-se a primeira parte, compostos de "Simples contorno", de 10 a 12 "Claro Escuro" e 13 a 16 de "Figuras Claro Escuro", s.d, s.l, impresso, caderno 4. 
- LACCHINI, Luiz. Curso preparatório de desenho à mão livre para o uso das escolas secundárias e profissionaes pelo professor Luiz Lacchini compreendendo 16 cadernos divididos em 3 partes, sendo que os cadernos de 1 a 9 referem-se a primeira parte, compostos de "Simples contorno", de 10 a 12 "Claro Escuro" e 13 a 16 de "Figuras Claro Escuro", s.d, s.l, impresso, caderno 5.

- LACCHINI, Luiz. Curso preparatório de desenho à mão livre para o uso das escolas secundárias e profissionaes pelo professor Luiz Lacchini compreendendo 16 cadernos divididos em 3 partes, sendo que os cadernos de 1 a 9 referem-se a primeira parte, compostos de "Simples contorno", de 10 a 12 "Claro Escuro" e 13 a 16 de "Figuras Claro Escuro", s.d, s.l, impresso, caderno 6.

- LACCHINI, Luiz. Curso preparatório de desenho à mão livre para o uso das escolas secundárias e profissionaes pelo professor Luiz Lacchini compreendendo 16 cadernos divididos em 3 partes, sendo que os cadernos de 1 a 9 referem-se a primeira parte, compostos de "Simples contorno", de 10 a 12 "Claro Escuro" e 13 a 16 de "Figuras Claro Escuro", s.d, s.l, impresso, caderno 7.

- LACCHINI, Luiz. Curso preparatório de desenho à mão livre para o uso das escolas secundárias e profissionaes pelo professor Luiz Lacchini compreendendo 16 cadernos divididos em 3 partes, sendo que os cadernos de 1 a 9 referem-se a primeira parte, compostos de "Simples

contorno", de 10 a 12 "Claro Escuro" e 13 a 16 de "Figuras Claro Escuro", s.d, s.l, impresso, caderno 8.

- LACCHINI, Luiz. Curso preparatório de desenho à mão livre para o uso das escolas secundárias e profissionaes pelo professor Luiz Lacchini compreendendo 16 cadernos divididos em 3 partes, sendo que os cadernos de 1 a 9 referem-se a primeira parte, compostos de "Simples contorno", de 10 a 12 "Claro Escuro" e 13 a 16 de "Figuras Claro Escuro", s.d, s.l, impresso, caderno 9.

- LACCHINI, Luiz. Curso preparatório de desenho à mão livre para o uso das escolas secundárias e profissionaes pelo professor Luiz Lacchini compreendendo 16 cadernos divididos em 3 partes, sendo que os cadernos de 1 a 9 referem-se a primeira parte, compostos de "Simples contorno", de 10 a 12 "Claro Escuro" e 13 a 16 de "Figuras Claro Escuro", s.d, s.l, impresso, caderno 10.

- LACCHINI, Luiz. Curso preparatório de desenho à mão livre para o uso das escolas secundárias e profissionaes pelo professor Luiz Lacchini 
compreendendo 16 cadernos divididos em 3 partes, sendo que os cadernos de 1 a 9 referem-se a primeira parte, compostos de "Simples contorno", de 10 a 12 "Claro Escuro" e 13 a 16 de "Figuras Claro Escuro", s.d, s.l, impresso, caderno 11.

- LACCHINI, Luiz. Curso preparatório de desenho à mão livre para o uso das escolas secundárias e profissionaes pelo professor Luiz Lacchini compreendendo 16 cadernos divididos em 3 partes, sendo que os cadernos de 1 a 9 referem-se a primeira parte, compostos de "Simples contorno", de 10 a 12 "Claro Escuro" e 13 a 16 de "Figuras Claro Escuro", s.d, s.l, impresso, caderno 12.

- LACCHINI, Luiz. Curso preparatório de desenho à mão livre para o uso das escolas secundárias e profissionaes pelo professor Luiz Lacchini compreendendo 16 cadernos divididos em 3 partes, sendo que os cadernos de 1 a 9 referem-se a primeira parte, compostos de "Simples contorno", de 10 a 12 "Claro Escuro" e 13 a 16 de "Figuras Claro Escuro", s.d, s.l, impresso, caderno 14.

- Secretaria de Educação e Saúde Publica. Superintendência do Ensino Profissional. Programa do Curso Industrial de Mecânica de Maquinas em experiência nas Escolas Industriais do Estado, s.d., impresso.

\section{I.2 Acervo artístico}

\section{I.2.1 Mobiliário}

- Armário - estante, s.d., madeira, vidro.

- Armário com vidro, s.d., madeira, vidro.

- Armário- estante, s.d., madeira, vidro.

- Armário, s.d., madeira, espelho.

- Armário, s.d. madeira.

- Cabideiro de pé, s.d., madeira.

- Cadeira, s.d., madeira, estofada em tecido.

- Cadeira, s.d., madeira, estofada em tecido.

- Cadeira, s.d., madeira, estofada em tecido.

- Cadeira, s.d., madeira, estofada em tecido.

- Cadeira, s.d., madeira, estofada em tecido.

- Cadeira, s.d., madeira, estofada em tecido.

- Cadeira com assento em couro, s.d., madeira.

- Cadeira com assento em couro, s.d., madeira.

- Cadeira com assento em couro, s.d., madeira. 
- Cadeira de braço, s.d., madeira.

- Cadeira de braço, s.d., madeira.

- Cadeira de braço, s.d., madeira.

- Cadeira de braços com assento de couro, s.d. madeira.

- Cadeira de couro, s.d., madeira.

- Cadeira Savanarola, s.d., madeira.

- Cama, s.d, madeira.

- Chapeleira, s.d., madeira, metal.

- Cômoda com gavetas, s.d., madeira, metal.

- Cômoda, s.d, madeira, metal.

- Criado-mudo, s.d., madeira, mármore?

- Criado-mudo, s.d., madeira, mármore?

- Cristaleira (?), s.d., madeira, vidro.

- Espelho, s.d., moldura com douração.

- Espelho pequeno, s.d., moldura com douração.

- Mesa- aparador, s.d., madeira imitando pedra.

- Mesa com gaveteiro, s.d., madeira, metal.

- Mesa com tampo de mármore, s.d.

- Mesa de reuniões (cf) com 30 cadeiras, s.d., madeira, estofadas em couro.

- Mesa, s.d., madeira, laca?.

- Mesa, s.d., latão?, com tampo de vidro.

- Mesa, s.d., latão?, com tampo de vidro.

- Mesa, s.d., madeira.

- Mesa, s.d., madeira.

- Móvel- estante, s.d., madeira, vidro.

- Prancheta com pés de ferro, s,d.

- Poltrona, s.d., madeira, couro.

- Poltrona, s.d., madeira, estofada.

- Poltrona, s.d., madeira, estofada.

- Poltrona, s.d., estofada em couro.

- Sofá de quatro lugares, s.d., madeira, couro.

- Sofá de quatro lugares, s.d., madeira, estofado em tecido. -

- Sofá de três lugares com braço- aparador, s.d., madeira, estofado em tecido.

- Sofá de três lugares, s.d., estofado em couro. 


\section{I.2.2 Esculturas}

- Ettore Ximemes. Busto Ramos de Azevedo, s.d., bronze.

- Busto, s.d., bronze

- Busto, s.d., bronze.

- Busto, s.d., bronze.

- [Cavaleiro], s.d., bronze.

- Crucifixo, s.d.,bronze

- Diana, s.d., bronze.

- M. Giribaldi. A Fúria do Vento. O desalinho com a ação do Tempo, s.d., bronze.

- [M. Giribaldi.]. [Bailarina], s.d., mármore.

- [M. Giribaldi]. [Casal], s.d., mármore.

- M. Giribaldi. O Outono. O momento em que a árvore dá seu fruto, s.d., bronze.

- M. Giribaldi. Sem título, s.d., mármore.

- [Inverno], s.d., bronze.

- [Lutadores], s.d., bronze.

- Medalhão-busto Conde Álvares Penteado, s.d., bronze.

- Medalhão, s.d., bronze

- O menino e a rã, s.d., bronze

- [Outono], s.d., bronze.

- [Primavera], s.d., bronze.

- Santa Ceia, s.d, bronze

- Santa Ceia, s.d, bronze

- [Verão], s.d., bronze.

\section{I.2.3 Pinturas}

- Enrico Vio. Retrato de Ramos de Azevedo, s.d., pintura.

- [Retrato elíptico], s.d., pintura sobre tela, 61,0 x 50,5 cm

- [Retrato], s.d., pintura sobre tela, $58 \mathrm{~cm}$ de diâmetro.

- Retrato de Azevedo Marques, s.d., pintura.

- [Retrato], s.d., pintura sobre tela.

\section{I.2.4 Gipsoteca (galeria de reproduções em gesso)}

- Afrodite agachada, atribuída a Dédalo de Bitínia, s.d., gesso. 
- [Anatomia], s.d, gesso.

- Capitel- Colunata, s.d., gesso.

- Capitel - Colunata, s.d., gesso.

- Capitel, s.d., gesso - [Coluna], s.d, gesso.

- Davi de Michelangelo (detalhe da cabeça), s.d., gesso.

- Davi por Michelangelo, s.d., gesso.

- Discóbulo de Naukydes, s.d., gesso.

- Friso Cantoria por Luca della Robbia, s.d., gesso.

- Friso putti, s.d., gesso.

- Galileu, busto, s.d., gesso.

- [Grifo], painel, s.d., gesso.

- [Grifo], s.d., gesso.

- Medalhão-busto, s.d., gesso

- Moisés salvo das águas por Barzachi, s.d., gesso.

- [Ornamento], s.d., gesso.

- [Ornamento], s.d., gesso.

- Pietá por Michelangelo, s.d., gesso.

- [Retrato], painel, s.d, gesso.

- Sem título [cabeça de soldado], s.d., gesso.

- Sem título [cabeça de soldado], s.d., gesso.

- Sem título [cabeça de soldado], s.d., gesso.

- Sem título [cabeça de soldado], s.d., gesso.

- Sem título [cabeça], s.d, gesso.

- Sem título [cabeça], s.d, gesso.

- Sem título [cabeça], s.d., gesso.

- Sem título [cabeça], s.d., gesso.

- Sem título [cabeça], s.d., gesso.

- Sem título [cabeça], s.d., gesso.

- Sem título [cabeça], s.d., gesso.

- Sem título [cabeça], s.d., gesso.

- Sem título [estatueta], s.d., gesso.

- Sem título [estatueta], s.d., gesso.

- Sem título[busto soldado], s.d., gesso.

- Sem título[busto soldado], s.d., gesso.

- Sem título[busto], s.d., gesso.

- Sem título[busto], s.d., gesso. 
- Sem título[busto], s.d., gesso.

- Sem título[busto], s.d., gesso.

\section{I.3 Fotográfico}

\section{I.3.1 Fotografias avulsas (modelos)}

- Fotos Cidade- Europa (modelo estilo), s.d., s.l., fotografia, p\&b, etiqueta M 6.

- [Modelos de loja - banheiros]. S.l.: S.n., s.d., il., p\&b, desencadernado, etiqueta M 8.

- [Modelos de móveis]. S.l.: S.n, s.d., il., fotografia, p\&b, desencadernado, etiqueta M7.

- Dresden. S.l.: S.n., s.d., fotogravura, p\&b, etiqueta M 10.

- Decorações e mobiliário da Colônia no Brasil, s.d., fotografia, p\&b, capa e contracapa deslocadas, pacote anotado 36.

- Igrejas São Paulo, Rio de Janeiro e Minas Gerais, s.d., 21 fotografias, p\&b. pacote $n^{\circ} 42$.

\section{Coleção Institucional}

\section{II.1 Acervo de manuscritos}

\section{II.1.1 Atas e livros manuscritos}

- Liceu de Artes e Ofícios de São Paulo. Atas da Diretoria, 1893 a 1909, maço manuscrito.

- Liceu de Artes e Ofícios de São Paulo. Livro de Associados, 1916-1926.

- Liceu de Artes e Ofícios de São Paulo. Livro de chamada. Cursos de Geometria e Desenho Geométrico. Professor Bruno de Santi, 19301935, manuscrito e impresso.

- Liceu de Artes e Ofícios de São Paulo Livro de matrículas na aula de desenho série $\mathrm{C}$ n 8, 1918-1923.

- Liceu de Artes e Ofícios de São Paulo. Livro de visitantes, 1923, manuscrito, capa em madeira.

- Liceu de Artes e Ofícios de São Paulo. Livro das solenidades, 1936-1971, manuscrito, encadernado com capa de madeira e guardas em couro de crocodilo?

- Liceu de Artes e Ofícios de São Paulo. Livro para Termos dos Exames do Lyceu de Artes e Ofícios de 1884 a 1941. 


\section{II.2 Acervo fotográfico}

\section{2.1 Álbuns fotográficos (mostruário) e fotografias avulsas}

\section{Álbuns fotográficos (mostruário)}

- Liceu de Artes e Ofícios de São Paulo. Banca Italiana di Sconto San Paulo, s.d., fotografia, p\&b, capa deslocada, sem etiqueta.

- Liceu de Artes e Ofícios de São Paulo. Palace Hotel Rio de Janeiro, s.d., fotografia, p\&b, etiqueta 2.

- Liceu de Artes e Ofícios de São Paulo. Alfândega de Santos, 1938, fotografia, p\&b, etiqueta 3 .

- Liceu de Artes e Ofícios de São Paulo. Instalações Comerciais e Wagon São Paulo Railway, s.d., fotografia, p\&b, etiqueta 4.

- Liceu de Artes e Ofícios de São Paulo. Novas Thermas Poços de Caldas, s.d., fotografia, p\&b, etiqueta 5 .

- Liceu de Artes e Ofícios de São Paulo. Dormitórios e Salões, s.d., fotografia, p\&b, timbre 6

- Liceu de Artes e Ofícios de São Paulo. Salas de visita, s.d., fotografia, p\&b, etiqueta 6.

- Liceu de Artes e Ofícios de São Paulo. Mobiliário para dormitórios, s.d., fotografia, p\&b, etiqueta 8 .

- Liceu de Artes e Ofícios de São Paulo. Móveis Lyceu, s.d., fotografia, p\&b, etiqueta 9.

- Liceu de Artes e Ofícios de São Paulo. Banquetes, cadeiras, poltronas e canapés - gôndolas Luiz XVI, s.d., fotografia, p\&b, etiqueta 12.

- Liceu de Artes e Ofícios de São Paulo. Sofás, poltronas e cadeiras Luiz XIV e Luiz XV, s.d., fotografia, p\&b, etiqueta 13.

- Liceu de Artes e Ofícios de São Paulo. Salões. Mesas, consolos, floreiras e vitrinas Luiz XVI e Império, s.d., fotografia, p\&b, etiqueta 14.

- Liceu de Artes e Ofícios de São Paulo. Boudoirs. Sofás, poltronas, cadeiras e móveis de vime, s.d., fotografia, p\&b, etiqueta 15.

- Liceu de Artes e Ofícios de São Paulo. Salões. Sofás, poltronas, cadeiras, mesas, consolos, floreiras e vitrinas Luiz XIV e Luiz XV, s.d., fotografia, $\mathrm{p} \& \mathrm{~b}$, etiqueta 16 .

- Liceu de Artes e Ofícios de São Paulo Móveis para salas de jantar, s.d., fotografia, p\&b, etiqueta 17. 
- Liceu de Artes e Ofícios de São Paulo. Salas de jantar e dormitórios, s.d., fotografia, p\&b, etiqueta 18.

- Liceu de Artes e Ofícios de São Paulo. Salas de jantar, Império Jacobino, Florentino, Renascença, colonial e Oriental, s.d., fotografia, p\&b, etiqueta 19.

- Liceu de Artes e Ofícios de São Paulo. Buffets, etageres, crystaleiras, mesas e cadeiras, s.d., fotografia, p\&b, etiqueta 20.

- Liceu de Artes e Ofícios de São Paulo. Móveis de escritórios e dormitórios (modelos de Milão), s.d., fotografia, p\&b, etiqueta 21.

- Liceu de Artes e Ofícios de São Paulo. Dormitórios ingleses, s.d., fotografia, p\&b, etiqueta 22.

- Liceu de Artes e Ofícios de São Paulo. Dormitórios Luiz XVI, s.d., fotografia, p\&b, etiqueta 23.

- Liceu de Artes e Ofícios de São Paulo. Pratas repuxadas e cinzeladas Época Dom João V, s.d., fotografia, p\&b, etiqueta 24.

- Liceu de Artes e Ofícios de São Paulo. Cerâmica, s.d., fotografia, p\&b, etiqueta 25.

- Liceu de Artes e Ofícios de São Paulo. Cerâmicas, s.d., fotografia, p\&b, etiqueta 27.

- Liceu de Artes e Ofícios de São Paulo. Cerâmica artística, s.d., fotografia, p\&b, etiqueta 28 .

- Liceu de Artes e Ofícios de São Paulo. Maiolicas, s.d., fotografia, p\&b, etiqueta 29.

- Liceu de Artes e Ofícios de São Paulo. Lustres, Arandella, Columnas para abat-jours e lustres de prata, s.d., fotografia, p\&b, etiqueta. 30.

- Liceu de Artes e Ofícios de São Paulo.Ferro batido, Lanternas, Pendentes e com braços, s.d., fotografia, p\&b, etiqueta 31.

- Liceu de Artes e Ofícios de São Paulo. Paraventos, Floreiras e Vitrinas, s.d., fotografia, p\&b, etiqueta 32.

- Liceu de Artes e Ofícios de São Paulo. Ferro batido. Acessórios para chaminés e corre - mão de escadas, s.d., fotografia, p\&b, etiqueta 33.

- Liceu de Artes e Ofícios de São Paulo. Ferro batido, Plafoniers, Lustres e Arandelas Tripodes e vasos, s.d., fotografia, p\&b, etiqueta 34.

- Liceu de Artes e Ofícios de São Paulo. Carro Leito. Salão das Estradas de Ferro Sorocabana e Arco do Triunfo, s.d., fotografia, p\&b, etiqueta 35.

- Liceu de Artes e Ofícios de São Paulo. Porcelanas, s.d., fotografia, p\&b, algumas numeradas e identificadas em italiano, etiqueta 37.

- Liceu de Artes e Ofícios de São Paulo. Modelagem, s.d., fotografia, p\&b. 
- Liceu de Artes e Ofícios de São Paulo. Dormitórios e salões, s.d., fotografia, p\&b.

- Liceu de Artes e Ofícios de São Paulo. [Mobiliário], s.d., fotografia, p\&b.

- Sociedade Comercial e Construtora Ltda. Palácio dos Campos Elíseos. Homenagem da Sociedade Comercial e Construtora Ltda. a Armando de Salles Oliveira, 25.01.1936, fotografia, p\&b, etiqueta 1 A.

- Sociedade Comercial e Construtora Ltda. Palácio dos Campos Elíseos. Homenagem da Sociedade Comercial e Construtora Ltda. a Armando de Salles Oliveira, 25.01.1936, fotografia, p\&b, etiqueta 1 B.

\section{Fotografias avulsas reunidas em pacotes}

- Liceu de Artes e Ofícios de São Paulo. Cerâmica, móveis e ambientes, s.d., fotografia, p\&b, 34 fls., deslocadas de álbum, pacote $n^{\circ} 35$.

- Liceu de Artes e Ofícios de São Paulo. Mesas, poltronas, sofás, s.d., fotografia, p\&b, 29 fls., deslocadas de álbum, pacote $n^{\circ} 36$.

- Liceu de Artes e Ofícios de São Paulo.Grades, portões, ambientes, s.d, fotografia, p\&b, 28 fls., deslocadas de álbum, pacote $n^{\circ} 37$, também anotado 56

- Liceu de Artes e Ofícios de São Paulo. Grades, portões, ambientes, s.d., fotografia, p\&b, 40 fls., deslocadas de álbum, pacote no 38

- Liceu de Artes e Ofícios de São Paulo. Grades, lustres, bronzes, s.d., fotografia, p\&b, 17 fls., deslocadas de álbum, pacote no 39

- Liceu de Artes e Ofícios de São Paulo. Móveis de quarto, sala de jantar, s.d., fotografia, p\&b, deslocadas de álbum, pacote $\mathrm{n}^{\circ} 40$.

- Liceu de Artes e Ofícios de São Paulo. Mostruário, 28-janeiro de 1929. Poltronas, cadeiras, sofás, divãs, 1929, fotografia, p\&b, deslocadas de álbum, pacote $\mathrm{n}^{\circ} 41$.

- Liceu de Artes e Ofícios de São Paulo. Móveis de sala e escritório, s.d, fotografia, p\&b, deslocadas de álbum, pacote $n^{\circ} 43$.

- Liceu de Artes e Ofícios de São Paulo. Móveis de sala e quarto, s.d, fotografia, p\&b, deslocadas de álbum, pacote no 44 .

- Liceu de Artes e Ofícios de São Paulo. Residências, clubes, espaços públicos, s.d, fotografia, p\&b, deslocadas de álbum, pacote $\mathrm{n}^{\circ} 45$.

- Liceu de Artes e Ofícios de São Paulo. [Móveis, e ambientes], s.d, fotografia, p\&b, 23 fls. deslocadas de álbum, fotografias avulsas, pacote $n^{\circ} 48$. 
- Liceu de Artes e Ofícios de São Paulo. Residências, interiores e exteriores. Igrejas, Teatro Municipal?, s.d, fotografia, p\&b, 12 fls., deslocadas de álbum, avulsas, pacote no 49.

- Liceu de Artes e Ofícios de São Paulo. Residências, interiores, exteriores, s.d, fotografia, p\&b, fls., deslocadas de álbum, pacote no 50 .

- Liceu de Artes e Ofícios de São Paulo. Interiores, s.d., fotografia, p\&b, deslocadas de álbum, pacote n ${ }^{\circ} 64$.

- Liceu de Artes e Ofícios de São Paulo. Móveis de Sala, s.d, fotografia, p\&b, 4 fls., deslocadas de álbum, pacote $n^{\circ}$. 65 .

- Liceu de Artes e Ofícios de São Paulo Residências, interiores, exteriores, folhas deslocadas de álbum, s.d, fotografia, p\&b, deslocadas de álbum, pacote sem $n^{\circ}$.

- Liceu de Artes e Ofícios de São Paulo Lustres, arandelas e castiçais, s.d, fotografia, $\mathrm{p} \& \mathrm{~b}$, deslocadas de álbum, pacote sem $\mathrm{n}^{\circ}$.

- Liceu de Artes e Ofícios de São Paulo Esboços e projetos, s.d, fotografia, $\mathrm{p} \& b$, deslocadas de álbum, pacote sem $\mathrm{n}^{\circ}$.

\section{Fotografias avulsas (proto- álbuns)}

- Liceu de Artes e Ofícios de São Paulo. Balneário Araxá, Araxá.

- Liceu de Artes e Ofícios de São Paulo. Banco do Brasil, São Paulo.

- Liceu de Artes e Ofícios de São Paulo. Banco do Comércio e Indústria de Santos.

- Liceu de Artes e Ofícios de São Paulo. Banco do Comércio e Indústria de São Paulo.

- Liceu de Artes e Ofícios de São Paulo. Banco Hipotecário Agrícola, São Paulo.

- Liceu de Artes e Ofícios de São Paulo.Banco Ítalo Belga, São Paulo.

- Liceu de Artes e Ofícios de São Paulo. Banco Nacional do Comércio de São Paulo, São Paulo.

- Liceu de Artes e Ofícios de São Paulo. Banco Português do Brasil, São Paulo e Rio de Janeiro.

- Liceu de Artes e Ofícios de São Paulo. Bolsa de Valores de São Paulo.

- Liceu de Artes e Ofícios de São Paulo. Caixa Econômica Federal, São Paulo.

- Liceu de Artes e Ofícios de São Paulo. Casa Guinle, São Paulo.

- Liceu de Artes e Ofícios de São Paulo. Casa Palmares, São Paulo.

- Liceu de Artes e Ofícios de São Paulo. Catedral Sé, São Paulo. 
- Liceu de Artes e Ofícios de São Paulo. Club Comercial, São Paulo.

- Liceu de Artes e Ofícios de São Paulo. Colégio São Luiz, São Paulo.

- Liceu de Artes e Ofícios de São Paulo. Colégio Sion, São Paulo.

- Liceu de Artes e Ofícios de São Paulo. Companhia Ítalo Brasileira, São Paulo.

- Liceu de Artes e Ofícios de São Paulo. Companhia Paulista de Estradas de Ferro, São Paulo.

- Liceu de Artes e Ofícios de São Paulo. Companhia Predial Alvares Penteado, São Paulo.

- Liceu de Artes e Ofícios de São Paulo. Copacabana Palace, Rio de Janeiro.

- Liceu de Artes e Ofícios de São Paulo. Correios e Telégrafos, São Paulo.

- Liceu de Artes e Ofícios de São Paulo. Departamento Administrativo do Estado São Paulo.

- Liceu de Artes e Ofícios de São Paulo. Estádio Municipal de São Paulo.

- Liceu de Artes e Ofícios de São Paulo. Externato São Jose, São Paulo.

- Liceu de Artes e Ofícios de São Paulo. Faculdade de Direito do Largo Francisco, São Paulo.

- Liceu de Artes e Ofícios de São Paulo. Igreja da Ordem Terceira do Carmo, São Paulo.

- Liceu de Artes e Ofícios de São Paulo. Instituto Adolpho Lutz, São Paulo.

- Liceu de Artes e Ofícios de São Paulo. Instituto Bacteriológico de São Paulo.

- Liceu de Artes e Ofícios de São Paulo. Instituto de Educação, São Paulo.

- Liceu de Artes e Ofícios de São Paulo. Jahu Clube, Jaú.

- Liceu de Artes e Ofícios de São Paulo. Jockey Clube, São Paulo.

- Liceu de Artes e Ofícios de São Paulo. London and Brazilian Bank, São Paulo.

- Liceu de Artes e Ofícios de São Paulo. Ministério da Fazenda, Rio de Janeiro.

- Liceu de Artes e Ofícios de São Paulo. Novas Termas "Antonio Carlos", Poços de Caldas.

- Liceu de Artes e Ofícios de São Paulo. Paço Municipal de Santos.

- Liceu de Artes e Ofícios de São Paulo. Palácio da Justiça, São Paulo.

- Liceu de Artes e Ofícios de São Paulo. Pirie, Villares e Cia., São Paulo.

- Liceu de Artes e Ofícios de São Paulo. Polyclinica, São Paulo. 
- Liceu de Artes e Ofícios de São Paulo. Prédio Ramos de Azevedo, São Paulo.

- Liceu de Artes e Ofícios de São Paulo. Recebedoria de Rendas da Secretaria da Fazenda, São Paulo.

- Liceu de Artes e Ofícios de São Paulo. Santa Casa de Misericórdia, São Paulo.

- Liceu de Artes e Ofícios de São Paulo. Teatro Municipal, São Paulo.

- Liceu de Artes e Ofícios de São Paulo. Teatro Santana, São Paulo.

- Liceu de Artes e Ofícios de São Paulo. Tribunal Municipal de São Paulo.

\section{Fotografias avulsas em caixas}

- Camas com e sem criados-mudo, guarda-roupa, cômoda com espelho, s.d., s.l., fotografia, $\mathrm{p} \& \mathrm{~b}$, caixa arquivo em polionda verde $\mathrm{n}^{\circ} 1$.

- Guarda-roupa, cômoda com e sem espelho, biombos, s.d., s.l., fotografia, p\&b, caixa arquivo em polionda verde $\mathrm{n}^{\circ} 2$.

- Decoração vasos, molduras, retratos, azulejos, esculturas, monumentos, s.d., s.l., fotografia, p\&b, caixa arquivo em polionda verde $n^{\circ} 3$.

- Mesinhas, mesas, mesas/cadeiras, cozinhas, s.d., s.l., fotografia, p\&b, caixa arquivo em polionda verde $\mathrm{n}^{\circ} 4$.

- Esboços, projetos, cerâmicas/vasos, mesas/mesinhas, s.d., s.l., fotografia, p\&b, caixa arquivo em polionda verde $n^{\circ} 5$.

- Salas de jantar, s.d., s.l., fotografia, p\&b, caixa de polionda verde n 6 .

- Salas de jantar, sala de jantar/visitas/genéricos, s.d., s.l., fotografia, p\&b, Caixa arquivo em polionda verde $\mathrm{n}^{\circ} 7$.

- Penteadeiras com cadeiras/cômodas, divãs, berços, interiores de quartos, s.l., fotografia, $\mathrm{p} \& \mathrm{~b}$, caixa arquivo em polionda verde $\mathrm{n}^{\circ} 8$.

- Interiores, criados mudos, espelhos, mesinhas/genéricos, s.d., s.l., fotografia, p\&b, caixa arquivo em polionda verde $n^{\circ} 9$.

- Poltronas, cadeiras, bancos, s.d., s.l., fotografia, p\&b, caixa arquivo em polionda verde $\mathrm{n}^{\circ} 10$.

- Poltronas, cadeiras, bancos, s.d., s.l., fotografia, p\&b, caixa arquivo em polionda verde $\mathrm{n}^{\circ} 11$.

- Sofás, interiores, salas de jantar/visita, s.d., s.l., fotografia, p\&b, caixa arquivo em polionda verde $\mathrm{n}^{\circ} 12$.

- Painéis com fotos, exposição e loja do Liceu de Artes e Ofícios de São Paulo, Igrejas, Motores e máquinas, documentos, s.d., s.l., fotografia, $\mathrm{p} \& \mathrm{~b}$, color., caixa arquivo em polionda verde $\mathrm{n}^{\circ} 13$. 
- Exteriores, s.d., s.l., fotografia, p\&b, caixa arquivo em polionda verde $\mathrm{n}^{\circ} 14$.

- Vários, escadas, carrinhos, escadas, portas, portões, janelas, s.d., s.l., fotografia, $\mathrm{p} \& \mathrm{~b}$, caixa arquivo em polionda verde $\mathrm{n}^{\circ} 15$.

- Lustres, arandelas, castiçais, s.d., s.l., fotografia, p\&b, caixa arquivo em polionda verde $n^{\circ} 16$.

- Exemplos [da produção do Liceu de Artes e Ofícios de São Paulo], s.d., s.l., fotografia, p\&b, caixa arquivo em polionda verde $\mathrm{n}^{\circ} 17$

- Escritórios, s.d., s.l., fotografia, p\&b, caixa arquivo em polionda verde $\mathrm{n}^{\circ} 18$.

- Termas Antonio Carlos, Poços de Caldas, 16 registros, s.d, fotografia, $\mathrm{p} \& b$, pacote $\mathrm{n}^{\circ} 70$, caixa arquivo em polionda verde Instituições $\mathrm{n}^{\circ} 70 \mathrm{a}$ 81 , sem recontagem analítica.

- Alfândega de Santos, 25 registros, s.d., fotografia, p\&b, pacote n ${ }^{\circ} 71$, caixa arquivo em polionda verde Instituições no 70 a 81.

- Palácio dos Campos Elyseos, 23 registros, 1944-1952-1953, fotografia, $\mathrm{p} \& \mathrm{~b}$, pacote $\mathrm{n}^{\circ} 72$, caixa arquivo em polionda verde Instituições $\mathrm{n}^{\circ} 70 \mathrm{a}$ 81.

- Hotel Central, Rio de Janeiro, 48 registros, s.d., fotografia, p\&b, pacote $\mathrm{n}^{\circ} 73$, caixa arquivo em polionda verde Instituições nº 70 a 81.

- Club Comercial, 3 registros/ Banco do Brasil, 2 registros/ Banco do Commercio e Indústria, 1 registro/ Banco Português, Rio de Janeiro, 3 registros/ Banco Nacional do Comercio de São Paulo, 2 registros/ Banco do Comercio e Indústria de Santos, 1 registro, s.d., fotografia, $p \& b$, pacote $n^{\circ} 74$, caixa arquivo em polionda verde Instituições $n^{\circ} 70$ a 81 .

- Consórcio Paulista, 54 registros, s.d., fotografia, p\&b, pacote $n^{\circ} 75$, caixa arquivo em polionda verde Instituições no 70 a 81 .

- Jockey Club, 99 registros, s.d., fotografia, p\&b, pacote $n^{\circ} 76$, caixa arquivo em polionda verde Instituições no 70 a 81 .

- Jahu Clube, 1 registro/ Rec. de Rendas, 1 registro/ Cia. Ítalo Brasileira, 4 registros/ Regina Hotel, 1 registro/ Banco Ítalo-Belga, 10 registros/ Tribunal Municipal de São Paulo, 7 registros/ Club Comercial, 1 registro, s.d., fotografia, $\mathrm{p} \& \mathrm{~b}$, pacote $\mathrm{n}^{\circ} 77$, caixa arquivo em polionda verde Instituições n $\mathrm{n}^{\circ} 70$ a 81.

- Congresso Eucarístico, 18 registros/ Candelária, Rio de Janeiro, 2 registros/ Regimento Sampaio, 2 registros, s.d., fotografia, $p \& b$, pacote $n^{\circ}$ 78, caixa arquivo em polionda verde Instituições $\mathrm{n}^{\circ} 70$ a 81. 
- Cia. Paulista de Estrada de Ferro, 19 registros, s.d., fotografia, p\&b, pacote $\mathrm{n}^{\circ} 79$, caixa arquivo em polionda verde Instituições $\mathrm{n}^{\circ} 70$ a 81.

- Balneário Araxá, 60 registros, fotografia, p\&b, pacote no 80, caixa arquivo em polionda verde Instituições no 70 a 81.

- Faculdade de Direito de São Paulo, 30 registros, s.d., fotografia, p\&b, pacote $n^{\circ} 81$, caixa arquivo em polionda verde Instituições $n^{\circ} 70$ a 81 .

- Copacabana Palace, Rio de Janeiro, 51 registros, s.d., fotografia, p\&b, pacote $\mathrm{n}^{\circ} 82$, caixa arquivo em polionda verde Instituições no 82 a 93.

- Instituto Bacteriológico de São Paulo, 31 registros, s.d., fotografia, p\&b, pacote $n^{\circ} 83$, caixa arquivo em polionda verde Instituições no 82 a 93.

- Departamento Administrativo do Estado São Paulo, 19 registros/ Colégio São Luiz São Paulo, 6 registros, s.d., fotografia, p\&b, pacote $n^{\circ}$ 84 , caixa arquivo em polionda verde Instituições $n^{\circ} 82$ a 93, sem recontagem analítica.

- Theatros - auditórios, 11 registros, s.d., fotografia, p\&b, pacote $n^{\circ} 85$, caixa arquivo em polionda verde Instituições no 82 a 93.

- Banco Commercio e Indústria de São Paulo, 7 registros/ Banco da Província do Rio Grande do Sul, 21 registros, s.d., fotografia, p\&b, pacote $\mathrm{n}^{\circ} 86$, caixa arquivo em polionda verde Instituições $\mathrm{n}^{\circ} 82$ a 93 .

- Instituto de Educação, São Paulo, 4 registros/, Pirie, Villares e Cia., 5 registros/ Colégio Sion, São Paulo, 3 registros/ Instituto Adolpho Lutz, São Paulo, 2 registros, s.d., fotografia, p\&b, pacote $n^{\circ} 87$, caixa arquivo em polionda verde Instituições no 82 a 93 .

- Paço Municipal de Santos 7 registros/ Associação Comercial de Porto Alegre, 9 registros/ Hotel Araxá, 8 registros/ O Estado de S. Paulo, 7 registros, s.d., fotografia, $\mathrm{p} \& \mathrm{~b}$, pacote $\mathrm{n}^{\circ} 88$, caixa arquivo em polionda verde Instituições no 82 a 93.

- [Palácio da Justiça], s.d., fotografia, p\&b pacote no 89 , caixa arquivo em polionda verde Instituições no 82 a 93.

- Companhia Siderúrgica Nacional, Volta Redonda, 10 registros/ Externato São Jose, 1 registro/ Polyclinica, 1 registro/ Casa Guinle, 1 registro/ Prédio Ramos de Azevedo, 2 registros/ Sociedade Harmonia de Tênis, São Paulo, 3 registros/ Collegio dos Anjos, 2 registros, s.d., fotografia, $\mathrm{p} \& b$, pacote $\mathrm{n}^{\circ} 90$, caixa arquivo em polionda verde Instituições $\mathrm{n}^{\circ} 82$ a 93.

- Estádio Municipal de São Paulo, 1 registro/ Telégrafos, 3 registros/ Theatro Municipal, Rio de Janeiro, 3 registros, s.d., fotografia, p\&b, pacote $n^{\circ} 91$, caixa arquivo em polionda verde Instituições no 82 a 93. 
- Banco do Estado de São Paulo, 4 registros/ Departamento de Estradas e Rodagem, 1 registro/ Banco do Commercio e Indústria da Bahia, 1 registro/ Hotel Quitandinha, 1944, 5 registros, s.d., fotografia, p\&b, pacote $n^{\circ} 92$, caixa de polionda verde Instituições nº 82 a 93.

- Ministério da Fazenda, reproduções fotográficas, p\&b, pasta - arquivo

\section{II.3 Acervo de projetos (desenhos) \\ II.3.1 Desenhos, projetos, estudos e esboços originais}

\section{Álbum}

- Liceu de Artes e Ofícios de São Paulo. [Álbum de desenhos de lustres], s.d., col.

- Liceu de Artes e Ofícios de São Paulo. Companhia Itaquerê, 1934, s.l., p\&b, com orçamento datiloscristo, desenho a cores e páginas impressas, etiqueta D7.

\section{Avulsos}

- [Armário], s.d., s.l., 1 fl., desenho, lápis, p\&b, não planificado. [Armário], s.d., s.l., 1 fl., desenho, lápis, p\&b, não planificado.

- BORSOI, Antonio. Sem título, 28.5. [19]09, s.l., 1 fl., desenho, lápis, $\mathrm{p} \& \mathrm{~b}$.

- BORSOI, Antonio. [Estudo] nº. 1, [19]10, s.l., 1 fl., desenho, lápis, p\&b, não planificado.

- BORSOI, Antonio. [Estudo], 18.02. [19]13, s.l, 1 fl., desenho, lápis, p\&b, não planificado.

- BORSOI, Antonio. [Estudo], 26.02. [19]15, s.l., 1 fl., desenho, lápis, p\&b, não planificado.

- BORSOI, Antonio. [Estudo], 08.03. [19]15, s.l., 1 fl., desenho, lápis, p\&b, não planificado.

- BORSOI, Antonio. [Estudo], 15.03. [19]15, s.l., 1 fl., desenho, lápis, p\&b, não planificado.

- BORSOI, Antonio. [Estudo], 20.03. [19]15, s.l., 1 fl., desenho, lápis, p\&b, não planificado.

- BORSOI, Antonio. [Estudo], 23.3. [19]15, s.l. 1 fl., desenho, lápis, p\&b.

- BORSOI, Antonio. Motivo decorativo, esboço, 23.03.1915, s.l., s.l., 1 fl., desenho, lápis, p\&b. 
- BORSOI, Antonio. [Estudo], 08.04. [19]15, São Paulo, 1 fl., desenho, lápis, p\&b, não planificado

- BORSOI, Antonio. [Estudo], 13.04. [19]15, s.l., 1 fl., desenho, lápis, p\&b, não planificado.

- BORSOI, Antonio. [Estudo], 26.04. [19]15, s.l., 1 fl., desenho, lápis, p\&b, não planificado.

- BORSOI, Antonio. [Estudo], 29.04. [19]15, s.l., 1 fl., desenho, lápis, p\&b, não planificado.

- BORSOI, Antonio. [Estudo], 10.05. [19]15, s.l., 1 fl., desenho, lápis, p\&b, não planificado.

- Borsoi, Antonio. [Estudo], 14.11. [19]16, s.l., 1 fl., desenho, lápis, p\&b, não planificado

- BORSOI, Antonio. [Estudo], nº. 10, s.d., s.l., 1 fl., desenho, lápis, p\&b, não planificado.

- BORSOI, Antonio. [Estudo], nº. 10, s.d., s.l., 1 fl., desenho, lápis, p\&b, não planificado.

- BORSOI, Antonio. [Estudo], nº. 10, s.d., s.l., 1 fl., desenho, lápis, p\&b, não planificado.

- BORSOI, Antonio. [Estudo], no. 10, s.d., s.l., 1 fl., desenho, lápis, p\&b, não planificado.

- BORSOI, Antonio. [Estudo], nº. 10, s.d., s.l., 1 fl., desenho, lápis, p\&b, não planificado.

- BORSOI, Antonio. [Estudo], nº. 10, s.d., s.l., 1 fl., desenho, lápis, p\&b, não planificado.

- BORSOI, Antonio. [Estudo], nº. 10, s.d., s.l., 1 fl., desenho, lápis, p\&b, não planificado.

- BORSOI, Antonio. [Estudo], nº. 10, s.d., s.l., 1 fl., desenho, lápis, p\&b, não planificado.

- Borsoi, Antonio. [Estudo], no. 10, s.d., s.l., 1 fl., desenho, lápis, p\&b, não planificado.

- BORSOI, Antonio. [Estudo], nº. 10, s.d., s.l., 1 fl., desenho, lápis, p\&b, não planificado.

- BORSOI, Antonio. [Estudo], nº. 10, s.d., s.l., 1 fl., desenho, lápis, p\&b, não planificado.

- BORSOI, Antonio. [Estudo], no. 10, 2º anno, s.d., s.l., 1 fl., desenho, lápis, p\&b, não planificado.

- BORSOI, Antonio. [Estudo], s.d., s.l., s.l., 1 fl., desenho, lápis, p\&b, não planificado. 
- [BORSOI, Antonio]. [Motivo decorativo], s.d., s.l., 1 fl., desenho, lápis, $\mathrm{p} \& \mathrm{~b}$, não planificado.

- [BORSOI, Antonio]. [Motivo decorativo], s.d., s.l., 1 fl., desenho, lápis, $\mathrm{p} \& \mathrm{~b}$, não planificado.

- [BORSOI, Antonio]. [Motivo decorativo], s.d., s.l., 1 fl., desenho, lápis, $\mathrm{p} \& \mathrm{~b}$, não planificado.

- [BORSOI, Antonio]. [Motivo decorativo], s.d., s.l., 1 fl., desenho, lápis, p\&b, não planificado.

- [BORSOI, Antonio]. [Motivo decorativo], s.d., s.l., 1 fl., desenho, lápis, p\&b, não planificado.

- [BORSOI, Antonio]. [Motivo decorativo], s.d., s.l., 1 fl., desenho, lápis, p\&b, não planificado.

- [BORSOI, Antonio]. [Motivo decorativo], s.d., s.l., 1 fl., desenho, lápis, $\mathrm{p} \& b$, não planificado.

- [BORSOI, Antonio]. [Motivo decorativo], s.d., s.l., 1 fl., desenho, lápis, $\mathrm{p} \& \mathrm{~b}$, não planificado

- [BORSOI, Antonio]. [Motivo decorativo floral], s.d., s.l., 1 fl., desenho, lápis, p\&b, não planificado.

- [BORSOI, Antonio]. [Motivo decorativo floral], s.d., s.l., 1 fl., desenho, lápis, $\mathrm{p} \& b$, não planificado.

- [BORSOI, Antonio]. [Motivo decorativo floral], s.d., 1 fl., s.l., desenho, lápis, $\mathrm{p} \& b$, papel neutro.

- [BORSOI, Antonio]. Motivo decorativo, esboço, s.d., 1 fl., s.l., desenho, lápis, $\mathrm{p} \& \mathrm{~b}$.

- [BORSOI, Antonio]. [Motivo decorativo], s.d., s.l., 1 fl., desenho, lápis, p\&b, não planificado.

- Liceu de Artes e Ofícios de São Paulo. [Cadeira de braços], s.d., s.l., 1 fl., desenho, lápis, p\&b.

- Liceu de Artes e Ofícios de São Paulo. Cadeira de braço, s.d., s.l., 1 fl., desenho, lápis, p\&b, no verso [Mesas de centro], s.d., desenho, color.

- Liceu de Artes e Ofícios de São Paulo. [Cadeiras, mesinhas e armários], Exmo. Sr. Felipe Luftalla, s.d., 1 fl., desenho, lápis, p\&b.

- Liceu de Artes e Ofícios de São Paulo. [Credência], s.d., s.l., 1 fl., desenho, lápis, p\&b.

- Liceu de Artes e Ofícios de São Paulo. [Mesinha de apoio], s.d., s.l., desenho, lápis, p\&b.

- Liceu de Artes e Ofícios de São Paulo. [Mesa e armário], s.d., s.l., 1 fl., desenho, lápis, p\&b, em verso de prancha. 
- Liceu de Artes e Ofícios de São Paulo. [Mesa, cadeira e mesinha], s.d., s.l., 1 fl., desenho, lápis, p\&b.

- Liceu de Artes e Ofícios de São Paulo. [Mesinha de apoio], s.d., s.l., desenho, lápis, p\&b.

- Liceu de Artes e Ofícios de São Paulo. [Poltrona, sofá e mesa de centro], s.d., s.l., 1 fl., desenho, lápis e pastel, color.

- Liceu de Artes e Ofícios de São Paulo. [Poltrona], s.d., s.l., 1 fl., desenho, lápis, color.

- Liceu de Artes e Ofícios de São Paulo. Projeção de sombra natural, s.d, s.l., 1 fl., desenho, lápis, p\&b.

- Liceu de Artes e Ofícios de São Paulo. Stand do Liceu de Artes e Ofícios de São Paulo, s.d., s.l., 1 fl., desenho, lápis, color.

- Liceu de Artes e Ofícios de São Paulo. Projeto Adolfo Milani, nº M 673, arq. 1-5, s.d.

- Liceu de Artes e Ofícios de São Paulo. Projeto Adolfo Milani, no M 1389, arq. 1-7, s.d.

- Liceu de Artes e Ofícios de São Paulo. Projeto Afifi Cury, nº M 1114, arq. 1-8, s.d.

- Liceu de Artes e Ofícios de São Paulo. Projeto Alberto Assad, nº M396, arq. 1-7, s.d.

- Liceu de Artes e Ofícios de São Paulo. Projeto Alvaro Bento, M no 140, arq. 1-4, s.d, desenhista A.G.

- Liceu de Artes e Ofícios de São Paulo. Projeto Assad Abdalla, nº M 1091, arq. 1-8, s.d.

- Liceu de Artes e Ofícios de São Paulo. Projeto Basilio Jafet, nº 1119, arq. $1-3$, s.d.

- Liceu de Artes e Ofícios de São Paulo. Projeto luminária Dr. Eduardo Prado, no 995 , arq. 2-26, s.d.

- Liceu de Artes e Ofícios de São Paulo. Projeto Gladstone Jafet, nº M 1118, arq. 1-9, s.d.

- Liceu de Artes e Ofícios de São Paulo. Projeto João José Resende, $\mathrm{n}^{\circ}$ 4370, arq. 2-27, 25.5.1940, estilo K, desenhista A.G.

- Liceu de Artes e Ofícios de São Paulo. Projeto Jockey Club, n 2050, arq. 1-2, 14.1.1940, estilo J, desenhista A.A.

- Liceu de Artes e Ofícios de São Paulo. Projeto José Kalil, nº M 219, arq. 1-4 s.d. Obs. Não executado

- Liceu de Artes e Ofícios de São Paulo. Projeto Lauro Cardoso de Almeida, $\mathrm{n}^{\circ} \mathrm{M} 714$, arq. 1-7, s.d. 
- Liceu de Artes e Ofícios de São Paulo. Projeto Luiz Nazareno Assumpção, no 2424, arq. 1-5, 25.2.1946, estilo L, desenhista A.G.

- Liceu de Artes e Ofícios de São Paulo. Projeto lustre Igreja da Ordem $3^{a}$ do Carmo, no 1047, arq. 2-26, s.d.

- Liceu de Artes e Ofícios de São Paulo. Projeto [lustre] Sr. José Francisco de Camargo, proj. no 1030, anno 02, [19]26, s.l., 1 fl., desenho, lápis, $\mathrm{p} \& \mathrm{~b}$.

- Liceu de Artes e Ofícios de São Paulo. Projeto cortina Nene Cunha Bueno, no 1020 , arq. 2-26, s.d.

- Liceu de Artes e Ofícios de São Paulo. Projeto [Lustre da] Sala de Bilhar do Palácio dos Campos Elyseos, proj. no 1033, anno 02, [19]26, s.l., 1:10, 1 fl., desenho, lápis, p\&b.

- Liceu de Artes e Ofícios de São Paulo. Projeto Terraço e Hall de Cima. Exmo. Senhor Pedro Morganti (para sua Exma. Filha), 22.03.1935, s.l., $1 \mathrm{fl}$., desenho, impresso.

- Liceu de Artes e Ofícios de São Paulo. Projeto MMe. Rene Thiolier, n ${ }^{\circ}$ M 535, arq. 1-14, s.d.

- Liceu de Artes e Ofícios de São Paulo. Projeto Roberto Alves Almeida, $\mathrm{n}^{\circ} \mathrm{M} 276$, arq. 1-4, 8.8.1936.

- Liceu de Artes e Ofícios de São Paulo. Projeto Sem titulo, s.d.

- Liceu de Artes e Ofícios de São Paulo. Projeto Sr. Vicente Scandurra, proj. $n^{\circ}$ 1819, arq. 1-2, Des. A. G., estilo S, 28.11. [19]35, s.l., 1 fl., desenho, impresso.

- Liceu de Artes e Ofícios de São Paulo. Quadro de Formandos, Escola Polythecnica, São Paulo, 1930, s.l., 1 fl., desenho, papel vegetal.

- Liceu de Artes e Ofícios de São Paulo de São Paulo. Quadro de Formandos, Escola Polythecnica, São Paulo, 1930, s.l., 1 fl., desenho, papel vegetal.

- Liceu de Artes e Ofícios de São Paulo. [Poltrona, sofá e mesa de centro], s.d., s.l., 1 fl., desenho, lápis e pastel, color.

\section{Impressos (diazotipos)}

- Liceu de Artes e Ofícios de São Paulo. Halls, Cabides, porta chapeos, bases, bancos e mesas, s.d., p\&b, impresso, etiqueta D1.

- Liceu de Artes e Ofícios de São Paulo. Halls, Cabides, porta chapeos, bases, bancos e mesas, s.d., p\&b, impresso, etiqueta D2. 
- Liceu de Artes e Ofícios de São Paulo. Portas, entradas, alisares, ascensores, divisões, balcões e instalações diversas, s.d., p\&b, impresso, etiqueta D3.

- Liceu de Artes e Ofícios de São Paulo. Portas, entradas, alisares, ascensores, divisões, balcões e instalações diversas, s.d., p\&b, etiqueta D4.

- Liceu de Artes e Ofícios de São Paulo. Escritórios, cadeiras, mesas, carteiras, bureaux, secretarias, estantes caixas, giratórias, conjuntos e grupos, s.d., p\&b, impresso, etiqueta D5.

- Liceu de Artes e Ofícios de São Paulo. Cerâmicas, s.d., p\&b, com lista de preços, impresso, etiqueta D8.

- Liceu de Artes e Ofícios de São Paulo. Exma Snta. Bice Morganti, 1935, p\&b, impresso, etiqueta D9.

- Liceu de Artes e Ofícios de São Paulo. Palácio da Justiça, s.d., s.l., p\&b, desmontado, impresso, etiqueta D 11.

- Liceu de Artes e Ofícios de São Paulo. Faculdade de Medicina de São Paulo, 1929, p\&b, impresso.

- Liceu de Artes e Ofícios de São Paulo. Desenhos de objetos em madeira, s.d., p\&b, impresso.

- Liceu de Artes e Ofícios de São Paulo Desenhos de objetos em madeira, s.d., p\&b, impresso.

- Liceu de Artes e Ofícios de São Paulo. [Desenhos de cadeiras], 1929, p\&b, impresso

- Liceu de Artes e Ofícios de São Paulo. Congresso Legislativo de São Paulo s.d., p\&b, ex. 1.

- Liceu de Artes e Ofícios de São Paulo Congresso Legislativo de São Paulo s.d., p\&b, impresso, ex. 2 (agrupado ao ex. 1).

- Liceu de Artes e Ofícios de São Paulo Banco do Brazil, São Paulo, s.d., p\&b, impresso, desmontado.

- F. P. Ramos de Azevedo e Cia. Eng. Architectos, projeto 14-5, des. nº. 707, 1.20, Cia Paulista de Seguros, Rua Álvares Penteado no 19, São Paulo, detalhe, 09.06.1926, 1 fl., heliografia

\section{4 Outros}

\section{1 Diplomas, prêmios, documentos e impressos}

\section{Diplomas e prêmios}

- Diploma Gran Premio. Esposizione Internationale delle Industrie e Dell Lavoro, Torino, 1911, il., color., impresso, emoldurado com vidro. 
- Dyplome de Médaille d'or. Exposition Universelle de Bruxeles, 1910. Sous le Haute Patronage de S.M. Le Roi des Belges, 1910, il., color., impresso, emoldurado com vidro.

- Escola Técnica Ramos de Azevedo do Liceu de Artes e Ofícios de São Paulo. Diploma de Habilitação em Desenho Arquitetônico, 1957, 1 fl., color., impresso.

- Escola Técnica Ramos de Azevedo do Liceu de Artes e Ofícios de São Paulo. Diploma de Habilitação Desenho de Máquinas, 1965, 1 fl., color., impresso.

- Liceu de Artes e Ofícios de São Paulo. Diretoria do Liceu de Artes e Ofícios de São Paulo confere ao Sr. Pedro Vaz de Mello, aluno da aula de Desenho Superior o prêmio de menção pelo $1^{\circ}$. Grau. São Paulo, 15.11.1896, 1 fl., il., p\&b, impresso, sobre chassi, assinatura de Ramos de Azevedo.

\section{Documentos}

- Companhia de Saneamento Básico do Estado de São Paulo - SABESP. Laudo de aferição de hidrômetro LAO, 1930, manuscrito e impresso, $1 \mathrm{fl}$.

- Liceu de Artes e Ofícios de São Paulo. Saletas, Bibliotecas e Escritórios Modernos e Clássicos nº. 4, s.d., catálogo datiloscrito, com lista de preços, ex. 1.

- Liceu de Artes e Ofícios de São Paulo. Saletas, Bibliotecas e Escritórios Modernos e Clássicos nº. 4, s.d., catálogo datiloscrito, com lista de preços, ex. 2.

- Liceu de Artes e Ofícios de São Paulo. Móveis de estilo para Hall e Salas $\mathrm{n}^{\circ}$. 5, s.d., catálogo datiloscrito, com lista de preços.

- Liceu de Artes e Ofícios de São Paulo. Planta do primeiro pavimento do Liceu de Artes e Ofícios de São Paulo, escala 1:100, s.d., cópia impressa.

- Liceu de Artes e Ofícios de São Paulo. Planta do segundo pavimento do Liceu de Artes e Ofícios de São Paulo, escala 1:100, s.d., cópia impressa.

- Liceu de Artes e Ofícios de São Paulo. Planta de res do chão do Liceu de Artes e Ofícios de São Paulo, risco II, escala 1:100, s.d., cópia impressa.

- Liceu de Artes e Ofícios de São Paulo. Planta das oficinas do Liceu de Artes e Ofícios, desenhada por Wenceslau G[-], 27.07.1945, desenho, col. 


\section{Impressos}

- Ex - líbris Cerca de 650 amostras clichês, p\&b, color., impresso.

- Liceu de Artes e Ofícios de São Paulo. Ensaio de Fadiga em Hydrometros LAO. Typo D, 3 m3. São Paulo: s.d., il. p\&b, impresso.

- Liceu de Artes e Ofícios de São Paulo. Escola Pratica de Artes e Ofícios. Programa e organização das classes profissionais e oficinas. São Paulo, MCMXXXIV, 14 p., impresso, ex.1.

- Liceu de Artes e Ofícios de São Paulo. Escola Pratica de Artes e Ofícios. Programa e organização das classes profissionais e oficinas. São Paulo, MCMXXXIV, 14 p., impresso, ex. 2.

- Liceu de Artes e Ofícios de São Paulo. Escola Pratica de Artes e Ofícios. Programa e organização das classes profissionais e oficinas. São Paulo, MCMXXXIV, 14 p., impresso, ex. 3.

- Liceu de Artes e Ofícios de São Paulo. Estatutos do Liceu de Artes e Ofícios, 1934, impresso.

- Liceu de Artes e Ofícios de São Paulo. Estatutos do Liceu de Artes e Ofícios, 1939, impresso.

- Liceu de Artes e Ofícios de São Paulo. Extrato e resumo do Catalogo Geral da Galeria de Arte, 1934, impresso, ex 1.

- Liceu de Artes e Ofícios de São Paulo. Extrato e resumo do Catalogo Geral da Galeria de Arte, 1934, impresso, ex 2.

- Liceu de Artes e Ofícios de São Paulo. Extrato e resumo do Catalogo Geral da Galeria de Arte, 1934, impresso, ex 3.

- Liceu de Artes e Ofícios de São Paulo. Instituto de Ensinos Profissionais, s.d., 12 p., impresso, ex. 1.

- Liceu de Artes e Ofícios de São Paulo. Instituto de Ensinos Profissionais, s.d., 12 p., impresso, ex. 2.

- Liceu de Artes e Ofícios de São Paulo.. Instituto de Ensinos Profissionais, s.d., 12 p., impresso, ex. 3.

- Liceu de Artes e Ofícios de São Paulo. Instituto de Ensinos Profissionais, s.d., 12 p., impresso, ex. 4.

- Liceu de Artes e Ofícios de São Paulo. Regulamento das oficinas do Liceu de Artes e Ofícios, 1934, impresso, ex. 1.

- Liceu de Artes e Ofícios de São Paulo. Regulamento das oficinas do Liceu de Artes e Ofícios, 1934, impresso, ex.2.

- Liceu de Artes e Ofícios de São Paulo. Regulamento das oficinas do Liceu de Artes e Ofícios, 1934, impresso, ex. 3. 
- Liceu de Artes e Ofícios de São Paulo. Tradução de Gli Italliani nel Brasile, s.d., fotografia, p\&b, ex. 1.

- Liceu de Artes e Ofícios de São Paulo. Tradução de Gli Italliani nel Brasile, s.d., fotografia, p\&b, ex.2.

- Liceu de Artes e Ofícios de São Paulo. Tradução de Gli Italliani nel Brasile, s.d., fotografia, p\&b, ex.3.

- Liceu de Artes e Ofícios de São Paulo Tradução de Gli Italliani nel Brasile, s.d., fotografia, $p \& b$, ex.4.

- Liceu de Artes e Ofícios de São Paulo. Tradução de Gli Italliani nel Brasile, s.d., fotografia, p\&b, ex.5.

- Liceu de Artes e Ofícios de São Paulo. Tradução de Gli Italliani nel Brasile, s.d., fotografia, p\&b, ex.6.

- Liceu de Artes e Ofícios de São Paulo. Tradução de Gli Italliani nel Brasile, s.d., fotografia, p\&b, ex.7.

- Liceu de Artes e Ofícios de São Paulo. Tradução de Gli Italliani nel Brasile, s.d., fotografia, p\&b, ex.8.

- Liceu de Artes e Ofícios de São Paulo. Tradução de Gli Italliani nel Brasile, s.d., fotografia, p\&b, ex.9.

- Liceu de Artes e Ofícios de São Paulo.Tradução de Gli Italliani nel Brasile, s.d., fotografia, p\&b, ex. 10.

- Liceu de Artes e Ofícios de São Paulo. Tradução de Gli Italliani nel Brasile, s.d., fotografia, p\&b, ex.11.

- Liceu de Artes e Ofícios de São Paulo. Tradução de Gli Italliani nel Brasile, s.d., fotografia, p\&b, ex.12.

- Liceu de Artes e Ofícios de São Paulo. Tradução de Gli Italliani nel Brasile, s.d., fotografia, p\&b, ex.13.

- Liceu de Artes e Ofícios de São Paulo. Tradução de Gli Italliani nel Brasile, s.d., fotografia, p\&b, ex. 14.

- Liceu de Artes e Ofícios de São Paulo. Tradução de Gli Italliani nel Brasile, s.d., fotografia, p\&b, ex.15.

- Liceu de Artes e Ofícios de São Paulo. Tradução de Gli Italliani nel Brasile, s.d., fotografia, p\&b, ex.16.

- Liceu de Artes e Ofícios de São Paulo. Tradução de Gli Italliani nel Brasile, s.d., fotografia, p\&b, ex.17.

- Liceu de Artes e Ofícios de São Paulo. Tradução de Gli Italliani nel Brasile, s.d., fotografia, p\&b, ex.18.

- Liceu de Artes e Ofícios de São Paulo. Tradução de Gli Italliani nel Brasile, s.d., fotografia, p\&b, ex.19. 
- Liceu de Artes e Ofícios de São Paulo. Tradução de Gli Italliani nel Brasile, s.d., fotografia, p\&b, ex.20.

- Liceu de Artes e Ofícios de São Paulo. Tradução de Gli Italliani nel Brasile, s.d., fotografia, p\&b, ex.21.

- Liceu de Artes e Ofícios de São Paulo. Tradução de Gli Italliani nel Brasile, s.d., fotografia, p\&b, ex.22.

- Liceu de Artes e Ofícios de São Paulo. Tradução de Gli Italliani nel Brasile, s.d., fotografia, p\&b, ex.23.

- Liceu de Artes e Ofícios de São Paulo. Tradução de Gli Italliani nel Brasile, s.d., fotografia, p\&b, ex.24.

- Liceu de Artes e Ofícios de São Paulo. Tradução de Gli Italliani nel Brasile, s.d., fotografia, p\&b, ex.25.

- Liceu de Artes e Ofícios de São Paulo. Tradução de Gli Italliani nel Brasile, s.d., fotografia, p\&b, ex.26.

- Liceu de Artes e Ofícios de São Paulo. Tradução de Gli Italliani nel Brasile, s.d., fotografia, p\&b, ex.27.

- Liceu de Artes e Ofícios de São Paulo. Tradução de Gli Italliani nel Brasile, s.d., fotografia, p\&b, ex.28.

- Liceu de Artes e Ofícios de São Paulo. Tradução de Gli Italliani nel Brasile, s.d., fotografia, p\&b, ex.29.

- Liceu de Artes e Ofícios de São Paulo. Tradução de Gli Italliani nel Brasile, s.d., fotografia, p\&b, ex.30.

- Liceu de Artes e Ofícios de São Paulo. Tradução de Gli Italliani nel Brasile, s.d., fotografia, p\&b, ex.31.

- Liceu de Artes e Ofícios de São Paulo. Tradução de Gli Italliani nel Brasile, s.d., fotografia, p\&b, ex.32.

- Liceu de Artes e Ofícios de São Paulo. Tradução de Gli Italliani nel Brasile, s.d., fotografia, p\&b, ex.33.

- Liceu de Artes e Ofícios de São Paulo. Tradução de Gli Italliani nel Brasile, s.d., fotografia, p\&b, ex.34.

- Liceu de Artes e Ofícios de São Paulo. Tradução de Gli Italliani nel Brasile, s.d., fotografia, p\&b, ex.35.

- Liceu de Artes e Ofícios de São Paulo. Tradução de Gli Italliani nel Brasile, s.d., fotografia, p\&b, ex.36.

- Liceu de Artes e Ofícios de São Paulo. Tradução de Gli Italliani nel Brasile, s.d., fotografia, p\&b, ex.37.

- Liceu de Artes e Ofícios de São Paulo. Tradução de Gli Italliani nel Brasile, s.d., fotografia, p\&b, ex.38. 
- Liceu de Artes e Ofícios de São Paulo. Tradução de Gli Italliani nel Brasile, s.d., fotografia, p\&b, ex.39.

- Liceu de Artes e Ofícios de São Paulo. Tradução de Gli Italliani nel Brasile, s.d., fotografia, p\&b, ex.40.

- Liceu de Artes e Ofícios de São Paulo. Tradução de Gli Italliani nel Brasile, s.d., fotografia, p\&b, ex.41.

- Liceu de Artes e Ofícios de São Paulo. Tradução de Gli Italliani nel Brasile, s.d., fotografia, p\&b, ex.42.

- Liceu de Artes e Ofícios de São Paulo. Tradução de Gli Italliani nel Brasile, s.d., fotografia, p\&b, ex.43.

- Liceu de Artes e Ofícios de São Paulo. Tradução de Gli Italliani nel Brasile, s.d., fotografia, p\&b, ex.44.

- Liceu de Artes e Ofícios de São Paulo. Tradução de Gli Italliani nel Brasile, s.d., fotografia, p\&b, ex.45.

- Liceu de Artes e Ofícios de São Paulo. Tradução de Gli Italliani nel Brasile, s.d., fotografia, p\&b, ex.46.

- Liceu de Artes e Ofícios de São Paulo. Tradução de Gli Italliani nel Brasile, s.d., fotografia, p\&b, ex.47.

- Relatório sobre o Liceu de Artes e Ofícios de São Paulo apresentado ao Doutor Cezário Motta Junior pelo Doutor Domingos Jose Nogueira Jaguaribe, presidente em exercício, 1895, impresso, ex.1.

- Relatório sobre o Liceu de Artes e Ofícios de São Paulo apresentado ao Doutor Cezário Motta Junior pelo Doutor Domingos Jose Nogueira Jaguaribe, presidente em exercício, 1895, impresso, ex.2.

\section{Outros}

\section{Arte sacra}

- Paixão de Cristo, s.d., azulejo esmaltado.

\section{Marchetaria}

- Sem título, s.d., madeira, 33,0 x 44,5 cm.

- Sem título, s.d., madeira, 27,0 x 31,5 cm.

- Sem título, s.d., madeira, $24,0 \times 36,0 \mathrm{~cm}$.

- Sem título, s.d., madeira, 22,0 x 31,0 cm.

- Sem título, s.d., madeira, 21,5 x 33,0 cm. 
- Sem título, s.d., madeira, 23,5 x 34,0 cm.

- Sem título, s.d., madeira, 25,0 x 21,0 cm.

- Sem título, s.d., madeira, 20,5 x 26,0 cm.

- Sem título, s.d., madeira, 22,5 x 27,0 cm.

- Sem título, s.d., madeira, 27,4 x 20,0 cm.

- Sem título, s.d., madeira, 27,0 x 22,0 cm.

- Sem título, s.d., madeira, 27,0 x 22,0 cm.

- Sem título, s.d., madeira, 27,0 x 22,0 cm.

- Sem título, s.d., madeira, 27,0 x 22,2 cm.

- Sem título, s.d., madeira, $18,3 \times 12,1 \mathrm{~cm}$.

- Sem título, s.d., madeira, 14,4 x 20,8cm.

- Sem título, s.d., madeira, $14,0 \times 20,0 \mathrm{~cm}$.

- Sem título, s.d., madeira, $22,4 \times 16,0 \mathrm{~cm}$.

- Sem título, s.d., madeira, $21,0 \times 14,8 \mathrm{~cm}$.

- Sem título, s.d., madeira, $20,5 \times 14,5 \mathrm{~cm}$.

- Sem título, s.d., madeira, 20,5 x 14,0cm.

- Sem título, s.d., madeira, $24,5 \times 18,0 \mathrm{~cm}$

- Sem título, s.d., madeira, $24,8 \times 17,8 \mathrm{~cm}$.

- Sem título, s.d., madeira, 25,0 x 18,0cm.

\section{Material sobre o antigo aluno e professor Cleto B. Correa (proto-fundo)}

- Contendo negativos coloridos / Carteira de trabalho do Liceu de Artes e Ofícios/ Livreto de 1927 com o Regulamento das oficinas/ Cartas entre professor e o diretor pedagógico/ Desenho em papel vegetal de lustre de madeira datado de 1932/ Croqui para quadro cartela da Escola Politécnica, 1932/ Reprodução de certificado do Liceu de Artes e Ofícios de 1940 em Cartório de Registros de Documentos/ Reprodução de declaração do Royal Bank of Canada, 1940 sobre o Liceu de Artes e Ofícios.

\section{Objetos}

- Estojo com compassos, s.d., incompleto.

- Estojo de compassos A 60 Riefler, s.d., com capa em tecido.

- Estojo de compasso, s.d. - Estojo de compasso Kern \& Co.S.A. s.d, com inscrição Henrique Braga e Co. e selo AARAU (Suisse), Instruments de précision.

- Aerógrafo Aerograph. Air brush. London, s.d. 
- Esquadro, s.d., $13,0 \mathrm{~cm}$.

- Esquadro, s.d., $13,0 \mathrm{~cm}$.

- Esquadro, s.d., fragmentado.

- Esquadro, s.d., fragmentado.

- Hidrômetros.

- Placa Banco do Commercio de S. Paulo S. A, s.d, ferro.

- Medalha comemorativa 'Ramos de Azevedo', bronze, s.d.

- Medalha comemorativa 'Ramos de Azevedo' 1, bronze, s.d.

VARIA

- Recorte de artigos de jornais s.d. 





